\title{
Política e cultura no governo de Dom João VI imprensa, teatros, academias e bibliotecas (1792-1821)
}

\author{
Juliana Gesuelli Meirelles
}

\section{SciELO Books / SciELO Livros / SciELO Libros}

MEIRELLES, J. G. Política e cultura no governo de Dom João VI: imprensa, teatros, academias e bibliotecas (1792-1821) [online]. São Bernardo do Campo, SP: Editora UFABC, 2017, 497 p. ISBN 97885-68576-87-8. https://doi.org/10.7476/9788568576878.

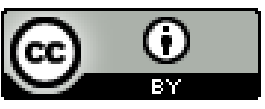

All the contents of this work, except where otherwise noted, is licensed under a Creative Commons Attribution 4.0 International license.

Todo o conteúdo deste trabalho, exceto quando houver ressalva, é publicado sob a licença Creative Commons Atribição $\underline{4.0}$.

Todo el contenido de esta obra, excepto donde se indique lo contrario, está bajo licencia de la licencia $\underline{\text { Creative }}$ Commons Reconocimento 4.0. 

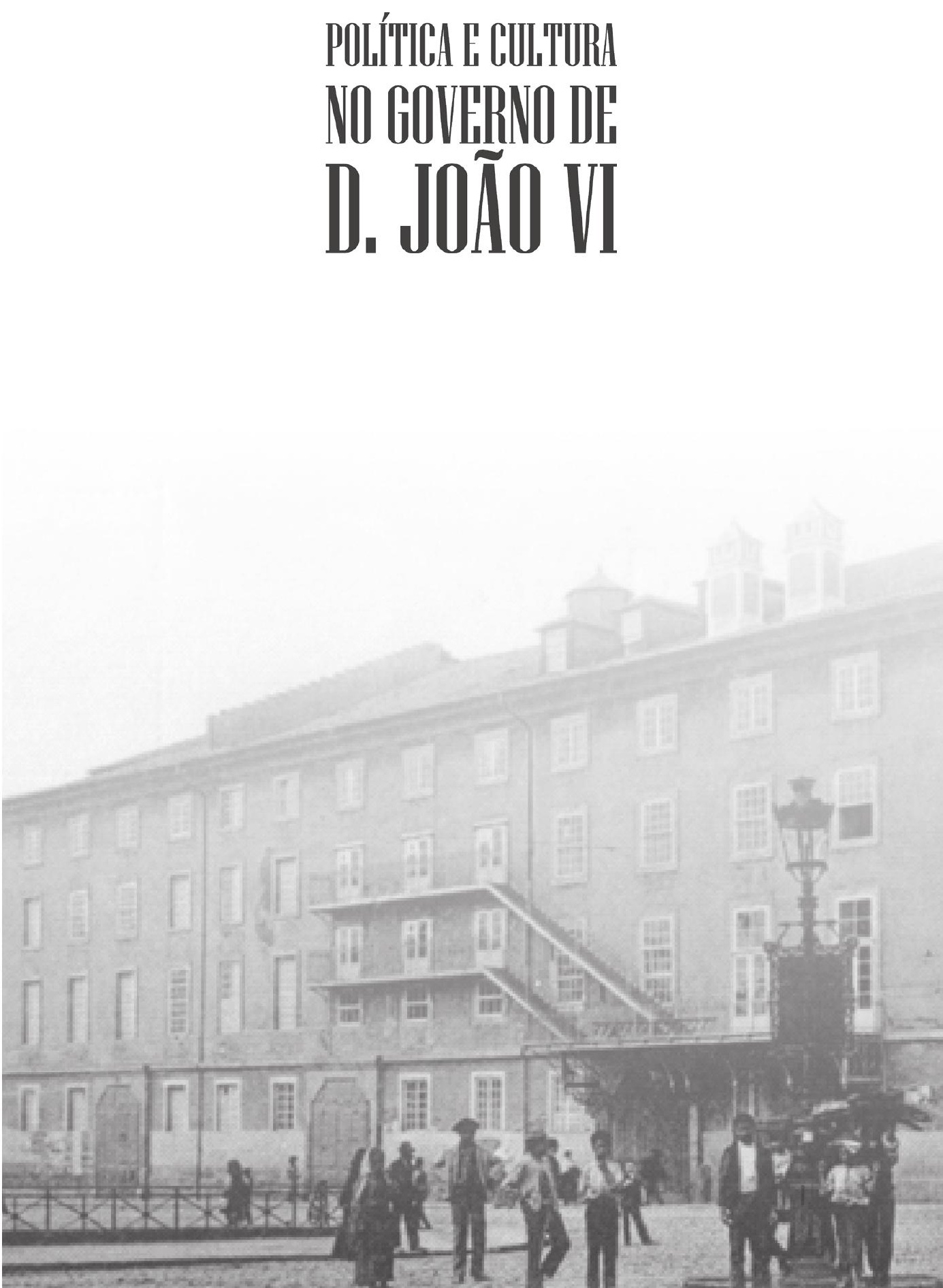


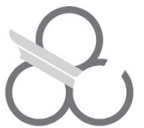 \\ UFABC}

\section{UNIVERSIDADE FEDERAL DO ABC}

Klaus Werner Capelle - Reitor

Dácio Roberto Matheus - Vice-Reitor

\section{Editora da UFABC}

Coordenação

Adriana Capuano de Oliveira

Conselho Editorial

Ana Claudia Polato e Fava

Ana Paula de Mattos Arêas Dau

Andrea Paula dos Santos Oliveira Kamensky

Artur Zimerman

Christiane Bertachini Lombello

Daniel Pansarelli

Daniel Zanetti de Florio

Douglas Alves Cassiano

Fernando Luiz Cássio Silva

João Rodrigo Santos da Silva

Júlio Francisco Blumetti Facó

Luciana Pereira

Marcelo Augusto Leigui de Oliveira

Márcia Helena Alvim

Margarethe Born Steinberger-Elias

Mario Alexandre Gazziro

Rodrigo de Alencar Hausen

Sidney Jard da Silva

Sílvia Dotta

Equipe Técnica

Cleiton Klechen

Natalia Gea 
Juliana Gesuelli Meirelles
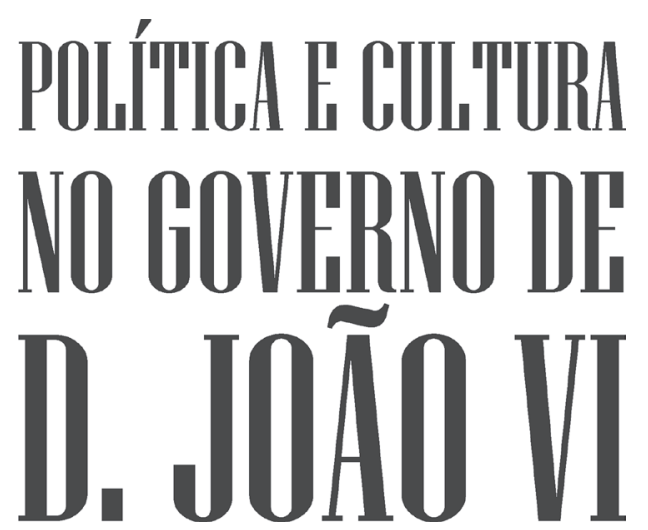

imprensa, teatros, academias e bibliotecas (1792.1821)

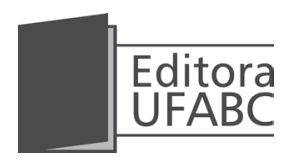

São Bernardo do Campo - SP

2017 
(C) Copyright by Editora da Universidade Federal do ABC (EdUFABC)

Todos os direitos reservados.

\title{
Equipe Técnica sob Coordenação da Gráfica e Editora Copiart
}

\author{
Revisão \\ Sérgio Meira \\ Projeto Gráfico, Diagramação e Capa \\ Rita Motta \\ Impressão \\ Gráfica e Editora Copiart
}

\begin{abstract}
CATALOGAÇÃO NA FONTE
SISTEMA DE BIBLIOTECAS DA UNIVERSIDADE FEDERAL DO ABC

Responsável: Kátia Ellen Chemalle CRB: 8/7720
\end{abstract}

Meirelles, Juliana Gesuelli

Política e cultura no governo de Dom João VI: imprensa, teatros, academias e bibliotecas (1792-1821) / Juliana Gesuelli Meirelles - São Bernardo do Campo, SP : EdUFABC, 2017.

$x, 477 p$

ISBN: 978-85-68576-68-7

1. Regência de Dom João (1808-1821) - Brasil. 2. Impressão Régia. 3. Teatro Luso-Brasileiro. 4. Real Biblioteca. 5. Política e administração Luso-Brasileira. I.Título

CDD 22 ed. - 981.033

\author{
EDITORA ASSOCIADA

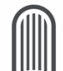 \\ Associação Brasileira \\ das Editoras Universitárias
}


[...] onde eu existo, e resido é que necessariamente se deve considerar a sede, e ponto central do Império.

Príncipe Regente D. João, 1808. 


\section{LISTA DE ABREVIATURAS E SIGLAS}

BNRJ - Biblioteca Nacional do Rio de Janeiro

BNP - Biblioteca Nacional de Portugal

ANRJ - Arquivo Nacional do Rio de Janeiro

ANTT - Arquivo Nacional da Torre do Tombo

AHU - Arquivo Histórico Ultramarino

GL - Gazeta de Lisboa

GRJ - Gazeta do Rio de Janeiro

CB - Correio Braziliense

IP - Investigador Portuguez em Inglaterra 


\section{PREFÁCIO}

O chamado "período joanino", termo utilizado para identificar os anos da permanência da corte portuguesa no Rio de Janeiro, é mais do que um simples recorte cronológico na história do Brasil. O impacto da mudança da sede da monarquia portuguesa e a consequente administração do império luso-brasileiro, a partir da América, alteraram não apenas o centro das decisões políticas, mas toda uma forma de ser e de pensar da monarquia e de seus súditos. Não é difícil, portanto, entender o interesse e o intenso trabalho dos historiadores sobre o assunto, o que acabou por transformá-lo em um tema de estudo extremamente abrangente e recorrente na historiografia brasileira, o qual envolve múltiplos aspectos e abordagens.

O livro que agora se apresenta ao público participa dessa tradição historiográfica, plenamente consolidada e, juntamente com outros estudos recentes, oferece uma leitura renovada sobre a prática política de D. João VI, enfatizando, especialmente, seus aspectos culturais. Este é o ponto original do livro de Juliana Meirelles, pois aborda a questão a partir da seleção de quatro instituições - alvo das atenções do monarca - que tiveram efeito transformador na vida da corte, no Rio de Janeiro, tanto em termos sociais, quanto artísticos e científicos: a Imprensa Régia, a Academia Militar, o Teatro São João e a Biblioteca Real. São as conexões existentes entre esses quatro espaços, os quais 
estimularam a circulação de ideias e a produção do conhecimento científico que interessam à autora desvendar. Nesse sentido, Letras, Artes e Ciências se entrecruzam com o complexo mundo da política portuguesa, envolvendo o leitor em suas tramas dos dois lados do Atlântico. De fato, um dos grandes trunfos do livro é a perspectiva comparada adotada pela autora. O olhar de Juliana Meirelles cruza constantemente o oceano integrador das diferentes partes do império, a fim de confrontar as instituições culturais fundadas por D João VI, no Rio de Janeiro, com as suas congêneres portuguesas. Mas o faz sem deixar de perceber as diferenças e as especificidades. Afinal, a América não era a Europa e o Brasil não era Portugal.

Como o leitor poderá apreciar, trata-se de uma análise criativa e estimulante que tem o mérito de reunir, em um só trabalho, um grande contingente de informações dispersas em diferentes fontes sobre as instituições estudadas, aliada ao diálogo permanente com uma vasta historiografia. Um desafio que Juliana enfrenta, manejando com sucesso, suas habilidades de historiadora, conquistadas ao longo dos anos de sua formação, os quais tive o prazer de acompanhar como professora e orientadora.

Embora este livro represente para mim o fim de uma trajetória de aluna - da graduação em História ao doutorado - significa também a confirmação de uma profissional talentosa, autora de outros estudos sobre o governo e a permanência de D. João no Brasil, pesquisadora e professora profundamente envolvida com seu ofício.

A alegria de prefaciar esse livro, portanto, é dupla. De um lado me deparar com a obra concluída e de outro, apreciar um estudo pesquisado com afinco. Este, como verá o leitor, passa longe de uma história institucional e nos apresenta um amplo conjunto 
de agentes históricos que se posicionam frente aos acontecimentos políticos, mas despontam também em seu universo cotidiano. São personagens cujas vidas passaram por transformações intensas ao se deslocarem da Europa à América em diferentes circunstâncias. Guiados pela autora, acompanhamos desde o choque cultural dos recém- chegados, os quais se depararam com uma cidade desconhecida e quase africana, em termos populacionais, para poucos anos depois assistirem ao surgimento de uma vida cultural e artística, reconstruída nos moldes europeus. Tudo isso, porém, se passa absolutamente integrado à paisagem, uma vez que, onde o rei se encontrasse, lá estariam os artefatos (os livros, os panfletos e peças de teatro, a prataria, as carruagens), bem como as pessoas e as instituições necessárias para dar suporte e significado ao exercício da realeza e de sua soberania.

Instituições essas que assumem, na cidade, um sentido pedagógico de instrução e de civilização dos costumes, indispensáveis à consolidação do espaço no qual a Corte se encontrava, assim como de formação de quadros políticos destinados à administração do império. Locus de cultura e de saber, nas palavras da autora, as instituições culturais estudadas confirmavam o poder régio no ultramar - não à toa foram intituladas Real biblioteca, Real Academia militar, e assim por diante - e alargavam as bases de sustentação política do império português.

É na perspectiva de uma visão diferenciada de D. João VI e do "período joanino", que Política e Cultura no governo de D. João $V I$ instiga o leitor e apoia o que há de melhor na historiografia sobre o tema. Contudo, apesar dos esforços de vários historiadores para desconstruírem as imagens de uma corte nos trópicos pobre e sem brilho, cujos personagens encontram-se marcados por estereótipos profundos, tais imagens persistem ainda hoje 
em muitos livros didáticos e na representação popular. Acredito que a contribuição de Juliana Meirelles é contundente neste sentido e espero, sinceramente, que possa contribuir para reverter à situação. Mas esta é já outra história - minha talvez - que gostaria de contar.

Março de 2017

Leila Mezan Algranti 


\section{SUMÁRIO}

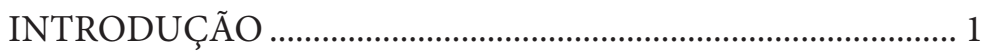

1. A IMPRENSA COMO LOCUS DE SABER.......................... 25

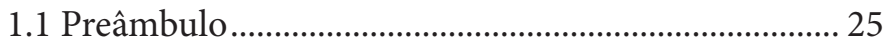

1.2 Hipólito José da Costa na política cultural joanina .... 28

1.3 O Investigador Portuguez em Inglaterra e a disputa com o Correio Braziliense............................................ 55

1.4 O Patriota e O Observador Lusitano em Paris: dois periódicos pontuais................................................... 102

2. O TEATRO LUSO-BRASILEIRO NO PERÍODO JOANINO

E A CIVILIZAÇÃO DOS COSTUMES .................................... 125

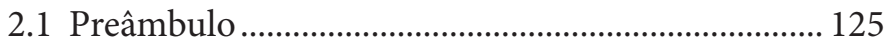

2.2 Arte e política no Antigo Regime Português: o Teatro de São Carlos .............................................................. 133

2.3 A particularidade d'O Real Teatro de São João no

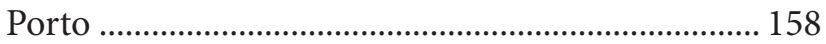

2.4 A chegada da Família Real e os usos do espaço artístico no Rio de Janeiro ......................................... 187

2.5 O Real Teatro de S. João no Rio de Janeiro.............. 207 


\section{O UNIVERSO MILITAR NA SUSTENTAÇÃO DO}

\section{IMPÉRIO PORTUGUÊS............................................................. 247}

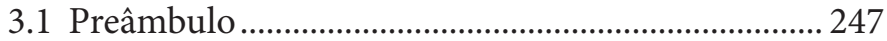

3.2 O Reformismo Ilustrado Português: as instituições militares de D. José I a D. João VI............................... 250

3.3 A Real Academia Militar e a educação dos súditos ilustrados da Coroa...................................................... 279

4. A REAL BIBLIOTECA E A GRANDEZA DA MONARQUIA

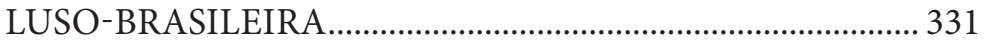

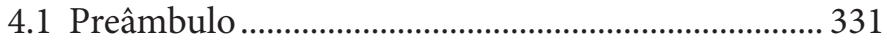

4.2 Soberania política e a constituição da Real Biblioteca Pública da Corte .......................................................... 337

4.3 A nova Corte do Rio de Janeiro joanino: a Impressão Régia e o mundo dos livros...................................... 378

4.4 O governo joanino e o projeto de uma Biblioteca Pública no Rio de Janeiro

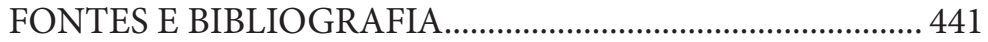




\section{INTRODUÇÃO}

Apenas se anunciou na capital e nas províncias, que se achava em perigo a sua vida, jamais se viu manifestar-se o amor público de maneira

menos equívoca: cada um dos portugueses caiu enfermo com o príncipe do Brasil. Isto era natural: os destinos da nossa pátria achando-se intimamente ligados aos seus destinos, à saúde de SAR, e à saúde pública vinham a ser a mesma coisa. Convencidos da mesma importância, importunamos ao céu por ele e por nós: o céu se comoveu; e condoído das nossas lágrimas, o restituiu aos nossos desejos, è nossa extrema necessidade. Então cada português se deu por salvo, e considerou nos progressos da sua melhora a ressurreição da monarquia.

Frei Joaquim Forjaz, Set. 1789. ${ }^{1}$

Escrita pouco tempo depois da morte do príncipe D. José (1761-1788), o primeiro na linha da sucessão da Dinastia de Bragança, esta Oração congratulatória de um importante súdito real

\footnotetext{
${ }^{1}$ FORJARZ, J. Oração congratulatória pelo restabelecimento da importantíssima saúde do sereníssimo príncipe do Brasil nosso senhor na solene festa que celebrarão dos gentis-homens de sua Câmara no dia 5 de setembro de 1789.
} 
nos diz muito sobre as dificuldades políticas que a monarquia lusitana começava a enfrentar. Sem o primogênito, a sucessão da Coroa de $\mathrm{D}^{\mathrm{a}}$ Maria passava para seu segundo filho varão, o príncipe D. João. Se este tivera uma "existência discreta" até os dezoito anos, na expressão de Jorge Pedreira e Fernando Costa, o seu casamento com D. Carlota Joaquina e a repentina necessidade de assumir a sucessão da Coroa como Regente mudariam definitivamente a sua vida. ${ }^{2}$ Portanto, a vulnerabilidade da saúde do Príncipe do Brasil era questão temerária, refletindo-se, de certo modo, nas angústias espirituais e nos anseios políticos dos súditos ilustrados da Coroa portuguesa. ${ }^{3}$ Em outras palavras, a saúde de D. João simbolizava a vitalidade da monarquia, atestando, por outras vias, a proteção da nação lusitana contra as intempéries políticas europeias.

A escrita da Oração coincidiu com um momento de radicalismo político na França. Em 14 de julho de 1789, a sociedade parisiense colocava abaixo a Bastilha, maior símbolo do Antigo Regime francês. A despeito da voracidade com que se deu o início do processo revolucionário na Corte de Luís XVI, as primeiras notícias dos fatos não suscitaram grandes preocupações em

\footnotetext{
2 PEDREIRA, Jorge; COSTA, Fernando Dores. D. João VI. Um príncipe entre dois continentes. São Paulo: Cia das Letras, 2008. p. 31.

${ }^{3}$ Nesta obra utilizamos a ideia de súdito ilustrado baseados na definição da historiadora Tereza Cristina Kirschner. Segundo ela, "Os [súditos] ilustrados portugueses do final do século XVIII e início do XIX formavam um grupo, principalmente de funcionários régios, que pregava a ideia de civilização e progresso da sociedade, ancoradas em princípios científicos, e defendia reformas que não abalassem as estruturas do Antigo Regime. Apropriaram-se das ideias de Newton e Adam Smith, do direito natural renovado da época moderna, separaram a teologia da filosofia, mas reconheciam os limites da razão humana, e por isso justificavam a necessidade da Revelação nos casos em que a Razão mostrava-se insuficiente. " KIRSCHNER, Tereza Cristina. "D. Rodrigo de Souza Coutinho e os ilustrados da Corte de D. João" In: MARTINS, Ismênia; MOTTA, Márcia. 1808: a corte no Brasil. Rio de Janeiro: Editora da UFF, 2010. p. 221.
} 
Portugal. No Reino, a percepção das transformações foi lenta. "Durante vários anos as mudanças foram entendidas em um nível que causava estupefação e mesmo horror, mas que nada alterava de essencial na ordem europeia”, explicam Pedreira e Costa. ${ }^{4}$

Durante a década de 1790, os rumos da Revolução Francesa afetariam de forma patente o destino das demais monarquias absolutistas no Velho Continente, mormente na Península Ibérica. Tal foi a ebulição política em solo francês que a circulação das ideias consideradas sediciosas pela realeza portuguesa tornou-se um sério problema a ser enfrentado. Em finais de 1794, para evitar a contaminação dos “maus princípios”, Da Maria I sancionava mudanças importantes: houve o restabelecimento da censura tríplice, quando se deu a revogação da censura unificada da época pombalina (cujo órgão de destaque era a Real Mesa Censória). Na prática, o controle de livros e escritos no país retrocedia às antigas instâncias de poder com domínios de atuação tripartidos entre a Inquisição, o Ordinário e a Mesa do Desembargo do Paço. ${ }^{5}$

\footnotetext{
4 PEDREIRA, Jorge; COSTA, Fernando Dores. D. João VI... Op. Cit., p. 59.

5 D. João VI, em nome de $\mathrm{D}^{\mathrm{a}}$ Maria I, sancionou em 30 de julho de 1795 um alvará que regulamentava os novos critérios de censura de livros, sendo que a Inquisição, o Ordinário e o Desembargo do Paço passavam a ter funções distintas. Ao Ordinário autorizava-se a censura das doutrinas religiosas e referentes à disciplina eclesiástica; o tribunal da Inquisição tinha como responsabilidade o zelo pela pureza doutrinal, cujo foco era a repressão das heresias e, por fim, o Desembargo do Paço se reservava ao exame e a censura das doutrinas que pudessem corromper os "bons costumes públicos da Nação", as leis e os direitos da Coroa, que, por ventura perturbassem a paz geral do Estado. Para uma análise detalhada acerca da diversidade da atuação desses órgãos, ver: ALGRANTI, Leila Mezan. Livros de Devoção, Atos de Censura: cultura religiosa na América Portuguesa. São Paulo: Editora Hucitec /FAPESP, 2004; NEVES, Lúcia Maria Bastos P. "Comércio de livros e censura de ideias: a atividade dos livreiros franceses no Brasil e a vigilância da Mesa do Desembargo do Paço (1795-1822).” In: Ler História, 23, 1992; VILLALTA, Luiz Carlos, "Censura literária e inventividade dos leitores no Brasil Colonial”. In: TUCCI, Maria Carneiro (Org.), Minorias Silenciadas: História da Censura no Brasil. São Paulo: Edusp, 2002.
} 
Apesar de essas alterações na política impressa da Coroa portuguesa estarem diretamente vinculadas à figura da Rainha, desde 1792, D. João atuava como Regente de fato da monarquia portuguesa; em decorrência da constatação da doença da mãe. A governança informal do Príncipe do Brasil durou até 1799, quando foi sancionada a regência de jure. ${ }^{6} \mathrm{~A}$ partir de então, ele passava a ser assumidamente a cabeça absoluta do Império Português, chancelada na sua assinatura como "Príncipe Regente". A despeito da formalização de sua condição política, a interinidade da regência continuava a ser um problema. Para Jorge Pedreira e Fernando Costa, esta situação foi invariavelmente de fragilidade, uma vez que suscitava maior dificuldade em dirigir os conflitos e as rivalidades entre seus ministros e conselheiros. "A fonte da autoridade era imperfeita", asseguram os autores. A partir desta realidade, justificam que a própria capacidade pessoal do monarca era prejudicada diante da atuação de seus ministros que acabavam por ter preponderância diante da figura de um Regente. ${ }^{7}$

Mesmo concordando com o ponto de vista dos autores acerca da fragilidade da natureza do poder regencial, por outro lado, acreditamos que a ação política de D. João, considerada tradicionalmente como hesitante, e procrastinada, tinha essas características justamente pelo monarca ter uma profunda consciência do seu lugar enquanto governante da monarquia lusitana. Se essa posição se traduzia em um estilo de governar fortemente marcado pelo ouvir (talvez em demasia) os seus ministros, acreditamos que ele o fazia, precisamente, para conservar a Coroa sob sua cabeça, manipulando astutamente os conflitos e diferenças entre

\footnotetext{
${ }^{6}$ PEDREIRA, Jorge; COSTA, Fernando Dores. D. João VI... Op. Cit., p. 59-88.

7 Ibid., p. 79.
} 
seus homens de Estado. ${ }^{8}$ Aliás, diante da frágil natureza do seu poder, ter ministros com posições político-ideológicas divergentes, como foi o caso de D. Rodrigo de Souza Coutinho e Antonio de Araújo de Azevedo, provavelmente aparecia ao Regente como uma importante vantagem para manter-se à frente da governabilidade imperial e acima das disputas "partidárias". Como já ressaltaram os historiadores Guilherme Pereira das Neves e Lúcia Bastos Pereira das Neves, nas grandes ou pequenas decisões políticas, D. João foi um governante guiado por um sólido bom senso. ${ }^{10}$

No que tange à "educação política” do Príncipe Regente, é fundamental salientar dois vieses. O primeiro deles refere-se à influência patente da concepção da monarquia temperada, a categoria política que permeou a "arte de governar" de D. João, seja como Príncipe Regente ou Rei do Império Português. Para esta concepção política em particular, destacou-se a grande influência

\footnotetext{
8 Sobre esse tipo de conduta, ver: GUIMARÃES, Alberto Carlos de Araújo. "Ação Cultural e Política no governo de D. João VI". In: Anais da Revista do Instituto Histórico e Geográfico, Rio de Janeiro, v.3, p. 259-292, 1938, 1941.

9 Enquanto D. Rodrigo de Souza (Conde de Linhares) foi o líder do "Partido Inglês", Antonio de Araújo de Azevedo (Conde da Barca) era o representante por excelência do "Partido Francês". Neste aspecto, importa estabelecer os sentidos de um "partido" no mundo português, em fins do século XVIII e início do século XIX, em uma sociedade de Corte. Na acepção de Pedreira e Costa, “Trata-se de agrupamentos de pequeniníssima dimensão, completamente informais e muito instáveis, constituídos por homens de corte unidos por 'amizades' em função da distribuição de lugares de governo. A designação de partidos era negativa, usava-se contra os adversários e ninguém a reconhecia em relação a si próprio e ao seu grupo". Neste contexto, dois vieses foram fundamentais na luta pela ascensão política: as orientações diplomáticas em relação à França e Inglaterra e as divergências entre a primeira nobreza do Reino e os cortesãos denominados de "pombalinos." PEDREIRA, Jorge; COSTA, Fernando Dores. D. João VI... Op. Cit., p. 82.

10 NEVES, Guilherme Pereira das; NEVES, Lúcia Bastos Pereira das. "D. João VI”. In: NEVES, Lúcia Bastos Pereira das; VAINFAS, Ronaldo. Dicionário do Brasil Joanino. Rio de Janeiro: Objetiva, 2008. p. 121.
} 
dos escritos políticos de Antônio Ribeiro dos Santos (1745-1818), súdito real de grande envergadura política em finais do século XVIII e início do XIX. Ao refletir sobre a natureza da monarquia temperada, Ribeiro dos Santos asseverava que "Os mesmos escritores que derivam de Deus o Poder supremo dos Reis nem por isso deixam de assentar que vem do Povo". ${ }^{11}$ Esta máxima determinava que nem na figura do monarca tampouco na do homem residia a natureza do poder: esta advinha de Deus. Por este prisma, a fonte do poder do rei era resultado de um consentimento do povo, que mantinha a legitimidade da monarquia, e cuja lei fundamental era fruto de um ato da vontade de todos, em que pese o papel das Cortes. A prática política da monarquia temperada, portanto, ao mesmo tempo em que afastava do Rei a figura do ser inatingível que governava por intermédio de um valido, também o aproximava de seus súditos. ${ }^{12}$ Nas palavras da historiadora Iara Schiavinatto,

O poder do rei se constituiu na discussão política, no processo pelo qual o pacto e a soberania se elaboraram, nas práticas sociais e nos debates jurídicos, mas também implicou uma dimensão litúrgica, na qual festas, músicas, fogos, desfiles, procissões não são apanágio ou têm um peso menor. $\mathrm{Na}$ conjunção destes sentidos encontramos o rei sacralizado e, ao mesmo tempo, a participação política. ${ }^{13}$

A partir dessa concepção teórica, compreendemos melhor a atuação política de D. João durante a sua governança (17921826), já que uma de suas mais destacadas “qualidades” era saber

\footnotetext{
11 O texto em questão foi intitulado Sobre a Origem do Poder do Príncipe e faz parte do acervo da BNP. Seção de Reservados. Cód. 4668.

12 SCHIAVINATTO, Iara Lis Franco. Pátria Coroada: o Brasil como Corpo Político Autônomo 1780-1831. São Paulo: Ed. Unesp, 1999. p. 31.

13 Ibid., p. 36.
} 
ouvir os seus ministros e conselheiros e, em maior extensão, os seus súditos em geral. ${ }^{14}$ Ao longo de sua governança D. João foi um monarca que consultava e parecia se orientar pelas opiniões, no geral contrastantes, de seus súditos ilustrados, quer sejam ministros ou escritores. Um governante que negociava mercês com seus súditos, que, de alguma forma, o auxiliavam nas múltiplas tarefas da governança. Um rei que também se movimentava pela pressão da sociedade, visando, sobretudo, a garantir a coesão e integridade do todo, em outras palavras, a conservação do Império; tomando a iniciativa de propor e administrar instituições que atendessem a seus interesses particulares, mas também às expectativas desta sociedade. Um rei situado entre a preservação do poder para a dinastia, as reivindicações conflitivas da sociedade e a competição internacional.

O segundo viés faz menção à sua educação formal propriamente dita. Mesmo não sendo o primogênito, sua formação foi primorosa. Afinal, a possibilidade de "ser Rei", como, de fato foi, existia no horizonte. O domínio das leis e da língua francesa - base para a diplomacia europeia no século XVIII - esteve entre os principais quesitos de seu conhecimento. A história nacional, assim como a geografia mundial, também eram itens primordiais. Quanto às obras de literatura, algumas inclusive usadas com propósitos pedagógicos, a exemplo de François Fénelon, destacavam-se, principalmente as de Cícero, de Santo Ambrósio e de Erasmo. ${ }^{15}$

A governança de D. João (1792-1826) se desenrolou em um período de grandes turbulências políticas na Europa. Em meio aos acontecimentos da Revolução Francesa, com destaque

\footnotetext{
${ }^{14}$ Ibid., p. 30-8. Sobre a importância das Cortes nesse acordo, ver também esta obra. 15 PEDREIRA, Jorge; COSTA, Fernando Dores. D. João VI... Op. Cit., p. 42-43.
} 
para a ascensão e queda de Napoleão Bonaparte como Imperador da França (1804-1814) até o eclodir da Revolução do Porto (1820), as responsabilidades do monarca português eram cada vez maiores. Para ele, governar esteve intrinsecamente associado à salvaguarda da integridade política do Império Português, constantemente ameaçada ao longo de mais de duas décadas devido aos meandros de um intricado jogo político de dimensões interatlânticas. Não nos atearemos aqui em detalhar todos os pormenores desse complexo jogo político ${ }^{16}$; destacamos, todavia, dois pontos que consideramos centrais para o sucesso da sua missão como governante de uma monarquia absolutista na Europa: a difícil diplomacia do governo joanino com as nações do Velho e do Novo Mundo, e a busca pela constituição da soberania política, especialmente através da preponderância de projetos culturais voltados para a formação intelectual de seus súditos ilustrados. ${ }^{17}$

Para o alcance desses objetivos, D. João não mediu esforços. No Reino, o monarca deu continuidade à política cultural do governo mariano de fomento artístico e científico que, na prática, destinava especial atenção a quatro locus de saber voltados ao

\footnotetext{
16 Há uma ampla e importante bibliografia sobre a particular inserção de Portugal na diplomacia europeia entre os anos de 1780 a 1820 bem como sobre seu governo. Dentre algumas obras, citamos: ALEXANDRE, Vazlentim. Os sentidos do Império: questão nacional e questão colonial na Crise do Antigo Regime Português. Lisboa: Edições Afrontamento, 1993; ALVES, José Augusto dos Santos. A opinião pública em Portugal. (1788-1820). Lisboa: Universidade Autónoma, 2000; NEVES, Lúcia Bastos Pereira das. Napoleão Bonaparte: imaginário e política em Portugal (c.1808-1810). 1. Ed. São Paulo: Alameda, 2008; NOVAIS, Fernando. Portugal e Brasil na Crise do Antigo Sistema Colonial: séculos XVI-XVIII. São Paulo: Ed. Hucitec, 1974; LIMA, Oliveira. D. João VI no Brasil. 3. ed., Rio de Janeiro: Topbooks, 1996.

17 Para uma minuciosa análise acerca da diplomacia da Coroa portuguesa e depois luso-brasileira no período ver: MENEZES, Lená Medeiros. "Diplomacia joanina” In: NEVES, Lúcia Bastos Pereira das; VAINFAS, Ronaldo. Dicionário do Brasil Joanino... Op. Cit., p. 132-136.
} 
progresso da arte e da ciência: a Academia de Ciências de Lisboa, a Academia da Marinha, a Biblioteca Pública da Corte e o Teatro de São Carlos. Com o avanço das tropas napoleônicas em Lisboa, em novembro de 1807, e a mudança da sede da Coroa para o Brasil, os desígnios eram grandiosos. O projeto de implantação de um novo e poderoso Império deste lado do Atlântico era intrínseco à reestruturação do Rio de Janeiro como uma nova corte à semelhança de Lisboa. Afinal, a partir de 1808, a cidade tornava-se a residência da Dinastia de Bragança. ${ }^{18}$

Com o Rio de Janeiro como sede imperial, houve numerosas e significativas mudanças que passaram a ocorrer cotidianamente nos múltiplos universos da América Portuguesa. De acordo com Lilia M. Schwarcz, "o governo percebeu que precisava amenizar as tensões e agradar aos comerciantes lesados; para a preservação da monarquia, era preciso, também, atrair o apoio dos proprietários de terras, que sempre garantiram a produção agrícola para a exportação". Nessa análise, a autora ressalta a importância da estruturação e/ou criação das instituições reais. "Sem perder tempo, foi criada a Câmara de Registros das Mercês e, em 1810, a Corporação de Armas para organizar com eficiência o nascimento de uma nobreza e de uma heráldica em terras brasileiras" ${ }^{19}$ Foram criados a Real Academia da Marinha (1808), a Real Academia Militar (1810), o Teatro S. João (1813), a Real

\footnotetext{
18 Para a compreensão do projeto político de constituir um novo e poderoso Império no Brasil, ver o clássico trabalho de Maria de Lourdes Viana Lyra. A utopia do poderoso império. Portugal e Brasil: bastidores da política (17981822). Rio de Janeiro: Sette Letras, 1994. Já sobre a o Rio de Janeiro como nova corte, ver CARVALHO, Marieta Pinheiro de. Uma idéia de cidade ilustrada: as transformações urbanas no Rio de Janeiro de D. João VI (1808-1821). Rio de Janeiro: Odisséia, 2008.

19 SCHWARCZ, Lilia Mortiz. A longa viagem da biblioteca dos reis: do terremoto de Lisboa à Independência do Brasil, São Paulo: Cia das Letras, 2002. p. 255.
} 
Biblioteca (1814), o Jardim Botânico, e a Escola Médico-Cirúrgica (1813), instituições régias que proporcionaram o nascimento de uma nova dimensão do saber e da circulação das ideias, mesmo que essas estivessem alicerçadas por um aparato censório de extensa monta. ${ }^{20}$ "Tal novidade vinha inserida numa retórica normatizada do poder, da burocracia, cheia de etiquetas, de modo a arrefecer o impacto do acontecimento", analisa a historiadora Iara Lis Schiavinatto. ${ }^{21}$ A pesquisadora, salienta, ainda, que inserir a sociedade fluminense neste novo mundo e também em uma nova sociabilidade e prática discursiva mantinha a "tendência e tentativa de conservar o mundo tal qual era conhecido [...] com o próprio poder monárquico que mudava desde que se conservasse, [pois] buscava sua manutenção e continuidade".22

A estruturação e o funcionamento dessas instituições régias, no entanto, estavam estritamente vinculados a um projeto político administrativo do Império Português, cujas raízes remontam aos debates do século XVI. ${ }^{23}$ Para além de suscitar uma

\footnotetext{
${ }^{20}$ ALGRANTI, Leila Mezan. Livros de Devoção... Op. Cit. Ver especialmente capítulos 4 e 7, em que a historiadora analisa os procedimentos da censura joanina e da atuação dos censores (cap. 4) tanto quanto mostra os sentidos e significados de ser censor na sociedade joanina do Antigo Regime, no Rio de Janeiro. (cap. 7). ${ }^{21}$ SCHIAVINATTO, Iara Lis. "D. João VI no Rio de Janeiro: entre festas e representações. " In: Seminário Internacional D. João VI: um rei aclamado na América, Rio de Janeiro, Museu Histórico Nacional, 2000. p. 51.

22 Ibid., p. 51.

${ }^{23}$ Há uma bibliografia muito vasta sobre o período joanino que engloba os mais diferentes assuntos. Entre as obras clássicas citamos LIMA, Oliveira. D. João... Op. Cit. ALEXANDRE, Valentim. Os sentidos do Império: questão nacional e questão colonial na Crise do Antigo Regime Português, Edições Afrontamento, Lisboa, 1993; LYRA, Maria de Lourdes Viana. A utopia do poderoso império: Portugal e Brasil: bastidores da política (1798-1822), Rio de Janeiro, Sete Letras, 1994. Uma importante discussão historiográfica sobre a contribuição das obras referentes ao período joanino (1809-1821) pode ser encontrada em CASTRO. Giovanna Milanez de. O Palco da realeza: as transformações no espaço urbano e nas práticas sociais no Rio de Janeiro (1808-1821). Monografia. 2012.
} 
discussão sobre as bases de um projeto político, a transladação da monarquia no início do século XIX também objetivava atingir metas culturais mais amplas, as quais o historiador Afonso Carlos Marques dos Santos denominou de "projeto civilizatório", cuja principal finalidade era a ocidentalização, que comportava tanto "a importação de padrões civilizatórios europeus como uma tentativa de inserir esta parte do mundo no Ocidente", transformando o Rio de Janeiro em um autêntico laboratório de civilização sob a perspectiva de uma Europa possível. ${ }^{24}$

O fato central é que, ao longo de treze anos (1808-1821), essas novas instituições mudariam, definitivamente, a face da América Portuguesa. Para além da criação de um conjunto significativo de órgãos administrativos, militares e judiciários como a Intendência da Polícia, a Real Academia Militar, a Casa da Suplicação, os régios tribunais do Desembargo do Paço, a Mesa de Consciência e Ordens, o Conselho de Justiça, entre muitos outros, houve a implantação de instituições régias, as quais, mesmo vinculadas à manutenção da ordem política, possuíam um caráter científico e cultural que propalava uma nova perspectiva e realidade acerca da constituição do saber.

Em 13 de maio de 1808, por exemplo, D. João sacramentava a primeira oficina tipográfica, a Impressão Régia, que nascia como uma atividade administrativa necessária para o estabelecimento

p. 15-41. (Trabalho orientado pela Prof. ${ }^{a}$ Dr. ${ }^{a}$ Leila Mezan Algranti). Sobre o debate historiográfico recente e as principais obras que vieram a público em 2008 devido ao bicentenário da chegada da Corte portuguesa ao Brasil ver: LUSTOSA, Isabel. "O período joanino e a eficiência de alguns textos desbravadores". Disponível em: <http://www.casaruibarbosa.gov.br/dados/DOC/revistas/Escritos_2/ FCRB_Escritos_2_16_Isabel_Lustosa.pdf.> Acesso em: 20 mar. 2010.

24 SANTOS, Afonso Carlos Marques dos. "A fundação de uma Europa possível" In: Seminário Internacional D. João VI: um rei aclamado na América, Rio de Janeiro, Museu Histórico Nacional, 2000. p. 9-10. 
da Coroa deste lado do Atlântico, onde se manteve "sem interrupção com as mesmas praxes e rotinas" ${ }^{\prime 2}$, cujas funções eram imprimir exclusivamente todos os papéis ministeriais e diplomáticos do real serviço de todas as repartições, imprimir obras de particulares e produzir a Gazeta do Rio de Janeiro. ${ }^{26}$ Segundo Rubens Borba de Moraes, também foi uma excelente editora, publicando dezenas de livros de grande valor cultural que convergiam "de maneira extraordinária para o progresso dos espíritos" deste lado do Atlântico. ${ }^{27}$

O nascimento da Real Academia Militar, em 1810, aparecia aos contemporâneos como um espaço de saber no qual a produção e a troca de conhecimento científico de ponta foram indissociáveis de uma meta política mais ampla: a segurança dos domínios imperiais através da defesa do bem público de todo o corpo social, além da formação intelectual dos súditos ilustrados da Coroa. Em tempos de guerra contra Napoleão Bonaparte, era premente a preocupação com a formação de um exército, assim como de bons engenheiros.

Com a fundação do Teatro São João, em 1813, a sociedade da corte passava a ter acesso a um amplo universo de representação artística: peças teatrais, concertos musicais, enfim uma ampla gama de produções artísticas encenadas por artistas europeus acabava por englobar a sociedade fluminense, agora em estrito contato com valores "civilizados". Como bem observou Jurandir Malerba, havia uma continuidade entre o palco, o púlpito, a rua

\footnotetext{
${ }^{25}$ MORAES, Rubens Borba de. Livros e Bibliotecas no Brasil colonial. São Paulo: Livros Técnicos e Científicos, 1979. p. 100.

${ }^{26}$ CAMARGO, Ana Maria de Almeida; MORAES, Rubens Borba de. Bibliografia da Impressão Régia do Rio de Janeiro. São Paulo: Edusp 1993. p. XVIII.

27 Cf. MARTINS, Wilson. A palavra escrita: história do livro, da imprensa e da biblioteca. 2. ed. São Paulo: Editora Ática, 1996. p. 310.
} 
e o palácio real, uma vez que os mesmos símbolos circulavam por toda a cidade. "Servia o teatro para as mais variadas formas de reverência dos fluminenses de extração elevada e da corte [...] era ali o lugar privilegiado onde se reiteravam os vínculos de fidelidade dinástica", considerado também o centro da vida cortesã, explica o historiador. ${ }^{28}$

Já em 1814, era aberta ao público a Real Biblioteca, que, ao institucionalizar o acesso à leitura e a um amplo universo cultural vigente no Velho Mundo, também trazia consigo novas práticas e hábitos culturais. "As estantes, as papelarias, os mapas, os enfeites, as canetas de pena, os tinteiros, os livros falsos de guardas douradas, - mas também as ideias de sedição, as novas soluções e as tertúlias literopolíticas que tinham como alvo certo a própria ordem cultural" faziam agora parte de um universo que transcendia o rigor que a proibição das leis e a atuação dos censores poderiam prever. $^{29}$

Se, durante os anos das guerras napoleônicas (1808 a 1815), a Coroa praticou uma política real baseada em um rígido controle sobre a entrada de estrangeiros, sobretudo de origem francesa e espanhola, assim como na proibição da circulação de obras de origem francesa, consideradas "sediciosas"; também é fato que, com o fim do apogeu napoleônico, Portugal e França reataram as relações comercias. Neste novo cenário, houve uma visível

\footnotetext{
${ }^{28}$ MALERBA, Jurandir. A corte no exílio: Civilização e poder no Brasil ás às vésperas da Independência (1808-1821). Cia. das Letras, São Paulo, 2000. p. 98. O paralelo que se pode traçar entre as mudanças na estrutura da sociedade ocidental e o mundo da representação artística, sobretudo do teatro, desde a segunda metade do século XVIII, é riquíssima. Há um clássico de Diderot a esse respeito. Mais recentemente, voltam ao assunto Jürgen Habermas e Richard Sennett, com interpretações contraditórias.

29 SCHWARCZ, Lilia. A longa viagem... Op. Cit., p. 256-257. Para a atuação da censura e dos censores no período ver ALGRANTI, L. Livros de Devoção, Atos de Censura... Op. Cit.
} 
mudança de enfoque em relação tanto às notícias de origem francesa, que eram veiculadas na Gazeta do Rio de Janeiro, quanto em relação à política cultural da Coroa no universo luso-brasileiro. ${ }^{30}$ Como salienta a historiadora Lúcia Neves, a principal consequência desse processo é que a "influência francesa passou a ter um papel significativo nas relações culturais". ${ }^{1}$

Para além dessas instituições, em 1818, era fundado o Museu Real que, sob a direção do Frei José Batista da Costa Azevedo, franciscano e professor de botânica e zoologia da Real Academia Militar, tinha como objetivo estimular os estudos de botânica e zoologia no local. Mesmo não possuindo um rico acervo, foi "aberto com uma pequena coleção doada pelo próprio D. João e composta de peças de arte, gravuras, objetos de mineralogia, artefatos indígenas, animais empalhados e produtos naturais"32, também sendo concebido como um local onde se preservava a memória da nobreza portuguesa ao longo das gerações. ${ }^{33}$ Além dessas instituições de grande importância científica e cultural, vemos, ainda, o florescimento de outras iniciativas reais, como a fundação, em 1813, da primeira revista literária, O Patriota. Dirigida por Manuel Ferreira de Araújo Guimarães, homem de letras e ciência de notória expressão do Império Português, o periódico circulou até fins de 1814, sendo uma respeitável iniciativa da política cultural joanina.

\footnotetext{
${ }^{30}$ MEIRELLES, Juliana Gesuelli. Imprensa e poder na corte joanina: A Gazeta do Rio de Janeiro (1808-1821). Rio de Janeiro: Ed. Arquivo Nacional, 2008. p. 130.

31 NEVES, Maria Bastos P. "O privado e o público nas relações culturais do Brasil com França e Espanha no governo joanino”. In: Seminário Internacional D. João VI: um rei aclamado na América. Rio de Janeiro, Museu Histórico Nacional, 2000. p. 195. Em relação ao projeto da Missão Artística Francesa há controvérsias dentro da historiografia que serão devidamente enfocadas no capítulo 2 desta tese, intitulado: Teatro e cultura artística no mundo luso-brasileiro.

32 SCHWARCZ, Lilia. A longa viagem... Op. Cit., p. 256-257 (Grifo nosso).

${ }^{33}$ MALERBA, Jurandir. A corte no exílio:... Op. Cit., p. 165.
} 
Todos esses empreendimentos e transformações também apareciam no comportamento político e cultural da sociedade joanina que, desde a chegada da Corte, tinha acesso a periódicos, obras literárias, almanaques e folhinhas portuguesas que contribuíam para o fim da restrição das práticas de leitura nos espaços de intimidade pessoal ou, mais propriamente, familiares. ${ }^{34}$ De acordo com a historiadora Andréa Slemian, a prática de leitura de periódicos e a discussão das questões políticas em estalagens e bares passavam a ser atividades rotineiras, naturalizando-se, portanto, o exercício da crítica e, ao mesmo tempo, minando-se as bases da ordem instituída. "Era aí que a crise política se desdobrava na esfera do cotidiano, informando novas ideias e opiniões que coexistiam com aquelas predominantes da monarquia absolutista", conceitua a autora. ${ }^{35}$ Nesse sentido, compreendemos que essas transformações resultam de um processo histórico amplo, singular e complexo, cujas mudanças perpassaram os diversos âmbitos da vida no Império Português.

Entre as realidades vividas em Lisboa e no Rio de Janeiro, todavia, havia uma diferença fulcral: a escravidão. À época da chegada da Corte, em 1808, o Rio de Janeiro tinha em torno de 60.000 mil habitantes. No final do período joanino, em 1821, população havia crescido $32,2 \%$, sendo deste total, 43.139 homens livres e 36.182 escravos. ${ }^{36}$ Como nos mostra Manolo Florentino, por volta de 1808, 640 mil escravos foram embarcados para o Brasil. "Tratava-se do maior tráfico negreiro das Américas,

\footnotetext{
34 VILLALTA, Luiz Carlos. "O que se fala e o que se lê: língua, instrução e leitura”. In: SOUZA, Laura de Melo (Org.). Cotidiano e vida privada na América Portuguesa, História da vida privada no Brasil. São Paulo: Cia das Letras, 1997. p. 332-385.

35 SLEMIAN, ANDRÉA. O difícil aprendizado da política na Corte do Rio de Janeiro (1808-1824). Dissertação de Mestrado, USP, 2000. p. 88.

36 ALGRANTI, Leila Mezan. O feitor ausente. Estudo sobre a escravidão urbana no Rio de Janeiro (1808-1821). Petrópolis: Ed. Vozes, 1988. p. 29.
} 
desvelando a firme opção das elites luso-brasileiras de reprodução externa de sua principal mão-de-obra, na contramão do abolicionismo [que se iniciava na época]". ${ }^{37}$

Se a escolha das elites luso-brasileiras foi pela preservação do trabalho escravo, e, se a interiorização da metrópole, na acepção da historiadora Maria Odila da Silva Dias, era um processo irreversível, as consequências da mudança de status do Rio de Janeiro, invariavelmente, tinham um alto preço a ser pago: por mais que a nova Corte tenha se tornado, ao longo desses treze anos de residência real, uma urbe com fortes traços cosmopolitas, a escravidão urbana pelas ruas do Rio de Janeiro era uma realidade. Aos olhos da grande maioria dos viajantes europeus, que já viviam a força transformadora das relações de trabalho livre, advinda da Revolução Industrial no Velho Mundo, a manutenção da escravidão no Brasil era um abismo intransponível para a civilização e o progresso tão almejados pelo ideal iluminista.

Ao adentrarmos no Rio de Janeiro joanino no alvorecer d'Oitocentos, encontramos o que o historiador Sérgio Barra denominou de duas cidades sobrepostas: a Corte, em busca da civilização dos costumes à moda europeia; e a Cidade, vivida pela grande população de negros, libertos, mestiços, homens livres e homens pobres. $\mathrm{O}$ entrecruzamento de sujeitos históricos absolutamente tão diversos redesenhava, na nova Corte, cotidianamente, duas sociabilidades distintas. "Duas cidades que, apesar de divergentes em muitos pontos, não existiam isoladamente, que, por dividir o mesmo espaço apresentavam necessários pontos de

37 FLORENTINO, Manolo Garcia. “Escravidão”. In: NEVES, Guilherme Pereira das; NEVES, Lúcia Bastos Pereira das. “D. João VI”. In: NEVES, Lúcia Bastos Pereira das; VAINFAS, Ronaldo. Dicionário do Brasil Joanino... Op. Cit., p. 150. 38 BARRA, Sérgio. Entre a Corte e a Cidade: o Rio de Janeiro no tempo do rei (1808-1821). Rio de Janeiro: José Olympio Editora, 2008. p. 20-21. 
contato, trânsito e trocas culturais", conceitua Barra. ${ }^{39}$ A ciência desta importante transformação cultural provocada pelo contato cotidiano entre os "donos do poder" ${ }^{40}$ e a grande massa de escravos pelas ruas da capital nos coloca diante da política da Coroa para os cativos. Pelo Código Criminal do Império, que previa a permanência dos castigos corporais, defendia-se a punição física feita às portas bem abertas do espaço público, com a constante repressão policial maculada na figura do Intendente Geral da Polícia (Paulo Fernandes Viana). ${ }^{41}$

Apesar da centralidade da escravidão como problemática histórica para o Brasil Oitocentista, ressaltamos que nosso foco de análise neste estudo é voltado para a compreensão da política cultural de D. João em quatro diferentes locus de cultura sob uma perspectiva interatlântica. E para a constituição destes espaços de saber de profícua interlocução social, a monarquia bragantina, invariavelmente, excluiu essa grande e fundamental parcela da sociedade joanina. Mesmo assim, há ainda um longo caminho de investigação histórica para que compreendamos com maior clareza os interstícios das constantes trocas culturais entre mundos e sujeitos históricos tão díspares com convivências cotidianas tão próximas no espaço público no período joanino. Investigação tão importante, contudo, foge aos limites e propostas deste trabalho.

O objeto de investigação deste estudo nasceu da seguinte indagação: houve uma política cultural no período joanino? Em caso afirmativo, o que teria sido esta política cultural e como

\footnotetext{
${ }^{39}$ Ibid., p. 21.

40 Utilizamos aqui e famosa expressão cunhada pelo trabalho clássico do historiador Raymundo Faoro In: FAORO, Raymundo. Os donos do poder: formação do patronato politico brasileiro. 10. ed. 2 vols. São Paulo, SP: [s.n.]; [S.l.]: Globo: Publifolha, 2000.

41 ALGRANTI, Leila Mezan. O feitor ausente... Op. Cit., p. 37.
} 


\section{poderíamos compreendê-la. ${ }^{42}$ A maior dúvida recaía sobre a ação do Estado monárquico voltada para os espaços de cultura,}

42 Uma análise mais detida da historiografia luso-brasileira sobre as transformações da monarquia portuguesa na Idade Moderna aponta-nos a utilização recorrente do termo política cultural para a compreensão das ações governamentais no campo da cultura nos mais diversos espaços, tais como bibliotecas, museus, universidades, teatros, tipografias, academias científicas e literárias entre outros. Para os estudos portugueses, destacamos: DIAS, José Sebastião da Silva. A política cultural da época de D. João III. Coimbra: Instituto de Estudos Filosóficos, 1969. 2 vols; FERRAUD, Luís Almeida. "D. João V e a biblioteca real”. Revista da Universidade de Coimbra. N. ${ }^{\circ} X X X V I, 1991$. p. 415-437; CLUNY, Isabel; BARATA, Paulo. J. S. "A propósito de um documento da política cultural joanina”. In: Leituras. Revista da Biblioteca Nacional, Lisboa, S. 3. N. 3, p. 129-139, 1998; CURTO, Diogo Ramada. "Cerimônias públicas e academias no Brasil”. In: Cultura Imperial e Projetos Coloniais (séculos XV a XVIII). Campinas, SP: Editora da Unicamp, 2009. p. 419-442; SILVA, Maria Beatriz Nizza da. "A impressão Régia do Rio de Janeiro e a Cultura Científica" In: Revista Portuguesa de História do livro, Lisboa; Edições Távola Redonda, Ano XII, Vol. 23, p. 215-231, 2009. Para aqueles estudos que investigam a interseção entre o universo da polítca e da cultura sem, no entanto, utilizar-se do termo política cultural há uma enorme gama de autores que são analisados ao longo deste trabalho. Nesta nota, citamos apenas aqueles que consideramos referênciais teóricas para nossa investigação. ALGRANTI, Leila Mezan, Livros de Devoção... Op. Cit.; ARAÚJO, Ana Cristina, A Cultura das Luzes em Portugal. Temas e ProblemasI. Lisboa: Livros Horizonte, 2003; DIAS, Maria Odila da Silva, "Aspectos da Ilustração no Brasil". Revista do Instituto Histórico Geográfico e Brasileiro, Rio de Janeiro, vol. 278, 1968; HOLANDA, Sérgio Buarque de. Raízes do Brasil. 26. ed. São Paulo: Cia das Letras, 1995; MORAES, Rubens Borba de. Livros... Op. Cit.; SCHWARCZ, Lilia Mortiz. A longa... Op. Cit.; MEIRELLES, Juliana Gesuelli. Imprensa... Op. Cit.; MOREL, Marco. As transformações dos espaços públicos. Imprensa, Atores Políticos e Sociabilidades na Cidade Imperial (1820-1840). São Paulo: Editora Hucitec, 2005; LYRA, Maria de Lourdes Viana. A utopia... Op. Cit.; NEVES, Lúcia Maria Bastos P. "O privado e o público nas relações culturais do Brasil com França e Espanha no governo joanino", In Seminário Internacional D. João VI: um rei aclamado na América, Rio de Janeiro, Museu Histórico Nacional, 2000; SILVA, Ana Rosa Cloclet da. Inventando a Nação: intelectuais ilustrados e estadistas luso-brasileiros no crepúsculo do Antigo Regime Português: 1750-1822. São Paulo: HUCITEC, 2006; SCHIAVINATTO, Iara Lis Carvalho. Pátria Coroada: o Brasil como Corpo Político Autônomo 1780-1831. São Paulo: Ed. Unesp, 1999; VILLALTA, Luiz Carlos. "O que se fala... Op. Cit., p. 332-385; VILLALTA, Luiz Carlos. Usos do livro no mundo luso-brasileiro sob as luzes: reforma, censura e contestação. Belo Horizonte: Ed. Fino Traço, 2015; SILVA, Maria Beatriz Nizza da. A cultura luso-brasileira. Da reforma da Universidade à independência do Brasil. Lisboa: Estampa, 1999. 
ou seja, interrogávamo-nos de que maneira esta prática da Coroa havia ocorrido. Neste sentido, objetivamos a reflexão sobre a política do governo joanino voltada para quatro locus de cultura da sede do Império Português, seja Lisboa ou Rio de Janeiro. A escolha da investigação recaiu sobre a imprensa interatlântica, os Reais Teatros, as Reais Academias Militares e as Reais Bibliotecas Públicas da Corte, uma vez que esses espaços mantêm uma característica em comum: em graus díspares, todas essas instituições foram prioritariamente locus de produção e circulação de informação e saber, além de impulsionarem a discussão e a sociabilidade pública. Ademais, todos os espaços foram pensados, estruturados e vivenciados pela sociedade joanina, tendo o forte incentivo governamental pautado pelo diálogo com as luzes advindas da cultura da Ilustração.

A opção por esses quatro locus (e não outros) igualmente se justifica pelo nosso interesse em compreender suas particularidades culturais. Nosso desígnio, contudo, não era produzir quatro teses diferentes - uma para cada instituição de saber/cultura -, mas, antes, visualizar em que medida existia um elo entre esses espaços. Isto é, interessava-nos conhecê-los através da percepção das diferentes estratégias administrativas do governo joanino para cada um dessas instituições, em que pese (em um âmbito mais amplo) a política imperial ilustrada como mola mestra da sustentação do Império luso-brasileiro, mormente em um momento de grave crise política. Neste sentido, e devido à amplitude dos enfoques de pesquisa para cada um desses locus, optamos por circunscrever nossa discussão historiográfica para cada uma dessas instituições de cultura ao longo dos capítulos.

A imprensa interatlântica foi eleita como objeto de estudo por ser a grande novidade no Brasil no início do século XIX. Diferentemente da América Espanhola, que contava com tipografias 
e universidades desde o século XVI, a América Portuguesa fora privada por mais de três séculos de um contato mais amplo com a palavra impressa, fosse através da livre circulação de livros, fosse pela leitura de periódicos estrangeiros. Para além disso, a imprensa é um dos principais espaços de formação da opinião pública. No caso da imprensa oficial joanina, ainda podemos visualizar a constituição do discurso real dentro de um contexto histórico específico de crise política. Neste sentido, estudá-la como locus de saber nos permite também olhar para as relações culturais tecidas pelo governo joanino através da ação política e diplomática.

A análise dos Reais Teatros nos despertou interesse justamente por serem estes o espaço da arte, onde dramaturgos, atores e empresários teatrais desempenhavam suas funções em prol da criação artística através de peças de teatro, recitais etc. e, com isso, reiteravam os valores morais da sociedade de corte no espaço público. Ademais, não podemos nos esquecer de que o teatro era o espaço da pedagogia política da monarquia, onde a visibilidade da figura real ganhava uma magnitude ímpar no espaço público.

A Academia Militar foi escolhida por três razões: a primeira, por ser o maior espaço de ensino formal no Brasil; a segunda, pelo fato de o Império Português estar imerso em um contexto histórico de crise política e de guerra explícita contra a França napoleônica que colocava em cena a manutenção da integridade imperial; e a terceira, pela grande repercussão que a criação deste locus teve na imprensa periódica da época. Se, em 1812, o Correio Braziliense e O investigador Portuguez em Inglaterra travaram uma interessante polêmica acerca dos sentidos de se possuir uma Academia Militar na nova sede do poder político, ainda ao longo de todo o período joanino, a Gazeta do Rio de Janeiro destacou as notícias voltadas para o universo militar, independentemente de serem referentes à Real Academia Militar ou, mais amplamente, à importância do papel dos militares para o Império Português. 
Já quanto às Reais Bibliotecas, nossa preocupação esteve intimamente associada à compreensão do complexo mundo das letras. A primazia dava-se para a ação da Coroa voltada para as práticas de leitura dentro de um locus específico, cuja preocupação era a constituição de um importante acervo documental materializado nos livros. Por esse prisma, se o sentido da estruturação, vigência e manutenção de tal instituição em si nos despertou grandes curiosidades, também a atividade de seus principais agentes culturais (bibliotecários e ministros régios) nos aparecia como digna de estudo. Por outro lado, consideramos também a produção dos livros, a circulação das novas ideias e a visibilidade dos limites entre a censura e a crítica ao status quo.

O recorte temporal desse trabalho é a governança de D. João (1792-1821) nos dois lados do Atlântico, sendo o ponto de partida da nossa investigação o início de sua Regência de fato (1792) e o ponto final, o seu retorno a Lisboa (1821). Ademais, para melhor delimitarmos as especificidades de cada um desses espaços de cultura, partimos de um viés transatlântico. Exceto para a imprensa, em que tentamos delinear a natureza da política cultural a partir do discurso de periódicos financiados ou apoiados pela Coroa portuguesa (O Investigador Portuguez em Inglaterra, O Patriota, a Gazeta do Rio de Janeiro e Observador lusitano em Paris), os demais espaços foram enfocados a partir de um viés comparativo de análise: sob esse prisma, percebermos em que medida há semelhanças e singularidades entre os diferentes locus de cultura vigentes no Brasil (Reais Teatros, Real Academia Militar e Biblioteca Pública da Corte) e suas congêneres lisboetas. Por fazerem parte do mesmo Império, porém com as devidas singularidades, esses dois mundos que se entrecruzaram, afastaram-se e se complementaram ao longo da governança joanina no Brasil. 
Assim, o Capítulo primeiro deste trabalho investiga os possíveis sentidos discursivos da imprensa interatlântica joanina e o debate entre os principais jornais produzidos em Londres, O Correio Braziliense (1808-1822) e O Investigador Portuguez em Inglaterra (1811-1819), com especial atenção para a relação entre o monarca D. João e o jornalista Hipólito José da Costa. As demais produções periódicas financiadas ou apoiadas pela Coroa portuguesa como a Gazeta do Rio de Janeiro, O Patriota e O Observador lusitano em Paris também foram foco de nossa análise. Nesse sentido, repensamos o papel da própria imprensa como fonte e objeto de pesquisa para história da cultura, assim como tentamos evidenciar a importância da imprensa interatlântica como elo fundamental de sustentação da política e das ações culturais de D. João demonstradas também pelos bastidores da diplomacia portuguesa nos dois lados do Atlântico.

O segundo capítulo tem como tema a estruturação e vigência dos principais teatros régios nos dois lados do Atlântico, o Teatro de São Carlos, em Lisboa, o Teatro de São João, no Porto, e o Teatro de São João, no Rio de Janeiro. O foco de análise é a compreensão da importância do teatro como locus de cultura fundamental da política cultural joanina, concebido como uma prática espiritual não secularizada com intuito pedagógico e civilizador. Nesse sentido, discutimos a relação da vigência do espaço de cultura com a transmissão dos valores morais a serem difundidos na sociedade de Corte; fator indissociável da formação moral dos súditos ilustrados da monarquia luso-brasileira.

O capítulo terceiro tem como tema a estruturação e vigência dos principais locus de cultura científica no Império Português, com destaque para a Real Academia de Ciências de Lisboa e a Real Academia Militar do Rio de Janeiro. Precisamente, a discussão gira em torno da capitalidade imperial do governo 
português, sobretudo dentro de um contexto histórico beligerante europeu, no qual o Reino sofreu três invasões do exército de Napoleão Bonaparte, além de circunscrevê-lo como um espaço primordial de educação formal dos súditos ilustrados da monarquia luso-brasileira.

O quarto e último capítulo da pesquisa tem como tema a compreensão da importância das Reais Bibliotecas, com destaque para a Biblioteca Pública de Lisboa e a Biblioteca Pública do Rio de Janeiro. A política cultural joanina na transladação, estruturação e vigência da Biblioteca de Lisboa para o Brasil, assim como a figura do bibliotecário como agente fundamental no processo de secularização do saber são os focos de nossa discussão. Nesse sentido, discutimos em que medida era fundamental para a Coroa portuguesa possuir uma Real Biblioteca na sede da sua residência, reiterando a produção de novas práticas culturais no universo da cultura letrada, que é indissociável da formação intelectual dos súditos ilustrados.

Esta investigação não esgota as múltiplas possibilidades de estudo acerca dos loci de cultura/saber ou mesmo das ações governamentais isoladas do Estado monárquico luso-brasileiro no universo da cultura. Pelo contrário, nosso estudo é apenas uma tentativa inicial em busca da compreensão da complexidade intrínseca à vigência dessas ações culturais em um âmbito oficial que perpassaram o governo joanino ao longo de pouco menos de três décadas (1792-1821). Talvez, a nossa busca quase obcecada em descortinar o que possa ter sido a política cultural de D. João seja mais uma leitura possível acerca de um período histórico já clássico dentro da historiografia luso-brasileira. 


\section{A IMPRENSA COMO LOCUS DE SABER}

\subsection{Preâmbulo}

A nação que não possui indivíduos capazes de arriscar-se pelo bem da Pátria, está conrompida [sic], e, portanto, arruinada; porque a nação viciosa, e sem patriotismo, há de por força ser escrava e miserável. O melhor dos soberanos, se tem a infelicidade de governar uma nação de aduladores, não poderá fazer florentes os seus Estados, nem conferir aos súditos aquela liberdade racionável, que todos os homens têm direito de exercitar, mas que a sábia Providência não deixa gozar senão às nações que praticam as virtudes civícas, as quais exornam o Cidadão, assim como as virtudes morais condecoram o pai de família.

Hipólito da Costa.

Publicada no Correio Braziliense em março de 1810, a reflexão acima era dirigida ao Partido Francês no Brasil. E a mensagem do redator era clara: a bajulação política daqueles que "não 
olham à qualidade dos meios que empregam com tanto que obtenham os seus fins" era nefasta e poderia arruinar o progresso cívico e moral da nação portuguesa. ${ }^{1}$ Seu dever diante de tal perigo era iluminar os espíritos patrióticos através do incentivo ao exercício crítico da razão. A imprensa livre das amarras da censura era o espaço por excelência para a prática desse ofício - o esclarecimento. Como cidadão da nação portuguesa, exercia-o independente do quilate político de seus interlocutores: chefes de Estado, políticos poderosos, homens comuns. Todos estavam sob a mira de Hipólito da Costa. ${ }^{2}$

Jornalista destemido, Hipólito fez do Correio Braziliense o baluarte da liberdade de pensamento da imprensa luso-brasileira no raiar do século XIX. Em um momento de grande tensão política, devido aos ecos e consequências da Revolução Francesa no Velho e no Novo Mundo, a redefinição do papel da imprensa era crucial. ${ }^{3} \mathrm{O}$ florescimeto da tipografia no Brasil e a circulação transatlântica da Gazeta do Rio de Janeiro, a partir de 1808, quase simultaneamente ao nascimento do Correio Braziliense, em Londres, mostra-nos que a imprensa se tornava um poderoso instrumento de poder político no Império Português: a disputa pelos leitores, pela conquista do lugar de primazia na formação (e condução) da opinião pública - através de linhas editoriais bem demarcadas - foi uma tônica muito marcante no período joanino,

1 CB. Vol. IV, p. 314.

2 Sobre as controvérsias do exercício de Hipólito da Costa como homem de imprensa, ver. MUNARO, Luís. "A unidade do Reino luso-brasileiro: uma discussão jornalística em Londres." VIII Encontro Nacional de História da Mídia. 2011. (p. 1-15). Disponível em: <http://paginas.ufrgs.br/alcar/encontros-nacionais-1/8o-encontro-2011-1/artigos/>. Acesso em: 20 jul. 2011.

3 Para informações mais precisas da política anti-francesa em Portugal, ver ALVES, José Augusto dos Santos. "A Revolução Francesa e o seu eco em Portugal nos arquivos da Intendência Geral da Polícia em finais do século XVIII e princípios do século XIX”. In: Revista de História e Teoria das Ideias, Lisboa, Vol. XVIII, 2004. 
sobretudo entre os anos de 1808 e 1821. Deste lado do Atlântico, a Gazeta do Rio de Janeiro e o Patriota foram, ao longo desse período, os principais meios de comunicação impressa da realeza com o Velho Mundo.

$\mathrm{Na}$ Europa, mais especificamente na capital britânica, a Coroa portuguesa fez d'O Investigador Portuguez em Inglaterra o seu jornal por excelência no combate às ideias de Hipólito da Costa. Sob a égide da liberdade de imprensa, esses dois periódicos debateriam questões centrais para a manutenção e sobrevivência da monarquia lusitana diante da crise do Antigo Regime: da defesa dos ideais políticos liberais à importância da educação pública, o novo conceito de progresso, advindo das Luzes, era o foco a ser pensado. Segundo o historiador Reinhart Koselleck, criado no final do século XVIII,

O conceito de progresso único e universal nutria-se de muitas novas experiências individuais de progressos setoriais, que interferiam com profundidade cada vez maior na vida quotidiana que antes não existiam [...] O progresso reunia, pois, experiências e expectativas a serem afetadas por um coeficiente de variação temporal. Um grupo, um país, uma classe social tinham consciência de estar à frente dos outros, ou então procuravam alcançar os outros ou ultrapassá-los. Aqueles dotados de uma superioridade técnica olhavam de cima para baixo o grau de desenvolvimento dos outros povos, e quem possuísse um nível superior de civilização julgava-se no direito de dirigir esses povos. ${ }^{4}$

Dentro dessa nova concepção de progresso, a imprensa luso-brasileira "na emigração"5 também ganhou novos atores:

\footnotetext{
4 KOSELLECK, Reinhart. Futuro Passado: contribuição a semântica dos tempos históricos. Rio de Janeiro: Ed. PUC-Rio: Contraponto, 2006. p. 317 (Grifo nosso). ${ }^{5}$ Essa expressão faz referência ao título do livro do historiador João Pedro Rosa Ferreira sobre o Correio Braziliense. FERREIRA, João Pedro Rosa. O Jornalismo na emigração. Ideologia e Política no Correio Braziliense. Lisboa: CLC/UNL, 1992.
} 
em Londres, no ano de 1814, nascia O Portuguez, de Bernardo da Rocha Loureiro, e em 1821 O Campeão Portuguez, de José Liberato de Carvalho. Em Paris, surgia em 1815 o Observador Lusitano em Paris, de Francisco Solano Constâncio, também redator dos Annaes das Sciências, das Artes e das Letras, publicação que circulou entre 1818 e 1822. Os três jornalistas, assim como Hipólito da Costa, compunham a seleta órbita da elite ilustrada luso-brasileira.

Neste capítulo, o nosso foco está na compreensão da política cultural do governo joanino, tendo a imprensa periódica como um de seus pilares fundamentais de sustentação da monarquia portuguesa. A complexidade de tal empreitada será discutida, sobretudo, pela importância que o desenvolvimento da arte e da ciência na época tinha na luta pela manutenção da independência política trilhada nas sendas dos que as concebiam como progresso.

Sob esse prisma, abordaremos a complexa produção discursiva dos diferentes atores históricos envolvidos na produção e circulação da palavra impressa, tendo em vista que, como a Europa, especificamente Portugal vivia tempos difíceis: a guerra contra Napoleão, a restauração do poder absoluto do rei no Velho Mundo, as rebeliões contra o Antigo Regime nos dois lados do Atlântico, a Revolução do Porto e as consequências advindas desse processo.

\subsection{Hipólito José da Costa na política cultural joanina}

Em junho de 1808, o jornalista Hipólito José da Costa lançava O Correio Braziliense, um dos jornais mais combativos do período joanino. De sólida formação intelectual, "Mr. da Costa", 
como era conhecido nos círculos elitizados de Londres, teve uma trajetória muito peculiar. Nascido na Colônia de Sacramento (atual Uruguai), em 1774, Hipólito era filho do alferes de ordenanças Félix da Costa Furtado de Mendonça, um rico proprietário de terras. ${ }^{6} \mathrm{O}$ contato com as leis deu-se provavelmente na adolescência, nos primeiros anos de formação, através de lições ministradas por seu tio - o padre Pedro Pereira Fernandes de Mesquita - doutor em Cânones.

Com efeito, segundo frei Manoel Veloso [...], o clérigo teria desempenhado um papel marcante na formação do jornalista não só pela instrução clássica e humanista que ele ministrou, como também pela forma como o sensibilizou para os estudos científico-naturalistas, incutindo nele uma área de interesse que o acompanharia ao longo de toda a sua vida. ${ }^{7}$

Desde a reforma da Universidade de Coimbra em 1772, a formação dos bacharéis em Leis ganhara uma nova direção. Os cursos iniciavam-se por um conjunto de cadeiras propedêuticas, em que avultavam matérias históricas e filosóficas. Segundo os estatutos, nenhum direito podia ser bem entendido sem um claro conhecimento prévio, tanto do Direito Natural, como da História Civil das Nações e das Leis para elas estabelecidas. ${ }^{8}$ Em 1791, ocorria a reforma da Faculdade de Filosofia, que incorporara

\footnotetext{
6 Para maiores informações sobre a vida familiar de Hipólito, ver DOURADO, Mecenas. Hipólito da Costa e o Correio Braziliense. Rio de Janeiro: Biblioteca do Exército, v. 234, t.1. p. 15-29.

7 PEDROSA, Alcino. “Introdução”. In: COSTA, Hipólito José da. Diário da minha viagem a Filadélfia (1798-1799). Lisboa: ICS. Imprensa de Ciências Sociais, 2007. p. 14-15 (Grifo nosso).

8 Informações sobre a Reforma Pombalina até o final do século XIX. Disponível em: <http://www.uc.pt/ciuc/fduc/faculdade/a_nossa_historia/historia_3>. Acesso em: 23 nov. 2010.
} 
algumas disciplinas científicas ao currículo. No ano seguinte, o governo português decretou uma carta régia que julgava o aproveitamento técnico e intelectual dos que cursavam a universidade. A lei tinha por objetivo conhecer "sobre as qualidades de prudência, probidade e desinteresse de cada um dos bacharéis, e mais circunstâncias que devem ter as pessoas que se destinam ao serviço do Estado".

Foi precisamente no curso de Filosofia que Hipólito ingressou em 1792, antes de seguir o curso de Direito, a partir de 1793. Portanto, a formação intelectual do futuro redator do Correio Braziliense era diferenciada: durante o ano em que frequentou a cadeira da Faculdade de Filosofia, teve aulas de Botânica, Agricultura, Zoologia, Mineralogia, Física, Química e Metalúrgia. Em Botânica, foi discípulo de Félix de Avelar Brotero, mestre muito admirado "porque humanizava os seus sólidos conhecimentos científicos com o amor às ideias liberais". ${ }^{10}$ Esta postura política de viés liberal obrigaria o cientista a exilar-se em Paris em 1778, onde viveu até $1790 .^{11}$

${ }_{9}$ DOURADO, Mecenas. Hipólito... Op. Cit., p. 34.

${ }^{10}$ Ibid., Cap. VI, t.1, p. 45.

${ }^{11}$ Doutor em medicina pela Universidade de Reims, Félix de Avelar Brotero (1744-1828) foi lente da cadeira de Botânica e Agricultura na Universidade de Coimbra e diretor do Museu Real e Jardim Botânico do Paço da Ajuda. Sócio da Academia Real das Ciências de Lisboa; da Academia de História Natural e Filomática de Paris; da Fisiográfica de Lunden na Suécia; da de História Natural de Rostock, e da Academia Cesarea de Bona na Alemanha, etc. Na Inglaterra, foi membro da Sociedade de Horticultura de Londres, e da Lineana de História Natural. Em meio às primeiras convulsões políticas da Revolução Francesa, deixou Paris e retornou à Lisboa em 1790, na companhia de D. Francisco de Meneses. Voltava a Portugal com grande reputação de sábio: foi logo nomeado lente de Botânica e Agricultura na Universidade de Coimbra, pelo decreto de 25 de Fevereiro de 1791. Na capital francesa, publicou a obra que o deixaria célebre na Europa, o Compendio de Botânica ou noções elementares desta ciência, segundo os melhores escritores modernos, expostos na língua portuguesa, de 1788. Nas primeiras preleções, Brotero foi ouvido com grande entusiasmo tanto por 
A atenção e zelo que Hipólito despendeu para os mestres e os estudos o distinguiam dos demais estudantes da universidade aos olhos dos ministros reais, sobretudo D. Rodrigo de Souza Coutinho, que já em $1798^{12} \mathrm{o}$ incumbia de uma missão muito especial nos Estados Unidos: enviava-o "com a finalidade de estudar os progressos verificados neste país no campo das artes plásticas, da agricultura e das manufaturas". Nesse momento, D. Rodrigo ocupava o cargo de Ministro de Estado da Marinha e Domínios Ultramarinos (1796-1801), época em que publicou a obra Sobre os melhoramentos dos domínios de S. Majestade na América (1797), que já delineava as linhas de seu programa de reformas ilustradas. Como assevera o historiador Guilherme Pereira das Neves, esse projeto pretendia

[...] reforçar a unidade do império como um todo, por meio da concepção de um império luso-brasileiro, cuja ideia deveria ser inculcada nos portugueses das quatro partes do mundo, graças a uma elite de talentos, através de mecanismos modernos como a escola, e de outros nem tanto, como a Igreja. ${ }^{13}$

discípulos quanto por muitos doutores e mestres de outras faculdades, atraídos pelo vasto saber, clareza e amenidade de tão hábil professor de Botânica. Iniciou a primeira Escola Prática de Botânica, organizando o jardim com uma classificação científica, e enriquecendo-o com os exemplares indispensáveis para o estudo. A sua atuação na direção do Jardim Botânico da Ajuda será tema detalhada ao longo do capítulo. BROTERO, Félix de Avelar. In: Dicionário Histórico PORTUGAL. Disponível em: <http://www.arqnet.pt/dicionario/brotero.html>. Acesso em: 23 nov. 2010.

12 Neste ano, Hipólito se formava em Leis pela Universidade de Coimbra com importante destaque acadêmico.

13 NEVES, Guilherme Pereira Das. "Rodrigo de Souza Coutinho, conde de Linhares”. In: NEVES, Lúcia Bastos Pereira das; VAINFAS, Ronaldo. Dicionário do Brasil Joanino. Op. Cit., p. 399 (Grifo nosso). Para uma análise mais detalhada sobre o projeto reformista de D. Rodrigo de Souza Coutinho, ver: LYRA, Maria de Lourdes Viana. A utopia... Op. Cit., p. 61-106. ; SILVA, Andrée Mansuy-Diniz da. Portrait d'un homme d'État: D. Rodrigo de Souza Coutinho, Comte de Linhares, 1755 - 1812. Lisboa: Fundação Calouste Gulbenkian, 2006. p. 63-126. 
Hipólito da Costa era um dos destaques promissores dessa elite de talentos; razão pela qual Souza Coutinho também lhe destinava um encargo secreto de espionagem econômica, relacionado à recolha do inseto e planta da cochonilha, criados no México pelos espanhóis e que mantinham um alto valor para a indústria têxtil. ${ }^{14}$ Em carta enviada ao ministro real, Hipólito explicava detalhadamente as suas dificuldades na obtenção e conservação da cochonilha, que deveria ser de muita utilidade para o desenvolvimento econômico do Brasil.

[...] há grandes obstáculos para obter a semente, porque não havendo daqui comunicação com o México, é necessário passar a Havana para me poder transitar a Vera Cruz. A primeira dificuldade é poder exportar de Vera Cruz para Havana a planta e inseto sem que seja percebido, porque tal exportação é proibida debaixo de grandes penas.

A questão da diferença climática entre o Brasil e os Estados Unidos era outro viés relevante no transporte da semente. "O único meio que lembro para vencer esta dificuldade será esperar um navio que vá dos Estados Unidos com escala para o Brasil, e fazer passar nele a planta, no caso de se poder obter de Havana"15, informava o enviado. Para além desta obrigação econômica, a breve temporada nos Estados Unidos lhe deixaria uma marca fundamental: a iniciação na Maçonaria, na Filadélfia, que acabaria por encerrar, em 1805, as relações amistosas e de proteção que tivera desde então com Souza Coutinho e o governo português. Sua iniciação na Maçonaria foi justificada pelo fato de a associação ser um espaço de circulação de ideias com debates intelectuais profícuos para o homem desenvolver e aprimorar

${ }^{14}$ PEDROSA, Alcino. "Introdução”... Op. Cit., p. 17.

15 COSTA, Hipólito José da. Diário... Op. Cit., p. 151-152 (Grifo nosso). 
o espírito público através da virtude. “[...] Por todos os homens que, naquele País [Estados Unidos], conheci notáveis, em ciência e representação civil: este contraste foi o poderoso motivo, que excitou a minha curiosidade e me fez solicitar a admissão a esta Ordem", dizia Hipólito, ao exaltar perante os inquisidores lusitanos o comportamento retrógrado das autoridadades portuguesas, que perseguiam homens intitulados francomaçons "talvez sem que o fossem e que a voz pública afirmava", tratando-os com um "rigor indesculpável". 16

A partir desta época, sua permanência em Londres estaria atrelada à profunda relação de amizade que travara com o Duque de Sussex, filho do rei Jorge III da Inglaterra, quando este vivera em Portugal, entre 1801 e $1805 .{ }^{17}$ Destarte, foi sob a proteção de Sussex que Hipólito garantiu a "imunidade [necessária] contra as tentativas da Coroa Portuguesa de extraditá-lo" 18 por conta das suas influências maçônicas. Como assevera o historiador Alexandre Mansur Barata, desde o final do século XVIII, a repressão da Coroa portuguesa aos maçons foi "aos poucos deixando de ser tratada apenas como um crime contra a fé católica e, portanto, sob a alçada precípua do Santo Ofício, para ser tratada como um crime político, uma ameaça ao Estado absoluto." ${ }^{19}$ Ainda segundo

\footnotetext{
16 MENDONÇA, Hipólito José da Costa Pereira F. de. Narrativa da Perseguição de Hippolyto Joseph da Costa Pereira Furtado de Mendonça, natural da Colonia do Sacramento, no Rio da Prata. Preso e processado em Lisboa pelo presente crime de Framaçon ou Pedreiro Livre. Londres: W. Lewis, 1811. v. 1, p. 22. Sobre a posição de Hipólito da Costa dentro da hierarquia maçônica na Inglaterra, ver DOURADO, Mecenas. Hipólito... Op. Cit., Cap. VIII, t.1, p. 119-120.

17 Sobre o drama pessoal do Príncipe de Gales (Duque de Sussex) vivido em Portugal, ver DOURADO, Mecenas. Hipólito... Op. Cit., Cap. VII, t.1, p. 101-110.

18 LUSTOSA, Isabel. "A pátria de Hipólito" In: COSTA, Hipólito José da. Correio Braziliense ou Armazém Literário. São Paulo: SP: Imprensa Oficial do Estado; Brasília, DF: Correio Braziliense, 2001, p. XLIX.

19 BARATA, Alexandre Mansur. Maçonaria, Sociabilidade Ilustrada e Independência do Brasil (1790-1822). São Paulo-Juiz de Fora: Annablume-EDUFJF-
} 
Barata, a maçonaria se consolidava no mundo luso-brasileiro como um instrumento político muito sedutor, já que seu discurso "enfatizava a imagem de uma sociedade que se estruturava a partir da ideia de igualdade, onde reis e súditos dividiam o mesmo espaço e cumpriam as mesmas obrigações, comprometendo a se amarem, a se ajudarem e a se respeitarem". ${ }^{20}$ Em contrapartida, a ação política e administrativa da monarquia também construía no interior da sociedade "uma imagem de maçonaria identificada com o complô, com a maldade, com a sedição". ${ }^{21} \mathrm{Na}$ prática, portanto, a Inquisição - como tribunal eclesiástico e da Coroa -, perseguia os maçons por considerá-los ao mesmo tempo "maus católicos e maus vassalos". ${ }^{22}$

Na capital inglesa, Hipólito da Costa não só foi nomeado o "secretário para assuntos estrangeiros da Grande Loja”, como ainda escreveria o Correio Braziliense ou Armazém Literário (1808 - 1822), considerado por muitos historiadores o primeiro jornal brasileiro independente. ${ }^{23} \mathrm{O}$ fato é que a proximidade com um

-FAPESP, 2006. p. 65-70, (Grifo nosso). No item "A inserção da sociabilidade maçônica na América Portuguesa" (p. 53-91), o autor mostra os pontos centrais do desenvolvimento da Maçonaria em Portugal (Lisboa, Coimbra, Madeira), assim como casos específicos ocorridos no Brasil, no período. Um bom exemplo é o do carioca Antonio Morais Silva, que sofreu as consequências da denúncia de Francisco Cândido Chaves à Mesa do Tribunal do Santo Ofício, em 1799, por ser considerado maçom.

${ }^{20}$ Ibid., p. 110.

${ }^{21}$ Ibid., p. 148.

22 Ibid., p. 154. “... a principal preocupação [dos inquisidores] era perceber até que ponto o pertencimento à maçonaria significava a adoção de um afrontamento aos dogmas católicos e colocava em perigo o poder do rei." (Ibid., p. 166.).

23 ARAÚJO, Paulo Cabral. "Construção da Memória” In: Correio Braziliense. Vol. I, p. xix. Sobre os diversos olhares acerca da figura de Hipólito e do Correio Braziliense, ver os artigos de Barbosa Lima Sobrinho, José Mindlin, Sérgio Kobayashi, Alberto Dines e Isabel Lustosa, publicados neste mesmo volume, p. ix a liv. Para a compreensão do nascimento e desenvolvimento da maçonaria em Londres durante o século XVIII, ver BARATA, Alexandre Mansur. Maçonaria... 
membro da família real britânica, também maçom, garantia-lhe "desfrutar na Inglaterra certo prestígio social e comodidades materiais, difíceis, senão quase impossíveis, sem ela, para quem não possuía grandes haveres". ${ }^{2}$

Esta situação particularizada do jornalista teve importantes contornos políticos no mundo da imprensa interatlântica, conforme veremos mais adiante. As negociações e a tentativa de controle da pena de Hipólito por parte da Coroa foram atividades constantes ao longo dos quatorze anos de vigência do Correio Braziliense. ${ }^{25}$ A estreita ligação com a maçonaria e as críticas ao governo português e à política internacional, fossem contundentes ou não, justificavam esta postura real. Porém, o que nos interessa mostrar é que a Coroa tentava amenizar a influência do jornalista, porque conhecia o potencial intelectual de Hipólito e o provável alcance das suas reflexões na formação moral e,

Op. Cit., p. 22-26. O pesquisador José Carlos de Oliveira também faz uma interessante discussão historiográfica sobre a importância do Correio Braziliense para a História da Imprensa no Brasil no seu artigo. Cf. OLIVEIRA, José Carlos. "Os periódicos portugueses de Inglaterra e a Cultura Científica Brasileira (18081821)". Revista da SBHC, n.19, 1998, p. 31-62.

${ }^{24}$ DOURADO, Mecenas. Hipólito... Op. Cit., Cap. VII, t.1, p. 108-109. Segundo Mansur, o auxílio mútuo era outro fator que impulsionavam as pessoas a se iniciarem na maçonaria. "Outra motivação muito citada era que o pertencimento à maçonaria facultava ao iniciado uma ampla rede de auxílios mútuos. Num tempo em que os meios de comunicação eram precários, de guerras, de diferenças religiosas, onde os deslocamentos, tanto por mar quanto por terra, eram demorados e inseguros, pertencer a uma sociedade que apontava para o estabelecimento de uma rede de proteção era algo extremamente sedutor", afirma Mansur. Ibid., p. 111.

${ }^{25}$ A circulação d' O Correio foi proibida pela Coroa em três momentos diferentes - em 1810, 1812 e 1817- porém sem grandes efeitos, uma vez que tanto o Brasil quanto Portugal recebiam o jornal pelos circuitos clandestinos de informação. PAULA, Sérgio Goes de. "Hipólito José da Costa e o Correio Braziliense ou Armazém Literário". In: PAULA, Sérgio Goes de. (Org.). Hipólito José da Costa. São Paulo: Ed. 34, 2001. p. 22. 
consequentemente, educacional de seus súditos. Muitas das propostas e análises do redator do Correio entravam em choque com a concepção da monarquia portuguesa do que seria um vassalo fiel.

$\mathrm{Na}$ sociedade do Antigo Regime, a civilidade era o atributo por excelência de um súdito exemplar. Não por acaso, o ato de ser civil era pedagogicamente ensinado para os jovens da sociedade joanina através de obras de ficção e não-ficção de caráter moral, ou pela força da tradição aristocrática portuguesa. ${ }^{26} \mathrm{Como}$ bem definia a obra Elementos da Civilidade e da decência, para instrução da mocidade de ambos os sexos,

Não é a verdadeira civilidade outra coisa senão $a$ prática das regras da decência, ou a ciência do bem regrar os discursos, e ações na vida civil. Esta ciência não é uma virtude adventícia, nem simples dom da natureza, mas uma ciência adquirida, e como definem os antigos, uma ciência que ensina e põe no seu devido lugar o que temos de fazer, ou dizer. ${ }^{27}$

No capítulo XV, "Da Importunação", o autor definia as características do homem inoportuno, considerado incivil. Como ciência a ser "adquirida" social e moralmente, a incivilidade era

${ }^{26}$ Para conhecer a diversidade das obras de ficção produzidas pela Impressão Régia no período joanino e seu caráter moralizador, ver: SOUZA, Simone Cristina Mendonça de. Primeiras impressões: romances publicados pela Impressão Régia do Rio de Janeiro (1808-1822). Tese de doutorado. IEL. Unicamp. 2007. Em relação às leituras consideradas libertinas e sua relação com a maçonaria, ver: VILLALTA, Luiz Carlos. "Libertinagens e livros libertinos no mundo luso-brasileiro". In: ALGRANTI, Leila Mezan, MEGIANI, Ana Paula Torres (Org.). O Império por escrito: formas da transmissão da cultura letrada no mundo ibérico (Sécs. XVI-XIX). São Paulo: Ed. Alameda, 2009. p. 523-563.

27 "Discurso Preliminar" In: Elementos da Civilidade e da decência, para instrução da mocidade de ambos os sexos: traduzidos do francês em vulgar. Lisboa: Tipografia Rollandiana, 1801, s/n. Com Licença do Desembargo do Paço (Grifos do original). 
considerada o maior dos pecados de um vassalo leal, já que este era um erro voluntário que não merecia desculpas. O inoportuno era insolente e petulante, sendo a insolência sinal de desprezo e ofensa que aliena o espírito; assim como a petulância, sinônimo de insubordinação e desrespeito ${ }^{28}$, não só com a figura real, mas, sobretudo, com o status quo. Por esse prisma, vemos que o desenvolvimento moral do súdito esclarecido estava circunscrito à esfera da responsabilidade do Estado. Isto é, para manter a integridade política do Império Português nos dois lados do Atlântico, o "esclarecimento" de seus súditos - que deveriam ser úteis ao governo - era uma prerrogativa fundamental. Propositadamente, a fundação do Seminário de Olinda (1796) estava sob a direção do bispo Azeredo Coutinho, um dos homens mais destacados da Colônia. Como já demonstrou a historiadora Maria de Lourdes Viana Lyra, a leitura do estatuto da instituição coloca em evidência a faceta deste órgão como um locus de ampla educação dos homens que comporiam o quadro administrativo do Império, um viés de destaque na prática política do reformismo ilustrado português. Nas palavras da autora,

O objetivo central da proposta [do Seminário era]: "criar e estabelecer na cidade de Olinda um Colégio para se instruir a mocidade", no estudo das ciências e das artes, com o devido alerta para que fossem transmitidas somente "aquelas que são necessárias" à formação dos agentes integrados na execução do projeto político implícito no programa reformista, ou seja, a formação de uma nação atlântica representada pelo novo império. ${ }^{29}$

\footnotetext{
${ }^{28}$ Elementos da civilidade e da decência, para instrução da mocidade de ambos os sexos: traduzidos do francês em vulgar. Lisboa: Tipografia Rollandiana, 1801. p. 118-119.

29 LYRA, Maria de Lourdes Viana. A utopia... Op. Cit., p. 89 (Grifos do original). Para informações mais aprofundadas sobre a carreira e atuação de Azeredo Coutinho no Seminário de Olinda, ver a mesma obra, p. 88-96.
} 
Portanto, a grade curricular do espaço tal como as leituras indicadas eram itens de relevância, incluindo-se aí o já citado Elementos da civilidade e da decência. ${ }^{30} \mathrm{O}$ destaque também se dá para a segunda parte da obra, intitulada "Arte de Agradar na Conversação". Neste capítulo, o autor ressaltava a atenção que o homem civil deveria ter no uso das palavras nas contendas e debates, e na narração de histórias, feitos e novidades. Mesmo referindo-se à oralidade, tais regras também podiam ser estendidas para a palavra escrita. A finalidade deste aprendizado - a ciência da civilidade -, era tão valorizada na sociedade de Corte que, já em 1809, encontramos na Gazeta do Rio de Janeiro um anúncio sobre o início de aulas de Gramática Portuguesa e Latina, ministradas por um professor recém-chegado de Lisboa: suas aulas aconteciam na freguesia de Santa Rita no Beco dos Quartéis, n. 5, e tinham como foco o ensino da ampla moral aristocrárica. O professor se comprometia a

Ensina[r] com perfeição possível a Gramática de Língua Portuguesa, com a sua Ortografia; e Escrituração debaixo de um Caráter de letra, o mais perfeito: Ciência de Contar, debaixo de todos os preceitos Matemáticos; Gramática Latina, Filosofia racional, e moral, em diferentes horas do dia: também as tratará em certos dias de Política e Civilidade Cristã: desde às7 horas da noite por diante, estará a Aula aberta, só propriamente para Caixeiros, que, em razão das suas ocupações, não poderão concorrer de dia. O Professor terá muita satisfação e honra em que os Pais de Família entrem bem na indagação do sistema, porque o

\footnotetext{
${ }^{30}$ Esta obra compunha a coleção de livros do servidor público da Coroa Jerônimo da Silva Guimarães em Sabará (MG) no início do século XIX. FONSECA, Thais Nivia de Lima e. "Portugueses em Minas Gerais no Século XVIII: cultura e escrita e práticas educativas” In: Anais do II Encontro Internacional de História Colonial. Mneme - Revista de Humanidades. UFRN. Caicó (RN), v. 9. n. 24, Set/ out. 2008, p. 8.
} 
dito ensina cada uma das coisas, que promete. Abre-se a Aula no $1^{\circ}$ de Julho de $1809 .{ }^{31}$

Segundo a historiadora Iara Lis Schiavinatto,

As finalidades da leitura - diziam os tratadistas de fins do Setecentos - residiam na formação do estilo de escrita, na instrução, na diversão com vícios e perigos inclusos, no aprendizado da organização dos próprios textos, na memorização dos saberes e na tentativa (bem sucedida ou não) de imitar estilos. ${ }^{32}$

Como súdito da monarquia portuguesa e também formador da opinião pública, Hipólito da Costa cometia o "pecado mortal" da incivilidade: além de maçom, muitas vezes, era "inoportuno" no uso de suas palavras. Ao produzir o Correio em Londres, onde vigorava a imprensa livre, o periodista fazia da arena pública de debate político seu espaço por excelência. Apesar disso, não podemos nos esquecer de que Hipólito era explicitamente partidário dos ideais políticos da monarquia constitucional britânica, tendo estreitado ao longo da vida seus laços "afetivos" no país. $\mathrm{O}$ redator ainda escrevia em um contexto de grave crise europeia, que ganhou mais força desde o Bloqueio Continental, quando França e Inglaterra passaram a disputar explicitamente a hegemonia política e econômica no Velho Mundo. Como principal aliada da Coroa Portuguesa, a Inglaterra foi a grande financiadora das guerras napoleônicas. Nas palavras de Eric Hobsbawm, “o fardo britânico deveu-se ao custo de suportar não só o próprio

\footnotetext{
${ }^{31}$ GRJ. 1809. N. ${ }^{\circ} 81$ (Grifos nossos).

32 SCHIAVINATTO, Iara Lis. "Entre os manuscritos e os impressos" In: LESSA, Mônica Leite; FONSECA, Sílvia C. Pereira de Brito. Entre a monarquia e a república: imprensa, pensamento político e historiografia (1822-1889). Rio de Janeiro: Eduerj, 2008. p. 14.
} 
esforço de guerra do país, mas também, através dos seus tradicionais subsídios aos aliados continentais". ${ }^{33}$ Tal estratégia deu aos britânicos o fardo mais pesado desse conflito bélico; sendo entre três e quatro vezes maior do que o gasto francês. Até a queda de Bonaprte (1814), portanto, a imprensa europeia, em geral, e a luso-brasileira, em particular, usavam seu discurso jornalístico como arma de guerra. Especialmente em relação à tradição ibérica, o pesquisador Fernando Nicolazzi nos mostra que desde o início do século XVIII

[...] letras e armas são termos que se coadunavam para estabelecer as relações entre pretensões políticas e intenções literárias. [...][e] estabelecem certa reciprocidade a partir da qual linguagem e experiência, palavra e ação, ciência e política misturam-se de modo que a tarefa do literato e aquela do militar podem ser equiparadas segundo príncipios equivalentes. ${ }^{34}$

Por esse prisma, consideramos a delimitação do público leitor do Correio de suma importância, sobretudo se considerarmos as ideias maçônicas um ponto de diálogo muito frutífero entre os homens de letras e armas da época. Ademais, as leituras habituais dos pedreiros-livres - como Cândido, de Voltaire, Cartas Persas de Montesquieu e Júlia ou a Nova Heloísa, de Rousseau -, faziam parte do rol das obras consideradas ímpias e estritamente proibidas pela Coroa. Segundo Luiz Carlos Villalta, tais autores "constituiriam uma espécie de biblioteca maçônica, que traria os

\footnotetext{
${ }^{33}$ HOBSBAWM, Eric. J. A era das revoluções. Europa 1789-1848. Trad. Maria Tereza Lopes Teixeira. Marcos Penchel. 6. ed. Rio de Janeiro: Ed. Paz e Terra, 1988. p. 116.

34 NICOLAZZI, Fernando. Entre 'letras \& armas', a história como disputa. Considerações sobre a historiografia luso-brasileira no século XVIII. Almanack Braziliense. São Paulo, n.11, p. 41-42. (maio de 2010).
} 
ensinamentos fundamentais a serem seguidos pelos irmãos"35; aspecto que tornava ainda mais temerosa a figura de "Mr. da Costa" diante dos detentores do poder.

Com circulação nos dois lados do Atlântico, inclusive na América Espanhola, o Correio era lido prioritariamente por intelectuais, médicos, advogados, negociantes e, obviamente, por homens de Estado do governo joanino e hispânico. O amplo circuito de comunicação em que estava imerso o jornal de Hipólito despertava a máxima atenção da Coroa joanina, especialmente de D. João. O chefe supremo da monarquia portuguesa soube utilizar de forma perspicaz as inteligentes reflexões desse "perigoso" vassalo na condução política de seu governo. ${ }^{36}$

$\mathrm{Na}$ prática, portanto, as ações reais no combate às ideias de "Mr. Da Costa" demonstram um viés importante da política cultural joanina: cercear ao máximo a circulação na comunidade luso-brasileira de ideais políticos que ameaçassem ainda mais a já frágil estabilidade da monarquia absolutista portuguesa ${ }^{37}$, até porque os leitores do Correio eram, prioritariamente, aqueles a

35 VILLALTA, Luiz. "Libertinagens e livros... Op. Cit., p. 538.

${ }^{36}$ Em relação à circulação e leitura do Correio Braziliense na América Espanhola, o historiador João Paulo G. Pimenta, afirma: "Não há dúvidas de que, desde o início, [o Correio] circulava profusamente em toda a América, sendo folheado até mesmo pelos homens de Estado [...] por figuras de destaque da política hispânica, como Francisco de Miranda e muito provavelmente Simón Bolívar." PIMENTA, João Paulo Garrido. O Brasil e a América Espanhola (1808-1822). Tese de doutorado. São Paulo: USP, 2003. p. 43.

37 Sobre o debate público da Coroa portuguesa contra o Correio Braziliense pela imprensa oficial (Gazeta de Lisboa e Gazeta do Rio de Janeiro), ver MEIRELLES, Juliana. Imprensa e poder ... Op. Cit., p. 137-140. Quanto às primeiras tentativas diplomáticas da Coroa de cerceamento da pena do jornalista, conferir: BARATA, Alexandre Mansur. Maçonaria... Op. Cit., p. 190-195. DOURADO, Mecenas. Hipólito... Op. Cit., t.1., p. 263-313; t.2, p. 373-422.; RIZZINI, Carlos. Hipólito da Costa e o Correio Braziliense. São Paulo: Companhia Editora Nacional, 1957. p. 26-50. 
quem a Coroa desejava atingir. Segundo a historiadora Rossana Nunes, "era preciso evitar que o espírito revolucionário se infiltrasse em Portugal e seus domínios, garantindo, dessa maneira, a permanência da ordem tradicional, abalada pelos acontecimentos que seguiram a 1789". Ainda de acordo com a pesquisadora, essa postura se refletia no cotidiano do Império Português através da vigilância dos indivíduos - desde suas práticas e conversas à política de evitar que estes mantivessem contato com estrangeiros supostamente afeiçoados aos princípios franceses e residentes em Portugal. A atenção para os discursos desrespeitosos em relação ao poder monárquico e à religião, assim como o impedimento de práticas consideradas libertinas e obscenas também faziam parte do rol das "regras" sociopolíticas aceitáveis. Obviamente, a coibição, introdução e difusão de obras ditas ímpias e sediciosas eram alvo de atenção das autoridades luso-brasileiras. ${ }^{38}$

O fato de Hipólito ser um árduo defensor do modelo monárquico constitucional britânico era um fator de grande preocupação das autoridades oficiais. Na série de ensaios intitulada $\mathrm{Pa}$ ralelo da constituição Portuguesa com a Inglesa, o escritor iniciou a interlocução com seus leitores, chamando-os a atenção para os benefícios da verdade. "Jamais pude acomodar-me à opinião que muitas verdades se não deve dizer ao público. Verdade é a conformidade das nossas ideias com os objetos que elas representam; ou com as ideias eternas; a verdade logo nunca pode ser nociva aos homens: o engano é mister de outros enganos para se sustentar", defendia. ${ }^{39}$ Nessa longa reflexão, publicada em sete partes na seção "Miscelânea", o autor apontava as diferenças entre os sistemas

38 NUNES, Rossana Agostinho. Nas sombras da libertinagem. Francisco de Mello Franco: entre luzes e censura no mundo luso-brasileiro (1757-1822). Dissertação de Mestrado. UFF. 2011. p. 44.

39 CB, Vol.III, p. 175. 
políticos português e inglês, ressaltando as razões da superioridade inglesa. ${ }^{40}$

[...] a forma de Governo, em Portugal, é monárquica, e a monarquia hereditária e absoluta; em Inglaterra, a forma de Governo é monárquica, e hereditária, porém mista; por quanto [sic] o poder legislativo reside no Parlamento [...] e com o poder de fazer leis existe nesta corporação à que o Rei pertence; a ela atribuem graves Jurisconsultos Ingleses a suprema, e absoluta autoridade do Estado. ${ }^{41}$

A despeito das diferenças conceituais dos sistemas monárquicos em questão, Hipólito defendia o respeito dos súditos à autoridade real. Não era partidário, contudo, de que o "Soberano possa tudo, em toda a parte e em todas as ocasiões", sendo este obrigado a obedecer às leis, uma vez que "os governos foram instituídos a benefício dos povos e não dos que governam". ${ }^{42}$ Nesse sentido, ao mesmo tempo em que incentivava os portugueses a conservarem a pureza desta forma de governo por tê-los feito felizes durante séculos, também os alertava de que o conhecimento era necessário para que saíssem do estado de ignorância em que a Coroa os inserira com a vigência de um rigoroso sistema de censura, ao qual o jornalista era radicalmente contrário. ${ }^{43}$ Aliás, para

\footnotetext{
40 Para uma análise pormenorizada sobre a importância desta discussão, ver: DOURADO, Mecenas. Hipólito... Op. Cit., t.II, cap. XXV, "Paralelo da Constituição Portuguesa com a Inglesa" (p. 449-470). Sobre a tentativa de uma aliança entre Hipólito e o governo português, D. Domingos de Souza Coutinho lhe prometia a compra de 500 exemplares do Correio, caso o jornalista moderasse e/ou suprimisse suas análises, sobretudo nos temas mais espinhosos: a maçonaria, a religião e o paralelo entre as duas constituições (inglesa e portuguesa). Ibid., t. II, p. 375.

${ }^{41}$ CB, Vol.III, p. 379 (Grifos nossos)

${ }^{42}$ Ibid., p. 529 e 536, respectivamente.

43 Para conhecer o sistema de censura ver ALGRANTI, Leila Mezan. Livros de Devoção... Op. Cit.
} 
Hipólito, a irrestrita liberdade de imprensa era intrínseca ao progresso de uma nação que se pretendia civilizada." "Os homens, que desejam atraiçoar o Soberano, começam, por insinuar-lhe que lhe deve quartar [sic] a liberdade de imprensa, e que se não deve deixar saber ao público nem verdades, nem novidades algumas: porque a ignorância geral é o seu melhor escudo" ${ }^{35}$, bradava o periodista, ao criticar a postura dos ministros reais na relação com o Príncipe Regente. A maneira como supostamente Antonio de Araújo Azevedo teria conduzido as notícias acerca da invasão francesa a Lisboa antes da saída da Corte, foi alvo de sua análise em novembro de $1808 .{ }^{46}$

A maior parte das gazetas Inglesas asseverou, e se fez publicíssimo: que o Ministro dos Negócios Estrangeiros e da

${ }^{44}$ Utilizamos aqui o conceito de civilização defendido pelo filósofo alemão Norbert Elias em O Processo Civilizador: uma história dos costumes. Rio de Janeiro: Jorge Zahar Editor,1994. Vol.1., p. 23. Segundo o autor, "O conceito de "civilização" refere-se a uma grande variedade de fatos: ao nível da tecnologia, ao tipo de maneiras, ao desenvolvimento dos conhecimentos científicos, às ideias religiosas e aos costumes. Pode-se referir ao tipo de habitações e às maneiras como homens e mulheres vivem juntos, à forma de punição determinada pelo sistema judiciário ou ao modo como são preparados os alimentos [...]. Se examinarmos o que realmente constitui a função geral do conceito de civilização, e que qualidade comum leva todas essas várias atitudes e atividades humanas a serem descritas como civilizadas, partimos de uma descoberta muito simples: este conceito expressa a consciência que o Ocidente tem de si mesmo. Poderíamos até dizer: a consciência nacional."

${ }^{45} \mathrm{CB}$, Vol.III, p. 563

46 Antônio de Araújo de Azevedo (1754-1817) acumulou as pastas de Ministro e Secretário de Estado dos Negócios Estrangeiros e da Guerra e de Ministro do Reino entre os anos de 1804 e 1806. Neste período, sua ação na Corte Joanina se destacou pelo seu trabalho em prol do desenvolvimento artístico, científico, industrial e militar de Portugal. Mais informações sobre a trajetória política de Azevedo em PINHEIRO, Andréa de Souza; MUNIZ, Luciana."Antônio de Araújo de Azevedo, o Conde da Barca: política, ciências e saberes na biblioteca de um diplomata português." Disponível em: <http://bndigital.bn.br/200anos/ araujense.html>. Acesso: 15 jan. 2011. 
guerra de S.A. o Príncipe Regente de Portugal, ao tempo de sua partida para o Brasil, ocultara do Conhecimento do Soberano a marcha das tropas Francesas: disse-me mais, que ele ou fizera por querer atraiçoadamente entregá-lo aos seus inimigos. Eu declaro altamente, que não sei se isso é assim, senão; só repito o rumor que se fez público, e que ninguém até agora contradisse; para nisso fundamentar o meu raciocínio; basta-me o rumor, para que eu admita a possibilidade do caso. Mas como pela precipitação da retirada de S.A. se prova que S.A. não sabia da chegada dos Franceses, cuido que se segue, que os seus Ministros o não informaram da marcha daquelas tropas inimigas; marcha, que ninguém ignorava aqui em Inglaterra. Por uma de duas razões aquele ministro da guerra não informou a S. M., ou porque não sabia da marcha dos Franceses, ou porque a queria ocultar; no primeiro caso a sua ignorância o declara incapacíssimo de lugar [sic], que ocupava; no segundo caso, nada menos que uma forca devia ser o prêmio de seus merecimentos. ${ }^{47}$

O rígido olhar do jornalista para o possível silêncio (e traição) de Azevedo indicava, inclusive, uma provável aliança do ministro com as tropas francesas. Essa desconfiança ganha mais sentido se levarmos em conta a lógica diplomática do ministro dos Negócios Estrangeiros e da Guerra, que tentava evitar ao máximo o choque com Napoleão Bonaparte. Às vésperas da partida da Corte para o Brasil, Azevedo era partidário de que tal decisão ficasse mais explícita para a França, acreditando, com isso, ser capaz de evitar a entrada dos exércitos napoleônicos em solo português. Como nos aponta Jorge Pedreira e Fernando Costa, Araújo não só tinha conhecimento sobre o perigo iminente da invasão das tropas napoleônicas na Península Ibérica, como também tinha ciência de que Portugal podia "se tornar uma peça

${ }^{47}$ CB, Vol.I, p. 519 (Grifos nossos). 
importante no xadrez da repartição em escala europeia das ambições e influências políticas que Bonaparte administrava." 48 A despeito da gravidade da situação, o ministro optara por se calar; o que causou a revolta de Hipólito.

A postura "incômoda" de Azevedo já tinha sido anotada por D. Rodrigo de Souza Coutinho em 1797, em meio à ebulição da Revolução Francesa. Dizia Coutinho:

Estimo muito Antonio de Araújo, mas estou persuadido que não pode Portugal fazer uma paz particular com a França que lhe seja vantajosa, e que toda a paz sem risco não pode S.A.R. afastar-se da aliança de Inglaterra. As cartas de Araújo provam claramente que S.A.R. o Príncipe Nosso Senhor não é informado de todas as ordens que se deixam aos Ministros, e de outro modo tenho toda a razão de crer que a voz púbica não deixa de ter fundamento, no que diz da venalidade da Repartição. ${ }^{49}$

Nesta insinuação acerca do reprovável comportamento de Araújo, Souza Coutinho igualmente enaltecia a sua maneira de administrar as questões da órbita política, uma vez que ele "fiel e escrupulosamente" encaminhava tudo o que recebia "à Real

48 PEDREIRA, Jorge; COSTA, Fernando Dores. D. João VI... Op. Cit., p. 178. Ainda segundo os autores, "Na carta dirigida a D. João, em 21 de novembro, Antônio Araújo sugeriu que se convocasse logo o Conselho de Estado. Estando o perigo vizinho, era necessário que os conselheiros voltassem a votar e se pronunciassem a respeito dos preparativos para a retirada do príncipe, se deviam prosseguir menos ocultamente até porque, conhecendo os preparativos, talvez os franceses não entrassem. Para o ministro dos Negócios Estrangeiros, tudo servia como instrumento diplomático para a dissuasão da invasão francesa, até os preparativos da retirada. A verdade, porém, é que as bases em que até então se assentavam a estratégia do governo de Lisboa haviam ruído estrondosamente". (Idem)

${ }^{49}$ ANRJ, Negócios de Portugal, caixa 716, pacote 3. Apud SILVA, Andrée Mansuy-Diniz da. Portrait... Op. Cit., p. 426. 
Presença sem alteração alguma." ${ }^{50}$ Este comentário já sinalizava para as diferenças e disputas político-ideológicas que permearam a conflituosa relação desses dois personagens durante o governo joanino. Particularmente em relação à ida da Coroa portuguesa para a América, as posições também eram díspares. Enquanto para D. Rodrigo a criação de um grande Império no Brasil era a melhor forma de defender a sustentação do Império Português, para Antônio de Araújo a partida só se faria em caso de extrema necessidade, isto é, diante da inevitabilidade da guerra com a França ${ }^{51}$ Ademais, nesse contexto de acirradas disputas ideológicas, as correspondências políticas dos ministros reais mantêm uma lógica discursiva própria de um tipo de cultura diplomáti$\mathrm{ca}^{52}$ do período, cujo principal interlocutor era o rei: convencê-lo da viabilidade de seus projetos era a disputa principal que movia esses homens de Estado.

Da mesma forma que Hipólito fazia uma crítica veemente a Araújo, este também ressaltava a máxima probidade de D. Rodrigo de Souza Coutinho. "S.A.R. não tem a seu serviço nenhum Ministro mais inteligente, nem mais desinteressado do que D. Rodrigo; e de seu patriotismo não quero outra prova senão o De-

\footnotetext{
50 Ibid.

51 PEDREIRA, Jorge; COSTA, Fernando Dores. D. João VI... Op. Cit., p. 183.

52 Utilizamos aqui o conceito de cultura diplomática defendido pelo historiador Diogo Ramada Curto. Segundo o autor, a "maneira de pensar a política em função das acções de personagens concretas não diz apenas respeito à esfera das relações diplomáticas [...]. Trata-se, aliás, do resultado de hábitos de escrita que implicam a capacidade de observar e descrever outras unidades políticas, que tanto podem incluir uma sistematização por temas, como por personagens ou facções. A par destas práticas de escritas de cartas, ofícios e relatórios, será necessário considerar hábitos de leitura bastante enraizados, tanto no que respeita jornais e gazetas, como no que concerne à obras de referência." CURTO, Diogo Ramada. "D. Rodrigo e a Casa Literária do Arco do Cego". In: Cultura Escrita. Lisboa: ICS, Imprensa de Ciências Sociais, 2007. p. 249-250. Para a análise pormenorizada do conceito, ver p. 248-261.
} 
creto que acabei de transcrever", referindo-se à notícia de que a Impressão Régia do Rio de Janeiro estava apta para imprimir toda e qualquer obra, além de ter as portas abertas à contratação de aprendizes nas diversas áreas da impressão. ${ }^{53}$ Muito possivelmente, o elogio ao ministro real se deve aos antigos laços de amizade e admiração que os uniam, quando Hipólito ainda servia diretamente à monarquia portuguesa. Esse fato, entretanto, não o impediu de tecer rígidas críticas ao comportamento de D. Rodrigo de Souza Coutinho na estruturação do governo Português no Brasil. Em 1802, D. Rodrigo prometia a Hipólito cessar a perseguição aos maçons, tendo para isso a posterior anuência do Príncipe Regente. ${ }^{54}$ Como sabemos, a promessa não se cumpriu e Hipólito foi preso pela inquisição portuguesa, tendo chegado a Londres depois do sucesso da sua fuga, apoiada pelos irmãos da ordem.

A réplica à acusação de traição foi escrita provavelmente pelo próprio Araújo, que assinou com o pseudônimo Amigo da Justiça, em fevereiro de 1809. A íntegra da defesa foi publicada em 1810 sob o título Provas da Falsidade, e Injustiça com que o editor do Correio Braziliense intentou desacreditar Antonio de Araújo Azevedo e algumas reflexões acerca desse jornal oferecidas aos seus leitores. Nesta contestação, o autor rememorava a sua proposta de enviar D. Pedro de Alcântara para o Brasil, além do muito desvelo que tivera na organização e no aumento do exército português, mesmo quando muitos eram contrários à ideia. ${ }^{55}$

\footnotetext{
53 Obviamente, o Decreto real fazia alusão à alta qualidade técnica da tipografia brasileira e não a livre publicação dos conteúdos dos livros.

${ }^{54}$ Cf. VILLALTA, Luiz. "Libertinagens... Op. Cit., p. 548.

55 Amigo da Justiça. Provas da Falsidade, e Injustiça com que o editor do Correio Braziliense intentou desacreditar Antonio de Araujo Azevedo e algumas reflexões acerca desse jornal oferecidas aos seus leitores, Lisboa: Nova Oficina de João Rodrigues Neves, 1810, p. 19. Com Licença da Mesa do Desembargo do Paço. "[...] a publicidade [do projeto político de trazer D. Pedro para o Brasil] foi tal, que até se imprimiu uma Proclamação feita por S.A.R. aos povos do Brasil”, afirmava o
} 
Com isso, Araújo tentava provar sua lealdade e inocência, já que sua intenção era salvaguardar a integridade da monarquia portuguesa. ${ }^{56}$ Por fim, o interlocutor centrava suas críticas na personalidade do editor do Correio que, segundo ele, era "obrigado a fazer o papel de Caturra Literato para subsistir". ${ }^{57}$ Para além de qualificá-lo de caturra - bobo, chocarreiro, aquele que se metia sempre em encrencas, sendo digno de escárnio ${ }^{58}$ - ainda o acusava de ter-se corrompido:

Seja-me lícito fazê-lo certo, de que é chegado o tempo em que os Leitores do seu jornal devem saber que as indignas linhas lançadas a pag.519, do I. ${ }^{\circ}$ vol. não foram suscitadas como ele pretende inculcar, pelo rumor que corria em algumas das gazetas Inglesas, foram sim movidas pela força de quatrocentas libras esterlinas, a que sua alma fraca, e venal não pode resistir!.. Tenha ele igualmente a certeza, de que, assim, no Brasil, como em Portugal, se fala já e não pouco deste seu torpe procedimento. ${ }^{59}$

Por muitas vezes, Hipólito foi acusado de "vender sua pena”. As negociações entre o jornalista e o embaixador português em

autor (p. 7). Este decreto assinado por D. João se encontra na Seção de Manuscritos da BNRJ sob o título Decreto de S.AR. para se publicar no Brasil quando chegasse o Príncipe Menino àquele Estado, com a data de 2 de outubro de 1807. (Mss. I,9,11,15, n004).

56 "A insistência de Araújo de Azevedo na partida de D. Pedro correspondia afinal à ideia de que ainda seria possível evitar a invasão, por meio da satisfação do essencial das injunções com a França. Assim, se salvaguardaria a soberania sobre o Brasil, facultando, ao mesmo tempo, os ingleses a faculdade de encontrarem na eventual abertura de um outro porto brasileiro uma compensação pelas perdas suportadas pelo seu comércio como resultado do encerramento dos portos de Portugal." PEDREIRA, Jorge; COSTA, Fernando Dores. D. João VI... Op. Cit., p. 166.

57 Amigo da Justiça. Provas da Falsidade... Op. Cit., p. 19 (Grifos do Original).

58 SILVA, Antonio de Moraes. Diccionário de Língua Portuguesa Recopilado, Tipographia Lacerdina, 1813. VERBETES: CATURRA, p. 362, v.1.

59 Amigo da Justiça. Provas da Falsidade... Op. Cit., p. 13. 
Londres, D. Domingos de Souza Coutinho foram sempre muito tensas, sendo imprescindíveis algumas intermediações, como a de Vicente Pedro Nolasco da Cunha, ou mesmo o Duque de Sussex. Já com o Príncipe Regente, o acordo acerca das "conveniências materiais do jornal" foi secretíssimo e também necessitou de um intermediário: Heliodoro Carneiro, médico da câmara de D. João e amigo particular do redator, que foi de Londres ao Rio de Janeiro resolver a questão da manutenção da folha, em meados de 1812. Na Corte, o médico encontrou o Príncipe Regente muito insatisfeito com o jornal.

Contextualiza Mecenas Dourado: ${ }^{60}$

[...] As críticas acerbas à administração do intendente de Polícia continuavam, e os ataques ao Conde de Funchal como aos governadores do reino e de certas capitanias do Brasil, ocupavam, sem cessar, as páginas do Correio Braziliense. D. João estava disposto, assim, a fazê-lo mudar de linguagem ou acabá-lo 'custasse o que custasse'.

Segundo as palavras do próprio Heliodoro Carneiro, D. João fizera-o "criatura sua". ${ }^{61}$ Assim, tendo a conduta de vassalo fiel "à calada, e sem os Ministros d'Estado saberem o auctor"62, informava-o diretamente da situação política "por que via cá por fora a opinião pública e o estado da Europa, e nunca quis [lhe] enganar." ${ }^{63}$ Em outras palavras, o Príncipe exigia uma mudança na linha editorial do Correio Braziliense e para isso propôs um pacto vantajoso a ambas as partes.

\footnotetext{
${ }^{60}$ DOURADO, Mecenas. Hipólito... Op. Cit., t. II, p. 388.

${ }^{61}$ CARNEIRO, Heliodoro. Cartas dirigidas a S. M. el-rei D. João VI desde 1817: A cerca do estado de Portugal e Brazil, e outros mais documentos escritos Imprenta Londres : Impreçaô de Mess. Cox e Baylis, [1821], p. 41.

${ }^{62}$ Ibid., p. 40

${ }^{63}$ Ibid., p. 58.
} 
De caráter secretíssimo, o acordo de subvenção do Correio sairia dos cofres da repartição da Intendência Geral da Polícia do Rio de Janeiro e custaria ao governo joanino a significativa quantia de $£ 2.000$ (duas mil libras) anuais. Hipólito solicitava o pagamento antecipado da primeira parcela do acordo para garantir o mesmo "tratamento" recebido pelo Investigador Portuguez em Inglaterra, jornal financiado pela Coroa que circulava em Londres desde meados de 1811. A aliança secreta foi firmada e durou até 1821, quando D. João VI regressou a Portugal. ${ }^{64}$

De Londres, em agosto de 1814, Heliodoro Carneiro explicava a Paulo Fernandes Viana o porquê da demora na remessa dos exemplares do Correio para o Brasil:

Não tem havido navio algum para essa cidade [Rio], e por isso se ajuntaram aqui os números de abril, maio, junho e julho: e no momento que se foram despachar para irem no [][sic] navio português $D$. Rodrigo foram tomados pela Alfândega, dando por pretexto que valiam mais do que aquilo em que eram avaliados, porquanto deve saber V.S. que sempre se dá e determina o valor ao que se despacha para deste valor receber o governo seis por cento. ${ }^{65}$

Para além de apontar as vantagens financeiras governamentais, o médico também advertia sobre a queda no número de subscritores depois da "mudança de linguagem":

Dizendo mais a V.S. que Hipólito tem perdido muito subscritor do jornal depois que tem seguido e tomado

\footnotetext{
${ }^{64}$ DOURADO, Mecenas. Hipólito... Op. Cit., t.II, p. 396.

${ }^{65}$ Carta Autografa de Heliodoro Carneiro, de 17 de agosto de 1814, remetida ao Intendente Geral da Polícia nos seguintes termos: "Ilmo. Sr. ${ }^{\circ}$ Paulo Fernandes Viana, do Conselho de S.A.R. o Príncipe Regente. Rio de Janeiro”. Coleção Particular Dr. Marcos de Mendonça. Apud, DOURADO, Mecenas. Hipólito... Op. Cit., t.II, p. 396 (Grifo nosso).
} 
outra linguagem no seu jornal: o que eu sei e o que me tem alegado muitas vezes o Hipólito para me fazer ver os seus serviços e sacrifícios. ${ }^{66}$

Esta transação, portanto, ficou circunscrita da seguinte maneira: no Rio de Janeiro, D. João confiou a Paulo Fernandes Viana a tarefa de receber as "correspondências privadas" ${ }^{67}$ vindas de Hipólito. De Londres, Heliodoro Carneiro intermediava secretamente as possíveis divergências políticas entre o Príncipe e o jornalista. Aos embaixadores portugueses em Londres, sobretudo, era vedada a hipótese de qualquer conhecimento sobre essa aliança. Ao final de 1815, Funchal informava D. João dos constantes boatos sobre o pagamento da atividade jornalística do redator do Correio, o que bem demonstra o seu desconhecimento do acordo. "É voz pública nesta cidade [Londres] que para esse fim recebe 4 ou 5 mil cruzados". ${ }^{68}$ Segundo o historiador Luís Munaro,

Ainda que Hipólito da Costa esteja vinculado à monarquia através de uma relação ela mesma clientelar - seu Correio Braziliense é subvencionado ao rei D. João VI através do intendente de polícia Paulo Fernandes Viana -, o jornalista não se furta a denunciar a urgência das reformas administrativas, nomeando nas decisões oficiais aquilo que julga incoerente com as 'luzes do século. ${ }^{69}$

Para o autor, Hipólito fazia parte de um momento de transição política em que a própria imprensa estava situada "entre formas tradicionais de mecenato e o incentivo de comerciantes

\footnotetext{
${ }^{66}$ Ibid., t.II, p. 396.

67 Expressão utilizada pelo próprio Intendente da Polícia, Paulo Fernandes, para referir-se a tais correspondências. [Para maiores informações, ver Dicionário Biobibliográfico Português Francisco Inocencio da Silva, tomo X, p. 383-385.]

68 BNRJ. Seção de Manuscritos. I - 29,18,1, n² . Coleção Linhares.

${ }^{69}$ MUNARO, Luís. "A unidade do Reino luso-brasileiro... Op. Cit., p. 4-5.
} 
empolgados com a ideia de montar um club em Londres". ${ }^{70}$ Para além da capital britânica, o apoio financeiro de autoridades políticas brasileiras também despertava a desconfiança dos contemporâneos. Em fevereiro de 1821 - no auge do movimento constitucional - D. José Luís de Sousa comentava a questão.

[...] o que nesta matéria faz requintar a desordem ao último ponto é crer-se geralmente que uma das autoridades do Rio de Janeiro tem a seu soldo o Correio Braziliense e que se serve daquele jornal para caluniar e injuriar descarada e impunemente pessoas que ocupam os mais altos empregos e que Sua Majestade honra com sua confiança... Se há, pois, uma autoridade que pague este jornal tem atraiçoado os interesses de Sua Majestade e da monarquia. $^{71}$

A participação real nesta transação confirmar-se-ia anos mais tarde, em 1826, data da morte de D. João VI. Por essa época, em uma conversa com o Conde de Barbacena, Heliodoro Carneiro ainda tentava amenizar as funestas consequências políticas advindas da publicação das cartas que enviou a El Rei entre 1817 e $1821 .^{72}$ Nesse episódio, o médico relembrou uma importante ocorrência de 1821, referente à intermediação que fazia entre Hipólito e D. João VI. Vejamos:

[...] Depois de ele divagar muito contra o Senhor Infante, teve a fraqueza de me ler, e mostrar a parte que levava escrita a El Rei a respeito do meu negócio, isto é, que eu

\footnotetext{
${ }^{70}$ Ibid., p. 4-5.

71 Arquivo Histórico do Itamarati. Legação de Londres. Correspondência ostensiva e reservada a D. Luís de Sousa.

${ }^{72}$ CARNEIRO, Heliodoro Jacinto de Araújo. Exposição resumida do que durante os dezoito mezes que estive em Lisboa soffri à facção e os acelerados que dominavam el-rei e o levaram à sepultura. Pariz: Officina Typ. de Paulo Renourd, 1826.
} 
produzia uns recibos de Hipólito José da Costa em uns bocados de papel, e sem serem reconhecidos pelo Cônsul Inglês. $^{73}$

Para além de Carneiro assumir a sua posição de intermediador no negócio entre a Coroa e o Correio Braziliense, ainda exaltava a sua indignação diante da atitude considerada desrespeitosa dos Condes de Barbacena e Porto-Santo; fato que o fez recorrer diretamente a D. João VI. Sua descrição é reveladora:

[...] Saí dali, e quase sem saber o que fazia, fui direto à Ajuda, onde se achava El Rei; mas achando-o então na Capela, assistindo a festa do Espírito Santo, deixei isto para o primeiro dia de audiência, que era sexta-feira, em cujo dia fui à Bemposta [sic], e disse a S.M "Que o Conde de Porto-Santo não só estava conluiado com os meus inimigos, mas até se servia agora de chicanas as mais pueris e ridículas para se opor ao pagamento daquilo que S.M. Tinha Mandado pagar, e que melhor que ninguém Sabia dever-me; que S.M conhecia muito bem a letra de Hipólito, $e$ até ele Conde, pois pertencia a mesma súcia; que a primeira coisa que S.M. me tinha recomendado na transação com Hipólito, e nas outras, era segredo absoluto; portanto, como havia eu de fazer pública uma coisa tal, mostrando ao Cônsul Inglês? Que em quanto a serem [sic] os recibos passados em pequenas porções de papel, isso nada mudava a essência do recibo, pois consistia a sua validade na grandeza do papel. ${ }^{74}$

A despeito da importância de Heliodoro Carneiro nessa negociata, notamos que as grandes vantagens dessa transação foram restritas às autoridades diretamente interessadas: D. João VI e Hipólito da Costa. Durante todo o período joanino, o jornalista

${ }^{73}$ Ibid., p. 40.

74 Ibid., p. 40. 
fez críticas diretas aos principais homens de confiança do monarca. Todos estavam sob a sua lupa: ministros, diplomatas, governadores do Reino e intendentes da polícia. Nesse sentido, suas ponderações e críticas eram uma parte essencial no olhar que D. João teceria sobre seus súditos mais influentes; aqueles que compunham a órbita real e atuavam diretamente na sustentação do Império Português. Observá-los por uma análise externa lhe dava a chance de vê-los mais detalhadamente e, portanto, melhor conduzir as intrigas políticas inerentes ao seu governo: toda essa sigilosa estratégia é parte significativa da política cultural da Coroa Portuguesa no universo da imprensa interatlântica. Por esta ótica, Hipólito também atuava como um orientador político indispensável do próprio D. João, que astutamente sabia se aproveitar de um olhar iluminado, advindo da Inglaterra, berço do liberalismo onde vigorava a liberdade de imprensa desde 1695.

\subsection{O Investigador Portuguez em Inglaterra e a disputa com o Correio Braziliense}

A primeira edição do Correio Braziliense já marcava a posição de Hipólito da Costa no novo cenário que se delineava na imprensa periódica da imigração acerca do universo luso-brasileiro: no diálogo com os leitores esclarecia seus objetivos políticos, como também balizava as principais temáticas que permeariam as páginas do jornal. Dizia o escritor:

O primeiro dever do homem em sociedade é ser útil aos membros dela; e cada um deve, segundo as suas forças Físicas, ou Morais, administrar, em benefício da mesma, os conhecimementos, ou talentos, que a natureza, a arte, ou a educação lhe prestou [...] Longe de imitar só, o primeiro 
despertador da opinião pública nos fatos, que excitam a curiosidade dos povos, quero além disso, traçar as melhorias das Ciências, das artes, e numa palavra, de tudo aquilo que pode ser útil à sociedade em geral. ${ }^{75}$

Neste discurso inaugural, as melhorias da ciência e da arte já apareciam como assuntos prioritários do redator, que as considerava campos do conhecimento de suprema utilidade para o progresso da sociedade. ${ }^{76}$ Enquanto a ciência teve espaço garantido prioritariamente na seção "Literatura e Ciências" (onde o jornalista debatia os mais variados temas de interesse para a cultura científica), a discussão sobre as artes esteve circunscrita ao espaço denominado "Comércio e Artes", dois ramos ainda muito próximos entre o final do século XVIII e início do XIX, como atesta o historiador João Luís Lisboa. Nas palavras do pesquisador,

Entende-se então "arte" não no seu exclusivo sentido estético de "belas-artes" que o século XIX consagrou, mas como "habilidade", "técnica", "produção", "arte manual" ou "indústria". Esta limitação no sentido de "arte" [...] tem claramente a ver com a automização e com o ganhar corpo da noção de ciência como saber teórico estruturado e com o alargamento da economia manufatureira. ${ }^{77}$

As reflexões do jornalista no campo das artes ou da ciência eram compreendidas como um meio privilegiado de propagação das luzes para o avanço do progresso. Segundo Alberto Dines, o Correio era "mais do que um projeto jornalístico, [era] uma revolução cultural" sendo a "literatura tomada no sentido mais amplo,

${ }^{75}$ Correio Braziliense, N. I, Introducção, p. 3-4.

76 Tal era o foco, que o jornal era estruturado em quatro seções: "Política", "Miscelânia", "Comércio e Artes" e "Literatura e Ciências".

77 LISBOA, João Luís. Op. Cit., p. 91 (Grifo nosso) 
o conteúdo dos livros - as ideias"78; que na prática englobavam a universalidade dos campos dos conhecimentos do Homem.

Como já dissemos, para Hipólito, a liberdade de pensamento era condição sine qua non no aprimoramento do saber, considerado a base para a constituição de uma sociedade livre: pôr em vigor a autonomia das instituições de ensino, como as Universidades e Academias era medida imprescindível para o progresso espiritual. ${ }^{79}$ Ao defender valores caros aos homens do iluminismo, em outubro de 1808, a censura do governo português nos diferentes ramos de produção, sobretudo literária e científica, foi alvo de suas críticas:

[...] a nação portuguesa tem muitos homens de talentos, e alguns de erudição, e conhecimentos; somente disse que os entraves, que se põem às ciências, às perseguições, que sofrem os homens de letras, e outras causas que atribuo ao Governo, fazem com que esses talentos estejam sopitados [sic], e que não haja, nem possa haver, produções literárias. ${ }^{80}$

Não podemos esquecer que, entre 1800 e 1802, Hipólito ocupou dois cargos de grande responsabilidade: fez parte da equipe editorial da Casa Literária do Arco do Cego (1799-1801), dirigida pelo frei Mariano da Conceição Veloso ${ }^{81}$, e também atuou como diretor literário da Impressão Régia, em 1802, "lugar

78 DINES, Alberto. “O patrono e o seu modelo.” In: Dines e Isabel Lustosa. (Org.). Correio Braziliense. São Paulo: Imprensa Oficial do Estado de São Paulo/UNIEMP/Correio Brasiliense, 2001, v. 1, p. xxvii-xxviii.

79 OLIVERIA, José Carlos. "Os periódicos portugueses de Inglaterra e a Cultura Científica Brasileira (1808-1821)”. Revista da SBHC, n.19, 1998, p. 35-37.

${ }^{80} \mathrm{CB}$, Vol. I, p. 383 (Grifos nossos).

${ }^{81}$ Sobre a vigência da Casa Literária do Arco do Cego ver: CURTO, Diogo Ramada. "D. Rodrigo e a Casa Literária do Arco do Cego". In: Cultura Escrita... Op. Cit., p. 239-280; LYRA, Maria de Lourdes. A utopia.... Op. Cit., p. 83-88. 
que exerceria com empenho e dedicação e no exercício do qual procuraria dar continuidade ao projeto anteriormente assumido, traduzindo para edição algumas obras de caráter técnico e econômico, entre as quais os Ensaios Económicos e Filosóficos, de Benjamin Rumford". ${ }^{82}$ Detalhe: em ambos os cargos, Hipólito esteve imerso na lógica de um complexo sistema de censura, conhecendo todos os seus trâmites por dentro, inclusive com a atuação da Inquisição e da Polícia. ${ }^{83}$ Porém, a vivência nos Estados Unidos da prática da liberdade de imprensa o colocava diante de um dilema: a realização de seu trabalho como homem de imprensa em Portugal - como a tradução e a seleção de textos para publicação - não era livre; diferentemente do que acontecia na Inglaterra, onde tinha total liberdade para escrever e, assim, ressaltar os prejuízos da prática da censura exercida por homens escolhidos pela Coroa portuguesa. Para ele, a censura era "um absurdo, só por si, capaz de aniquilar inteiramente o gênio de uma nação" ${ }^{84}$ Segundo a avaliação da historiadora Ana Cristina Araújo, em relação às diretrizes e problemas intrínsecos à prática do pensamento ilustrado em Portugal no final do século XVIII,

[...] a polêmica e o confronto entre dois mundos culturais se travou na fronteira entre a ordem pública e privada, a meio caminho entre o usufruto das letras e o domínio das regras de utilização da palavra. No que concerne à utilização da mensagem escrita, as várias fases que o livro percorre, produção, aprovação e difusão, concitam a análise prévia da relação triangular do autor (tradutor), editor, censor. ${ }^{85}$

82 PEDROSA, Alcino. “Trajetória Biográfica.... Op. Cit., p. 18 (Grifo do original).

${ }^{83}$ CB, Vol. I, p. 384.

${ }^{84}$ Ibid., p. 383.

${ }^{85}$ ARAÚJO, Ana Cristina, A cultura das Luzes em Portugal: temas e problemas. Lisboa: Livros Horizontes, 2003, p. 11 
Sob a ótica das Luzes e a maçônica, Hipólito da Costa desenvolveu a sua visão de progresso, intrínseca à ideia da necessidade de cada um "superar os seus "vícios", ou seja, os fanatismos, as tiranias, as supertições e a ignorância" " 86 ; compreendidos como um retrocesso que deveria ser evitado a todo custo, se Portugal realmente desejasse andar em compasso com os valores da Europa civilizada. ${ }^{87}$ E Hipólito considerava que muitos "vícios" ainda estavam fortemente presentes no governo português. A perseguição aos franco-maçons e também o incentivo da Coroa às obras antimaçônicas, como Os Pedreiros Livres e os Iluminados, Que mais propriamente se deverião denominar os Tenebrosos, De cujas seitas se tem formado a pestilencial Irmandade, a que hoje se chama Jacobinismo ${ }^{88}$, eram, na prática, manifestações dessa ignorância.

Posto isso, entre agosto e setembro de 1809, o redator respondia ao conteúdo considerado incidioso dessa publicação:

As acusações, e perseguições contra os Franco-maçons têm seguido estes passos de todas as outras; porque sendo fundadas na ignorância, acabaram já em Inglaterra, e em todos os demais países, onde as ciências têm feito progressos, e assim em Portugal, será talvez a última parte onde estas perseguições acabem; porque o atraso naquela infeliz nação é tão proverbial na Europa, que se julga andarem os portugueses três séculos atrás das demais nações. ${ }^{89}$

Como agente civilizador, portanto, o jornalista desnudava problemáticas políticas espinhosas da monarquia portuguesa e

${ }^{86}$ BARATA, Alexandre Mansur. Maçonaria... Op. Cit., p. 118 (Grifo nosso).

${ }^{87} \mathrm{CB}$, Vol. III, p. 146.

${ }^{88}$ A obra publicada pela Impressão Régia do Rio de Janeiro em 1809, sendo vendida na loja do livreiro Paulo Martins Filho.

${ }^{89}$ CB, Vol. III, p. 146 
abria um espaço poderoso de debate e formação da opinião pública. De acordo com o historiador português José Alves, opinião pública na época era concebida como "o resultado deste debate político e desta discussão pública, radicados no conceito de autoridade debatida, cuja base é a esperança de que a verdade e a justiça surgirão da sociedade constituída como um grande organismo de livre e pública discussão".90

Desde a decisão da partida da Corte para o Brasil, a atuação de D. Domingos de Souza Coutinho (Conde de Funchal) na política externa portuguesa ganhava relevo. ${ }^{91}$ Mesmo sem o consentimento do Príncipe, durante a viagem da família real para a América, o embaixador português em Londres assumiu plenamente a representação diplomática do país. Com a constituição do governo no Rio de Janeiro, sua influência política seria intermediada por d. Rodrigo - seu irmão - e por Lord Strangford, ministro plenipotenciário inglês. ${ }^{92}$ Apesar de ter sua ação limitada

\footnotetext{
${ }^{90}$ ALVES, José Augusto dos Santos. A opinião... Op. Cit., p. 26 (Grifo nosso).

${ }^{91}$ D. Domingos António de Sousa Coutinho (1760-1833), formado em Leis, seguiu a carreira diplomática, tendo ocupado os cargos de enviado na Dinamarca (1790-1795), representante de Portugal em Turim (1796-1803) embaixador em Londres (1803-1814) e em Roma (1814-1828). Em 1810 foi governador do Reino de Portugal. Foi-lhe concedido o título de Conde do Funchal em 17 de Dezembro de 1808, tendo sido elevado a Marquês em Junho de 1833, pouco tempo antes do seu falecimento. Foi autor de numerosos escritos políticos e diplomáticos. Disponível em: www.aatt.org. Acesso em: 12 de julho de 2010. Para informações mais detalhas sobre o diplomata, ver MACHADO, Adelaide Maria Muralha Vieira. "Domingos António de Sousa Coutinho (1760-1833) $1^{\circ}$ Conde e Marquês de Funchal. Pensamento e acção". In: Congresso Histórico 98. Amarante: 1998. p. 471-481; COUTINHO, Domingos António de Sousa $1^{\circ}$ Conde e Marquês de Funchal (1760-1833). In: Dicionário do Vintismo e do Primeiro Cartismo (1821-1823 e 1836-1828). Lisboa: Edições Afrontamento, Vol. I, 2002. p. 534-545.

92 Percy Clinton Sydney Smythe. Lorde Strangford. (1780-1855). Nobre inglês, Strangford foi embaixador britânico junto à Corte de D. João, primeiro em Lisboa, depois no Rio de Janeiro. Com pouco mais de vinte anos, já era funcionário
} 
por outros agentes políticos, Funchal seria responsável por um importante projeto da política impressa da Coroa: em 1811, tinha sob suas mãos a direção d'O Investigador Portuguez em Inglaterra.

A primeira edição d' O Investigador Portuguez em Inglaterra saiu em julho de 1811. Redigido em Londres, O Investigador tinha o intuito de combater a ressonância dos ideais políticos de independência do Brasil presentes no Correio Braziliense que ecoavam nos dois lados do Atlântico, sendo o resultado de um projeto explicitamente apoiado e patrocinado pela Coroa Portuguesa. ${ }^{93}$ Entre os anos de 1811 e 1814, o periódico teve como redatores os médicos portugueses Bernardo José de Abrantes e Castro e Vicente Pedro Nolasco da Cunha, ambos exilados na Inglaterra. A partir 1814, Abrantes e Castro foi substituído por José Liberato Freire de Carvalho na redação, onde permaneceu até 1819, quando a folha deixou de circular. ${ }^{94}$

do Ministério dos Negócios Estrangeiros da Inglaterra, atuando como secretário da missão diplomática em Lisboa. Defensor acérrimo dos interesses britânicos, nas palavras de Patrick Wilson, tornou-se embaixador às vésperas da partida da Corte portuguesa para o Brasil. No Rio de Janeiro, foi um dos principais estrategistas para a assinatura do Tratado de 1810, que concedia amplos privilégios comercias à Inglaterra. A impopularidade do ministro, entretanto, era imensa; sendo por muito tempo considerado o símbolo do poder imperial britânico sobre D. João. VAINFAS, Ronaldo. In: NEVES, Lúcia Bastos Pereira das; VAINFAS, Ronaldo (Org.). Dicionário do Brasil joanino... Op. Cit., p. 369-370.

${ }_{93}$ Segundo Adelaide Machado, "A mensagem política não diferia tanto quanto os polemistas de ambos os jornais queriam fazer querer, no essencial, e para este período, era até a mesma: moderada e lutando pela reforma do abuso, baseava-se na admiração pelo modelo inglês." MACHADO, Adelaide Maria Muralha Vieira. O Investigador Português em Inglaterra, Jornal Literário, Político. \& C., nos primeiros anos de publicação (1811-1813). Lisboa: UNL/CLC, 1998. p. 474.

94 MACHADO, Adelaide Maria Muralha Vieira. O Investigador Portuguez em Inglaterra, Jornal Literário, Político. \& C., nos primeiros anos de publicação (1811-1813). Dissertação de Mestrado. Universidade Nova de Lisboa, 1996. p. 7. Sobre a problemática acerca da segunda fase d'O Investigador Portuguez, sobretudo referente à atuação do redator José Liberato Freire de Carvalho, ver: BOISVERT, Georges. "La presse périodique portugaise de Londres. Notes sur les 
Um Jornal escrito na Língua Portuguesa [...] apresenta notícias gerais de Literatura e Ciências, e dos progressos que as mesmas vão fazendo neste Reino, e nas mais partes da Europa, (com a brevidade, que as circustâncias da Guerra permitirem), não só parece recomendável, mas até de suma necessidade.

Mudanças extraordinárias, nova ordem nas públicas ocorrências requerem do Filósofo, e do Estadista, uma profunda investigação sobre a origem, condição e autenticidade dos fatos, assim como uma judicosa censura, e imparcialidade ingênua na sua exposição. [...]. ${ }^{95}$

Publicado no "Prospecto" do jornal, o primeiro discurso exaltava o português como língua nacional, já na tentativa de circunscrever suas peculiaridades e possíveis diferenças com o Correio Braziliense, que desde a edição de estreia criticava a pequena produção literária em língua portuguesa em um país de homens com grande capacidade literária que poderiam dar vivacidade à literatura, se não fosse as "constantes perseguições, que naquele país sofrem os homens de letras". ${ }^{96}$ Era justamente contra tal ideia que $O$ Investigador tentava contrapor-se. Para além de elevar a língua e a identidade nacional através da literatura, concebendo-a como um elo de união entre os vassalos da monarquia portuguesa, também seus redatores tinham claro que tanto a literatura portuguesa quanto as ciências europeias eram consideradas pilares fundamentais na delimitação do seu espaço

circonstances de son apparition et de son développement." Sillages. Sus la direction de R.A. Lawton. N. 4. (1974). Poitiers: Département d'Études Portugaises et Brésiliennes de l'Université de Poitiers, 1974. p. 69-88; BOISVERT, Georges. "Le comte de Palmela et la presse potugaise libre (1816-1820) d’aprés des documents diplomatiques inédites." Arquivo do Centro Cultural Português. Paris: Fundação Calouste Gulbenkian/Centro Cultural Português, 1982. p. 459-509.

95 O Investigador Portuguez em Inglaterra, N.I, Prospecto, p. 1-2.

${ }^{96}$ CB, Vol. I, p. 30 
de intervenção política enquanto agentes históricos responsáveis pelo esclarecimento na trilha do progresso. Particularmente em relação à poesia, defendiam a sua utilidade à pátria e ao Estado, vangloriando poetas consagrados como Luiz de Camões, cuja obra enaltecia a grandeza da nação. Eis o discurso do jornal em julho de 1813:

Quem tem concorrido mais que a poesia para a civilização e melhoramento das nações? A fábula que representa a lira de Orpheu arrancando os rochedos pela melodia de seus acentos é o emblema de uma verdade reconhecida; o influxo da poesia na agricultura e na moral. ${ }^{97}$

A poesia como orgulho patriótico. Símbolo máximo do alto grau de civilização. Força inalienável cujo mérito no aperfeiçoamento moral da sociedade também se estendia para o reconhecimento, valorização e aprimoramento da agricultura, concebida como o principal meio de o país conquistar a liberdade e a independência econômica e política. ${ }^{98}$ Tal proposição é confirmada na Carta Régia, de 7 de março de 1810. Neste documento, D. João "apontava a agricultura como atividade em que o país devia basear o seu desenvolvimento e a sua participação, num mundo cada vez mais permeado pelas trocas internacionais." ${ }^{99}$ De inspiração de d. Rodrigo de Souza Coutinho, o programa sugerido pela Coroa propunha a reforma do regime senhorial agrícola, apoiando novas formas institucionais mais modernas da posse da terra. Com a morte do ministro e pouco apoio dos governadores do Reino, o programa acabou por não ser executado.

97 IP, Vol. VII, p. 86.

98 Artigo "Estabelecimento da Sociedade da Agricultura”. Idem, p. 84.

99 PEDREIRA, Jorge; COSTA, Fernando Dores. D. João VI... Op. Cit., p. 282. 
Estas medidas faziam ainda mais sentido se compreendermos que desde o início do século XVIII, o sistema de alianças entre as potências europeias colocava Portugal alinhado à Coroa britânica, numa clara situação de desvantagem. Desta constatação, interessa-nos ressaltar a proteção inglesa à navegação Atlântica, que durante todo esse período garantiu a comunicação entre os portos portugueses e brasileiros, e o pioneirismo inglês na revolução industrial. ${ }^{100}$ Já no início do século XIX, em meio às guerras napoleônicas, escancaravam-se ainda mais a dependência política, econômica e militar de Portugal em relação à Inglaterra. Para além da proteção britânica aos navios portugueses no processo de transladação da família real para o Brasil, o Tratado de 1810 selava as vantagens econômicas da Coroa inglesa no comércio anglo-luso-brasileiro. Isso sem contarmos com a presença do exército inglês em Portugal entre os anos de 1808 e 1821, simbolizado na constante presença de Lord Beresford. Para o historiador Valentim Alexandre, a abertura portuguesa às negociações do tratado de comércio pode ser lida como a garantia dada pela Grã-Bretanha de que a legitimidade da monarquia bragantina estaria assegurada em solo português. ${ }^{101}$

100 "A Grã-Bretanha [...] possuía uma economia bastante forte e um Estado suficientemente agressivo para conquistar os mercados de seus competidores. De fato, as guerras de 1738-1815, a última e decisiva fase do duelo secular anglo-francês, virtualmente eliminaram do mundo não-europeu todos os rivais dos britânicos, exceto até certo ponto os jovens EUA. Além do mais a Grã-Bretanha possuía uma indústria admiravelmente ajustada à revolução industrial pioneira sob condições capitalistas e uma conjuntura econômica que permitia que se lançasse à indústria algodoeira à expansão colonial. A indústria algodoeira britânica, como todas as outras indústrias algodoeiras, tinha originalmente se desenvolvido como um subproduto do comércio ultramarino." HOBSBAWM. Eric. A era das revoluções... Op. Cit., p. 49.

101 ALEXANDRE, Valentim. Os sentidos do Império. Questão nacional e questão colonial na crise do antigo regime português. Porto: Afrontamento, 1993. p. 210. 
Em meados de 1813, o Visconde da Lapa - sócio da Academia Real das Ciências de Lisboa -, produzia o documento Ideias Gerais sobre a Polícia, muito provavelmente a pedido da Coroa. ${ }^{102}$ Ao pensar um novo paradigma para a instituição policial na cidade sob a perspectiva imperial ${ }^{103}$, o autor evidenciava a relação entre o bem geral do Estado e a administração do espaço urbano pela polícia. Sobre isso, refletia:

O conhecimento do todo [da cidade], e de cada uma das suas partes, é indispensável, e sem isso, não é possível estabelecer salutíferas [sic] ativas providências. A ciência da polícia consiste em adotar no estado atual de qualquer Nação ou Império, aquelas prudentes medidas, que mais concorram para conservar e aumentar a fortuna do Estado, na sua constituição interior, e no seu progresso sucessivo em todas as partes. Deve ser o princípio geral da Polícia, dar tal tendência a este ente constitucional político, que se conserve e aumente o bem do Estado. ${ }^{104}$

Durante o Século das Luzes, a cidade teve uma importância capital: neste espaço, as ideias circulavam e a prática política da crítica ao status quo se fazia presente. ${ }^{105}$ Essas mudanças na transformação do olhar dos homens para a cidade puderam ser

102 O manuscrito é datado de fevereiro de 1813.

103 Nos itens 19 e 20 deste manuscrito, o autor define a cidade como "uma agregação de sociedades, famílias e pessoas que vivem juntos [sic] debaixo de uma certa vigia da polícia, para com mais comodidade e proveito, promoverem, certos ofícios, e meios de subsistência, necessários ao bem e aumento do país. 20. Quanto maiores e florescentes forem as cidades de um país, tanto melhor se cuidará do todo." BNP. Res., Mss. 246, n. 28. [Ofício de 28 de Setembro de 1820 para o $1^{\circ}$ Conde da Lapa, Manuel de Almeida e Vasconcelos, ministro plenipotenciário na Corte da Rússia] (Grifo nosso).

104 Ibid. (Grifo nosso).

105 Para o conceito de crítica, ver KOSELLECK, Reinart. Crítica e Crise. Rio de Janeiro: Eduerj/Contraponto, 1999. 
acompanhadas pela Encyclopédie, que já delineara a preocupação com a ordem e a racionalidade do universo urbano. Era a sobreposição da estética das luzes à estética medieval. Posto isso, era necessário refletir sobre novas maneiras de idealizá-la. No Império Português, particularmente, essa nova concepção de cidade ilustrada e suas transformações advindas do processo de reurbanização eram indissociáveis do Estado de polícia, concebido como uma ciência de governo em busca do "bem-estar geral" da nação. ${ }^{106} \mathrm{~A}$ interdependência entre o Estado absolutista e a ação da polícia simbolizava, em última instância, a força (e independência) política do Império Português sob uma perspectiva civilizadora. Como sabemos, O Investigador circulou em grande parte do território brasileiro e, portanto, a divulgação no periódico da leitura de Ideias Gerais sobre a Polícia na Academia Real das Ciências de Lisboa, em setembro de 1813, não foi mero acaso: a Coroa noticiava vieses importantes de seu projeto político através da exaltação do discurso de seus súditos leais que a elevavam à principal agente cultural do Império luso-brasileiro. ${ }^{107}$

\footnotetext{
106 Como homem do governo, o Visconde da Lapa compreendia a ideia de bem-estar geral por uma vertente oficial e, obviamente, socialmente hierarquizada. Dizia o autor: "O fim da polícia é contudo promover, por meios de bons regulamentos, a conservação e aumento da boa prosperidade interior do Estado, e como esta não só compreende todos os bens públicos, e particularmente, porém as disposições e capacidades dos membros da Nação, é evidente portanto, que a polícia pertence vigiar sobre o encadeamento destes objetos, apartando os obstáculos, e promovendo os meios mais conducentes ao bem comum." O fim do manuscrito terminava com a seguinte reflexão: "Não se deve porém admitir que a polícia deve promover, e proteger todos aqueles estabelecimentos, que entretendo as diferentes classes, os impedem, ou da aplicação a objetos mais prejudiciais do Estado, ou as desviam de considerações pouco úteis." BNP. Res., Ideias Gerais sobre a Polícia. Mss. 246, n. 28 (Grifos nossos).

107 IP, Vol. VII, p. 494-495. Sobre o sistema de assinaturas e a circulação de $O$ Investigador Portuguez no Brasil, ver as seguintes edições da Gazeta do Rio de Janeiro - 1811, n. ${ }^{\circ} 63$ e 1813, n. $^{\circ} 81$.
} 
Em Janeiro de 1814, O Investigador publicava uma longa reflexão sobre Gil Vicente, um dos escritores "com que mais se honra a nossa Literatura Nacional". ${ }^{108}$ Os redatores tinham escolhido Gil Vicente (e não outros) por razões muito especiais: porque "desgraçadamente se vê tão pouco conhecido", por ser reconhecidamente o "nosso Plutarco português" 109 entre sábios nacionais e estrangeiros, e, sobretudo, pelo fato de "ter sido um português, e isto é quanto basta para crédito das Musas Lusitanas". ${ }^{110}$ Ao contextualizar a fama e destaque de Gil Vicente, os redatores exaltavam a atitude de Erasmo, um sábio de renome no Velho Mundo que "de propósito aprendera Língua Portuguesa para entender as superiores belezas de Gil Vicente". ${ }^{111}$ Essa afirmação não estava desvinculada de um mote muito caro à filosofia iluminista: a relação entre razão e linguagem, que teve em Rousseau um dos

\footnotetext{
108 Ibid., p. 591.

109 Plutarco foi um estudioso grego (46 d. C.-119 d. C.), nascido na Beócia, autor de uma obra que exerceu grande influência sobre o ensaio e a biografia na literatura ocidental. A sua vasta obra integra dois grupos: Vidas Paralelas, que consiste em 46 biografias de vultos gregos e romanos, e Ética, uma coletânea de pequenos escritos em que são dominantes diatribes e diálogos. Embora tivesse orgulho na sua nacionalidade grega, Plutarco aceitou o domínio romano. $\mathrm{Plu}$ tarco. In: Infopédia [Em linha]. Porto: Porto Editora, 2003-2011. Disponível em: <http://www.infopedia.pt/\$plutarco>. Acesso em: 15 fev. 2011.

${ }^{110}$ Idem, p. 591-592. "Gil Vicente está no "cânone”, desde há muito, e colocado na prateleira dos clássicos, surgindo deste pressuposto consolidado pela passagem do tempo, um sem número de implicações para os seus leitores e investigadores. No panorama ibérico e europeu, a Compilaçam faz, inequivocamente, parte do Cânone, na medida em que a produção dramatúrgica vicentina se fez ecoar pela Europa ocidental de Quinhentos e aparece ainda hoje, passados já os quinhentos anos da apresentação da Visitação, com suficiente fulgor para interessar a críticos, investigadores e gente das artes cénicas. A excepcionalidade da obra de Gil Vicente, o primeiro escritor português a ultrapassar os muros da nacionalidade, chegou até nós com as marcas indeléveis do tempo. FARIA, Paulo Manuel Miranda. Gil Vicente - o Mestre da Corte de D. Manuel e de D. João III. Dissertação de Mestrado. Universidade do Minho. Braga: 2005. p. 8-9

111 Ibid., p. 593 (Grifo nosso)
} 
seus principais expoentes. Em Ensaio sobre a origem das línguas (1781), refletia: “Quando se quer estudar os homens, é preciso olhar perto de si; mas para estudar o homem é preciso estudar mais longe, é preciso primeiramente observar as diferenças para descobrir as particularidades".

Para o filósofo, a "principal causa que as distingue [as línguas] é local, ela vem das regiões em que nascem e da maneira pela qual se formam", o que daria a base para remontar e conceber as suas diferenças e peculiaridades. ${ }^{112}$ Nesse sentido, portanto, Erasmo buscava conhecer não apenas o homem, mas a cultura nacional da qual Gil Vicente não apenas fazia parte, mas era também um grande expoente. A reflexão sobre o escritor português desembocaria em um diálogo crítico do jornal com os leitores, "para a glória e reputação da nossa Pátria". ${ }^{113}$ Ao se colocarem na posição de ousados questionadores com muitas dúvidas, os redatores perguntavam:

Por que razão Gil Vicente, tão famoso em Portugal e na Europa, veio a ser esquecido entre nós a um ponto tal, que nem as suas mesmas obras aparecem; quando dos autores seus contemporâneos, e outros mais que se lhe seguiram, nos tem chegado quase todos os escritos, e deles se tem feito diversas edições?

Por que, sendo nos, ao que parece, os primeiros restauradores do teatro cômico na Europa, e andando quase a par no trágico com a Itália, aonde apareceu a primeira tragédia moderna regular, não havemos tido desde Gil Vicente até o Judeu ${ }^{114}$ autor algum cômico de nome?

112 ROUSSEAU, J. J. Ensaio sobre a origem das línguas. Trad. Fulvia M. L. Moretto. 2. ed. Campinas, SP: Editora da Unicamp, 2003. p. 125 (Grifo nosso).

113 IP, Vol.VIII, p. 593-594.

114 O livro O Judeu é de autoria do luso-brasileiro Antonio José da Silva (1705-1739), considerado o mais representativo autor dramático português da primeira metade do século XVIII português. Aos 34 anos foi preso e executado 
Foram na realidade os Poetas Espanhóis, e mui particularmente, Lopo da Vega e Francisco de Quevedo, imitadores e os díscipulos de Gil Vicente? Ainda mais: Foi ele indisputavelmente o primeiro autor cômico regular da Europa moderna e civilizada? ${ }^{115}$

Com essas interrogações, os editores incentivavam a participação do significativo público leitor, não apenas como forma de endossar a fama literária que pretendiam para o jornal, mas, sobretudo, como meio de valorizar as suas reflexões intelectuais, no sentido de convencê-los a ler a tradição literária da cultura portuguesa como superior, por exemplo, à espanhola, país vizinho com maior ressonância sociopolítica e cultural no Continente. ${ }^{116}$ Novamente, a poesia aparecia como ícone do mais alto grau de civilização. "A poesia, como nos aponta a história, segue a sorte da linguagem. $\mathrm{Na}$ infância das nações, ela é rude, inculta como elas. [...] À medida que as línguas se civilizam perdem esse ressaibo [sic] de barbaridade, a poesia de consoantes", defendiam os redatores. ${ }^{117}$ Neste sentido, a exaltação da cultura portuguesa dá-se tanto para a língua - tida como a filha mais próxima do latim - quanto em relação aos seus poetas modernos, superiores, já que "não escrevem [mais] em consoantes, graças ao progresso da

pela Inquisição em Lisboa, sob a acusação de praticar o judaísmo. DINES, Alberto. Vínculos do fogo I: Antonio Jose da Silva, o Judeu, e outras historias da Inquisição em Portugal e no Brasil. São Paulo: Companhia das Letras, 1992. 115 IP, Vol.VIII, p. 593.

116 Segundo Tengarrinha, O Investigador tinha larga procura em Portugal, sendo lido seguramente por milhares de pessoas. TENGARRINHA, J. "Os comerciantes e a imprensa portuguesa da Primeira Emigração”. Estudos em Homenagem a Luís Antonio de Oliveira Ramos. Faculdade de Letras da Universidade do Porto, 2004. p. 1.077.

117 IP, Vol. VII, p. 393. As consoantes são definidas pelo periódico como "certas toadas uniformes e monótonas", cuja única distinção está no metro. Idem. 
iluminação, e do gosto". ${ }^{118}$ Como bem demonstra a obra seminal de Immanuel Kant, Resposta a pergunta: "Que éo esclarecimento?" (1784), o homem só sairia da menoridade ao atingir a liberdade, concebida como a capacidade de "fazer um uso público de sua razão em todas as questões". ${ }^{119}$

A elevação de Gil Vicente como o (possível) mestre do teatro cômico Europeu, colocava-o como um dos ícones da alta cultura humanista da Europa Ocidental, cuja tradição era indiscutível no avanço das artes e das ciências. "Antes do aparecimento de Gil Vicente, não podemos falar em um teatro em Portugal", pontua o pesquisador Segismundo Spina, que enaltece a obra vicentina pela "presença expressiva do estilo - como quem diz a superioridade estilística do texto literário - a constante renovação dos temas e das formas, a primazia dessa arte em terras portuguesas e a superioridade de suas criações, pelo talento cômico e a estrutura doutrinária dos seus temas". ${ }^{120}$ Gil Vicente em Portugal, e Willian Shakespeare, em Inglaterra, eram os representantes por

\footnotetext{
118 Ibid., p. 393. "Os redatores explicavam a superioridade da poesia nesses termos. Mas nem todas as línguas têm harmonias da Grega e Latina e é singular que as duas modernas, notoriamente as mais cultivadas, são excluídas deste número, a Francesa e a Inglesa; pois uma é pelo gênio abreviador, e a outra alongador das suas sílabas, não podem com facilidade metrificar-se com a elegância hexamétrica, por mais tentativas que se tenham feito sobre isso. O que não acontece com a nossa Portuguesa, que a este respeito nos parece muito superior à Alemã; a única moderna que apresenta a metrificação característica de Homero, e de Virgílio [...]. Em todo o gênio da glória nacional, pode a nação portuguesa distinguir-se. Ela tem mostrado ao mundo que tem criado Heróis, capazes de manejar a massa de Hércules, de imitar a rapidez e valor de Aquiles." (Idem, p. 396) (Grifos nossos).

119 KANT, Immanuel. Resposta a pergunta: “Que é o esclarecimento?”. In: Immanuel Kant. Textos Seletos. 2. ed. Trad. Raimumdo Vier e Floriano de Sousa Fernandes. Petrópoles: Editora Vozes, 1985. p. 104.

120 SPINA, Segismundo. "Introdução". In: Gil Vicente: O Velho da Horta; Auto da Barca do Inferno; A Farsa de Inês Pereira. São Paulo: Editora Brasiliense, 1996. p. 8-9 (Grifos nossos).
} 
excelência nas artes teatrais do humanismo europeu. Com esta mensagem, O Investigador colocava os dois países diante de um equilíbio cultural que, implicitamente, disputava o espaço de hegemonia entre os paradigmas literários das nações consideradas mais civilizadas do Velho Mundo. ${ }^{121}$

Incentivar a participação dos leitores tinha um objetivo claro no jornal: formar, evidenciar e consolidar a força intelectual da comunidade luso-brasileira - que se pretendia em consonância com as decisões políticas da monarquia portuguesa - no universo da imprensa londrina. Em abril de 1812, quase um ano depois do início da publicação, Funchal enviava para o Brasil dois ofícios que justificavam a continuidade d'O Investigador: os governadores do Reino informavam-lhe sobre a circulação do Correio Braziliense em Lisboa, escrito pelo "libelista revolucionário". ${ }^{122}$ Dizia o diplomata:

Os ofícios por si falam, e creio que justificam a necessidade da espécie de protesto que eu faço pelas consequências futuras. Os motivos que me persuadem a assim obrar a respeito da probidade do Correio Braziliense são os mesmos que tenho levado à Real Presença, e que S.A.R., parece aprovar completamente, e em que representei a necessidade absoluta, e urgente de um Jornal como o Investigador para servir de antídoto aos métodos usados para desacreditar o Governo de S.A.R. e fazê-lo odioso ao Ministério Britânico. ${ }^{123}$

A questão é que a comunidade luso-brasileira em Londres também tinha interesses e divergências muito particulares.

121 A importância de Gil Vicente no teatro se estende até os dias atuais, sendo considerado por Segismundo Spina tão importante quanto Homero, Camões e Shakespeare. Idem, p. 7.

122 ANTT/ MNE_ Livro 451, N. 552.

123 Ibid., N. 347. 
"Quatro forças, com frequências divergentes, exerceram influência relevante nesta imprensa em língua portuguesa em Londres: os negociantes portugueses (sobretudo através do seu Clube em Londres), a Corte e o governo do Rio, os governadores de Lisboa e a maçonaria", analisa José Tengarrinha, ao mapear a sobrevivência e as relações políticas dos "jornais na emigração". ${ }^{24}$

Disputar a atenção dessa gama heterogênea de leitores, tornando-se um órgão de destaque na formação da opinião pública, era o que movia O Investigador Portuguez e o Correio Braziliense nesse debate. Hipólito da Costa, por exemplo, tinha muito interesse pelo comércio luso-anglo-brasileiro por uma razão central: seus leitores (e subscritores) eram, na maioria, negociantes portugueses que viviam e atuavam como profissionais liberais na Inglaterra. Entre 1811 e 1819, esses dois periódicos, considerados pelo pesquisador José Carlos Oliveira "paradoxalmente irmãos siameses", viveriam em disputa, discórdia e concorrência, procurando cada um à sua maneira se mostrar mais imparcial e confiavél que o outro.

Em maio de 1812, Hipólito se posicionava negativamente diante do desafio de "guerra" proposto pelo Investigador Portuguez. Dizia:

Não aceitamos o desafio: porque não temos razão de interesse público para fazer guerra às pessoas daqueles Redatores; nem o nosso jornal deve servir de veículo de observações individuais, a menos que não julguemos que elas interessem o público. Não julgamos também que devemos fazer guerra ao Jornal; porque é obra literária que pode produzir bens à Nação; e já produziu um, que é estimular a que se escrevam obras da mesma natureza. ${ }^{125}$

124 TENGARRINHA, José. “Os Comerciantes e a Imprensa... Op. Cit., p. 1.078.

125 CB. Vol. VIII, p. 716. 
Apesar de negar o embate com o Investigador nos moldes de uma "guerra impressa" e reconhecer os méritos literários da publicação, Hipólito não se eximia de suas responsabilidades como homem de imprensa: sempre que as provocações fossem postas à prova, ele estaria pronto para respondê-las. Vejamos:

Mas parece-nos que sem incorrer da nota de cavaleiros errantes da escola do grande guerreiro de La Mancha, podemos reservar-nos o direito de responder, e seguramente o faremos, aos argumentos que os Senhores desafiantes produzirem, quando as nossas ideias os não aprovarem; e parece-nos que o podemos fazer sem mandar um Arauto a aceitar o desafio de guerra. ${ }^{126}$

Em agosto do mesmo ano, os redatores d'O Investigador respondiam a Hipólito da Costa, na tentativa de menosprezar os seus conhecimentos nos diferentes campos do saber.

\begin{abstract}
Sr. Editor,
Depois de V.Mce ter acumulado o quanto pode de invectivas e acusações especiais contra o Investigador, sai-se a página $746[\mathrm{sic}]^{127} \mathrm{com}$ a singular observação, de que nao aceita o nosso desafio. Nós dizemos mais; é que não o desafiamos; nem sabemos como jornalistas qual seria o campo de batalha para que o desafiássemos. Ciências? O seu jornal não trata disso. Literatura Portuguesa? Vmce já declarou magistralmente que a tinha em não mui elevado conceito (expressão feliz sua que compreende em si mesma a doutrina e o exemplo). Literatura Estrangeira? Vmce é tão avaro da que possui, que [a]inda não quis dar desse tesouro a mais pequena amostra a seus leitores. Onde poderíamos pois encontrarmos com Vmce?
\end{abstract}

\footnotetext{
126 Ibid.

127 Aqui fazemos uma errata. A resposta do Correio Braziliense foi publicada originalmente no periódico, Vol. VIII, p. 716.
} 
Sendo também $O$ Investigador uma folha subsidiada pelo governo português, algumas questões se impuseram ao longo dos anos de vigência do periódico (1811-1819), dentre elas a relação dos redatores com o poder público - nas temáticas e enfoques que seriam apresentados no periódico - e a própria sobrevivência econômica da folha. ${ }^{128}$ Diante dessa realidade, os redatores continuavam as alfinetadas no redator do Correio.

Seria por ventura nas suas reflexões, que contém os dois artigos Portugal e Brasil, que se vê serem o único objeto do seu Jornal? Aí estimamos não ter nada de comum com Vmce porque a superficialidade daquelas reflexões se tem algum vulto, é só o que lhe dão as personalidades, as notórias calúnias, e incitamentos revolucionários, de que elas abandão [sic], de maneira que todo o leitor quando acaba de as ler [sic], (e mesmo o malévolo que gosta de maledicência), acha por único resultado um verdadeiro caput mortuum. ${ }^{129}$

Mais do que tentarem circunscrever a idoneidade dos valores jornalísticos pela livre escolha dos diversos tipos de leitores, os redatores do Investigador tentavam minar o tipo de jornalismo praticado por Hipólito - segundo eles calcado em valores muito duvidosos: a calúnia e o incitamento revolucionário. ${ }^{130}$ Para o

128 Para a compreensão da questão, ver BOISVERT, Georges. "La presse périodique portugaise de Londres. Notes sur les circonstances de son apparition et de son développement." Sillages. Sus la direction de R.A. Lawton. N. 4. (1974). Poitiers: Département d'Études Portugaises et Brésiliennes de l'Université de Poitiers, 1974. p. 69-88; BOISVERT, Georges. "Le comte de Palmela et la presse potugaise libre (1816-1820) d'aprés des documents diplomatiques inédites." Arquivo do Centro Cultural Português. Paris: Fundação alouste Gulbenkian/Centro Cultural Português, 1982. p. 459-509.

129 IP, Vol.IV, p. 280.

130 Sobre a discussão acerca dos valores predominantes na imprensa da época ver: MEIRELLES, Juliana. Imprensa e poder..., cap. 2., p. 91-146. 
historiador Georges Boisvert, no entanto, a colaboração intelectual de Vicente Pedro Nolasco da Cunha era mais fictícia que real, uma vez que ele priorizava as vantagens econômicas no exercício do seu ofício. ${ }^{131}$ Em Abril de 1813, Funchal discutia a problemática do subsídio financeiro da Coroa aos jornalistas. Em documento Secretíssimo, o diplomata informava às autoridades do Rio de Janeiro que novamente passava "a consultar com os Redactores do Investigador [sobre] a precisão de lhes continuar por algum tempo mais as conveniências que lhes tem feito". ${ }^{132}$ A carência de recursos para a manutenção da folha era um desafio constante. Portanto, fazia-se necessária a busca de apoio financeiro de novos subscritores para promover a leitura no Brasil, e assim "confirmar nos ânimos Portugueses os sentimentos de lealdade e Patriotismo que Malévolos procuram destruir." ${ }^{133}$ Realmente, a dipusta entre os dois jornais estava presente em muitos campos do conhecimento: da economia à ciência, perpassando a política e a literatura. Em março de 1813, Hipólito da Costa fazia um breve comentário sobre a reflexão de um dos redatores d'O Investigador, intitulado "Regulamentos do Governo sobre o comércio em Portugal. Resposta a certa passagem do Jornal, pseudo Científico". Sem meias palavras, a análise do jornalista desqualificava os atributos de seu interlocutor e rival.

A p. 227 acha uma providência interina a respeito da legalidade dos vasos e mercadorias Britânicas, que exigem de nós algumas observações, as quais as arranjaremos de maneira, que sirva, também de resposta a um artigo, que sobre esta matéria apareceu no Jornal Pseudo Científico,

131 BOISVERT, Georges. "Le comte de Palmela et la presse potugaise libre (18161820)..., Op. Cit., p. 472

132 ANTT/ MNE_ Livro 451, N.445.

133 Ibid. (Grifo nosso). 
que se supõem o foco das ciências e boa lógica a tal ponto, que não resta nada dessas coisas boas a outro algum jornal. Quanto ao escritor de tal parágrafo ${ }^{134}$, que mostra muito bem quem é, pelo muito que se picou com nossas observações passadas, e pela confusa trapalhada de ideias com que fala todas as matérias em que se mete, e com que trata todos os negócios que tem a infelicidade de lhe cair nas mãos, melhor lhe fora não se meter a redator, e escritor de parágrafos, para jornais, para o que tem mui pouco jeito: as intrigas de Corte lhe são um tanto mais familiares: e contentar-se com ela seria mostrar prudência, já que não tem juízo. ${ }^{135}$

Sob os mais diversos temas, as réplicas e tréplicas entre os redatores da imprensa luso-brasileira produzida em Londres se sucederam ao longo de todo o período, compondo uma documentação muito rica sobre as principas preocupações vigentes no universo público no período joanino. O foco dessa disputa no campo retórico era o leitor. Porém, como bem definiu Roger Chartier, "cada leitor, a partir de suas próprias referências, individuais ou sociais, históricas ou existenciais, dá um sentido mais ou menos singular, mais ou menos partilhado, aos textos de que se apropria". ${ }^{136}$ Esse fato tornava ainda mais complexa a atividade dos homens de letras no raiar do século XIX, uma vez que eram conscientes de que dependiam dessa gama heterogênea de

${ }^{134}$ O parágrafo a que Hipólito se refere é “O Princípio de que partimos sempre em nossas observações sobre o comércio de Portugal, é um teorema geralmente admitido por todos os economistas, em todas as nações, que "o comércio deve ser livre, e que o Governo sempre lhe fará mais mal do que bem, todas as vezes que se intrometer nesta matéria em coisa alguma, além da imposição bem pensada, e cobrança bem regulada dos direitos de alfândega" e foi publicado antes da citação supracitada no texto. CB. Vol. X, p. 281.

135 Ibid.

136 CHARTIER, Roger. “Prefácio”. In: CHARTIER, R. Práticas de leitura. Trad. Cristiane Nascimento. São Paulo: Estação Liberdade, 1996. p. 20. 
leitores reais para manterem a liderança no processo de formação da opinião no espaço público. Dessa forma, os redatores buscavam conquistar a todo custo a confiança de seus interlocutores; já que esta garantia-lhes maior prestígio e credibilidade dentro da sociedade de Corte. Aos leitores, por fim, cabia-lhes o papel tanto de espectadores das habilidades do orador ${ }^{137}$, quanto de críticos de suas condutas.

Como espectadores, adentravam no universo da observação estrutural do jornal enquanto um documento com status social preciso: este fora produzido com o intuito de instruí-los acerca dos fatos presentes, e, assim, conduzi-los à reflexão. Como críticos, buscavam o rastro das contradições presentes nos diferentes discursos jornalísticos para, assim, encontrar uma verdade isenta de contradições. Na prática, o crítico tinha em si a figura do acusador e defensor em uma só pessoa. Nas palavras de Reinhart Koselleck, “o crítico eleva-se à instância suprapartidária e torna-se o advogado da razão." ${ }^{138}$ Ao se posicionar acima dos partidos políticos, tem como tarefa "estabelecer" a verdade, para assim construir o melhor dos futuros possíveis.

Um exemplo interessante desse tipo de disputa retórica ocorreu entre os meses de agosto e outubro de 1813. A discussão central girava em torno das divergências acerca da posição política de Lord Strangford diante da aplicação do Tratato de 1810 entre Portugal e Inglaterra. A crítica d'O Investigador acerca da postura do ministro foi interpretada por Hipólito como uma ação de má fé, cuja finalidade era seguir adiante com o plano de intrigar ingleses e portugueses. Afirmava o jornalista:

137 SOUZA, Roberto Acízelo de. O Império da Eloquência. Retórica e Poética no Brasil Oitocentista. Rio de Janeiro: EdUERJ, EdUFF, 1999, p. 8.

138 KOSELLECK, Reinart. Crítica e Crise... Op. Cit., p. 96-97. 
Este plano está tão palpável neste N. ${ }^{\circ}$ do Jornal Científico, desde o princípio até o fim; que não nos admiraremos se virmos todo traduzido em francês, e impresso em Paris, antes do tempo. E lá julgarão, que não é este o primeiro serviço, que antes tanto em prosa como em verso, tem os redatores feito ao Senhor Imperador Napoleão o Magno \&c. \&c. \&c. ${ }^{139}$

Para além de insinuar certa simpatia dos redatores com Napoleão, também colocava Funchal em uma situação deveras delicada: assegurava que o embaixador português "recebe em sua casa, e aparece em público com um homem condenado à morte em Portugal, por crimes de alta traição; ao mesmo tempo em que recusa admitir em sua ala a presença de homens, banidos sim de Portugal; mas sem crime, sem sentença, sem acusação." ${ }^{140}$ Não bastasse a dúvida levantada sobre o caráter de Funchal, Hipólito ainda rotulava os redatores d'O Investigador de "partidistas dos Souza", isto é, da família Souza Coutinho. Como assevera o historiador José Alves, as tensões ideológicas desse período "não podem ser reduzidas apenas a uma oposição entre utopia e política pragmática, entre pensamento filosófico e razão de Estado. Há que ter em conta, para além das ideias e das obras, das instituições e das suas práticas, a explosão da sociabilidade, da conversação, do oral, do escrito." ${ }^{141}$ Todas essas múltiplas dimensões - das correspondências diplomáticas às recepções de leituras desses periódicos -, englobavam o complexo universo da imprensa interatlântica, constituindo, dessa forma, o emergir de um novo espaço público.

139 CB. Vol. XI, p. 229.

140 Ibid. (Grifo original).

141 ALVES, José Augusto dos Santos. A opinião... Op.Cit., p. 17. 
A ampla defesa dos redatores do Investigador saía a público em outubro de 1813.

O arrumador do Armazém dá a entender que a carta que principiamos a inserir em o N. ${ }^{\circ} 26$ do nosso Jornal sobre o Tratado de Comércio entre Portugal e Inglaterra é forjada por nós. Dizemos que dá a entender, porque ele faz uma mexerufada [sic] de coisas, que mostra bem o desarranjo de sua cabeça, ou o acesso de raiva (mas raiva impotente) em que estava, quando escreveu a dita diatribe. ${ }^{142}$

Ao adentrarem na seara política, os redatores assumiam a "falta de luzes o bastante" para discutirem os pormenores do Tratado de 1810; o que não invalidava as análises da sua publicação, guiadas sempre pelo valor da imparcialidade. ${ }^{143}$ De fato, esse acordo comercial selava a preeminência britânica sobre Portugal e o Brasil. Em meio a uma guerra europeia que limitava drasticamente a perspectiva de lucros da indústria britânica, a expansão do comércio inglês para a América do Sul ganhava cada vez mais peso. Segundo Hobsbawm, a região "veio realmente a depender de importações britânicas durante as guerras napoleônicas, e depois que se separou de Portugal e Espanha, tornou-se quase que totalmente dependente economicamente da Grã-Bretanha." ${ }^{144}$ Já quanto à acusação de partidários da família Sousa Coutinho, reiteravam o seu respeito e aliança sem, no entanto, demonstrarem a subserviência apontada por "Mr. Da Costa."

Respeitamos, e respeitamos muito a família dos Souzas; bastaria para isso o dizer mal dela o arrumador do Armazém; porque ele tem empreendido a honrosa tarefa de

142 IP, Vol.VII, p. 726.

143 Ibid.

144 HOBSBAWM, E. A era das revoluções... Op. Cit., p. 51. 
ocultar o crime, e deprimir a virtude; de canonizar monstros, e de caluniar inocentes. Respeitamos a família dos Souzas; e a parte da Nação que é justa a respeita conosco, porque sabe que esta família e a nenhuma cede em honra, em patriotismo, em limpeza de mãos, e em amor a S.A.R. De resto são homens, e como tais podem errar. Somo-lhes muito obrigados; e a nossa gratidão acabará quando acabarmos de existir. ${ }^{145}$

Particularmente, tentavam justamente mostrar a deslealdade de Hipólito para com a mesma família, desde que este rompera com D. Rodrigo de Souza Coutinho. "Nunca voltamos a casaca aos nossos Benfeitores, ou amigos, quer na bonança, quer na desgraça: desafiamos o arrumador do Armazém, e todos os nossos inimigos para que apontem um só fato, que nos desminta a este respeito"146, concluíam.

O fato é que a exaltação das iniciativas socioeconômicas e culturais, tanto dos ministros portugueses pertencentes à família Souza Coutinho quanto da própria monarquia portuguesa no Brasil era recorrente no Investigador Portuguez. Em Março de 1812, por exemplo, os redatores comentavam sobre as notícias publicadas na Gazeta do Rio de Janeiro, que se referiam às atitudes do governador do Mato Grosso e seu esforço para avivar as comunicações do interior do "vasto Império do Brasil."

Na excelente Gazeta do Rio de Janeiro de 16 de Outubro próximo achamos um artigo que mostra com a maior evidência os paternais Desvelos de Sua Alteza Real o Príncipe Regente Nosso Senhor, e as suas grandes vistas que só tem por mira a Pública Felicidade, o bem de seus Vassalos em cujos corações impera. É para nós um bem doce dever

${ }^{145}$ IP, Vol. VII, p. 727

146 Ibid. (Grifo original.) 
o termos de transcrever para o nosso Jornal um artigo tão interessante; e os nossos leitores imparciais sentirão, quando o lerem o mesmo prazer sincero, e puro, que nós temos em copiar, e que todo o Português, que ama cordialmente a Glória do seu soberano, e o Bem da sua $\mathrm{Na}$ ção, deve necessariamente experimentar. ${ }^{147}$

Nesse discurso, os editores deixavam explícita a relação existente entre as duas publicações: mesmo sendo de naturezas distintas - O Investigador Portuguez, um jornal de caráter enciclopédico, e a Gazeta do Rio de Janeiro, uma folha cuja missão era cumprir o papel de um relato "fiel" da história política do tempo presente (sendo a cronologia, a narração e a coleção de documentos públicos os pontos centrais para que esse papel fosse assimilado de maneira verossímil) ${ }^{148}$-, ambas eram veículos de comunicação subsidiados pela realeza, cuja produção editorial tinha o dever de veicular a força (e o suposto sucesso) dos projetos políticos governamentais. Não era à toa que a Gazeta e O Investigador elogiavam-se mutuamente, circulando nos dois lados do oceano. Essa comunhão de ideias (ou linhas editoriais) também fazia parte de uma política cultural eficaz, da qual um dos pilares era a imprensa interatlântica.

Com a conquista de novos subscritores e, consequentemente, leitores mais bem (in)formados, vemos mais claramente a defesa d'O Investigador pelo direito à educação. No que concerne ao papel pedagógico da imprensa do período,

[...] a informação associada à formação faz da opinião pública ponto nuclear da sociedade, já que, como centro denso, influente nas decisões políticas, no comportamento

${ }^{147}$ Ibid., Vol. III, p. 88.

148 MEIRELLES, Juliana. Imprensa e poder ... Op. Cit., p. 135. 
dos homens de Estado e da própria sociedade, emerge como fator de pressão política, económica e social. ${ }^{149}$

O conceito educacional d'O Investigador, particularmente, "envolvia uma forte componente moral completando a autonomia afirmada, e fazia coincidir no plano da ética o homem social com o homem moral". ${ }^{150}$ É nesse sentido que evidenciar temas considerados de grande relevância para os leitores, como a literatura, era uma maneira de O'Investigador persuadir a Coroa de sua importância, explicitando sua autoimagem através das seguintes palavras: "que o nosso Jornal cada vez mais se faça digno de heróica nação, de quem temos tanta vaidade de ser filhos, e leais admiradores"151. Além de cumpridores competentes e responsáveis de sua missão, na visão de Adelaide Machado, os redatores do jornal se julgavam capazes de regenerar o homem através de uma concepção inovadora de cultura e de íntima relação com o desenvolvimento civilizacional. ${ }^{152}$ Em janeiro de 1814, os redatores veiculavam a reflexão "Memória em que se mostram as vantagens do Estado da Geografia Náutica nas Reais Aulas da Marinha, e o Plano do seu ensino", de D. António da Vesitação Freire de Carvalho. Neste artigo, esclareciam seus leitores sobre a indispensável necessidade do estudo da geografia em geral entre os homens civilizados. Por esse prisma, delineavam o conceito de civilização que defendiam. Vejamos:

\footnotetext{
149 ALVES, José Augusto dos Santos. O poder da Comunicação. A história dos Media dos primórdios da imprensa aos dias da Internet. Lisboa: Casa das Letras, 2005. p. 106.

${ }^{150}$ MACHADO, Adelaide Maria Muralha Vieira. "O Investigador Português em Inglaterra, Jornal Literário, Político. \& C., nos primeiros anos de publicação (1811-1813)". Lisboa: UNL/CLC, 1998. p. 484.

151 IP, Vol. VIII, p. 594.

${ }^{152}$ MACHADO, Adelaide Maria Muralha Vieira. O Investigador Português em Inglaterra, Jornal Literário, Político. \& C., nos primeiros anos de publicação (1811-1813). Dissertação de Mestrado. UNL, 1996. p. 21.
} 
[...] Sendo a civilização da espécie humana uma consequência imediata das repetidas combinações de todos os objectos físicos e morais, que apresenta a ordem do universo; e deduzindo-se as leis gerais, que dirigem a economia da espécie, da multiplicidade de observações de fatos individuais, quando se apreciam para as relações de tempo e lugares, circunstâncias que tanto servem para promover a faculdade de combinar, e deduzir resultados úteis aos interesses do Estado, do que apresentar à mocidade, pouco experiente, o quadro de todos os lugares em que podem passar-se todas as transacções da vida, combinando a ordem presente do globo com todas as situações certas ou prováveis do passado. ${ }^{153}$

A preocupação educacional era de tal monta que, em novembro de 1811, o jornal imprimia dois artigos muito relevantes na seção literatura, intitulados: "Será a educação necessária ou avantajosa [sic] às classes inferiores?" e "Misérias da ignorância e vantagens da ciência". ${ }^{154}$ Neste espaço, os redatores refletiam sobre a necessidade de se educar os súditos, com base nos dois pilares considerados fundamentais à instrução de qualidade: a ciência e a arte, sendo a primeira responsável por estender "as suas benéficas consequências ao gênero humano" e a segunda, por "adornar a humanidade". ${ }^{155}$

No primeiro artigo, a discussão girava em torno da tensão entre as classes sociais e o desenvovimento das virtudes das classes inferiores, sobretudo aquelas relativas à cultura do espírito. $\mathrm{O}$ autor não só ressaltava a falta de espaços educacionais destinados à formação dessas pessoas (escolas, academias e colégios), como também admitia a responsabilidade das classes superiores

\footnotetext{
153 IP, Vol. VIII, p. 408.

${ }^{154}$ Ibid., Vol. II, p. 21-30.

155 Ibid., p. 21.
} 
nesse processo; uma vez que, além destas terem acesso ao conhecimento em espaços específicos de valorização da cultura, ainda vedavam aos pobres a chance de "adquirir" a ciência da civilidade. $\mathrm{O}$ questionamento acerca da postura retrógrada de muitos leitores do periódico era explícito:

Mas talvez alguns de nossos leitores nos perguntem para que é dar educação aos pobres? Serão eles mais úteis nos campos, ou mais hábeis nas lojas dos nossos manufactores? Manejarão eles o malho, e os foles [sic] com mais eficácia por saber ler, ou contar do que se não soubessem o seu alfabeto, ou a sua tabuada? De certo que sim [sic]; estendendo a educação das classes inferiores nos aumentamos as suas faculdades; nós os fazemos vassalos mais respeitáveis, e mais úteis servos. ${ }^{156}$

Como filósofos responsáveis por apontar o caminho para o progresso da nação, os autores defendiam a união das classes superiores em prol das menos abastadas, para que estas pudessem adentrar no mundo das luzes. "Se pois as necessidades da sua situação os privam realmente de tudo aquilo, que se chama educação, diminuamos aquelas necessidades [...] deixemo-los participar de uma porção daquela luz, que deve esclarecer todo o homem que veio ao mundo"157, elucidavam. Já a explicação acerca da necessidade do Império Português constituir, valorizar e usufruir de todos os benefícios advindos da cultura da razão foi o tema do artigo "Misérias da ignorância e vantagens da ciência". Mais do que exemplificarem os diversos comportamentos do

\footnotetext{
156 Ibid., p. 22-23 (Grifos nossos).

157 Ibid., p. 23. Para conhecer o espaço de sociabilidade das classes menos abastadas e suas práticas culturais no período em Lisboa, ver: LOUSADA, Maria Alexandre. Espaços de Sociabilidade em Lisboa: finais do século XVIII a 1834. Lisboa: Tese de doutoramento. 1995.
} 
homem ignorante, os autores exaltavam vivamente as peculiaridades da sociedade portuguesa, nesse processo.

Leitor [...] Levanta o teu espírito com gratidão para o querido objeto do culto cristão. Vê o estabelecido num trono firmado sobre a indagação, sobre a cultura da razão humana, sobre o saber, e benevolência.[...] Louva o Autor de todos os bens, por teres nascido numa idade, e num país onde a benevoência prospera, onde a razão se cultiva, e se anima a indagação; numa palavra, onde a ciência se espande, e é apreciada pelos seus benefícios, e a moralidade, aquele código de deveres, que nós nos devemos reciprocamente, reduzida a uma ciência, está fixando as suas leis sobre a natureza do homem, e não sobre objetos mudáveis de uma nefaria [sic], e sanguinolenta, ou cerimonial, e impostora superstição. ${ }^{158}$

A cultura da razão em Portugal era indissociável da fé católica, principal marco do reformismo ilustrado português. A crítica à laica Ilustração Francesa aparece com maior nitidez em março de 1812. Sobre a vida pública e privada naquele país, antes e depois da Revolução, refletiam:

O sistema do governo, e dos costumes em França deve refundir-se primeiro que possam florescer as virtudes sociais e domésticas, ou mesmo o decoro público reassumir a sua influência. Exemplo diverso deve ser dado pelos regentes da França, se pretenderem seriamente dar eficácia a medidas legislativas, para a reforma da moral pública. Aristóteles disse já, nos seus princípios políticos, que o povo em geral se torna como os chefes que o governam. Se jamais houve país a que esta máxima pudesse aplicar-se é a França. (...) A história nos ensina, que em ponto de costume, os estados têm sido sempre tais quais seus

158 Ibid., p. 28. 
chefes; e de que toda alteração efetuada nos costumes dos grandes tem passado para os pequenos. ${ }^{159}$

De fato, a Revolução Francesa subvertia os valores do Antigo Regime. Na análise de Hobsbawm, a Declaração dos Direitos do Homem e do Cidadão (1789) foi um manifesto contra a sociedade hierárquica de privilégios nobres; o que, contudo, não significava ser a favor de uma sociedade igualitária e democrática. A atuação efetiva do Terceiro Estado, no entanto, colocava em cena um elemento de suma relevância: a vontade geral do povo passava a ser identificada à nação francesa. Essa novidade, na prática, já era a grande revolucão dos conceitos; e era justamente as consequências advindas desse processo que geravam muito medo aos detentores do poder absoluto na Europa. ${ }^{160}$

É sob esse prisma que o discurso dos redatores do jornal ganha maior sentido. Ao criticarem a cultura francesa, os autores tentavam convencer seus interlocutores das qualidades intrínsecas à ciência, sobretudo se esta fosse sempre iluminada pela ética cristã. A providência divina estava acima da humanidade, sendo responsável por "criar homens em muitas nações civilizadas, cujo amor pela moral, e pelas ciências, lançou os fundamentos de todas as vantagens, que atualmente gozamos". ${ }^{161}$ Como podemos notar, tal discurso chocava-se frontalmente com as novas possibiliades de ascensão social abertas pela Revolução Francesa: com a queda da Bastilha (1789), os franceses mostravam ao mundo que

159 Ibid., Vol.III, p. 22-23.

${ }^{160}$ HOBSBAWM, E. A era das revoluções... Op. Cit., p. 77-8. Ainda segundo o autor, "Sem dúvida, a nação francesa, como suas subsequentes imitadoras, não concebeu inicialmente que seus interesses pudessem se chocar com os de outros povos, mas pelo contrário, via a si mesma como inauguradora ou participante de um movimento de libertação geral dos povos contra a tirania."

161 IP, Vol. II, p. 30. 
as leis do homem ganhavam, definitivamente, a primazia sobre as leis divinas. Quanto às profissões, estas agora podiam ser guiadas pelo mérito e talento. Outra grande conquista revolucionária, que apontava nesta direção, foi a promulgação da Constituição de 1793, durante o governo jacobino (1792-1795). Neste documento,

[...] dava-se ao povo o direito ao sufrágio universal, o direito à insurreição, trabalho ou subsistência, e - o mais significativo - a declaração oficial de que a felicidade de todos era objetivo do governo e de que os direitos do povo deveriam ser não somente acessíveis, mas também operantes. ${ }^{162}$

O conceito de povo da Encyclopédie, tendo como referência particularmente a França da segunda metade do século XVIII, considerava-o a parte mais útil, a mais preciosa e, por consequência, a mais respeitável de toda a nação. Segundo o verbete, sendo o povo o estado geral da nação, este se opunha justamente à nobreza. Dessa forma, era composto por trabalhadores, operários, artesãos, comerciantes e financistas, além dos literatos e homens de leis. ${ }^{163}$ Entretanto, a despeito da importância da Encyclopédie para a época, é fundamental que consideremos as especificidades

\footnotetext{
162 HOBSBAWM, E. A era das revoluções... Op. Cit., p. 87.

163 PEUPLE, le, s. m. (Gouvern. politiq.). Autrefois en France, le peuple étoit regardé comme la partie la plus utile, la plus précieuse, \& par conséquent la plus respectable de la nation. Alors on croyoit que le peuple pouvoit occuper une place dans les états - généraux; \& les parlemens du royaume ne faisoient qu'une raison de celle du peuple \& de la leur. Les idées ont changé, \& même la classe des hommes faits pour composer le peuple, se retrécit tous les jours davantage. Autrefois le peuple étoit l'état général de la nation, simplement opposé à celui des grands \& des nobles. Il renfermoit les Laboureurs, les ouvriers, les artisans, les Négocians, les Financiers, les gens de Lettres, \& les gens de Lois [Jaucourt] [Page Link page 12:475] [Gouvernement politique]. Disponível em: <http://encyclopedie.uchicago.edu/>. Acesso em: 28 nov. 2010.
} 
do contexto filosófico português. Como aponta a pesquisadora Carlota Boto, uma "das marcas do Iluminismo português foi a sua dimensão religiosa, convivendo com a ideia de um Estado condutor dos assuntos temporais". ${ }^{164}$ Por essa vertente, o exemplo magno de conduta moral a ser seguida estava circunscrito à figura do chefe supremo da nação, neste caso D. João, responsável por incutir vícios e virtudes no universo público. Em um "mundo de ponta cabeça”, na expressão do historiador Cristopher Hill, era necessário a máxima vigilância sobre os súditos do Imperio Português. As insurreições vinham dos dois lados do Atlântico. Da América, a independência dos EUA (1776) e do Haiti (1791), no final do século XVIII, e o início do processo de independência da América Espanhola, no alvorecer do século XIX. Da Europa, para além da França, a autonomia da Irlanda (1782), Bélgica (1787), Holanda (1783) e Genebra (1782) ${ }^{165}$ também emergiam como exemplos de insubordinação política. ${ }^{166}$

Se por um lado a monarquia portuguesa tentava evitar a todo custo o contágio das ideias sediciosas vigentes em todos os movimentos políticos de contestação à antiga ordem; por outro, o discurso da Coroa exaltava as nações europeias que deveriam ser tidas como exemplos a serem seguidos. Neste particular, o destaque dava-se para a Inglaterra, considerada no período um exemplo singular de civilização política e dos costumes. Durante todo o governo de D. João, o diálogo com os valores da cultura britânica foi uma constante: entre os temas mais caros à política

164 BOTO, Carlota. A dimensão iluminista da reforma pombalina de estudos: das primeiras letras à universidade. Revista Brasileira de Educação vol.15 n.44. Rio de Janeiro maio/ago. 2010. p. 282.

165 Para uma análise da leitura de Rousseau sobre a tradição política de Genebra, ver VENTURI, Franco. Utopia e Reforma no Iluminismo. Trad. Modesto Florenzano. Bauru: Edusc, 2003 (Cap. 3. “De Montesquieu à Revolução”, p. 139-179).

166 HOBSBAWM, E. A era das revoluções... Op. Cit., p. 72. 
cultural joanina estavam o desenvolvimento no campo das artes e das ciências.

Tal era a integração cultural ${ }^{167}$ entre os dois países que, em janeiro de 1813, o Conde de Funchal escrevia aos ministros de D. João sobre a petição referente à ajuda financeira a José Martins Carvalho, um "artista que veio com grandes recomendações dos Senhores Governadores do Reino para aperfeiçoar-se na Pintura e Desenho; para que mostra um decisivo talento". ${ }^{168}$ A guerra peninsular impedia-o de se aperfeiçoar nos países onde o desenho e a pintura eram os grandes berços da arte europeia, como Itália e França, sendo-lhe, portanto, recomendada a escola de Londres; também um bom centro cultural. Nesta comunicação, Funchal solicitava o auxilio financeiro do Príncipe Regente para o aprimoramento artístico de seu súdito. ${ }^{169}$ Ao contrário do que nos aponta o discurso do ministro português, o sistema educacional na Inglaterra era precário. "Oxford e Cambridge, as duas únicas universidades inglesas, eram intelectualmente nulas, como o eram também as sonolentas escolas públicas", afirma o historiador Eric Hobsbawm. A ressalva do autor, porém, dá-se para a importância das Academias inglesas. Estas, contudo, por mais que

\footnotetext{
167 Utilizamos aqui o conceito de Integração Cultural, assim definido no Dicionário Crítico de Política Cultura: "Intercâmbio de produtos e serviços culturais entre localidades de uma mesma região, regiões de um mesmo país ou de países e territórios distintos, de tal modo que populações ou comunidades diferentes passem a fazer parte de um mesmo sistema de produção cultural, isto é, de modo que seus produtos culturais penetrem num certo circuito e sejam passíveis de uso e consumo por todos que fazem parte desse sistema. [...] Em todo o processo de integração está em jogo a questão das hegemonias e das diferenças [...]." COELHO, Teixeira. Dicionário Crítico de Política Cultural: Cultura e Imaginário. 3. ed. São Paulo: Editora Iluminuras/Fapesp, 2004. p. 221-222 (Grifos do original).

168 ANTT/ MNE _ Livro 451, N.389, p. 124.

169 Ibid.
} 
fossem bem conceituadas na Europa, tinham sido fundadas por dissidentes inlgeses, sendo, portanto, excluídas do sistema educacional anglicano. ${ }^{170}$

Para os redatores d'O Investigador, enxergar o universo britânico como uma importante referência cultural igualmente se estendia para os progressos que a monarquia pretendia para a América, considerada "um Continente imenso, e rico em que se está formando um vasto Império". ${ }^{171}$ Como locus de onde se emanava toda a ordem monárquia, o Novo Mundo carecia "de todos os auxílios que as Artes, e as Ciências pod[iam] prestar-lhe"172, necessitando ser detalhadamente pensado para se "elevar ao grau de esplendor e grandeza de que é suscetível". ${ }^{173}$ Segundo Maria de Lourdes Viana Lyra, esta ideia estava em consonância com os pressupostos do reformismo ilustrado, cujo projeto era a edificação de um império atlântico, onde haveria a união entre o Velho e o Novo Mundo português. ${ }^{174}$ Ainda de acordo com Lyra, uma vez que o Rio de Janeiro se tornara "o ponto referencial da unidade nacional portuguesa e o garantidor da prosperidade geral" ${ }^{175}$, o embasamento político-ideológico voltava-se para a concretização de um projeto posterior da fundação do Império brasílico.

É particularmente sob esse viés que se se estruturava o discurso político d'O Investigador. Ao assumir a missão de ter como mote o progresso dos conhecimentos científicos vigentes

\footnotetext{
${ }^{170}$ HOBSBAWM. Eric. A era das revoluções... Op. Cit., p. 46.

171 IP, N.I, Prospecto, p. 2.

172 Ibid. (Grifos nossos).

173 Ibid.

${ }^{174}$ LYRA, Maria de Lourdes Viana. A utopia... Op. Cit., p. 18. (Grifos do Original).

175 Ibid., p. 19. Uma análise instigante sobre o papel d'O Investigador Portuguez na Inglaterra é a da historiadora Angela Domingues em DOMINGUES, Angela. "Notícia do Brasil Colonial: a imprensa científica e política a serviço das elites (Portugal, Brasil e Inglaterra).” Revista Varia História. Belo Horizonte. Vol. 22. N.35, 2006, p. 150-174.
} 
na época, o jornal se comprometia a exibi-los e analisá-los tendo como foco principal a aplicação para a utilidade geral. ${ }^{176} \mathrm{Com}$ essa prédica, sua linha editorial buscava demarcar as diferenças existentes com o Correio Braziliense no que se referia à ciência. ${ }^{177}$ Entre setembro de 1812 e abril de 1813, a seção "Literatura" apresentava a tradução de Travels in the Interior of Brazil, do mineralogista inglês John Mawe. O livro era digno de ser veiculado no periódico, sobretudo por duas razões: por ser dedicado ao Príncipe Regente e ser a primeira relação impressa sobre as viagens no interior do país, com a prévia e plena aprovação do Soberano. Dois outros detalhes não menos relevantes destacavam a obra de Mawe como literatura científica: esta tinha caráter pragmático e era voltada exclusivamente para o melhoramento do Brasil. O cientista inglês admirava D. João justamente por ser "um homem dado às indagações minerológicas, e que desejava explorar o vasto campo que oferecem os seus vastos e ricos domínios"; o que o levou a patrocinar o seu projeto. ${ }^{178}$ Além disso, também o livro teve grande ressonância na Europa. ${ }^{179}$

\footnotetext{
176 IP, N.I, Prospecto, p. 2. Segundo Adelaide Machado, "Podemos acompanhar no Investigador o debate em torno das principais questões científicas coevas, principalmente no campo da medicina, já que esta ciência adquirira estatuto privilegiado em nome duma filosofia que preconizava relações de interdependência entre saúde física e moral. Sendo assim, as descobertas naquele campo, coadjuvadas com as inovações da química assumiam a máxima importância e provocavam extensa polémica. Neste âmbito vários temas foram debatidos, envolvendo os redactores nuns casos, e pondo o jornal à disposição de investigadores portugueses noutros. Ao mesmo tempo traduziam-se e divulgavam-se debates em curso em Inglaterra”. MACHADO, Adelaide. O Investigador Portuguez..., p. 25.

177 Para uma análise comparativa entre os dois jornais no que concerne à divulgação científica (sobretudo estruturalmente - os diferentes temas e seções), ver OLIVERIA, José Carlos. Os periódicos portugueses de Inglaterra e a Cultura Científica Brasileira (1808-1821). Revista da SBHC, n.19, 1998, p. 31-62; TENGARRINHA, José. Os Comerciantes e a Imprensa ... Op. Cit.

178 IP, Vol. IV, p. 369-370.

179 John Mawe (1764-1829), mineralogista inglês, viveu no Brasil entre 1807 e 1811. Acolhido pelo governo joanino, desenvolveu seu trabalho de pesquisa
} 
Travels in the Interior of Brazil teve duas edições em Londres em um período de nove anos (1812-1821). ${ }^{180}$ Durante a mesma época, a obra foi traduzida também para o francês, italiano, holandês, sueco, alemão, russo e, obviamente, para o português; com uma edição da Impressão Régia de Lisboa, em 1819, sob o título Viagens ao interior do Brasil, com huma exata descripção das Ilhas dos Açores, por João Mawe, Inglez. Authorizadas pelo Rei Fidelíssimo D. João VI, Nosso Senhor, a benefício da Livraria do Convento de S. Francisco da Cidade. ${ }^{181}$

O diálogo entre o mineralogista britânico e o governo de D. João foi tão amplo que, em julho de 1812, o Conde de Funchal remetia para o Brasil uma carta de Mawe para o Príncipe. Além da correspondência, o diplomata esclarecia o que compunha o restante da correspondência:

científica sob o convite de D. Rodrigo de Sousa Coutinho, principal ministro de D. João na época. Com mais de uma dezena de trabalhos impressos sobre mineralogia e geologia, e uma memória inédita intitulada On a Gold Mine in South America. Em 1811, já em Londres, Mawe abriu uma loja às margens do Rio Tâmisa, onde adquiriu grande renome como perito conhecedor de minerais e pedras preciosas em particular. LESSA, Clado Ribeiro de. "Introdução" In: MAWE, John. Viagens ao interior do Brasil. Trad. Selena Benevides Viana. Belo Horizonte: Editora Itatiaia; São Paulo: Edusp, 1978. p. 16.

${ }^{180}$ Publicado pela mesma editora, a Longman, Hurst, Ress, Orme \& Brown. Paternoster-Row, os títulos das duas edições são ligeiramente diferentes. Vejamos: Mawe, John. Travels in the Interior of Brazil, particularly in the Gold and Diamond Districts, by authority of the Prince Regent of Portugal. Including a Voyage to the Rio the la Plata and a Historical Sketch of the Revolution of Buenos Aires. Longman, Hurst, Ress, Orme \&Brown. Paternoster-Row. 1812. Já a edição de 1821 é intitulada Travels in the Interior of Brazil; with notices on this climate, agriculture, commerce, population, mines, manners, and customs: and a particular account of the Gold and Diamond districts. Including a Voyage to the Rio the la Plata by John Mawe, second edition.Longman, Hurst, Ress, Orme \&Brown. Paternoster-Row; and sold by the author, 149, Strand, 1821 (Grifos nossos).

${ }^{181}$ O título ainda era composto por: "a obra foi promovida pelo R.P. M. Fr. Polidoro de N.S. da Lapa, leitor de Theologia e Bibliothecario da mesma." Apud LESSA, Clado Ribeiro de. "Introdução". Op. Cit., p. 16. 
Tenho a honra de remeter igualmente um exemplar que mandei encadernar, e que J. Mawe oferece a S.A.R. assim como três exemplares para os Ex.mos Secretários de Estado. Junto vai um maço com outro exemplar, e Carta do Autor para Lord Strangford. ${ }^{182}$

A leitura de Travels era de tal forma considerada importante para o avanço científico do Brasil que o livro era antes remetido aos homens de confiança do Príncipe, para que estes não apenas conhecessem os resultados da pesquisa do mineralogista acerca do território brasileiro, mas também formulassem novas maneiras de cuidar desse imenso espaço, a partir do que propunha Mawe. Como já apontara D. Rodrigo de Souza Coutinho no final do século XVIII, o Brasil era uma parte fundamental do Império, e era necessário discutir amplamente as potencialidades do que o País poderia vir a ser. ${ }^{183}$

A estrita relação do mineralogista inglês com a orientação científica dos ministros reais é tão evidente que, em março de 1813, o viajante traduzia para o português algumas das suas sugestões acerca da limpeza e navegação dos rios, com base na experiência realizada no Rio Tâmisa. Na correspondência enviada à Corte, Funchal detalhava a conversa que tivera com Mawe:

\footnotetext{
182 ANTT/ MNE_Livro 451, N.374, p. 39.

183 COUTINHO, D. Rodrigo de Sousa. "Sobre os melhoramentos dos domínios de S. Majestade na América”, 1810, p. 25 in LIMA, Américo Pires de. Memória de D. Rodrigo de Sousa Coutinho ( $1^{\circ}$ Conde de Linhares) "Sobre os melhoramentos dos domínios de S. Majestade na América”. Coimbra: Coimbra Editora Limitada, 1948. Em relação à posição geopolítica e às medidas a serem tomadas, o ministro refletia: "A feliz posição do Brasil dá aos seus possuidores uma tal superioridade de forças pelo aumento da povoação, que se alimenta de seus produtos, e facilidade do comércio, que sem grandes erros políticos jamais os vizinhos do norte e do sul lhes poderão ser fatais [...] Para assegurar os meios da nossa superior força, é que com os olhos políticos se deve estabelecer a divisão das nossas capitanias, e aí salta aos olhos a necessidade de formar dois grandes centros de força, um ao norte, outro ao sul [...]." Ibid, p. 25-26.
} 
[Ele] assegurando [me] que um modelo dos Barcos chatos que se usam no Rio Tâmisa para limpar o seu Alveo [sic], se fosse mandado por ordem de S.A.R.P.R.N.S para a Capitania das Minas Gerais, o aumento dos quintos compensaria toda a despesa, e participações que se concedessem à ferragem que fosse do Rio de Janeiro; mandei-lhe fazer o Modelo, que, em seu nome, tenho a honra de oferecer a S.A.R. ${ }^{184}$

Mais adiante, o diplomata ressaltava a explicação do mineralogista sobre o emprego deste barco no Tâmisa, podendo o mesmo método ser empregado no Brasil "para levantar o cascalhão do Alveo dos Rios um pouco profundos, e cujo curso não se pode mudar com facilidade”. Mawe não só entregava nas mãos de Funchal o modelo encomendado, como também se responsabilizava pelas despesas do pedido. ${ }^{185}$ No fim do ano seguinte, em dezembro de 1813, Funchal recomendava a Mawe a "Colecção de Minerais pedida para S.A.R., o Sr. Príncipe da Beira”, prometida para o paquete daquele dia, 1 de Abril de 1814. Tendo ido à sua presença, o mineralogista assegurava mandá-la "bem encaixotada e cada fóssil embrulhado por si até as horas de ir com esta mala”. Por fim, esperava que o inglês não faltasse até a saída do paquete. ${ }^{186}$ Dentre as correspondências de Funchal nesse período, encontramos uma carta de caráter Secretíssimo, que pedia ao Príncipe Regente uma mercê muito especial: a concessão exclusiva de 14 anos ao negociante português, José Sebastião de França, para que este introduzisse "máquinas úteis ao Brasil" na capitania de Pernambuco. Vejamos o documento na íntegra:

\footnotetext{
184 ANTT/ MNE _ Livro 451, N.426.

185 Ibid.

186 Ibid., N. 563.
} 
Ilmo. Exmo. Sr.

Londres, 9 de Abril de 1813.

Tenho a honra de pedir a V. Ex. a, que se digne por na presença de S.A.R. o Príncipe Regente N.S. a petição que faz um muito digno negociante Português José Sebastião de França. Eu inquiri no Inventor Mr. Braanh a verdade [:] se ele se obrigava a vender ao suplicante todas as Imprensas que fossem pedidas para a Capitania de Pernambuco enquanto durasse o Privilégio. - obrigação muito real porque ele tem a Patente Ordinária (ou Privilégio Exclusivo) para 14 anos.

Com esta certeza que desfaz o embaraço que poderia haver se alguém no intervalo da Mercê exportasse a mesma Máquina para Pernambuco. $2 .^{\circ}$. Com a declaração que a Mercê não abrangeria as outras Capitanias - prometi de representar a S.A.R. que seria muito justo este privilégio exclusivo - limitado como prémio da primeira feliz lembrança e estímulo para todos os mais Vassalos que introduzirem máquinas úteis no Brasil. ${ }^{187}$

Como sabemos, não houve qualquer mudança na política impressa do governo joanino até a lei de 28 de Agosto de 1821, que suspendia a censura prévia no Brasil, permitindo aos autores e editores a liberdade de imprensa. A negação deste tão "nobre pedido" indica-nos o alto grau de importância da arte de imprimir e a preocupação da Coroa em manter sob suas rédeas o controle da produção e circulação de ideias políticas. Neste período, o negociante português Manuel Antonio da Silva Serva foi o único que obteve a licença real para imprimir a gazeta Idade d'Ouro do Brasil, produzida na capitania da Bahia, a partir de 1811. Durante boa parte de sua vigência (1811-1823), o periódico baiano esteve sob a estrita vigilância do Conde dos Arcos, governador da capitania. ${ }^{188}$

\footnotetext{
187 Ibid., N. 443 (Grifos nossos).

${ }^{188}$ NIZZA DA SILVA, Maria Beatriz. A Primeira Gazeta da Bahia: Idade d' Ouro do Brasil. São Paulo: Editora Cultrix, 1978.
} 
A discussão pública ou privada dos diversos temas que, de alguma forma, relacionavam-se à formação da opinião pública mostram como a rede de relações entre a Corte do Rio de Janeiro, Londres e Lisboa estava alicerçada em uma problemática política interatlâtica stricto sensu: a sustentação do Império Português nos dois lados do Atlântico era intrínseca à diplomacia lusitana no Velho Mundo. Nesse sentido, destaca-se o cargo de plenipotenciário em Londres. Ao ocupar o posto por 11 anos (1803-1814), o Conde de Funchal teceu relações de grande importância no diálogo entre as capitais do Império Português e Britânico. Irmão de D. Rodrigo de Souza Coutinho, D. Domingos vinculava-se ideologicamente ao "partido inglês", que defendia tenazmente uma aliança estreita entre Portugal e Inglaterra. Além disso, Strangford (plenipotenciário inglês no Brasil) era seu maior interlocutor.

Não por acaso, em finais de 1813, Funchal foi substituído pelo Conde de Palmela. ${ }^{189}$ Já em 1814, com a queda de Napoleão e a Paz Geral, Portugal reatava as relações comerciais e políticas com a França, em um explícito apoio à volta de Luís XVIII ao

189 Pedro de Sousa Hostein. Conde de Palmela. (1781-1850). Diplomata de grande envergadura, Palmela serviu a Portugal em diferentes Cortes europeias. Durante a primeira metade do século XIX, esteve presente como protagonista ou espectador em diferentes fatos histórico. No governo joanino, especialmente, atuou junto às Cortes de Cádiz, a fim de garantir os direitos de Carlota Joaquina à sucessão do pai, Carlos IV. Em 1813, foi designado ao cargo de Ministro em Londres, onde assumiu o cargo, efetivamente, por volta de 1816; uma vez que mantinha grandes diferenças com o Conde de Funchal. Neste mesmo período, porém, sua atuação foi de grande envergadura. Foi um dos três plenipotenciários portugueses nas negociações do Congresso de Viena (1815), além de ser um dos idealizadores da elevação do Brasil a Reino de Portugal e Algarves. Segundo Oliveira Lima, juntamente com D. Rodrigo de Souza Coutinho e Antonio de Araújo Azevedo, foi considerado a "trindade" dos mais distintos homens de Estado do período. SOUZA, Laura de Mello e. In: NEVES, Lúcia Bastos Pereira das; VAINFAS, Ronaldo (Org.). Dicionário do Brasil joanino... Op. Cit., p. 367-368. 
trono francês. "Para Portugal, a Paz Geral representava uma mudança profunda. Com ela, a extrema dependência em que se encontrava em relação à Grã-Bretanha começava a suscitar reticências, desde logo na própria Corte do Rio de Janeiro", ${ }^{190}$ onde coincidentemente, o Conde da Barca - o principal representante do "partido francês" -, tornava-se o ministro de maior influência do Príncipe Regente. Palmela era um dos seus homens de confiança.

Com a preeminência de Azevedo na política joanina, houve uma explícita mudança nas relações diplomáticas luso-brasileiras. Apesar do protesto veemente de Strangford quanto aos novos rumos, D. João manteve sua decisão a ponto de pedir a sua substituição ao rei da Inglaterra. ${ }^{191}$ Com o fim das guerras napoleônicas na Europa, e a distância continental, foi possível que a Coroa portuguesa vivenciasse uma maior margem de autonomia política, muito bem articulada pelos homens de Estado joanino. A mudança ministerial e as consequências diplomáticas advindas desse fato retratavam os novos tempos. E é justamente dentro da manutenção de um equilíbrio de forças entre as grandes potências europeias que destacamos as preocupações da monarquia portuguesa com as questões culturais. Portugal precisava tornar-se peça de relevância dentro desse complexo tabuleiro político. $\mathrm{Na}$ análise de Pedreira e Costa,

Enquanto a Corte do Rio de Janeiro via a monarquia portuguesa como uma potência vitoriosa, que contribuíra

\footnotetext{
190 PEDREIRA, Jorge; COSTA, Fernando Dores. D. João VI... Op. Cit., p. 286.

191 "A escolha [de Azevedo] suscitou, de resto, o protesto indignado do representante diplomático britânico, lorde Strangford, que procurou mesmo suster a nomeação. E o fez em tais termos que D. João acabou por dirigir-se à Sua Majestade britânica solicitando a sua substituição.” PEDREIRA, Jorge; COSTA, Fernando Dores. D. João VI... Op. Cit., p. 286.
} 
decisivamente com seus sacríficios e o seu Exército para a restauração da Espanha e a derrota de Napoleão, os outros países viam-na como um protetorado secundário da Grã-Bretanha [...] [que] chegara, por intermédio dos seus representantes, a ter assento no seu governo. ${ }^{192}$

Nesse contexto, a principal moeda de troca do governo português era mostrar ao Antigo Continente o quanto o Novo Mundo avançava em muitos campos do conhecimento; o que simbolicamente apregoava a integridade e ascendência dos valores do Antigo Regime à erupção revolucionária. Por esta ótica, o avanço das artes e da ciência faziam parte da agenda central da Coroa, que as considerava uma base fundamental de sustentação política do Império Português.

A entrada de José Liberato Freire de Carvalho na redação d'O Investigador e a saída do Conde de Funchal da embaixada de Londres foram dois fatores de relevância para a mudança das tonalidades políticas no discurso do jornal. Em 1812, o periódico foi criticado pelo poeta e clérigo português, José Agostinho de Macedo, absolutista fervoroso que o considerava tão incendiário quanto o Correio Braziliense. ${ }^{193}$ A partir de 1816, depois do Congresso de Viena e da elevação do Brasil a Reino Unido a Portugal e Algarve, a tônica política tornava-se cada vez mais liberal, apesar do então embaixador em Londres - Conde de Palmela - tentar cercear os artigos políticos de José Liberato Freire de Carvalho, crítico da sua postura no Congresso de Viena. ${ }^{194}$ Palmela era

192 Ibid., p. 292.

193 MACEDO, José Agostinho de. “Cartas aos Senhores Investigadores". In: Obras Inéditas de Agostinho de Macedo. Lisboa: 1900. p. 191.

194 Palmela teve importância capital no Congresso de Viena. Foi o representante português mais influente nas negociações políticas europeias que discutiam a reestruturação do Continente, após a Revolução Francesa. A despeito disso, sua proposta diplomática criou obstáculos a uma intervenção mais efetiva de 
assaz diferente de Funchal, seu antecessor, e considerava que $O$ Investigador deveria ser o jornal do Governo, e não do ministro. Ao referir-se à acirrada "guerra desigual de invectivas" entre O Investigador e o Correio, justificava essa nova diretriz para o jornal.

Para evitar semelhante inconveniente, é necessário pois que o ministro de S. Mag. em Londres não seja ou pareça ser nem redactor nem censor desse periódico. É justo porém que os redatores, a quem S. Mag. se digna auxiliar com a despesa total da impressão do jornal e da remessa dele para os estados, receberam de seus ministros instruções conducentes para os fins louváveis que o governo se propõe [...] de modo que o Investigador possa considerar-se como o Jornal do Governo e não do ministro de Portugal em Londres. ${ }^{195}$

Nesta correspondência, Palmela assumia as diretrizes da política impressa do governo joanino, particularmente no que se referia à imprensa interatlântica produzida em território britânico: a Coroa não só arcava com todos os custos de produção d'O Investigador Portuguez em Inglaterra, como também se preocupava em distribuí-lo nos principais estados do Império Português. Ademais, o ministro instruía seus redatores a escrever de forma moderada e imparcial, "que convém a um jornal adicto aos

Portugal nas negociações. Palmela propunha a Portugal que as negociações deveriam ter um caráter bilateral. Assim sendo, Portugal deveria tratar em separado com a Inglaterra, França e Espanha. Segundo os pesquisadores Jorge Pedreira e Fernando Costa, tal atitude tinha o objetivo de contrabalancear o poder de negociação da Grã-Bretanha no Congresso e também em Portugal. Tal postura, na prática, refletia o pensamento diplomático do Conde da Barca, ministro mais influente de D. João neste período. PEDREIRA, Jorge; COSTA, Fernando. D. João VI... Op. Cit., p. 291.

195 O Conde de Palmela aos Senhores Redatores do Investigador Português. ANTT/ MNE. Londres, 26 de Dezembro de 1816. Apud BOISVERT, G. "Le Comte de Palmela..., p. 482-483 (Grifo nosso). 
interesses bem entendidos do Governo e da Nação" sem, contudo, abdicar da "exposição de uma decente liberdade das suas ideias na certeza de que um governo justo, liberal e tão paternal como o de S. Mag. não se opõe à propagação das luzes nem pode recear que se interpretem nunca mal as suas intenções." ${ }^{196}$

Neste particular o artigo $3^{\circ}$ das Instruções era bem claro: os jornalistas deveriam observar com prudente silêncio as diretrizers do governo de D. João e as atitudes de seus ministros. ${ }^{197}$ Este item ia de encontro com a política diplomática de Palmela, que enfatizava com grande vigor a dimensão europeia do Imperio Português em detrimento da sua porção americana. Porém, sua postura entrava em confronto com o viés geral da diplomacia portuguesa, que valorizava cada vez mais o território americano, efetivamente desde a elevação do Brasil a Reino Unido. Note-se, ainda, que, sobretudo depois dos fatos políticos de contestação ao regime em 1817 nos dois lados do Atlântico - a insurreição Pernambucana no Brasil e a revolta militar de Gomes Freire de Andrade em Portugal -, o discurso liberal e a crítica inversão de papéis entre Brasil e Portugal nas páginas d'O Investigador era explícita, como mostra a reflexão de dezembro de 1817.

A conspiração, e revolta declarada de Pernambuco atentou diretamente contra a autoridade de El Rei e contra a integridade da nação; a conspiração de Lisboa não foi realmente contra El Rei e contra a Pátria, mas só contra o Marechal General Beresford, e influência estrangeira em Portugal. ${ }^{198}$

Os redatores ressaltavam ainda que as penas aos réus portugueses tinham sido mais severas. Segundo os escritores, essa

\footnotetext{
196 Ibid., p. 483 (Grifo nosso)

197 Ibid. (Grifo nosso).

198 IP, Vol. XX, p. 270.
} 
"injusta" diferença de tratamento jurídico era uma das fatalidades intrínsecas à supremacia política do Brasil no Império luso-brasileiro. A progressiva radicalização política de José Liberato Freire de Carvalho impediu um acordo amigável entre ele e Palmela, ambos figuras polêmicas. Em dezembro de 1818, o governo suspendeu definitivamente os subsídios ao Investigador e Carvalho assinava a sua demissão. ${ }^{199}$

O último número do jornal circulou em fevereiro de 1819. A seção "Correspondência" era dirigida "Aos Senhores Subscritores e Correspondentes do Investigador Português em Inglaterra”, participando-os do fim da publicação e agradecendo a eles a honra e liberalidade "com que sempre protegeram esta empresa literária, particularmente nesses últimos tempos". ${ }^{200}$ No mesmo ano, José Liberato Freire de Carvalho fundava o jornal O Campeão Portuguez, cuja linha editorial seria composta pela defesa da Revolução Liberal e crítica ácida acerca dos desmandos administrativos dos ministros e mesmo de D. João VI. Segundo Munaro, esse fato indica que o financimento de José Liberato provinha dos negociantes vinculados ao Club Português em Londres. ${ }^{201}$

$\mathrm{Na}$ prática, o fim d'O Investigador Portuguez em Inglaterra escancarava a aguda crise política vivenciada pela monarquia portuguesa em um âmbito antes inimaginável: iniciava-se o processo de autonomia intelectual dos homens de letras - ainda muito vinculados às intermitências do poder real -, e de seus leitores, que compunham a grande parcela da opinião pública em disputa.

\footnotetext{
199 Para análise detalhada acerca das controvérsias sobre o fim do Investigador, ver. BOISVERT, G. "Comte de Palmela... Op. Cit., p. 472-476.

${ }^{200}$ IP, Vol.XXIII, p. 474. Para a compreesão detalhada do fim d'O Investigador e a relação de Palmela com Vilanova Portugal, ver BOISVERT, G. "Le Comte de Palmela..., p. 472-473.

201 MUNARO, Luís. "A unidade do Reino luso-brasileiro... Op. Cit., p. 7.
} 


\subsection{O Patriota e O Observador Lusitano em Paris: dois periódicos pontuais}

O Patriota apareceu na Corte, em fevereiro de 1813, sob a direção do então redator da Gazeta do Rio de Janeiro, o matemático Manoel Ferreira de Araújo Guimarães. Apesar de ter tido vida curta com apenas três subscrições, entre 1813 e $1814^{202}$, foi "o primeiro jornal brasileiro a publicar artigos densos e analíticos sobre ciência e arte, cultura e letras". ${ }^{203} \mathrm{O}$ prospecto desta nova empreitada cultural na capital do Império já delimitava o diálogo com as produções científicas europeias então vigentes:

[...] socorrido em jornais estrangeiros de decidido merecimento, e (o que é mais) ajudado pelos seus úteis trabalhos, e interessantíssimas descobertas dos sábios de nosso país, esperançado em que nenhum homem de letras quererá escusar-se a cooperação de um periódico, que nos vingará da acusação de ineptos, que nos fazem autores estrangeiros, e por desgraça alguns nacionais. ${ }^{204}$

Mais adiante, o jornalista declarava que o periódico seria "consagrado às Ciências, Literatura, Política, Comércio, Agricultura etc.", sendo a primeira parte destinada às "últimas descobertas nas Ciências e Artes, com preferência as que forem devidas a Autores Nacionais, observações físicas e metalúrgicas do nosso Continente”. ${ }^{205}$ Ao contrário dos “jornais na emigração", o discurso

${ }^{202}$ Foram publicados 18 números. 12 mensais (1813) e 6 bimestrais (1814). Segundo Lorelai Kury, "A leitura do periódico permite a apreensão de um conjunto de temas e questões que constituíram as Luzes imperiais no Brasil". KURY, Lorelai. "Apresentação". In: KURY, Lorelai. (Org.) Iluminismo e Império no Brasil: O Patriota (1813-1814). Rio de Janeiro: Editora Fiocruz, 2007. p. 9.

203 Ibid., p. 9 (Grifos nossos).

204 BNRJ-OR-Doc.37, 5, 13 1B.

205 Ibid. 
inaugural d'O Patriota destacava a agricultura entre os campos do conhecimento considerados prioritários. A Encyclopédie definia a agricultura dentro das ciências da natureza e também a concebia no campo das artes ou, mais especificamente, como a arte de cultivar a terra. "Esta arte é a primeira, a mais útil, a mais ampla e talvez a mais essencial das artes"206, afirmavam os enciclopedistas. Este conceito estava em consonância com os objetivos d'O Patriota que pretendia "formar leitores, agricultores, homens de ciência, escritores" sendo voltado para o "pragmatismo das letras e das artes, [e] à utilidade”. ${ }^{207} \mathrm{Na}$ Introdução da primeira edição, Araújo Guimarães refletia sobre o nascimento de sua empreitada cultural.

Convencido de que apodreciam no esquecimento Obras assaz recomendáveis, e notícias de sobra interessantes, sem que uma mão hábil coligisse e ordenasse aqueles dispersos membros, e formasse um todo digno da atenção pública, doendo-me de que não acordasse a emulação à vista de tantos modelos das nações cultas, como se a posição física retardasse a luz a chegar ao nosso horizonte; cego à insuficiência de minhas forças, mas desperto ao brado da Pátria; eu não hesitei um momento em empreender aquilo, que todos os Literatos, primeiro que eu [sic], haviam pensado, e de que (infelizmente) abriram mão aterrados com os embaraços, que circunstâncias melindrosas tornavam quase insuportáveis. ${ }^{208}$

Muito provavelmente Guimarães se referia ao fim da Sociedade Literária do Rio de Janeiro em 1794. Espaço de intenso

\footnotetext{
206 AGRICULTURE: “Cet art est le premier, le plus utile, le plus étendu, \& peut être le plus essentiel des arts." (Ordre Encycl. Histoire de la Nat. Philos. Science de la Nat. Botan. Agricult.) [Agriculture] [Diderot2] [Page Link 1:183]. Disponível em: <http://encyclopedie.uchicago.edu/>. Acesso em: 1. dez. 2010.

207 KURY, Lorelai. “Apresentação ..., p. 12.

208 O Patriota. Introdução, p. v.
} 
debate intelectual, a Sociedade Literária foi o principal alvo de desconfiança do Conde de Resende, o vice-rei da capitania. A fim de evitar a disseminação dos ideais revolucionários franceses, que acreditava serem discutidos nesse espaço, Resende prendeu os líderes do suposto complô sedicioso: o poeta e advogado Manoel Inácio da Silva Alvarenga, Jacinto José da Silva e Marianno José Pereira da Fonseca ${ }^{209}$. Em 1813, esses ilustrados de destaque no universo intelectual brasileiro se tornaram colaboradores e subscritores d'O Patriota. ${ }^{210}$ Como salientou Marco Morel, a necessidade dessa iniciativa literária visava à conformação e consolidação de uma esfera pública cultural moderna no Brasil..211

Por esta razão, O Patriota contou com subscritores de peso na órbita política e cultural joanina. Para além das figuras da realeza - a Princesa do Brasil, Carlota Joaquina e a Infanta, Maria Izabel - encontramos políticos de grande infulência como Antonio de Araujo de Azevedo (Conde da Barca), o Conde dos

\footnotetext{
209 Diplomado em direito canônico pela Universidade de Coimbra, Manoel Inácio da Silva Alvarenga atuava como Professor de Retórica no Rio de Janeiro no ano de sua prisão. Nesta cidade sua residência tornou-se um importante ponto de encontro intelectual, tanto de reuniões informais quanto as referentes à estruturação da Sociedade Literária. Já o filósofo e matemático Marianno José Pereira da Fonseca (também diplomado por Coimbra) tinha importantes laços de amizade com vários cortesãos luso-brasileiros. SCHULTZ, Kirsten. Versalhes Tropical: império, monarquia e a Corte Real portuguesa no Rio de Janeiro, 18081821. Trad. Renato Aguiar. Rio de Janeiro: Civilização Brasileira, 2008. p. 87.

${ }^{210}$ Para o acesso aos textos desses autores publicados n' O Patriota, ver o índice do jornal organizado por Diana Zaidman, sob a direção de José Honório Rodrigues. As principais obras desses autores são: ALVARENGA, Manoel Inácio da Silva. Sátira dos Costumes. 1813; FONSECA, Marianno José Pereira da. Maximas, Pensamentos e Reflexões Morais por um brasileiro; e SILVA, Jacinto José da. Memória sobre a Cochonilha. (Na Seção de Agricultura e Botânica).

211 MOREL, Marco. "Pátrias Polissêmicas: República das Letras e Imprensa na Crise do Império Português na América”. In: LORELAI. (Org.) Iluminismo e Império no Brasil. O Patriota (1813-1814). Rio de Janeiro: Editora FIOCRUZ, 2007. p. 16.
} 
Arcos e o Conde das Galveias. ${ }^{212}$ A Condessa de Linhares, viúva do Conde de Linhares, cujo nome também aparece na primeira subscrição, ${ }^{213}$ é o principal destaque feminino da lista de assinantes, composta, majoritariamente, por pessoas ilustres da nobreza portuguesa. $\mathrm{Na}$ área administrativa, as figuras de relevo eram a do Intendente Geral da Polícia, Paulo Fernandes Viana e a do físico-mor, Manoel Viera da Silva, autor do livro Reflexões sobre alguns dos meios propostos por mais conducentes para melhorar o clima do Rio de Janeiro. ${ }^{214}$

Quanto aos homens ligados ao comércio livreiro, temos: Francisco Luiz Saturnino, Manoel Joaquim da Silva Porto e Paulo Martin, responsável pela venda da primeira subscrição do jornal na sua loja, localizada na R. da Quitanda, n. 34. Na lista inaugural dos assinantes, o nome do livreiro aparece da seguinte forma: "Paulo Martins [sic] e filhos em Lisboa, 25 ex.." ${ }^{215}$ Muito possivelmente, assim como seu pai, seus filhos estavam ligados ao comércio livreiro no Reino e tinham se encarregado da distribuição desses 25 exemplares da folha para a Imprensa Régia de Lisboa e outras tipografias do Reino que mantinham as devidas

212 D. João de Almeida Melo e Castro (Conde das Galveias) ocupou o cargo de Ministro e Secretário dos Negócios Estrangeiros e da Guerra, entre janeiro de 1812 e janeiro de 1814. Ou seja, era o principal ministro e conselheiro de D. João nas duas primeiras subscrições d'O Patriota; a partir de fevereiro de 1814. 213 Apesar de o Conde de Linhares ter falecido em janeiro de 1812 e a primeira edição de $O$ Patriota ter saído exatamente um ano mais tarde, esse é um importante indício de que este projeto literário tenha sido gestado em vida por Linhares e seu grupo político. Também é possível que ele tenha deixado reservada uma quantia de suas finanças para esse projeto, motivo pelo qual aparece o nome de ambos, Conde e Condessa de Linhares. Ou talvez, o seu nome apareça como uma forma de reverência à sua memória, feita por seus aliados.

214 Rio de Janeiro: Impressão Régia, 1808.

215 O Patriota. Junho de 1813, p. 108. Na 2a subscrição, seu nome aparece "Paulo Martin e filhos em Lisboa, 25 exemplares”, o que dá maior sustentabilidade à nossa hipótese. 
licenças reais. ${ }^{216}$ No universo dos espaços de cultura e seus agentes culturais ligados ao governo de D. João, destacamos: a Biblioteca Pública da Bahia, o bibliotecário da Corte, Luiz Joaquim dos Santos Marrocos, o bispo capelão mor; os diretores da Impressão Régia - José Bernardes de Castro, Marianno José Pereira da Fonseca (ambos colaboradores d'O Patriota) e José da Silva Lisboa - que, juntamente com Francisco da Borja Garção Stockler, também eram censores régios. ${ }^{217}$ Curiosamente, ainda encontramos a assinatura de um Enviado dos Estados Unidos. Este fato talvez possa indicar que, da mesma forma que jornais norte-americanos aportavam no Brasil, eram lidos, editados e publicados na Gazeta do Rio de Janeiro, também a Gazeta e O Patriota poderiam fazer parte do rol de periódicos lidos nos Estados Unidos.

Para além de estreitar a rede de contatos entre os principais agentes culturais do governo joanino, o jornal tinha como principal objetivo divulgar as linhas gerais da concepção desse iluminismo luso-americano. ${ }^{218}$ Diferentemente do Correio Braziliense,

\footnotetext{
216 Sobre a atuação do livreiro Paulo Martin Filho e as suas relações em Lisboa, ver: SOUZA, Simone. Primeiras Impressões... Op. Cit., p. 48-50.

217 Para maiores detalhes sobre as funções e atuação da Direção da Impressão Régia, ver CAMARGO, Ana Maria de Almeida; MORAES, Rubens Borba de. Bibliografia da Impressão Régia... Op. Cit.; MEIRELLES, Juliana. Imprensa e poder..., p. 64-82. Sobre a vida de Lisboa no período tanto quanto sua atuação como censor régio ver ALGRANTI, L. Livros de Devoção, Atos de Censura... Op. Cit., especialmente cap. 4 e 5.

218 A expressão iluminismo luso-brasileiro é da historiadora Lorelai Kuri. Segundo a autora, "O Patriota pretendeu influenciar a própria formação dos homens de letras locais, tanto na qualidade de leitores, quanto na de escritores. Seu didatismo é também manifesto em sua maneira de fundar uma síntese do que era sabido sobre as terras brasileiras. Essa síntese, no entanto, tinha por referência o quadro europeu, com o qual os principais colaboradores estavam familiarizados. Assim, é nessa confluência entre a construção de uma singularidade brasileira, inserida no universo imperial português, e os modelos científicos dos centros europeus que se constitui uma das principais manifestações do iluminismo luso-americano." KURY, Lorelai. "Descrever a Pátria, difundir o saber... Op. Cit., p. 142.
} 
d'O Investigador Portuguez e d'Observador Lusitano em Paris, que discutiam pela perspectiva europeia os benefícios que a arte e a ciência trariam para o progresso do Império Português, o periódico debateria os mesmos temas pela perspectiva americana.

Sendo o principal objeto deste Periódico fazer conhecer este continente, tão ignorado, ou tão desfiguado por aqueles que às cegas, ou prevenidos tem escrito a seu respeito; e desejando aproveitar todas as notícias verídicas, que chegam a nossa mão, temos hoje a satisfação de apresentarmos ao Público o progresso da povoação e civilização dos lugares mais centrais, há pouco desertos ou infestados por nações bárbaras e feroces [sic] ${ }^{219}$

Durante este período, O Patriota circulou no Brasil, em Portugal e na Inglaterra, sendo uma importante fonte de informação da história do país, com ênfase para o viés cultural. ${ }^{220} \mathrm{Com}$ a reflexão supracitada, o redator aprofundava as informações já veiculadas na Gazeta do Rio de Janeiro sobre a criação de uma povoação denominada São Pedro de Alcântara, às margens do Rio Tocantins, onde habitava a nação dos índios Macameirans. $\mathrm{Na}$ Gazeta, Araújo Guimarães havia justificado o novo projeto pelo avanço civilizacional da região: com a população devidamente domesticada, o "país" já poderia usufruir das facilidades comerciais advindas da comunicação por terra entre as capitanias do Pará e do Maranhão. ${ }^{221}$ Aliás, desde a chegada da Corte, o projeto de civilização dos índios brasileiros era uma preocupação da monarquia portuguesa. Já em fevereiro de 1809, era publicada na seção "Avisos" da Gazeta do Rio de Janeiro a Carta Régia de 2

219 O Patriota, Setembro, 1813, p. 61.

220 Para ter acesso à lista dos assinantes d'O Patriota ver Subscrição 1, n. 6, p. 103-108 e Subscrição 2, n. 6, p. 89-91.

221 GRJ. 1813. N65 (Grifos originais). 
de Dezembro de 1808, dirigida ao Governador e Capitão General da Capitania de Minas Gerais e vendida na Loja da Gazeta e do livreiro Manoel Jorge. O documento dava "várias providências sobre a Civilização dos Índios, Navegação do Rio Doce, Cultura, e Mineração dos Terrenos, escolha de Eclesiásticos para a educação Religiosa, e Civil do Gentil, \& c." ${ }^{222}$, já enunciando os diferentes vieses que comporiam esse processo civilizatório.

Já o artigo d'O Patriota enfatizava a trilha do progresso e da civilização detalhadamente arquitetada pelo governador da capitania de Goiás e pelos fazendeiros portugueses que por lá viviam. "Construídas as habitações, se cuidou em estabelecer oficinas, fazer plantações, erigir uma casa de oração e outros místeres"223, revelava o escritor. Com total aprovação do Príncipe Regente, os índios eram "acolhidos" pelos portugueses da região e iam, pouco a pouco, civilizando-se:

Instruídos na nossa língua, doutrinados na Religião, e educados nos usos e costumes; e temos a satisfação de anunciar que amaciados e contentes se dão ao trabalho da agricultura, não tendo fugido um só para as suas aldeias, como muito facilmente poderiam fazer [...] fornecidos de instrumentos, de que careciam, tornados úteis à socieda$d e$, cultivam a terra, e esta lhes paga liberalmente os seus suores. $^{224}$

A tentativa de inserção desses gentios nos códigos culturais do colonizador - como a língua e a religião - tinha o intuito de torná-los mais aptos para o trabalho e, consequentemente, mais úteis na colaboração do progresso da região. Portanto, para tirá-los

${ }^{222}$ Ibid., N44 (Grifos originais).

223 O Patriota, Setembro, 1813, p. 62.

${ }^{224}$ Ibid., p. 63-64 (Grifos nossos). 
da barbárie e torná-los civilizados, o processo de conquista não tinha sido nada pacífico. ${ }^{225}$ A batalha da Junta da Civilização e Conquista dos Índios contra os botocudos foi tema da Gazeta do Rio de Janeiro de 17 de maio de 1809.

O Rio de Janeiro também foi um tópico muito presente nos artigos d'O Patriota. Como mostra a historiadora Tânia Ferreira, os assuntos mais comuns eram "as primeiras ocupações, a luta contra os franceses, a insegurança nas ruas, os principais episódios políticos". 226 Era necessário que os súditos aquém e além-mar, assim como o mundo europeu, conhecessem a história e as transformações da nova capital do Império Português, especialmente as mais recentes e que colocavam D. João na posição de redentor do Novo Mundo. No bojo dessas mudanças, a comunicação entre a Corte e as capitanias brasileiras ganhava grande destaque. Correios e estradas eram abertos para facilitarem a integração do território; o que deu impulso decisivo no que se refere à comunicação interna. ${ }^{227}$ Enfim, se o Brasil vivenciou transformações estuturais significativas no período, fazia parte da política cultural da Coroa que estas fossem amplamente divulgadas. Todos os jornais apoiados e patrocinados pela monarquia destacavam as medidas inovadoras e cumpriam tal finalidade. Na edição de junho de 1814, por exemplo, O Investigador Portuguez anunciava o recebimento dos doze números d'O Patriota, saídos no Rio no ano anterior.

Sobre o processo de conquista dos Macameirans, ver O Patriota. Setembro de 1813. p. 62-64. Sobre a violência na colonização dos Botocudos, ver. Gazeta do Rio de Janeiro. 1809. N.71. Para a análise dessa mesma questão, ver: SILVA, Maria Beatriz Nizza. A Gazeta do Rio de Janeiro (1808-1821): cultura e sociedade. Rio de Janeiro: EDUERJ, 2007. p. 238-242.

226 FERREIRA, Tânia M. Tavares Bessone da Cruz. "Redatores, Livros e Leitores em O Patriota”. In: KURY, Lorelai. (Org.) Iluminismo e Império no Brasil: O Patriota (1813-1814). Rio de Janeiro: Editora Fiocruz, 2007. p. 56.

227 PEDREIRA, Jorge; COSTA, Fernando. D. João VI... Op. Cit., p. 271. 
Vemos com o maior contentamento imaginável quanto as artes e as Ciências prosperam em aquele abençoado país, e como a presença de S.A.R. tem feito indústria e actividades dos habitantes daquelas vastas Regiões [... $]^{228}$

A valorização da presença de El Rei no Brasil era benéfica, sobretudo no que se referia ao avanço das atividades úteis, no campo das artes e ciências, como a Estatística, cujos artigos seriam publicados n' O Investigador "para darmos a conhecer à Europa o interior de um país que por tantos séculos tem estado por assim dizer, escondido aos olhos do mundo, apesar de merecer tanto o ser conhecido e aproveitado". ${ }^{229}$ Já em novembro de 1808 , no artigo denominado "Da Estatística” o redator da Gazeta do Rio de Janeiro esclarecia seus leitores sobre a importância dessa ciência. "A Estatística tem por objeto fazer conhecer as forças físicas, morais e políticas de um País, e se pode comparar à Anatomia; pois ensina a fazer a dissecação do Corpo Social para depois examinar separadamente cada uma de suas partes" ${ }^{230}$

Para além de o novo periódico tratar de temas considerados respeitáveis, também o avanço das reflexões inovadoras de seus colaboradores era exaltado.

Até parece, pela sua tão bem principiada carreira, em que tem desenvolvido grandes esforços sobre objectos mui variados e úteis, que darão mui depressa muito o que aprender e imitar à Mãe Pátria, que desgraçadamente nem sempre tem olhado para as artes e para as Ciências com aquela importância que elas devem merecer a todos os povos, e Governos que não querem fazer uma figura insignificante entre os mais indivíduos da grande família social. ${ }^{231}$

${ }^{228}$ IP, Vol. IX., p. 656.

229 Ibid.

230 GRJ. 1808. N.22.

231 IP, Vol. IX, p. 656. 
Para os redatores d'O Investigador, os colaboradores d'O Patriota estavam aptos tanto a aprender quanto a ensinar à mãe pátria o devido valor que deveria ter as artes e ciências na sociedade. Como podemos notar, a coerência da estratégia discursiva governamental é reiterada nos diferentes veículos de comunicação por eles produzidos, seja a Gazeta do Rio de Janeiro, $\mathrm{OPa}$ triota ou $O$ Investigador Portuguez em Inglaterra. Toda essa valorização real tinha uma razão de ser: como sede da monarquia desde 1808, os olhos da comunidade luso-brasileira que vivia em Londres estavam muito voltados para o Brasil. Já deste lado do Atlântico, era preciso repensar o sentido da história do Império Português. Segundo o historiador Manoel Salgado Guimarães,

Na melhor tradição do iluminismo setecentista, o jornal filiava-se a uma concepção de história como mestra da vida, como condutora dos homens pelo mundo, guiados pelos exemplos hauridos dos homens do passado. História e política parecem indissociáveis nessa perspectiva, uma vez que cada vez mais o exercício desta demanda o conhecimento adequado daquela. ${ }^{232}$

Ao lerem, discutirem e divulgarem na Europa as notícias de diversas naturezas vigentes n'O Patriota, os redatores d'O Investigador não apenas mostravam as transformações políticas $\mathrm{e}$ culturais que paulatinamente vinham ocorrendo no país, mas também participavam ativamente desse processo de mudanças históricas ocorridas na própria concepção do Império Português. ${ }^{233}$ Nesse sentido, exaltar a preponderância do Brasil na

232 GUIMARÃES, Manoel Luiz Salgado. "As luzes para o Império: história e progresso nas páginas de O Patriota”. In: KURY, Lorelai (Org.) Iluminismo e Império no Brasil:.... Op. Cit., p. 67.

${ }^{233}$ Para conhecer as transformações nesta concepção, ver: ALEXANDRE, Valentim, Os sentidos do Império: Op. Cit.; LYRA, Maria de Lourdes Viana. 
prática e a ampla utilidade dos ensinamentos teóricos colocava a discussão do papel das artes e das ciências na esfera pública. Em ambos os lados do Atlântico, a agricultura era o maior exemplo. Em Memória sobre a cultura dos algodoeiros, o renomado médico brasileiro Manoel da Camara Arruda ressaltava a relação do homem com a natureza. ${ }^{234}$ Vejamos:

A necessidade e o acaso são as duas principais mãys ou fontes [sic], donde nascem as ciências e as artes: as necessidades crescem, e se multiplicam à proporção que se civilizam os povos; nos homens que vivem rusticamente, perto, para assim dizer, de uma vida selvagem, as suas necessidades não se estendem a muito: assim as mais antigas artes e ciências devem ser aquelas que interessem a existência e o cômodo, tal qual podiam ter os primeiros homens, vivendo frugalmente, formando quando muito

A utopia... Op. Cit.; SILVA, Ana Rosa Cloclet da. Inventando a Nação:... Op. Cit.; SOUZA, Iara Lis Carvalho. Pátria...Op. Cit.

${ }^{234}$ Manoel da Camara Arruda (1752-1810) era filho do agricultor Francisco de Arruda Câmara e D. Maria Saraiva da Silva. Realizou seus estudos preliminares na cidade de Goiana, Pernambuco, onde foi ordenado padre no Seminário dessa cidade (1773), adotando o nome de Frei Manuel do Coração de Jesus. Estudou na Universidade de Coimbra, em Portugal, e doutorou-se e em Montpellier, na França. Foi correspondente das Ciências de Agricultura em Paris e da Academia Real das Ciências de Lisboa, sendo na época da publicação do artigo, um naturalista empregado ao serviço da monarquia portuguesa, na capitania de Pernambuco. No final do século séc. XVIII, classificou a flora paraibana e produziu inúmeros trabalhos científicos sobre botânica, zoologia e mineralogia. Deixou uma importante bibliografia: Centúria (nunca foi publicada); A memória sobre a cultura do algodoeiro, 1797; Dissertação sobre as plantas do Brasil, 1817; Discurso sobre a vitalidade da instituição de jardins nas principais províncias do país, 1810; Aviso aos lavradores sobre a suposta fermentação de qualquer qualidade de grãos ou pevides para aumento da colheita, Lisboa, 1792; Memórias sobre as plantas de que se podem fazer baunilha no Brasil, (nas memórias da Academia Real das Ciências de Lisboa, v.40, 1814). Disponível em: <http://bndigital.bn.br/redememoria/arrudadacamara.html >. Acesso em: 25 mar. 2011. O Patriota. Janeiro de 1813, p. 22. 
pequenos arraiais, de costumes simples, como eles mesmos, saídos há pouco das mãos da Natureza. ${ }^{235}$

De início, dois aspectos deste artigo nos despertam a atenção: a atualidade de seus ensinamentos na arte de tecer (o texto é de 1797) e o fato de ter sido publicado na seção "Agricultura" já na primeira edição d'O Patriota. Camara indicava mais adiante que a necessidade de sobrevivência era a mola-mestra do homem no caminho para a civilização. Portanto, fazia-se urgente veicular o conhecimento dos principais meios que garantiriam o sucesso deste desafio. "Pelo que a Agricultura dos alimentos, a Medicina, a Cirurgia que interessam imediatamente à saúde, e a existência, devem ocupar o $1^{\circ}$ lugar na ordem dos tempos"236, instruía o homem de ciência. No mesmo ano, era veiculado n'O Investigador Portuguez uma carta política intitulada "Sobre o melhoramento da Agricultura Portuguesa”. ${ }^{237}$ Neste diálogo com os nobres súditos da monarquia, o autor explicava as razões da revalorização da agricultura em Portugal, sobretudo em um momento político tão conturbado.

É dificultozíssimo [sic] poder-se alguém persuadir, que seja possível subsistir Reino algum sem cultura, e sem uma cultura muito ativa, e cuidadosa; quanto esta mais se aumenta [sic], tanto mais forte se faz o povo por esta causa; sendo pelo contrário evidente prova de miséria, pobreza, e pequena povoação as terras incultas. [...].

Ao relacionar a agricultura à prosperidade econômica do Reino, o escritor advertia os governos de sua responsabilidade no encaminhamento deste processo.

235 CAMARA, Manoel Arruda. "Memória sobre a cultura dos algodoeiros", 1797. In: O Patriota. Janeiro 1813, p. 23 (Grifos nossos).

236 CAMARA, Manoel Arruda. "Memória sobre a cultura dos algodoeiros", 1797. In: O Patriota. Janeiro 1813, p. 23 (Grifos nossos).

237 IP, Vol. VIII, p. 223-228. 
A natureza dos governos é quem determina a sorte dos lavradores, e a maior, ou menor vigilância da cultivação. [...] E que preciosos exemplos não colhem os homens da cultura! Nenhuma dependência nos estados deixa [sic] de ter com ela necessária conexão: alimentos, povoação, artes, comércio, navegação, exércitos, rendas, classes, riqueza: tudo a agricultura sustenta, tudo dela depende, e quanto mais cresce e se revigora, tanto mais os Reinos florescem, e se aumentam por terem no seu âmago maior número de recursos. ${ }^{238}$

A agricultura como meio indispensável do esplendor político da nação portuguesa. Eis o debate que o escritor desejava reavivar na esfera pública, sobretudo para os ministros reais nos dois lados do Atlântico, os vigilantes da sociedade luso-brasileira. O recado estava dado: era, agora, necessário ver florescer os frutos. Entretanto, não era novidade que o triunfo deste empreendimento dependia do modo como a monarquia portuguesa concebesse a educação dos lavradores, em particular, e de seus súditos, em geral. "Separar o menos que for possível a prática da teoria. Quem possui a primeira com uma facilidade compreende e alcança os princípios teóricos e deles se serve utilmente para dirigir as suas operações"239, afirmava o médico português Francisco Solano Constâncio, ao debater as "condições essenciais de um bom método de ensinar a fundo as ciências naturais e todas as artes práticas" ${ }^{240}$

No raiar de 1815, este mesmo médico anunciava ao público o nascimento d'O Observador Lusitano em Paris. De sua autoria, o jornal circulou na capital francesa entre janeiro e abril do

\footnotetext{
238 Ibid., p. 223-224.

239 CONSTÂNCIO, Francisco Solano, "Ideias sobre a Educação da Mocidade portuguesa...” Op. Cit., p. 396.

240 Ibid.
} 
dito ano. Diferentemente do Correio Braziliense e d'O Investigador Portuguez em Inglaterra, ambos produzidos em Londres, o título do novo periódico já delimitava o locus onde as ideias seriam debatidas: o "jornalismo na emigração" também era pensado, produzido e debatido em Paris, a "inimiga" capital revolucionária e principal centro político de Napoleão Bonaparte e seus aliados, cuja queda ocorrera em finais de 1814. Com o Observador Lusitano em Paris, Solano Constâncio tinha o objetivo de refletir sobre o destino político da Europa, com foco particular para a monarquia portuguesa.

Contudo, a volta inesperada de Napoleão a Paris e o governo dos Cem Dias foram os fatores responsáveis pela vida efêmera d'Observador Lusitano, que tinha como seu redator um homem cuja "envergadura intelectual e a formação de suas convicções liberais, não cedia em nada a Hipólito José da Costa". ${ }^{241}$ Porém, diferentemente de Hipólito, a sua pena esteve muito mais voltada ao enaltecimento do papel político exercido pela monarquia portuguesa no período joanino; o que não o eximia de fazer suas próprias críticas, mormente no que se referia ao sistema educacional português. Neste particular, entretanto, tal problemática era estendida a todo o continente europeu: nenhuma nação dita civilizada era poupada em suas reflexões - Inglaterra, França e Alemanha, respeitando as suas pecualiridades históricas, também tinham muito a melhorar. Segundo o homem de letras, a educação europeia ainda era para uma pequena elite de letrados. ${ }^{242}$

Na seção "Discurso Preliminar" d'Observador Lusitano em Paris, o jornalista circunscrevia o seu plano de trabalho por dois

\footnotetext{
${ }^{241}$ BOISVERT, G. "La Presse Periodique Portugaise de Londres..., Op. Cit., p. 72-73. ${ }^{242}$ CONSTÂNCIO, Francisco Solano. "Ideias sobre a Educação da Mocidade portuguesa...", Op. Cit., p. 390-401.
} 
pilares centrais da concepção de imprensa europeia do período: as bases da responsabilidade de um redator e o diálogo profícuo com os seus leitores. ${ }^{243}$ Já de início, Constâncio ressaltava a relação existente entre política, arte e ciência para a "propagação das luzes, e a extensão das relações comerciais entre as nações" ${ }^{244}$ Tal proposição ganhava maior notoriedade sobretudo em meio à ebulição política e militar do Velho Mundo advinda da Revolução Francesa. "A política, que nos séculos passados era exclusivamente a ciência dos gabinetes e a ocupação dos homens de Estado, se tem tornado nos nossos tempos o objecto da curiosidade de todos", afirmava o escritor. ${ }^{245}$ Desde o final do século XVIII, a política passava a ser concebida como um corpo de conhecimento autônomo, com conceitos bem definidos ${ }^{246}$ tanto pelos governantes, quanto pela própria elite ilustrada. Mormente com o sucesso da Encyclopédie, esta compreensão impunha aos detentores do poder político e à sociedade em geral uma nova discussão acerca dos usos e conceitos da ciência. Como afirma o historiador João Luís Lisboa, pouco a pouco se ia formando uma "consciência da necessidade de conjugar saber e atuação política, como [também] é clara a relação entre intervenção científica e o questionar das estruturas sociais e económicas". ${ }^{247}$

Esta relação fica mais evidente no discurso do médico no periódico, quando ele agradece o fato de ter sido pensionista do governo português em 1791, ano em que se diplomou nos estudos realizados em Edimburgo e Londres: "À munificiência desta

${ }^{243}$ MEIRELLES, Juliana Gesuelli. Imprensa... Op. Cit., p. 91-154.

${ }^{244}$ CONSTÂNCIO, Francisco Solano. "Ideias sobre a Educação da Mocidade portuguesa... Op. Cit., p. ij.

${ }^{245}$ Ibid. (Grifos nossos).

246 LISBOA, João Luís. Ciência e Polílita: ler nos finais do Antigo Regime. Lisboa: CLC/UNL, 1991. p. 157.

${ }^{247}$ Ibid., p. 100. 
Senhora ( $\mathrm{D}^{\mathrm{a}}$ Maria I) liberalmente continuada por seu Augusto Filho, o Príncipe Regente, devo em grande parte a minha educação". Tal atitude fazia parte da expedição empreendida pela Coroa, cuja finalidade era a aprendizagem e aperfeiçoamento da medicina e da cirurgia, considerada pelo escritor uma importante ciência ${ }^{248}$ para o avanço do Reino.

Principalmente diante dos avanços científicos e tecnológicos propugnados pela Revolução Industrial na Europa, a questão da especialização do trabalho ganhava cada vez mais centralidade. Na Inglaterra, particularmente, a argumentação liberal de John Locke teve muita aceitação. Ao conceber a constituição do Estado como uma sociedade anônima cujos acionistas são os proprietários, o filósofo colocava em pauta o lugar do trabalhador na sociedade civil. Para a historiadora Maria Stella Bresciani, tal concepção

Possibilitou diferenciar a propriedade do corpo das outras formas de propriedade e localizar o trabalhador dentro da sociedade do trabalho mas fora da comunidade política. [...] A imagem pública do trabalho relaciona-se especificamente com o mercado, não vem colada à imagem do cidadão politicamente ativo. ${ }^{249}$

Diante dessas mudanças de ordem sociopolítica, a questão da organização do espaço público na Inglaterra era intrínseca às tensões referentes à determinação do sistema de trabalho. O processo de autonomização das artes e dos ofícios - já muito

\footnotetext{
${ }^{248}$ O Observador Lusitano em Pariz..., p. 83. Para uma análise mais detalhada sobre o ensino da medicina em Portugal, ver: SOUSA, Maria Leonor Machado de. "The Ghost" e Francisco Solano Constâncio. Lisboa: Universidade Nova, 1978. p. 10-22.

249 BRESCIANI, Maria Stella Martins. Londres e Paris no século XIX. O espetáculo da pobreza. 2. ed. São Paulo: Ed. Brasiliense, 1984. p. 89.
} 
presente na Europa do início do século XIX -, teve, em estágio mais avançado, a especialização da sociedade industrial, que passou a reger suas atividades gerais. Tal fato impôs novas reflexões dos homens de letras europeus. É justamente diante de tal realidade que Solano Constâncio pautava a temática de um importante ensaio, em que discutia a formação da mocidade "à virtude, às ciências e às artes úteis". ${ }^{250}$ Ao valorizar a educação como cerne central para o progresso científico, concebia-a no campo das artes, isto é, como a arte de ensinar ${ }^{251}$, defendendo a necessidade de um método eficiente de ensino das "ciências que se compõem da Medicina ou arte de prevenir as doenças dos Homens". ${ }^{252}$ De acordo com o dicionário de Moraes e Silva, a educação estava vinculada à criação de alguém, ao ensino das coisas, aquilo que aperfeiçoa o entendimento ou dirige a vontade e, sobretudo, àquilo que respeita ao decoro. ${ }^{253}$ Apesar de Francisco Solano Constâncio ter vivido boa parte da sua vida em Paris, ele foi sempre um súdito leal da monarquia portuguesa, mesmo tendo se naturalizado francês, por volta de $1820 .{ }^{254}$

A veiculação dos descobrimentos no campo das artes e das ciências foi um dos destaques das preocupações do médico português nesta obra periódica, política e literária como a definiu em seu "Discurso Preliminar". Nas palavras do escritor, dava-se preeminência, nomeadamente, "[a] aqueles [conhecimentos] que

\footnotetext{
250 CONSTÂNCIO, Francisco Solano. "Ideias sobre a Educação da Mocidade portuguesa nas Ciências Físicas e nas Artes”. In: SOUSA, Maria Leonor Machado de. Portugal e o mundo nos primeiros decênios do século XIX: Francisco Solano Constâncio. Lisboa: Arcádia, 1979, p. 383.

251 Ibid., p. 385.

252 Ibid., p. 388.

253 Dicionário Moraes e Silva, Vol. I., p. 647.

${ }^{254}$ Cf. SOUSA, Maria Leonor Machado de. "The Ghost” e Francisco Solano Constâncio. Lisboa: Universidade Nova, 1978. p. 88.
} 
em julgar poderem ser com mais utilidade adoptados entre nós, serão expostos com clareza acompanhados das reflexões práticas." Pedagogicamente, o redator incitava de forma explícita os seus leitores a fazerem uma leitura ativa das novas informações surgidas nestes campos do saber para, assim, executarem com inteligência os inventos úteis à manufactura. ${ }^{255} \mathrm{~N}^{\prime}$ Observador $\mathrm{Lu}$ sitano em Paris, a agricultura aparecia como uma de suas preocupações principais, sendo considerada central para o desenvolvimento econômico da monarquia portuguesa:

A agricultura mãe de todas as artes e origem principal da riqueza dos povos, acabrunhada em Portugal como em quase toda a Europa tem feito rápidos progressos, terá um distinto lugar no Observador; e nele se achará uma notícia do que aparecer de mais interessante sobre este importantíssimo objecto $[\ldots] .{ }^{256}$

Se, para Francisco Solano, a agricultura era concebida dentro do campo das artes, para o acadêmico português, Mendes Trigoso, a mesma atividade era a primeira das ciências, por isso mesmo servia de base e prosperidade dos estados. ${ }^{257}$ Mesmo que os dois pensadores vissem a agricultura por óticas relativamente diversas - da arte e da ciência - também, para ambos, a agricultura tinha uma importância capital para o progresso do Estado e dos povos. Nessa altura, por “'Sciencia e Artes' [sic] entende-se geralmente a procura da realidade terrena que o homem pode conhecer e sobre a qual pode, em muitos casos, agir" ${ }^{258}$, afirma João Luís Lisboa.

\footnotetext{
255 “Discurso Preliminar" In: O observador Lusitano em Paris, p. iv.

${ }^{256}$ Ibid., p. iv-v.

257 Cf. Memórias Económicas da Academia das Ciências de Lisboa, t. V., 1815, p. 63. (Grifo nosso).

${ }^{258}$ LISBOA, João Luís. Ciência e política... Op. Cit., p. 89-90.
} 
Apesar das críticas de Francisco Solano Constâncio aos governadores do Reino no que concerne à lógica da censura portuguesa em relação aos periódicos produzidos no exterior (especialmente em relação às diferenças de comportamento diante do seu periódico e dos produzidos em Londres), o que muitas vezes prejudicava a sua ação na formação da opinião pública, o intelectual sempre respeitou o decoro vigente na política cultural do Império português. Na seção "Advertência", Francisco Solano justificava o seu comportamento:

Contra a minha esperança, contra a justiça, e apesar das representações de pessoas de maior consideração e caráter ao atual serviço de S.A.R. o Príncipe Regente, consta-me que a Regência de Portugal recusou de me nomear em Lisboa um censor, que examinando o meu jornal apenas os $\mathrm{N} .^{\circ}$ s chegassem, me forrasse a inevitável demora das três censuras a que estão sujeitas todas as obras impressas; favor que antes de 1808 se concedia em Portugal a todo o editor de obras periódicas. Este rigor, causando uma grande demora diminui singularmente o valor de uma obra periódica, cuja parte política se recomenda principalmente pela novidade dos fatos que encerra. Se S.A.R. residisse em Lisboa, estou bem certo que não me trataria pior que os escritores periódicos de jornais portugueses em Londres, os quais, à sombra de proteção inglesa do agente dos paquetes, introduzem em Portugal e nos seus domínios, sem maior obstáculo nem censura, as suas produções, que nem sempre se distinguem pela decência, moderação e respeito com que falam dos membros do governo português, dos funcionários e empregados da nossa Corte, designando até pelos seus nomes as pessoas que são o alvo dos seus bem ou mal fundados ataques. ${ }^{259}$

Ainda sobre a determinação da Regência, Constâncio destacava o fato de a censura ter ocorrido anteriormente à leitura

259 O Observador Lusitano em Paris, N. ${ }^{\circ}$. Maio de 1815, p. 652-653. 
dos seus primeiros cadernos. Segundo o autor, esta atitude "enigmática" dos governadores do reino seria desvendada ao longo do tempo pela postura desses homens diante das novas publicações. O que lhe chamava a atenção, porém, era a sua posição particular neste contexto: escrevia da França e ainda assim não tinha amarras políticas. ${ }^{260}$ Nas suas palavras, ele se autodesignava um "autor que escreve como pensa, que não serve nem nunca serviu governo algum estrangeiro, que não foi prescrito, nem fugiu da pátria!" ${ }^{61}$ A contribuição literária e científica de maior destaque no currículo de Constâncio, no entanto, foi a obra Annaes das Sciências, das Artes e das Letras, também publicada em Paris, entre os anos de 1818 e 1822. Como redator principal desta obra, o médico anunciava seus objetivos:

Oferecer à sua pátria, e a todos os outros países, que com ela constituem a soberania da Real Casa de Bragança, um extrato resumido, mas exato, dos progressos das luzes na Europa, preferindo, na seleção, aqueles objetos, que tiverem relação mais imediata com as nossas precisões e, conveniência, e mais analogia com o estado físico e moral da Nação. ${ }^{262}$

O Prospecto dos Annaes foi publicado na íntegra n'O Investigador Portuguez em março de 1818 e ressaltava o progresso que as ciências e as artes têm tido nos últimos trinta anos na Europa culta. ${ }^{263}$ Um ano depois, em março de 1819, a Gazeta do Rio de

260 Sobre a censura dos periódicos franceses durante a Revolução Francesa e o Período Napoleônico ver DARNTON, Robert; ROCHE, Daniel. Revolução Impressa: a imprensa na França (1775 - 1800). São Paulo: Edusp, 1996; NEVES Lúcia M. Bastos P. Napoleão Bonaparte: ... Op. Cit.

${ }^{261}$ O Observador Lusitano em Paris, N. ${ }^{\circ}$. Maio de 1815, p. 653.

262 IP, Vol. XXI. p. 84.

${ }^{263}$ Ibid., p. 83. 
Janeiro também anunciava as novas diretrizes dessa empreitada cultural. Participava aos seus

[...] assinantes, correspondentes e mais pessoas residentes nos domínios portugueses, ou em países estrangeiros" que se encarregavam de "comprar e expedir, a quem desejar, quaisquer livros, estampas, mapas geográficos, máquinas, modelos, instrumentos de física e química [...] e em geral todos os objetos das relativos às Ciências e às Artes, pelos preços de catálogos, e das fábricas, tudo da melhor qualidade e sem defeito. ${ }^{264}$

Segundo o anúncio, os interessados deveriam enviar suas cartas diretamente ao diretor dos Annaes, José Diogo de Mascarenhas, residente na Rua des Grands-Augustins, n. 5, em Paris. ${ }^{265}$ Como já anunciado no Prospecto, a Política seria objeto excluído nos Annaes, exceto quando tratasse de atos importantes "das diversas Potências, que forem relativos à Agricultura, Indústria, Comércio e Educação Pública". ${ }^{266}$

Como vimos, a missão dos homens de imprensa era discutir os melhores caminhos do progresso para que a sociedade civil os interiorizasse e praticasse seus ensinamentos: assim, trilhava-se o caminho para que a sociedade luso-brasileira fosse instruída e educada dentro da concepção de progresso da época, cujo sentido estava intrínseco ao adiantamento em proveito das artes e ciências, como atesta o dicionário Morais e Silva. ${ }^{267}$ Ainda nas palavras de Francisco Solano Constâncio, "sem esta condição [a união da teoria e prática] é quase impossível conseguir um grau

\footnotetext{
264 GRJ. 1819. N.26 (Grifo do Original).

265 Ibid. (Grifo do Original).

266 IP, Vol. XXI. p. 84.

267 Verbete PROGRESSO. 1813, p. 510. <http://www.brasiliana.usp. br/dicionario/2/progresso >. Acesso em: 03 fev. 2011.
} 
notável de superioridade; e é unicamente por tal sistema que cada nação tem em diversas épocas adquirido a preeminência nas artes, nas ciências, na navegação, na arte da guerra etc." ${ }^{268}$ Todos esses exemplos demonstram a força do pragmatismo pedagógico veiculado pelos seus diversos agentes culturais que atuavam na imprensa periódica, considerada um importante pilar da política cultural vigente no Império Português.

A formação intelectual dos vassalos ilustrados da corte luso-brasileira também adentrava em outro terreno de sociabilidade cortesã: os teatros régios. Em um momento de profundas transformações políticas, o olhar sobre a civilização dos costumes e a reiteração da aliança entre o rei e a sociedade era uma questão central que devia ser apregoada. Neste cenário, a constituição de teatros régios e a veiculação de peças teatrais de amplo viés moralizante apareciam como parte fundamental da política cultural joanina intrínseca à sustentação do Império Português nos dois lados do Atlântico, como veremos no próximo capítulo.

${ }^{268}$ CONSTÂNCIO, Francisco Solano, "Idéias sobre a Educação da Mocidade portuguesa... Op. Cit., p. 396. 


\section{O TEATRO LUSO-BRASILEIRO NO PERÍODO JOANINO E A CIVILIZAÇÃO DOS COSTUMES}

\subsection{Preâmbulo}

O Reinado de D. José I (1750-1777) é um marco político na história da realeza portuguesa. O reformismo ilustrado de seu primeiro-ministro, o Marquês de Pombal, delinearia outra conformação às questões socioculturais do Império Português: da expulsão dos jesuítas (1758) à reforma da Universidade de Coimbra (1772), o que estava em voga era a entrada de Portugal no universo das Luzes europeias. Se a compreensão do sentido paradoxal do iluminismo português ${ }^{1}$ não é tarefa das mais simples, impõe-nos, ao menos, uma investigação acerca da reconfiguração dos espaços institucionais de sociabilidade artística - nomeadamente os referentes às artes cênicas - como os teatros -, que foram afetados de maneira patente. Dessa forma, interessa-nos aqui averiguarmos os princípios norteadores da política cultural portuguesa e as principais transformações ocorridas neste domínio das artes, sobretudo entre o governo de $\mathrm{D}$. José I e a regência de D. João VI (1792-1821), foco capital de análise neste capítulo.

${ }_{1}$ Utilizamos essa expressão do historiador em Kenneth MAXWELL. Marquês de Pombal: paradoxo do Iluminismo. 2. ed. Rio de Janeiro: Paz e Terra, 1997. 
No período pombalino, particularmente, o terremoto de $1^{\circ}$ de novembro de 1755 teve proporções catastróficas e exigiu a reconstrução quase total de Lisboa: do âmbito político ao urbanístico e cultural, a capital do Império se viu imersa em um momento de intensas transformações. Segundo o especialista Mário Vieira de Carvalho, a Ópera do Tejo foi o lugar por excelência dos teatros representativos da Corte de D. José I, cujo destaque das representações dava-se para a ópera séria, valoração semelhante às das principais Cortes ilustradas europeias. A grandiosidade da construção - que durou apenas sete meses - significou, segundo o autor, o "testemunho da secularização crescente da Corte portuguesa sob o domínio de D. José I.”

Para além das trágicas consequências advindas do terremoto, a reconstrução dos locus de sociabilidade foi uma das preocupações do governo de D. José. "A nova cidade é o resultado de uma reflexão erudita, na qual pesa a memória da cidade e seus espaços", assevera a pesquisadora Maria Alexandre Lousada. ${ }^{3}$ Tal fato manteve acesa a apreciação de todas as camadas da sociedade lisboeta pelo teatro musicado; gosto que se desenvolvia não só nos pequenos teatros reais (Queluz, Salvaterra e Ajuda), mas também nos palcos públicos de Lisboa (Bairro Alto, Rua dos Condes e Salitre). ${ }^{4}$ Como pontuou Carvalho, os diversos teatros portugueses tinham como função institucional o divertimento.

2 CARVAlHO, Mário Vieira de. Pensar é Morrer ou o Teatro de São Carlos na mudança de sistemas sociocomunicativos desde fins do séc. XVIII aos nossos dias. Lisboa: Imprensa Nacional Casa da Moeda, 1993. p. 42 (Grifo Nosso).

${ }^{3}$ LOUSADA, Maria Alexandre. Espaços de Sociabilidade em Lisboa: finais do século XVIII a 1834. Lisboa: Tese de doutoramento. 1995. p. 99.

${ }^{4}$ Sobre as a qualidade e diversidade das apresentações musicais nos teatros públicos de Lisboa, ver: BENEVIDES, Francisco da Fonseca. O Real Theatro de S. Carlos de Lisboa. Desde a fundação até à atualidade. Lisboa: Typ. Castro \& Irmão, 1888. p. 7-8. 
Apesar disso, as diferenças de enfoque eram evidentes. Enquanto no teatro do Bairro Alto, as ações dramáticas privilegiavam as situações cotidianas que estimulavam o olhar crítico da realidade; já no teatro Trindade/Condes, o deleite artístico estava circunscrito ao mero divertimento. ${ }^{5}$

O pesquisador ressalta ainda que desde a política reformista de Pombal o teatro passava a "ser considerado escola dos povos contra o vício e a ignorância". Pela primeira vez predominava em Portugal um discurso iluminista sobre as artes cênicas, cuja tessitura provinha da burguesia e era homenageada pelo rei. Apesar disso, tal praxis não significava necessariamente a adesão a uma nova concepção teatral, que ainda mantinha traços barrocos. ${ }^{6}$ A valorização da arte cênica e da música, especialmente a tradição da ópera italiana, como um importante espaço de formação moral e intelectual, ganhou contornos mais precisos no Alvará de 17 de Julho de $1771 .^{7}$

Eu EL REI Faço saber aos que este Alvará de Confirmação virem: Que os homens de Negócio da praça de Lisboa Me representaram, que o grande esplendor, e utilidade, que resulta a todas as Nações do Estabelecimento dos Teatros públicos, por serem estes, quando são bem regulados, Escola, onde os povos aprendem as máximas sãs da Política, da Moral, do Amor à Pátria, do Valor, do Zelo, e da Fidelidade com que devem servir aos seus Soberanos: civilizando-se, e desterrando insensivelmente alguns restos

\footnotetext{
${ }^{5}$ CARVAlHO, Mário Vieira de. Pensar é Morrer ou o Teatro de São Carlos... Op. Cit., p. 37 (Grifo Original).

${ }^{6}$ Ibid., p. 37-46.

7 Para uma breve história do teatro português, ver: CARVALHO, Mário Vieira de. Pensar é Morrer ou o Teatro de São Carlos... Op. Cit., p. 21-39. Para um conhecimento específico sobre as diferentes fases do teatro português entre os séculos XVI e XIX ver BRAGA, Teófilo. História do Theatro Portuguez. 4 Vols. Porto: Imprensa Portugueza Ed., 1870-1871.
} 
de barbaridade, que neles deixaram os séculos infelizes da ignorância: Tinham determinado entre si formarem uma Sociedade que se empreguem em sustentar os mesmos Teatros com aquela pureza, e decoro, que os fazem permitidos, e necessários debaixo dos trinta e três Artigos que serão com este. E porque sendo examinados com prudente, e madura deliberação, e conselho, se achou serem muito convenientes ao Meu Real serviço, e de notória utilidade para os meus vassalos. ${ }^{8}$

Neste período, os quarenta grandes negociantes lisboetas fundaram a Sociedade estabelecida para a subsistência dos Teatros Públicos da Corte; fato que os tornava acionistas dos diversos espaços de cultura artística. Não por acaso, esses homens "desempenhavam um papel de primeiro plano na realização da política econômica do marquês de Pombal". ${ }^{9}$ Assim sendo, na prática tinham o monopólio teatral em Lisboa e representavam simbolicamente a figura real, como atesta o alvará supracitado. Entretanto, por mais destaque econômico que tivesse a burguesia lusitana desde o terremoto - como principal financiadora da nova cidade e dos antigos teatros ${ }^{10}$ - a dificuldade em fundir-se com a aristocracia bragantina alçando status social (traduzido na conquista

\footnotetext{
8 Disponível em: <http://iuslusitaniae.fcsh.unl.pt>. Acesso em: 28 jul. 2011.

9 CARVAlHO, Mário Vieira de. Pensar é Morrer... Op. Cit., p. 44.

10 Ibid., p. 44. "Simplesmente, após o terremoto, os condicionalismos de espaços dos teatros de Corte que haviam sobrevivido já não permitiam o regresso àquele modelo de comunicação teatral, e a burguesia, que financiara uma nova cidade burguesa, não se dispunha a abrir os cordões à bolsa para um novo palácio real (com um palácio tão grandioso como a Ópera do Tejo). Os antigos teatros públicos, destruídos pelo terramoto, são reconstruídos modestamente: em 1761, o Teatro do Bairro Alto, e em 1765 o Teatro da Rua dos Condes. O primeiro recomeça a funcionar como teatro de bonecos e, mais tarde (desde 1765) passa a dar espetáculos de peças portuguesas em alternância com ópera italiana com atores e actrizes ao vivo. No segundo, realizam-se espetáculos de ópera italiana."
} 
da proximidade com a realeza) era um sério problema a ser enfrentado. Portanto, era a serviço da aliança política com a Coroa que esta atuava de forma a garantir os seus direitos de classe, cujo foco era a manutenção da sociabilidade. Como bem analisou Norbert Elias, a sociedade regida pelas etiquetas cortesãs "apresenta os membros da Corte como eles gostariam de ser, e, ao mesmo tempo, como os príncipes absolutos os querem ver. [...] O vínculo com a estratificação social é muito claro no juízo estético". ${ }^{11}$

Durante os reinados de D. José I a D. João VI (1750-1826), a produção de espetáculos artísticos extrapolava as questões meramente financeiras. No período pombalino, por exemplo, a estratégia de ascensão sociopolítica da burguesia lisboeta tinha no teatro um papel decisivo, como nos revelam os artigos VII. e VIII. do Alvará. Vejamos:

VII - Antes de seis anos não se distribuíam lucros, ainda que houvesse, pois o principal fim da sociedade não era ganhar dinheiro, mas, sim, sustentar o teatro cujos rendimentos são sempre muito incertos.

VIII - A sociedade obriga-se a sustentar, pelo menos dois teatros, um de óperas e comédias italianas, outro de dramas e comédias portuguesas. Não era permitido haver em Lisboa teatro algum que não pertencesse à sociedade. ${ }^{12}$

Mormente durante a segunda metade do século XVIII, a burguesia europeia se reapropriava politicamente do espaço público ao mesmo tempo em que vivia a constante tensão entre a crescente importância social e a impossibilidade de ter expressão

11 ELIAS, Norbert. O Processo Civilizador: uma história dos costumes. Rio de Janeiro: Jorge Zahar Editor, 1994. Vol.1, p. 34.

12 Alvará de 17 de Julho de 1771. In: BENEVIDES, Francisco. O Real Theatro de S. Carlos... Op. Cit., p. 13. Para o conhecimento na íntegra do documento, consultar a obra do mesmo autor, p. 13-15. 
política pela lógica das relações rigidamente hierárquicas do Antigo Regime, seu grande objeto de contestação. Nesse contexto, sob a ótica da Ilustração, o teatro foi um tema capital. Particularmente na França, pensadores do quilate de Diderot, Voltaire e Rousseau debatiam o poder pedagógico da arte cênica na sociedade. Como bem analisou Franklin de Mattos, Voltaire e Diderot consideravam o teatro um espaço que ia além da mera diversão: era, antes, um meio poderoso de educação. Discordavam apenas sobre a maneira de tornar mais eficaz esse instrumento. ${ }^{13}$ Enquanto Voltaire considerava o palco uma "tribuna da Ilustração" ${ }^{14}$ com forte poder de denúncia, por exemplo, do fanatismo religioso e de suas nefastas consequências ${ }^{15}$, Diderot confiava à missão das artes cênicas o esclarecimento dos homens; cuja finalidade última era o aprimoramento moral através do combate ao vício e o amor à virtude. ${ }^{16}$ Já Rousseau, afirmava ser tal convicção ilusória: não atribuía ao teatro esse poder. Para ele, a cena teatral só fazia espelhar

${ }^{13}$ MATTOS, Franklin de. "A querela do teatro no século XVIII. Voltaire, Diderot, Rousseau." Revista O que nos faz pensar. PUC-RJ. N. ${ }^{\circ 25}$. 2009, p. 8.

${ }^{14}$ Ibid., p. 11.

15 Ibid., p. 11. Por esse prisma, Mattos destaca duas peças importantes de Voltaire. Mahomet, considerada "uma denúncia ao fanatismo religioso e as funestas consequências da confusão entre política e religião" e Zaire, cujo conteúdo "mostra a existência de uma moral universal que tornaria possível o entendimento entre as pessoas de bem de diferentes civilizações, não fossem os preconceitos religiosos."

16 Para Diderot, a vocação pedagógica ou utilitária do teatro é justificada pelo axioma que liga substancialmente o verdadeiro, o bom e o belo, subordinando-os à maneira de uma processão [sic], onde a beleza aparece como termo derradeiro, derivação última das duas primeiras instâncias. [...] Exclui-se, portanto, desde o início, que uma forma qualquer de arte possa guardar seu valor, se entrar em conflito com a virtude: a imitação da bela natureza é por assim dizer espontaneamente moral, mesmo quando se choca com a decência e com as "bienséances" - não há valores puramente estéticos." PRADO JR, Bento. Gênese e estrutura dos espetáculos (Notas sobre a Lettre à D’Alembert de Jean-Jacques Rousseau). Estudos CEBRAP, 14, 1975, p. 8. 
as paixões de seu público, sem força suficiente para mudar a sociedade. Em Lettre à d'Alembert, Rousseau definia sua posição:

A cena, em geral, é um quadro das paixões humanas, cujo original encontra-se em todos os corações: mas, se o pintor não cuidasse de adular as paixões, os espectadores, logo contrariados, não mais gostariam de ver-se sob um aspecto que lhes traria o desprezo por si mesmos. Que dê apenas a algumas paixões cores odiosas, será somente àquelas que não são gerais e que são naturalmente odiadas. Assim, o autor nada mais faz senão seguir o sentimento do público; e então as paixões condenadas servirão para valorizar outras, senão mais legítimas, pelo menos mais do agrado dos espectadores. Só a razão não serve para nada em cena. Um homem sem paixões ou que as domine sempre não interessa a ninguém; já se notou que um estoico numa tragédia seria um personagem insuportável; na comédia, quando muito, faria rir. ${ }^{17}$

A discussão acerca do papel do teatro no século XVIII nos mostra a importância que os filósofos atribuíam aos caminhos possíveis para que a circulação de suas ideias produzisse os efeitos "desejáveis" na sociedade que se pretendia construir. Nesse período, moral e representação estavam profundamente ligadas no processo de criação artística. Pelo viés iluminista, a função primordial do espetáculo era imitar o que consideravam a bela natureza. $\mathrm{O}$ forte elo entre natureza e moral, no entanto, era garantido pela natureza humana, considerada por Rousseau e Diderot boa em sua essência. Como destaca Bento Prado Jr, a "imitação da natureza é igualmente imitação da virtude, e a moral é o objeto próprio da arte, sua matéria e o éter em que circula". ${ }^{18}$

17 ROUSSEAU, J-J. Lettre à D’Alembert. Apud PRADO JR, Bento. "Gênese e estrutura dos espetáculos. (Notas sobre a Lettre à D’Alembert de Jean-Jacques Rousseau). Estudos CEBRAP, 14, 1975, p. 29.

18 PRADO JR., Bento. Ibid, p. 9. 
A despeito das diferenças conceituais, uma questão era unanimidade entre os entre os três filósofos: a transformação da sociedade pelas luzes da razão era intrínseca ao espírito crítico. E o teatro era o locus de cultura por excelência na instrumentalização desse ideal. "Há muito que só se fala ao público através de livros e, se alguma coisa ainda lhe é dito de viva voz, é no teatro", apregoava Jean-Jacques. ${ }^{19}$ Com a deflagração da Revolução Francesa (1789), a crítica ao Antigo Regime tomava as ruas de Paris. E a queda da Bastilha pelas mãos do povo ratificava o fim do despotismo. Nas palavras de Robert Darnton, "Por volta de 1789, o iluminismo já cumprira a sua tarefa". ${ }^{20}$ Certamente, ao longo de todo esse processo pela busca da maioridade ${ }^{21}$, as peças de teatro foram uma força propulsora de grande poder de intervenção nas transformações sociopolíticas. Em outras palavras, durante a segunda metade do século XVIII, os escritos e peças teatrais dos filósofos que vigoraram na França contribuíram sobremaneira no processo de conscientização do Terceiro Estado de que os direitos do Homem vigoram acima dos deveres dos súditos. "Com o Iluminismo, a separação entre homem e súdito deixa de ser compreensível. Entende-se que o homem deve realizar-se politicamente como homem, o que provoca a desagregação do Estado absolutista".22

Fundamentalmente, este capítulo discute a estruturação e vigência dos Reais teatros em três cidades capitais do Império Português - Lisboa (Teatro de São Carlos), Porto (Teatro

\footnotetext{
19 Ibid., p. 16

20 DARNTON, Robert. O grande massacre de gatos e outros episódios da história francesa, tradução de Sonia Coutinho. 4. ed. Rio de Janeiro: Ed Graal, 2001. p. 146.

21 KANT, Immanuel. Resposta à Pergunta: Que é "Esclarecimento"? ... Op. Cit., p. 101.

${ }^{22}$ KOSELLECK, R. Crítica e Crise... Op. Cit., p. 39.
} 
São João) e Rio de Janeiro (Teatro São João). A compreensão da política cultural joanina para estes locus de cultura cujo foco é a emergência de novas relações sociais que começavam a nascer no espaço público luso-brasileiro constitui o nosso principal objeto de investigação.

\subsection{Arte e política no Antigo Regime Português: o Teatro de São Carlos}

O universo português também manteve especificidades importantes no campo artístico. Durante o governo de D. José I, o reformismo ilustrado de Pombal foi o meio político encontrado para tentar minimizar essas tensões da burguesia lusitana que, por mais que já se expressasse pelo uso público da razão, ainda tinha vínculos muito fortes com o status quo. Neste contexto, ser acionista dos teatros da capital era o meio mais seguro que os negociantes encontraram para mantê-los em funcionamento e garantir a vigência da sociabilidade burguesa: os palcos públicos tornavam-se um importante espaço de controle, domínio e manipulação do poder econômico nas esferas sociopolíticas e culturais. ${ }^{23}$

Entre o final do século XVIII e o início do XIX, o diálogo com a tradicional dramaturgia europeia foi constante no universo teatral português. Da Commédia dell' Arte à tragédia moderna, autores consagrados como Goldoni, Corneille, Racine, Molière,

\footnotetext{
${ }^{23}$ Para uma análise refinada acerca do crescente poderio político da burguesia europeia ver. KOSELLECK, R. Crítica e Crise... Op. Cit.; HABERMAS, Jurgen, Mudança Estrutural da esfera pública: investigações quanto a uma categoria da sociedade burguesa. Trad. de Flávio R. Kothe. Rio de Janeiro: Ed. Tempo Brasileiro, 1984.
} 
Richardson ${ }^{24}$, Diderot, Pedro Metastado, entre outros, eram tidos como mestres da literatura e das artes cênicas que mereciam ser divulgados nos circuitos da alta cultura portuguesa; desde que suas obras fossem de grande valor moral. Vejamos a reflexão de um escritor anônimo de 1805:

O Criado de dois anos; ou Quatro Nações, de Godeni [sic] são Comédias muto dignas de se representarem, sem embargo de servirem só para entreter, com a [ilegível] dos incidentes de que são tecidas, e de não contarem as lições de moral que se acham no Pai de Família ${ }^{25}$, no Цogador, na Pamela ${ }^{26}$. É certo apenas que teremos uma ou outra Peça de origem portuguesa, que possa entrar nesta classe, mas há muitas em italiano, e em francês e que se tem traduzido em nossa língua, e não seria difícil traduzir outras que o merecessem, tanto das que já estão impressas, como das que fossem saindo nos países estrangeiros. ${ }^{27}$

Ao esclarecer seus interlocutores da necessidade de se imprimir em Portugal peças de elevado valor pedagógico, o escritor exaltava os autores italianos, franceses e ingleses. Considerados os representantes por excelência da arte dramática ocidental, seus ensinamentos primavam não só pela estética da linguagem, como também pelo conteúdo, que visava a moralizar os costumes; como foi o caso de O Pai de Família, de Denis Diderot. No Discurso sobre a poesia dramática (1758), Diderot elucidava seus objetivos teatrais:

\footnotetext{
24 Sobre a importância da obra desses autores na sociedade francesa de Luís XIV, ver: BURKE, Peter. A fabricação do rei. A construção da imagem pública de Luis XIV. Rio de Janeiro: Jorge Zahar, 1994.

${ }^{25}$ O Pai de Família. Peça teatral de autoria do filósofo francês Denis Diderot (1713-1786), publicado em Paris, em 1758.

${ }^{26}$ Pamela ou a virtude recompensada. Romance de autoria do escritor inglês Samuel Richardson (1689-1761), publicado em Londres em 1740.

${ }_{27}$ Memória sobre a regulação do teatro do Porto, de 1805. BNP. Seção Res._Mss. 184,30 (Grifos do Original).
} 
Para o poeta dramático, os deveres dos homens constituem um filão tão rico quanto seus vícios e ridículos. As peças honestas e sérias sempre alcançarão êxito, mas certamente ainda mais entre povos corrompidos do que em outra parte. Indo ao teatro eles se esquivarão da companhia dos perversos que os cercam; é lá que encontrarão aqueles com quem gostariam de viver; é lá que verão a espécie humana tal qual é, reconciliando-se com ela. ${ }^{28}$

Na segunda metade do século XVIII, o diretor da Encyclopédie já era uma figura célebre por toda a Europa também como dramaturgo. Em Portugal, particularmente, suas peças de teatro de forte cunho moral eram tidas como bons exemplos a serem exaltados para a sociedade. A valorização de autores iluministas, no entanto, não significava que seus escritos deveriam ser publicados e encenados na íntegra, sem maiores cuidados. Ao referir-se às Comédias "dignas de aprovação" ${ }^{29}$, o empresário teatral do Porto $^{30}$ destacava as obras de Goldoni e Molière; já quanto às peças de Diderot, Voltaire e Beaumarchais seu ponto de vista era que poderiam ser proveitosas, sim, porém, "[com a] reprova de algumas cenas e expressões licenciosas" ${ }^{31}$ que incitassem um comportamento sedicioso. Em relação à Tragédia Moderna, o autor salientava os "grandes mestres" 32 do teatro francês: Corneille e Racine. Para o empresário, "tirando-lhes na tradução os versos líricos [tais obras] formam excelentes tragédias". Na sua lista de "boas" produções artísticas também apareceram nomes

\footnotetext{
28 DIDEROT, Denis. Discurso sobre a poesia dramática. Tradução, apresentação e notas L. F. Franklin de Matos. São Paulo: Editora Brasiliense, 1986. p. 39.

${ }^{29}$ Memória sobre a regulação do teatro do Porto, de 1805. BNP. Seção Res._ Mss. 184,30 .

${ }^{30}$ Trabalhamos com a hipótese de esse escritor anônimo ser um empresário do universo artístico do Porto no item III deste capítulo.

31 Ibid.

${ }^{32}$ Ibid.
} 
de peso como Crebillon. Contudo, as obras desse dramaturgo só poderiam ser encenadas no país, "talvez com algumas pequenas correções". ${ }^{33}$

Assim como ocorria em relação às obras literárias, no universo teatral português também havia uma grande preocupação com a seleção dos autores considerados dignos de publicidade. Com a devida "adequação" dos textos originais, os empresários de teatro, juntamente com os censores, salientavam os valores morais que mais lhes interessavam debater. Essa estratégia de persuasão aproximava-os, ainda mais, dos ministros reais e das mercês que, por ventura, conquistariam da Coroa, pois delineava de forma mais precisa o perfil do público que almejavam formar e, consequentemente, conquistar. Nesse particular, a figura feminina era o centro das maiores preocupações. A questão que se colocava adentrava o campo da moral das atrizes cômicas. Em outras palavras, a problemática que perpassava os administradores teatrais era: como essas atrizes poderiam influenciar a sociedade? Vejamos, novamente, a reflexão do diretor de teatro do Porto:

Ora [,] eu não pretendo que para uma mulher poder entrar no Teatro se lhe tirem as requisições, como se houvesse de ser freira, mas não posso deixar de me escandalizar que esta indulgência chegue ao ponto de se admitirem

${ }^{33}$ Ibid. (Grifos Nossos). Segundo o pesquisador Luís Tarugo Ferreira, a recusa das peças estrangeiras pelos censores era justificada com os seguintes argumentos: "apresentariam uma "tradução desfigurada"; muitos textos não eram capazes de cumprir as funções de "recrear" e "instruir" e seriam redigidos "sem galantaria", perdendo o "carácter de Drama". Os escritos eram, muitas vezes, acusados de terem uma "fantasia corrupta", de exibirem "frioleiras" [sic] e de perderem verossimilhança. No seu conjunto aquelas obras, a serem publicadas, serviriam de "ofensa a uma Nação Civilizada”. FERREIRA, Luís Tarujo. “Teatro de Cordel e a Censura em Portugal: contributos para a compreensão das suas complexas relações na segunda metade do século XVIII", p. 5. Disponível em: <web.letras. up. pt/porprisao/Luís\%20Tarujo\%20Ferreira.pdf>. Acesso: 12/12/2011. 
mulheres nascidas por seus costumes, a vida desfruta como muitas vezes tem acontecido, [...] tem péssimas consequências não só da moral público [sic], mas mesmos interesses do teatro. A mascote busca arrumar-se com essas imaturas; a ter e às vezes, nem os velhos lhes escapam: os pais aborrecem um divertimento ainda seus filhos se vão perder; e temem levar suas mulheres e filhas a ver objetos de ma[u] exemplo: os costumes das outras cómicas mais honestas correm quando da risco, principalmente os das raparigas que olham com inveja para as jóias, e enfeites admirados por tais infames meios, e [riscado] ambicionam de brilhar com o mesmo fausto, se entregam ao início e se fazem desgraçadas. ${ }^{34}$

Para o autor, tais circunstâncias criavam problemas morais irreconciliáveis para o avanço da arte em Portugal: tanto as mães quanto os pais eram responsáveis pela educação de suas filhas e, justamente por isso, não permitiam que elas adentrassem no universo das artes. Esta postura era justificada através do discurso da manutenção da honra e da consientização dos lugares sociais de cada um na sociedade de corte. Tal situação gerava uma grave consequência para os empresários teatrais que, segundo ele, eram "obrigados a receber mulheres de reputação duvidosa, o que perpetuará a corrupção, e dificilmente saem boas cômicas, porque são tiradas de uma classe mal educada”. Estas atrizes (corruptas pelo meio que habitavam), além de trazerem os maus hábitos para a arena pública - podendo influenciar diretamente o comportamento das mulheres da sociedade cortesã -, ainda corroboravam para perpetuar outros problemas: por não saberem "falar corretamente, nem apresentar-se, e encenar com dignidade e decência

${ }^{34}$ Memória sobre a regulação... Op. Cit. Seção Res._. Mss. 184,30. 
e delicadeza" contribuíam para empobrecer a qualidade literária das encenações artísticas no país. ${ }^{35}$

Dessa forma, o "lucro" da atividade teatral adentrava, sim, em um território politicamente complexo: da tentativa da garantia do mérito do status social desses negociantes burgueses perante a Coroa - pela lógica da conquista das mercês - à inserção na política cultural governamental; que buscava (em última instância) a civilização dos costumes através da vigência dos espaços de cultura. ${ }^{36}$ De acordo com o memorialista Francisco Benevides, apesar disso,

Os teatros não prosperavam em Lisboa, e sobre tudo [sic] os artistas passavam amarga vida. Estavam então em todo o seu vigor os prejuízos contra os cômicos; a carreira teatral era tida com pouca consideração; se os actores não eram bem olhados por grande número de indivíduos orgulhosos ou hipócritas, as actrizes ainda inspiravam menos confiança [...] para a maior parte da gente os cómicos talvez que ainda se pudessem salvar, mas as cómicas jamais, pois eram instrumentos de Beuzebuth [sic]; estas ideias quadravam bem na época em que os sopranistas castrados faziam as delícias dos dilettanti da Europa culta. ${ }^{37}$

Em concordância com a ótica de Benevides, mesmo com o forte preconceito moral contra a classe artística, ainda assim, era claro o predomínio do viés iluminista na política cultural referente às artes cênicas durante o período josefino. ${ }^{38}$ No governo de

\footnotetext{
35 Ibid.

${ }^{36}$ Para a compreensão da lógica mercê no Antigo Regime Português, ver: OLIVAL, Fernanda. As ordens militares e o Estado Moderno. Honra, mercê e venalidade em Portugal (1641-1789). Lisboa: Estar, 2001.

37 BENEVIDES, F. O Real Theatro de S. Carlos de Lisboa... Op. Cit., p. 11 (Grifo Original).

38 Sobre as bases e contradições dessa concepção de teatro, ver: CARVALHO, Mário. Pensar é morrer... Op. Cit., p. 40-50.
} 
$\mathrm{D}^{a}$ Maria I, rainha "bem instruída, mas muito piedosa e bastante influenciada pelo seu confessor" 39 , a forte sobreposição dos valores religiosos se fez presente na política cultural.

"Não tardou que a devota rainha proibisse que representassem mulheres nos teatros, sendo necessário recorrer aos sopranistas (castrados) para desempenharem os papéis de mulheres nas óperas líricas", contextualiza Benevides, que justifica a decadência dos espetáculos teatrais até fins do século XVIII por conta desse "absurdo e imoral costume". ${ }^{40}$

Sobre essa situação, o comentário do viajante francês J.B.F. Carrère nos aponta como o teatro português era visto por outros sujeitos:

Os portugueses, singulares em tudo, singularizam-se também nos teatros da capital [...] É ridículo ouvir uma voz máscula sair do corpo de uma jovem pastora, duma princesa, duma amante; é igualmente ridículo ver jovens pastoras, jovens camponesas, e ninfas, executar um ballet com uma barba que repugna aos olhos dos espectadores; o vermelho que lhes cobre o rosto faz realçar ainda mais o negro da barba, e dá-lhes um ar de fúria que contrasta grotescamente com as personagens que representam. ${ }^{41}$

Outro depoimento importante sobre a situação teatral em Portugal na virada do século XVIII e início do século XIX é o do

\footnotetext{
${ }^{39}$ NEVES, Guilherme Pereira das. Verbete "D. Maria I". In: NEVES, Lúcia Bastos Pereira das; VAINFAS, Ronaldo (Org.). Dicionário do Brasil joanino... Op. Cit., p. 128.

40 BENEVIDES, F. O Real Theatro de S. Carlos de Lisboa... Op. Cit., p. 18.

${ }^{41}$ CÀRRERE, J.B.F. Tableau de Lisbonne em 1796, p. 70. Apud CARREIRA, Laureano. O teatro e a censura em Portugal na segunda metade do século XVIII. Lisboa: Imprensa Nacional - Casa da Moeda, 1988. p. 408.
} 
historiador inglês Robert Southey. O estudioso esteve no país em dois momentos diferentes: pela primeira vez em 1797, e depois entre os anos de 1800 e 1801.

Quando cheguei tinha sido autorizado que uma dançarina se exibisse ela mesmo [sic], e o teatro estava por tal motivo cheio. Onde estava a preocupação de sua majestade quanto à moral pública, quando permitiu isto? Nenhum divertimento deveria ser autorizado quando não fosse benéfico para o espectador, e aviltasse o actor. Tais proibições de características espartanas seriam consideradas despóticas nos nossos Estados modernos e liberais onde leis sumptuárias são sólidos entraves à usurpação da liberdade; uma forte Constituição pode enfrentá-las, mas o homem doente sucumbe quando lhe tocam nas feridas. ${ }^{42}$

O testemunho dos viajantes estrangeiros em Portugal durante o período mariano nos mostra, portanto, as limitações da vida artística no país devido à preeminência social da nobreza tradicional e do clero. Como salientou Southey, tal situação colocava o Império Português imerso em uma fase de grande conservadorismo, cuja tônica política restringia drasticamente o horizonte do desenvolvimento das artes, especialmente quando comparado às demais nações europeias. ${ }^{43}$

Em fevereiro de 1792, com o agravamento da doença de $\mathrm{D}^{\mathrm{a}}$ Maria I, iniciava-se a regência de fato de D. João. Neste mesmo ano, a França vivia o momento de maior radicalização política

\footnotetext{
42 SOUTHEY, Robert. Letters written during a short residence in Spain and Portugal, p. 492-493. Apud CARREIRA, Laureano. O teatro e a censura em Portugal... Op. Cit., p. 411.

${ }^{43}$ Sobre a decadência do teatro no reinado de $\mathrm{D}^{\mathrm{a}}$ Maria I, ver: CARVALHO, Mário. Pensar é morrer... Op. Cit., p. 51-52; BRANCO, João de Freitas; Jayme Duarte de Almeida. O teatro de São Carlos (1793-1956). Lisboa: 1956. p. 82-83.
} 
desde o início da Revolução. Com a queda da monarquia, em agosto, e a proclamação da república, os franceses estabeleciam uma nova contagem do tempo histórico: nascia o Ano I do calendário revolucionário que, não por acaso, objetivava marcar a chegada de uma nova era da história humana. ${ }^{44}$ Como bem contextualizam os autores Jorge Pedreira e Fernando Costa, "A Europa em que D. João vai assumir o governo do reino é uma Europa que se modifica sob o impacto, tão inesperado como os próprios acontecimentos da Revolução Francesa". ${ }^{45}$ A despeito da constante tensão política europeia, o regente português implementou mudanças significativas na política cultural voltada para as artes cênicas. A começar pela edificação do Teatro de S. Carlos.

Inspirado nos moldes do antigo Teatro Real de S. Carlos de Nápoles, S. Carlos teve investimento maciço da burguesia lusitana, financiadora do novo locus que visava substituir a magnificência da Ópera do Tejo. Assinado por José da Costa e Silva, arquiteto português que vivera na Itália sob o patrocínio do Estado, a construção do Teatro de S. Carlos foi defendida tenazmente pela figura de Diogo Ignácio de Pina Manique. ${ }^{46}$ Isto é, com o

\footnotetext{
44 ARENDT, Hannah. Da Revolução. São Paulo: Brasília: Ed. Ática. Ed. da UnB, 1988. p. 23.

45 PEDREIRA, Jorge; COSTA, Fernando Dores. D. João VI... Op. Cit., p. 58-59.

46 José da Costa e Silva (1747-1821) estudou em Lisboa e, estudando engenharia com Filipe Rodrigues e Desenho com o mestre italiano Carlos Maria Ponzoni, que ao regressar a Itália o levou consigo como pensionista da Coroa, a fim de prosseguir os seus estudos na Universidade de Bolonha. Lá trabalhou Pintura e Arquitetura Civil. Alcançou dois importantes prêmios, sendo recebido entre os Acadêmicos de Honra e Mérito da Universidade de Bolonha (1775). Neste período conheceu as principais obras da arquitetura antiga e contemporânea em Nápoles, Veneza, Florença, Pisa etc. Em 1781, quando retornou a Portugal, assumiu a cadeira de Arquitetura da Aula de Desenho, criada por Da Maria I. Sua carreira docente se tornou notável: as maiores distinções e prestígio fizeram parte de seu caminho. Entre as suas principais obras, além do Teatro de S. Carlos, foram: Palácio Real d’Ajuda, Hospital da Marinha e o Asilo Militar da Runa.
} 
apoio financeiro dos negociantes lusitanos, associado ao persuasivo discurso do intendente da Polícia - que o justificava como meio de glorificar a gravidez de Carlota Joaquina do primogênito real - o espaço não só estava pronto em seis meses (de dezembro de 1792 a junho de 1793), como também chamaria São Carlos em homenagem à Princesa do Brasil, que evocava indiretamente a figura de seu pai, o rei espanhol Carlos IV (1788-1808). Além disso, a chegada de um herdeiro "afastava o risco da esterilidade dos príncipes, salvava a Coroa e a emancipava da obsessiva procura da sucessão." 47

Em 30 de Junho de 1793, o Teatro de S. Carlos era inaugurado em Lisboa. Coincidentemente, no mesmo ano em que Luís XVI e Maria Antonieta eram decapitados na guilhotina, fato que simbolizava o fim derradeiro do Antigo Regime francês. Desde 1789, a agitação das ruas de Paris colocava em xeque o sentido da palavra revolução, até então compreendida como restauração da ordem natural do cosmos. A palavra ganhava um novo sentido. Com a conscientização dos revolucionários de seu poder enquanto agentes históricos capazes de subverter as bases políticas do Antigo Regime, o termo passou a significar "o fim definitivo de uma velha ordem, e provoca[r] o nascimento de um novo mundo" 48

Em 1812, o regente D. João chamava-o para o Brasil, para que fosse o responsável pelo traçado do Teatro de S. João, no Rio de Janeiro. Morre nesta cidade, em março de 1821. CRUZ, Manuel Ivo. O Teatro Nacional de S. Carlos. Lisboa: Lello e Irmão - Editores, 1992. p. 12-14.

${ }^{47}$ PEDREIRA, Jorge; COSTA, Fernando Dores. D. João VI... Op. Cit., p. 64.

48 ARENDT, Hannah. Da Revolução... Op. Cit., p. 34. De acordo com a autora, A palavra revolução foi, originalmente, um termo astronômico que ganhou importância crescente nas ciências naturais através do De Revolutionibus Orbium Coelestium de Copérnico. Nesse emprego científico, o vocábulo reteve seu preciso significado latino, designando o movimento regular sistemático e cíclico das estrelas, e que, era, portanto, irresistível, não era certamente caracterizado 
Especialmente diante dessa turbulência revolucionária, a ereção de um teatro digno de uma monarquia europeia - cujo diferencial era o acesso "das várias classes sociais sem desdouro da nobreza nem acanhamento dos que a ela não pertenciam" ${ }^{49}$, foi um dos meios encontrados pela Intendência da Polícia para tentar dominar as possíveis contestações políticas ao regime absolutista em solo português. Não foi à toa que no auge do domínio jacobino (1792-1795) - mais conhecido como período do Terror - nascia um teatro na capital do Império Português, cuja prédica do intendente da polícia destacava que os espectadores "entrem por dinheiro; entrando nesta generalidade os Teatros não só da Capital, mas de todo o Reino." ${ }^{50}$ Ou seja, os espetáculos eram sustentados pelo público e os administradores tinham a incumbência de contribuir para o custeamento das receitas de uma obra de caridade: a Casa Pia. ${ }^{51}$

nem pela novidade, nem pela violência [...]. A palavra revolução significou originalmente restauração, algo, portanto, que para nós representa exatamente o oposto. (p. 34)

${ }^{49}$ BRANCO, João de Freitas; Jayme Duarte de Almeida. O teatro de São Carlos... p. 84.

50 Offício que o Intendente da polícia da Corte e reino dirigiu ao Ministro do Reino, sobre o novo teatro lírico, em 21 de Junho de 1793. In: BENEVIDES, F. O Real Theatro de S. Carlos de Lisboa... Op. Cit., p. 33 (Grifo Nosso).

51 Em 1782 Pina Manique obteve autorização da Coroa para criar a Casa Pia. Constava este estabelecimento do colégio de S. Lucas em Lisboa, e outro em Coimbra, filial do de Lisboa, chamado vulgarmente o Colégio da broa. Em 1804 tinha o de Lisboa 150 estudantes e o de Coimbra 84. Havia também o recolhimento da rainha Santa Isabel, onde em 1801 sustentava e educava 220 órfãs desamparadas; o colégio de Santa Margarida de Cortona, casa de correcção de mulheres, onde chegaram a estar 280, outro para a correcção e doutrinamento de rapazes libertinos. Tinha também uma casa de correcção para mendigos de um e de outro sexo, um laboratório químico, onde se fabricavam gratuitamente remédios para os pobres. Em Roma Manique estabeleceu um colégio para estudo de belas artes; em Edimburgo e em Londres colégios para o estudo de cirurgia. Ainda mais: sustentava num colégio em Coimbra, destinado ao estudo das ciências naturais, 18 religiosos de S. João de Deus, distribuía quinhentas e 
Ei por bem que a Casa do Novo Teatro, edificado no Bairro Alto, junto ao Tesouro com Permissão Minha, debaixo das ordens do intendente geral da Polícia, se incorpore à Casa Pia, e que fique fazendo parte do seu fundo para a subsistência, debaixo da Direção da Intendência da Polícia, ou daqueles que pelo tempo For Servida encarregar da Inspeção da Dita Casa Pia. ${ }^{52}$

Este decreto real de 28 de abril de 1793 colocava em evidência dois aspectos fundamentais das novas diretrizes da política cultural joanina para os teatros: a atuação da Polícia na manutenção da ordem tinha necessariamente que respeitar a nova situação de preeminência social da grande burguesia, que não só alcançava um "nível mais refinado de sociabilidade" na Corte, mas, sobretudo, contribuía economicamente para conservar um importante projeto social da Coroa, a já citada Casa Pia. Os grandes negociantes burgueses já "podiam agora por direito próprio, que lhes era conferido pelo dinheiro, apresentar-se em público nos camarotes que ladeavam a família real, e não raro, com precedência sobre a aristocracia tradicional". ${ }^{33}$ Além disso, o regente começava a admitir a presença de mulheres: o nascimento da Princesa da Beira, $\mathrm{D}^{\mathrm{a}}$ Maria Teresa, sua primogênita,

tantas rações a homens impossibilitados de trabalhar, depois de terem servido no exército, nas artes ou nas manufacturas; criava e educava no colégio de Santo António 190 órfãos. Enfim, a Casa Pia de Pina Manique era um conjunto de colégios educacionais e de beneficência dirigido e administrado pelo intendente, com o objetivo de formar sobretudo homens eminentes e úteis ao país. Quando Pina Manique deixou de ser intendente de polícia, a Casa Pia começou a declinar sensivelmente, até que foi extinta no tempo dos franceses, reorganizando-se depois em outras bases muito mais insignificantes. Pina Manique (Diogo Inácio da). Dicionário Histórico PORTUGAL Disponível em: <http://www.arqnet.pt/ dicionario/pinamanique.html>. Acesso em: 31 ago. 2011 (Grifos Nossos).

52 Decreto de 28/04/1793. In: BENEVIDES, F. O Real Theatro de S. Carlos de Lisboa... Op. Cit., p. 32.

53 CARVAlHO, Mário Vieira de. Pensar é Morrer... Op. Cit., p. 59. 
foi celebrado na voz de Luísa Todi, cantora lírica portuguesa de renome internacional..$^{54}$

Com a regência de jure de D. João no início de 1799, os festejos públicos invadiram as ruas das principais cidades do Reino, como determinava a tradição absolutista. Na Corte, as comemorações foram constantes e eram necessárias, uma vez que se formalizava a condição de Príncipe regente de D. João. Com essa medida, tentava-se superar a fragilidade intrínseca à condição de interinidade do poder monárquico, especialmente porque tal decisão política fora tomada sem que houvesse a reunião de Cortes. ${ }^{55}$ Mais uma vez, notamos o medo das autoridades portuguesas diante das possíveis influências políticas advindas da Revolução Francesa. Fora sobretudo depois da chamada da Assembleia dos Estados Gerais (1789), que não ocorria na França desde 1614, que o processo revolucionário teve seu início. "O grande medo", na expressão do historiador Georges Lefebvre, ainda era uma sombra deveras ameaçadora na Europa: as Cortes portuguesas não eram ouvidas desde 1698.

Para além das habituais luminárias, um evento organizado e dirigido por Pina Manique nos chama a atenção. Em 28 de

${ }^{54}$ Luísa Todi (1753-1833) começou a sua carreira pelo teatro musical, aos 14 anos. Casada com o violinista napolitano Francesco Saverio Todi, seu grande admirador, teve aula de canto com o compositor David Perez, conceituado mestre de capela da Corte portuguesa. Seu aperfeiçoamento profissional trouxe-lhe uma importante dimensão internacional que a levariam a todas as Cortes da Europa, como cantora lírica. Em 1793 foi à Corte de Lisboa por ocasião do batizado de mais uma filha do herdeiro do trono, o futuro D. João VI. Neste evento, a cantora precisou de uma autorização especial para cantar em público, o que era então proibido às mulheres. Em 1799 terminou a sua carreira internacional em Nápoles. Regressou a Portugal e cantou ainda no Porto, onde morou por dez anos (1801-1811) Em Lisboa, viveu de 1811 até ao final da vida. Luísa Todi. In: Infopédia [Em linha]. Porto: Porto Editora, 2003-2011. Disponível em: <http:// www.infopedia.pt/\$luisa-todi; http://pt.wikipedia.org/wiki/Luísa_Todi>. Acesso em: 11 ago. 2011 (Grifos nossos).

55 PEDREIRA, Jorge; COSTA, Fernando Dores. D. João VI... Op. Cit., p. 79. 
julho do dito ano acontecia uma enorme solenidade no Teatro de $\mathrm{S}$. Carlos para que os súditos reais congratulassem a regência do Príncipe. De acordo com as notícias publicadas na Gazeta de Lisboa, o espetáculo contou com a presença

[da] primeira Nobreza, ao Corpo Diplomático e a um crescido número de Pessoas conspícuas de todas as classes, uma representação gratuita do drama Julio Sabino, com um refresco geral tão delicado e copioso, quanto bem servido. SS.AA.RR. por darem uma pública demonstração da estima que lhes merece o dito Magistrado, se dignaram não só de assistir à mesma representação, mas até de tomar o refresco, que lhes foi servido de diferentes Mesas [...] Após o Drama, em meio cujos Atos houve a Dança intitulada a Conquista da Flórida Branca; se cantou a licença ou Poema Natalício dedicado ao Príncipe Regente N.S., que traz a mesma peça e conclui-se o Espetáculo com um solo de Rabeca que tocou a celebre Professora Luiza Gerbini. ${ }^{56}$

Detalhe: o Príncipe Regente raramente assistia aos espetáculos, apresentando-se em público apenas no Teatro de S. Carlos, nas festividades oficiais. A aparição da realeza nesses eventos tinha como meta a exaltação ou a representação do próprio poder real, já tão abalado na Europa desde o início da Revolução Francesa. No plano internacional, a situação diplomática portuguesa mudara de configuração. Desde 1800, Portugal vivia sob o perigo iminente de uma guerra com a França. Sendo a Espanha aliada de Napoleão Bonaparte, a relação luso-hispânica adquiria contornos cada vez mais delicados: D. João tentava a todo custo convencer o governo de Madri a resistir diante da presença francesa em território espanhol. Em vão. A Espanha não só reforçou a aliança com

${ }^{56}$ Gazeta de Lisboa. 2 set. 1799. 
a França como também declarou guerra a Portugal. Diante dessa situação beligerante, conhecida como a Guerra das Laranjas, a Coroa Portuguesa ainda sofreu a perda do apoio militar britânico; o que agravava em muito a situação. A sobrevivência da monarquia lusitana estava por um fio.

Em contrapartida, no plano interno, o Príncipe Regente tentava minimizar os efeitos dessa grave crise política. Principalmente no que se refere ao universo artístico, a mudança no espectro teatral de Lisboa antes e depois do terremoto era evidente. Se antes de 1755 os grandes negociantes eram convidados para frequentarem a Ópera do Tejo dentro dos domínios reais, depois de 1793 era a vez da Corte se deslocar dos palácios reais para adentrar na cidade burguesa e assistir à ópera italiana no novo teatro de caráter representativo.

Entre a fundação do Teatro de S. Carlos e a partida da Corte para o Brasil (1793 - 1807), a capital viveu um período de grande esplendor nas artes cênicas, cujo destaque deu-se particularmente entre os anos de 1799 e $1806 .{ }^{57}$ A turbulência política europeia, especialmente depois da ascensão de Napoleão Bonaparte ao trono francês, evidenciava a função política que o teatro português adquiria, sobretudo pelos temas das óperas, peças e Elogios dramáticos encenadas em S. Carlos. Como analisou Teófilo Braga,

No meio das tempestades do mundo político, o teatro tornava-se para o povo português um novo fórum, aonde ia dar largas aos pulmões, e expandir o pasmo da sua curiosidade expectante. Era este o caráter do tempo; sob o despotismo militar de Napoleão floresciam os teatros,

7 BENEVIDES, F. O Real Theatro de S. Carlos de Lisboa... Op. Cit., p. 83. 
e um tipo novo criado por Talma ou uma Tragédia nova ocupavam tanto a atenção pública como a batalha de Austrelitz..$^{58}$

Por mais grandeza que tivessem as encenações artísticas na Corte neste período - com músicos do quilate de Girolamo Crescentini $^{59}$, Angélica Catalani ${ }^{60}$ e Marcos Portugal ${ }^{61}$-, o momento era de grave crise política e econômica. E, apesar do imenso esforço da burguesia lusitana em se aproximar da Europa "civilizada" nos espaços de cultura, o olhar dos estrangeiros, muitas vezes, era de repúdio. Eis a definição do duque do Châtelet sobre as artes cênicas portuguesa, em 1799:

O teatro português está, de resto, no último grau entre os teatros da Europa. Tem todos os defeitos do teatro espanhol, mas sem ter as suas belezas: por todo o lado um

\footnotetext{
58 BRAGA, Teófilo. História do Theatro... Op. Cit., p. 9 (Grifo Original).

59 Cantor italiano de renome internacional, Crescentini fez grande sucesso nas principais cidades europeias: de Lion a Viena, passando por Roma, Veneza e Londres, sempre foi acolhido pelo público com grande entusiasmo. Em 1798, o sopranista mudava-se para Lisboa onde fez um estrondoso sucesso no Teatro de S. Carlos sendo um de seus administradores, no ano de 1802. Para maiores detalhes sobre a vida do cantor, ver: BENEVIDES, F. O Real Theatro de S. Carlos de Lisboa... Op. Cit., p. 57-58.

${ }^{60}$ Angélica Catalani (1779-1849) foi uma cantora italiana das mais destacadas do período, que viveu em Lisboa entre os anos de 1801 e 1806, sendo uma das estrelas do Teatro de S. Carlos. Segundo Benevides, Catalani era dotada de uma voz "verdadeiramente fenomenal, tanto em extensão como em qualidade" (p. 66). Mais informações sobre a vida e importância de Angélica Catalani no cenário da musica europeia e lisboeta, ver: BENEVIDES, F. O Real Theatro de S. Carlos de Lisboa... Op. Cit., p. 65-67; RUDERS, Carl Israel. Viagem em Portugal. 1798-1802. Trad. de António Feijó, pref. e notas de Castelo Branco Chaves. Lisboa: Biblioteca Nacional, 1981.

${ }^{61}$ Sobre a vida e importância de Marcos Portugal no cenário da musica europeia e luso-brasileira, ver: SARRAUTE, Jean-Paul. Marcos Portugal. Lisboa: fundação Calouste Gulbenkian, 1979.
} 
tom enfático, empolado, e trivial: uma mistura ridícula do sério e do grotesco, do sagrado e do profano. ${ }^{62}$

De fato, desde 1800 quando o Conde da Ribeira ${ }^{63}$ tinha sob suas mãos a direção do teatro, notamos que a relação existente entre os administradores e a Coroa ainda conservava traços típicos da sociedade do Antigo Regime na manutenção do espaço. Considerado "testa de ferro do governo" ${ }^{64}$, o Conde recebeu de D. João uma loteria no valor de "11:200\$000 réis, 7:000 bilhetes a $1 \$ 600$ réis cada um, sendo 1:010 os prêmios e, e 5:990 os números brancos." ${ }^{65}$ Dinheiro, camarotes e lugares na plateia constituíam a base dessa premiação. Em julho de 1801 Crescentini assumia a administração do espaço. A situação financeira ainda era de grande dificuldade.

Para obter recursos que o habilitassem a poder continuar com os espetáculos e pagar aos artistas, Crescentini implorou do príncipe regente a concessão de casas de sortes, espécie de jogatina em que os bilhetes se vendiam

\footnotetext{
${ }^{62}$ Voyage du ci-devant Duc du Châtelet en Portugal, 1799. Apud CARREIRA, Laureano. O teatro e a censura em Portugal... Op. Cit., p. 410.

${ }^{63}$ D. José Maria Gonçalves Zarco da Câmara, 7. ${ }^{\circ}$ Conde da Ribeira Grande (1784-1820). Filho do $6 .^{\circ}$ conde da Ribeira Grande, D. Luís António José Maria da Câmara, e de sua primeira mulher, D. Margarida Rita da Cunha. Foi Grã-cruz da ordem de Nossa Senhora da Conceição de Vila Viçosa, comendador de Avis, $11 .^{\circ}$ alcaide-mor do castelo de S. Brás. Sucedeu a seu pai em 1802, foi coronel de infantaria, e serviu na Guerra Peninsular. Casou-se duas vezes: a primeira em 1810, com $D^{\text {a }}$ Maria de Vasconcelos e Sousa, falecida em 1813, filha dos $2^{\text {os }}$ Marquêses de Castelo Melhor; e a segunda em 1814, com Da Mariana de Almeida Portugal, dama da rainha $\mathrm{D}^{a}$ Maria I, e dama da ordem de Santa Isabel, filha dos $3^{\text {.os }}$ Marquêses do Lavradio. Faleceu no Rio de Janeiro a 13 de Fevereiro de 1820. Disponível em: <http://www.arqnet.pt/dicionario/ribeira7c. html>. Acesso em: 15 mar. 2011.

${ }^{64}$ BENEVIDES, F. O Real Theatro de S. Carlos de Lisboa... Op. Cit., p. 61.

${ }^{65}$ Ibid., p. 62.
} 
por baixo preço, em diversos pontos da cidade. Foi-lhe deferida a pretensão por aviso de 29 de Agosto de 1801. ${ }^{66}$

Não obstante a concessão das loterias em cinco pontos de Lisboa, o empresário ainda teve prejuízos, saindo do comando da empresa no carnaval de 1802. Nesse contexto, destacamos outro viés de relevância na política cultural joanina: os teatros portugueses eram alugados a empresários responsáveis por organizar os espetáculos. O fato de estes não pertencerem ao Estado, contudo, não excluía a participação direta do poder real no subsídio às temporadas musicais. "As óperas sérias nem em Lx. ${ }^{67}$ poderia[m] subsistir, se o governo não auxiliasse o empresário com subsídios extraordinariamente e avultados", afirmava um homem do universo artístico do Porto. ${ }^{68}$ Ademais, a Dinastia de Bragança tinha como tradição o amor pela música clássica. Como demonstrou o musicólogo Alberto Pacheco, D. João foi um grande financiador das atividades musicais em Portugal. Segundo o pesquisador, nos Diários de Despesas do Particular, encontram-se "várias ordens de pagamentos a músicos em geral, ajudas de custo por atividades musicais e para transporte de cantores, despesas com composição e montagem de espetáculos [...]". ${ }^{69}$ Para Pacheco, estes documentos evidenciam que os gastos com música eram, na prática, contabilizados como despesas particulares do rei.

Quanto ao aspecto estritamente artístico, a briga entre Crescentini e Catalani pela conquista dos espectadores nos desvenda os diferentes vieses da lógica existente na manutenção

${ }^{66}$ Ibid., p.64.

67 Abreviação de Lisboa.

${ }^{68}$ Memória sobre a regulação do teatro do Porto, de 1805. BNP. Seção Res._Mss. 184,30 .

69 PACHECO, Alberto José Vieira. Castrati e outros virtuoses. A prática vocal carioca sobre a influência de D. João VI. São Paulo: Annablume; Fapesp, 2009, p. p. 28. 
do principal teatro de Lisboa. O depoimento do pastor suíço Carl Israel Ruders nos revela o grande prestígio da ópera séria, representado pela figura da artista na Corte:

A peça também produz uma extraordinária impressão sobre os espectadores; e a senhora Catalani ou se apresente com o carácter altaneiro de conquistadora, ou se mostre cheia de terror fugindo ao espectro do esposo assassinado [...] A atriz e a cantora se auxiliam mutuamente, fundindo-se no mais belo conjunto, para traduzirem com a mais alta verdade em toda a sua força, os encontrados sentimentos que tumultuam na alma da rainha. ${ }^{70}$

Nessa disputa, Catalani, que contava com o apoio de Francisco Antonio Lodi ${ }^{71}$, conseguiu a publicação de um anúncio na Gazeta de Lisboa, onde denunciava a querela entre os artistas.

Finalizando no dia 2 de Março próximo a empresa atual do Real Teatro de São Carlos, termina ao mesmo tempo o arrendamento que os Empresários fizeram do mesmo teatro, o que se dá a saber ao Público, para que se alguém quiser arrendá-lo de então para diante, haja de dirigir-se a Francisco Antonio Lodi, Administrador da Real Fábrica de Rapé, o qual se acha munido com os poderes necessários para tratar este negócio. ${ }^{72}$

$\mathrm{O}$ aviso despertou a ira de Crescentini. O artista além de recorrer aos ministros reais, a fim de tentar resolver a situação ${ }^{73}$,

\footnotetext{
70 RUDERS, Carl Israel. Viagem em Portugal 1798 a 1802. Prefácio e Notas de Castelo Branco Chaves. Tradução de Antonio Feijó. Lisboa: Biblioteca Nacional, 2002. p. 258 [Carta XXX].

71 Antigo empresário do teatro e à época administrador da real fábrica de rapé. BENEVIDES, F. O Real Theatro de S. Carlos de Lisboa... Op. Cit., p. 70.

${ }^{72}$ Gazeta de Lisboa. 8/01/1802.

${ }^{73}$ Crescentini mandava um ofício à D. Rodrigo de Souza Coutinho datado de 18/02/1802.
} 
ainda "disse a diversos que a Catalani não mais havia de cantar em S. Carlos, se ele não quisesse, pois pegaria nas partituras e as mandaria para a Itália, em um navio que em breve devia sair para Gênova". ${ }^{74}$ Tudo em vão: a administração passava para as mãos de Lodi e a decisão a favor de Catalani é atestada no documento de 1 de Abril de 1802. O ofício de Pina Manique sobre o caso era dirigido a D. Rodrigo de Souza Coutinho, à época presidente do Real Erário cuja missão era redinamizar a economia do país. ${ }^{75}$ Eis a posição de Manique frente ao caso:

É certo também que o P.R.N.S. quer que o dito Teatro de S. Carlos se abra, e se ponha em trabalho, e V. ${ }^{\text {a }}$ Ex..$^{\text {a tam- }}$ bém assim mo tem comunicado de ordem do Mesmo Augusto Senhor, e como eu desejo cumprir as Reais Ordens, e o tempo é curto para se comporem novas Músicas para algumas óperas, que se queiram por em cena, e ser o costume e prática, que todas as Obras de Música, que se tem feito naquele Real Teatro, ficarem no Gabinete de Música do mesmo Teatro, e se lhe manda fazer uma avaliação, e paga o Empresário, que entra na Empresa àquele que sai, que é o mais que podia pretender o suposto, estando autorizado pela Companhia de Cômicos e Dançarinos, que entraram na Empresa, que finalizou pelo Carnaval Pretérito: isto é o que me informam se[r] prática, não só neste artigo de Música, mas também da Guarda Roupa, e Cenário; e é também o que me obrigou a mandar recolher aos ditos Gabinetes a referida Música, cuja diligência se não efetuou e ficou em depósito em poder do suposto Jerônimo Crescentini, como mostra o documento que ele junta em seu requerimento.

\footnotetext{
74 BENEVIDES, F. O Real Theatro de S. Carlos de Lisboa... Op. Cit., p. 71. Sobre a importância de Catalani no cenário musical lisbonense, ver: CRANMER, David John. Opera in Portugal 1793-1828: a study in repertoire and its spread. Tese de Doutorado. London: University of London, 1997. p. 38-45.

75 SILVA, Andrée Mansuy-Diniz da. Portrait... Op. Cit., p. 177.
} 
É o que posso informar a V. ${ }^{\mathrm{a}}$ Ex. ${ }^{\text {a }}$ sobre esta matéria, e fico esperando as Reais Ordens, que V. ${ }^{\mathrm{a}}$ Ex. ${ }^{\mathrm{a}}$ me comunicar a este respeito, para me servirem de regra, para poder diferir não só no suposto Jerônimo Crescentini ${ }^{76}$, mas às partes, que me recorreram mandar recolher no Real Teatro de S. Carlos a Música das duas Óperas -Semiramis - e Zaira -.

Nesta ordem fica explícita a força da intervenção real na resolução dos conflitos internos do Teatro de S. Carlos. Por mais que a polícia e os ministros do regente atuassem como intermediadores privilegiados nas contendas internas entre artistas, funcionários e administradores, tentando evitar que os ecos das possíveis problemáticas extrapolassem para o universo público o que no caso da rivalidade entre Catalani e Crescentini acabou por ser inevitável -, cabia ao monarca dar a palavra final sobre os trâmites e dificuldades vigentes nos bastidores do teatro. Por mais que seus homens de Estado tivessem a força política necessária para minimizar o alcance das querelas entre as "gentes do teatro"; em última instância competia a D. João decidir acerca do rumo que o espaço tomaria na Corte. Ademais, a manutenção de um locus artístico como S. Carlos era uma atividade complexa: da organização física ao pagamento dos diversos funcionários, as despesas eram vultosas e, como vimos, muitas vezes saíam dos cofres do Real Erário. A tabela referente aos gastos entre os anos de 1802 e 1803 nos ajuda a visualizar quão difícil era a sobrevivência de um teatro de Corte em Portugal na virada do século XVIII para o XIX.77

\footnotetext{
${ }^{76}$ Jerônimo: versão inglesa de Girolamo; forma como o sopranista foi chamado na capital portuguesa.

77 ANTT. Ministério do Reino. Teatro de São Carlos, n 6. Apud BENEVIDES, F. O Real Theatro de S. Carlos de Lisboa... Op. Cit., p. 78.
} 
Tabela 1. Despesas do Real Teatro de S. Carlos de Lisboa na época de 1802 a 1803

\begin{tabular}{ll}
\hline Aluguel do teatro & $2: 700 \$ 000$ \\
\hline Aluguel da mobília & $2: 400 \$ 000$ \\
\hline Cabeleiras & $341 \$ 100$ \\
\hline Impressos & $285 \$ 920$ \\
\hline Iluminação & $3: 499 \$ 375$ \\
\hline Cenário & $2: 956 \$ 165$ \\
\hline Salários & $2: 292 \$ 510$ \\
\hline Ordenados & $34: 618 \$ 209$ \\
\hline Sapatos & $502 \$ 200$ \\
\hline Vestuário & $60: 974 \$ 665$ \\
\hline Cópia de Música & $745 \$ 650$ \\
\hline Coristas & $1: 494 \$ 745$ \\
\hline Guarda Militar & $577 \$ 000$ \\
\hline Jornais e Carpinteiros & $655 \$ 950$ \\
\hline Porteiros e arrumadores & $433 \$ 840$ \\
\hline Carpinteiros da noite & $1: 020 \$ 020$ \\
\hline Comparsas & $105 \$ 850$ \\
\hline Orquestra & $9: 756 \$ 470$ \\
\hline Despesa com móveis & $93 \$ 490$ \\
\hline Total & $72: 453 \$ 159$ \\
\hline Co & \\
\hline
\end{tabular}

Fonte: Offício dirigido ao ministro régio pelo intendente geral da Polícia da Corte e reino sobre as intrigas de Crescentini contra Catalani, em 1 de Abril de 1802.

Como podemos observar, todos os itens são indispensáveis para o bom funcionamento de um teatro real português no início d'Oitocentos. Porém, cada um tem a sua importância particular: do aluguel do espaço à despesa com os móveis, a empreitada era árdua e muito custosa. Entre as despesas com a Companhia, o ordenado e o pagamento dos coristas aparecem como os principais investimentos. Os demais componentes podem ser divididos em 
duas categorias: 1. Estrutura, que perpassa os custos fixos que vão do aluguel do teatro aos coristas. 2. Ordem e Segurança, que compõem os gastos com a manutenção integral (externa e interna) do espaço. Da guarda militar à despesa com móveis (excetuando o papel da orquestra, que adentra no item estrutura), todas as demais funções estão vinculadas à organização de um empreendimento de caráter empresarial, porém, respaldado pelo Estado.

Dentro desse contexto, compreendemos o sentido da observação de um possível empresário das artes cênicas do Porto, em 1805, que evidenciava a importância de uma capital imperial consagrar o seu teatro nacional. Dizia:

Não sei que haja exemplo de Nação civilizada que estabelecesse teatros estrangeiros sem primeiramente terem um bom Teatro Nacional. Londres tem uma Casa de ópera e vários teatros ingleses, Paris aonde há uns 20 teatros nacionais se tem também um único de música italiana; o $\mathrm{n}$ [ilegível] em S. Petersburgo. [...] Finalmente em Lx.a há atualmente 3 portugueses, o que apenas o de S. Carlos nota[se] apenas $[\mathrm{sic}] .^{78}$

Muito provavelmente, o Teatro de S. Carlos destoava dos demais, Bairro Alto e Condes, pelo fato de o seu repertório operático ser quase inteiramente italiano; sendo este o gênero de maior influência no universo musical português do período. ${ }^{79}$ Em 10 de maio de 1804, quando a relação diplomática entre a França e Portugal ainda não era de conflito explícito, como seria três anos à frente por conta do Bloqueio Continental decretado por Napoleão Bonaparte em 21 de novembro de 1806, houve na capital

\footnotetext{
${ }^{78}$ Memória sobre a regulação do teatro do Porto, de 1805. BNP. Seção Res. Mss. 184,30.

${ }^{79}$ PACHECO, Alberto. Castrati e outros virtuoses... Op. Cit., p. 31.
} 
portuguesa um tributo ao novo cônsul da República Francesa, o próprio Bonaparte. Na comemoração ocorrida na casa do general Lannes, embaixador francês em Portugal, compareceram os principais nomes da cena musical lisboeta, entre eles Catalani e Marcos Portugal. Figura controversa da diplomacia francesa, Lannes causou grandes constrangimentos a $\mathrm{D}$. João no período em que viveu em Lisboa (1802-1804). Além de não comparecer às solenidades públicas, tentava imiscuir-se nas decisões políticas da Coroa, nomeadamente às referentes às mudanças ministeriais. Pelo decoro da época, o comportamento do general francês era considerado uma afronta ao poder real. Por se tratar de um homem de Bonaparte, contudo, D. João acabava por ceder aos seus caprichos. ${ }^{80}$ Nesta data, também houve um festejo oficial em ação de graças ao novo cônsul: foi rezada uma missa solene seguida de Te Deum na Igreja do Loreto. Segundo Benevides, "Dirigiu a música o maestro Marcos Portugal. Tocaram e cantaram os músicos da real capela e do teatro de S. Carlos. Todos os convidados tiveram aonde assentar-se comodamente; assim o asseverava a Gazeta de Lisboa."11 Como podemos notar na fala no memorialista, os artistas do Teatro de $\mathrm{S}$. Carlos estavam à disposição das celebrações políticas que interessavam à Coroa louvar. Ainda nas palavras do autor,

\footnotetext{
80 "Lannes não apenas não cumpria as regras de diplomacia ou da própria Corte, como agia com ostensiva má educação com o príncipe, de uma forma que apenas era admitida porque constituía a manifestação da arrogância de alguém que falava em nome de uma grande potência que sabia deter um poder ilimitado sobre os pequenos estados. Ele recusava-se a tratar os assuntos com o secretário de Estado dos Negócios Estrangeiros, que considerava demasiado próximo da diplomacia britânica, e consequentemente, forçou a marcação de audiências príncipe [...] [e] queria desde o início forçar o príncipe a alterar a composição do seu governo." PEDREIRA, Jorge; COSTA, Fernando Dores. D. João VI... Op. Cit., p. 119.

81 BENEVIDES, F. O Real Theatro de S. Carlos de Lisboa..., p. 82 (Grifo do Original).
} 
À noite houve grande iluminação na igreja, em cujas portas estavam na parte superior grandes grinaldas de carvalho e oliveira, com a iniciais do primeiro cônsul e do príncipe regente D. João. Via-se em grandes letras a legenda Deus protege a França. ${ }^{82}$

Desde o carnaval de 1805, Junot ocupava o cargo de embaixador francês em Portugal. Ambicioso, arrogante e temperamental, o marechal de Napoleão tinha a incumbência de chegar a um acordo com a Coroa lusitana que primasse pelo equilíbrio dos mares. Em outras palavras, sua missão era pressionar Portugal a fechar os portos nacionais aos navios ingleses; o que significava romper com a Inglaterra. Era isso ou a guerra. ${ }^{83}$ Até a efetiva invasão de Bonaparte a Portugal, em novembro de 1807, o Príncipe Regente conseguiu manter uma diplomacia de evasivas e dissimulações, o que garantia à Coroa mais tempo para discutir sobre os planos futuros, ou seja, a transferência da Corte para o Brasil.

Nesse período, Francisco Antonio Lodi esteve à frente da administração do Teatro de S. Carlos. Com a entrada dos franceses em Portugal, Lodi foi substituído por Jacinto Fernandes da Costa Bandeira e João Pereira de Sousa Caldas, que se apropriavam do seu guarda-roupa, cenário e arquivo, além de outras peças. O principal teatro de Lisboa também estaria a serviço dos inimigos. Se a fuga de Caldas para Londres foi razão suficiente para o fechamento de S. Carlos, já no carnaval de 1809 o governo francês exigia que Lodi encenasse peças em seu nome. ${ }^{84}$

Durante todos esses anos a relevância da figura do maestro Marcos Portugal é indiscutível. Em maio de 1801, por ordem

\footnotetext{
${ }^{82}$ Ibid., p. 82. (Grifo do Original).

83 PEDREIRA, Jorge; COSTA, Fernando Dores. D. João VI... Op. Cit., p. 152.

${ }^{84}$ Apontamentos. V. Nogueira (Ricardo Raimundo). BNL _Res. COD. 7207. Doc. 10 (II)
} 
expressa de Napoleão Bonaparte o Teatro Italiano de Paris reabria suas portas após as convulsões revolucionárias com uma canção do compositor português. ${ }^{85}$ Para a música clássica luso-brasileira, em particular, e para a política cultural joanina, em geral, sua importância é de tal monta que sua persona merece uma análise mais detida, o que faremos mais adiante. Por ora, destacamos a contribuição desse maestro para o "refinamento do gosto" da sociedade cortesã luso-brasileira do período, que passava a conviver com novos hábitos e costumes dito iluminados. Como observou o francês Jácome Ratton em 1813, desde a fundação do Teatro de S. Carlos, a sociabilidade e a polidez praticada nesse espaço colocava a nação portuguesa em compasso com as mais polidas da Europa, já que desterrava os restos "bárbaros” dos costumes mouriscos que ainda conservavam. ${ }^{86}$ Era justamente esses resquícios de barbárie que a Coroa e a sociedade portuguesa tanto desejavam sepultar. A vigência e sustentação do Teatro S. João, no Porto, é um bom exemplo dessa batalha, como veremos a seguir.

\subsection{A particularidade d'O Real Teatro de São João no Porto}

Dois anos depois da fundação do Teatro de S. Carlos, nascia na cidade do Porto o Real Teatro de São João. Do início da construção (1794) à fundação, quatro anos depois, em 13 de Maio de 1798, o Real Teatro S. João esteve diretamente ligado à figura

\footnotetext{
85 SARRAUTE, J-P. Marco Portugal. Op. Cit., p. 25-26.

${ }^{86}$ RATTON, Jacome. Recordaçõens sobre ocurrencias do seu tempo em Portugal, durante o lapso de sessenta e três anos e meio, aliás de Maio de 1747 a Septembro de 1810 [...], Londres: H. Breyer, 1813. p. 349-350.
} 
do Príncipe Regente: do nome (João) à data de inauguração - dia do seu nascimento, a homenagem era explícita. ${ }^{87}$

Erguido por determinação do desembargador Francisco de Almada e Mendonça, homem de preeminência na cidade ${ }^{88}$, o teatro teve seu projeto arquitetônico concebido pelo italiano Vicente Mazzoneschi, arquiteto de prestígio no período. Como ressalta Joaquim Jaime B. Ferreira Alves, na segunda metade do século XVIII, o norte de Portugal contava com a presença de artistas italianos "que, directa ou indirectamente, relacionam o seu nome com a arte nortenha, alguns dos quais se fixaram definitivamente no Norte." ${ }^{\text {"9 }}$ Se a construção não seguiu à risca o plano original - uma grande decoração exterior - por falta de recursos, é fato também que o interior do edifício foi detalhadamente lapidado por Mazzoneschi, que já havia sido cenógrafo do Teatro de São Carlos em Lisboa. ${ }^{90}$ À época, ter a composição próxima à dos teatros italianos era considerado uma regra de sucesso.

Apesar de a arquitetura ser semelhante à do Teatro de S. Carlos, as questões administrativas referentes à manutenção do

\footnotetext{
87 Teatro Nacional de S. João. Disponível em: <http://www.infopedia.pt/\$teatro -nacional-de-s.-joao>. Acesso em: 03 ago. 2011.

${ }^{88}$ Francisco de Almada e Mendonça (1757-1805), fidalgo da Casa Real e doutor em Leis formado pela Universidade de Coimbra, foi Comendador da Ordem de Cristo, primeiro senhor donatário de Ponte da Barca e primeiro alcaide-mor de Marialva, pertencente ao conselho do rei e sendo desembargador do mesmo no Paço. Na comarca do Porto foi provedor, corregedor, presidente do cofre, intendente da Marinha, presidente da Junta Administrativa da Fazenda, das saboarias e do tabaco, conservador no juízo das encomendas e do sal, avaliador das obras literárias produzidas, assim como nos processos policiais, contrabando e moeda. Disponível em: <https://www.infopedia.pt/\$francisco-de-almada-e-mendonca>. Acesso em: 03 ago. 2011.

${ }^{89}$ ALVES, Joaquim Jaime B. Ferreira. "Ensaio sobre a arquitectura barroca e neoclássica a norte da bacia do Douro". In: Revista da Faculdade de Letras Ciências e técnicas do Património. Porto: 2005. I Série vol. IV, p. 137.

90 Ibid., p. 150.
} 
estabelecimento foram muito diferentes das vivenciadas no teatro da capital. A começar pelo fato de os administradores estarem ao norte do país, isto é, fisicamente distantes do centro do poder político, Lisboa. Mesmo sendo o Porto a segunda cidade em importância econômica do Reino e contar com uma respeitável instância de apelação, o Tribunal da Relação do Porto ${ }^{91}$, esta situação colocava-os diante da dependência de um circuito de comunicação eficaz, o que, na prática, exigia desses empresários portuenses a sustentação de uma retórica ainda mais convincente daquela utilizada pela "gente do Teatro"92 lisboeta, já que necessitavam da aprovação real para manterem a vigência de seu espaço cultural.

Um documento anônimo de 1805, intitulado Memória sobre a regulação do teatro do Porto nos coloca diante de algumas questões centrais que faziam parte do universo desses empresários. Escrito possivelmente por um de seus dirigentes, o início da correspondência já evidencia as principais bases estruturais que deviam reger o espaço e ao mesmo tempo seus integrantes. Vejamos:

A resolução com que contas os Senhores Administradores do Teatro do Porto de vigiarem sobre a escolha e a boa execução das Peças que nele se houverem por representar por muita honra à sua probidade e patriotismo, sendo certo que são tantas as utilidades, que se podem tirar de um Teatro bem dirigido, como os males que ele produzirá uma vez que se permitam espetáculos licenciosos e indecentes. Devo agradecer-lhes muito o obséquio que me fazem, em me querer ouvir sobre este assunto pelo qual

\footnotetext{
91 O Tribunal da Relação do Porto era uma instância de apelação das terras a norte do Mondego, mas com recursos para Lisboa. Cf. LOUSADA, Maria Alexandre. Espaços de sociabilidade... Op. Cit., p. 59.

92 Expressão utilizada no manuscrito da época intitulado Memória sobre a regulação do teatro do Porto, de 1805. BNP. Seção Res._. Mss. 184,30.
} 
só posso corresponder propondo com toda a sinceridade as minhas ideias, e desejando que entre elas haja alguma que se mereça aproveitar-se. ${ }^{93}$

O agente cultural não só enumerava as vantagens da "boa" direção de um teatro, como também circunscrevia a seriedade com que os valores morais deveriam fundamentar os espetáculos. O teor do documento, em formato de resposta a um pedido de análise do espaço teatral pelos administradores, nos indica que, muito provavelmente, o diálogo antes se travava com os ministros do regente, homens de grande influência na aprovação e orientação dos projetos culturais vigentes no Império Português. "O bom regulamento de um Teatro (e para que o público seja bem servido) depende de 4 coisas: Peças, Atores; Acessórios; Polícia [sic]", afirmava o diretor ${ }^{94}$, que enxergava a estruturação do espaço sempre sob o prisma indissociável da relação dialógica travada com o público, os espectadores das peças. "[O] teatro é por excelência a arte de comunicar com o povo [...] nenhuma outra forma de comunicação, com exceção dos sermões, chegava tão diretamente ao povo analfabeto" 95 , afirma o pesquisador Graça Almeida Rodrigues. Assim como as peças de teatro, os manuais de boas maneiras também foram muito populares na sociedade de Corte do Antigo Regime europeu e compunham uma importante expressão dos códigos morais e dos modelos de comportamento vigentes. Segui-los, significava a inserção em um determinado grupo que se diferenciava dos outros pela postura, pelo gosto e pelo costume. ${ }^{96} \mathrm{E}$ a disputa entre os súditos pelo

\footnotetext{
${ }^{93}$ Ibid.

94 Ibid.

95 RODRIGUES, Graça Almeida. Breve historia da censura literária em Portugal. Lisboa: ICALP, 1980. p. 79.

96 MONTEIRO, Maurício. A construção do gosto: música e sociedade na Corte do Rio de Janeiro 1808 -1821. São Paulo: Ateliê Editorial, 2008. p. 67.
} 
reconhecimento do rei era um dos maiores desafios da sociedade de Corte.

Dentro da lógica desses valores igualmente veiculados nas peças de teatro, os quatro componentes ressaltados pelo autor de "Memórias..." foram detalhadamente analisados. No primeiro item - I. Peças -, considerava:

Para que uma peça se ponha em cena não é necessário que seja escrita segundo o rigor dos preceitos da Poesia Dramática, porque as composições dessa natureza são poucas e o diretor de um Teatro não tem a obrigação de ser um crítico conservado, e como nesta casa seria pouco para o nosso fim basta que a peça seja interessante, porque aliás não terá aceitação, e que seja correta, quanto a moral, e se for possível, também quanto à linguagem. Chamo peças corretas quanto à moral todas aquelas que não ofendem os bons costumes, ainda que o seu fim seja a correção dos vícios. ${ }^{97}$

Como podemos notar, o escritor evidenciava as características que diferenciavam a atividade de um diretor de teatro da de um crítico teatral: o primeiro devia ater-se mais às questões estruturais (como a escolha, a tradução e a adaptação das peças) ao passo que o segundo deveria conhecer a fundo os principais dramaturgos europeus; assim como os preceitos teóricos que regem os gêneros e produções artísticas.

Já no Alvará de 1771, a figura do diretor teve grande destaque. $\mathrm{O}$ artigo II determinava que a sociedade estabelecida para a subsistência dos teatros públicos da Corte deveria ser gerida por quatro diretores (acionistas) eleitos anualmente pelos sócios. ${ }^{98}$

97 Memória sobre... Op. Cit. Seção Res._Mss. 184,30.

98 Alvará de 17 de Julho de 1771. Apud BENEVIDES, F. O Real Theatro de São Carlos... Op. Cit., p. 13. 
Mais adiante, os artigos de XVII a XXIII circunscreviam em pormenores as funções que estes deveriam exercer cotidianamente. Vejamos:

XVII - A um dos diretores incumbia a inspeção da contabilidade, as finanças, a administração e correspondência estrangeira.

XVIII - Outro diretor escolhia as peças, distribuía as partes, regulava os ensaios, etc.

XIX - Ao terceiro diretor incumbia a parte cênica, decorações, cenário, adornos, iluminação, etc.

$\mathrm{XX}$ - Ao quarto diretor pertencia a inspeção das obras, as comodidades do teatro e do público, o arquivo, os armazéns, as habitações dos cômicos conforme as cláusulas das suas escrituras, etc.

XXI - A distribuição indicada dos serviços não dispensava as conferências dos diretores, que deviam reunir-se em conselho pelo menos todas as segundas-feiras.

XXII - Os diretores determinavam os dias e horas dos espetáculos, pondo-se cartazes públicos. $\mathrm{Na}$ Quaresma não havia representações nos teatros.

XXIII - Um dos diretores devia assistir, e dirigir sempre a representação, em um camarote da direção. ${ }^{99}$

Para além das funções definidas pelo Alvará, o autor do manuscrito ainda ressaltava uma responsabilidade fundamental dos diretores: a especial atenção à tradução das peças, uma vez que estavam associadas à função pedagógica do teatro - a moralização dos costumes. No caso português, esta perpassava, necessariamente, pela atuação dos censores, responsáveis pela coerção das ideias consideradas sediciosas.

Desgraçadamente a maior parte das traduções que temos são miseráveis, e seria de desejar que se reformassem para

99 Ibid., p. 14. 
que o Teatro fosse, como deve ser, uma escola de boa ${ }^{100}$ linguagem pura e correta. Mas conheço que isto no tempo presente seria exigir mais do que se pode fazer. Mas a pouco meio em que as traduções tão, ${ }^{+}$[sic], sem perder de vista a necessidade de se irem corrigindo pouco a pouco as que estão feitas quando as circunstâncias o permitirem. ${ }^{101}$

O que seria uma linguagem pura e correta? A resposta vem do próprio autor, quando se refere à responsabilidade dos diretores na escolha de peças nacionais ou na tradução das estrangeiras. "O objeto principal do exame [das peças] deve ser a pureza da moral, mas a seria corrente [sic] que o Censor a corrigisse ao mesmo tempo os principais defeitos de linguagens que encontrasse". ${ }^{102} \mathrm{Na}$ prática, a exata averiguação de tais distorções deveria ser feita por um sujeito hábil, capaz de executar as adaptações, os Cortes e as mudanças "necessárias" das peças dramáticas às circunstâncias do tempo, assim como às peculiaridades do teatro português, adequando da maneira mais coerente possível a forma e o conteúdo, para assim alcançar o objetivo da elevação moral e espiritual.

Dentro desse contexto, o conselho de Diderot para o dramaturgo foi de suma pertinência. "Ao escrever deve-se sempre ter em vista a virtude e as pessoas virtuosas". ${ }^{103}$ Mais à frente, o filósofo reiterava o ensinamento: "Insisto, pois: o honesto, o honesto. Ele nos comove de forma mais intima e doce do que aquilo que provoca nosso desprezo e nossas risadas. Poeta, pois sensível

100 Memória sobre... BNP. Seção Res._ Mss. 184,30. [Palavra rasurada no original] que nos permitiu a leitura que ora transcrevemos.

101 Ibid.

102 Ibid. (Grifos nossos).

103 DIDEROT, Denis. Discurso sobre a poesia dramática... Op. Cit., p. 40. 
e delicado? Vibrai essa corda e a ouvireis ressoar ou fremir em todas as almas". ${ }^{104}$ Ao analisarmos o discurso do empresário portuense, parece-nos que ele tentava seguir os preceitos propalados pelo ilustrado francês. No entanto, sempre mantendo o decoro às regras da Real Mesa Censória, que lutava contra o teatro ao gosto português. ${ }^{105}$ Afinal, para atingir a máxima utilidade do teatro - a “correção dos vícios"106 - devia-se ter em conta as peculiaridades da sociedade portuguesa.

Sobretudo depois de 1792, as autoridades olhavam com repúdio para as possíveis consequências dos "abomináveis princípios franceses" em Portugal. Para a Coroa, a "extraordinária e temível Revolução Literária e Doutrinal” francesa era uma fortíssima ameaça para "as opiniões estabelecidas" e atingia todos os campos do saber: das artes à ciência, as ideias francesas consideradas ímpias eram vistas como um agente capaz de abalar os alicerces da tradição do Antigo Regime, mormente nas esferas religiosa e política. Em 17 de dezembro de 1794, D. João ordenou o restabelecimento da censura tríplice. Revogava-se a censura unificada, quebrando o "compromisso com a legislação pombalina"107 e o controle de livros e escritos no país retrocedia

104 Ibid., p. 42-43.

105 "As licenças [das peças de teatro] seriam concedidas apenas aos textos que utilizassem uma linguagem elitista e que abordassem, na perspectiva dos censores, temas sóbrios, sérios e úteis. Para além disso, a censura decidiu lutar contra o chamado teatro ao gosto português, uma espécie de teatro concebido desde a Idade Média, e que colocava em destaque as situações satíricas aliadas a um conjunto de linguagem e situação bastante presentes em todas as peças, que maioritariamente [sic], resultavam de adaptações, imitações e traduções que pouco tinham a ver com os originais espanhóis, franceses e italianos." FERREIRA, Luís Tarujo. "Teatro de Cordel e a Censura em Portugal... Op. Cit., p. 5.

106 Memória sobre... Op. Cit. Seção Res._Mss. 184,30.

107 TENGARRINHA, José. História da imprensa periódica portuguesa. 2. ed. Lisboa: Editora Caminho, 1989, p. 104. Durante a administração pombalina a censura foi submetida exclusivamente ao poder Régio, com o alvará de 18 de 
às antigas instâncias de poder: a Inquisição, o Ordinário e a Mesa do Desembargo do Paço, cada qual com distintas funções. Redobravam-se os cuidados com a circulação das ideias no espaço público.

Como asseverou a historiadora Leila Mezan Algranti, todo o sistema de censura se apoiava integralmente na vontade do monarca, responsável por manter em primeiro plano os seus deveres com seus súditos dentro das prerrogativas gerais que imperavam no sistema absolutista. Na prática, portanto, era a figura real que em última instância liberava as licenças solicitadas tanto para a circulação de livros quanto para a encenação de peças de teatro. ${ }^{108}$ Dentro desse contexto, compreendemos a alta valorização do autor para o olhar preciso do tradutor, que também não se dissociava da função de censor. Mais adiante, relacionava a tradução das peças àquelas que "tiverem merecimento": neste caso, exaltava a produção das Comédias e Dramas “sérios" produzidos nos países dito civilizados como Inglaterra, França e Espanha. ${ }^{109}$ Ao estudar os pareceres dos censores para as peças de teatro, na segunda metade do século XVIII, o pesquisador português Luís Tarujo Ferreira delineia os diferentes vieses do discurso desses homens ilustrados. Segundo o autor, a negação da impressão de uma obra teatral, "pugnava pelo rigor gramatical e defendia a pu-

maio de 1768, que estruturou a Real Mesa Censória, sujeita à autoridade real e com jurisdição própria. Como afirma a historiadora Leila Mezan Algranti, "Com a criação da Real Mesa Censória, em 1768 Pombal retirou do Tribunal do Santo Ofício e do Ordinário a prerrogativa de responsáveis pela censura religiosa, e passou-a para a ação do Estado.” Assim, a Real Mesa Censória estava única e exclusivamente submetida a autoridade real, cabendo a este órgão fiscalizar a impressão e circulação de todos os livros do Reino e também aqueles que eram direcionados às Colônias. ALGRANTI, Leila Mezan. Censura e comércio de livros no período de permanência na Corte portuguesa no Rio de Janeiro (18081821), Faculdade de Letras da Universidade de Coimbra, Coimbra, 1999, p. 633.

108 ALGRANTI, Leila Mezan. Livros de Devoção... Op. Cit., p. 139.

109 Memória sobre... BNP. Seção Res._. Mss. 184,30. 
reza linguística, apesar de por vezes não conseguir tal intento". ${ }^{110}$ O mesmo preceito - as regras poéticas - era utilizado para justificar as alterações feitas nos textos originais, quando aprovados pela Mesa Censória. Na análise de Ferreira,

Um tão apertado crivo arredava numerosas obras de impressão, reimpressão ou representação por não cumprirem "as regras da decência", ou por serem "chulas"; por vezes negavam-se as obras que abordavam questões como o "adultério" e outros "pecados"; muitos textos eram "contra a Fé e as Escrituras", ou "contra os Príncipes" ou "contra o Governo". Pela meticulosa análise linguística, outras peças eram proibidas "devido a impropriedades", por "má locução", por não respeitarem o "vernaculismo" ou por apresentarem um "estilo duro", "insultuoso" ou "afectado". 111

No Antigo Regime Português a atuação da censura estava intimamente ligada à ação da Intendência Geral da Polícia. Segundo o memorialista Francisco Benevides, neste período o intendente da polícia era a primeira autoridade abaixo do rei, sendo de imensa amplitude o poder que exercia sobre os ministros criminais e civis, além de sua tropa; em muitos ramos da sua administração este tinha que prestar contas apenas ao chefe do Estado. ${ }^{112}$ Como bem demonstrou o historiador José Alves, no período em que Pina Manique esteve à frente da Intendência da Polícia (1780-1805), houve um rígido controle tanto dos tipos de espetáculos que se realizavam em Lisboa, como das datas em que os teatros deveriam estar fechados. Não bastasse isso, o intendente igualmente determinava os dias de festas e das corridas de

110 FERREIRA, Luís Tarujo. “Teatro de Cordel... Op. Cit., p. 5.

111 Ibid., p. 5.

112 BENEVIDES, F. O Real Theatro de S. Carlos de Lisboa... Op. Cit., p. 92. 
touros. ${ }^{113}$ Este grande poder policial justifica ser a Polícia um dos quatro componentes considerados essenciais no bom funcionamento de um teatro. No item IV. Polícia, o autor de "Memórias..." afirmava:

Nenhum teatro pode ser bem regulado sem que a sua polícia cometida a um Magistrado prudente, grave, imparcial e austero. [...] A inspeção do Ministro da Polícia do Teatro tem dois objetivos: 1. Fiscalizar $\mathrm{o}^{114}$ desempenho das obrigações dos cómicos e de mais gente empregada no serviço do Teatro. 2. Fiscalizar o bom comportamento dos espectadores. ${ }^{115}$

Advertia, ainda, que as "Regras ou Leis da Casa" deveriam ser afixadas em local público seja por meio da impressão, com a devida licença real, ou por tábuas manuscritas, que seriam fixadas "na mesma casa do Teatro em lugar próprio". ${ }^{116}$ Segundo Daniel Roche, no Antigo Regime o cartaz tinha uma grande importância política dentro do circuito de comunicação: transmitia a força da autoridade monárquica legislada, inclusive, pelos regulamentos municipais de polícia, que englobavam todo o universo das produções culturais. ${ }^{117}$ Nas palavras do historiador:

113 ALVES, José. A opinião pública em Portugal... Op. Cit., p. 63. Para a concepção de Pina Manique acerca do teatro como escola de moral e repreensão do vício, ver: CARVALHO, Mário Vieira de. Pensar é Morrer... Op. Cit., p. 52-55.

114 [o compromisso das obrigações que]. Sentença rasurada no original. Contudo, foi possível a realização da leitura que ora transcrevemos. Memória sobre... BNP. Seção Res._ Mss. 184,30.

115 Ibid.

116 Ibid.

117 Utilizamos aqui o conceito de produto cultural definido no Dicionário Crítico de Política Cultural. Definição: “Tratados regionais de integração econômica e cultural definem os produtos culturais como aqueles que expressam ideias, valores, atitudes e criatividade artística e que oferecem entretenimento, informação ou análise sobre o presente, o passado (historiografia) ou o futuro 
As notícias, as novidades, os espetáculos, os teatros, as convocações para as festas - como as justas no rio ou os fogos de artificio -, tudo age como manifestação do poder, mas ao mesmo tempo permite uma transformação das atitudes para com a cidade, uma mudança dos hábitos, uma modificação dos costumes, uma familiaridade de todos com a informação escrita. ${ }^{118}$

Como já dissemos, neste período a reapropriação do espaço urbano pela sociedade portuguesa era intrínseca à teoria do estado de polícia que se amparava em dois conceitos centrais: a ordem e o bem-estar. De acordo com Marieta Carvalho, promover a ordem era um ato de interferência política; sentido que elevava o conceito de política e polícia ao mesmo nível, uma vez que "a política tinha por objetivo, e ao mesmo tempo, por fim, promover a ordem". Isto, na prática, equivalia a garantir a segurança dos súditos esclarecidos tanto em âmbito externo - na proteção e defesa do território -, como no plano interno, nas atividades de policiamento cotidianas que muitas vezes significavam uma administração eficiente da justiça. ${ }^{119}$ Já o bem-estar dos súditos estava intimamente relacionado à prosperidade do Estado. "Referia-se tanto à concessão das 'comodidades' da vida, no seu significado material - 'limpeza, asseio, fartura de víveres, e vestiaria' - como, essencialmente à promoção da economia, à realização de intervenções persuasivas ou dissuasivas em relação às atividades econômicas", contextualiza a autora. Dentro dessa perspectiva, compreendemos melhor a fala do diretor do Porto, quando este

(prospectiva, cálculo de probabilidade, intuição)." COELHO, Teixeira. Dicionário Crítico... Op. Cit., p. 318.

118 ROCHE, Daniel, O Povo de Paris, ensaios sobre a cultura popular no século XVIII. Trad. de Antonio de Pádua Danesi, EDUSP, SP, 2004. p. 303.

119 CARVAlHO, Marieta Pinheiro de. Uma idéia... Op. Cit. p. 51. 
concebia a autoridade dos empresários do teatro sob as ordens do ministro de Polícia: estes deveriam "cumprir a risca tudo o que tiverem prometido". Alertava, ainda, que na impossibilidade da execução da lei por qualquer razão, ficavam obrigados a se justificarem perante o público, restituindo-lhes o preço da entrada. ${ }^{120}$

A relação de poder entre a "gente do teatro", o público e a autoridade policial era de tal forma hierarquizada que as características necessárias do magistrado - prudência, gravidade, imparcialidade e austeridade - garantiam-lhe a liberdade de atuação para que a ordem fosse conservada. No caso dos espetáculos teatrais, em particular, um dos vieses da manutenção dessa disciplina estava circunscrito ao início das peças. Segundo o escritor, estas deveriam começar precisamente "na hora determinada, sem se esperar por pessoa alguma, por mais autoridade que seja, e nem ainda pela Min.[sic] do Teatro", uma vez que os gerenciadores do espetáculo deviam dar o exemplo de ordem e regulamentação das Leis da Casa, cultivando, para isso, o princípio máximo: o respeito ao público. ${ }^{121}$ Ainda diante da função do magistrado policial, alertava:

O Ministro procederá a castigar todas as faltas da gente do Teatro, que fossem relativas à execução do que devem ao Público, quando eles o merecerem, e com pena de que forem dignas, já repreendendo os culpados, já mandando-os [sic] prender: para o que se deve estar plenamente autorizado[...]. ${ }^{122}$

Para além de exaltar as normas da polícia vigentes na sociedade portuguesa, o autor circunscrevia outros meios possíveis

\footnotetext{
120 Memória sobre... Op. Cit. _ Mss. 184,30 (Grifos nossos).

121 Ibid.

122 Ibid.
} 
de atuação da autoridade policial, considerados lícitos justamente por se tratar da "gente do teatro", tão diferenciada dos demais grupos sociais. Tais "diferenças" foram salientadas na correspondência, especialmente no item II. Atores [sic].

Seja-me licito aqui acrescentar uma breve reflexão sobre o caráter moral dos atores. É bem sabido que entre eles não reina os melhores costumes, e as mulheres de Teatro são pólo comum e notarás por sua desenvoltura certamente. Esta regra tem exceções ilustres, e nas Cortes mais polidas da Europa, admirará ainda não há muitos anos uma portuguesa que se distinguindo-se superiormente na sua arte foi há muito tempo um modelo de virtude digna de ser imitado pelas pessoas da mais alta esfera. ${ }^{123}$

Muito possivelmente, o escritor se referia à já citada Luísa Todi, casada com o destacado violinista napolitano Francesco S. Todi. Entre 1778 e 1799, Luísa encantou as Cortes mais destacadas da Europa: de Londres à São Petersburgo, quando foi convidada pela Imperatriz Catarina II da Rússia a fazer parte do coro real (1784 a 1788), a cantora se apresentou nos palcos de Versailles e Paris, Madri, Berlim, Turim, entre outras grandes cidades do Velho Mundo. Apesar da fama nos mais conceituados meios artísticos europeus, a meio-soprano teve sua trajetória vinculada à Corte portuguesa. Quando voltou a Portugal, residiu no Porto entre 1801 e 1811.

Pelo prisma do diretor, portanto, Luísa era o exemplo de retidão moral de mulher muito talentosa que adentrava para o universo da arte musical vivendo sob a condição sagrada do matrimônio. Mas Luísa também era exceção. E é justamente sob

${ }^{123} \mathrm{Ibid}$. A análise sobre a posição das mulheres atrizes será tratada na última parte deste capítulo. 
aqueles que compunham "a norma" que a sua crítica se fazia patente: era necessário educar os valores morais dos profissionais das artes cênicas nem que para isso a polícia cumprisse "à risca" a lei penal do Reino. Afinal de contas, os "caprichos, as rivalidades, e as intrigas [...] frequentes entre esta gente"124 supunha-se a regra, sendo a polícia o órgão de vigilância complementar do aparelho de justiça. ${ }^{125}$

A defesa da polícia como autoridade máxima na regulação do espaço público reapareceria oito anos mais tarde, em finais de 1813. A grande novidade, neste caso, é que agora eram os próprios atores da Companhia Nacional da cidade que justificavam essa ideia. Em um documento coletivo dirigido ao administrador do teatro, estes expunham a problemática vivida nos últimos tempos: a grande tensão com os seus pares italianos pelo domínio do espaço cênico. Ou seja, os atores portugueses não queriam subordinar-se "à direção dos Fautores, e imaginários Empresários da Companhia da Burleta Italiana”. ${ }^{126}$ Segundo eles, se isso ocorresse a Companhia Nacional poderia ser excluída do teatro; o que causaria a falência de sua classe. Tal querela adquiria contornos cada vez mais graves e deveria urgentemente ser resolvida, se necessário, sob a ação policial. Vejamos:

Um teatro não é uma casa particular, é um Edifício destinado a funções públicas; e sujeito, por isso, segundo nossas Leis, à inspeção, e regulamento da Polícia; e assim como a Polícia pode (e já o tem feito no mesmo Teatro

124 Ibid.

125 LOUSADA, Maria Alexandre. Espaços de sociabilidade... Op. Cit., p. 69.

${ }^{126}$ Memória com que se demonstra a preferência, que a Companhia Nacional deve ter à Italiana no arrendamento do Real Teatro São João da Cidade do Porto para o futuro ano de 1814, p. 3. BNP. Seção de Obras Gerais. (Microfilme). Discutiremos sobre a importância da Burleta e a disputa entre portugueses e italianos no teatro nacional no último item deste capítulo. 
desta Cidade) inibir os Proprietários, para que alguém, ou conservem nas suas Propriedades Inquilinos, que por qualquer modo escandalizem, ou prejudiquem o Público, como se protegessem prostíbulos, ou lupanares, jogos proibidos, ou congressos perniciosos, pela mesma razão pode, e até obrigar o Administrador da Casa do Teatro a dá-lo em aluguer àquela Companhia, ou Sociedade, que mais estiver em proporção para desempenhar as intenções do Legislador relativamente aos Espetáculos. ${ }^{127}$

Consideravam, ainda, que a função do administrador era alugar o espaço apenas para aqueles "a quem estiver nas circunstâncias da Lei, e a quem, segundo ela, a Polícia lhe indicar. Em uma palavra, os Teatros devem regular-se, não pelas ordinárias Leis da propriedade, mas pela de uma vigilante Polícia”, que tinha a obrigação de seguir a norma apontada no Alvará de $1771 .^{128}$ Com esta fala, tentavam mostrar, precisamente, que os italianos não concebiam o teatro da mesma forma que os portugueses e, por isso, deveriam ser rigorosamente vigiados. Ao mapear a atividade policial no Reino entre 1780 e 1834, a geógrafa Maria Alexandre Lousada nos mostra que a mobilidade e o conhecimento do território foram fatores indispensáveis à conservação da ordem e manutenção da tranquilidade pública. Porém, alerta que o sucesso desse projeto dependia da visibilidade da guarda: esta deveria alternar com a ocultação, o meio mais eficaz de impedir a fuga dos transgressores. ${ }^{129}$ Sob o mesmo prisma de análise, Michel Foucault situa a situação da Europa, na virada do século XVIII para o XIX. De acordo com o filósofo, o Velho Continente vivia um processo de transformação de toda a economia dos castigos.

\footnotetext{
127 Ibid., p. 3.

128 Ibid., p. 8-9.

129 LOUSADA, Maria Alexandre. Espaços de sociabilidade... Op. Cit., p. 75.
} 
A própria condenação passava a marcar o delinquente com sinal negativo e unívoco. Fazia-se, então, a publicidade dos debates e da sentença: a execução tornava-se uma vergonha suplementar, da qual a justiça tentava guardar distância, tendendo confiá-la a outros pelo viés do sigilo. ${ }^{130}$ Portanto, a interiorização desta nova concepção do ato de vigiar a cidade e punir os infratores colocava em cena a repressão pelo paradigma de que o domínio social perpassava a prevenção criminal, intrínseca a um trabalho detalhado de controle do espaço urbano pelo uso da estatística. ${ }^{131}$

Esta nova práxis não estava desvinculada do que a Coroa compreendia como sendo a arte do teatro ao longo do século XVIII. Seja por Raphael Bluteau (1728) "metaforicamente, o lugar em que tem uma coisa todo o seu luzimento, e estimação. Neste sentido, chama Cícero Theatrum ingenii, o lugar em que se faz ver o engenho. Ficam as suas virtudes expostas em mais amplo teatro, isto é, aos olhos de mais gente" ${ }^{132}$, ou pela definição de Moraes e Silva (1789) "o lugar em que se representam dramas e onde se assiste a representação deles [com] publicidade" e cujas "regras [...] do que respeita aos dramas, representadores; e decoração do teatro"133; salienta-se o fato de este ser um espaço público voltado para o diálogo pedagógico com a plateia. Neste caso, todos que estivessem vinculados à atividade artística teatral no Império Português - empresários, atores, espectadores e críticos

\footnotetext{
${ }^{130}$ FOUCAULT, Michel. Vigiar e Punir. Nascimento da Prisão. Trad. Raquel Ramalhete. Petrópolis: Ed. Vozes, 2000. p. 13.

131 Para uma análise detalhada da prática da Intendência da Polícia em Lisboa no período, ver: LOUSADA, Maria Alexandre. Espaços de sociabilidade..., Op. Cit.; ALVES, José. A opinião púbica em Portugal... Op. Cit.

132 BLUTEAU, Raphael. Vocabulario portuguez \& Latino: aulico, anatomico, architectonico ... Coimbra: Collegio das Artes da Companhia de Jesus, 1712 1728. Vol. 8. p. 150.

133 Dicionário Moraes e Silva, Vol. 2, p. 773.
} 
teatrais (independente da nacionalidade) -, deviam estar cientes de que a obediência às diretrizes régias era sinônimo de ser um bom cidadão, como atestava uma das Máximas Morais (LXVI) defendidas na obra Elementos da Civilidade e da Decência.

As leis fazem o mesmo efeito na sociedade, que os alicerces em um edifício, e as molas em um relógio: porque estas sustentam o peso de toda a sua economia, e lhe regulam todos os movimentos: ou servindo-se de expressão mais natural, assim como o cego necessita de um bordão, para seu arrimo e guia, da mesma sorte os homens em geral precisam de leis para os encaminhar, e reduzir à ra$z \tilde{a} o$. Estas constituem a segurança pública, e particular: da maneira que cada indivíduo tanto interfere tem na sua conservação, como os membros na saúde do corpo. ${ }^{134}$

Ainda nesta Máxima, o autor reiterava o que considerava um verdadeiro cidadão: o homem de bem que se conforma com as leis e costumes do país em que se acha; que considera-o como pátria, servindo de seus talentos, em utilidades daqueles com quem vive. ${ }^{135}$ Não por acaso, tal concepção foi amplamente debatida pela Companhia Nacional, membros da elite cultural portuguesa. Segundo os atores, uma das fortes razões que os justificava a suplicarem aos superiores uma posição política diante da disputa com os empresários italianos era o fato de estes serem "patriotas anfíbios, que mudam de nome e Pátria, segundo o requerem os seus interesses, e circunstâncias". ${ }^{136} \mathrm{O}$ início do documento não deixa margem a dúvidas:

134 Elementos da Civilidade e da Decência..., p. 279-280 (Grifos Nossos).

135 Ibid.

${ }^{136}$ Memória com que se demonstra... Op. Cit., p. 5-6. BNP. Seção de Obras Gerais. (Microfilme). 
Ilmo. Exmo. Sr.

Os poucos Atores Italianos, que a Sociedade Nacional presentemente empregada no Real Teatro desta Cidade, chamou, assalariou e agregou a si, para melhor serviço do mesmo Teatro, voltando-se agora contra os seus benfeitores, contra aqueles que lhes abriram caminho para adquirirem a sua sustentação, expondo-se ao risco de lhes faltar a sua própria, estes homens ingratos, tentam agora apoderar-se do Teatro, e excluírem dele os Atores Nacionais, que se não tivessem sido tão generosos, e benéficos não passariam presentemente pelo desgosto de se verem forçados a entrar com eles em disputa, e ficariam pelo tempo que eles aprouvesse $[\mathrm{m}]$ no pacífico exercício da sua Arte, que ninguém lhes tinha disputado, nem poderia disputar-lhes. ${ }^{137}$

Ao se posicionar na condição de benfeitora do teatro nacional, a Companhia exigia uma atitude de seu superior sob a alegação de que este atuava sempre com "retidão e justiça"138 diante das possíveis intrigas e calúnias que ocorriam nos bastidores. O medo das consequências advindas dessa contenda era visível. Afinal de contas, estavam conscientes dos limites impostos pela profissão que exerciam. "É certo que neste modo de vida está firmada [sic] a sua necessária sustentação, a de seus filhos, e famílias; que eles não tem outros ofícios, de que lhes possa provir a sua subsistência, ou porque os não aprenderam alguns, o desuso deles o constituiu na impossibilidade de os exercitarem"139, defendiam.

Desde a saída de D. João para o Brasil e, principalmente depois do fim das guerras napoleônicas, a manutenção da carreira artística era uma empreitada dificílima. No Porto, a concorrência com os atores da Burleta Italiana ameaçava cotidianamente

137 Ibid., p. 2. BNP. Seção de Obras Gerais. (Microfilme).

138 Ibid., p. 3. BNP. Seção de Obras Gerais. (Microfilme).

139 Ibid., p. 2. BNP. Seção de Obras Gerais. (Microfilme). p. 5 
a conservação da Companhia Nacional. Tal situação circunscreveria o discurso da classe artística por dois vieses distintos. O primeiro estava ligado diretamente à prática do seu ofício - caso os empresários italianos arrendassem o teatro, a sobrevivência dos atores nacionais e de suas famílias estaria ameaçada, uma vez que corriam o sério risco do desemprego. Já o segundo apreendia o plano do simbólico: a perda da preeminência de status social no universo cultural da cidade significava um grande dano para a autoestima da nação portuguesa, que desde fins de 1807 vivia na prática uma difícil inversão de papéis na relação Metrópole-Colônia.

[...] as conversações aqui são sempre fundadas no que se leem nos jornais; e agora não se diz se não que V.M. estava promovendo, e animando que todas as primeiras famílias do Reino, os primeiros negociantes, e todos os artistas emigrassem, e abandonassem Portugal, para se estabelecerem no Brasil. ${ }^{140}$

Tal comentário do médico português Heliodoro de Araújo Carneiro, em 1817, nos coloca diante de um importante processo de transformações sociopolíticas. Com o fim das guerras napoleônicas (1814) não havia mais justificativa plausível para a permanência do regente em terras americanas. A despeito disso, no final de 1815 a Coroa elevava o Brasil à posição de Reino Unido a Portugal e Algarves; fato que além de indicar uma mudança significativa na direção política do Império Português, sensibilizava sobremaneira os vassalos da monarquia: estes, independentemente dos seus lugares na sociedade, se mostravam cada vez mais insatisfeitos por estarem relegados a um plano político periférico, agora institucionalizado.

${ }^{140}$ CARNEIRO, Heliodoro. Cartas dirigidas a S. M. el-rei D. João VI desde 1817: Op. Cit., p. 2. [Carta escrita de Londres, em 4 de Junho de 1817] 
Particularmente no que se refere à manutenção do teatro em Portugal, o artigo XVI do Alvará de 1771 concedia importantes vantagens à entrada de artigos importados que compusessem a arte teatral, sobretudo aqueles referentes à decoração, vestuário e cenário. Determinava que os empresários tivessem isenções de direitos nas novas aquisições, destacando que a posse desses objetos deveria ser assinada pelos diretores e registrada na alfândega sem, contudo, serem vendidos a terceiros. ${ }^{141} \mathrm{O}$ ofício de Pina Manique, de junho de 1793, todavia, apontava algumas diferenças com as diretrizes veiculadas em 1771 . Vejamos:

Que aos Empresários dos teatros lhes será facultado poderem saldar-se todas as vezes que lhes parecer necessário para mandarem vir de fora destes Reinos todos os gêneros, ainda aqueles cujo é proibido [sic], que forem necessários para as decorações, e vestuário do mesmo teatro, isento de todos e quaisquer direitos, e contribuições: indo as relações dos ditos gêneros e fazendas aprovadas pelo Intendente Geral da Polícia para não haver algum excesso ou descaminho, nos Empresários, e remover todo o escrúpulo nas Alfândegas. ${ }^{142}$

Como podemos notar, os dois documentos oficiais davam oportunidade aos produtores de espetáculos artísticos para que estes mantivessem o teatro nacional dentro das melhores condições materiais vigentes na época. O governo incentivava os investimentos no plano material nas artes cênicas a fim de que o Reino alcançasse o mesmo grau de esplendor das mais destacadas

${ }^{141}$ Alvará de 17 de Julho de 1771. In: BENEVIDES, F. O Real Theatro de São Carlos... Op. Cit., p.14.

${ }_{142}$ Officio que o Intendente geral da polícia da Corte e reino, dirigiu ao Ministro do Reino, sobre o novo teatro lyrico, em 21 de junho de 1793. Apud BENEVIDES, F. O Real Theatro de São Carlos... Op. Cit., p. 33-34. 
capitais europeias. Apesar do apoio, a realidade não era das mais felizes. $\mathrm{O}$ teatro nacional português não apenas lutou pela sobrevivência durante todo o século XVIII, como também a situação da classe artística se agravava ano após ano, mormente depois da transmigração da Corte para o Brasil, em 1807. ${ }^{143}$

Dez anos depois, em 1817, os governadores do Reino enviavam uma carta a $\mathrm{D}$. João. O conteúdo do documento dimensiona-nos acerca do profundo pesar existente na sociedade portuguesa pela ausência da realeza.

Não devemos porém, Senhor, ocultar a V. Mage., por nossa honra e obrigação, o descontentamento geral de todos os seus fiéis vassalos pela demora de V. Magestade no Reino do Brasil, depois dos ordinários sacrifícios e heroicidades que fizeram, para conseguirem a salvação da Monarquia e a pronta restituição de V. Mage. à antiga sede da mesma... E todos suplicamos a Deus Nosso Sr. que inspire a V. Mage., que se compadeça da necessidade que temos da Sua Augusta Presença nestes Reinos para a conservação dos mesmos, e nosso amparo e se digne pela sua misericórdia dispor tudo de maneira que V. Mage. possa vir com toda a brevidade. ${ }^{144}$

Por outra perspectiva, a reflexão anônima de um português pelos idos de 1818 também é reveladora:

Agora por nossa desgraça, estamos vendo os louros voltados, o que vinha do Brasil, para Portugal, vai agora de Portugal para o Brasil ... e não somos nós por ventura, vassalos de V. M. para sermos tratados pela mesma ma-

143 Discutiremos os conflitos sociopolíticos e econômicos para a sustentação do teatro no Império português nos dois lados do Atlântico no próximo item deste capítulo

144 ANTT, Ministério do Reino, Governadores do Reino, Registro de Cartas ao Príncipe Regente, Livro 317, Carta 466, 17.3.1817, fl.377. 
neira que são hoje os brasileiros? que tão felizes se acham e nós em tanta desgraça? há muito bem pode V. M. socorrer-nos, quando não, será por tempos, V. M. Rei de um Povo mendigo, e desgraçado. ${ }^{45}$

Ambos os registros refletiam, em graus díspares, um sentimento coletivo de angústia e desesperança do povo português que ganhava cada vez mais força desde 1814, quando as discussões sobre o (in)evitável retorno da realeza começaram a fazer parte do debate político. Desde então, pelas duas margens do Atlântico os bastidores do alto escalão governamental versavam sobre os prós e contras acerca das controvérsias inerentes à permanência ou ao regresso. A necessidade de resposta à questão fundamental Qual deveria ser o lugar hegemônico do poder no mundo luso-brasileiro? fazia-se urgente. De acordo com a historiadora Ana Rosa C. da Silva,

De um lado, pela tentativa dos habitantes do Reino de reaverem a antiga centralidade de Portugal no conjunto do Império; de outro, pelos anseios dos setores coloniais beneficiados com a presença da Corte e, particularmente, dos estadistas sediados na capital do Rio de Janeiro, a qual já contava com toda uma conformação de interesses e um status político-econômico não passíveis de serem simplesmente abolidos, revertidos ou ignorados. ${ }^{146}$

As múltiplas vozes - anônimas ou oficiais - dos súditos da monarquia pelas ruas do Reino davam a "impressão generalizada de que Portugal estava órfão, sem seu rei, e que o epicentro do

145 "Carta de hum fiel vassallo a El rei D. João VI, relatando o estado do reino de Portugal sob o governo regencial e pedindo a volta se S. M." Documentos para a História da Independência, 1923. p. 6.

146 SILVA, Ana Rosa. Inventando a nação... Op. Cit., p. 247 (Grifo do Original). 
Império residia no Rio de Janeiro". ${ }^{147}$ Em 1820, a correspondência do principal ministro de D. João no Brasil - Thomaz Antonio Vilanova Portugal com o acadêmico Visconde da Lapa - apontava que a percepção dos portugueses possivelmente tinha muito sentido.

Quanto à proposta de M. Scafer [...] a respeito da vinda de estabelecimento de artistas e cultivadores, devo deixar à V. S. a a aquisição de gente industriosa e este será sempre apreciado neste Reino, onde encontrarão grandes vantagens e fácil estabelecimento, mas este deverá ser procurado a própria custa de cada um, e não por conta do governo de sua Majestade, que aliás tem tido muitas proposições dessa espécie. ${ }^{148}$

Como observamos, estimular a vinda de artistas para o Brasil era um viés relevante da política cultural joanina, entretanto, mantendo as devidas "ressalvas": aqueles que quisessem viver no Novo Mundo seriam bem-vindos, desde que arcassem com as despesas da empreitada. Neste caso, portanto, a Coroa concedia apenas o apoio institucional necessário aos interessados. As responsabilidades financeiras ficavam a cargo de cada um. Se para os portugueses assumirem a posição de inferioridade dentro e fora da Europa era uma situação muito constrangedora, os atores nacionais deviam convencer os superiores da qualidade do trabalho desempenhado antes em nome da elevação da pátria à condição de nação civilizada, em pé de igualdade com qualquer cidade/nação europeia. A comemoração dos festejos militares ocorridos na urbe em 18 de julho de 1813 é, nesse sentido, de grande destaque.

O triunfo do exército inglês contra Bonaparte, ou "Opressor da humanidade"149 na cidade de Victória mereceu várias

147 SCHIAVINATTO, Iara Lis. Pátria Coroada:... Op. Cit., p. 58 (Grifo Original). 148 BNP. Seção Res._. Mss. 246, n. 28. Ofício de 28 de Setembro... Op. Cit.

149 Gazeta de Lisboa. 1813. n. ${ }^{\circ} 206$. 
solenidades no Porto, que foram dirigidas pelo corregedor e provedor da Comarca. Segundo notícia veiculada na Gazeta de Lisboa, houve uma missa majestosa na paróquia de Santo Idelfonso, com as práticas habituais dos ritos políticos e religiosos do Antigo Regime - o sacramento exposto e o sermão, assim como o canto do Te Deum Landamus, ao fim da cerimônia. Nas palavras do redator:

Estava a igreja pomposamente armanda, e junto do Arco do Cruzeiro havia dois majestosos obeliscos, em que se liam por ordem cronológica dispostas, as insignes vitórias, que contra o inimigo comum tem alçado na Península o invicto duque da Victória, indicadas pelos nomes dos sítios onde foram ganhadas. Liam-se também ao entrar da Porta alguns dísticos engenhosos em louvor do Vencedor; tendo precedido ao dia da Festa uma vistosa iluminação na fachada do Templo. Foi cantada a Missa pelo M.R. Antonio José de Meireles, Arcediago do Porto na Catedral (...). ${ }^{150}$

Durante a missa também foi feita uma pregação sobre o tema político em questão, que deixou a seleta plateia deveras satisfeita. Composta por “todos os Magistrados Seculares, Eclesiásticos daquela cidade, o Ilmo. Cabido da Catedral, o Prelado e as Ordens Religiosas, o Governador das Armas, e muitos militares de distinção e a Nobreza principal da cidade”, o público ainda assistiu à música - dirigida pelo mestre da capela Antonio da Silva Leite e executada pelos "hábeis Cantores e Instrumentistas" - e à parada militar, com "salva de 21 tiros, e um corpo de infantaria, que no fim da festa salvou com três descargas de mosquetaria." ${ }^{151}$ Nesta festividade, porém, o que nos chama mais a atenção é o evento artístico da noite, celebrado no Teatro de S. João. Mais uma vez, temos a descrição do gazeteiro:

${ }^{150}$ Ibid. (Grifos do Original).

151 Ibid. 
No mesmo dia à noite no Real Teatro de S. João, cuja Companhia Nacional o fez iluminar, houve Representação, precedida de um Elogio Dramático em honra do Duque de Victória, recitando-se depois dele um Soneto, em que se recapitulavam seus triunfos, e distribuindo-se pelos camarotes e plateia um hino impresso por ordem do mesmo Ministro sobre o mesmo objeto. ${ }^{152}$

Todos esses fatos nos mostram quão intimamente relacionadas estavam a arte, a política e a religião como práticas culturais e de sociabilidade nas cerimônias acontecidas no espaço público no Antigo Regime Português. Sob esse prisma e, sobretudo diante de uma aguda crise política vivida pela monarquia portuguesa desde fins do século XVIII, a alegação de "autonomia” profissional no discurso dos artistas do Porto diante da ameaça italiana tem um novo sentido. Assim, finalmente declaravam:

Ora [,] dir-se-á no presente caso a todos estes infelizes "Sai para a rua: não queremos que exerciteis a vossa profissão: ide morrer desesperados de fome, e de miséria com vossos filhos, e famílias; ou ide ser ladrões e assassinos nas estradas? Mas que homem tão ímpio se atreveria a falar assim? Estes atores por isso mesmo que são Nacionais, tem jus à sua cômoda sustentação, um jus sagrado, um jus inauferível, fundado em todos os princípios do Direito Natural, e das Gentes, e de que nenhum Magistrado ou Autoridade os pode esbulhar, a não ser por crime, que os faça considerar como expatriados e banidos. ${ }^{153}$

Dada à gravidade da situação, a Companhia Nacional fazia a defesa da sobrevivência da profissão apelando para um debate

\footnotetext{
152 Ibid. (Grifo do Original).

153 Memória com que se demonstra a preferência, que a Companhia Nacional... Op. Cit., p. 5. BNP. Seção de Obras Gerais. (Microfilme) (Grifos Nossos).
} 
de natureza jurídica: o direito natural, inato ao povo, sendo-lhe irrevogável. De acordo com a historiadora Iara Lis Schiavinatto, a concepção da monarquia temperada que vigorava em Portugal era firmada em dois pilares: as leis fundamentais - inerentes a qualquer monarquia -, e a de direito - referente às leis feitas pelas Cortes. Por essa concepção, tanto os reis quanto os súditos eram obrigados a seguir ambas as leis; o que, na prática, representava o mútuo consentimento caso houvesse qualquer alteração de status político e/ou jurídico. Ou seja, "a lei fundamental é fruto de um ato da vontade de todos". 154

Como fica claro nessa prédica, a interlocução da Companhia agora se fazia diretamente com o monarca. A classe artística enquanto povo fiel à monarquia também exigia de seu soberano a lealdade que tanto lhe proporcionava a existência, a despeito das graves crises políticas que maculavam a sua ausência no Reino. Em outras palavras, simbolicamente exigiam a sua presença na resolução desse conflito. Afinal de contas, não eram mendigos, ladrões ou assassinos: eram profissionais da dramaturgia nacional. E como súditos fieis, responsáveis por traduzir pela arte a complexidade dos valores morais intrínsecos à civilização, exigiam os seus diretos. Caso contrário, também tinham a consciência de que poderiam se tornar uma ameaça à estabilidade política da Coroa. Sobre o impacto do desenvolvimento das artes e das ciências na sociedade europeia, refletia Rousseau em 1750:

Enquanto o governo e as leis atendem à segurança e ao bem-estar dos homens reunidos, as ciências, as letras e as artes, menos despóticas e talvez mais poderosas, estendem guirlandas de flores sobre as cadeias de ferro de que estão eles carregados [...]. A necessidade levantou os

${ }^{154}$ SCHIAVINATTO, Iara Lis. Pátria Coroada... Op.Cit., p. 31. 
tronos; as ciências e as artes os fortaleceram. Potências da terra, amai os talentos e protegei aqueles que os cultivam. ${ }^{155}$

Apesar do rigor da censura portuguesa diante das obras consideradas revolucionárias, sendo Rousseau um dos autores proibidos, muito provavelmente o ensaio premiado do filósofo Discurso sobre as ciências e as artes -, fez parte do rol das leituras desses artistas; que possivelmente despertou-lhes a atenção para o uso que os governantes da Antiguidade fizeram das "luzes" advindas desses conhecimentos ao longo da História. ${ }^{156}$

Não sabemos como se deu a resolução do conflito entre a Companhia Nacional e a Companhia da Burleta Italiana no Porto. Sabemos, contudo, que pouco mais de seis anos depois da publicação da Memória com que se demonstra a preferência, que a Companhia Nacional deve ter à Italiana no arrendamento do Real Teatro São João da Cidade do Porto para o futuro ano de 1814, a cidade seria palco da Revolução Vintista de caráter liberal, que convocava as Cortes à revelia de D. João VI. Diante da grave crise política, a principal bandeira da Junta Provisional do Governo Supremo do Porto era a vigência da monarquia constitucional. Muito possivelmente, os atores da Companhia Nacional fizeram parte desse importante movimento político, ocorrido no Porto em 1820. Se os limites dessa investigação não nos permitiram a averiguação dessa hipótese de pesquisa, ao menos fica a sugestão para futuras inquirições.

155 ROUSSEAU, Jean Jacques. Discurso sobre as ciências e as artes. Trad. Lourdes Santos Machado. São Paulo: Ed. Victor Civita, 1983. p. 334-335.

156 Na Primeira Parte de Discurso sobre as ciências e as artes (1983, p. 333-342), J. J. Rousseau faz uma análise sobre a relação entre o progresso das artes e decadência da moral e dos costumes. Para comprovar sua tese, analisa detidamente a trajetória dos povos da Antiguidade (com ênfase para os governantes), especialmente a civilização Greco-romana, egípcia e chinesa. 


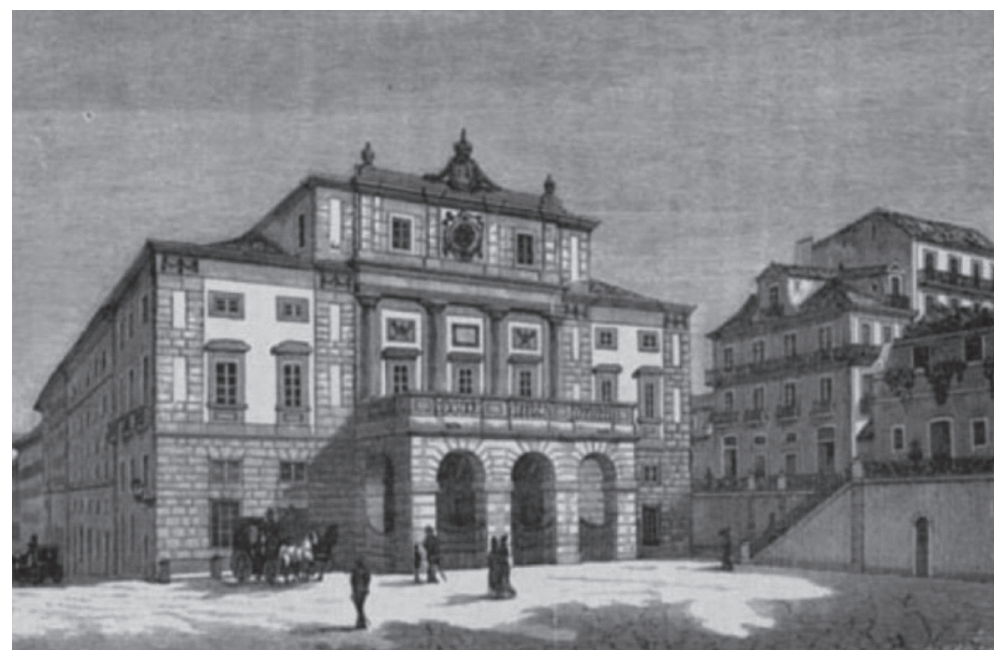

Real Teatro de S. Carlos (Lisboa). Séc. XIX

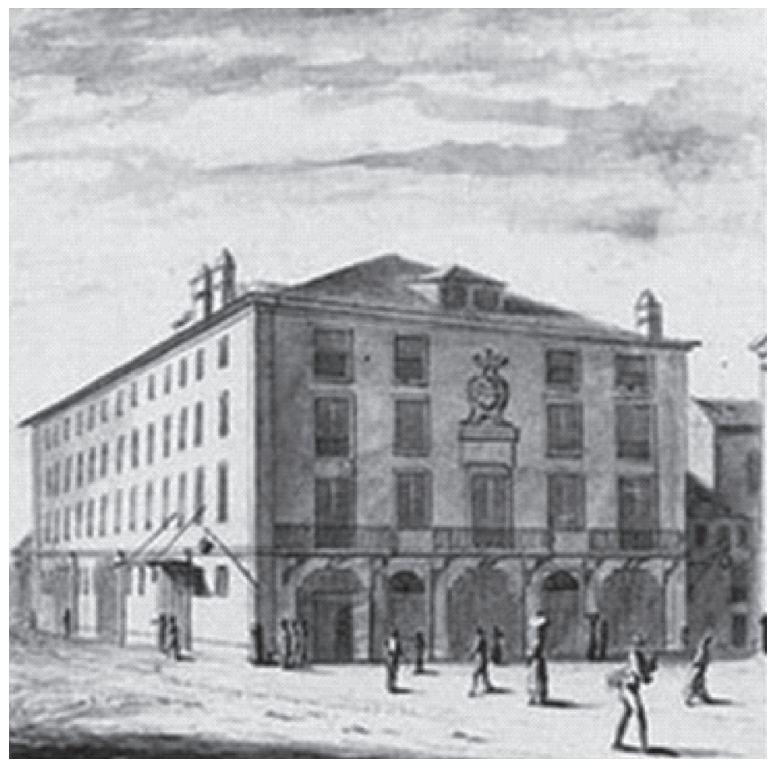

Real Teatro de S. João (Porto). Início do Séc. XIX

Fonte: <http://www.portoantigo.org/2008/05/teatro-so-joo.html> 


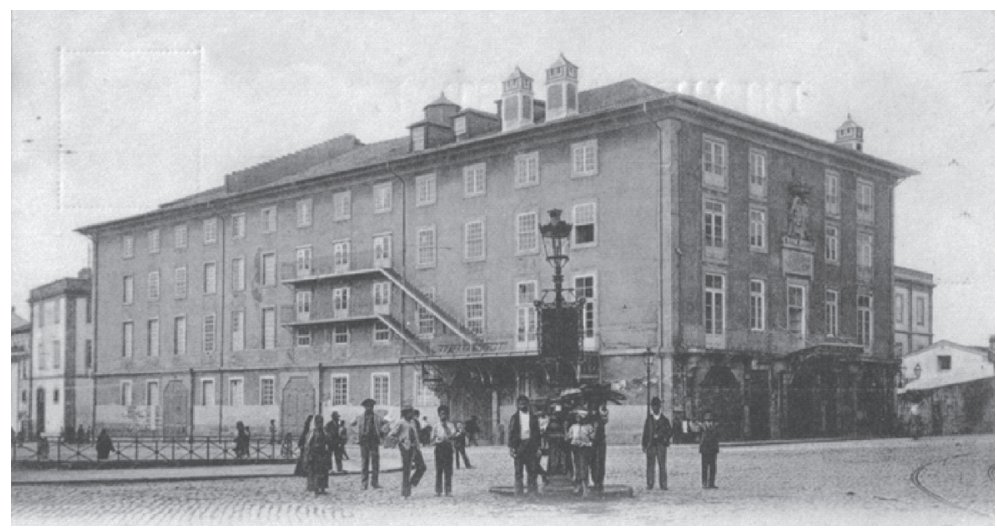

Real Teatro de S. João (Porto)

Fonte: <http://www.caravelas.com.pt/fontes.htm>

\subsection{A chegada da Família Real e os usos do espaço artístico no Rio de Janeiro}

Em maio de 1810, o casamento da Princesa da Beira, $D^{a}$ Maria Teresa, com o Infante D. Pedro Carlos de Bourbon e Bragança foi comemorado publicamente no Paço. Como bem noticiou a Gazeta, a celebração de uma boda real ocorria pela primeira vez nesta "nova e feliz Corte do Rio de Janeiro."157 Segundo Frei Tibúrcio, o enlace matrimonial também foi visto como "um novo penhor da felicidade futura da Europa"158, que poria fim à subjugação política de Napoleão Bonaparte no Velho Mundo, reiterando a força dos vínculos dinásticos ibéricos. "Tudo no Paço respirava Grandeza, as paredes estavam forradas de Damasco e Tapeçarias", informava o redator aos seus leitores. A riqueza de pormenores que compunha a cerimônia também era narrada: 98

\footnotetext{
157 GRJ. 1811. n. 40 (Grifo do Original).

158 Ibid. n. 39 (Grifo do Original).
} 
lampiões, ricos tapetes e cortinados, alcatifas da Pérsia que "ainda felizmente escaparam à rapina dos Monstros Franceses." Para além desses detalhes cênicos, a consagração do matrimônio contou com a presença de uma banda de música e com uma escolta da Guarda Real. ${ }^{159}$

Onze anos depois (1821), Paulo Fernandes Viana rememorava a sua particular percepção acerca dos festejos públicos e circunscrevia a importância da polícia nesses eventos. Vejamos:

Passearei em silêncio a magnificência dos festejos que a polícia fez na ocasião do casamento da senhora Princesa d. Maria Tereza, da Aclamação de Sua Majestade, e do recebimento da senhora Princesa Real; porque as narrações impressas que disto saíram e principalmente os testimunhos [sic] presenciais, que ainda estão no Brasil, e das pessoas que estiveram então, e hoje se acham na Europa, abonarão a verdade de tudo, e reconhecerão que era um dever da polícia entrar nestes objetos, não só pela utilidade que se tira em trazer o povo alegre e entretido, como promovendo ao mesmo tempo o amor e o respeito dos vassalos com o soberano e a sua real dinastia. ${ }^{160}$

Apesar dos diferentes olhares dos sujeitos sociais para os festejos públicos - Frei Tibúrcio enaltecendo a riqueza de adereços

159 Ibid., n. 40 (Grifo do Original). De acordo com o historiador Paulo de Assunção, "A música de um dos regimentos supria falta dos timbaleiros reais; logo atrás destes vinham seis porteiros da cana com 'grandes massas de prata ao ombro', seguida dos arautos, seis homens vestidos de damasco de ouro encarnado. O conjunto era acompanhado por três reis de armas, vestidos com as suas fardas de criados particulares, que portavam no pescoço as insígnias de seu ofício”. ASSUNÇÃO, Paulo. Ritmos da Vida: momentos efusivos da família real nos trópicos. Rio de Janeiro: Arquivo Nacional, 2008. p. 110.

160 VIANA, Paulo Fernandes. "Abreviada demonstração do trabalho da polícia em todo o tempo que a servio o desembargador do paço Paulo Fernandes Viana." Revista do Instituto Histórico e Geográfico Brasileiro, Rio de Janeiro, v. 55. Parte 1, p. 379. 
dos eventos e Paulo Fernandes justificando a presença da polícia -, notamos uma convergência discursiva na fala dos dois súditos reais: tanto o redator da Corte quanto o intendente da Polícia reiteravam a fidelidade ao monarca como valor fundamental para a sustentação do Império Português. Ao circunscrever a sua posição diante dos seus contemporâneos, que provavelmente eram críticos dos métodos violentos utilizados pela polícia para a manutenção da "ordem", Paulo Fernandes tentava esclarecer seus interlocutores da necessidade da ação policial na cidade: a vigilância do espaço urbano era fator primordial no cumprimento de sua tarefa suprema, o dever de primar pela ordem assim como pela alegria e entretenimento dos vassalos do rei. ${ }^{161}$

Como bem demonstrou o historiador Sérgio Barra, neste período o Rio de Janeiro passou a conviver com dois tipos distintos de sociabilidade, a da Corte - cujos hábitos eram tidos como "civilizados" - e a da Cidade - que congregava a população marginalizada desse processo, sobretudo os escravos e os homens livres pobres. No dia a dia, porém, a população de colonizados $^{162}$ circulava por todas as áreas da cidade, estando, muitas vezes, mais próxima das Cortes do que o desejado pelos próprios cortesãos.

\footnotetext{
161 "Para esse protagonista [...] os momentos fundamentais do período joanina transcorreram em 1808, chegada da Corte no Rio de Janeiro, 1810, 1815-1816, elevação do Brasil a Reino, 1817-1818. Os critérios de seleção de Paulo Fernandes Vianna revelam-se associados ao exercício de suas funções na Corte, pois cabia a ele também zelar pela organização dos festejos públicos." LOPES, Emílio. Festas Públicas, Memória e Representação: um estudo sobre manifestações políticas na Corte do Rio de Janeiro: 1808-1822. São Paulo: Humanitas, 2004. p. 144-145.

162 Utilizamos aqui o conceito do historiador Ilmar Mattos que define as seguintes categorias sociais no período: colonizadores, colonos e colonizados. Os colonizadores seriam os administradores, leigos e eclesiásticos; comerciantes. Colonos, os senhores de engenho, fazendeiros e proprietários de lavras auríferas, e colonizados, os escravos índios e negros, homens livres e pobres. MATTOS, Ilmar. R. O tempo saquarema. 2. ed. São Paulo: Ed. Hucitec, 1990. p. 18-26.
} 
Por esse prisma, compreendemos a grande apreensão da sociedade cortesã no amplo contato que teciam cotidianamente com os colonizados; o que devia gerar grandes apreensões, pelo seu potencial de desordem. ${ }^{163}$ E todo o trabalho de controle desses sujeitos ficava sob a responsabilidade da Guarda Real da Polícia, que não hesitava em repreendê-los. $\mathrm{O}$ dever compreendido como obrigação, justiça, subordinação a outrem. Neste caso, especificamente, o respeito, conexão e/ou correlação do intendente da polícia dava-se diretamente às normas estabelecidas pelo poder real. ${ }^{164}$ Como podemos apreender da observação de Fernandes Viana, quanto ao "júbilo" e "comoção da alma com prazer"165, isto é, a alegria, esta deveria ser exaltada desde que fosse manifestada dentro dos limites admitidos pelo chefe de Estado, D. João. "As duas cidades não tinham fronteiras físicas. Sobrepunham-se, tocavam-se e interpenetravam-se"166; razão pela qual a presença da polícia se fazia imprescindível.

No universo cultural português, desde a construção da Ópera do Tejo (1755), a liturgia do poder real foi associada ao teatro. Tradicionalmente, destacava-se o gosto pela música clássica italiana, cultivado pela Dinastina de Bragança nos diferentes festejos públicos. Estes eventos festivos diferenciavam-se de acordo com a finalidade da comemoração: alguns eram lembrados com uma missa cantada; outros assinalados pelo beija-mão no Paço; além daqueles de maior relevo, como as uniões e aclamações reais, que articulavam diversos tipos de celebrações. ${ }^{167}$

${ }^{163}$ BARRA, Sérgio. Entre a Corte e a cidade...Op. Cit., p. 224-225.

164 Dicionário Moraes e Silva, Vol. 1, p. 611.

165 Ibid., p. 88.

166 BARRA, Sérgio. Entre a Corte e a cidade... Op. Cit., p. 225.

167 LOPES, Emilio Carlos Rodrigues. Festas Públicas... Op. Cit., p. 30. 
No Rio de Janeiro, porém, até a edificação do Teatro de S. João, em 1813, essas comemorações ocorreriam em diferentes espaços públicos da cidade, como foi o caso do casamento da Princesa Maria Tereza, realizado no Campo de Santana. De acordo com Iara Schiavinatto, para esse evento a Intendência da Polícia erigiu uma praça no local, tendo o cuidado de delimitar o lugar no qual se dariam os bailados, os festejos e a participação popular. Segundo a autora, tratava-se de um anfiteatro, estruturado em um palco central, camarotes, com destaque para o camarim real e, claro, um espaço reservado à plateia. ${ }^{168}$

Enfim, mesmo na falta de um teatro à altura da nova capital, - como o Teatro de S. Carlos, em Lisboa, onde aconteciam às principais celebrações políticas da realeza -, notamos a vigência da liturgia real no espaço público: a arquitetura e realização do festejo foram dignas de uma Coroa europeia. Como analisou Emílio Lopes, as celebrações monárquicas tinham um duplo caráter, ao mesmo tempo englobavam um espaço de debate político e uma profícua interlocução social. ${ }^{169}$ Neste evento, particularmente, o diálogo transatlântico pautava-se na seguinte mensagem: da América, a Coroa Portuguesa reconquistava a "vitalidade e a saúde política" do Império Português.

A alta consideração da Família Real pela música já apareceria em 1808. Neste ano, D. João transformava a Ópera Nova em Teatro Real. A mudança de nome já denotava a importância adquirida pelo espaço. De acordo com a pesquisadora Ariadna Moreira, para o monarca era fundamental dar continuidade ao alto nível cultural da Corte portuguesa. Para tanto, a Coroa ofereceu patrocínio à Ópera Nova, que foi rebatizada como Teatro

168 SHIAVINATTO, Iara. Pátria Coroada... Op. Cit., p. 226 (Grifos Nossos).

169 LOPES, Emilio. Festas Públicas... Op. Cit., p. 29. 
Régio. O administrador da Opera Nova, Manuel Luís, foi também incentivado a fazer a principal reforma do teatro - para que este estivesse à altura da Corte portuguesa e da família real - como também foi o responsável pela organização de novos concertos artísticos nesse espaço. ${ }^{170}$

Ainda segundo Moreira, a reestruturação do locus contou com a construção de uma galeria no ponto mais alto dos camarotes destinados aos oficiais da Corte, assim como prezou pela decoração. José Leandro, o principal artista da realeza, pintou outra cortina que tinha a Baía de Guanabara, isto é, a geografia do Rio de Janeiro, a sua principal representação. Nesta tela, a figura de Netuno situava-se ao meio. ${ }^{171}$ Os símbolos que reiteravam a estima da monarquia pela nova capital Imperial deveriam ser exaltados, sobretudo no então principal espaço de cultura destinado às artes cênicas e musicais da cidade.

No período de 1808 a 1813 muitos músicos chegaram ao Rio. Aqueles que vieram com a família real logo se juntaram à companhia de ópera e à orquestra, e tiveram como função melhorar a qualidade das apresentações musicais. Outros artistas europeus de renome também fizeram parte do cenário artístico da nova Corte. Em 1811, por exemplo, a cidade recebia no mesmo navio três nomes ilustres: a soprano italiana Mariana Scaramelli e seu marido, o dançarino e coreógrafo Luís Lacombe, além do

\footnotetext{
170 MOREIRA, Ariadna Gonçalves. The Influence of the Portuguese Royal Court on the development of opera, the opera nova, and the real teatro São João in Rio de Janeiro from 1808 to 1824 . Doctoral Essay. University of Miami, 1998. p. 21. Sobre a importância da figura de Manoel Luís, ver também ANDRADE, Francisco Ayres de. Francisco Manuel da Silva e seu tempo (1808-1865). Uma fase musical do Rio de Janeiro à luz de Novos Documentos. Rio de Janeiro: Ed. Tempo Brasileiro, Ltda, 1967. p. 63-111.

171 Ibid., p. 21.
} 
famoso compositor lusitano Marcos Portugal. ${ }^{172}$ Por aqui também podíamos encontrar Carlota Donay, assim como a brasileira Joaquina Lapinha, Maria Cândida, Manuel Rodrigues da Costa, Antonio Ferreira e os irmãos Luís Inácio Pereira, Geraldo Inácio Pereira e João dos Reis Pereira.

Neste mesmo ano, o Príncipe Regente comemorou seu aniversário no Teatro Real, o que demonstra a valorização desse espaço artístico pela Coroa. O aviso veiculado na Gazeta do Rio de Janeiro não só informava aos seus leitores da ocorrência do fato, como também os colocava a par das atividades da Impressão Régia, que publicava o "Drama com Música, A União Venturosa", de autoria de Antonio Bressane Leite, representada no "Faustíssimo Dia dos Anos de S.A.R". A obra ainda era vendida na loja da Gazeta, e no Teatro Real na noite da festividade, a 480 réis. ${ }^{173}$ Novamente, arte e política se imiscuíam nas representações artísticas. Já na Dedicatória, o autor apontava a situação política do Império Português em meio às turbulências vividas no Velho Continente.

Eu sou luso, Senhor, leal quais foram Meu honrados avós, guardo no peito

O puro amor e fé que eles juraram, E que eu jurei também ao luso sólio. [sic] No mesmo berço em que eles me embalaram,

Por ilustres virtudes bafejado, Desvelado embalei meus filhos caros; E apenas divisei seus tenros braços, Capazes de brandir a nobre espada, Ufano os conduzi de Marte ao campo, Onde à frente das filas lusitanas,

${ }^{172}$ Ibid., p. 21. Sobre a chegada de artistas portugueses no Rio de Janeiro e a presença de artistas brasileiros ver: PACHECO, Alberto. Castrati e outros virtuosoes... Op. Cit., p. 41-72.

173 GRJ. 1811. n. 38. 
Tocando as quinas, empunhando o ferro,

Com os olhos no céu, ao céu juraram

Constantes dar a vida, dar o sangue

À cara pátria, ao Rei e ao Ser Supremo.

Oxalá que o seu sangue o preço fosse

Da vitória com que os céus enchessem

De padrões imortais o vosso império. ${ }^{174}$

Notemos que a exaltação da fidelidade ao príncipe perpassava não apenas a sua condição de súdito da monarquia, mas, principalmente, a lealdade a Deus e aos seus antepassados, que também haviam defendido o solo português em prol da independência política da Coroa. A reiteração do valor da nacionalidade, isto é, do ser português em outro hemisfério - por forças das imperiosas circunstâncias - não o amedrontava; ao contrário, causava-lhe júbilo e satisfação. $\mathrm{O}$ autor, entretanto, falava em nome de toda a nação, mormente daqueles que continuaram a luta pela pátria em solo lusitano; os compatriotas que enfrentavam sem amarras as consequências do tirano Napoleão Bonaparte.

E sobre férreo trono o vil engano

De leis cruentas lhe manchava os lares

Enquanto os caros lusos desarmados

Ao som dos duros ferros que arrastavam

Juravam sobre as aras da constância

Dar a vida por vós, salvar a pátria. ${ }^{175}$

Como bem analisou Kirsten Schultz, para os portugueses vindos com a Corte, a experiência do exílio trazia consigo a busca pela regeneração política e moral, cuja base era a obediência à

${ }^{174}$ LEITE, Antonio Bressane. "A União Venturosa”. Rio de Janeiro: Impressão Régia, 1811. p. 1-2. Disponível em: <http://www.iar.unicamp.br/cepab/libretos/ uniao.htm>. Acesso em: 5 dez. 2011.

175 Ibid., p. 2. 
monarquia. Já para os residentes do Rio, a nova Corte simbolizava o ressurgimento do poder e da prosperidade nacional. Para ambos, no entanto, "a novidade de um império americano era circunscrita pela tradição: vassalagem e identidade nacional portuguesa." ${ }^{176}$ Finalmente, no plano das representações políticas de caráter oficial, ${ }^{177}$ a vitória contra a França estava selada: por duas vezes a nação portuguesa havia expulsado os franceses do território nacional, fato que sinalizava a fragilidade militar de Bonaparte na Europa. Se o apoio do exército inglês sob a liderança de Beresford fora fundamental nessa batalha, interessava também vangloriar a luta incessante dos portugueses diante da ameaça do invasor.

A estruturação dos personagens de A União Venturosa condizia com a nova realidade vivida pelos portugueses radicados no Brasil: a perspectiva interatlântica, agora vista pelo viés americano. Nesta peça, há quatro figuras dramáticas: Gênio Lusitano, Gênio Americano, América e Tempo. Ao mesmo tempo em que a "América" é a personagem de grande destaque desse drama, a força política e militar de Portugal é exaltada por Bressane. Vejamos, portanto, sua concepção acerca do Novo Mundo.

\footnotetext{
176 SCHULTZ, Kirsten. Versalhes Tropical: Op. Cit., p. 136.

177 Utilizamos aqui o conceito de representação do historiador Roger Chartier. Ao analisar as sociedades do Antigo Regime, Chartier assim as define: "As formas de teatralização da vida social na sociedade de Antigo Regime dão o exemplo mais manifesto de uma perversão da relação de representação. Todas visam, de fato, a fazer com que a coisa não tenha existência a não ser na imagem que exibe, que a representação mascare ao invés de pintar adequadamente o que é seu referente. [...] A relação de representação é, desse modo, perturbada pela fraqueza da imaginação, que faz com que se tome o engodo pela verdade, que considera os signos visíveis como índices seguros de uma realidade que não o é. Assim desviada, a representação transforma-se em máquina de fabricar respeito e submissão, num instrumento que produz uma exigência interiorizada, necessária exatamente onde faltar o possível recurso à força bruta." CHARTIER, Roger. O mundo como representação. Estudos Avançados. [online]. 1991, vol. 5, n. 11 , p. 185-186.
} 


\section{América.}

A ninguém mais do que eu, Gênios divinos, Pertence a alta glória deste dia,

Dia, que o deus imenso consagrara Ao maior dos mortais, ao nosso Augusto,

Para nele unir meu vasto império

Em laços ternos ao império luso.

Quanto aos lusos heróis sou devedora, Que sem temer a morte, em frágeis lenhos,

Por mares até ali jamais trilhados, Tocando o abismo, topetando os astros, Arrostando o furor de ímpias procelas, Sem pavor os meus lares penetrando, Ao facho aceso da razão divina Das trevas da ignorância me arrancaram! Quanto sou devedora aos reis augustos, Que com mão majestosa abrilhantaram A régia coroa que me adorna a fronte! Quanto devo ao JOÃO, ao digno neto

De tão altos avós, herói quais eles! A cada instante as vestes me enriquece, As magnas vestes que vaidosa estendo Por meus vastos limites, que resistem Ao choque horrendo de empolados mares. Que glória! Filhos meus, já somos lusos.

Cumpre-nos defender o luso sólio;

Eu à frente de vós marcho vaidosa, No peito levo o amor, no braço o alfanje.

Ou vencer, ou morrer, filhos amados, Sem brio, sem valor a vida é nada. Baqueie de uma vez no Averno horrendo $\mathrm{O}$ monstro enganador que assola o mundo. ${ }^{178}$

Apesar de extenso, o texto de Bressane nos é muito revelador. A sua particular percepção da América reiterava, de certa

${ }^{178}$ LEITE, Antonio Bressane. "A União Venturosa". Op. Cit, p. 6-7. 
forma, o forte imaginário social europeu da época, que enxergava o Novo Mundo como um jovem continente na trilha pelo progresso moral e científico. ${ }^{179}$ Especificamente no que se refere ao Império Português, a América era, sim, uma parte fundamental, porém, devia-lhe amor e devoção, uma vez que atingira tal posição porque os reis lusitanos haviam lhe concedido a honra de disseminar pelo vasto país os valores civilizacionais que tanto prezavam. Enfim, a América aparecia, primordialmente, no papel de devedora, o que não era visto como um problema. Muito pelo contrário: o contato dos habitantes americanos com os europeus colonizadores era a mola mestra no avanço desse processo civilizacional. Como bem circunscreveu Bressane, a figura do Gênio Lusitano mostrava todos os tentáculos do poder imperial português que, com glória, sustentava há séculos o trono.

Do invito JOÃO, o terno, o justo.

Tanto deveis ao gênio que no berço

Em suaves chuveiros copiosos

Vos influíra ufano o amor mais puro À pátria, ao trono, à lei e ao deus eterno. As ciências e as artes que em vós moram Têm enchido de pasmo o mundo inteiro.

$\mathrm{Na}$ Atenas lusitana vossos nomes

Em eternos padrões estão gravados.

$$
\text { [...] }
$$

Cumpre a grandes virtudes, grande prêmio;

O céu vos premiou, o céu é justo.

O grande rei dos reis que os reis exalta, Que abate cetros e que eleva tronos, Esgota os cofres do poder imenso, Do refulgente sólio vos envia

Nas asas níveas dum sorriso brando

179 GERBI, Antonello. O Novo Mundo: História de uma polêmica: 1750-1900. Trad. Berrnando Joffily. São Paulo: Companhia das Letras, 1996. 
O PRÍNCIPE, que rege o luso império,

O PRÍNCIPE melhor que há tido o mundo. ${ }^{180}$

Era necessário que o autor exaltasse a coragem e amor do Príncipe Regente aos seus súditos dos dois lados do Atlântico. Afinal de contas, a transladação da sede do governo para o Brasil significava uma escolha política muito precisa: D. João optara por salvar uma parte expressiva do Império. E Portugal, mesmo sob o comando dos governadores do Reino, ficara à mercê dos invasores franceses. O monarca, símbolo da força paternal que sustentava a monarquia, estava agora exilado em outro hemisfério. Abandonara-os. Portanto, quando os súditos do Príncipe elevavam-no em seus discursos à figura de redentor do Novo Mundo, tinham como foco mostrar a sua preocupação com todo o corpo social.

Ainda em 1811, mas agora do outro lado do Atlântico, a sociedade lisboeta comemorava no Teatro de $S$. Carlos as vitórias da Terceira Restauração contra os franceses. O glamour do espetáculo ocorrido em 12 de agosto, no entanto, tinha como principal homenageado o Príncipe de Gales da Grã-Bretanha, o rei Jorge III. A celebração de seu aniversário no principal teatro do Reino contou com a presença de dois ilustres espectadores britânicos: Lord Beresford e Almirante Barkley. ${ }^{181}$ A documentação do então Governador do Reino Ricardo Raimundo Nogueira é deveras elucidativa:

Esperando-se na Capital o seu libertador, o Marechal General Lord Wellington, a sociedade (já então instalada no Teatro de S. Carlos), representou ao Governo, por Ofício do seu Inspetor, o Desembargador Sebastião José Xavier

${ }^{180}$ LEITE, Antonio Bressane. "A União Venturosa”. Op. Cit., p. 5.

181 Apontamentos. V. Nogueira (Ricardo Raimundo). BNP_Res. COD. 7207. Doc. 8 . 
Botelho, os ardentes desejos que tinha de concorrer com todas as suas forças para a digna recepção, e que o mesmo governo preparava a tão ilustre Personagem, oferecendo no dito teatro o mais maravilhoso espetáculo; o que foi tanto da satisfação do Governo, que lhe gratificou estes sentimentos de Fidelidade, e patriotismo, honrando-a com a carta que lhe dirigiu, assinada por D. Miguel Pereira de Forjaz N.6. ${ }^{182}$

Os festejos artísticos encenados em S. Carlos por ocasião dos aniversários da Família Real portuguesa igualmente são referidos neste documento. Segundo Nogueira, "sempre a sociedade solenizou com grande aparato e despesa, não só os Faustos Dias de V.A.R, e de toda a Real Família, mas também os dias natalícios de SS. MM. o Rei, e Rainha de Inglaterra e Príncipe de Gales, como íntimos aliados de Portugal". ${ }^{183} \mathrm{O}$ que notamos, porém, no discurso do governador é a valorização das duas Coroas europeias em pé de igualdade dentro do cenário político do país. E tal fato, a exaltação pública da Inglaterra em Lisboa, tinha um sentido político muito particular: com a ida de D. João para o Brasil, os portugueses do Reino contaram cotidianamente durante cinco anos (1808-1813) com a maciça presença do exército britânico em solo português. ${ }^{184} \mathrm{E}$, a despeito dos conflitos e diferenças de perspectivas táticas, a força militar luso-britânica unia-se em prol de um mesmo ideal: a expulsão dos franceses da Península Ibérica e o fim do governo de Napoleão Bonaparte. Nesses anos, a importância dessa união foi solenizada no Teatro de S. Carlos também em nome "das mais notáveis batalhas, que se deram na

182 Ibid.

183 Ibid. (Grifos Nossos).

${ }^{184}$ MEDINA, João. História de Portugal: dos tempos pré-históricos aos nossos dias. Lisboa: Ediclube,1993. p. 17-40. 
Península para a sua salvação, como a do Vimeiro, Porto, Cidade Rodrigo, Badajoz, Victória, etc." ${ }^{185} \mathrm{O}$ depoimento de Ricardo Raimundo Nogueira ainda circunscrevia a atuação do seleto público nesses espetáculos: a constante presença das personalidades do governo, da nobreza, e principais personagens da Capital, segundo ele, sempre foi patenteada pelo exaltado patriotismo. ${ }^{186}$

De acordo com David Cranmer, há uma importante diferença em relação à presença britânica e francesa em Portugal. Enquanto os ingleses buscavam manter a "liberdade política e econômica" do país através do maciço apoio militar, os franceses mantinham em vigência um projeto cultural e artístico, cujas manifestações ocorriam nos teatros da capital portuguesa, e extrapolavam os objetivos meramente econômicos e militares dos britânicos. Nas palavras de Cranmer, "With the Prince Regent and Court in Brazil, and the French gone, what was left was a cultural vacuum that the Britsh had no brief to fill." ${ }^{187}$ A despeito das questões artísticas, não podemos nos esquecer da hostilidade do povo português aos inimigos franceses.

Enquanto isso, deste lado do Atlântico, cabia ao Príncipe a responsabilidade de edificar uma nova Corte à imagem e semelhança de Lisboa. Ao erigir diferentes locus de cultura no Rio de Janeiro, o regente buscava reafirmar os códigos de moralidade e civilidade que regiam a outra capital. E tal disposição demarcava o cuidado e respeito que a autoridade real tinha para os seus súditos que ficaram à margem do Tejo. Com esse drama, Antonio Bressane Leite tentava apagar a mácula de abandono tão presente na memória coletiva portuguesa. ${ }^{188}$ "A união venturosa a que se

185 Apontamentos. V. Nogueira... Op. Cit._Res. COD. 7207. Doc. 8.

186 Ibid.

187 CRANMER, David. Opera in Portugal... Op. Cit., p. 51.

${ }^{188}$ Com o desaparecimento do rei D. Sebastião, na batalha de Alcácer Quibir (1578), Portugal se viu envolto na crença do retorno de um rei salvador que 
referia o título era justamente aquela entre os dois gênios, representantes dos vassalos dos dois continentes que sustentavam o 'Augusto Trono do Invicto João, o Terno, o Justo'", analisa o historiador Jefferson Cano. ${ }^{189}$ Foi precisamente por esta razão que essa peça foi escolhida para celebrar o primeiro aniversário do Príncipe Regente em um espaço público de cultura artística no Brasil. Quanto às datas festivas neste período, o historiador Emílio Lopes elucida um de seus sentidos: estas pretendiam imortalizar uma determinada representação sobre o Império e a ação real. ${ }^{190}$ A arquitetura efêmera produzida pelo governo, assim como o apoio da classe mercantil e das corporações de ofício contribuíam de maneira decisiva para a veiculação da ideia de que todo o Império Português estava a salvo.

Dentre as numerosas modificaçoes urbanísticas e culturais ocorridas no Rio de Janeiro no período, é preeminente o destaque que o regente concedeu para a construção do Teatro de S. João. Por mais consideração que a Coroa tivesse para com o Teatro Real, utilizando-o, como vimos, nas festividades da monarquia, a justificativa para a edificação de um novo locus de cultura artística era a absoluta necessidade de a nova capital do Império possuir um teatro "decente, e proporcionado à população, e ao maior grau de elevação e grandeza em que hoje se acha pela minha residência nela, e pela concorrência de estrangeiros, e de outras pessoas

\footnotetext{
viria a resgatar o reino português das mãos dos castelhados, restaurando assim a soberania e honra perdida do povo, depois da anexação de Portugal a Castela, em 1580. A ausência ou não retorno do rei e a vinculação ao Mito do Encoberto - cujo rei emerge sempre em contextos de crise e de derrota marcava uma visão maniqueísta do bem contra o mal. Verbete Sebastianismo. In: VAINFAS, Ronaldo. (Direção). Dicionário do Brasil Colonial (1500-1808). Rio de Janeiro: Ed. Objetiva, 2000. p. 523-524.

189 CANO, Jefferson. O fardo do homem de letras. Tese de doutorado. UNICAMP. 2000. p. $129-130$.

190 LOPES, Emilio. Festas Públicas... Op. Cit., p. 39.
} 
que vêm das extensas Províncias de todos os meus Estados." ${ }^{191}$ De fato, depois de construído e inaugurado, durante o século XIX, o Real Teatro de S. João tornou-se um dos mais importantes estabelecimentos culturais da América, com apresentações regulares de todos os gêneros teatrais: possuía quatro camarotes, além de comportar 1.200 lugares para a plateia. ${ }^{192}$

Assim como o Teatro de S. Carlos, a construção do Real Teatro de S. João também ficava sob a responsabilidade da Intendência Geral da Polícia. O sucesso desse empreendimento, entretanto, dependia em grande medida da capacidade do intendente Paulo Fernandes em gerenciar os recursos necessários junto à nobreza migrada e aos negociantes fluminenses, seus principais financiadores. A viabilidade do projeto deu-se através da formação de uma sociedade por ações, encabeçada pelo militar português Fernando José de Almeida, homem de posses e proprietário do terreno situado no largo do Rocio (atual Praça Tiradentes), onde se erigiu o edifício. ${ }^{193}$

Em forma de loterias, os negociantes do Paço visavam obter rapidamente os fundos necessários. Fernando Carneiro Leão, um dos fluminenses mais ricos da Corte, ficou responsável pelas contas e pagamentos dos prêmios. ${ }^{194}$ Já o bibliotecário real Luís Joaquim dos Santos Marrocos era um dos acionistas de destaque na órbita cultural da cidade. No final de 1811, o bibliotecário informava seu pai sobre suas atividades no Rio de Janeiro. Nesta

191 Fonte: Brasil. Leis etc. Coleção das Leis do Brazil de 1810. Rio de Janeiro: Imprensa Nacional, 1891. p. 112. Disponível em: <http://www.planalto.gov.br/ CCIVIL_03/revista/Rev_66/Decreto.htm>. Acessado em: 27 jul. 2011.

${ }^{192}$ MARZANO, Andrea. Verbete Teatro. In: NEVES, Lúcia Bastos Pereira das; VAINFAS, Ronaldo (Org.). Dicionário do Brasil joanino... Op. Cit., p. 418.

193 CAVALCANTI, Nireu. O Rio de Janeiro setecentista: a vida e a construção da cidade da invasão francesa até a chegada da Corte. Rio de Janeiro: Ed. Jorge Zahar, 2004. p. 178. Para maiores informações sobre a vida e atuação de Almeida no período, ver a obra acima citada.

194 GERJ. 1811. n. 6. 
missiva, o remetente não apenas pedia-lhe "o favor de não mostrar minhas Cartas a pessoa alguma”, sugerindo, ainda, que este tivesse "nesse ponto a maior reserva, comunicando vocalmente apenas o que não for susceptível de sentidos sinistros". 195 Marrocos fazia tal súplica, muito provavelmente, porque nesse escrito ele fornecia todos os detalhes sobre seus investimentos:

N.B. Aqui entrei na $1^{\text {a }}$ Lotaria do Teatro de São João desta Corte, comprando um Bilhete ( $8 \$ 000$ réis), e entrando em outro de Sociedade ( $4 \$ 000$ réis): o primeiro saiu em branco, o segundo teve prêmio de $12 \$ 000$. Agora entrei na Lotaria do mesmo Teatro, em um Bilhete de Sociedade com o meu Clérigo, e por isso lá vão à ventura $4 \$ 000$ réis. ${ }^{196}$

Marrocos avisava, ainda, que o Príncipe Regente havia concedido 7 loterias para a ajuda das obras do que denominou de "Magnífico Teatro Novo de São João", que estava a edificar-se à moda do Teatro de S. Carlos. ${ }^{197}$ A partir de 1811, o plano das seis loterias anuais do Real Teatro de S. João assim como a lista dos prêmios com seus respectivos valores eram cotidianamente anunciados na Gazeta do Rio de Janeiro, principal veículo de comunicação do Rio de Janeiro. Neste caso em particular, o destaque dava-se para as notícias de viés mercantil: pelas páginas da gazeta, os comerciantes que investiam suas finanças na loteria do Teatro de S. João tomavam conhecimento do andamento de seus negócios. ${ }^{198}$

195 MARROCOS, Luís Joaquim dos Santos. Cartas do Rio de Janeiro (18111821). Coordenação. Elisabet Carceller Guillamet; Pesquisa e Revisão. Maria Conceição Geada; Transcrição e Índices. Cristina Pinto Basto, Elisabet Carceller Guillamet. Lisboa: Biblioteca Nacional de Portugal, 2008. p. 96 [Carta N. ${ }^{\circ}$ 10].

196 Ibid.

197 Ibid.

198 Para maiores informações sobre a estrutura e natureza das notícias veiculadas na Gazeta ver MEIRELLES, Juliana. Imprensa e poder... Op. Cit., p. 64-146. 
Como bem assinalou Marrocos, esse "compromisso" custava caro àqueles que se dispusessem a investir nos novos projetos culturais apoiados pela Coroa. Porém, na sociedade de Corte, em que a sociabilidade no universo público ainda mantinha vieses muito hierarquizados, o fato de se estar associado a um empreendimento cultural de peso - como a ereção de uma casa de espetáculos na nova capital imperial com o explícito apoio da Coroa -, era uma maneira eficiente de se atingir a distinção social almejada especialmente aos olhos do monarca. Vejamos os diferentes modelos de Avisos publicados na Gazeta:

\section{Aviso I}

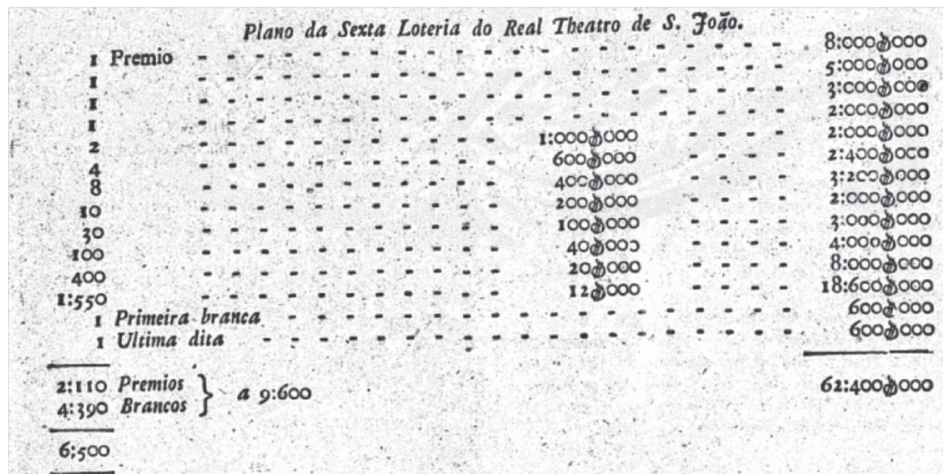

Os Bilhetes se acháo á venda, na rua Direita, em caza do Thesoureiro, onde tambem se vendem os da Loteria mensal, que se hade extrahir no primeiro do mez de Setembro, na mesma caza, onde se está extrahindo a Loteria de $S$. Fosé ás to horas da manhá.

RIO DE JANEIRO NA IMPRESSXO REGIA. 1815.

Fonte: Gazeta do Rio de Janeiro. 1815. n. 67

Como podemos notar, o plano da loteria (Aviso I) informava em ordem decrescente a quantia dos prêmios, o local de venda, a data e o horário do sorteio do bilhete. Durante todo o período joanino, os moradores da cidade podiam comprar os bilhetes na sede do espaço, geralmente entre as nove horas da manhã e duas 
horas da tarde. ${ }^{199}$ Depois da abertura do Teatro de S. João, em outubro de 1813, e a vigência dos espetáculos artísticos, notamos um aumento sensível no interesse dos negociantes do Paço na venda das loterias e bilhetes. Em 1816, os bilhetes podiam ser adquiridos na rua Direita na casa de Fernando José Pinheiro, na rua do Rosário, na de Antonio José Airosa ${ }^{200}$ e na rua da Quitanda, na de Joaquim do [ilegível] Pinto. ${ }^{201}$ No final de 1817, além das casas já citadas, os habitantes da Corte também podiam comprá-los na rua dos Pescadores, na casa N. ${ }^{\circ} .^{202}$

\section{Aviso II}

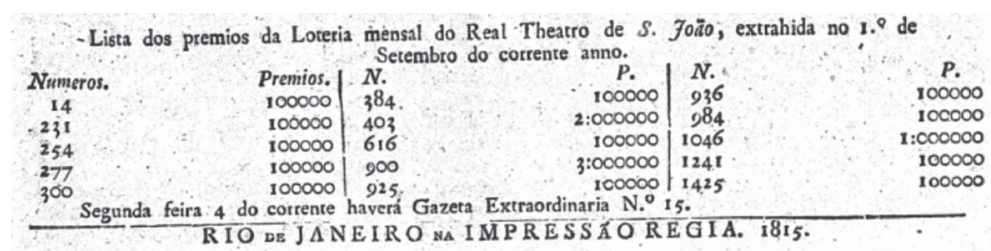

Fonte: Gazeta do Rio de Janeiro. 1815. n. 70.

A lista dos prêmios (Aviso II) destacava os números dos bilhetes sorteados e seus respectivos valores. Tal foi a seriedade desta iniciativa, que a publicação de um aviso de fevereiro de 1812 nos chama a atenção pela grandiosidade do prêmio. Denominado de Plano de uma pequena Loteria a benefício do Real Teatro de S. João, desta vez os compradores concorriam a "uma morada de casas no Sítio da Gamboa, pertencentes ao Proprietário do Teatro, cujas casas se entregarão a quem lhe saírem por prêmio na extração da Loteria, e acabadas de todo; e os mais prêmios são a

\footnotetext{
199 GRJ. 1816. n. 8.

200 Ibid., n. 20.

201 Ibid., n.61.

202 Ibid., n.105.
} 
dinheiro, sem que haja desconto". ${ }^{203}$ Um viés relevante deste empreendimento é que $12 \%$ do valor de cada bilhete era descontado em benefício da sustentação/administração do próprio teatro. ${ }^{204}$ Ou seja, se de início as emissões das loterias tinham o propósito de cobrir os custos da construção do teatro, ao longo do período estas serviram para subsidiar os espetáculos. Todos esses fatores demonstram o vivo interesse do proprietário em manter seu locus de cultura artística em constante atividade.

O empreendimento de Fernando José de Almeida também contou com o forte incentivo do governo, que não só o beneficiava com seis loterias assim que o espaço entrasse em funcionamento, como também concedia isenção alfandegária a todos os materiais necessários à obra - incluindo-se ornato e vestuário. Ademais, o negociante recebia do governo 150 mil réis pelos camarotes do ministro do reino, do encarregado das armas e do intendente geral da polícia, e 100 mil réis pela tribuna real. ${ }^{205}$ Além disso, a autoria do projeto era de José da Costa e Silva - o mesmo arquiteto que projetou o Teatro de S. Carlos. Na análise do historiador Jurandir Malerba, o "esmero do príncipe em construir rapidamente uma casa à altura de sua majestade, que em nada devesse aos proscênios lisboetas, é um índice diminuto de como o teatro se tornaria o centro de todas as suas manifestações políticas e sociais" 206 , principalmente depois de inaugurado.

Aqui fazemos uma importante ressalva: apesar de o teatro ter sido um locus de cultura financiado pelos negociantes e nobres da Corte, sua construção teve amplo apoio do real erário e da máquina governamental. A despeito de seu estatuto de espaço

\footnotetext{
${ }^{203}$ Ibid., n.11 (Grifo do Original).

${ }^{204}$ Ibid., n. 38.

${ }^{205}$ MARZANO, Andrea. Verbete Teatro. In: NEVES, Lúcia Bastos Pereira das; VAINFAS, Ronaldo (Org.). Dicionário do Brasil joanino... Op. Cit., p. 418. Para maiores detalhes ver SILVA, Maria Beatriz Nizza da. D. João. Príncipe e Rei no Brasil. Lisboa: Livros Horizonte, LDA, 2008. p. 95.

${ }^{206}$ MALERBA, Jurandir. A Corte no exílio:... Op. Cit., p. 92.
} 
particular (ou não estatal), o teatro de S. João foi notícia constante nas páginas da Gazeta do Rio de Janeiro. ${ }^{207}$ A Coroa não só fez grande uso do espaço entre os anos de 1813 e 1821 - comemorando datas natalícias e causas políticas da monarquia -, como também trouxe para o Rio de Janeiro, o maestro Marcos Portugal, um dos nomes de destaque da música clássica do período. Com Portugal regendo as apresentações artísticas da realeza, a partir de 1811, ratificava-se tanto a superioridade artística do espaço quanto a supremacia política do Império Português na América.

\subsection{O Real Teatro de S. João no Rio de Janeiro}

O teatro de S. João ficou pronto em 1813. A inauguração deu-se no dia 12 de outubro, no aniversário do Príncipe da Beira, D. Pedro de Alcântara. O destaque do espetáculo foi o Drama lírico O juramento dos Numes, de autoria de João Fausto da Camara Coutinho. ${ }^{208}$ Quatro dias depois, o gazeteiro informava aos seus leitores os detalhes da noite de gala.

\footnotetext{
207 Quanto à natureza oficial da Gazeta do Rio de Janeiro, ver MEIRELLES, Juliana. Imprensa e poder... Op. Cit., p. 71. Sobre a natureza do teatro S. João concordamos com a ótica do pesquisador Alberto Pacheco de que "o teatro, apesar de não ser estatal, estava intimamente relacionada com as atividades da Corte. [...] de certa forma, [foi] subsidiado pelo rei através de concessão de loterias e isenção de impostos". PACHECO, Alberto. Castrati e outras virtuoses... Op. Cit., p. 60.

208 D. Gastão Fausto da Câmara Coutinho (1772-1852), escritor e dramaturgo português, entrou para a Armada Real em 1792, onde se tornou capitão de fragata. Também exerceu o cargo de bibliotecário da Marinha. Era membro do Conservatório Real de Lisboa e acompanhou a vinda da Família Real ao Rio de Janeiro, onde produziu a peça O Juramento dos Numes, apresentada na noite de abertura do Real Teatro de São João, no dia 12 de outubro de 1813. De volta a Portugal, aderiu à Revolução de 1820, também conhecida como Revolução do Porto, da qual foi um dos poetas oficiais. Recebeu a comenda de Cavaleiro da Ordem de Cristo. "O Arquivo Nacional e a História luso-brasileira: a vida artística urbana." Disponível em: <http://www.historiacolonial.arquivonacional.gov.br/cgi/ cgilua.exe/sys/start.htm?infoid=828\&sid $=101 \&$ tpl=printerview $>$. Acesso em: 01 mar. 2012.
} 
Este teatro, situado em um dos lados da mais bela praça desta Corte, traçado com muito gosto e construído com magnificência, ostentava naquela noite uma pomposa perspectiva, não só pela Presença já mencionada de S.A.R., e pelo imenso e luzido concurso da Nobreza; e das outras classes mais distintas, mas também pelo aparato de formosas decorações; e pela pompa do Cenário e Vestuário. [...] A iluminação exterior do teatro, ordenada com exquisito gosto [sic], realçava o esplendor do espetáculo. Ela representava as letras J.P.R. alusivas ao Augusto Nome do PRÍNCIPE REGENTE NOSSO SENHOR, cuja mão liberal protege as Artes, como fontes perenes da riqueza e da civilização das Nações. ${ }^{209}$

Notemos que primeiramente a prédica do redator Manoel Ferreira de Araújo Guimarães destacava os aspectos arquitetônicos do edifício. Segundo o arquiteto Nireu Cavalcanti, a grandiosidade desta construção teve características "realmente capazes de destacarem-no em meio ao conjunto de edificações que ladeavam o largo do Rocio". ${ }^{10}$ Na prática, a elevação de S. João foi parte essencial de um processo de metropolização que, ao longo do tempo, tornar-se-ia irreversível. Nesse sentido, concordamos com a perspectiva da historiadora Maria Odila da Silva Dias de que a "vinda da Corte para o Brasil e a opção de fundar um novo império nos trópicos já significava por si uma ruptura interna nos setores políticos do velho reino." 211

Além de ter sido construído em uma região privilegiada da cidade, o Teatro S. João tinha a função de demarcar o novo território político da capital. E a mensagem era explícita: com a

\footnotetext{
${ }^{209}$ GRJ. 1813.n.83.

210 CAVALCANTI, Nireu. O Rio de Janeiro setecentista... Op. Cit., p. 178.

211 DIAS, Maria Odila da Silva. “A interiorização da Metrópole (1808-1853)”. In: MOTTA, Carlos Guilherme (Org.). 1822: Dimensões. São Paulo: Ed. Perspectiva, 1972. p. 165.
} 
sua vigência, o Rio de Janeiro definia um importante espaço de sociabilidade por onde circulariam seus principais expoentes. $\mathrm{Na}$ análise do historiador Sérgio Barra, algumas construções, tal como o Teatro de S. João, são "marcos físicos de poder e Civili-

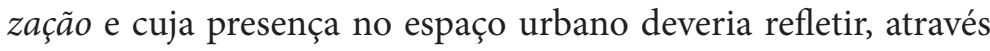
de sua arquitetura e de sua função, a magnificência, o poder e a Civilização do Império." ${ }^{212}$ Sob esse prisma, a Coroa portuguesa abria as portas do Rio de Janeiro aos valores vigentes na alta cultura do mundo civilizado para, assim, civilizar os costumes ditos bárbaros da antiga Colônia.

E, de fato, boa parte da sociedade joanina estaria presente nos eventos. A Família Real, os ministros de Estado, os membros da nobreza portuguesa, assim como os negociantes fluminenses de grosso trato e os viajantes, teriam a oportunidade de circularem pelo imponente prédio e também participarem ativamente do calendário artístico que se desenvolveria em S. João ao longo dos anos. ${ }^{213}$ Para grande parte desses sujeitos históricos, ser um dos "escolhidos" pelo rei para adentrar no universo da alta cultura europeia - assistindo aos espetáculos, contribuindo para a manutenção do espaço ou mesmo marcando presença em um local de grande prestígio social -, tinha um significado muito valioso: atestava o pertencimento à civilização, ou aos valores do mundo tido como civilizado. Em 1815, o redator da Gazeta do Rio de Janeiro anunciava as novas condições àqueles que desejassem comprar um camarote no teatro da Corte.

\footnotetext{
212 BARRA, Sérgio. Entre a Corte... Op. Cit., p. 116 (Grifos do Original).

213 O historiador Jefferson Cano realizou um importante estudo sobre as diferentes peças de teatro apresentadas no Teatro S. João no período joanino. Ao nomeá-las e analisá-las, o autor verificou o caráter áulico dessas produções, sobretudo antes dos ecos políticos da Revolução do Porto no Rio, em 1821. Para a análise pormenorizada dessa questão, ver: CANO, Jefferson. O fardo do homem de letras... Op. Cit., p. .129-135.
} 
Faz-se saber ao Público as condições, com que se alugam os Camarotes efetivos do Real Teatro de S. João, neste ano de 1815 até ao Entrudo de 1816. Quem ocupar o camarote efetivamente, sem fazer transação com ele, terá abatimento [de] dez por cento, pagando sempre doze récitas adiantadas, não contando com o camarote quem não as tiver pago. Na casa dos bilhetes do referido Teatro, se acha todos os dias de manhã, e de tarde o Camaroteiro, até o dia 20 do corrente, para efetuar este negócio, com quem o quiser fazer. ${ }^{214}$

Pelo que podemos apreender desse aviso, a edificação e manutenção de um teatro no Rio de Janeiro parece ter sido um investimento de boa rentabilidade. Para o proprietário, a garantia dos seus lucros dava-se pelo alto preço dos ingressos e o aluguel de camarotes (o valor adquirido cobria os gastos com a montagem das peças); já para a sociedade cortesã, alugar um camarote em S. João era sinônimo de status social e respeitabilidade. Para Sérgio Barra, a própria estrutura interna do teatro já demonstrava a hierarquização social tão presente nas sociedades do Antigo Regime. E é por essa razão que muitos homens da órbita política e econômica da cidade se interessavam em manter-se sempre visível aos olhos reais. ${ }^{215}$ Nessas ocasiões, além de a proximidade com o monarca significar uma chance na conquista de mercês, tinham a oportunidade de constituir novas relações sociopolíticas que poderiam lhes garantir, no futuro, maior visibilidade e riqueza. $\mathrm{O}$ divertimento e as regras de etiqueta eram dois outros vieses importantes nessa sociabilidade. Particularmente, frequentar o teatro divertindo "os sentidos, o pensamento de reflexões, e [tendo] cuidados sérios"216, também expressava a possibilidade

214 GRJ. 1815, n. 20.

215 BARRA, Sérgio. Entre a Corte e a cidade... Op. Cit., p. 194-195.

216 Verbete Divertimento. Dicionário Moraes e Silva, Vol.1, p. 630. 
de polir as maneiras e tentar corrigir os modos. No Rio de Janeiro joanino, tornar-se efetivamente um membro da sociedade cortesã no sentido mais tradicional do termo, perpassava uma atitude individual muito peculiar: cada membro da sociedade deveria ser um bom observador. Isto é, aquele que especula, reflete, pondera, faz reparo e, por fim, faz uso de suas observações. ${ }^{217}$

$\mathrm{Na}$ prática, a cada apresentação os ilustres espectadores delineavam o seu capital cultural nesse jogo de disputas pela atenção real. ${ }^{218}$ Portanto, as vantagens financeiras anunciadas na Gazeta para os interessados no aluguel dos camarotes era uma proposta conveniente para "quase" todos. No início de 1814, a mesma Gazeta denunciava a existência de "pessoas mal intencionadas que andam desacreditando a Administração do Real Teatro de S. João". ${ }^{219}$ Para remediar as possíveis consequências desse "bochicho", o proprietário publicava uma nota em que justificava seus gastos administrativos: ao abrir o espetáculo no dia 12 de Outubro de 1813, tinha pagado

[...] um mês adiantado a Companhia Cômica, e de Dança, e que a 15 a 17 do corrente, pagou o terceiro mês que se venceu a 12 , vindo por esse modo a estar de contas justas com todas as pessoas que trabalham dentro dele, a saber [:] Cômicos, Cantores, Dançarinos, Músicos, Pintores, Alfaiates, Comparses [sic], Carpinteiros e Porteiros, \&c. ${ }^{220}$

Boato ou não, na realidade nem tudo eram flores. Em junho de 1816, por exemplo, Paulo Fernandes Viana escrevia a D.

217 Verbete Observar. Dicionário Moraes e Silva, Vol. 2, p. 357.

218 BOURDIEU, Pierre. Economia das trocas simbólicas. [Introdução, organização e seleção de Sergio Miceli]. São Paulo: Perspectiva, 2007.

${ }^{219}$ GRJ. 1814, n. 6.

220 Ibid. 
João sobre a difícil situação do Real Teatro de São João, que por razões de déficit econômico, encontrava-se fechado. Nesta missiva, o intendente da Polícia rogava ao Regente a licença para imprimir pela Impressão Régia quatro rifas "de trastes e joias encostadas às Loterias mensais para tirar um prêmio com que se ajude naquelas despesas". 221 Segundo Viana, cada rifa custaria aos cofres reais seis contos e quatro réis e muito ajudaria o empresário Fernando José de Almeida a subsidiar os cômicos portugueses e estrangeiros que estavam vivendo sob penúria, inclusive dependendo do empresário para se alimentarem. ${ }^{222}$

A despeito dos problemas, ao longo do tempo a sociabilidade na região foi ganhando contornos cada vez mais amplos. A partir de finais de 1817, os leitores da Gazeta, possivelmente, já eram cientes do poder de pulverização que as notícias possuíam ao circularem como mercadorias pelas ruas da cidade, o que os colocava na posição de leitores e sujeitos ativos diante das notícias. ${ }^{223}$ Em janeiro de 1819, por exemplo, abria-se "uma aula de dança gratuita de que é mestre Augusto Tonssaint, primeiro dançarino no Real Teatro de S. João". ${ }^{224} \mathrm{O}$ anúncio informava que "nela se aceitam pessoas de ambos os sexos, de sete anos até doze, para serem empregados no serviço do mesmo Teatro". Para conhecer as condições da proposta, os interessados deveriam procurar o administrador do Teatro, Carlos José da Costa. ${ }^{225}$ No mesmo ano, o comerciante José Antonio Severino abria uma nova casa de pasto e botequim "pegado ao Real Teatro de S. João, na propriedade que pertence ao mesmo Teatro". O negociante ainda

\footnotetext{
221 ANRJ. Ministérios dos Negócios do Brasil. Fundo Diversos. GIFI (OI), 6J-83.

222 Ibid.

${ }^{223}$ MEIRELLES, Juliana. Imprensa e poder... Op. Cit., p. 164-165.

${ }^{224}$ GJR. 1818, n. 98.

225 Ibid.
} 
anunciava que no estabelecimento "se acharão boas comidas de todas as qualidades, e por preços cômodos." ${ }^{226}$ Um dos principais fatores para tamanha popularidade desse espaço de cultura era o fato de D. João comparecer aos eventos artísticos de maior relevância política, como revela o vivo depoimento do artista francês Jean-Baptiste Debret, radicado na Corte desde 1816.

Os portugueses, apreciadores da arte musical, mantinham em Lisboa certo número de virtuoses italianos e de excelentes instrumentistas a serviço da Capela Real. Esse precioso conjunto figurava igualmente no teatro da Corte, principalmente nas representações de gala honradas com a presença dos soberanos. Nessas circunstâncias, também, o estro dos poetas nacionais, sempre pródigos em louvores exagerados, parecia ainda insuficiente ao orgulho do soberano, habituado a vir quatro a cinco vezes por ano ao teatro sujeitar-se ao fogo ininterrupto das metáforas ousadas que formam esse prólogo dialogando bastante longo e que se intitula francamente Elogio.227

Para além de nos informar sobre a presença anual das idas reais ao teatro S. João, Debret nos coloca a par das práticas culturais ocorridas no Rio de Janeiro, que muito se aproximavam daquelas vividas nos espaços de cultura artística em Lisboa, sobremaneira a Capela Real e o teatro de S. Carlos. A valorização das virtuoses, por exemplo, foi de extrema importância: ajuda-nos a percebermos as continuidades dessas práticas culturais da Coroa, assim como a reiteração do gosto real na manutenção de um cotidiano artístico que primasse pela tradição absolutista. ${ }^{228}$ Nesse

\footnotetext{
226 Ibid. n. 25

227 DEBRET, Jean-Baptiste. Viagem Pitoresca e Histórica ao Brasil. São Paulo: Martins/Edusp, 1972, t.II, p. 242 (Grifos do Original).

228 Segundo Alberto Pacheco, "Mesmo durante o período joanino, com as atividades da Real Câmara e do Teatro S. João e a consequente produção da música
} 
sentido, os Elogios de caráter eminentemente político reiteravam a glorificação de uma "arte do passado - exagerada, artificial e submissa." ${ }^{229}$ Porém, mesmo que o rei estivesse ausente, sua figura era representada por um retrato que condizia com o enredo, e tinha propósitos didáticos: visava enaltecer alguma qualidade do soberano. Fosse bondade, afabilidade ou magnanimidade, o sentimento exaltado estava intimamente relacionado ao caráter da representação. ${ }^{230}$

Pela ótica do poder real, ou da constante prédica de enaltecimento público pela pena do gazeteiro da Corte, receber de seus súditos manifestações tão prestigiosas era uma forma indelével de manter vivo o discurso de soberania política e cultural diante do Velho Mundo, ainda imerso em conflitos políticos de grande magnitude: primeiro as guerras napoleônicas e, a seguir, o processo de restauração do Antigo Regime na Europa. ${ }^{231}$ A preleção

profana como óperas, bailados, elogios e cantatas, boa parte da prática musical carioca continuou acontecendo dentro das igrejas. A influência de D. João VI nessa produção musical sacra foi fundamental, não só pela conhecida predileção do Rei pelas pela música eclesiástica, mas também porque durante o período joanino além da religião oficial do Brasil ser o catolicismo, as relações entre Igreja Católica e o Estado do Brasil se davam através da instituição do padroado." PACHECO, Alberto. Castrati e outros virtuoses... Op. Cit., p. 52.

229 CANO, Jefferson. O fardo do homem de letras... Op. Cit., p. 129.

${ }^{230}$ BARRA, Sérgio. Entre a Corte e a cidade..., p. 188.

231 MEIRELLES, Juliana. Imprensa e poder... Op. Cit. Especificamente sobre o teatro de S. João, afirma o historiador Jefferson Cano: "Seria repetitivo, e de todo desnecessário prolongar o relato das vezes em que, segundo a imprensa oficial a família real transportou-se em grande estado ao real teatro, dos vivas que se repetiram sempre com entusiasmo, do teatro que esteve sempre profusamente iluminado, e cujo concurso foi sempre brilhante [...]. Mas se supostamente não mudava o ardente entusiasmo do público, nem o Benigno Acolhimento do monarca, alguma coisa por fim mudava, como no espetáculo de 26 de fevereiro de 1821, cujo motivo não era nenhum faustíssimo natalício, mas sim a aceitação da constituição que viesse a ser elaborada pelas Cortes em Lisboa." CANO, Jefferson. O fardo do homem de letras... Op. Cit., p. 134. 
de Debret sobre as apresentações teatrais, contudo, acenava para um certo cansaço do público nessas apresentações: as improvisações poéticas "declamadas por autores espalhados pela sala" duravam, muitas vezes, "mais de cinco quartos de hora" e, apesar de encher de prazer o espírito do rei "enfarava[m] impunemente todo o resto do auditório." 232

Não obstante os diferentes discursos e olhares para a nova realidade artística da Corte, é fato que os concertos musicais, as encenações de dramas, comédias e danças, além das festividades políticas, as paradas militares e espetáculos artísticos em geral, ocorridos dentro e fora do teatro, representavam uma gama importante do novo universo cultural que passava a fazer parte do cotidiano da capital. De acordo com Alberto Pacheco,

Quando passou a funcionar a Capela Real, a orquestra foi bastante ampliada com a entrada de músicos que foram sendo contratados da Europa. As cerimônias religiosas passaram a ser muito mais suntuosas, de acordo com a pompa usual na Corte portuguesa, afinal a Real Capela do Rio de Janeiro deveria ter como modelo a Real Capela de Lisboa. ${ }^{233}$

A rigor, os pressupostos e conceitos da arte europeia estavam, agora, presentes também na América. Vejamos dois anúncios saídos no periódico da Corte, entre 1815 e 1816:

Sexta-feira 27 do corrente no Real Teatro de S. João, se há de representar a nova comédia mágica, intitulada o Mágico de Valença, peça muito galante, além das tramóias com que a [sic] ator Luiz Xavier Pereira, maquinista atual do mesmo Teatro, pertende [sic] mostrar a tão erudito

${ }^{232}$ DEBRET, Jean-Baptiste. Viagem Pitoresca... Op. Cit., p. 242.

233 PACHECO, Alberto. Castrati e outros virtuoses... Op. Cit. p. 53. 
público o seu préstimo, como maquinista, e igualmente na pintura Jaconio de Argencio, arquiteto pintor do mesmo Teatro. ${ }^{234}$

Sábado 6 do corrente no Real Teatro de S. João, se há de representar uma nova comédia intitulada Dever e Natureza, produção de Antonio Xavier Ferreira de Azevedo. ${ }^{235}$

Como podemos notar, importava aos homens de teatro delinear uma relação profícua com o seu público: o destaque não se limitava aos aspectos técnicos, referia-se, sobremaneira, ao nível cultural da escolha das peças e do apurado trabalho do arquiteto e pintor do teatro, responsável por primar pela estética e magnificência desse espaço. Na prática, portanto, os valores e simbologias monárquicos que vigoravam pelos diferentes espaços públicos de Lisboa também passaram a ser partilhados pela sociedade joanina no Rio de Janeiro, que começou a ter acesso às célebres obras da dramaturgia europeia. Em julho de 1815, por exemplo, a Gazeta do Rio de Janeiro anunciava as peças dramáticas publicadas pela Impressão Régia, à venda na Loja da Gazeta. Os diversos títulos eram anunciados com seus respectivos preços. Entre outras, encontramos Ephigenia, por 800 réis, Merope, por 960 réis, Juramento dos Numes, por 640 réis. Já entre as coleções de peças, bem mais caras, temos: Teatro Estrangeiro, 2 vol., que contém o Cid, o Avarento, o Jogador, O Pai de Família, Alzira, Os Dois Amigos, por 4000 réis; Teatro Cômico Portuguez, ou Coleção das Operas Portuguezas, que se representaram no Teatro do Bairro Alto em Lisboa, 4 vol., por 8000 réis. ${ }^{236}$

Em relação aos romances produzidos pelas tipografias reais nos dois lados do Atlântico, a análise comparativa de preços

${ }^{234}$ GRJ. 1815, n. 7.

${ }^{235}$ Ibid., n. 2 (Grifo do Original).

${ }^{236}$ Ibid., n. 53 (Grifos do Original). 
realizada pela pesquisadora Simone Souza constatou que a mesma obra produzida em Portugal e no Brasil poderia ser três vezes mais cara no Rio de Janeiro. ${ }^{237}$ Segundo a autora, o maior número de pontos de venda e de tipografias em Portugal assim como a maior disponibilidade da matéria-prima para as impressões podem ser fatores relevantes na elevação dos preços no Rio de Janeiro, onde os recursos eram mais escassos. Tal fato nos indica que, provavelmente, a Coroa praticou o mesmo tipo de política editorial para as peças de teatro. Porém, apesar do alto custo das obras, nascia no Brasil a possibilidade de as pessoas conhecerem-nas - seja pela leitura ou pelas encenações. Um bom indício desse tipo de política editorial pode ser apreendido pelos anúncios da Gazeta do Rio de Janeiro. Em 1819, o periódico anunciava: “O Drama em Música, que se há de por em cena no dia nove do corrente [outubro], no Benefício de Paulo Rasquellas, acha-se à venda no Teatro, e na loja de Mr. Troyon N. ${ }^{\circ} 23$, rua do Ouvidor."238 Já em 1820, era a vez de a folha noticiar aos seus leitores sobre a publicação da tragédia Vestel, que estava em cena no Real Teatro de $S$. João, ao mesmo tempo em que se achava impressa em português. A obra era vendida na loja da Gazeta por 800 réis. ${ }^{239}$

Com o fim do apogeu napoleônico, sobretudo a partir de 1815 quando Portugal e França já haviam reatado as relações comerciais ${ }^{240}$, houve uma visível mudança de enfoque em relação

\footnotetext{
237 SOUZA, Simone. Primeiras impressões... Op. Cit., p. 63.

238 GRJ. 1819, n. 80.

239 Ibid., 1820, n. 82 (Grifos do Original).

240 Sobre o restabelecimento das relações comerciais entre Brasil/Portugal e França ver MALERBI, Eneida Maria Cherino. Relações Comerciais entre Brasil e França: 1815-1848. Dissertação de Mestrado. USP. São Paulo, 1993; STOIANI, Raquel. Napoleão visto pela luneta d'El Rei: construção e usos políticos do imaginário francês e napoleônico na América Portuguesa. Tese de Doutorado. USP. São Paulo, 2009. p. 360-378.
} 
tanto às notícias de origem francesa que eram veiculadas na $\mathrm{Ga}$ zeta do Rio de Janeiro, quanto em relação à política cultural da Coroa no universo luso-brasileiro. ${ }^{241}$ Como salienta a historiadora Lúcia das Neves, a principal consequência desse processo é que a "influência francesa passou a ter um papel significativo nas relações culturais." ${ }^{242}$ Particularmente em relação às Tragédias, notamos um crescente interesse pela publicação de autores franceses. Entre 1816 e 1817, duas tragédias de Racine - Iphigenia ${ }^{243}$ e Phedra ${ }^{244}$ - foram traduzidas para o português "verso a verso" por homens ilustres da Corte, o Doutor Antonio José de Lima Leitão e o livreiro Manoel Joaquim da Silva Porto, respectivamente.

Em julho de 1817, era anunciada a venda da "mui moderna tragédia El Rei D. Sebastião em África" e podia ser comprada na loja da Gazeta por 1.280 réis. Coincidentemente, esta peça havia sido impressa em Lisboa no mesmo ano. ${ }^{245} \mathrm{O}$ teor político da

${ }^{241}$ MEIRELLES, Juliana Gesuelli. Imprensa... Op. Cit., p. 130.

${ }^{242}$ NEVES, Lucia Bastos P. , "O privado e o público nas relações culturais do Brasil com França e Espanha no governo joanino”. In: Seminário Internacional D. João VI: um rei aclamado na América, Rio de Janeiro, Museu Histórico Nacional, 2000. p. 195

${ }^{243}$ GRJ. 1816.n.64.

${ }^{244}$ Ibid., n. 8.

${ }^{245}$ Ibid., n. 60. D. Sebastião em África é uma tragédia de autoria de Manoel Caetano Pimenta de Aguiar, foi impressa em Lisboa, pela Impressão Regia, 1817. Nota descritiva da peça: No Argumento que acompanha a publicação de $D$. Sebastião em África, Manuel Caetano Pimenta de Aguiar não deixa de enfatizar o tema escolhido para a sua tragédia ao identificá-lo como "o facto mais trágico da nossa história”. O público depara-se, desta forma, com a glorificação da figura de D. Sebastião, vincadamente marcado pela sua "natural inclinação pelas armas" e, através dele, de um Reino indiscutivelmente no "auge da sua glória e prosperidade". Como refere o autor, e como é do conhecimento comum, o gênio belicoso do jovem monarca assim o conduziu, após uma primeira vitória alcançada no norte de África, a uma segunda e derradeira expedição que lhe custou a vida e mergulhou o reino na dor e no desamparo. Ora a tragédia não é mais do que a curta e pomposa encenação do conflito que opõe o rei de Portugal, nas proximidades de Arzila e junto ao rio Mucazane, ao imperador de Marrocos e ao seu 
tragédia e a rapidez com que ela foi executada nas duas principais cidades do Império Português demonstram o nítido empenho da Coroa em exaltar os temas de seu interesse, cujo conteúdo, muito provavelmente, reiterava o infortúnio real ocorrido com D. Sebastião por força da Providência Divina. A semelhança com a situação vivida por D. João VI não era mera coincidência. Em 1818, a ópera Zaira, de Voltaire era vendida na Loja da Gazeta por 1.280 réis. $^{246}$

O novo status também delineado no campo político permitia o livre trânsito de franceses no mundo luso-brasileiro, atestado, inclusive, pela nomeação de um cônsul-geral da França no Brasil, o Coronel Jean-Baptiste Maler. ${ }^{247}$ A partir de então, e com destaque para a preeminência política do ministro Antonio de Araújo de Azevedo entre os anos de 1814 e 1817, a cultura francesa teve um importante destaque na Corte joanina. Francófilo assumido, Azevedo conduziu explicitamente uma política externa de aproximação com o governo de Luís XVIII. Pela ótica da restauração da antiga ordem, o interesse da paz geral entre as

plano estratégico. A edificação da tragédia, durante os seus cinco actos, entre o campo português e o campo inimigo, concorre para a acentuação do terror e compaixão a favor do exército luso e a elevação da figura de D. Sebastião a herói nacional. A peça encontra-se digitalizada e pode ser consultada em Disponível em: <http://ww3.fl.ul.pt/biblioteca/biblioteca_digital/publicacoes/th/obras/ULFLOM02430-1/ULFLOM02430-1_item1/index.html>. Acesso em: 10 fev. 2012. ${ }^{246}$ Ibid., n. 39.

247 Jean-Baptiste Maler foi cônsul-geral da França no Brasil entre 1816 e 1821. Antes de ser diplomata, foi soldado nas hostes contra-revolucionárias, quando adquiriu patente militar, tendo emigrado em 1792, fugido do Terror. Viveu então em Portugal, voltando à França em 1814 para servir à Restauração Bourboun com Luís XVIII. De lá veio para o Brasil. [...] No Rio de Janeiro, Maler correspondeu-se frequentemente com o duque de Richelieu, chanceler da França, além de manter conversas constantes com D. João VI e figuras expoentes da Corte como o Conde da Barca.” MONTEIRO, Rodrigo Bentes. Verbete Jean-Baptiste Maler. In: NEVES, Lúcia Bastos Pereira das; VAINFAS, Ronaldo (Org.). Dicionário do Brasil joanino... Op. Cit., p. 254. 
nações europeias estendia-se, igualmente, para o rei francês. E, de fato, foi o que ocorreu. Segundo o musicólogo Jean-Paul Sarraute,

Em 1816, Luís XVIII envia uma missão extraordinária ao Rio de Janeiro, no intuito de retomar as relações diplomáticas com a Corte portuguesa. A direção desta empreitada foi confiada ao Duque de Luxemburgo, que era irmão da Duquesa de Cadaval, então residente no Brasil. ${ }^{248}$

O Conde da Barca foi o responsável por intermediar a execução desse projeto, que trouxe, entre outras coisas, para o Brasil o renomado músico Sigismund Von Neukomm, discípulo de Joseph Hydn. Segundo Sarraute, Neukomm foi músico do célebre político francês Tayllerand, razão pela qual teve muito contato tanto com a vida política quanto com o universo musical parisiense. "Por ser mais exacto, fora o músico escolhido para todas as cerimônias marcantes da vida política da França e da Europa nos anos que se seguiram à derrota de Napoleão", afirma Sarraute. ${ }^{249}$ Neukomm viveu no Rio de Janeiro entre os anos de 1816 e 1821 e contribuiu sobremaneira para o refinamento do gosto. Ainda de acordo com o musicólogo, Neukomm não só foi muito bem recepcionado pelo Conde da Barca, como ainda foi pessoalmente nomeado por D. João como professor de piano do príncipe dom Pedro de Alcântara e da Infanta $\mathrm{D}^{\mathrm{a}}$ Maria. ${ }^{250}$ No aspecto cultural, o Conde da Barca também intermediou a vinda dos artistas franceses para o Brasil (1816) - projeto cultural definido pela historiografia tradicional brasileira como Missão Artística Francesa. ${ }^{251}$

\footnotetext{
248 SARRAUTE, J-P. Marcos Portugal. Op. Cit., p. 145.

249 Ibid., p. 144.

250 Ibid., p. 145.

251 TAUNAY, Afonso de. “A Missão Artística de 1816”. Publicações da Diretoria do Patrimônio Histórico e Artístico Nacional, 1956.
} 
No final de 1815, a dita "Missão Artística Francesa" teve explícito apoio político da Coroa, sendo seu principal intuito o de "facilitar o progresso das artes e proteger os artistas." ${ }^{252}$ Já em meados de 1816, o governo de D. João criou a Escola Real de Ciências, Artes e Ofícios. No que concerne ao projeto da "Missão Artística Francesa", há controvérsias dentro da historiografia. Lúcia das Neves afirma que "por ter como meta a civilização esta mesma Coroa tomou a iniciativa, após 1815, de convidar e hospedar missões francesas, que representavam nas suas condutas, aspectos 'louváveis ou desejáveis', segundo a ótica do período daquilo que a civilização francesa representava de positivo nas relações entre os povos" ${ }^{253}$ Já o recente trabalho da antropóloga Lilia M. Schwarcz enfatiza que "convém desconfiar das concepções finalistas, as quais tomam as consequências como causas e dão à 'Missão' um objetivo direto que, sem dúvida, ela não tinha, mas trataria de alcançar". 254

Segundo Schwarcz, há uma versão oficial da missão "que narra tudo, reservando para a Corte a proeminência e o controle sobre os fatos". A antropóloga defende, contudo, que "partiu dos próprios artistas toda a iniciativa e realização do projeto, e o governo português só apoiou o grupo quando este aqui chegou", liderado por Lebreton, secretário perpétuo do Instituto de França e chefe desse grupo de artistas franceses. ${ }^{255}$

\footnotetext{
${ }^{252}$ Ibid., p. 9.

253 Ibid., p. 9.

254 SCHWARCZ, Lilia M. O sol do Brasil: Nicolas Antoine Taunay e as desventuras artísticas dos artistas franceses na Corte de D. João. São Paulo: Companhia das Letras. 2008. p. 17. Esta pesquisa suscitou atualmente uma importante discussão na historiografia se realmente houve um projeto cultural acerca da vinda da Missão Francesa para o Brasil. Em nossa pesquisa, analisaremos detidamente esse fato.
}

255 Ibid., p. 176-177. 
Em relação ao papel desempenhado pelos artistas franceses no Brasil - seja como parte de um projeto idealizado e patrocinado pela Coroa portuguesa com intuito civilizador - como defende a historiografia tradicional ${ }^{256}$-, ou uma iniciativa autônoma desses artistas, como propõe a pesquisadora Lilia Schwarcz, o que nos interessa mostrar é que durante o período em que o grupo francês permaneceu no Brasil seus integrantes foram pensionados pela Coroa. ${ }^{257}$ Tal fato demonstra a relevância desse empreendimento cultural, porém o compreendemos como apenas um episódio proeminente de uma política cultural mais ampla do governo joanino.

O ano de 1817 foi crucial para o Império Português. Em meio à turbulência política pela qual passava a monarquia portuguesa desde o mês de março devido à Insurreição Pernambucana, de caráter republicano e separatista, fazia-se urgente reiterar a fidelidade dinástica que unia o monarca aos seus súditos. Em 13 de maio, o laço matrimonial entre D. Pedro de Alcântara e a princesa Leopoldina era confirmado, exaltado e publicamente comemorado no teatro da Corte.

Segunda-feira 26 do corrente [maio] houve grande gala na Corte, estiveram embandeiradas as fortalezas e embarcações, que deram as salvas Reais, e se patentearam outras demonstrações de júbilo pelo motivo faustíssimo de estar ajustado o casamento de S.A.R. o Senhor D. Pedro Príncipe do Reino Unido de Portugal e do Brasil, e dos Algarves, com a Sereníssima Senhora CAROLINA JOZEFA LEOPOLDINA, Arquiduquesa de Áustria. [...] A noite dignou-se El Rei Nosso Senhor de honrar com a

256 Oliveira Lima, classificou como melancolia o desenvolvimento da dita Academia no Brasil. Para a compreensão dos fatos, ver LIMA, Oliveira. D. João... Op. Cit., Capítulo V "Emancipação Intelectual” (p. 159-175).

257 SCHWARCZ, Lilia M. O sol do Brasil... Op. Cit., p. 209. 
Sua Presença e da Real Família, o Teatro desta Corte, que estava iluminado, e ao chegar à sua Tribuna um grande concurso de pessoas, que guarneciam os Camarotes, e a plateia, vestidas de Corte, bradaram em altos Vivas a El Rei Nosso Senhor e a toda a Sua Real Família, cantando os músicos o Hino Nacional. ${ }^{258}$

Esta grande festividade da Corte tinha sentidos políticos muito precisos: simbolizava a aliança vitoriosa de duas coroas europeias que "transfundia o sangue da continuidade monárquica nas casas reinantes aniquiladas ou oprimidas" ${ }^{\prime 259}$ por Napoleão e, portanto, merecia ser celebrada com grande pompa. Para além da missa ocorrida na Real Capela - que contou com a presença da Família Real e de todas as classes dos nobres cortesãos -, o evento artístico da noite no teatro S. João, teve como destaque a representação da Ópera séria a Vestal, "música excelente do grande Mestre Puccitta." No intervalo do $1^{\circ}$ ao $2^{\circ}$ ato, o público foi presenteado com a Dança Surpresa de Diana. ${ }^{260}$ Ademais, segundo Luís Norton, a educação de D. Leopoldina ${ }^{261}$ representava o ápice do exemplo de uma mulher civilizada da nova capital

\footnotetext{
258 GRJ. 1817, n. 43.

259 NORTON, Luís. A Corte de Portugal no Brasil: (notas, alguns documentos diplomáticos e cartas de imperatriz Leopoldina). 3. ed. Ilus. São Paulo: Nacional, 2008. p. 72.

${ }^{260}$ Ibid., p. 72.

261 Ibid., p. 92. Segundo Norton, “[D. Leopoldina] era uma mulher de espírito, calma, culta, dedicada às boas letras e às belas-artes; interessava-se vivamente pelas ciências naturais, tinha curiosidades científicas, lia Sismondi, colecionava animais e plantas, conhecia perfeitamente a mineralogia, a zoologia e a geometria descritiva $[\ldots] "$.
} 
e, portanto, deveria ser seguido pelos palacianos que desejavam polir os hábitos e maneiras.

D. Leopoldina trouxe para o Brasil, para junto de D. Pedro, o gosto pelos livros, pelo estudo metódico, pela boa cultura literária e científica, assim como foi animadora constante de todas as manifestações artísticas, pelas quais Linhares e Barca se haviam interessado. ${ }^{262}$

Em julho do dito ano, a mesma folha anunciava que os sócios do Teatro particular do Rocio, situado à rua de S. Pedro, desejavam "dar um público testemunho do seu regozijo pela gratíssima notícia", que, segundo o redator, "tem feito objeto de nosso júbilo." ${ }^{263}$ Araújo Guimarães referia-se ao triunfo militar da Coroa diante dos revolucionários pernambucanos. De acordo com o historiador Evaldo Cabral de Mello, a "facilidade e rapidez da vitória em Dezessete impressionaram os contemporâneos." A análise comparativa do viajante francês Tollenare entre a revolução pernambucana e francesa é ressaltada pelo autor: "o povo [em Pernambuco] não tomava parte alguma na insurreição' nem demonstrava 'nenhum entusiasmo, nenhum transporte'. E lembrando-se da jornada de Paris exclamava: 'Que diferença de ardor entre essa população e a nossa!'”265 $\mathrm{O}$ discurso do gazeteiro da Corte era deveras diferente da observação do viajante francês. Segundo Guimarães, o festejo do triunfo tinha atraído um grande número de espectadores, que se deleitaram com o refinamento do repertório.

\footnotetext{
${ }^{262}$ Ibid., p. 94.

263 GRJ. 1817, n. 56.

264 MELLO, Evaldo Cabral de. A outra independência: o federalismo pernambucano de 1817 a 1824. São Paulo: Ed. 34, 2004. p. 38.

265 Ibid., p. 38.
} 
Desempenhou-se então a Medeia, tragédia do célebre Longepierre, traduzida pelo insigne Francisco Manoel, e os atores se esmerarão e conseguiram retratar fielmente aquele original. A música tomou então a sua vez; e entre as escolhidas peças que se ouviram, ocuparam o primeiro lugar as belíssimas variações, que executou com a maior perfeição o Professor Ansaldi, músico da câmara de S.M. Concluiu-se o divertimento com o Entremez da Castanheira com toda a sua música, o qual se representou com a mais completa satisfação de todos os espectadores. ${ }^{266}$

A continuidade das comemorações ao sucesso real ocorria novamente no dia 05 do corrente mês. Nesta data, foi representado um elogio alegórico cujo intuito era "mostrar que o coração dos Portugueses era inabalável às sugestões do crime”. À noite também contou com a Comédia o Delirante por amor; que foi seguida de uma dança. Tanto a autoria do elogio quanto a composição da música tinham sido produzidas por um dos sócios do teatro. ${ }^{267}$ Diante da fragilidade política vivida pela monarquia, notamos que todos os eventos artísticos destacados pelo gazeteiro da Corte estavam em consonância com um discurso que exaltava a valorização e o respeito mútuo entre o monarca e seus súditos. Não foi à toa que em outubro de 1817, Araújo Guimarães rememorava o empenho dos negociantes fluminenses na elevação do Real Teatro de S. João. Ao construírem-no em menos de dois anos, mostravam "o quanto [eram] capaz[es] de produzir o amor e adesão a um Monarca Justo, que se preza sobretudo por ser o Pai dos Seus Vassalos". 268

Merope, peça em três atos de autoria do famoso libretista veneziano Apóstolo Zeno, por exemplo, foi publicada pela

266 GRJ. 1817. n. 56.

267 Ibid., n. 56.

${ }^{268}$ Ibid., n. 78. 
Impressão Régia, em 1815, e encenada no Teatro de S. João, em 08 de novembro de 1817. Segundo Guimarães, este espetáculo teve uma importante novidade que atraiu a atenção geral: Fernando José de Almeida, proprietário do teatro, ofereceu gratuitamente uma ópera ao seleto público, que contava, inclusive, com a presença de D. João e os demais membros da Família Real. ${ }^{269}$ Essa grande iniciativa realizava-se em nome do casamento de D. Pedro de Alcântara e D. Leopoldina, ocorrido três dias antes (05 de novembro de 1817). Vejamos a descrição do evento:

Começou então a apresentação da Ópera Séria ainda não vista nessa Corte, intitulada - Merope, Música da composição do insigne Marcos Portugal. ${ }^{270} \mathrm{O}$ Cenário e vestuário eram não só majestosos, mas inteiramente novos. No intervalo do $1^{\circ}$ ao $2^{\circ}$ Ato, executou-se um baile sério intitulado, Axur, ou o roubo d’Áspacia, com Cenário e vestuário igualmente ricos e novos.

Era para admirar a encantadora vista, que oferecia um prodigioso número de pessoas que vestidas de grande gala, que enchiam o Teatro; a pompa e a riqueza que ostentavam; e, sobretudo a ânsia com que procuravam fazer transluzir nos rostos os alegres sentimentos de corações fieis e amantes do Melhor Soberano. ${ }^{271}$

Toda essa prédica oficial expunha a inversão de papéis que começava a assolar o universo político luso-brasileiro: com a Revolução Pernambucana, ao nordeste do Brasil, e a Conspiração de Gomes Freire de Andrada, em Lisboa, a Coroa portuguesa vivia sob a constante (e real) ameaça da desintegração do Império

\footnotetext{
${ }^{269}$ Ibid., n. 91.

270 Segundo Jean-Paul Sarraute, Merope foi escrita por Marcos Portugal em 1804, para o teatro de S. Carlos, em Lisboa. SARRAUTE. Marcos Portugal. Op. Cit., p. 151.

271 GRJ. 1817, n. 91.(Grifos do Original).
} 
Português. E a defesa do Brasil era medida de caráter irrevogável. Como defendeu a historiadora Ana Rosa Cloclet da Silva, com tais acontecimentos "acentuava-se a tendência da fixação da Monarquia no Brasil, entendida na perspectiva anteriormente assinalada por Silvestre Pinheiro Ferreira, como medida essencial para se evitar a fragmentação desta parte do Império, sujeita às tendências republicanas então manifestas." 272 Por esse prisma, portanto, era necessário que D. João reconquistasse a confiança de seus súditos, que deveriam acreditar na saúde política do Antigo Regime.

Em outras palavras, a partir de 1817 as ações da Coroa no espaço público tinham como objetivo explícito a reconfiguração do apoio político de seus vassalos, pois só assim continuariam a existir nos moldes que tanto almejava manter. A viabilidade dessa empreitada, no entanto, mostrava-se cada vez mais complicada. Enquanto os revoltosos lisbonenses consideravam-no um rei ingrato que por sua ausência prolongada havia rompido o pacto social que sustentava a monarquia portuguesa; os revolucionários pernambucanos tinham ganhado uma importante batalha: por maior que fosse a derrota militar, a expansão do ideal republicano pelas outras capitanias do nordeste era uma realidade. ${ }^{273}$ Porém, como bem destacou o historiador Evaldo Cabral de Mello, "a independência foi o verdadeiro motor de Dezessete e se

272 SILVA, Ana Rosa Cloclet da. Inventando a Nação:... Op. Cit., p. 274 (Grifos do Original).

${ }^{273} \mathrm{Ibid}$. p. 270. "Além de contestar a soberania monárquica, um dos efeitos mais alarmantes do movimento, pela perspectiva das autoridades régias, residiu no seu alastramento para outras Capitanias do Nordeste Brasileiro, acenando com a possibilidade da fragmentação do projetado Império do Brasil. Ainda que, efetivamente, seu sucesso tenha se restringido às Capitânias da Paraíba e do Rio Grande do Norte - sendo abortada no Ceará onde se esboçou pretensa adesão, e na Bahia, pela ação fulminante do Governador Conde dos Arcos. 
incompatibilizou com a aspiração de constitucionalizar o Império luso-brasileiro." 274

A Coroa se situava exatamente na contramão dos ideias políticos pernambucanos. Por esta razão, era necessário que a monarquia exaltasse o valor e a solidez do sistema monárquico absolutista, tão contestado pelos súditos reais em ambas as margens do oceano. Dessa forma, no ano seguinte o Rio de Janeiro assistiria um dos mais destacados eventos de caráter político ocorrido na capital do Império: em 06 de fevereiro de 1818, a aclamação de D. João VI foi um festejo digno de uma monarquia europeia. Afinal de contas, era a primeira vez que um rei europeu era aclamado na América. ${ }^{275}$

Momento sui generis marcado por simbologias e conexões políticas cuidadosamente arquitetadas pela elite luso-brasileira, a Aclamação tinha como meta política a consolidação de um Império luso-brasileiro com sede na América. A cerimônia foi concebida como um espaço de legitimação do poder real que renovava a relação entre o rei e seus súditos. Nesse sentido, o alcance da adesão maciça de todas as camadas da sociedade era um fator de fundamental relevância, sobretudo depois de a monarquia ter vivenciado momentos de grande fragilidade política em decorrência dos movimentos revolucionários de 1817. Dia 10 de fevereiro, quatro dias depois das festividades públicas, o redator da Gazeta,

\footnotetext{
${ }^{274}$ MELLO, Evaldo. A outra independência... Op. Cit., p. 39 (Grifo Nosso).

275 A escolha do dia 06 de fevereiro como data que oficializava sua coroação também foi um aspecto particularmente arquitetado por D. João VI. Como nos informa o historiador Emílio Lopes, a associação com a fundação do Reino de Portugal "se prestava à rememoração das antigas tradições fincadas em torno do princípio legitimador da autoridade, do direito divino dos reis", em contraposição à "concepção de soberania popular defendida pelos revolucionários" na sedição pernambucana de 1817. Na prática, portanto, para além de a data da cerimônia tornar-se uma resposta aos princípios republicanos dos revolucionários, ainda perpetuaria no calendário monárquico uma versão vitoriosa da história que solapava a visão dos "vencidos".
} 
Manuel Ferreira de Araújo Guimarães, produzia o discurso da folha oficial com o objetivo de fixar a imagem de um povo que abençoa, apoia e adora o seu rei, irrestritamente.

Então salvaram as fortalezas e os navios surtos nesse porto, e se elevaram muitos fogos de artifícios, que arremedavam um regular fogo rolante com perto de dois mil tiros. Foi nesse afortunado momento que o imenso concurso de povo, que estava em frente a Varanda, e que atulhava as ruas contíguas, rompeu em unânimes vivas, que mostravam da maneira mais evidente o prazer que transbordavam no coração de todos. ${ }^{276}$

As celebrações começaram às 9 horas da manhã, com todas as pompas dignas de uma festa da realeza. Os tiros de canhões e os repiques dos sinos indicavam a importância da data. "Toda a família real estava resplandecente de diamantes e de todas as vestimentas da Corte eram notáveis pela riqueza e elegância”, observava Debret, ao acompanhar a chegada dos membros reais à missa solene, na Capela Real, que selava a magnitude do evento digno das circunstâncias "pela eloqüência política e religiosa."277

A questão central da aclamação, no entanto, estava intimamente associada a dois fatos políticos de suma importância para a manutenção da integridade da monarquia luso-brasileira. No que se refere à elevação do Brasil a Reino, consumada em dezembro de 1815, o festejo visava reafirmar a autonomia do Brasil dentro do Império Português, assim como imortalizar a figura de D. João VI como o monarca responsável por trazer a prosperidade e a civilização ao vasto continente do Brasil.

A festa de aclamação foi maciçamente financiada pelos negociantes de grosso trato como Fernando Carneiro Leão, Ama-

\footnotetext{
276 GERJ. 1817, n. 2.

277 DEBRET, Jean Baptiste. Viagem pitoresca... Op. Cit., p. 65.
} 
ro Velho da Silva, Francisco José Guimarães, Francisco Pereira de Mesquita e João Rodrigues Pereira de Almeida, entre outros. O grande dinheiro despendido por eles nos festejos tinha como estratégia enaltecer a figura do rei, para assim, consolidarem suas órbitas de influência junto a D. João VI. Um dos arcos construídos - o arco do triunfo - realçava a imagem de um rei ilustrado, cujo projeto era proteger e avançar as atividades comerciais e artísticas do Brasil, agora elevado a uma porção fundamental e civilizada do Império. Luís Gonçalves dos Santos, o Padre Perereca, descreveu com riqueza de detalhes as comemorações em torno da cidade, que toda iluminada, celebrava a coroação "pelas igrejas, e conventos, mas também todas as casas com maior, ou menos número de luzes" pareciam um "magnífico teatro, em que se desenvolvia em brilhantes chamas, fogos de artifício, o amor, e o prazer de seus fiéis vassalos." 278

Apesar de tantas solenidades durante os três dias em que duraram as comemorações, nem tudo foram flores. Quase um ano depois das sedições ocorridas em 1817, D. João ainda desconfiava da audácia das classes médias e populares, colocando em dúvida a lealdade de seu povo. "No primeiro e no segundo arco, onde eu me achava quase rente dele [D. João], pareceram-me

\footnotetext{
${ }^{278}$ SANTOS, Luís Gonçalves dos. Memórias para servir a História do Reino do Brasil, Belo Horizonte/São Paulo: Itatiaia/ Edusp, 1981, vol.2, p. 167. As luminárias e iluminações construídas por numerosos personagens endinheirados da cidade davam as diversas nuanças do regozijo que marcava o momento. O comendador Luís de Sousa Dias mandou construir um arco na porta da Alfândega que registrava a imagem da elevação do Brasil a Reino. Já a iluminação feita pelo tenente general José d'Oliveira Barbosa reafirmava o poder divino do rei com os dizeres "Deus e o meu Rei". Porém, as manifestações de apoio e fidelidade a D. João não chegavam apenas da parcela mais rica da sociedade. Bernardo Avelino Ferreira de Souza, um contemporâneo dos fatos, afirma que os mais pobres que viviam nos subúrbios também realizavam suas comemorações de acordo com suas possibilidades.
} 
provir de vagas suspeitas originadas de maus dizeres, que continuamente se estiveram a segredar em seu ouvido. Tive uma semelhante oportunidade de o observar, cerca de meia hora antes de seu início da cerimônia"279, comentava o viajante inglês John Luccock. O contato de Luccock com as classes médias e populares, no entanto, convencia-o de que não havia a menor razão para o temor, já que estava convicto "de que nunca houvera capital mais afeiçoada do que o Rio de Janeiro deste tempo". ${ }^{280}$

Para garantir a segurança pessoal do monarca e do cerimonial, a Intendência da Polícia distribuiu os soldados reais pela cidade. Munidos de cartuchos de pólvora, muitos deles se infiltravam em meio à gente miúda e cercavam o palácio para evitar possíveis badernas. Na multidão também foram implantados espiões para vigiarem os "elementos suspeitos" que poderiam atentar contra a vida do rei. O olhar privilegiado e crítico de Luccock destacava os meios repressivos com que as tropas reais se precaviam diante do povo e, sobretudo, contra os estrangeiros. "Não era permitido a ninguém falar língua estrangeira em meio do povo. No momento em que um senhor natural de Veneza se dirigiu a mim em inglês, um soldado lhe ordenou rudemente que falasse português ou calasse a boca." ${ }^{281}$

A grande participação popular nessa festividade tão marcante não escondia as normas e etiquetas vigentes na sociedade de Corte, perpetuada pela monarquia portuguesa em datas comemorativas. Todo esse cerimonial era regido por uma ordem hierárquica de acesso ao monarca. Primeiro, tinham vez os

\footnotetext{
279 LUCCOCK, John. Notas sobre o Rio de Janeiro e partes meridionais do Brasil, tomadas durante uma estada de dez anos nesse país, de 1808 a 1818, Trad. Milton da Silva Rodrigues, São Paulo, Livraria Martins, 1942. p. 379.

280 Ibid., p. 379.

281 Ibid., p. 379.
} 
maiores representantes da nobreza portuguesa, em seguida tinham espaço os procuradores das cidades e vilas - sempre determinados por graus de importância - e, por último, era a vez do clero que, diferentemente dos demais estamentos, não tinha o privilégio de tomar a mão do rei entre as suas; o que delineava os graus de influências e consequências políticas. A aclamação popular, por outro lado, também marcava um momento importantíssimo da celebração. Era a ocasião em que acontecia a ovação dos súditos do rei que, amontoados no Terreiro do Paço, legitimavam os laços políticos existentes entre o povo e o soberano. Logo após, o monarca e a Corte seguiam para a Capela Real, saudando o povo como exigia a tradição. Finalmente, às quatro horas da tarde, era chegada a hora de a majestade aparecer publicamente pela primeira vez para os seus vassalos em todo o seu esplendor real.

Os lugares e hierarquias tanto dos súditos ao redor de El Rei quanto das instituições em destaque - como o senado da Câmara do Rio de Janeiro e os representantes da Universidade de Coimbra - estavam bem delimitados e demonstravam a influência de cada um dos atores sociais nesse jogo de poder permeado por inúmeras representações e construção da memória coletiva.

Em meio às descrições da suntuosidade da festa, júbilo e participação popular, o redator da Corte ressaltou a demonstração de alegria e fidelidade de Paulo Fernandes Viana. O Intendente da Polícia não só erigia em sua casa uma grande iluminação como também expunha um interessante emblema. De acordo com Araújo Guimarães,

Dos dois lados do emblema da Coroação, se via em grandes quadros uma lira, e por cima a letra União; no centro as iniciais do Reino Unido, e em baixo Harmonia. [...] Em todas as três noites teve esse digno Magistrado coro de 
Música vocal e instrumental, que cantava o hino nacional, e várias peças de Música. ${ }^{282}$

Como podemos notar, Viana saudou o novo rei da maneira que mais lhe apetecia: com um discurso condizente às metas políticas da monarquia - a manutenção da união e harmonia no Reino Unido de Portugal, Brasil, e Algarves -, e também com um repertório musical ao gosto real. Linhas à frente, porém, o redator destacava a atitude "benigna" de Paulo Fernandes diante da Aclamação:

Aproveitamos esta ocasião para mencionar que o mesmo benemérito Magistrado fez chegar a alegria à habitação da miséria, mandado soltar 31 presos no Dia Faustíssimo da Aclamação de Sua Majestade, e nesse e nos dois seguintes [dias] dando alimento a 239 presos das cadeias que em razão de suas culpas não deviam gozar da liberdade. ${ }^{283}$

Como nos indica o relato do memorialista Alexandre de Melo Moraes, para além de o intendente geral da Polícia ser uma autoridade terrível, tinha a total confiança de D. João VI, de quem era muito amigo. ${ }^{284} \mathrm{Na}$ prática, como já dissemos, a responsabilidade pela manutenção da boa ordem na cidade estava nas mãos da Intendência da Polícia. E isso incluía a fiscalização das celebrações públicas, sejam aquelas ocorridas nas ruas do Rio de Janeiro ou no Teatro S. João. O policiamento dos teatros era objeto

282 GERJ. 1818, n. 4.

${ }^{283}$ Ibid., n. 4.

284 MORAES, Alexandre José de Melo, Dados sobre a chegada ao Rio de Janeiro da Família Real, problemas de habitação para a comitiva, vida social e política, hábitos da família real, volta para Portugal, falecimento de D, João VI e Pedro I como imperador, S.l, s.d, Original (transcrição feita por Cecília Coelho, maio de 2001), p. 116. BNRJ. Divisão de Manuscritos. II-30, 23, 6,7. 
de especial atenção do intendente. Neste particular, o comportamento dos frequentadores também deveria ser cuidadosamente fiscalizado e repreendido pela polícia, sempre que necessário. Em 1809, Paulo Fernandes Viana escrevia um ofício sobre o incidente ocorrido no Teatro Régio:

Tendo chegado a minha notícia que na noite da Ópera do dia último das Luminárias não se acabara a récita por atirarem da plateia uma pedrada no cômico Manoel Alvarez, e sendo este um procedimento que pela primeira vez se praticou nesta Corte; deveria V.M.ce ter-me logo dado parte dele, o que nao o fez. Pois nao deve ficar assim impune um fato que nao falta a quem o atríbua a frouxidão da Inspeção, e ainda mesmo a falta dela. ${ }^{285}$

Por esta fala, notamos a clara intenção de estabelecer limites para o público, que deveria não apenas conhecer os princípios da moralidade, da prudência e da civilidade, como também interiorizá-los, colocando-os em prática. Como bem pontuava a obra Elementos da civilidade e da decência,

SENDO os homens nascidos para viver uns com os outros, pior seria que os dos brutos o seu proceder, se eles só se unissem para o fim de maltratar-se. Qual era o fim, por que os nossos primeiros Pais se encerravam dentro das Cidades, senão para que a vida lhes fosse mais aprazível pelas delícias da sociedade; para socorrerem-se mutuamente contra seus inimigos; para participar igualmente dos bens, e dos males: e finalmente para não formar, por assim dizer, mais que uma só família, e viver como irmãos em comunidade de bens, obrigações, leis e costumes. ${ }^{286}$

285 ANRJ. Polícia da Corte. Códice 323, vol.1, f.8.

286 [Anônimo]. Elementos da Civilidade e da decência, para instrução da mocidade de ambos os sexos: traduzidos do francês em vulgar. Lisboa: Tipografia Rollandiana, 1801, s/n. Com Licença do Desembargo do Paço, p. 234. 
$\mathrm{O}$ autor ainda esclarecia acerca da responsabillidade individual de cada membro na sociedade:

[...] se cada indivíduo se persuadisse de que a sua particular felicidade dependia da comunidade geral, e contribuísse da sua parte para a massa comum, isto é, cada um satisfizesse para com seus irmãos as suas obrigações, que a boa ordem da sociedade requer, é certo que a circulação do corpo lhe restituiria a despesa que tivesse feito. ${ }^{287}$

Pela documentação da polícia, no entanto, vemos quão difícil era a prática desses valores ditos civilizados. Em 1814, quando o contato com viajantes e estrangeiros de toda ordem se fazia presente no Rio de Janeiro, a polícia se queixava da desordem. O incidente recaíra sobre Rosa Fiorine, primeira-dama bufa do teatro da Corte, que havia sido "insultada com um lenço que se lhe atirou à cara cheio de pedras e moedas de cobre". ${ }^{288}$ Sem conhecer o responsável por tal afronta, Paulo Fernandes Viana pedia ao juiz do crime que averiguasse "quem fez semelhante insulto, para me dar uma circunstanciada parte de tudo quanto puder alcançar a este respeito". ${ }^{89}$ No mesmo ano, o intendente referia-se a um importante ocorrido: desta vez o foco de sua atuação recaía para o escravo de José Coelho, de nome João Crioulo, que "foi preso por ser encontrado dentro de um camarote do Real Teatro de São João fechado por dentro, e fazer-se suspeito." ${ }^{290}$ Cinco anos antes, em 1809, Viana ainda recomendava ao juiz de crime da freguesia de São José, Luís Joaquim Duque Estrada, que nos dias de gala ele se apresentasse "no seu camarote muito antes de principiar

\footnotetext{
287 Ibid., p. 234.

288 ANRJ. Polícia da Corte. Códice 329, vol.2, f.207 v.

289 Ibid.

290 Ibid. Códice 403, vol.1. sem numeração de folhas.
} 
a Ópera para providenciar todo o motim que ali se possa fazer sem permitir assobios, gritos, pateadas e outros comportamentos e modos incivis que o povo pratica quando perde o respeito pelas autoridades constituídas" ${ }^{291}$

Em 1818, o intendente geral da polícia exigia a prisão de todos aqueles "que deitam da plateia e camarotes dinheiro aos cômicos e dão muxoxo e assobios" ${ }^{292}$ Adiante, determinava ao juiz do crime responsável pela inspeção do teatro que "esta diligência se faça pública, para que cessem os males que se querem antes evitar do que punir". Por fim, concluía: "É preciso por todos os meios desarraigar do Teatro este gênero de perturbação que reflete sobre a boa polícia com que se deve manter, ficando em pé todas as outras providências que a este respeito se tem dado". ${ }^{293}$ Diante de todos esses acontecimentos, podemos supor que, muito provavelmente, a valorização da boa ação de Fernandes Viana pelo redator da Gazeta, em meio aos festejos da Aclamação de D. João VI, tinha o intuito de reaproximá-lo da sociedade, que tanto se sentia amedrontada pela sua figura deveras autoritária.

Enquanto no Rio de Janeiro as iluminações pela cidade durante os festejos da aclamação demonstravam as manifestações de adesão do "povo" ao rei e ao seu projeto político, em Portugal o silêncio, a indiferença ou as ausências nos festejos marcavam a revolta e a resistência ao mesmo momento. Houve até destruição de luminárias. Segundo o relato do português José Ribeiro Pinto, não se ouvia os vivas quando foi mostrado o retrato de D. João VI. ${ }^{294}$ Assim, em meio às muitas manifestações artísticas decorrentes da Aclamação de D. João VI no Rio de Janeiro, alguns aconte-

${ }^{291}$ Ibid. Códice 323. Vol.1, f.54.

${ }^{292}$ Ibid. Códice 329. Vol.4, f.89, V/ 90 v.

293 Ibid.

${ }^{294}$ LOPES, Emílio. Festas Públicas... Op. Cit., p. 53. 
cimentos culturais ocorridos em Lisboa nos chamam a atenção. Enquanto o teatro S. João demonstrava viva saúde financeira, esplendor e constância nos espetáculos artísticos - inclusive com o maestro Marcos Portugal recebendo a pequena fortuna de 190 mil réis por mês saídos diretamente do Real Erário ${ }^{295}$ - o teatro de S. Carlos do outro lado do Atlântico sobrevivia de favores e mercês de importantes negociantes lisboetas. ${ }^{296}$ Esta aparente solidez do espaço artístico do Rio de Janeiro escondia, contudo, os problemas cotidianos da instituição, que sustentava em torno de 800 trabalhadores. ${ }^{297}$

A correspondência anônima que compõe o Códice do então governador do Reino, Ricardo Raimundo Nogueira, referia-se ao auxílio que D. João VI mandara dar ao teatro de S. Carlos pelo Aviso de 23 de agosto de $1818 .{ }^{298}$ E o documento nos traz o panorama da situação:

Podendo orçar-se o produto das loterias, e o preço dos camarotes em pouco mais de trinta mil cruzados, será este auxílio suficiente para sustentar o Teatro de S. Carlos junto com o que se recebe à ponta? Certamente não! Porque um Teatro de Música é por extremo dispendioso. Só a despesa diária de cada noite monta a trinta moedas, e talvez mais o que os 200 restas [sic] o que a presente sociedade se obrigou importa setenta e dois mil cruzados. Mas além disto há a enorme despesas dos salários, vestuário, cenário, compra e cópia de música, viagens dos atores e dançarinos que se manda vir da Itália e das comissões que os vai ajustar V.S. Este grande desembolso só admite a economia que pode resultar de uma administração

295 SARRAUTE, J-P. Marcos Portugal. Op. Cit., p. 119. Ainda segundo o musicólogo, um castrato recebia em torno de 40 a 50 mil réis por mês.

296 Apontamentos. V. Nogueira (Ricardo Raimundo). BNP_Res. COD. 7207. Doc. 3.

297 ANRJ. Ministérios dos Negócios do Brasil. Fundo Diversos. GIFI (OI), 6J-83.

298 A íntegra deste documento encontra-se nos Anexos desta tese. (Anexo I). 
vigilante e bem regulada; porque se se [sic] quiser aplicar ao mesmo espetáculo, diminuindo o seu aparato, enfraquecendo a orquestra, assalariando cantores, e bailarinos medíocres, V. S. será a perda muito maior, porque faltarão os espectadores. Isto é o que se principia a experimentar-se em São Carlos, aonde apesar da magnificência do Cenário e vestuário o pouco merecimento dos cantores faz que a casa seja pouco frequentada e cada vez o será menos, porque o espectador é todo para os olhos e nada interessante para os ouvidos. Por todas estas razões estou [ilegível] que a empresa, ainda recebendo o sobredito auxílio de trinta mil cruzados há de ficar no fim do ano alcançada em mais de trinta. ${ }^{299}$

Esta revelação mantinha um alto tom de denúncia e, pelo teor do documento, muito possivelmente o autor era um empresário teatral ou, quiçá, Sebastião José M. Botelho, desembargador e inspetor dos Teatros de S. Carlos e da Rua dos Condes. ${ }^{300}$ Para

\footnotetext{
${ }^{299}$ Apontamentos. V. Nogueira (Ricardo Raimundo). BNP_Res. COD. 7207. Doc. 3 .

300 Sebastião José M. Botelho assinou um documento escrito em Lisboa datado 12 de Maio de 1816. Em uma missiva, o inspetor dos teatros de $S$. Carlos e Conde detalhava tanto a situação financeira dos espaços quanto as celebrações ocorridas em ambos os teatros. Ao final da carta, afirmava: "Como inspetor que sou de ambos os Teatros, atesto na Real Presença, que os dois Teatros se conservam de más frases, e com boa doutrina e polícia, que os espectadores do de S. Carlos estão levados à maior pompa, e grandeza e com maior concurso de pessoas escolhidas; que esteve ornado, e com a maior riqueza nas épocas, e pelo espaço que alega em seu requerimento: que nos cinco meses que esteve à disposição do Senado, teve a sociedade lucros cessantes, pelo que deixou de ganhar nesse tempo, e danos emergentes pelo muito, que sem dúvida ganharia, trabalhando em quadra de tanto regozijo público: que são certos os adiantamentos e verdadeiras as escrituras feitas em Reinos Estrangeiros, e que muitas vezes se absorvem os fundos da caixa custeando-se o Teatro a crédito até se realizarem novos: e que havendo arrendado a casa, como arrendarão por três anos, feito escrituras e adiantado somas excessivas, ficarão arruinados, e perdidos os sócios se a Beneficência de V.A.R. não lhes acudir, concedendo-lhes a mercê que suplicam." Apontamentos. V. Nogueira... Op. Cit., Doc. 9.
} 
além de explicitar os gastos com cada peça ocorrida em S. Carlos e apontar para o declínio do interesse dos espectadores em assisti-las, mais à frente a carta ainda sinalizava para uma situação de grande penúria. Caso o governo joanino não subsidiasse a maior casa de espetáculos lisboeta em sessenta mil cruzados anuais $^{301}$, esta seria obrigada a fechar suas portas no verão de 1819 , da mesma forma que ocorrera no inverno de $1818 .^{302}$ Segundo o autor, os empresários seriam impelidos a tal atitude porque "nem tem capitais próprios para o sustentar [sic], nem os caixas e outros negociantes que lhe tem acudido com dinheiros adiantados serão tão nescios [sic] que sacrifiquem os seus cabedais a uma perda certa e considerável." ${ }^{303} \mathrm{E}$ as denúncias não paravam por aí. O empresário também apontava para o rombo financeiro. “[...] quando o [teatro] de S. Carlos se fechou, se achava a sua caixa onerada com uma dívida de quarenta mil cruzados". Ao se referir ao diretor Manoel Baptista de Paula, "único sócio abonado, que podia se responder por ela, e com quem os credores tinham contratado [sic]", concluía afirmando que este estava "exposto a uma ruína infalível". ${ }^{304}$

D. João não deixou o seu principal teatro em Lisboa à mingua. O rei não só aceitou o pedido dos empresários portugueses como também determinou que seu principal ministro de Estado no Rio de Janeiro, Thomaz Antonio Vilanona Portugal, intermediasse a contenda junto ao governador do Reino, Ricardo Raimundo Nogueira. ${ }^{305}$ Por esse mesmo período, especialmente entre os anos de 1819 e 1820, encontramos uma série de

\footnotetext{
301 Ibid. Doc. 6.

302 Ibid. Doc. 3.

303 Ibid.

304 Ibid. (Grifos Nossos).

305 Ibid. Doc. 6.
} 
requerimentos de atores e atrizes lusitanos que desejavam fazer carreira no Rio de Janeiro. Vejamos:

Diz João Evangelista da Costa, Ator do Teatro Nacional da Rua dos Condes, que pertendo [sic] transportar-se à Corte do Rio de Janeiro, alcançara da Intendência Geral da Polícia, o passaporte incluso, pelo qual mostra não ter impedimento algum; porém como para esse fim seja necessário expedir-se o respectivo passaporte pela Secretaria d'Estado dos Negócios da Marinha. Lisboa, 12 de fevereiro de 1820.306

Outra súplica referia-se ao novo contrato do ator Antonio José Pedro no teatro S. João.

Diz Antonio José Pedro, que este suplicante precisa fazer viagem para a Corte do Rio de Janeiro, em consequência de se achar escriturado para Ator do Real Teatro de S. João, e como o não pode efetuar sem Passaporte, precisa que a Vossa Majestade haja por bem de lhe mandar passar. ${ }^{307}$

Em 23 de fevereiro de 1820, a Intendência da Polícia de Lisboa consentia permissão para a ida ao Brasil da atriz Maria Amália, dita solteira, na idade de vinte e cinco anos. ${ }^{308}$

306 REQUERIMENTO do ator do Teatro Nacional [de Lisboa], João Evangelista da Costa, [natural de Lisboa], ao rei [D. João VI], solicitando passaporte com destino à Corte do Rio de Janeiro. AHU_ACL_CU_017, Cx. 284, D. 19948.

307 REQUERIMENTO do ator cômico do Real Teatro de São João, Antônio José Pedro, ao rei [D. João VI], solicitando passaporte com destino à Corte do Rio de Janeiro. AHU_ACL_CU_017, Cx. 284, D. 19952.

308 ATESTADO do intendente geral da Polícia, João de Matos Vasconcelos Barbosa de Magalhães, declarando que a atriz do Teatro Nacional, Maria Amália, natural de Lisboa, está apta para receber seu passaporte com destino à Corte do Rio de Janeiro levando em sua companhia uma órfã menor de idade por nome Teresa de Jesus. AHU_ACL_CU_017, Cx. 284, D. 19957. 
Atesto que Maria Amália, Atriz que foi no Teatro da Rua dos Condes [...] não tem impedimento pela Polícia para passar como pertende [sic] ao Rio de Janeiro, levando consigo Tereza de Jesus, de idade de dez anos, natural de Lisboa, órfã de Pai e Mãe. E para constar aonde lhe convier [sic], especialmente na Secretaria de Estado dos Negócios da Marinha, onde deve recorrer para conseguir o seu Passaporte [,] mandei passar o presente por mim assinado, ficando na Secretaria desta Intendência os documentos que legitimam as recorrentes. ${ }^{309}$

Por fim, sabemos da travessia do músico instrumentista da Real Câmara, Joaquim Antonio Nunes d'Oliveira, que, segundo seu requerimento, tinha "negócios urgentes a tratar pessoalmente na Corte do Rio de Janeiro". O pedido ainda exaltava que "os seus poucos meios não lhe permitem perder a oportunidade que presentemente se lhe oferece de ir comida e modicamente em um Navio que está próximo a sair, e desejando em todos os casos proceder com a obediência e legalidade próprias de fiel e digno súdito de V. Majestade." 310 Todos esses pedidos indicam-nos, mais uma vez, a crise pela qual passava a classe de artistas, agora em Lisboa. Além do fato de que muito possivelmente a política cultural de D. João VI pendia para a valorização dos espaços de cultura no Brasil, mormente no Rio de Janeiro.

Desde as primeiras notícias sobre a Revolução do Porto, em fins de 1820, que exigia a volta de D. João a Portugal e a instauração da monarquia constitucional, o Rio de Janeiro vivia um momento de grande ebulição política. Pelas ruas da cidade circulavam diferentes canais de expressões públicas e políticas

309 Ibid.

310 REQUERIMENTO do músico instrumentista da Real Câmara, Joaquim Antônio Nunes de Oliveira, ao rei [D. João VI], solicitando passaporte com destino à Corte do Rio de Janeiro. AHU_ACL_CU_017, Cx. 284, D.19976. 
que tinham como foco, explícita ou moderadamente, a crítica ao Antigo Regime Português. ${ }^{311}$ Como bem analisou o historiador Marco Morel, "a crer nas narrativas de $\mathrm{Maler}^{312}$, o Rio de Janeiro em 1821 seria perpassado com certa frequência por esse tipo de circuito: papéis manuscritos e anônimos em locais coletivos e portas de casas, avisos e proclamações destinados a certos públicos e visando alvos determinados", fato que, segundo o autor, resultaria "numa exasperação de comportamentos."313 Dessa forma, o ano de 1821 marcaria uma nova relação da sociedade joanina com a arena pública. Nesse particular, nos interessa aqui analisar as transformações políticas que marcaram a capital entre em meados de 1821, com especial atenção para as manifestações que tiveram o teatro $S$. João como palco principal.

Ao longo do mês de fevereiro, a cidade se viu imersa na contenda sobre o juramento de D. João à Constituição de Lisboa. Para além dos debates ocorridos na imprensa, o grupo dos "liberais" - liderado por Joaquim Gonçalves Ledo e Januário da Cunha Barbosa - exigia que o rei jurasse fidelidade às determinações políticas das Cortes de Lisboa, além da troca do ministério real com o afastamento de Thomaz Antonio Vilanova Portugal e Paulo Fernandes Viana. Esse intenso conflito teve seu ápice no dia 26 de fevereiro, quando os líderes do movimento conduziram o processo de manifestação militar na Praça do Rocio. Tal demonstração evidenciava o embate de posições políticas entre o governo e um grupo de cidadãos livres insatisfeitos. Estes homens

311 Sobre o debate da questão constitucional e das Cortes na imprensa do período, especialmente no primeiro semestre de 1821, ver MEIRELLES, Juliana. Imprensa e poder... Op. Cit., p. 190-225.

312 Jean-Baptiste Maler.

313 MOREL. Marco. As transformações dos espaços públicos: imprensa, atores políticos e sociabilidade na cidade imperial (1820-1840). São Paulo: Editora Hucitec, 2005. p. 226. 
mantinham importantes relações comerciais e de parentesco na Europa, cujas redes de contato com a maçonaria os aproximavam dos revolucionários vintistas. ${ }^{314}$

De acordo com a historiadora Iara Schiavinatto, na praça do Rocio D. Pedro se comprometeu a levar todos os pedidos dos revoltosos (a tropa, o povo e os oficiais) a D. João. Enquanto o príncipe se reunia com o seu pai - que acabou por consentir todas as reivindicações - o Senado da câmara se "reunia na grande sala do Real Teatro São João, o que aumentava o prestígio do movimento, pois, em certa medida, o legalizava, e demarcava um outro espaço de discussões, fora das ruas, no qual apenas os vereadores, oficiais e autoridades tinham acesso". 315 Ao voltar à praça, D. Pedro leu o decreto real de 24 de fevereiro, sendo ovacionado com vivas da população. A releitura de tão importante determinação política aconteceu na varanda do teatro S. João. Deste espaço jurava às Cortes feitas em Lisboa.

$\mathrm{Na}$ prática, era a primeira vez que a monarquia cedia às exigências do povo em plena praça pública. E sob esse prisma, concordamos com a análise do historiador Marco Morel quando conceitua a importância do teatro nesse período. Segundo Morel,

O próprio príncipe toma a iniciativa de fazer a saudação: render homenagem a seu pai, rei de Portugal, Brasil e Algarve. Dessa maneira, é a soberania monárquica que legitima a sala de espetáculos como lugar de expressão de uma vontade coletiva, a da Coroa. A autoridade moral desta voz pública identifica-se então com a palavra oficial. Trata-se de um espaço consentido, onde se dá a adesão recíproca entre os soberanos e os cidadãos, entre o rei e o

314 OLIVEIRA, Cecília Helena Lorenzini Salles. A astúcia liberal. Relações de mercado e projetos políticos no Rio de Janeiro (1820-1824). São Paulo: EDUSP e ICONE, 1999. p. 116-117.

315 SCHIAVINATTO, Iara Lis. Pátria Coroada... Op. Cit., p. 95-96. 
povo no sentido histórico mais tradicional. O Teatro não tinha a validade institucional deliberativa de uma assembléia, mas recebia uma consagração da parte da autoridade monárquica por meio da aclamação - mecanismo de legitimidade arcaico, em voga nos Antigos Regimes europeus. ${ }^{316}$

Às onze horas da manhã, era a vez de D. João ir ao Rocio a fim de reafirmar as palavras e o compromisso do filho. Igualmente aclamado, o monarca reverenciava o povo com beija-mãos, sinalizando, com isso, para o "restabelecimento da ordem."

Todos esses fatos ocorridos ao longo do período joanino demonstram duas ordens de fatores de suma importância, mormente no que concerne ao teatro como importante locus de cultura. Da estruturação desse espaço - seja em Portugal com os teatros de S. Carlos (Lisboa) e S. João (Porto) ou no Brasil com o teatro S. João - é notória a emergência e supremacia dos novos atores sociais que exigiam a sua representação (e aceitação) em um espaço de grande notoriedade na cidade, arquitetônica e culturalmente. Em Portugal, emergiam as vozes e interesses da burguesia portuguesa (seja em Lisboa ou no Porto); no Brasil, era a vez dos negociantes fluminenses de grosso trato mostrarem seu poder de transformação do espaço público, sendo eles, simbolicamente os responsáveis por mostrarem ao Velho Mundo também a civilidade de seus gestos culturais, traduzidos em um empreendimento de tal vulto, cuja função era entreter a sociedade exaltando a civilização.

Diante de tais mudanças, que vigoravam no universo luso-brasileiro principalmente a partir do último quartel do século XVIII, adentrando no século XIX, a Coroa não se furtou a

316 MOREL. Marco. As transformações dos espaços públicos... Op. Cit., p. 235. 
aceitá-las. Porém, a complexidade dessa negociação foi patente. Seja com D. José I, Da. Maria I ou D. João VI, os monarcas portugueses legitimaram as ações desses atores sociais, desde que os limites do contrato político da monarquia portuguesa fossem respeitados.

Contudo, o que vemos no alvorecer d'Oitocentos, nos dois lados do Atlântico, é a imposição dos súditos da monarquia por um diálogo político e cultural profícuo com o monarca. Se por um lado este diálogo de fato aconteceu, tendo como ápice a Revolução do Porto e seus ecos além-mar; por outro, essa interlocução não deixou de ser conflituosa. Como vimos, nesse embate o Brasil excluiu grande parcela da população - os homens livres pobres e os escravos - marginalizando-os de forma explícita: se os primeiros eram impedidos de adentrarem no universo da alta cultura europeia por falta de recursos financeiros, os segundos não possuíam qualquer status jurídico para tal. Ao mesmo tempo em que o Rio de Janeiro ganhava contornos mais sofisticados em matéria de sociabilidade, também grandes tensões sociais se faziam presente no cotidiano da cidade.

Dentro desse contexto, se a ação repressiva da polícia foi imprescindível, não foi suficiente para coibir definitivamente as manifestações individuais ou coletivas. Dentro ou fora do teatro, novos sentidos políticos e culturais se formavam, se impunham, se chocavam. Como magistralmente analisou Marco Morel, de fato, o teatro na Corte brasileira ocupa a dimensão da Ágora grega. Tal estruturação, consolidação e apropriação desse espaço de cultura, entretanto, têm seu início no mundo luso-brasileiro no período joanino, auge da crise do regime absolutista português.

Como sabemos, uma das principais expressões dessa crise política foi a transaldação da monarquia lusitana para o Brasil. No que tange à materialidade do poder real na porção americana 
do Império, destacou-se a criação da Real Academia Militar do Rio de Janeiro. Situada na nova capital, este locus de cultura foi de suma importância dentro do projeto político de D. Rodrigo de Souza Coutinho, de formação de um novo e poderoso império. Dentro desse nascente espaço de saber de cultura científica e educação formal dos súditos ilustrados da corte joanina, entrevemos múltiplos vieses de um novo tempo histórico. Em tempos de guerra ou de paz, a Real Academia Militar do Rio de Janeiro teve contribuição fundamental na compreensão da política cultural joanina. Desvendar algumas de suas contribuições políticas e culturais ao longo do processo histórico de crise da monarquia absolutista portuguesa é o tema a seguir. 


\section{O UNIVERSO MILITAR NA SUSTENTAÇÃO DO IMPÉRIO PORTUGUÊS}

\subsection{Preâmbulo}

[...] onde eu existo, e resido é que necessariamente se deve considerar a sede, e ponto central do Império.

Príncipe Regente ${ }^{1}$

Escrita do Rio de Janeiro, em maio de 1808, esta declaração de D. João aos seus governadores do Reino já demarcava uma mudança fundamental da perspectiva política que até então regia o Império Português: o Reino perdera o seu papel de nexo da unidade imperial ${ }^{2}$, fato que colocava em cena a questão da $c a$ pitalidade do Império Português. Ou, como demonstrou Maria Odila da Silva Dias, com a transferência da Família Real para o Brasil ocorria a interiorização da metrópole e com ela nascia o processo de ruptura com a velha política do Reino, assim como o "enraizamento de novos capitais e interesses portugueses, asso-

\footnotetext{
1 ANTT. Série Ministério do Reino. Registro de Ordens expedidas pelo Príncipe Regente aos governadores do Reino. Livro 380, p. 10.

2 LYRA, Maria de Lourdes Viana. A utopia do poderoso império. Portugal e Brasil: bastidores da política (1798-1822). Rio de Janeiro: Sette Letras, 1994. p. 119.
} 
ciados às classes dominantes nativas [do Rio de Janeiro] e também polarizadas em torno da luta pela afirmação de um poder executivo central". ${ }^{3}$ Já segundo a historiadora Maria Fernanda Bicalho, se o Rio de Janeiro fora desde 1763 a capital da Colônia, por ter-se tornado "a cabeça do Estado do Brasil e centro articulador de fronteiras, territórios, redes de interesses e negócios no Atlântico Sul"4, a partir de 1808 "a cidade se metamorfosearia em Corte e capital da monarquia e império português, redimensionando os elementos e o significado de sua capitalidade". ${ }^{5}$

A questão da capitalidade também é enfocada pela pesquisadora Kirsten Schultz. Para a autora, a elevação do Rio em capital imperial faz parte de um projeto de metropolização da urbe, o que, na prática, "representava uma procura para tornar a cidade não apenas 'esplendorosa', mas também ordeira, decorosa, fiel. Neste sentido, tornando-se uma corte real, a cidade tornou-se policiada." Ainda segundo Schultz, o sentido de policiar não era indissociável da ideia de seguridade pública. Torná-la metrópole, perpassava sobretudo pelo reconhecimento das "diferenças existentes entre a metrópole e a colônia de modo a poder diminuí-las" através de um projeto civilizador. ${ }^{6}$

Diferentemente de Bicalho e Schultz, a historiadora Maria de Lourdes Viana Lyra analisa esse processo de transladação da corte dentro de um projeto político mais amplo, que fora elaborado

\footnotetext{
3 DIAS, Maria Odila da Silva. “A interiorização...” Op. Cit., p. 179.

${ }^{4}$ BICALHO, Maria Fernanda. "O Rio de Janeiro no século XVIII: a transferência da capital e a construção do território centro-sul da América Portuguesa”, p. 20 (Grifos do Original). In: www.ifch.unicamp.br/ciec/revista/artigos/dossie1. pdf. (Acesso em 17 de Abril de 2012).

${ }^{5}$ Ibid., p. 20 (Grifo Original).

6 SCHULTZ, Kirsten. Versalhes Tropical: império, monarquia e a Corte Real portuguesa no Rio de Janeiro, 1808-1821. Trad. Renato Aguiar. Rio de Janeiro: Civilização Brasileira, 2008. p. 194.
} 
em fins do século XVIII pelos ilustrados luso-brasileiros. Segundo Lyra, este projeto buscava a regeneração do Estado Português, sendo o foco principal "o reforço dos laços de unidade entre Portugal e o Ultramar [...] com vistas ao desenvolvimento integrado de um novo império, unificador da grande nação portuguesa"?

É neste contexto da transferência da corte portuguesa e das mudanças políticas advindas deste processo no Rio de Janeiro, em particular, e no Império Português, em geral, que se insere a discussão deste capítulo. $\mathrm{O}$ foco de análise centra-se na compreensão da importância da Real Academia Militar como um dos locus de cultura centrais da política cultural do governo joanino no Brasil, cujo objetivo basilar era a rearticulação das bases de sustentação do Império Português. Até 1807, a complexa diplomacia portuguesa de "neutralidade" causava grandes apreensões no Velho Mundo. Depois de 1808, a agressividade da polítca joanina com seus vizinhos espanhóis e franceses também foi uma realidade. A despeito disso, não trataremos especificamente da defesa do terriório imperial nem tampouco nos aprofundaremos nos projetos de nacionalização da prática científica impulsionados pelo espaço. ${ }^{8}$ Antes, discutiremos a questão da defesa

\footnotetext{
7 LYRA, Maria de Lourdes Viana. A utopia... Op. Cit., p. 44.

8 Tema caro ao campo específico de investigação - a história da ciência -, considero o avanço que a historiografia luso-brasileira tem nas últimas duas décadas. Dentre os principais pesquisadores da área destaco os diversos trabalhos de Maria Margaret Lopes, O Brasil descobre a pesquisa científica: as ciências naturais e os museus no século XIX. 2a. ed. São Paulo: HUCITEC, UnB, 2009. LOPES, Maria Margaret; SILVA, Clarete Paranhos; FIGUEIRÔA, Sívia F. de M.; PINHEIRO, Rachel. Scientific culture and mineralogical sciences in the Luzo-Brazilian Empire-the work of João da Silva Feijó (1760-1824) in Ceará. Science in Context, v. 18, p. 201-224, 2005. BRIGOLA, João Carlos Pires. Colecções, gabinetes e museus em Portugal no século XVIII. Lisboa: Fundação Calouste Gulbenkian, 2003; VARELA, Alex Gonçalves. Atividades científicas na "Bela e Bárbara" capitania de São Paulo (1796-1823). São Paulo: Annablume, 2009. WEHLING, Arno. O fomentismo português no século XVIII: doutrinas,
} 
imperial a partir da vigência de uma Academia Militar como locus de saber indissociável de um projeto ilustrado em que a prioridade era a educação formal dos súditos reais, e que aparece-nos como um meio necessário de enfrentamento (mesmo que mais vinculado ao plano simbólico) da guerra contra Napoleão Bonaparte nos dois lados do Atlântico.

Nesse sentido, o estreito diálogo com as quatro autoras acima citadas foi de suma importância para repensarmos o papel político e cultural desempenhado pela Real Academia Militar do Rio de Janeiro, constituída no auge da crise política vivenciada pela monarquia portuguesa desde fins do século XVIII, tendo em vista a sua vinculação com a formação do novo Império português deste lado do Atlântico. Antes desse debate, no entanto, cabe-nos aqui refletirmos sobre a política educacional do Império Português antes da chegada da Corte joanina no Brasil.

\subsection{O Reformismo llustrado Português: as instituições militares de D. José I a D. João VI}

As academias que só apareceram muito tempo depois [das universidades], embora desprezassem as tolices das escolas, mas nem sempre ousaram elevar-se contra elas, porquanto há tolices que são respeitadas, atendendo a que se reportam a coisas respeitáveis.

Voltaire. $^{9}$

mecanismos, exemplificações. Revista do Instituto Histórico Geográfico Brasileiro, Rio de Janeiro, v. 316, p. 170-278, 1978.

9 VOLTAIRE. "Dicionário Filosófico" In: Voltaire. Vida e Obra. São Paulo: Editora Abril, 1978. Verbete: “Letras, gentes de Letras e Letrados”, p. 236. 
Eis a contextualização de um dos maiores filósofos do iluminismo sobre o nascimento das Academias: um espaço de saber onde se encontravam as letras, as gentes das letras ou os letrados. A despeito disso, o pensador lamentava a perseguição que ainda ocorria aos homens de letras, "os verdadeiros sábios encerrados nos seus gabinetes que não argumentaram nos bancos das universidades nem disseram as coisas pela metade nos bancos das academias". ${ }^{10}$ Para Voltaire, essa dramática situação ocorria pelo fato de eles serem julgados por "parvos", sujeitos guiados pelo fanatismo, pela inépcia e pelo espírito de vingança. ${ }^{11}$

Mesmo em tom de ironia, e conhecendo as "limitações" do meio literário ("O homem de letras paga igual tributo sem nada receber; desceu à arena por prazer, a si mesmo se condenou às feras" ${ }^{\prime 2}$ ), o filósofo francês defendia vivamente a propagação das luzes, consideradas intrínsecas ao progresso humano. No mundo de Voltaire e ao longo de todo o século XVIII as Academias desempenharam papel central no contexto da Ilustração europeia. Sendo um dos principais espaços da sociabilidade letrada, era nas Academias que os homens de letras debatiam os temas considerados caros ao progresso da nação pelas luzes da razão. No universo luso-brasileiro da primeira metade do século XVIII, os dois grandes destaques foram as Academias dos Esquecidos (1724) e a Academia dos Renascidos (1759), ambas em Salvador, à época capital da América portuguesa. Como bem conceitua a historiadora Iris Kantor, o academicismo deste período foi um importante estímulo no processo de reflexão dos laços entre Metrópole e Colônia, em que predominou a visão local da experiência

\footnotetext{
10 Ibid.

11 Ibid., p. 236-7.

12 Ibid., p. 237.
} 
colonial. ${ }^{13}$ Já sobre o sentido mais geral do fenômeno acadêmico na Europa das Luzes, a historiadora Ana Rosa Cloclet da Silva destaca a importância do pertencimento a esses espaços. O pensar os "problemas das nações no âmbito científico e técnico" em um locus institucionalizado do saber atribuía seriedade profissional a essa elite intelectual, que acabava por se tornar uma ponte profícua no diálogo entre o governo e a sociedade, já que eram a eles que as monarquias "dirigiam os governos na busca de conselhos, sugestões e pareceres."14 Para a autora, o fato de as Academias serem calcadas em um conhecimento pragmático que "proporcionava a conexão entre os diversos ramos da ciência, articuladamente ao desenvolvimento tecnológico e de ensino" elevava-as "à condição de peça fundamental de uma sociedade que se pretendia progressiva e dinâmica." ${ }^{15}$

Segundo a definição do Dicionário Moraes e Silva, a Academia representava a "Seita dos Filósofos Acadêmicos", sendo também a "Corporação de Sábios para comunicarem as suas luzes mutuamente, e promoverem as Artes, e Ciências, comunicando-as e patenteando-as ao público". Não por acaso, o status de "Escola" e "Universidade" eram vinculados a esse espaço do saber. ${ }^{16}$ Nesse sentido, a estruturação e vigência de Academias Científicas - compreendidas como locus de produção e veiculação de conhecimentos passíveis de serem aproveitados para o progresso político e econômico das nações -, simbolizava, em última instância, o alcance da máxima do pensamento iluminista, isto é, o uso público da razão.

13 KANTOR, Iris. Esquecidos e Renascidos: historiografia acadêmica luso-brasileira (1724-1759). São Paulo: HUCITEC/Centro Estudos Baianos, 2004. p. 16. 14 SILVA, Ana Rosa Cloclet da. Inventando a Nação: intelectuais ilustrados e estadistas luso-brasileiros no crepúsculo do Antigo Regime Português: 17501822. São Paulo: Hucitec: Fapesp, 2006. p. 111.

15 Ibid., p. 111.

16 Verbete "Academia”. Dicionário Moraes e Silva... Vol. 1, p. 18. 
Especificamente no universo intelectual português, as principais bases do Reformismo Ilustrado tiveram como vertente a supremacia do caráter pragmático e experimental do conhecimento. Ou seja, na prática, houve uma clara valorização do Estado Português para as Ciências Naturais. ${ }^{17}$ E neste particular nos interessa ressaltar o sentido da reforma pedagógica de vanguarda empreendida por Pombal ${ }^{18}$ especificamente no que se refere à valorização do conhecimento militar. Nesse sentido, destacamos a criação do Colégio dos Nobres (1761) e a reforma da Universidade de Coimbra (1772), cuja orientação também privilegiou as ciências naturais e a experimentação, primando pela educação dos quadros militares do Reino. Enquanto o estatuto do Colégio dos Nobres enfatizava a importância das disciplinas de Arquitetura Militar, Arquitetura Civil e Desenho, a Universidade de Coimbra criava as Faculdades de Matemática e Filosofia Natural "entre outros objectivos, para desenvolver as aptidões dos oficiais da Tropa de Linha, nomeadamente os engenheiros". ${ }^{19}$

Em relação ao caráter prático das reformas pedagógicas, foi notória a ênfase dada à Faculdade de Matemática. Segundo os estatutos, ao aprimorar o entendimento preciso da natureza, a matemática conduzia o Homem para uma atuação mais patente no processo de transformação do "grande número de artes úteis e necessárias ao Estado", o que significava regular "as épocas e medidas do tempo; as situações geográficas dos lugares; as

17 DIAS, Maria Odila da Silva. “Aspectos da Ilustração no Brasil”. Revista do Instituto Histórico Geográfico e Brasileiro. Rio de Janeiro: vol. 278, 1968; NOVAIS, Fernando. "O reformismo ilustrado luso-brasileiro: alguns aspectos". In: Aproximações: estudo de história e historiografia. São Paulo, SP: Cosac Naify, 2005.

18 VILLALTA, Luiz Carlos, Reformismo ilustrado e práticas de leitura: usos do livro na América Portuguesa, tese de doutorado, USP, 1999. p. 143.

19 SILVA, Maria Beatriz Nizza da. Cultura luso-brasileira: da reforma da universidade à independência do Brasil. Lisboa: Editorial Estampa, 1999. p. 65. 
demarcações e medidas do terreno; as manobras e derrotas dos pilotos; as operações táticas de campanha e de marinha; as construções de arquitetura naval, civil e militar”. Isto englobava precisamente o aperfeiçoamento das "máquinas, fábricas, artifícios e aparelhos que ajudam a fraqueza do homem a executar o que d’outra sorte seria impossível às suas forças". ${ }^{20}$ Para o sucesso de tal empreitada, portanto, era necessário que o Estado promovesse a formação de "matemáticos insignes", para que estes fossem empregados de forma proveitosa no Real Serviço. ${ }^{21}$ Como podemos notar, a valorização da Matemática como ciência de primeira ordem tinha um caráter político muito preciso: elevar Portugal entre as nações de maior relevo da Europa. Para tal intento valorizou-se a introdução de espaços de experimentação vinculados a esses dois cursos superiores: um observatório astronômico, um museu de história natural, um gabinete de física, um laboratório químico e um jardim botânico passaram a fazer parte da nova realidade educacional.

Se de forma mais geral a reforma pedagógica pombalina visava um maior diálogo cultural de Portugal em relação à Europa do Norte através de medidas modernizadoras que viabilizassem a laicização do conhecimento; na prática, contudo, manteve-se presente a "íntima conexão entre Universidade, Igreja e Estado", nitidamente expressada na influência eclesiástica no quadro de professores da Universidade de Coimbra. ${ }^{22}$ Isto é, para

\footnotetext{
${ }^{20}$ PORTUGAL. Carta de lei de 28 de agosto de 1772. Dispõe sobre os Estatutos da Universidade de Coimbra. Lisboa, Regia Officina Typografica,1772. [Parte referente à Faculdade de Matemática]. Vol III, Segunda Parte, p. 142-143. Disponível em: <http://scientia.artenumerica.org/estatutos_1772.html>. Acesso em: 24 mar. 2012.

21 Ibid.

22 SILVA, Ana Rosa Cloclet da. Inventando a Nação... Op. Cit., p. 78. De acordo com a autora, "A presença de clérigos em pontos-chaves das reformas do ensino
} 
além dos avanços teóricos e do suporte científico, o iluminismo português exprimia um de seus principais paradoxos: manteve a religião como base de sustentação do absolutismo monárquico. Mesmo primando pela secularização do saber - com a expulsão dos jesuítas da direção das instituições educacionais no Império Português -, as reformas pombalinas não permitiram, em última instância, a autonomização das instituições que formavam o aparelho do Estado. ${ }^{23}$ Como bem definiu Munteal e Dahás, "A obra da ciência da natureza, de certa forma, se fazia dentro e fora dos Gabinetes, Museus e dos Laboratórios de História Natural", uma vez que os "caminhos da ilustração luso-brasileira seguiam os passos da experiência aliada à ação". ${ }^{24}$

A execução desse projeto reformista estendeu-se também à Colônia e ficou sob a responsabilidade dos vice-reis Marquês do Lavradio (1769-1799), Luís de Vasconcelos (1779-1790) e também dos governadores do Grão-Pará e do Maranhão. Estes recebiam constantemente pedidos de estudo de exemplares da flora brasileira, assim como de produtos interessantes e comerciáveis para alavancar o processo de industrialização do Reino. ${ }^{25}$ Como

\footnotetext{
- como era o caso da Universidade e da Real Mesa Censória - a visão elitista da educação e da própria estrutura administrativa do Estado, e, por fim, o objetivo de submeter à hegemonia deste todas as ordens de coisas estabelecidas, apareciam como expressão particular de paradoxos que, em última instância, estiveram no próprio cerne do movimento Iluminista." (Idem).

23 FILHO, Oswaldo Munteal Filho; DAHÁS, Nashla. "Acadêmicos e letrados na crise do Antigo Regime luso-brasileiro - Século XVIII". Revista Intellectus. Ano 05. Vol. I. 2006, p. 3. Disponível em: <www2.uerj.br/ intellectus>. Acesso em: 23 abr. 2012. De acordo com os autores, "O Estado burocrático deve ser compreendido como um processo tendencial à autonomização relativamente aos estamentos eclesiásticos e nobiliárquicos no contexto da secularização geral da sociedade.".

24 Ibid., p. 8.

25 DOMINGUES, ÂNGELA. "Notícias do Brasil Colonial: a imprensa científica e política a serviço das elites (Portugal, Brasil e Inglaterra)". In: Varia História. Belo Horizonte. Vol. 22. n. 35., p. 150-174, 2006.
} 
já destacamos em trabalho anterior, a partir de 1770 tal política educacional da Coroa também incentivou os estudantes da elite rural brasileira a aperfeiçoarem seus conhecimentos em Coimbra, o que, na prática, significava a condução de uma política cultural estatal de fomento à ciência, sobretudo no campo das ciências naturais. ${ }^{26}$ Deste lado do Atlântico, durante os governos de D. José I e Da ${ }^{a}$. Maria I, floresceriam na Colônia dois estabelecimentos de destaque. Se entre os anos de 1772 e 1779 vigorou a Academia Científica do Rio de Janeiro - voltada para o estudo das ciências naturais, física, química, agricultura, medicina cirúrgica e farmácia $^{27}$-, em 1798 era a vez da fundação do Seminário de Olinda. Sob a direção do bispo d. José Joaquim Azeredo Coutinho, sócio da Academia Real das Ciências de Lisboa, o currículo do Seminário priorizava inteiramente a botânica e a mineralogia. ${ }^{28} \mathrm{Em}$ ambos os espaços, valorizou-se a atualização do ensino.

No período josefino o centro das reformas educacionais esteve atrelado primordialmente à Universidade de Coimbra. Já durante o governo de $\mathrm{D}^{\mathrm{a}}$. Maria I - apesar da valorização

\footnotetext{
${ }^{26}$ MEIRELLES, Juliana. Imprensa e Poder... Op. Cit., p. 60. Para detalhes acerca da política pombalina e mariana para a Colônia ver: DIAS, Maria Odila da Silva. “Aspectos da Ilustração..” Op. Cit.; VARELA, Alex. Gonçalves. Atividades Científicas ... Op. Cit.

27 MARQUES. Vera Regina Beltrão. "Escola de homens de ciências: a Academia Científica do Rio de Janeiro, 1772-1779”. In: Educar. Curitiba: Editora UFPR, n. 25. p. 39-57. 2005. Entre os anos de 1780 e 1785 a Academia esteve fechada sendo reaberta, apenas, em 1786 pelo vice-rei Luis de Vasconcelos e Sousa. Denominada de Sociedade Literária do Rio de Janeiro, o espaço foi liderado pelo poeta Manoel Inácio da Silva Alvarenga. Em 1794, seus membros foram denunciados e acabaram, por fim, presos. Este importante episódio político ficou conhecido na historiografia como a Devassa do Rio de Janeiro. Sobre as academias no Brasil na segunda metade do século XVIII, ver: SILVA, Maria Beatriz Nizza da. Cultura luso-brasileira... Op. Cit., p. 27-33. Para a importância das academias no Brasil na primeira metade do século XVIII, ver o trabalho clássico da historiadora Iris Kantor. KANTOR, Iris. Esquecidos e Renascidos: Op. Cit.

28 LYRA, Maria de Lourdes Viana. A utopia... Op. Cit.
} 
destinada ao espaço ${ }^{29}$-, a rainha voltou sua política educacional prioritariamente para a estruturação e funcionamento da Academia de Ciências de Lisboa, a partir de 1779; espaço eleito pelos ilustrados como o locus de saber onde a aliança entre ciência e política se faria presente. Para Ana Rosa Cloclet da Silva, tal Academia foi a instância articuladora da ilustração portuguesa, agora fortalecida nas suas tendências pragmática e cientificista. Nas palavras da autora,

Na produção intelectual da Academia iam beber os homens de poder - muitos deles, aliás, sócios da agremiação - orientando por esta literatura memorialista suas políticas fomentistas para o Reino e o Ultramar. Definia-se, assim, uma peculiar associação entre saber e poder, que daria o tom do reformismo do final do Setecentos. ${ }^{30}$

A Academia era composta por homens da elite ilustrada luso-brasileira, sendo estes divididos entre sócios e correspondentes. Os primeiros estavam distribuídos em três classes: Ciências da Observação, Ciências de Cálculo e Belas Letras; já os segundos, na maioria das vezes, eram naturais do Brasil que viviam na Colônia. ${ }^{31}$ Ambos, no entanto, produziam suas

\footnotetext{
29 Segundo Ana Rosa Cloclet da Silva, a partir de 1777 a rainha encaminhou reformas importantes para a Universidade visando o rompimento do isolamento cultural do Reino. Entre as medidas de destaque a autora cita: tornar pública a Biblioteca da Universidade; reorganizar o corpo das disciplinas segundo uma visão humanístico-científica bem como à organização de um Corpo de Legislação portuguesa antiga e moderna, que tinha como finalidade a efetivação da criação da cadeira de Direito Pátrio, em substituição ao Direito Romano. Para Silva, estas mudanças formam o sentido "da orientação mental e política do reformismo luso-brasileiro pós-pombalino.” SILVA, Ana Rosa Cloclet da. Inventando a Nação... Op. Cit., p. 108-109.

${ }^{30}$ Ibid., p. 113 (Grifos do Original).

31 "Quando a Academia passou a ter uma única publicação para as memórias de todas as classes (Ciências Naturais, Matemáticas e Belas Letras) o que ocorreu
} 
memórias, que eram lidas e discutidas nas sessões d'Academia com o intuito de avançar o conhecimento científico acerca do Império Português. ${ }^{32}$ Nizza da Silva ressalta que, independentes do tema tratado, as memórias tinham o propósito de "aperfeiçoar a sabedoria popular e tradicional fazendo experiências e aplicando o saber científico na exploração tecnológica de alguns produtos naturais". ${ }^{33}$

De fato, a política reformista da Coroa no período mariano esteve muito preocupada com os espaços de educação e se fez sentir nos dois lados do Atlântico. Sobretudo durante o último quartel do século XVIII, algumas instituições pedagógicas de caráter mais geral tiveram destaque, tais como a criação da Aula de Debuxo e Desenho, no Porto (1779), a Real Casa Pia de Lisboa, no Colégio de São Jorge (1782). Especificamente no que concerne ao ensino militar ou das ciências da guerra, alguns espaços ganhariam relevância no Império Português. Em Portugal, em 1779, era criada a Aula de Engenharia e Estudos Matemáticos da Academia Real da Marinha, cujo objetivo era aprimorar a formação dos oficiais da armada em ciências matemáticas e astronômicas. Em 1782, institucionalizava-se a Academia Real dos Guardas-Marinha, destinada "à formação dos oficiais 'hábeis e instruídos para a Armada Real"' ${ }^{34}$ Em 1790, surgia a Academia de Fortificação,

em 1815 com o aparecimento da História e Memórias, encontramos aí a lista dos sócios correspondentes. Aqueles que se encontravam no Brasil totalizavam 14, desigualmente distribuídos pelo território brasileiro: 7 no Rio de Janeiro (então sede da Corte), 3 na Baía, e 1 em cada uma das capitanias, São Paulo, Mato Grosso, Ceará e Pernambuco". SILVA, Maria Beatriz Nizza da. Cultura luso-brasileira... Op.Cit., p. 340.

32 CARDOSO, José Luís. Domingos Vandelli. Memórias de História Natural. Porto: Porto Editora, 2003.

33 SILVA, Maria Beatriz Nizza da. Cultura luso-brasileira...Op. Cit., p. 40.

34 DUARTE, Elaine. "Academia Real dos Guardas-Marinha”. In: NEVES, Lúcia Bastos Pereira das; VAINFAS, Ronaldo. Dicionário do Brasil Joanino. Rio de Janeiro: Objetiva, 2008. p. 22. 
Artilharia e Desenho. Segundo João Ferreira Campos, este espaço proporcionou ao oficialato português a instrução suficiente para "corresponder na parte militar às funções a que se destinavam". ${ }^{35}$ Em 1796, nasciam os estatutos d'Academia Real de Guardas Marinhos, que elevava a arte militar entre as mais úteis e necessárias ao Estado. Quanto às suas funções destacavam-se as manobras e percursos de pilotagem, operações práticas de campanha e da marinha, além da arquitetura naval e militar. ${ }^{36}$ Três anos antes, porém, a congênere americana da Real Academia da Artilharia, Fortificação e Desenho de Lisboa passava a existir no Rio de Janeiro, para "instrução das milícias e dos soldados do Rio". ${ }^{37}$

Ao analisar a relevância dos engenheiros militares e arquitetos para a Coroa portuguesa durante toda a colonização (1500 e 1822), a pesquisadora Beatriz Bueno destaca a importância dada ao desenho que, segunda ela, certamente era feito em mais de uma via: uma que se destinava aos conselhos ministeriais, e outra que seguia junto aos profissionais para melhor orientar o trabalho dos mestres de ofício. "O investimento na ciência do desenho (i, e., ciência do projeto) no âmbito das Aulas de Arquitetura Militar era, portanto, fundamental, tendo-se constituído num dos mais importantes instrumentos de uma ação política [da Coroa portuguesa]", analisa a autora. ${ }^{38}$

Datado de 17 de Dezembro de 1792, os estatutos da Real Academia da Artilharia, Fortificação e Desenho do Rio de Janeiro,

\footnotetext{
35 CAMPOS, João Ferreira. Apontamentos relativos à instrução pública, Lisboa, 1858, p. 12. Apud MARQUES, Fernando. Pereira. Exército e Sociedade em Portugal no declínio do Antigo Regime e advento do liberalismo. Lisboa: A regra do jogo, 1981, p. 79.

36 DUARTE, Elaine. “Academia Real dos Guardas-Marinha”... Op. Cit., p. 23.

${ }^{37}$ MARQUES, Fernando Pereira. Exército e Sociedade em Portugal... Op. Cit., p. 79.

38 BUENO, Beatriz Piccolotto Siqueira. Desenho e Desígnio: o Brasil dos engenheiros militares (1500-1822). São Paulo: EDUSP/fapesp, 2011. p. 137-138 (Grifos do Original).
} 
já enunciavam as principais bases e diretrizes do estabelecimento. De autoria do vice-rei Conde de Rezende, o documento proclamava ser a instrução dos discípulos o objetivo do novo locus de saber. Sobre a estrutura do curso de Matemática, dividido em seis anos, Rezende esclarecia:

Nos primeiros anos se ensinará a teoria de Belidor. No terceiro ano se ensinará a teoria de Artilharia, das Minas e Contra-minas, e a sua aplicação ao ataque e defensa das Praças, o que se fará pela doutrina de Sam Remy, na conformidade do Plano de Regimentos de Artilharia ou (o que é mesmo, ) pela Artilharia de le Blond. [...] [a] instrução dos ditos cinco anos será dada pelo Lente do Regimento de Artilharia desta cidade. ${ }^{39}$

Ao circunscrever o ataque e a defesa como linhas mestras do ensino da nova Academia, o vice-rei expunha a principal vinculação teórica do estabelecimento: a inspiração em Belidor, Sam Remy e le Blond, matemáticos europeus de grande destaque e influência da época, ${ }^{40}$ demonstrava o vivo interesse da Coroa em estimular o conhecimento científico de ponta tendo como finalidade última a prática e a experimentação. Esse foco era tão valorizado que o $4^{\circ}$ item do estatuto denominava-se Dos exercícios práticos. Sobre o currículo do terceiro ano, o documento enfatizava: "[Neste ano] se ensinará o manejo das bocas de fogo que se usam na Artilharia; fará construir bateria e exercitará os

\footnotetext{
39 Estatutos da Real Academia da Artilharia, Fortificação e Desenho, da Cidade do Rio de Janeiro. ANRJ. Coleção de Memórias, vol.12. Apud PIRASSINUNGA, Adailton Sampaio. O Ensino Militar no Brasil. Rio de Janeiro: Biblioteca do Exército, 1958. p. 89.

40 HUTTON, Charles. A Philosophical and Mathematical Dictionary Containing Memoirs of the Lives and Writings of the Most Eminent Authors.1815. Vol. 1., p. 147. Verbete "ARTILLERY". Disponível em: <http://books.google.com.br>. Acessado em: 05 maio 2012).
} 
discípulos em tudo o que for suscetível de praticar-se”. Já em relação às atividades do quinto ano, advertia que "se formará sobre o terreno alguma obra de fortificação da Campanha, assim como ensinará a Castrametação e tudo o quanto puder praticar-se relativamente às matérias que tiver tratado".41

Os estatutos também realçavam os critérios de admissão dos discípulos. Aqueles que desejassem se aprimorar no Curso Militar deveriam ter o conhecimento das "quatro espécies de Aritmética Ordinária", além de demonstrar que "entendem suficientemente a Língua Francesa”, já que as obras tratadas no curso, muito provavelmente, seriam estudadas nesta língua. Ademais, os que quisessem dar continuidade aos estudos - e seguirem a profissão de Engenheiro - seriam "obrigados a mostrar por exames que sabem a doutrina correspondente ao primeiro ano (ao menos) e que tenham uma constituição robusta, sem defeito algum na vista ou tremura nas mãos." ${ }^{42}$ Já os militares que se destinassem somente ao serviço de Infantaria e Cavalaria deveriam concluir os três primeiros anos do curso, tendo sido aprovados até o décimo livro do curso de Belidor. ${ }^{43} \mathrm{O}$ documento ainda informava aos interessados a estrutura do calendário letivo: as aulas ocorriam as segundas, quartas e sextas-feiras por "espaços de duas horas pelo que respeita as lições especulativas". Depois das aulas teóricas, os Lentes exercitavam seus discípulos "por espaço de uma hora e um quarto no desenho da doutrina correspondente àquele ano". As férias ocorriam de 21 de Dezembro a 06 de Janeiro, além dos descansos previstos durante a Semana Santa, Semana da Páscoa; e Festa do Espírito Santo. ${ }^{44}$ Aqui, uma

${ }^{41}$ Estatutos da Real Academia da Artilharia..., Op. Cit., p. 91.

${ }^{42}$ Ibid., p. 93.

${ }^{43}$ Ibid.

44 Ibid. 
ressalva: consideramos os estatutos uma importante representação do espaço que se desejava constituído deste lado do Atlântico pela Coroa, não sendo lido aqui como uma dimensão do real, que correspondia ao funcionamento cotidiano da Academia.

Ainda segundo os estatutos, a organização interna da Academia ficava sob a responsabilidade do secretário, que tinha "a obrigação de fazer as matrículas e assentos e de passar as Certidões do costume, como também de cuidar do arranjo e ordem da Biblioteca Militar, e na conservação da Planta e Mapas do Depósito." Esse locus também contava com um Arquivo onde toda a documentação era conservada: ali era possível encontrar informações detalhadas sobre o desempenho acadêmico dos alunos, incluindo seus desenhos, como também "todas as Plantas, Cartas, e projetos militares que devem resultar das diligências de que forem incumbidos os Oficiais Engenheiros." ${ }^{45}$ Aqui fazemos uma digressão sobre a valorização dos arquivos por parte das monarquias absolutistas. Como nos mostra o historiador espanhol Fernando Bouza, a alta consideração dos reis à preservação e amparo às fontes manuscritas, tendo estas faces públicas ou privadas, fez parte de uma importante estratégia política das Monarquias Absolutistas durante o processo de formação do Estado Moderno. ${ }^{46}$

Neste sentido, particularmente, a constituição e consolidação do Arquivo como o lugar da memória oficial ganha relevância e justifica toda a preocupação da Coroa em constituí-lo como parte fundamental dos locus de cultura e saber, uma vez que é nesse espaço que se dava a recolha de "escrituras públicas,

${ }^{45}$ Ibid., p. 95.

46 Para uma discussão pormenorizada sobre a importância dos manuscritos para o Antigo Regime Ibérico, ver: BOUZA, Fernando. Corre Manuscrito - uma historia cultural Del siglo de Oro. Madri: Marcial Pons. 2001. 
diplomas e outros monumentos por escrito." ${ }^{47}$ Por essa ótica, compreendemos a premente iniciativa real em instituir um Arquivo Central no Brasil, passado exatamente um mês de sua chegada ao Rio de Janeiro. Datado de 07 de abril de 1808, o documento instituía o Arquivo com o fito de

[...] nele se reunirem e conservarem todos os mapas e cartas, tanto das costas como do interior do Brasil, e também de todos os domínios ultramarinos portugueses, mandando-se-lhe agregar engenheiros e desenhadores, os quais examinariam as cartas das diversas capitânias e territórios do Brasil e exporiam o seu juízo sobre a autenticidade e exatidão das mesmas ou sobre a necessidade de serem corrigidas ou levantadas de novo. ${ }^{48}$

A correspondência dos Governadores do Reino para D. João, em fevereiro de 1812, é também muito reveladora. Ao avisar o Príncipe Regente sobre um "considerável furto de importantes papéis", ocorrido no Arquivo Real - a Torre do Tombo - em Lisboa, os governantes alertavam-no sobre as providências tomadas a "fim de se descobrir os delinquentes de um crime tão grave, e eles serem devidamente punidos". Iniciava-se, portanto, uma devassa com a ciência e o apoio do Corregedor do Crime da Corte da Casa da Suplicação e também da Intendência Geral da Polícia. Especificamente sobre a alta consideração da Torre do Tombo, justificavam a atitude por se tratar de um "Arquivo tão respeitável, como o em que se guardam os papéis mais recomendáveis, e preciosos e que por isso mereceu sempre a particular proteção, cuidado e vigilância dos Senhores Reis destes Reinos”. Tais

47 Verbete "Archivo". Dicionário Moraes e Silva... Vol.1, p. 173.

48 Decreto de 07 de abril de 1808. Disponível em: <http://www.planalto.gov.br/ ccivil_03/revista/Rev_23/dec_7abril.htm>. Acesso em: 02 jun. 2012. 
providências ainda eram explicadas com o fito de "remediar os males passados e obviar os [males] futuros". ${ }^{49}$ Infelizmente, a correspondência não nos dá maiores pistas nem sobre a natureza desses papéis, nem sobre o teor das informações.

Esse parêntese sobre a valorização da Coroa aos Arquivos nos ajuda a refletir também sobre suas escolhas políticas. No período colonial, a opção da monarquia portuguesa constituir deste lado do Atlântico uma Academia Científica com viés militar demonstra a viva preocupação não apenas com a educação científica de seus súditos de além-mar, mas também com a valorização da segurança da capital colonial. ${ }^{50}$ Segundo Maria Fernanda Bicalho, desde o século XVI a cidade fora alvo de "um intenso assédio por parte dos corsários e contrabanditas", o que reiterava a constante preocupação e iniciativa real em "encerrá-la sob fortalezas, trincheiras e muralhas" através da ação de funcionários e engenheiros militares ${ }^{51}$, cuja função, segundo Maria Beatriz Nizza da Silva, se concentrava principalmente no levantamento de plantas urbanas e no desenho de mapas das várias capitanias. ${ }^{52}$

Essa estratégia fazia parte do projeto reformista da Coroa Portuguesa, cuja política cultural, além de ter a pretensão de formar súditos fiéis e militarmente preparados para a defesa da Colônia, mantinha a continuidade do processo de fomento educacional de viés científico, agora com um locus de cultura destinado exclusivamente a tais aprendizados e reflexões. Em 1795, houve

\footnotetext{
${ }^{49}$ ANTT. Ministério do Reino. Livro 315. Correspondência n. ${ }^{\circ}$ 140, datada de 11/02/1812.

${ }^{50} \mathrm{O}$ historiador português Rogério Fernandes faz uma importante discussão sobre as diferentes vertentes do Iluminismo Português em relação à educação científica. FERNANDES, Rogério. Os caminhos do ABC: Sociedade Portuguesa e o Ensino das Primeiras Letras. Porto: Porto Editora, 1994. p. 122-165.

${ }^{51}$ BICALHO. Maria Fernanda. “O Rio de Janeiro no século XVIII...., Op. Cit., p. 8.

52 SILVA, Maria Beatriz Nizza da. Cultura luso-brasileira:... Op. Cit., p. 73.
} 
um desdobramento da Academia de Artilharia, que passou a ser denominada de "Academia de Aritmitética, Geometria Prática, Fortificação, Desenho e Língua Francesa”. O novo espaço seria voltado exclusivamente para o preparo dos oficiais da arma de Infantaria. De acordo com Adailton Pirassinunga, esta mudança ocorreu pela não adaptação dos alunos àquele meio, que tinham dificuldade com o aspecto abstrato da disciplina de Geometria e Fortificação. "[Foi] diminuto o proveito colhido pelos mesmos [alunos] que se escusavam de fazer a aplicação conveniente, seja pelos assuntos tratados na referida aula serem mais próprios aos oficiais de Artilharia, seja pelo pouco tempo que lhes restava, satisfazendo às obrigações do serviço diário do regimento. ${ }^{53}$ Sob as ordens do vice-rei Conde de Rezende, portanto, em novembro de 1795 era enviado para o Reino um novo estatuto, para aprovação real. Com o devido consentimento, o espaço funcionou até 1811, quando foi definitivamente substituído pela Real Academia Militar, instituição que discutiremos no próximo item. ${ }^{54}$ Como notamos, desde fins do século XVIII a Coroa buscava a institucionalização de um espaço militar no Rio de Janeiro.

Para além das questões de política de Estado, o cenário internacional desde fins do século XVIII também aparecia como um horizonte de grande instabilidade. Com a independência dos EUA (1776) e o início da Revolução Francesa (1789), a constante iminência de guerra a Portugal e a desagregação do sistema colonial era uma realidade. ${ }^{55}$ A crise política instaurava-se no coração do Império Português e tinha dimensões transatlânticas. Da Europa, os franceses eram os inimigos a serem evitados a todo

\footnotetext{
53 PIRASSINUNGA, Adailton Sampaio. O Ensino Militar ... Op. Cit., p. 43.

54 Ibid., p. 44-9.A íntegra do novo estatuto foi publicada por Adailton Sampaio. ${ }^{55}$ NOVAIS, Fernando. Portugal e Brasil... Op. Cit.
} 
custo; da América os próprios colonizados. No Brasil, a emergência da Inconfidência Mineira (1789) e da Conjuração Baiana (1798) já apontava para um novo horizonte de liberdade. A despeito disso, a sangrenta revolta de escravos no Haiti (1791), assim como o crescente processo de independência da América Espanhola apareciam como ameaças graves à ordem do Antigo Regime.

De acordo com o historiador István Jancsó, entre os anos de 1789 a 1801 as autoridades metropolitanas se viram diante de problemas políticos sem precedentes. Para o historiador, as razões das sedições na Colônia revelam a emergência de uma cultura política alternativa.

Ao contrário da cultura política do absolutismo ilustrado, circunscrita às elites e rigorosamente excludente, a nova que emerge tem por portadores os letrados, mas ao lado destes, estão agora, também, homens de ínfima condição no dizer da época, dotados, contudo, de visão política, qualquer que seja seu nível cultural. ${ }^{56}$

É dentro desse horizonte de instabilidade política que a instauração da Real Academia da Artilharia, Fortificação e Desenho ganha um sentido ainda mais amplo: a mudança do paradigma político dentro da Colônia justificava, por outros vieses, a sua existência. Com a transferência da monarquia portuguesa para o Brasil, sendo o Rio de Janeiro agora a sede da Coroa ou a capital imperial, a vigência de uma estrutura militar mais sofisticada justificava-se ainda mais fortemente. Afinal de contas, tratava-se da segurança da Família Real e sua corte. O universo militar na

${ }^{56}$ JANCSÓ. István. "A sedução da liberdade: cotidiano e contestação política no final do século XVIII.” In: SOUZA, Laura de Melo e (Org.), Cotidiano... Op. Cit., p. 398. 
nova capital passava a apresentar algumas (des)continuidades em relação à época em que ainda era sede do vice-reinado. A defesa aparecia como assunto de primeira grandeza.

Mormente entre os anos de 1808 e 1815 as guerras napoleônicas eram um fato deveras ameaçador para toda a Europa; sendo Portugal invadido três vezes pelas tropas francesas. ${ }^{57}$ Ou seja, desde 29 de novembro de 1807 quando a comitiva real iniciava a travessia atlântica, os súditos portugueses que ficaram à margem do Tejo viviam sob a dura realidade da guerra contra a França. Em 1808 a invasão napoleônica no Reino não apenas marcava a superioridade política e militar de Bonaparte no Continente como também atestava o abandono do Príncipe Regente, que deixava a pátria sob a direção de uma junta de governadores. ${ }^{58}$

57 Entre 1807 e 1813, Portugal esteve envolvido na designada Guerra Peninsular, resultado das sucessivas invasões que as tropas francesas infligiram à Península Ibérica.Portugal foi alvo de três invasões: em Novembro de 1807 (início da primeira invasão comandada pelo general Junot), em Março de 1809 (segunda invasão comandada pelo general Soult), e em Junho de 1810 (terceira invasão comandada pelo marechal Massena). Para mais informações, acessar: <http:// antt.dgarq.gov.pt/exposicoes-virtuais/eventos-em-documentos/invasoes-francesas/>. Acesso em: 13 jun. 2012.

58 Com a vinda da monarquia para o Brasil, Portugal ficou sob o comando político de um Conselho de Governadores, composto por nobres e magistrados da estreita confiança de D. João, que acreditava serem eles todos fervorosos combatentes das idéias francesas. De acordo com o historiador Joaquim Veríssimo Serrão, "Eram eles o Marquês de Abrantes, D. Francisco da Cunha de Meneses, tenente-general do exército, o principal Castro da Igreja patriarcal que servia de regedor das Justiças, Pedro de Melo Breyer. Que detinha a presidência do Real Erário, e o tenente general D. Francisco Xavier de Noronha, presidente da Mesa de Consciência e Ordens. [...] Para as secretarias de Estado foram escolhidos o conde de São Paio, que mais tarde abraçou o partido francês, e D. Miguel Pereira Forjaz, que na pasta da Guerra prestou ao país, no período das invasões os mais altos serviços. Do conselho fazia ainda parte, nas funções de secretário, o doutor João Antonio Sales de Mendonça, desembargador do Paço e procurador da Coroa." SERRÃO, Joaquim Veríssimo. História de Portugal: a instauração do liberalismo (1807-1832). 3a ed. Vol. VII. Lisboa: Ed. Verbo, p. 20. 
Neste período, a defesa do território nacional português contou com o apoio veemente dos governadores do Reino, homens de Estado de estrita confiança do Regente, como também e, sobretudo, com a maciça adesão do exército luso-britânico e da sociedade portuguesa na luta em prol da independência política e da regeneração nacional. Enquanto isso, em 07 de março do dito ano a realeza e sua comitiva chegavam sãos e salvos à América, sendo recebidos com vivas, fogos e tiros de canhões no Rio de Janeiro. Fato tão eminente para a história do Brasil, no entanto, não excluía a dívida do Príncipe Regente com os seus súditos que ficaram no Reino e sofriam as agrúrias da fome, do medo, da violência e da iminência da morte. Muito pelo contário: aumentava-a. Tal escolha política - administrar o Império da América -, marcava uma rearticulação das bases de sustentação de seu poder sob uma perspectiva transatlântica; o que justificava a declaração de guerra ao Imperador francês e seus vassalos tão logo a Coroa estivesse a salvo, o que realmente ocorreu em $10 \mathrm{de}$ junho de 1808. Do Rio de Janeiro, D. João ordenava que "por mar, e por terra se lhes façam todas as possíveis hostilidades" contra a Nação Francesa. ${ }^{59}$

Nesta posição, o Príncipe Regente deixava claro a sua ciência de que a regeneração do Estado Português perpassava, necessariamente, pelo enfrentamento de uma guerra contra Napoleão pelas duas margens do Atlântico. Se em Portugal o foco da atuação política e militar visava à expulsão dos inimigos do território lusitano, o que significaria a salvação e independência do Reino; no Brasil era mister construir uma estratégia eficiente de defesa de tão vasto continente e parte fundamental do Império, como

59 "Declaração de guerra aos franceses". ANRJ. Tribunal do Desembargo do PaçoCx. 231, pct. 1. Doc. 1. 
apregoava d. Rodrigo de Souza Coutinho desde 1803, para que a monarquia portuguesa se mantivesse a salvo. ${ }^{60}$

Para tanto, a estruturação de uma ampla base beligerante deste lado do Atlântico era intrínseca ao funcionamento de diversas instituições reais. Aqui, particularmente, nos interessa referir a três importantes instituições que passaram a vigorar no Rio de Janeiro: a Impressão Régia, a Intendência Geral da Polícia e a própria Real Academia Militar, conforme discutiremos adiante. Como bem circunscreveu a historiadora Maria de Fátima S. Gouvêa, "Munições militares e literárias eram instrumentos básicos em uma corte europeizada, cabeça de uma totalidade política e territorial muito mais ampla, como a do Império português, então reconstituído como Império luso-brasileiro". ${ }^{61}$

Primeiramente, destacamos a importância da fundação da Impressão Régia em 1808. De fato, entre 1808 e 1815 os súditos da monarquia portuguesa acompanharam a rearticulação do seu discurso político pelos prelos reais: nesses anos não só vigorou um importante "ciclo napoleônico"62 com uma grande gama de

${ }^{60}$ CHACON, Valmireh. O Conde de Linhares. Brasília: Theseaurus, 2008. p. 12. A preocupação com a defesa da Colônia e a importância das aulas de arquitura militar em todo o território foi patente desde o final do século XVII, quando a Coroa lusitana institucionalizou estes espaços nos principais centros urbanos, a saber: Salvador (1696), Rio de Janeiro (1698-1699), São Luís do Maranhão (1699), Recife (1701) e Belém (1758). Para uma análise mais precisa, ver: BUENO. Beatriz. Desenho e Designio... Op. Cit., p. 138-235.

${ }^{61}$ GOUVÊA, Maria de Fátima Silva. "As bases institucionais da construção da unidade. Dos poderes do Rio de Janeiro joanino: administração e governabilidade no Império luso-brasileiro”. In: JANCSÓ, István. Independência: história e historiografia. São Paulo: Hucitec: Fapesp, 2005. p. 726 (Grifo do Original).

${ }^{62}$ A historiadora Maria Beatriz Nizza da Silva denominou de "Ciclo Napoleônico”, a ampla produção de obras saídas da Impressão Régia entre os anos beligerantes (1808 a 1815). No capítulo de mesmo título, a historiadora fez um minucioso estudo sobre a produção, entrada e circulação dos folhetos napoleônicos no Brasil, através de um sistemático levantamento dos principais títulos produzidos e impressos pela Impressão Régia. Para além dessa circunscrição das 
obras contra o imperador da França, como também o discurso transatlântico da Gazeta do Rio de Janeiro foi pautado como arma de guerra. ${ }^{63}$

$\mathrm{Na}$ correspondência de maio de 1808, supracitada na epígrafe deste capítulo, o intento de $\mathrm{D}$. João não deixava margem a dúvidas. Segundo o Regente, "A moralidade das nações é a primeira [base] hoje da sua felicidade" e dela dependia "a Prosperidade, e a Grandeza do Estado". ${ }^{64}$ Para recuperar tão nobre desígnio, no entanto, o monarca conclamava os bispos, párocos e professores públicos a adentrarem nesta luta. Assim, então, pronunciava:

[...] concorram todos no limite do exercício de suas funções, a imprimirem aos Povos os melhores princípios de moral, o maior respeito à Minha Autoridade Real, aos Magistrados, e Delegados da mesma, e aquele amor da Pátria que mais que tudo segura a felicidade pública, e a estabilidade do Estado e pode mesmo revertê-la, quando perdida, como as últimas experiências acabam de mostrá-lo. ${ }^{65}$

O amor à Pátria e o respeito à autoridade real - seja na própria figura do Príncipe Regente no Rio de Janeiro, ou através de seus representes políticos no Reino -, perpassava, obrigatoriamente, por um processo de educação da sociedade luso-brasileira.

obras, Nizza da Silva também analisou as características e ressonâncias desses papéis na sociedade fluminense, comentando o conteúdo de alguns folhetos da época. SILVA, Maria Beatriz Nizza. Cultura e sociedade no Rio de Janeiro (18081821). São Paulo: Cia Nacional, 1978. p. 215-224.

${ }^{63}$ MEIRELLES, Juliana. Imprensa e poder... Op. Cit., p. 91-129. A historiadora Raquel Stoiani também faz uma análise pormenorizada sobre o uso da Impressão Régia como arma de guerra contra os franceses. STOIANI, Raquel. Napoleão visto... Op. Cit., p. 106-164.

${ }^{64}$ ANTT. Série Ministério do Reino. Registro de Ordens expedidas pelo Príncipe Regente aos governadores do Reino. Livro 380, p. 5.

${ }^{65}$ Ibid., p. 6. 
Como esclarece o pesquisador português Rogério Fernandes, "a ideia de educabilidade universal não desembocava na adoção de formas educacionais idênticas para todos os homens". Tal concepção pedagógica, segundo Fernandes, teve implicações de relevância: se por um lado foi aceita pelo Antigo Regime como expressão da "essência humana", por outro abriu caminho para a prática da "orientação profissional". 66

No que concerne especificamente às possessões ultramarinas, o historiador Diogo Ramada Curto chama a atenção para os espaços públicos nos seus cruzamentos com a cultura escrita $\mathrm{e}$ formas próprias de sociabilidade na colônia, como cerimônias da monarquia nas procissões, das representações teatrais ou dos sermões nas academias literárias e científicas. Em um âmbito mais amplo, Curto mostra que até fins do século XVIII, a "comparação com a América espanhola, onde é maior o número de instituições políticas e culturais, seguere que todo e qualquer esforço de concretização de uma política cultural era acompanhado de medidas centralizadoras, com as quais se reduzia o espaço para a diversidade local". ${ }^{67}$ Tal situação, segundo Curto, acarretou um ambiente educacional deveras peculiar no Brasil. O fato de os círculos privados estarem situados no mesmo patamar que a casa e a vida doméstica proporcionou que a sociedade colonial desenvolvesse maneiras próprias de educação, muito vinculada à configuração de espaços públicos aqui vigentes.

A despeito da importância de se delimitar as diversas formas de sociabilidade na segunda metade do século XVIII no Brasil, como bem demonstrou Curto, reiteramos que nosso objetivo

${ }^{66}$ FERNANDES, Rogério. Os Caminhos do ABC: Op. Cit, p. 124.

${ }^{67}$ CURTO, Diogo Ramada. Cultura Imperial e Projetos Coloniais (séculos XV a XVIII). Campinas, SP: Editora da Unicamp, 2009. p. 440. 
aqui é discutir as transformaçoes educacionais e práticas culturais vigentes nos locus de cultura selecionados neste trabalho, que regeram a Corte no raiar do Oitocentos a partir da chegada da Família Real.

Com a governabilidade monárquica sediada deste lado do Atlântico, tornava-se imperativa a reestruturação governamental na nova sede do Império. Se a ordem de transformações da antiga capital colonial dar-se-ia em diversos níveis - com destaque para os universos socioeconômico, político e cultural ${ }^{68}$-, o impacto da convivência cotidiana da sociedade fluminense com as figuras da Família Real e sua corte pelas ruas do Rio de Janeiro imporia à Coroa uma nova compreensão da realidade que se delineava na história do Império Português. Como bem balizou a historiadora Maria de Fátima Gouvêa, com tais mudanças "buscava-se estabelecer condições para o pleno exercício da soberania portuguesa a partir da cidade do Rio de Janeiro, garantindo não apenas a sobrevivência da Coroa, mas também a do próprio Império". ${ }^{69}$

Segundo a autora, na prática tal situação situava a governabilidade da nova capital intrinsecamente associada aos órgãos encarregados da gestão do Império. ${ }^{70}$ Nesse sentido, para além da Impressão Régia, há que se destacar a importância da Intendência da Polícia, do Rio de Janeiro que, sob a direção de Paulo Fernandes Viana também foi responsável pela obtenção do sucesso da guerra travada contra Napoleão Bonaparte. Como asseverou Lúcia das Neves, "em função do temor quanto à infiltração de

\footnotetext{
${ }^{68}$ Sobre as principais transformações ocorridas no Rio de Janeiro no período joanino, ver: MATTOS, Ilmar R. de. In: NEVES, Lúcia Bastos Pereira das; VAINFAS, Ronaldo. Dicionário do Brasil joanino... Op. Cit., p. 393-397. [Verbete: Rio de Janeiro].

${ }^{69}$ GOUVÊA, Maria de Fátima S. "As bases institucionais da construção da unidade..., Op. Cit., p. 708.

${ }^{70}$ Ibid., p. 711.
} 
agentes napoleônicos [Viana] cuidou de 'objetos secretos' que 'só tocavam ao soberano" referindo-se, sobremaneira, a tudo "aquilo que dizia respeito aos partidários franceses". ${ }^{71}$ Mesmo depois da Paz Geral, a partir de 1815, a preocupação do intendente quanto à defesa do Brasil e sobrevivência do Império foi uma constante. ${ }^{72}$ Nesse sentido, o cuidado e a diligência com todos que adentravam no Brasil constituiu uma das altas funções da Intendência da Polícia ao longo do período joanino. Ainda de acordo com Neves, "para cumprir esse objetivo, [o intendente] abriu um livro para a legitimação dos estrangeiros na polícia, no qual foram registrados, por ordem cronológica, os detalhes referentes a cada um [que aqui chegasse]”. A mesma intenção regulou as ações de Viana quando este legislou sobre a divulgação das obras estrangeiras, as quais seriam publicadas apenas sob a autorização da polícia.

Nesse processo de profunda reordenação política, enquanto a Intendência da Polícia ficou encarregada de "controlar

71 NEVES, Lúcia Bastos Pereira das. "Paulo Fernandes Viana”. In: NEVES, Lúcia Bastos Pereira das; VAINFAS, Ronaldo. Dicionário do Brasil Joanino... Op. Cit., p. 365.

72 Em Novembro de 1816, Paulo Fernandes Viana remetia ao Príncipe Regente um longo e importante Plano que tinha como foco a melhoria da atuação da Intendência da Polícia em todo o Reino do Brasil. Como Repartição responsável pela segurança da Corte, da família real e deste vasto continente, a correspondência de Viana versava, sobretudo, sobre o cuidado que o Regente deveria ter em relação à vigilância da costa brasileira e do interior do país. Se entre $1808 \mathrm{e}$ 1815 a rígida fiscalização havia garantido o sucesso da atividade policial, mormente quanto ao perigo da disseminação das ideias francesas, depois da Paz Geral, a entrada de estrangeiros no país tornava-se muito mais frequente. E essa nova realidade impunha um desempenho mais específico da polícia que deveria ser aprimorar a espionagem para que o governo tivesse conhecimento de todos que adentravam e/ou saíam do território da América Portuguesa. ANRJ. Ministérios dos Negócios do Brasil. GIFI (OI), 6J-83. Esta documentação é de suma importância para a compreensão da atuação da Intendência da Polícia no período. A investigação em detalhes da atuação e proposta de Paulo Fernando Viana, no entanto, estrapola os objetivos deste estudo. 
a ordem, administrar as obras públicas e organizar as tropas na corte", tendo também, entre outras funções de relevo, constituído a Guarda Real da Polícia (responsável pelo patrulhamento da cidade $)^{73}$, cabia aos diretores da Impressão Régia imprimir "exclusivamente toda a legislação e papéis diplomáticos, que emanarem de qualquer repartição do meu real serviço". ${ }^{74}$ A Tipografia Real primava pela divulgação e circulação das ordens reais nos dois lados do Atlântico, tornando público os papéis oficiais. Dessa forma, o monarca emanava para todo o corpo social as diretrizes políticas adotadas pelo governo; fossem essas de aliança política e/ou militar ou mesmo de guerra contra o inimigo. Convém não esquecermos que a Impressão Régia estava subordinada ao Ministério dos Negócios Estrangeiros e da Guerra, comandado pelo líder do partido inglês d. Rodrigo de Sousa Coutinho, entre os anos de 1808 e 1812. A partir de 1808, portanto, duas ordens de acontecimentos passaram a ser o grande foco da monarquia portuguesa sob a concepção diplomática de Souza Coutinho. Enquanto deste lado do Atlântico a Coroa reestruturava toda a máquina governamental para melhor governar o Império, no Reino os súditos de D. João travavam uma guerra contra a França, que visava à total expulsão do exército napoleônico, que desde $30 \mathrm{de}$ novembro de 1807 invadira Lisboa.

Se em um primeiro momento os portugueses teceram uma aparente posição de colaboracionismo com os invasores, inclusive a pedido do Príncipe Regente ${ }^{75}$, não demoraria muito tempo

73 ALGRANTI, Leila Mezan. In: NEVES, Lúcia Bastos Pereira das; VAINFAS, Ronaldo. Dicionário do Brasil joanino... Op. Cit., p. 230-234. [Verbete: Intendência Geral da Polícia].

${ }^{74}$ Decreto de 13 de maio de 1808 In: CAMARGO, Ana Maria de Almeida e MORAES, Rubens Borba de. Bibliografia da Impressão Régia ... Op. Cit. p. XVII. 75 NEVES, Lúcia M. Bastos P. Napoleão Bonaparte: imaginário e política em Portugal (c.1808-1810). 1. ed. São Paulo: Alameda, 2008, p. 91-118. 
para que a resistência coletiva se fizesse presente em Lisboa, através da proliferação de impressos clandestinos e da firme atuação do exército luso-britânico em solo português, com grandes repercussões dos dois lados do Atlântico. ${ }^{76}$ Já em 13 de dezembro de 1807, notamos as primeiras manifestações contra a França. Nesta data, Junot elevou a bandeira francesa no Castelo de São Jorge, o que resultou em um intenso repúdio da sociedade portuguesa contra o invasor.

Alguns tumultos entre os soldados franceses e o "baixo povo" registraram-se, então, no Terreiro do Paço, alastrando-se pelas ruas vizinhas e chegando ao Rossio. Soldados franceses eram insultados de "palavras por alguns homens abjetos" que, em seguida, gritavam: "Vivam Portugal, vivam as cinco chagas e morra a França". ${ }^{77}$

A reação francesa foi de grande violência. Junot não apenas proibia toda reunião de pessoas pelas ruas da cidade como também determinava o desarmamento das tropas portuguesas, decretando pena de morte àqueles que afrontassem seus militares. Dentro desse contexto, não demorou muito para que ocorresse a tomada do poder pelos aliados de Napoleão. Entre os meses de fevereiro e agosto de 1808, Portugal ficou sob o Conselho de Governo francês presidido por Junot, que decretou medidas administrativas de grande prejuízo para os portugueses. Na senda dessas mudanças, novos impostos foram decretados, sendo sequestrados os bens da família real portuguesa e dos nobres que atravessaram o oceano juntamente com $\mathrm{D}^{\mathrm{a}}$ Maria, D. João e Carlota Joaquina.

${ }^{76}$ MEIRELLES, Juliana Gesuelli. Imprensa... Op. Cit., p. 101-106.

77 NEVES, Lúcia M. Bastos P. Napoleão Bonaparte:... Op. Cit., p. 95. 
Com a chegada das notícias do Rio de Janeiro, em que pese à declaração de guerra contra a França assinada pelo Príncipe Regente, iniciava-se o processo de Restauração do Reino, que contou com o maciço apoio do temido exército inglês. Em finais de agosto, as tropas enfraquecidas de Junot saíam do Reino e assinavam a rendição. No dia 30 do dito mês, Inglaterra e França firmavam a polêmica Convenção de Sintra ${ }^{78}$ que, segundo Valentim Alexandre, "foi uma operação decidida de forma unilateral pelo governo britânico, sem concertação [sic] prévia com qualquer órgão de soberania portuguesa", incluindo sua embaixada em Londres, sob a liderança de d. Domingos de Sousa Coutinho. ${ }^{79}$

Tal foi o fato, que em fins de setembro de 1808, Lisboa proclamava a Restauração completa do Reino. Como observa Lúcia das Neves, no entanto, nas comemorações desta importante vitória pela sociedade portuguesa, foram Wellington e Beresford os exaltados como os libertadores de Portugal ${ }^{80}$, o que, na prática, representava a congratulação da aliança política e militar entre as duas Coroas, mesmo sob a forte (e desigual) liderança britânica. Depois da Convenção de Sintra, "o exército português [passou] a constituir claramente o corpo auxiliar, sem capacidade para

\footnotetext{
78 Assinada em 30 de agosto de 1808, a Convenção de Sintra foi um acordo de guerra que, ao expulsar o exército francês de Portugal, estipulava, entre outros artigos, a "entrega de todas as praças e fortes no Reino de Portugal ao exército britânico (Art.1) excluindo desse modo os portugueses das decisões políticas e militares a ser decidida em meio à guerra. A convenção provocou contestação generalizada dos portugueses que pediam maior contemplação e respeito com a sua alteza e o governo que a representava. Para maiores detalhes sobre o acordo ver, ARAÚJO, Ana Cristina de. "As invasões francesas e a afirmação das idéias liberais". In: MATTOSO, José. História de Portugal: o liberalismo. vol. 5. Lisboa: Editora Estampa, 1994. p. 17-44.

79 ALEXANDRE, Valentim. Os sentidos do Império: questão nacional e questão colonial na Crise do Antigo Regime Português. Lisboa: Edições Afrontamento, 1993. p. 183.

${ }^{80}$ NEVES, Lúcia M. Bastos P. Napoleão Bonaparte... Op. Cit., p. 105.
} 
influenciar minimamente os planos de campanha ou os objetivos da acção" ${ }^{\text {"1 }}$, contextualiza Valentim Alexandre. Ao olharmos por outro prisma, contudo, a saudação pública de tão iminentes militares ingleses também foi uma forma de reconhecimento das deficiências do exército português, com tropas insuficientemente organizadas e disciplinadas. De acordo com o historiador Fernando Pereira Marques, até as espingardas distribuídas nessa primeira batalha eram de origem britânica. ${ }^{82}$

A despeito da ampla importância das manobras militares ocorridas no período beligerante em Portugal, nos interessa aqui discutir o sentido da figura do militar no Reino e das instituições militares para a sustentação do Império Português deste lado do Atlântico, uma vez que, mesmo sem invasões ou perigo de guerra, a valorização da educação e preparo militar do Estado era pautada no princípio abstrato de autoridade e soberania. ${ }^{83}$ Não foi à toa que durante o governo de $\mathrm{D}$. José I uma das principais preocupações políticas das reformas pombalinas foi a modernização do exército nacional, que teve na figura do Conde de Lippe o seu grande expoente. ${ }^{84}$

\footnotetext{
81 ALEXANDRE, Valentim. Os sentidos do Império...Op. Cit., p. 183.

${ }^{82}$ MARQUES, Fernando Pereira. Exército e Sociedade em Portugal... Op. Cit., p. 143. Sobre esse tema, a pesquisadora portuguesa Ana Canas Delgado Martins faz uma importante reflexão. De acordo com a autora, "Quando o Reino recuperou a independência, com a expulsão dos franceses, em Setembro de 1808, a questão do seu governo foi levantada no Brasil. A guerra e as respectivas formas de financiamento, ancorada na aliança Anglo-Portuguesa contra a França napoleônica, eram as questões principais até 1814 e mesmo depois, embora em circunstâncias não urgentes. As condições excepcionais das forças armadas persistiam. Por isso, os negócios de Portugal foram grandemente dominados por essa realidade”. MARTINS, Ana Canas Delgado. Governação e Arquivos: D. João VI no Brasil. Lisboa: Instituto dos Arquivos Nacionais, 2007. p. 129.

${ }^{83}$ MARQUES, Fernando Pereira. Exército e Sociedade em Portugal...Op. Cit., p. 42.

${ }^{84}$ WEHLING, Arno; WEHLING, Maria José. "Exército, milícias e ordenanças na Corte Joanina: permanências e modificações". In: Revista Da Cultura, 14,
} 
De acordo com Arno Wehling e Maria José Wehling, durante a segunda metade do século XVIII Portugal também se inspirou no "estado de polícia" prussiano que despontava na Europa. Tal modelo primava por uma organização social que introduzisse critérios de racionalidade, ordem, segurança e disciplina no conjunto da sociedade. Segundo os autores, mais do que "um instrumento ou órgão encarregado de repressão às perturbações da ordem pública, o "estado de polícia" visava, antes, ser "um efetivo 'disciplinador' na sociedade", uma das bases de atuação do Despotismo Ilustrado. ${ }^{85}$

De fato, a partir de 1808 a monarquia portuguesa rearticulou as bases de sustentação do Império Português repensando a importância das diversas instituições de caráter cultural no espaço público. É dentro desse cenário de conturbada transição política que a instauração da Real Academia Militar do Rio de Janeiro, em 1810, situa-se como um dos espaços de cultura de grande importância da governança joanina para a sustentação do Império Português pelas duas margens do Atlântico. A vigência da Real Academia Militar ao longo do período joanino, associada à constante atuação da Intendência Geral da Polícia e ao apoio incondicional da Impressão Régia, é parte central desse processo.

p. 27-28. Disponível em www.funceb.org.br/revista14/pdf. Acesso em: 15. mar. 2012. Segundo os autores, "Entre as ações do governo pombalino em relação à organização das forças terrestres, destacam-se a reforma do Exército português pelo Conde de Schaumburg-Lippe, a criação de auditorias de guerra e a atribuições de um papel mais relevante às milícias e ordenanças para a defesa do território, em especial o colonial. [...] A reforma introduzida no Exército português pelo Conde de Lippe, mesmo que apenas motivada pelo fator da ameaça externa, visou modernizá-lo em relação ao que ocorria em outros países. Reviu-se organização militar - a substituição dos terços, que procediam o modelo espanhol de início do século XVI, pelos regimentos, de inspiração francesa, formas de seleção de recrutamento, armamento e disciplina [...].

85 Ibid., p. 28. 


\subsection{A Real Academia Militar e a educação dos súditos ilustrados da Coroa}

A travessia atlântica da Corte portuguesa para o Brasil teve muitos sentidos simbólicos. No plano da diplomacia europeia, significou a prova cabal de que a monarquia portuguesa optara pela aliança com a Coroa britânica de Jorge III, que a despeito de ser a principal patrocinadora da viagem, tornou-se a partir de então a grande "aliada" de Portugal e seus domínios ultramarinos, econômica e militarmente. No Reino, o temido exército inglês esteve maciçamente presente durante as guerras napoleônicas (1808-1814), sendo Lord Beresford a figura que mais fortemente representou a (in)desejada presença inglesa no país até meados de 1820, quando eclodiu a Revolução do Porto, que exigia a reunião das Cortes e a monarquia constitucional. No Brasil, depois da Abertura dos Portos às nações amigas, em 1808, os ingleses se tornavam o maior parceiro comercial, tendo, inclusive, vantagens aduaneiras em relação a Portugal. ${ }^{86}$

Deste lado do Atlântico, Lord Strangford - que desde 1807 era o representante diplomático da Inglaterra seja em Lisboa ou no Rio de Janeiro -, tornou-se figura emblemática da "amizade" entre os dois Impérios até meados de 1815. De acordo com o pesquisador Patrick Wilcken, Strangford "era o homem certo para o cargo: um manobrista diplomático, um defensor

\footnotetext{
${ }^{86}$ A partir de 28 de janeiro de 1808 era permitida a importação de gêneros e mercadorias estrangeiros, sobretudo das potências que mantinham boas relações com a Coroa Portuguesa. A lei referia-se, na prática, ao acordo com a Inglaterra, principal aliada de Portugal no âmbito da diplomacia européia, em meio às guerras napoleônicas e rompia definitivamente com o Pacto Colonial ou Exclusivismo Metropolitano. Quanto às questões alfandegárias, a entrada de mercadorias estrangeiras nos portos brasileiros elevava os impostos aos produtos portugueses para $16 \%$ e dos demais países para $24 \%$.
} 
arrogante dos interesses britânicos a qualquer preço, um egoísta que mal deixava transparecer a sua má-fé quando as circunstâncias o exigiam". ${ }^{87}$ Já para a pesquisadora Ana Canas Delgado Martins, no Brasil Lord Strangford "adquiriu um estatuto diferenciado em relação ao Príncipe Regente [...] teve um acesso fácil ao soberano e apresentou a perspectiva britânica - por vezes o seu próprio ponto de vista - directamente a $\mathrm{D}$. João e aos seus ministros". ${ }^{88}$ Um importante exemplo foi a assinatura do Tratado de 1810 que, definitivamente, dava primazia aos ingleses, tendo o forte apoio de d. Rodrigo de Souza Coutinho. ${ }^{89}$

Se por um lado, a vinda da Corte para o Brasil significava a chance de a monarquia portuguesa salvaguardar a integridade política da Coroa, e tentar manter vivo o sistema absolutista, em crise eminente desde o final do século XVIII; por outro lado, a transladação da Família Real não deixava de ter um certo caráter de humilhação política ${ }^{90}$, que por muito tempo maculou entre os

${ }^{87}$ WILCKEN, Patrick. Império à Deriva. A corte Portuguesa no Rio de Janeiro 1808-1821. Trad. de Vera Ribeiro. Rio de Janeiro: Objetiva. 2005. p. 22.

${ }^{88}$ MARTINS, Ana Canas Delgado. Governação e Arquivos:... Op. Cit., p. 145.

${ }^{89}$ O Tratado de 1810 foi resultado de uma longa e conflituosa relação comercial e diplomática entre Portugal e Inglaterra e englobou questões econômicas, políticas e religiosas. Aqui, particularmente, nos interessa destacar a preeminência britânica em relação às taxas alfandegárias, que passaram a ser no valor de 15\%, uma medida de grande vantagem inclusive sobre Portugal, que pagava uma taxa aduaneira de $16 \%$. Para maiores detalhes sobre o Tratado de 1810, consultar: FARIA, Sheila de Castro. “Tratado de 1810”. In: NEVES, Lúcia Bastos Pereira das; VAINFAS, Ronaldo. Dicionário do Brasil Joanino... Op. Cit., p. 434-437.

90 Aqui utilizamos o conceito de Humilhações Políticas do historiador francês Pierre Ansart. Segundo o autor, o conceito é intrínseco a compreensão dos sofrimentos, em que os afetos são repensados em toda sua complexidade, intimamente ligados aos mais diversos fatos, situações, acontecimentos. Os episódios traumáticos que se conservem na memória das vítimas ou seus descendentes devem ser repensados em uma dimensão política, em que o humilhado aspira, mesmo muito tempo depois, apagar a ofensa, restabelecendo o que considera como o direito de vingar a humilhação. Nas palavras de Ansart: "Portanto, 
portugueses a figura de D. João VI como o monarca que fizera da sociedade portuguesa a grande vítima de Napoleão Bonaparte. Por outro lado, este mesmo Rei manteve a Coroa e a Dinastia dos Bragança no poder. De qualquer modo, mesmo na América, D. João conservou o seu reinado, a corte e a sede do governo. Para tristeza e possível humilhação dos súditos reinóis, o Regente encontrava-se no ultramar.

Ademais, se a residência do rei europeu na América era uma absoluta novidade, a constituição de uma nova corte no Rio de Janeiro à imagem e semelhança de Lisboa, tampouco, deixava de sê-lo. Construir uma Corte saudável, policiada e, em última instância, civilizada era, portanto, tarefa das mais importantes. "Vista como simbolizadora do império português, porque fazia a 'representação de todo ele', a cidade deveria ter extirpado de si os hábitos bárbaros, os quais relacionavam à falta de beleza, de higiene, e de organização das ruas", explica a historiadora Marieta Carvalho, ressaltando que a presença do discurso civilizador foi uma constante no período. ${ }^{91}$

Nesse sentido, a questão da saúde pública aparecia como primordial. Por ordem do Príncipe Regente, o físico-mor Manoel

importam as lembranças da humilhação, o sofrimento que vem atrelado a um passado não esquecido. Este sentimento de humilhação é bastante particular, pois pode se alimentar de uma representação, de um trauma tão odioso que é sentido como indelével, ou referir-se de forma confusa a uma situação complexa, da qual o sujeito se encontra dependente e é importante para modificar. Pode-se ser humilhado violenta mas provisoriamente por uma situação de fracasso, que é na sequência superada. Pode-se também, viver um fracasso análogo e senti-lo de uma forma que a humilhação não possa ser esquecida, e se transforme, para o sujeito, em fonte de um sofrimento experimentado como insuperável, vivido de forma obsessiva." ANSART, Pierre. "As Humilhações Políticas". In: MARSON, Izabel; NAXARRA, Márcia. Sobre a humilhação: sentimentos, gestos, palavras. Uberlândia: EDUFU, 2005. p. 16-17.

91 CARVAlHO, Marieta Pinheiro de. Uma idéia... Op. Cit., p. 102. 
Viera da Silva publicava pela Impressão Régia, já em 1808, o livro Reflexões sobre alguns dos meios propostos por mais conducentes para melhorar o clima do Rio de Janeiro. ${ }^{92}$ Tal atitude demonstrava o vivo interesse de D. João em circunscrever o novo espaço urbano pela concepção de uma cidade ilustrada, pautada, obviamente, pelas singularidades intrínsecas ao universo cultural lusitano. Pela ótica da Ilustração portuguesa, as transformações urbanas foram concebidas como parte de uma política de reafirmação do poder real..$^{93}$ No período, o ato de policiar a cidade equivalia a civilizá-la. Para esse fim, entretanto, seus idealizadores políticos - como o físico-mor, por exemplo, tinham em vista o propósito de promover a ordem e o bem-estar, sempre através do Estado de Polícia. Nas palavras desse ilustrado, era chegada a "feliz época" de os habitantes do Rio de Janeiro saírem "da desgraça, que os rodeava, e entrar na história das Nações Policiadas". ${ }^{4}$

O início do processo das modificações urbanas no Rio de Janeiro ocorreu simultaneamente à reestruturação burocrática do Estado. ${ }^{95}$ Particularmente em relação ao universo administrativo, foi criado o Conselho Militar e da Justiça (1808), que ficava responsável por todas as matérias que pertenciam ao Conselho de Guerra, ao Almirantado e ao do Ultramar, no que referia somente à parte militar. Como já salientou Maria de Fátima Gouvêa, "Notória era a diferenciação observada na forma de a Coroa gerir as

\footnotetext{
92 SILVA, Manoel Viera da. Reflexões sobre alguns dos meios propostos por mais conducentes para melhorar o clima do Rio de Janeiro. Rio de Janeiro: Impressão Régia, 1808.

93 CARVAlHO, Marieta Pinheiro de. Uma ideia..., Op. Cit., p. 5.

94 SILVA, Manoel Viera da. Reflexões..., Op. Cit., p. 5.

95 Um importante trabalho sobre as mudanças urbanas é o da historiadora Madalena Lima, intitulado: Aspectos da vida cotidiana na cidade do Rio de Janeiro na visão de três viajantes estrangeiros: Debret, Rugendas e Maria Graham. Dissertação de Mestrado. UFRJ, 2000.
} 
finanças do seu Império em relação ao tratamento das matérias sob a Guarda do Conselho Militar e da Justiça”. Segundo a autora, neste particular "Lisboa mantinha quase intacta a sua jurisdição sobre assuntos em relação à maioria dos domínios ultramarinos, ficando o Rio de Janeiro como a cabeça de comando das forças e dos assuntos que diziam respeito apenas ao Estado do Brasil". ${ }^{96}$ Ainda em 1808, o Príncipe Regente criava o Arquivo Real Militar, destinado a preservar os mapas e plantas de fortalezas, baterias e artefatos de guerra já existentes no Brasil. ${ }^{97}$ Entre as funções do espaço destacava-se a conservação "em bom estado de todas as cartas gerais, particulares, geográficas ou topográficas” existente em todo o território brasileiro e demais domínios ultramarinos. ${ }^{98}$ O Arquivo estava diretamente subordinado ao Ministério dos Negócios Estrangeiros e da Guerra, sendo também dependente do Erário Régio e da Secretaria dos Negócios da Marinha e Domínios Ultramarinos, sendo seu diretor responsável por todo o acervo e demais planos militares em execução pelos engenheiros do espaço (como os planos de Fortalezas, Fortes e Baterias, ou ainda todos os projetos de estradas, navegações de rios, canais, portos etc.) que, por ventura, lhes fossem confiados. O Regimento ainda previa que todos os funcionários empregados no Arquivo ficariam "ligados ao maior segredo em tudo o que de sua natureza assim o exigir", tendo sob as mãos a responsabilidade de todas as

\footnotetext{
96 GOUVÊA, Maria de Fátima Silva. "As bases institucionais da construção da unidade..., Op. Cit., p. 719. Essa diferença de atuação entre os grupos políticos e economicamente ativos nas duas partes do Império, em última instância, foi um dos grandes fatores que gerou a eclosão da Revolução do Porto, em 1820.

97 Para informações mais detalhadas sobre o Real Arquivo Militar, acessar a Memória da Administração Pública Brasileira (MAPA), um projeto do Arquivo Nacional do Rio de Janeiro In: http://linux.an.gov.br/mapa/?p=2788.

98 Regimento do Arquivo Militar presente no Decreto de 07 de abril de 1808. In: http://www.planalto.gov.br/ccivil_03/revista/Rev_23/dec_7abril.htm (Acesso em 02 de junho de 2012).
} 
matérias ali desenvolvidas. ${ }^{99}$ De início, a direção do espaço coube a Henrique Isidoro Xavier de Brito, sargento-mor e engenheiro da Corte. ${ }^{100} \mathrm{O}$ regimento real reiterava a importância que a Coroa destinava à conservação dos documentos oficiais, sobretudo os referentes à defesa e progresso urbano do território.

A Academia Real dos Guardas-Marinha e sua Companhia foram transladadas para o Rio de Janeiro junto com a Família Real. Instalada nas dependências do Mosteiro de São Bento, o início de seu funcionamento deu-se em meados de 1809. Com um currículo de duração de três anos, os alunos se aprofundavam mais nas matérias náuticas, além de contarem com aulas práticas de fuzil, canhão, morteiro e obus, lições de esgrima e manobra naval. ${ }^{101} \mathrm{O}$ locus de saber também mantinha uma biblioteca especializada, aberta à consulta desde dezembro de 1809.102

Em um contexto em que a segurança da nova capital aparecia como preocupação de primeira grandeza, não nos causa espanto o grande número de ordens e regulamentos reais referentes ao universo militar, geralmente divulgado na Gazeta do Rio de Janeiro. Em 1816, por exemplo, um anúncio informava aos moradores da Corte que estes podiam encontrar na Loja da Gazeta as

\footnotetext{
99 Ibid. Regimento do Arquivo Militar... (Grifo Nosso). O Regimento ainda determinava os vencimentos do diretor e engenheiros do estabelecimento: "O Engenheiro Diretor e mais Engenheiros empregados nos catálogos e análise das cartas e obras, serão considerados como em diligencia ativa, e terão soldo e meio da sua patente e a gratificação correspondente, que era 800 réis para os subalternos, $1 \$ 000$ para os Capitães, $1 \$ 200$ para os Sargentos Mores, $1 \$ 400$ para os Tenentes Coronéis, e $1 \$ 600$ para os Coronéis. Os Oficiais empregados no desenho terão além do seu soldo mais $20 \$ 000$ mensalmente. O Porteiro terá de gratificação 50\$000".

100 PONDÉ, Francisco de Paula e Azevedo. “Academia Real Militar”. In: Anais do Congresso da Independência do Brasil. Rio de Janeiro: IHGB, 1975. p. 50.

101 SILVA, Maria Beatriz Nizza da. Cultura luso-brasileira:... Op. Cit., , p. 67.

102 A importância da estruturação dessa biblioteca na nova corte será discutida no próximo capítulo.
} 
seguintes obras: Regulamentos do Ex.mo Beresford, Regulamento de Infantaria, Dito de Cavalaria, Dito de Caçadores, Dito de Milicianos, Regulamento para o Exército de Portugal, Dito de Ordenanças, Prática para os Conselhos de Guerra, Máximas da Guerra e Instruções Militares, Privilégios dos Milicianos. O mesmo aviso ainda colocava a disposição do público "um grande sortimento de livros Militares tanto em Português como em Francês". ${ }^{103}$ Do recrutamento das tropas à administração dos recursos materiais necessários para a manutenção dos corpos militares, é patente a atuação dos homens fortes do governo joanino, com destaque para a figura do Ministro dos Negócios Estrangeiros e da Guer$\mathrm{ra}^{104}$ e do Intendente da Polícia (Paulo Fernandes Viana). Enquanto o primeiro ficava a cargo de "centralizar a operacionalização das relações externas da Corte Portuguesas [sic], a partir da sede brasileira"105, ao segundo era destinada a responsabilidade tanto pela organização da defesa militar quanto do abastecimento da cidade; uma articulação vasta e complexa que envolvia importantes atores históricos. ${ }^{106}$ Em maio de 1810, por exemplo, o governo decretava a criação de novos regimentos de Milícias de Caçadores de Henriques na Corte; atitude que contou com o

103 GRJ. 1816. n. 90 (Grifos do Original).

104 De acordo com Ana Canas, entre 1808 e 1821, o Brasil possuiu 08 Ministros do da Secretaria de Estado dos Negócios Estrangeiros e da Guerra, a saber: d. Rodrigo de Souza Coutinho/Conde de Linhares (1808-1812), d. Fernando de Portugal/Conde de Aguiar (1812), D. João de Almeida Melo e Castro/ Conde de Galveias (1812-1814), d. Fernando de Portugal/ Marquês de Aguiar (jan.1814 - jan.1817), d. Antonio de Araújo de Azevedo/ Conde da Barca (dez.1816 jun.1817), João Paulo Bezerra (interino em 1817), Thomaz Antonio Vilanova Portugal (nov.1817 - dez.1820) e d. Pedro de Sousa e Holtein/ Conde de Palmela (dez.1820 - fev.1821). MARTINS, Ana Canas Delgado. Governação e Arquivos... Op. Cit., p. 428.

${ }_{105}$ Ibid., p. 130.

106 GOUVÊA, Maria de Fátima Silva. "As bases institucionais da construção da unidade..., Op. Cit., p. 730-731. 
grande esforço empreendido por Paulo Fernandes Viana. É no bojo dessas transformações que se estruturou e vigorou a Real Academia Militar no período joanino.

Datado de 04 de Dezembro de 1810, o decreto real especificava detalhadamente as razões de uma corte imperial possuir uma Academia Militar. Vejamos:

Faço saber a todos que esta Carta virem, que Tendo consideração, ao muito que interessa ao Meu Real Serviço, ao Bem Público dos Meus Vassalos, e a defesa e segurança dos Meus Vastos Domínios, que se estabeleça no Brasil, e na Minha atual Corte e Cidade do Rio de Janeiro, um Curso regular das Ciências exatas, e de Observação, assim como de todas aquelas que são aplicações das mesmas aos Estudos Militares e Práticos, que formam a Ciência Militar em todos os seus difíceis e interessantes ramos, de maneira que dos mesmos Cursos de estudos se formem hábeis oficiais de Artilharia, Engenharia e ainda mesmo Oficiais da classe de Engenheiros Geógrafos e Topógrafos, que possam também ter o útil emprego de dirigir objetos administrativos de Minas, de Caminhos, Portos, Canais, Pontes, Fontes e Calçadas: Hei por bem, que na Minha atual Corte e Cidade do Rio de Janeiro, se estabeleça uma Academia Real Militar para um Curso completo de Ciências Matemáticas e Ciências de Observação, quais a Física, Química, Mineralogia, Metalurgia, e História Natural, que compreenderá o Reino Vegetal e Animal, e das Ciências Militares em toda a sua extensão tanto de Tática como de Fortificação e Artilharia. ${ }^{107}$

A constituição da Real Academia Militar era parte integrante do projeto reformista de d. Rodrigo de Souza Coutinho,

107 Carta de lei de 04 de dezembro de 1810. Dispõe sobre a criação da Academia Real Militar do Rio de Janeiro In: http://www2.camara.leg.br/legin/fed/carlei/ anterioresa 1824/cartadelei-40009-4-dezembro-1810-571420-norma-pe.html (Acesso em 10 de junho de 2012) 
que desde a decisão da transladação da Corte para o Brasil voltava à cena política com grande evidência. Sua nomeação para o comando do Ministério dos Negócios Estrangeiros e da Guerra não apenas reiterava a predominância das diretrizes ideológicas vigentes do partido inglês como também impunha aos demais homens de Estado - como, por exemplo, seu arqui-inimigo Antonio de Araújo e Azevedo - a preponderância de seus projetos políticos.

Pelo prisma ideológico de Souza Coutinho ${ }^{108}$, a segurança dos domínios imperiais, o bem público de todo o corpo social e a formação intelectual dos súditos compunha o tripé fundamental que justificava a criação de uma Academia Militar na nova corte; mormente em tempos de guerra declarada contra a França napoleônica, como esclarecia um documento anônimo, de 1815.

Em uma época em que o Mundo vacilava sobre seus eixos, e um terremoto político ameaçava uma catástrofe, cujas circunstâncias ninguém causaria prever, nem calcular, era próprio de uma alma verdadeiramente patriótica promover os estudos em um país onde eles eram quase desconhecidos, e muito particularmente a benefícios daqueles, que se dedicam a defesa do Estado, a qual está demonstrado que não bastam as virtudes civis, senão acompanhadas de sólidos conhecimentos. ${ }^{109}$

Como nos aponta o autor anônimo, se era imperativa a formação de homens hábeis na arte da guerra $^{110}$, para proteção

\footnotetext{
108 As diferentes posições ideológicas e diplomáticas entre D. Rodrigo de Souza Coutinho e Antonio de Araújo Azevedo é discutida no Capítulo 1 desta tese, no item II, intitulado: "O Investigador Portuguez em Inglaterra e a disputa com o Correio Braziliense."

109 Memória Histórica e Política sobre a creação e estado actual da Academia Real Militar. Arquivo do Instituto Histórico e Geográfico Brasileiro. L. 17 N. ${ }^{\circ}$ 366. In: Revista do Instituto Histórico e Geográfico Brasileiro. Vol. 236. Rio de Janeiro, 1957. p. 459.

${ }^{110}$ Carta de lei de 04 de dezembro de 1810. Título VIII. Dos exercícios práticos.
} 
e defesa da nova sede do Império, também era indispensável que a nova corte formasse engenheiros, geógrafos e topógrafos que viabilizassem - com sucesso - seu projeto político reformista: a formação do Império luso-brasileiro, um empreendimento audacioso que ganhava tonalidades reais a partir de 1808. "O novo império anunciado se colocava como elemento unificador das partes distintas do mundo português e o sentimento de pertencimento à nação lusa, explicitamente evocado, aparecia como a função objetiva de fortalecer essa unidade e, sobretudo, de assegurar a criação de um sentimento de identidade entre os habitantes do 'genérico' Brasil', conceitua a historiadora Maria de Lourdes Viana Lyra, ao apontar as diretrizes da concepção política de Souza Coutinho. ${ }^{11}$ Ainda segundo Lyra, foi com o início da regência do Príncipe Regente D. João, em 1792, que se deu o avanço da Ilustração Portuguesa e a implementação sistemática das bases administrativas com vistas à constituição desse novo império. ${ }^{112}$

Por essa vertente, portanto, não nos causa surpresa que as bases dos estatutos da Real Academia Militar representassem com clareza o direcionamento dessas mudanças, que dialogavam de perto com a tendência da época de profissionalização e burocratização da carreira militar. Isto é, dentro dos saberes, a "Arte da Guerra" aparecia como uma importante ciência a ser aprimorada. Como bem contextualizou a historiadora Elaine Duarte, foi a partir de 1800 que as academias militares na Europa e na América perderam o seu caráter rudimentar e tornaram-se "espaços específicos para a formação da oficialidade, contando para isso com o avanço e desenvolvimento da guerra". ${ }^{113}$ Neste contexto,

111 LYRA, Maria de Lourdes Viana. A utopia... Op. Cit., p. 69 (Grifo do Original). 112 Ibid., p. 64.

113 DUARTE, Elaine Cristina Ferreira. Da Real Academia à escola militar: a profissionalização das armas e a consolidação do ensino militar no Brasil (18101855). Dissertação de Mestrado. UERJ, 2004. p. 18. 
compreendemos melhor a reflexão do autor anônimo, para quem d. Rodrigo tinha sido "um ministro, que sem dúvida possuía as ciências opactas [sic], traçou este grande plano, e arrostando grandes dificuldades, conseguiu desempenhá-lo."114 Já de início, o decreto de 1810 colocava em foco a estrutura hierárquica de poder do novo lugar de ensino, que seria dirigido por uma Junta Militar, composta por cinco oficiais de alta patente do exército. Eis a definição do estatuto:

A Junta Militar será composta do presidente, que será um tenente general e sempre tirado do Corpo de Artilharia ou do Corpo de Engenheiros e de quatro ou mais Oficiais (se Eu assim For Servido) com a patente de coronel ou daí para cima, sendo um deles oficial engenheiro que for diretor do Meu Real Arquivo Militar e os outros três, os que, como mais hábeis nos estudos científicos e militares, eu for servido escolher e nomear para o mesmo serviço e for meu real agrado, servindo o mais moderno de secretário particular da mesma junta. A junta se reunirá uma vez cada mês ordinariamente, além da época do princípio e fim dos estudos em cada ano e extraordinariamente, quando for convocada pelo presidente ou por ordem especial do inspetor geral. ${ }^{115}$

114 Memória Histórica e Política sobre a creação e estado actual da Academia Real Militar. Arquivo do Instituto Histórico e Geográfico Brasileiro..., Op. Cit., p. 459.

115 Carta de lei de 04 de dezembro de 1810. A Junta Militar era composta pelo Tenente General Carlos Antonio Napion, no cargo de presidente, o Brigadeiro João Manuel da Silva (no cargo de Primeiro deputado e diretor do Real Arquivo Militar), Coronel Manoel Jacinto Nogueira da Gama (no cargo de Segundo deputado). Ao longo do período, fizeram parte da Junta os seguintes súditos: Francisco da Borja Garção Stockler, que sucedeu a Carlos A. Napion, por conta de seu falecimento, em 1815, o Marechal Joaquim de Oliveira Álvares (nomeado em 1820) e, por fim, o Comandante do Corpo de Engenheiros e diretor do Arquivo Militar, o Brigadeiro Joaquim Norberto Xavier de Brito, a partir de abril de 1821. 
A Academia também contaria com onze Lentes e cinco substitutos, responsáveis por ministrar as diversas disciplinas que contemplavam a grade curricular do Curso Militar, dividido em sete anos. Ser professor da Real Academia era um posto de alta consideração dentro da sociedade de corte. Como súditos que compunham a seleta órbita da elite ilustrada, eram detentores de "distintas luzes" sendo, por isso, dignos de serem escolhidos pela Junta Militar. Se o mérito da formação acadêmica aparecia como um dos atributos principais nesse processo de seleção, a fidelidade à monarquia tinha igual peso. Isto é, valorizavam-se muito as ações e projetos militares que estes homens desempenhavam dentro do Império Português, o que os colocava em uma posição hierárquica privilegiada: na corte joanina eram vistos como súditos fiéis que foram reconhecidos pelo monarca como tal. "Haverá toda consideração ao adiantamento dos oficiais, que forem lentes e que nos exercícios geodésicos e de reconhecimentos anuais e outros trabalhos militares tiverem feito ver que continuaram a praticar e distinguir-se no meu real serviço", ressaltava o estatuto, em uma clara valorização dos feitos militares da vida cotidiana como atitude de distinção. ${ }^{116}$

Tal era o fato, que os lentes contavam as "mesmas honras e graças das Academias Militares da Marinha e Exército de Terra, na Cidade de Lisboa", recebiam 400\$000 réis anuais além do soldo da patente $^{117}$ e ainda gozavam de uma prerrogativa muito especial: tinham os mesmos "privilégios, indultos e franquezas" dos mestres da Faculdade de Matemática da Universidade de Coimbra. ${ }^{118}$

\footnotetext{
116 Ibid.

117 Ibid. Já o ordenado dos substitutos foi estipulado em $200 \$ 000$ réis anuais.

118 Título X do Estatuto denominado Dos Privilégios e Prerrogativas da Academia Real Militar.
} 
Além disso, depois de vinte anos de magistério tinham a permissão para pedirem a jubilação do cargo. ${ }^{119}$

Quanto às disciplinas que ministravam, estas eram assim distribuídas: Aritmética, Álgebra, Geometria, Trigonometria Retilínea e as primeiras noções da Esférica compunham a grade curricular do primeiro ano, que já primava por um ensino voltado às aplicações e experimentos. Especificamente sobre as fórmulas trigonométricas, estas deveriam ser ensinadas "procurando desenvolver aquele espírito de invenção, que nas ciências matemáticas conduz às maiores descobertas". ${ }^{120}$ No segundo ano, ensinava-se Álgebra, Geometria, Geometria Analítica, Cálculo Diferencial e Integral, Geometria Descritiva e Desenho. Nesta fase da instrução, o estatuto destacava a preocupação com a apreensão das ciências estudadas, "até onde têm chegado nos nossos dias nas brilhantes aplicações à Física, à Astronomia e ao Cálculo das Probabilidades."121

O terceiro ano priorizava o ensino da Mecânica, da Balística e do Desenho. Ao referir-se à obra do matemático e astrônomo inglês Olinto Gilberto Gregory (1774-1841) sobre a mecânica, o estatuto destacava que dela deveria se extrair "tudo o que toca às máquinas e suas aplicações, de que deverá fazer a explicação sobre as estampas e os modelos, que sucessivamente se irão fazendo construir para uso da mesma Escola". ${ }^{122} \mathrm{O}$ quarto ano era voltado para a investigação da Trigonometria Esférica, da Física, da

\footnotetext{
119 O pesquisador José Carlos de Oliveira analisa minuciosamente a trajetória e o perfil dos professores d'Academia Militar. Para maiores informações sobre esses personagens, ver OLIVEIRA, José Carlos de, D. João VI, Adorador do Deus das Ciências? A constituição da cultura científica no Brasil (1808-1821). Rio de Janeiro: e-papers, 2005. p. 198-224.

${ }^{120}$ Carta de lei de 04 de dezembro de 1810.

121 Ibid.

122 Ibid.
} 
Astronomia, da Geodésia, da Geografia Geral e do Desenho. Sobre a mecânica celeste de Pierre-Simon Laplace (1749-1827), o lente deveria priorizar "os grandes resultados que ele tão elegantemente expôs e daí explicando todos os métodos às determinações das latitudes e longitudes no mar e na terra" afim de mostrar aos discípulos "as aplicações convenientes às medidas Geodésicas, que novamente, dará em toda a extensão". ${ }^{123}$ Se os quatro primeiros anos do Curso constituíam uma ampla base acadêmica de grau superior, os três últimos anos eram voltados exclusivamente para o estudo militar e de engenharia ${ }^{124}$, que deveriam ser realizados em sua totalidade apenas por aqueles que desejassem obter o diploma de Artilheiros e Engenheiros.

Do quinto ao sétimo ano os alunos contavam com a presença de dois lentes. No quinto ano, um professor ficava responsável pelas disciplinas de Tática, Estratégia, Castrametação ${ }^{125}$, Fortificação de campanha e reconhecimento do Terreno e o outro pela docência da Química, estudada através de autores célebres como Antoine Lavoisier (1743 - 1794), considerado o pai da Química moderna. No sexto ano, enquanto o primeiro docente ministrava Fortificação regular e irregular, ataque e defesa das praças, Arquitetura Civil, Estradas, Portos e Canais, o segundo lecionava Mineralogia e Desenho. Por fim, o sétimo ano contava com três disciplinas de grande importância para os engenheiros e militares: a Artilharia (Teórica e Prática) e Minas (que incluía o ensino da Geometria Subterrânea), ensinadas pelo primeiro lente;

\footnotetext{
123 Ibid.

124 MOTTA, Jehovah. Formação do oficial do Exército. Rio de Janeiro: Companhia Brasileira de Artes Gráficas, 1976. p. 20.

125 "Arte de assentar acampamentos e fortificar". BUENO, Beatriz. Desenho e Desígnio... Op. Cit., p. 227.
} 
e História Natural, de responsabilidade do segundo docente. ${ }^{126}$ O estatuto ainda previa a constituição de uma Biblioteca Científica e Militar, que teria como bibliotecário o professor responsável pelo magistério da "História Militar de todos os povos". Esta disciplina seria ministrada em um eventual oitavo ano e teria como foco os

[...] progressos que na mesma fez cada nação e dando idéia dos maiores generais nacionais ou estrangeiros, [o professor] explicará também os planos das mais célebres batalhas, que acabará de formar os alunos e os porá, no caso de poderem, com grande distinção, serem verdadeiramente úteis ao meu real serviço, em qualquer aplicação que eu seja servido dar-lhes. Os lentes serão obrigados a assistir aos exercícios práticos, segundo forem destinados todos os anos pela junta. ${ }^{127}$

Porém, como já demonstrou a pesquisadora Elaine Duarte, apenas no final da década de 1840 foi "possível verificar um esforço significativo no sentido de dotar a Academia de uma biblioteca científica e militar, tal qual se fazia necessário". ${ }^{128}$ A redação do estatuto foi feita pelo próprio Conde de Linhares, que desde o final do século XVIII alertava para a necessidade da formação de um contingente militar nas partes que constitui o todo para, assim, melhor defender o Império. De acordo com Maria de Lourdes Viana Lyra, já no seu Programa de Reformas, de 1798, é nítido “o

\footnotetext{
${ }^{126}$ De acordo com o pesquisador Jehovah Motta, "Tal como as coias eram tidas em 1810, o infante e o cavaleiro podiam ser formados em dois anos de estudo; um de Matemática Elementar e o outro de Tática, Estratégia, Castrametação e Fortificação Passageira. Diante deles, artilheiros e engenheiros, com seus longos estudos de sete anos, se colocavam como o patriciado intelectual do Exército, eram os 'cientistas' e os 'doutores'”. MOTTA, Jehovah. Formação do oficial do Exército... Op. Cit., p. 20.

127 Carta de lei de 04 de dezembro de 1810.

${ }^{128}$ DUARTE, Elaine Cristina Ferreira. Da Real Academia à escola militar... Op. Cit., p. 34-35.
} 
esforço empreendido pela metrópole na superação dos seus próprios limites: integrar o colonial como forma militar significava, por um lado, engajá-lo na luta da defesa da Monarquia portuguesa, a qual ele tinha a 'fortuna de pertencer"'. ${ }^{129}$ Nesse sentido, ainda segundo Lyra, a consciência prévia de pertencimento a nação portuguesa era fundamental para que não houvesse "desvios" e conflitos nos objetivos de luta que, mais uma vez, justificava a instauração da Real Academia da Artilharia, Fortificação e Desenho, em 1792. Já no início do século XIX, a implemetacao da Real Academia Militar tinha um sentido distinto. “Tratava-se de transformar a sede do vice-reinado na sede da monarquia portuguesa e a política cultural de D. João e seus ministros tem de ser realçada", afiança a especialista Maria Beatriz Nizza da Silva. ${ }^{130}$

Como já discutido no capítulo 1, de fato uma das linhas mestras da política cultural joanina foi a circulação de informações oficiais pela imprensa interatlântica e, consequentemente, a divulgação dos projetos políticos do governo monárquico na América através da arena pública. Esta prática justifica a posição de d. Rodrigo de Souza Coutinho, em 1811, quando pediu aos redatores d'O Investigador Portuguez em Inglaterra para publicarem um artigo sobre a Real Academia Militar, considerada por ele, uma instituição próspera que correspondia perfeitamente ao olhar iluminado do Príncipe Regente. ${ }^{131}$

129 LYRA, Maria de Lourdes Viana. A utopia... Op. Cit., p. 78 (Grifos do Original). 130 SILVA, Maria Beatriz Nizza da. "A impressão Régia do Rio de Janeiro e a Cultura Científica” In: Revista Portuguesa de História do livro. Ano XII Vol.23. Lisboa: Edições Távola Redonda, 2009. p. 231 (Grifo Nosso).

131 SILVA, Andrée Mansuy-Diniz da. Portrait d'un homme d'État:... Op. Cit., p. 263. Nas palavras da autora, "Un an plus tard d. Rodrigo considérait que si cette institution prosperait dèjá et correspondait parfaitment aux vues éclairées et au soins paternailes du Prince, il fallait la faire mieux connaitre du public: raison pour laquelle il écrivit aux deux responsables du journal portugais dont la publication venait de commercer à Londres, $\mathrm{O}$ Investigador Portuguez em Inglaterra, pour leur demander d'écrire un article à ce sujet." 
No ano seguinte, em abril de 1812, coincidentemente três meses depois da morte de Souza Coutinho ${ }^{132}$, os redatores d'O Investigador Portuguez publicavam uma longa reflexão sobre a importância de um Estado soberano possuir uma Academia Militar. “[...] a história do género humano é a história de suas guerras, e a superfície habitável e inabitável do globo tem sido e continua a ser o teatro da sua luta", conclamavam. Ao constatarem que tal realidade era "uma triste e terrível verdade", defendiam que a independência do Estado era intrínseca ao aperfeiçoamento do sistema militar: "Armar-se pois, e aprender a brigar deve ser a eminente característica de toda a nação que quer ser livre e independente; ou por outras palavras a Instituição de uma escola militar deve ser um dos primeiros objetos d’atenção de um sábio legislador"133; no caso d. Rodrigo de Souza Coutinho, homem "com requisitos mais que essenciais para a fundação de tal estabelecimento" já que este possuía "conhecimentos não superficiais das ciências, que tão magistralmente distribui no seu plano". ${ }^{134}$

$\mathrm{O}$ artigo desencadeou uma aguda polêmica com Hipólito da Costa no Correio Braziliense, o que deu ainda maior visibilidade a essa instituição régia. ${ }^{135}$ Ainda em abril de 1812, Hipólito

${ }^{132}$ De acordo com a Gazeta do Rio de Janeiro, D. Rodrigo morreu no dia 26/01/1812, aos 56 anos de idade. Eis como o redator informava o seu falecimento: "Comunicar tão infausta notícia aos nossos leitores é dizer-lhes que faltou um dos mais firmes esteios da Monarquia Portuguesa, um dos mais ativos, zelosos e amantes servidores do Príncipe Regente N.S., o varão mais interessado pelo aumento e prosperidade da Nação, Ornado de consumada literatura, e das mais amáveis virtudes sociais" GRJ. 1812. n. 09.

133 IP. Vol. III, p. 272-273.

134 Ibid., p. 275.

135 A polêmica entre os periódicos é detalhadamente analisada pelo pesquisador José Carlos de Oliveira no artigo OLIVEIRA, José Carlos. "Os periódicos portugueses de Inglaterra e a Cultura Científica Brasileira (1808-1821)”. Revista da SBHC, n. 19, 1998, p. 37-48. 
afirmava que Souza Coutinho "não possuía os conhecimentos necessários, para formalizar o Plano de estudos para todas as ciências", e defendia veementemente que "seria coerente com a dignidade do legislador, que o Conde de Linhares, havendo consultado os homens instruídos nestas matérias, os ajuntasse, lhes mandasse dirigir, e arranjar o plano de estudos, e por uma lei [...] confirmasse e mandasse executar o plano formalizado pelos respectivos Professores." O jornalista ainda ressaltava o desserviço ${ }^{136}$ de Linhares ao propor um estabelecimento que fugia totalmente da sua competência política: o pedantismo da proposta era marcado, nomeadamente, pelo fato de o ministro nunca ter seguido a vida militar, além de ter circunscrito a administração da Junta Militar da Academia ao Ministério dos Negócios Estrangeiros e da Guerra, ou seja, sob a sua total direção. ${ }^{137}$ Sobre o Plano pedagógico desse locus de saber, o redator era enfático:

O título segundo ${ }^{138}$ é o cumulo de pedantismo; em que um ministro, que nunca foi militar, e nunca brigou sequer com uma mosca; se intromete a escrever direções sobre os estudos da arte militar; e se apura a fazer uso de todos os termos técnicos, de que um professor da arte pode com toda a propriedade usar, mas que na boca de um Ministro de Estado, que não segue nem nunca seguiu a vida militar, não servem senão de demonstrar a ideias [sic] do pedante, a confusão do homem público e a arbitrariedade do ministro. ${ }^{139}$

Como bem asseverou o pesquisador José Carlos de Oliveira, Hipólito defendia a "não interferência do Estado na organização

136 CB. Vol. VIII, p. 487.

137 Ibid., p. 488-489.

138 Intitulado: Número de professores, Ciências que devem ensinar e dos seus Substitutos. Para maiores detalhes, ver Carta de lei de 04 de dezembro de 1810. 139 CB. Vol. VIII, p. 488-489. 
direta da instrução pública", considerando que a grade curricular e a conexão entre as disciplinas deveriam ser "assunto de especialista". ${ }^{40}$ Este julgamento indica o olhar inteiramente laico do jornalista, cuja influência iluminista era patente: os responsáveis por pensar a produção do conhecimento deveriam fazê-lo, antes, por mérito. As relações políticas, nesse sentido, necessariamente, ficariam em segundo plano. Por esse prisma, compreendemos a crítica feroz de Hipólito às diretrizes governamentais joaninas, de natureza absolutamente autoritária. Não podemos nos esquecer que a polêmica entre O Investigador e o Correio teve como foco o debate acerca das bases da Carta Régia de 1810 e ocorreu entre os meses de abril e junho de 1812, ano chave das negociações financeiras entre a Coroa e Hipólito da Costa ${ }^{141}$; sendo também o momento em que findava a influência política de Linhares na governança do Império Português.

Por um prisma mais amplo, destarte, também podemos dizer que a discussão entre os periódicos girava em torno de uma questão central para a monarquia portuguesa: o sentido político de uma Corte possuir uma Academia Militar. Segundo a historiadora Andrée Mansuy-Diniz da Silva, a Real Academia Militar foi uma das grandes realizações de ordem científica e cultural durante a regência de D. João VI no Brasil. Tal consideração, segundo a autora, justifica-se, sobretudo, diante da concepção da instituição: ter como meta o preparo dos futuros líderes militares e políticos do Império luso-brasileiro. Nas palavras de Silva, "Na

\footnotetext{
${ }^{140}$ OLIVEIRA, José Carlos. “Os periódicos portugueses..., Op. Cit., p. 39.

${ }^{141}$ As negociações políticas entre Hipólito e o governo joanino é o tema do Item 1.2, Capítulo 1 deste trabalho, intitulado: "Hipólito José da Costa na política cultural joanina”.
} 
verdade, a Academia Militar, de natureza acadêmica, formou o núcleo inicial de uma verdadeira escola de Engenharia”. ${ }^{142}$

Ter como foco de debate público a vigência de uma Academia Militar na nova sede do Império Português também garantia a D. João e seus ministros um espaço importante dentro da lógica diplomática europeia. Aos súditos reais, indicava o forte empenho da Coroa em manter seguro seus domínios territoriais ultramarinos; quanto aos países beligerantes do Velho Mundo (França e Inglaterra) divulgava a preocupação com o ensino militar e a formação de um exército nacional. Especificamente em relação à França, com quem travava uma guerra pelas duas margens do Atlântico, expunha a atenção e o esforço empreendidos para a obtenção da vitória contra Napoleão Bonaparte, mesmo que esta ocorresse mais através do plano simbólico. ${ }^{143}$

Ou seja, a regeneração nacional também perpassava pelo esquecimento da humilhação política que o Império Português vivenciara ao optar por transladar a sede da Coroa para a América, às vésperas da invasão francesa. Possuir um locus de saber exclusivamente voltado para o universo militar e a arte da guerra significava, em última instância, preparar-se pelas armas contra qualquer tipo de ameaça externa. Para o pesquisador Antonio Paim, Souza Coutinho teve uma "posição de iniciador de uma linha de desenvolvimento cultural de grande relevância na história do Brasil", cujas sementes "iriam vicejar enormemente" na

\footnotetext{
142 "La création de cet établissement prestigieux, entiérement conçu dans ses moindres détails par D. Rodrigo, fur sans aucun doute l'une des grandes réalisations d'order scientifique et culturel déstinée à préparer les futurs cadres de l'empire portugais (et plus tard de l'empire brésilien ). En fait, cette Académie Militaire, de caractère universitaire, constitua le noyau initial d'une veritáble École d'Ingénieurs, et de ce qu'on appelle une Ecol Polytecnique." SILVA, Andrée Mansuy-Diniz da. Portrait... Op. Cit., p. 263. (Tradução Livre).

143 STOIANI, Raquel. Napoleão visto... Op. Cit., p. 114.
} 
formação da Academia Militar Brasileira e, consequentemente, no Exército Brasileiro. ${ }^{144}$

De fato, em 1808 o Rio de Janeiro não possuía uma força militar organizada que constituísse um exército nacional. Como apregoa Oliveira Lima, por essa época a cidade contava com apenas dois regimentos de milícias compostos por lojistas e caixeiros constituindo

[...] um total de 1500 homens que não se exercitavam com regularidade, nem se uniformizavam decentemente, e tão pouco apego mostravam à sua nobre profissão que, quando não estavam na formatura, eram os escravos que lhes carregavam os mosquetes, os tambores e a própria bandeira do regimento: aqueles pseudo-militares iam armados de guarda-chuvas. ${ }^{145}$

Apesar das constantes tentativas da formação desse contingente social ao longo do período joanino (1792-1821), com maior predominância para a regência de $\mathrm{D}$. João durante a sua governança no Brasil, a constituição dessa realidade se mostrou uma tarefa árdua. A despeito do currículo de ponta da Academia Militar (cujo conteúdo primava pelo diálogo com os avanços científicos vigentes na Europa culta $\left.{ }^{146}\right)$ sugerido por Souza Coutinho para a formação dos novos oficiais, tendo o estatuto vigorado

${ }^{144}$ PAIM, Antonio. "D. Rodrigo de Sousa Coutinho (1755-1812): notícia biobibliográfica” In: PAIM, Antonio (Org.). Pombal e a cultura brasileira. Rio de Janeiro: Fundação Cultural Brasil-Portugal; Tempo Brasileiro, 1982. p. 92.

145 LIMA, Oliveira. D. João VI no Brasil... Op. Cit., p. 288.

146 Para o pesquisador José de Oliveira, "O que é mais importante, e de fato, novo é que os estudos militares deveriam ser feitos com orientação científica. Forçava-se, desta forma, o futuro oficial do exército, a possuir não apenas saberes práticos, mas impingia-lhes conhecimentos de ciências naturais, como base para o ensino de engenharia e das matérias militares” OLIVEIRA, José Carlos de, D. João VI, Adorador do Deus... Op. Cit., p. 160. 
até $1832^{147}$, os desafios no interior do espaço foram constantes, mostrando-se bem diferentes do ideal proposto pelo ministro no estatuto de 1810.

O início das aulas da Real Academia deu-se em 23 de abril de 1811, nas dependências da Casa do Trem da Artilharia (atual Museu Histórico Nacional). No ano seguinte, passou para o edifício no Largo de São Francisco (atual IFCS), que lhe era destinado. De acordo com o pesquisador Francisco de Paula Azevedo Pondé, em 1811 a instituição contou com a matrícula de 73 discípulos, sendo 68 provenientes da carreira militar; um índice relativamente alto de inscritos quando comparado com o número de matriculados entre os anos de 1812 e $1821 .{ }^{148}$ Esses dados nos mostram duas ordens de fatores: o pequeno interesse dos súditos reais em frequentar as aulas da Real Academia Militar e a visível dificuldade da Coroa em reverter esse processo. Porém, é mister destacarmos que a maioria dos alunos inscritos era de filhos de militares, o que sinaliza para a valorização da atividade no universo privado de suas famílias. ${ }^{149}$

Até meados de 1815, por exemplo, a Corte possuía três regimentos de infantaria, um de cavalaria e um de artilharia, em um total de quase dois mil homens. ${ }^{150}$ Apesar disso, em 1812 o Príncipe Regente ordenava a construção do quartel de Artilharia, assim como a conclusão das obras no Hospital Militar. No ano seguinte, dava-se também a edificação do quartel do $3^{\circ}$ Regimento de Infantaria. ${ }^{151}$ Os hospitais militares do Império contavam

147 MORMÊLLO, Ben Hur. O ensino de matemática na Academia Real Militar no Rio de Janeiro de 1811 a 1874. Dissertação de Mestrado. IMECC. Unicamp. 2010. p. 94.

148 PONDÉ, Francisco de Paula e Azevedo. “Academia Real Militar”... Op. Cit., p. 63.

149 Ibid., p. 53-63.

${ }^{150}$ LIMA, Oliveira. D. João VI no Brasil... Op. Cit, p. 287.

151 PIRASSINUNGA, Adailton Sampaio. O Ensino Militar no Brasil... Op. Cit., p. 64. 
com um Regulamento especial, de 1805, que deveria ser seguido tanto em tempos de paz como em tempo de guerra. ${ }^{152}$ Para o bom funcionamento do hospital, o regulamento determinava que o Físico-mor, o Cirurgião-mor e o Ministro dos Negócios Estrangeiros e da Guerra seriam suas principais autoridades. ${ }^{153}$

Apesar dessa difícil realidade, o governo joanino priorizou uma política que impulsionasse os estudos científicos e a carreira militar dentro e fora desse importante espaço de cultura científica. O destaque foi a valorização das ciências matemáticas que, segundo Elaine Duarte, congregaram a raiz do "matemacismo" dentro da Academia. ${ }^{154} \mathrm{O}$ estatuto de 1810 já definia a política de premiar os "discípulos que se distinguirem pela sua aplicação e

${ }^{152}$ Regulamento para os Hospitais Militares de Sua Alteza Real O Príncipe Regente Nosso Senhor, em tempo de Paz, como tempo em tempo de guerra. Lisboa: Impressão Régia, 1805.

${ }^{153}$ Ibid., p. 21. Os artigos V., VI., e VII. do Titulo Segundo intitulado "Do Físico e Cirurgião mor dos Exércitos" assim determinavam as suas funções. "V. O físico Mór publicará, quanto antes, um Tratado, ou Instruções Gerais de Higiena [sic] Militar, que sendo apresentado ao Ministro da Guerra, e merecendo a sua Aprovação, será impresso, e distribuído a todos os Oficiais Generais, Coronéis, e Cirurgiões Mores dos Regimentos, para que o cumpram, e façam executar. VI. O Físico e Cirurgião Mór dos Exércitos serão obrigados a ir visitar todos os Hospitais Militares, examinar com a maior atenção, e cuidado a sua situação, a distribuição e arranjo das Enfermarias, farão todas as investigações precisas para adquirir o maior, e mais exato conhecimento possível da Topografia Medica do País. Estabelecerão em casa Hospital a ordem, disciplina, e polícia determinadas pelo Regulamento. VII. Tanto o Físico, como o Cirurgião Mór dos Exércitos terão uma correspondência seguida com todos os Primeiros Médicos, e Primeiros Cirurgiões Subalternos, para que constantemente se saiba o estado de cada Hospital, e mensalmente o façam presente ao Ministro da Guerra, para prover a tudo o que faltar, e extirpar no seu princípio qualquer abuso, que se tenha introduzido, ou seja relativo ao tratamento dos Enfermos, ou diga relação aos Oficiais da saúde." Como podemos notar, há uma extrema preocupação com a saúde e cuidados físicos com os militares do Império Português.

${ }^{154}$ DUARTE, Elaine Cristina Ferreira. Da Real Academia à escola militar... Op. Cit., p. 19. 
estudo"155 a fim de incentivá-los a dar continuidade aos estudos. Tal impulso era indissociável do principal objetivo real que primava pela manutenção da segurança pública e da grandeza do Estado. ${ }^{156}$ Segundo Beatriz Bueno, um viés prático das atividades dos alunos era, justamente, o estágio no Arquivo Militar durante o período de férias, cujo intuito era o aperfeiçoamento na prática do desenho. ${ }^{157}$

Para animar o progresso das Ciências Matemáticas, de observação e militares, o título XI dos estatutos Dos Partidos e Prêmios deliberava o estabelecimento de três prêmios de duzentos e cinquenta mil réis cada, que eram referentes à produção intelectual dos discípulos do estabelecimento, circunscrita a "melhor e mais profunda memória com alguma descoberta ou útil aplicação em cada uma das ciências já apontadas". ${ }^{158}$ Ou seja, os próprios alunos eram vistos pelo governo joanino como produtores de conhecimento científico em potencial, até porque o estatuto justificava que estas memórias poderiam ser propostas em matéria se fosse conveniente à Academia. Como bem analisou a historiadora Elaine Duarte, a partir da segunda metade do éculo XVIII, as Academias Militares se inseriram nos moldes da ciência iluminista, ou seja, como espaço de produção científica de viés pragmático em que a experimentação e a prática eram os principais caminhos para o desenvolvimento do saber, resultante da fusão entre a física e a matemática por uma perspectiva prática. Esta nova concepção privilegiava a formação de um novo tipo de oficial. ${ }^{159}$ Ademais, ainda segundo a mesma autora, era para a

\footnotetext{
155 Carta de lei de 04 de dezembro de 1810.

156 Ibid.

157 BUENO, Beatriz. Desenho e Desígnio... Op. Cit., p. 237.

158 Carta de lei de 04 de dezembro de 1810.

159 DUARTE, Elaine Cristina Ferreira. "Academia Militar do Rio de Janeiro:..., Op. Cit., p. 242.
} 
"mocidade militar" que o estatuto era dirigido. A esse seleto grupo, "caberia não apenas uma formação científica, mas também uma formação moral" que dependia, na visão oficial, da "conservação dos saberes, da postura e dos sentimentos que se esperava encontrar na oficialidade do exército". ${ }^{160}$

Portanto, neste espaço, a Coroa visava formar os homens de ciência do novo Império, cuja missão era contribuir para a formação de uma esfera pública de divulgação e debate de novos saberes que atravessariam o Atlântico delineando, simbolicamente, a força e independência da nação luso-brasileira. Como bem denominou Marco Morel ao estudar o perfil dos colaboradores d'O Patriota, neste momento destacava-se no Brasil a figura do militar-cientista. Vinculados às atividades do Estado, segundo Morel, estes homens "enquadravam-se nas formas vigentes dos espaços públicos, sem abrir mão, porém, de tentar reforma-los, pela propagação das luzes do saber e da ciência, por meio do ensino, da palavra impressa, e da atuação administrativa." ${ }^{161}$ Apesar da intensa repressão da Coroa às Academias ilustradas no período colonial, o raiar do século dezenove já delineava uma mudança de posição política governamental em relação a tais espaços. Mesmo fortemente alicerçada aos interesses do Estado português, a Real Academia Militar já aparecia como um centro de dinamização do saber científico em várias frentes do conhecimento: da teoria metafísica da ciência ao pragmatismo de novas construções civis e militares por todo o território brasileiro, o novo locus era agora exaltado pelos detentores do poder. Ademais, seguia a tendência internacional da época, com destaque para a Europa e Estados Unidos, em que se priorizava a profissionalização e burocratização

${ }^{160}$ Ibid., p. 31-32.

161 MOREL, Marco. “Pátrias Polissêmicas:..., Op. Cit., p. 30. 
da carreira militar, mormente depois das guerras napoleônicas. Segundo Elaine Duarte, depois de 1815 “a maioria dos países ocidentais criou academias militares, abolindo ou relaxando as restrições quanto ao ingresso no corpo de oficiais". ${ }^{162}$ Tradicionalmente, os postos militares na Europa foram circunscritos à nobreza.

Para além da recompensa em dinheiro, os discípulos premiados ainda teriam seus trabalhos acadêmicos publicados pela Tipografia Real. Segundo os pesquisadores Rubem Borba de Moraes e Ana Maria Camargo, "o papel da Impressão Régia foi preponderante na divulgação dessas ciências e no auxílio que prestou ao ensino superior." Ao referirem-se especificamente à Academia Real Militar, os autores destacam a amplitude da política cultural governamental:

[...] não bastava criar a Academia e nomear os lentes; era preciso ter livros para os alunos. Surgia no Brasil o problema do livro didático. Para resolvê-lo, a Impressão Régia publicou uma série de manuais franceses "para uso dos alunos". O empenho do governo em resolver o problema é tão patente, que em 1809, antes mesmo de fundar a Academia Militar, já se providenciara a abertura das chapas para as gravuras do ELEMENTO DE GEOMETRIA, e se publicara o TRATADO DE TRIGONOMETRIA, ambas as obras de Legendre. ${ }^{163}$

As obras acima citadas foram traduzidas por Manuel Ferreira de Araújo Guimarães, à época Capitão do Real Corpo dos Engenheiros e Lente de matemática da Real Academia dos Guardas-Marinhas. Esta informação saía a publico em um aviso da

${ }^{162}$ DUARTE, Elaine Cristina Ferreira. “Academia Militar do Rio de Janeiro:..., Op. Cit., p. 242.

163 CAMARGO, Ana Maria de Almeida e MORAES, Rubens Borba de. Bibliografia da Impressão... Op. Cit. Vol.1, p. XXIII-XXIV. 
Gazeta do Rio de Janeiro de 1809, em que especificava as razões das impressões: eram destinadas "para o uso da Academia Militar", e representavam o "Paternal cuidado de S.A.R. na educação de seus Vassalos." ${ }^{164}$ Assim sendo, ao iniciarem o curso, os alunos já contavam com obras traduzidas pelos professores da Academia; atitude que explicita ainda mais a política cultural voltada para o aprimoramento do ensino e da produção científica que, neste caso, estava direcionada exclusivamente para a estruturação e funcionamento da Academia Militar, um espaço de saber tido como de grande consideração pela Coroa. Como bem nos lembra a pesquisadora Alessandra R. de Oliveira Harden, "na virada do século XVIII para o XIX, a tradução de textos científicos e técnicos era uma questão de estado para o governo português"165 sendo indissociável de uma concepção utilitarista da ciência, uma das marcas da Ilustração portuguesa. Ao considerar Manoel Jacinto Nogueira da Gama como tradutor "de relevância única para a historiografia da tradução luso-brasileira" por este ter abordado em seus paratextos os benefícios da atividade para o progresso científico ${ }^{166}$, a autora situa a sua ampla função para o Império Português, destacando que aos tradutores cabia a imensa tarefa de disponibilização do amplo conhecimento científico nas diversas áreas do saber, mormente o estudo das coisas do mundo natural, tão em alta no período. ${ }^{167}$

Neste quesito, o matemático baiano Manuel Ferreira de Araújo Guimarães (1777-1738) foi o docente mais ativo. Aliás, Araújo Guimarães teve uma vida de grande atividade intelectual

164 GRJ.1809, n. 115.

165 HARDEN, Alessandra R. de Oliveira. "Manoel Jacinto Nogueira da Gama: Ciência e tradução no final do século XVIII". Tradução em Revista. n. 9, 2010, p. 1.

166 Ibid., p. 2.

167 Ibid., p. 12. 
e política no Império Português tendo se destacado desde a época de sua formação acadêmica em Lisboa - onde foi aluno e lente da Academia Real da Marinha do Reino -, período em que já adentrara na seara da tradução. ${ }^{168}$ De acordo com Harden, no período a tradução "era uma atividade temporária, a porta de entrada para uma carreira na administração do império colonial português", que delineava as bases para uma futura vida pública, já que se tratava de uma atividade de grande reconhecimento por parte da Coroa. ${ }^{169}$

No caso de Guimarães, foi exatamente o que aconteceu. Já no Brasil, tornou-se um renomado homem de letras e de ciências, atuando como lente das Academias da Marinha (1808-1811) e Militar (1812-1821), além de ter sido o principal redator da Gazeta do Rio de Janeiro (1812-1821) e fundador de O Patriota (18131814). ${ }^{170} \mathrm{~A}$ contar por todas as atividades e ramos em que Guimarães atuou durante a governança joanina, o lente mostrou-se um súdito profundamente fiel, sendo uma das personalidades que mais contribuiu para o florescimento do espaço público no Brasil. Durante os anos em que assumiu a cadeira do $4 .^{\circ}$ ano da Academia Militar, foi elevado ao posto de Brigadeiro; chegando a Coronel, em 1821. ${ }^{171}$ Também dividiu com José Saturnino da

\footnotetext{
168 SILVA, Maria Beatriz Nizza da. A Gazeta do Rio de Janeiro: cultura e sociedade. Rio de Janeiro: EdUERJ, 2007. p. 13. De acordo com o pesquisador José Carlos de Oliveira, nesse período Guimarães foi responsável pelas seguintes traduções: Curso Elementar e Completo de Matemáticas puras de Lacaille; Explicação da Formação e uso das Tábuas Logarítmicas do Abadde André Marie Legendre (1802); Tratado Elementar de Análise Matemática de J.A.J Cousin (1802).

169 HARDEN, Alessandra. "Manoel Jacinto Nogueira da Gama... Op. Cit., p. 16.

170 Para a atuação de Araújo Guimarães como redator da Gazeta do Rio de Janeiro ver MEIRELLES, Juliana. Imprensa e poder... Op. Cit., Cap. 2. (p. 91-146) e Cap. 3 (p. 202-225).

171 BLAKE, Augusto Vicctorino Alves Sacramento. Dicionário Bibliográfico Brasileiro. Rio de Janeiro: Conselho Federal de Cultura, 1970, Vol.6, p. 75.
} 
Costa Pereira o status de ser um dos principais nomes da primeira geração de oficiais e de professores da Academia Militar. ${ }^{172}$

Quanto às obras por ele traduzidas, para além das já anteriormente citadas, destacamos: Complementos dos Elementos de Álgebra de Lacroix (1813) e Tratado Elementar de Trigonometria Retilínea e Esférica e da Aplicação da Álgebra à Trigonometria de Lacroix (1821). As obras Variação dos Triângulos Esféricos (1812), Elementos de Astronomia (1814) e Elementos de Geodésia (1815) são de sua autoria e foram escritas para o uso dos alunos da Academia. Especificamente sobre a publicação de Triângulos Esféricos, Ana Maria Camargo e Rubem Borba de Moraes nos chamam a atenção para o fato de ser "o primeiro trabalho original de ciência escrito por um brasileiro, impresso no Brasil." ${ }^{173}$ Em uma petição de 1812, Guimarães exaltava a sua atividade perante os seus pares:

Fui o primeiro que imprimiu nesta corte uma obra matemática, com artistas inteiramente ignorantes deste gênero, com imenso trabalho, incômodo de minha saúde e até despesa, devendo-se à minha assiduidade não só uma edição mais correta do que fora de esperar, mas a habilitação dos compositores para a continuação de semelhantes trabalhos. ${ }^{174}$

Para Maria Beatriz Nizza da Silva, esta representação pública de Manuel Ferreira teve o intuito de angariar uma promoção na carreira, uma vez que ao ser transferido da Academia dos

${ }^{172}$ DUARTE, Elaine Cristina Ferreira. Da Real Academia à escola militar... Op. Cit., p. 89.

173 CAMARGO, Ana Maria de Almeida e MORAES, Rubens Borba de. Bibliografia... Op. Cit. Vol.1, p. XXIV. Neste particular, concordamos com a ótica de Marco Morel de que Guimarães foi um dos primeiros intelectuais profissionais nascidos no Brasil, no sentido gramsciano do termo. MOREL, Marco. "Pátrias Polissêmicas..., Op. Cit., p. 25.

174 BNRJ. Ms., I-28, 32, 13. 
Guardas-Marinhas para a Academia Militar, em 1812, não obtivera nenhum posto superior. Segundo a pesquisadora, o documento ainda revela as qualidades que a Coroa ambicionava de um lente dessa instituição de ensino: a tradução das obras indispensáveis ao curso, a elaboração de compêndios e a atualização permanente na sua área de especialidade. ${ }^{175} \mathrm{E}$ de fato, Guimarães parecia tentar cumprir as suas funções. Em março de 1813, poucos dias antes do início das aulas, o lente fazia o seguinte pedido à Junta Militar:

Estando próxima a abertura da Academia, e havendo Discípulos habilitados para o $4^{\circ}$ ano, acho no meu dever por na Presença de V. Ex. ${ }^{a}$ o estado em que estão os Compêndios respectivos. A Ótica e a Astronomia se acham em metade, e a Geografia em pouco menos: nas 25 estampas, que são necessárias, nem uma se mandou ainda fazer nem creio que se mandem, porque em razão da grande dívida em que a Casa está com o abridor, este recusa gravar novas estampas. Daqui nasce um embaraço que me parece muito atendível, e que pode servir para governo de V. Ex. ${ }^{a}$ e Senhorias [sic], de cujas luzes se devem esperar as mais acertadas providências.

Deus Guarde V. Ex. ${ }^{a}$ e Senhorias [sic] com a prosperidade Acadêmica, e aumento das ciências. ${ }^{176}$

O pedido nos coloca diante de uma grave situação interna da Academia: mesmo com o trabalho das traduções - na maioria de obras francesas, consideradas à época a grande referência para os leitores especializados -, a falta de material científico de qualidade para o uso dos discípulos ainda era uma realidade.

175 SILVA, Maria Beatriz Nizza da. Cultura luso-brasileira:... Op. Cit., p. 66-67.

176 Ofício de Manuel Ferreira de Araújo Guimarães à Junta Militar (Carlos Antonio Napion, João Manoel da Silva e Manoel Jacinto da Gama), em 12 de março de 1812. ANRJ. IG3-2, (sem numeração de páginas). 
Para além das obras traduzidas, a questão da produção do conhecimento científico - no caso os Compêndios -, tinha grande relevância. Segundo Alessandra Harden, os homens de ciências da época "passaram a considerar justo registrar suas descobertas e experimentos em suas próprias línguas". Esse processo, apregoa a autora, "deve ser entendido dentro do movimento de fortalecimento dos estados nacionais e que contribuiu para a valorização das línguas vernáculas", o que dava a chance de esses sujeitos construírem seu próprio discurso científico. Esta tomada de posição também representava uma crítica dos ilustrados luso-brasileiros ao monopólio linguístico francês. ${ }^{177}$ Se por um lado vemos o vivo interesse de alguns docentes, como Guimarães, por outro, o relato do memorialista anônimo nos aponta o descaso de muitos professores diante da mesma atividade:

Abriu-se a Academia em 1811 e ainda se apostila em 1815! Quatro anos não bastaram para a tradução de um volume em $4^{\circ}$, e sua impressão! Não falarei da tradução que os discípulos vão copiando, é meio francesa, environantes [sic], atacados, passo de souvir, e outras imensas expressões Francesas: que erros de linguagem ou de ortografia! Com tanto é feito por $\mathrm{m}$ [sic] dos deputados da Junta! Ao menos se o lente corrigisse! ${ }^{178}$

Como sabemos, a responsabilidade da impressão das obras publicadas pela Tipografia Real era subordinada aos oficiais da secretária do ministério dos Negócios Estrangeiros e da Guerra, que esteve sob o comando de Souza Coutinho até 1812. Ao considerar o apelo de Araújo Guimarães digno de representação, a

177 HARDEN. Alessandra. "Manoel Jacinto Nogueira da Gama... Op. Cit., p. 11. 178 Memória Histórica e Política sobre a creação e estado actual da Academia Real Militar... Op. Cit., p. 463-464. 
Junta Militar escreveu para o Conde das Galveias, o substituto interino de Linhares.

Parecendo-nos atendível a representação inclusa do Lente do $4^{\circ}$ Ano desta Real Academia Militar, Manoel Ferreira de Araújo Guimarães levamo-la à Presença de V. Ex. ${ }^{a}$ pedindo-se digne de ordenar ao Diretor da Impressão Régia haja de por toda a atividade na conclusão das Impressões dos Compêndios da Academia, empregando-se na abertura das Estampas o abridor João Caetano Rivara ${ }^{179}$ à quem S.A.R. concedeu uma pensão de $600 \$$ réis com obrigação de fazer as obras, que lhe forem pedidas para a Impressão Régia e Arquivo Militar, e procurando-se que as ditas estampas sejam concluídas com a maior brevidade, mandando-se abrir também para por outros Abridores, à quem haja de satisfazer o seu trabalho. ${ }^{180}$

A morte do Conde de Linhares não só mudou a maneira de gerir a política de alto escalão no governo joanino, como também parece ter contribuído para a desvalorização da Academia

179 João Caetano Rivara foi um destacado gravador português com ampla experiência internacional. De acordo com Felix Avelar Brotero, Rivara viveu no Brasil no período joanino: "O Abridor Rivara logo depois da ausência de S. Mag. e Real Família para o Brasil, partia também para o Rio de Janeiro, e aí foi empregado, e depois em Londres, aonde se demorou até que regressando neste Reino ultimamente tornou a ser admitido no exercício efetivo da Casa de Gravura do Real Museu e Jardim Botânico pela Portaria, que em 11 de Outubro de 1822 me foi expedido pela Secretaria de Estado dos Negócios do Reino, que se acha no Arquivo dos dois Estabelecimentos”. Brotero, Félix de Avelar. Ofícios acerca do jardim botânico da ajuda (1823-1825). BNP. Seção de Reservados. Mss. 31, 41. Para maiores informações sobre a carreira de Rivara, ver PEREIRA, Esteves; RODRIGUES, Guilherme. (Org.) Portugal. Dicionário Histórico, Chorographico, Biographico, Bibliographico, Heraldico, Numistatico e Artístico. Lisboa: João Romano Torres \& Cia - Editores. 1885, Vol. VI., p. 316.

${ }^{180}$ Ofício de encaminhamento da Junta Militar para o Conde das Galveias sobre o pedido de Manoel Ferreira de Araújo Guimarães, em 21 de março de 1812. ANRJ. IG3-2, (sem numeração de páginas). 
Militar pelos seus substitutos. Essa importante perda política, ou "fatal acontecimento", na análise do autor anônimo ${ }^{181}$, causou grandes prejuízos para a continuação do "bom desenvolvimento" da instituição. Ao comunicar ao pai o falecimento de Linhares, Luís Joaquim dos Santos Marrocos referenciava a transição ministerial do momento que parecia sofrer um vácuo político:

É fama que foi daqui Ordem para vir para esta Corte Cipriano Ribeiro Freire, e agora acrescentam que também Dom Miguel Pereira Forjaz para uma das secretarias: o certo é que a dos Negócios Estrangeiros e da Guerra, vaga por morte do conde de Linhares, ainda está interina nas mãos do Conde das Galveias. ${ }^{182}$

A frágil situação do novo ministro joanino foi igualmente alvo de comentários do bibliotecário de D. João. Segundo Marrocos, Galveias convalescia de um "grande ataque de nervos", o que o paralisava politicamente. Os assuntos de sua vida privada pareciam invadir o espaço público. ${ }^{183}$ Neste sentido, ao repudiar o comportamento do político português, o funcionário real também levantava a hipótese da sua provável fraqueza na administração dos negócios públicos. É bom lembrar que a direção geral da Real Academia Militar estava entre uma das funções do ministro da Guerra. Logo, a missiva de Araújo Guimarães, assim como os

${ }^{181}$ Memória Histórica e Política sobre a creação e estado actual da Academia Real Militar... Op. Cit., p. 459.

182 MARROCOS, Luís Joaquim dos Santos. Cartas do Rio de Janeiro... Op. Cit., p. 127. (Carta 20).

${ }^{183} \mathrm{Ibid}$. "É de espantar e de enjoar o vício antigo, e porco deste homem, que a Vossa Mercê não será estranho; pois sendo homem e casado, desconhece inteiramente sua mulher, e nutre a sua fraqueza com brejeiros e sevandijas. Por causa deste vício, em que está mui debochado, tem padecido muitos ataques, que o paralisam totalmente; mas ele confessa que não pode passar sem a sua diária!" (Grifo do Original). 
diversos pedidos da Junta Militar para o Conde das Galveias ${ }^{184}$, parecem corroborar a suposição levantada por Marrocos nessa carta: a morte de Souza Coutinho reiterava sua ingerência em projetos culturais de seu exclusivo interesse, sendo sua morte a principal causadora do início do descrédito do novo locus de saber. Em outras palavras, a Academia Militar tornava-se uma instância cultural que teria pouco empenho político por parte do novo ministro.

No plano internacional, a morte de Linhares impulsionou a saída do Conde de Funchal da embaixada de Londres, que foi substituído por Palmela. ${ }^{185}$ Ademais, entre os anos de 1812 e 1815 as mudanças no cenário europeu foram de grande relevância. Com o fim das guerras napoleônicas (1814), a Paz Geral e o Congresso de Viena (1815), o Velho Mundo passava por um processo de restauração das monarquias absolutistas o que, na prática, significava uma rearticulação das alianças entre as Coroas. Em 1814, D. João saudava Luís XVIII e abria os portos brasileiros ao comércio francês. Esse rearranjo político também norteou a escolha do seu novo ministério na Corte do Rio de Janeiro. Se Galveias foi o nome escolhido pelo regente para substituir interinamente

\footnotetext{
${ }^{184} \mathrm{Na}$ correspondência da Junta Militar para o Conde de Galveias, uma carta nos chama a atenção. Na missiva de 21 de março de 1813, a Junta encabeçava o pedido de José Saturnino da Costa Pereira (professor do terceiro ano) e do físico Luís Antonio da Costa Barradas para que o ministro agilizasse o processo de conserto das máquinas necessárias ao ensino d’Academia. Diziam: “[...] sendo de agrado de V. Ex. ${ }^{\text {a }}$, se digne ordenar que no Arsenal Real do Exército se consertem, e aprontem as Máquinas, e Modelos, que forem necessários à Academia Rela Militar, tirando-se partido das que vieram para esse fim, e se acham em poder do Inspetor Geral do Arsenal Militar”. ANRJ. IG3-2. (Sem numeração de páginas).

185 Sobre a difícil transição ministerial portuguesa na embaixada de Londres, ver LIMA, Oliveira. D. João VI no Brasil...Op. Cit., p. 303-306.
} 
o Conde Linhares ${ }^{186}$, a partir de 1814 o principal ministro de D. João seria o Conde da Barca, que ao sair de um longo exílio político, enfim, pôde expressar publicamente sua francofilia entre os anos de seu ministério (1814 a 1817), como no caso da chegada da comitiva dos artistas franceses em $1816 .{ }^{187}$

Araújo de Azevedo era assaz diferente de Souza Coutinho. Como o seu antecessor, também era um erudito com ampla experiência internacional, porém, sua política em relação à cultura era mais voltada para o âmbito das artes, das belas letras e da história natural. Mesmo sendo um experiente diplomata, o avanço do conhecimento intrínseco à arte da guerra parece ter ficado em segundo plano ${ }^{188}$, até porque, como já dissemos, desde 1815 a Europa vivia um período de paz. Em 1818, precisamente um ano depois de sua morte, o professor de História Natural da Academia Militar, Francisco José da Costa Azevedo, escrevia para Thomaz

186 Com a morte de Souza Coutinho, em 1812, João de Almeida de Melo e Castro, o Conde das Galveias (1756-1814) foi nomeado ministro e secretário dos negócios estrangeiros e da Guerra, acumulando este cargo com a Secretaria dos Negócios da Marinha e dos Domínios Ultramarinos, da qual já era titular desde 1809. Manteve-os até a sua morte, em 1814, altura em que permanecia na condição de membro do Conselho de Estado. De acordo com a historiadora Ismênia Martins, Galveias foi um importante "defensor do Rio de Janeiro como centro político, econômico e social do reino português, sendo que suas correspondências revelam que "desde 1812, foi favorável à elevação do Brasil à condição de Reino”. MARTINS, Ismênia de Lima. In: NEVES, Lúcia; VAINFAS, Ronaldo. Dicionário do Brasil joanino...Op. Cit., p. 256-259.

187 Sobre as relações diplomáticas de Araújo com a França depois da Paz Geral, ver: SCHWARCZ, Lilia M. O sol do Brasil:... Op. Cit., p. 173.

188 Sobre os principais interesses do Conde da Barca enquanto viveu no Brasil, o pesquisador Antonio Pedro de Sousa Leite destaca as atividades científicas, como o seu laboratório químico, a instalação de uma fábrica de porcelanas, além de seus experimentos no Jardim Botânico com o chás estrangeiros. LEITE, Antonio Pedro de Sousa. O Conde da Barca e o seu papel em alguns aspectos das relações culturais de Portugal com a Inglaterra e a Alemanha. Braga: edição do autor, 1962. p. 13-42. 
Antonio Vilanova Portugal, informando-o sobre o pedido do então ministro Conde da Barca. Segundo o relato do docente, Araújo de Azevedo havia solicitado o exame e avaliação de uma "Coleção de Conchas, que Francisco Antonio Cabral pretendia vender

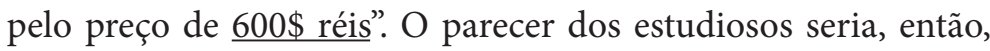
levado à Junta da Direção dos Estudos da Real Academia Militar para que esta resolvesse junto ao monarca a compra "como fosse conveniente". ${ }^{189} \mathrm{O}$ mineralogista ainda informava a Vilanova Portugal que, no que tangia à parte dos membros da Academia, o problema fora resolvido; porém, eles ainda estavam aguardando a resolução de D. João VI para disporem das conchas, já que o negócio do vendedor se encontrava empatado. Sutilmente, por fim, pedia agilidade na finalização de tal pendenga. ${ }^{190}$

$\mathrm{O}$ avanço da História Natural também parecia ser o interesse prioritário de Azevedo no que concerne especificamente à administração da Academia Militar. Em um âmbito mais amplo, o ministro foi um grande incentivador da vinda de naturalistas europeus para o Brasil. Especificamente sobre o tema, o pesquisador Antonio Pedro de Sousa Leite analisa que "este movimento cientifico em torno de tão importante parcela do território nacional, encontrou em Araújo o mais decidido apoio, que se traduziu sobretudo no solícito acolhimento dispensado pelo nosso compatriota a todos os homens de ciência que ao Brasil se deslocaram naquela época". Ainda de acordo com Leite, até Alexander Von Humbold recomendava três naturalistas à sua proteção, fazendo-o

189 Ofício de Francisco José da Costa Azevedo para Thomaz Ant. Vilanova Portugal, datado de 29 de junho de 1818. ANRJ. IG3-2. (sem numeração) (Grifos do Original).

190 Ibid. 
em consideração ao elevado prestígio do ministro português nos meios científicos franceses e alemães. ${ }^{191}$

$\mathrm{Na}$ documentação pesquisada, notamos que a correspondência entre a Junta Militar e os diferentes ministros dos Negócios Estrangeiros e da Guerra joaninos, além de uma prática habitual, compunha uma importante atribuição desses homens de Estado. Porém, a correspondência disponível ou preservada nos revela um dado muito curioso: durante o ano de 1817, período em que Azevedo esteve na direção de tal ministério, não encontramos nenhuma carta dirigida diretamente ao ministro. Tal fato nos coloca diante da hipótese do pouco interesse do Conde da Barca para com essa instituição régia ou, quiçá, de um conflito político entre os componentes da Junta Militar e Araújo Azevedo. Consideramos também a hipótese da perda de documentação, ou ainda, a carência de estudos historiográficos sobre este viés. De qualquer forma, é imprescindível lembrar que o projeto da Academia em questão era de autoria de d. Rodrigo de Souza Coutinho, o principal desafeto político de Azevedo. Por esse prisma, é bem plausível que os aliados do ministro anglófilo mantivessem as disputas e dificuldades no trato público com o Conde da Barca. Em uma publicação de 1820, o Conde de Funchal sob o pseudônimo de "R. da C. Gouvea"192, acusava Araújo de Azevedo de perseguir Linhares e seus amigos políticos. Segundo Funchal, Araújo de Azevedo

Denunciou muito em segredo o Conde de Linhares enquanto era vivo, perseguiu a sua memória depois de morto,

191 LEITE, Antonio Pedro de Sousa. O Conde da Barca... Op. Cit., p. 42.

192 BASTOS, Débora. "A trajetória de Domingos Antonio de Sousa Coutinho: o Conde de Funchal (1760-1833)”, p. 8. In: http://www.ecsbdefesa.com.br/defesa/ fts/TDAC.pdf . Acesso em: 18 nov. 2012. 
cevou a sua vingança imponente contra ele, em tudo quanto lhe pertencia pelos vínculos mais estreitos da natureza e da sociedade. Reentrando no Ministério, recolheu dentro de sua pequena alma as poucas forças que lhe restavam espalhadas por membros já cacheticos [sic], e em breve paralíticos, para brandir e voltear arremessões de Autoridade Real contra D.D. [D. Domingos de Souza Coutinho] até ver se podia com o peso d'ela esmagá-lo. ${ }^{193}$

Em agosto de 1816, a Junta Militar escrevia diretamente a D. João, rogando-lhe que ponderasse sobre a frágil situação da Academia, principalmente no que se referia à falta de docentes.

Este estado sobremaneira violento, e por certo danoso ao Real Serviço, pode de um instante para outro pode piorar ainda e consideravelmente se V. Majestade se não dignar prontamente de dar as precisas providências para remediar o mal presente, e atalhar os danos futuros. Sendo da obrigação da junta indicar a V. Majestade os meios que lhe parecem mais próprios para tirar a Academia desta urgente situação tem ela a honra de levar a Soberana Presença de V. Majestade o requerimento incluso de Luís Antonio de Mello[,] Tenente Assistente do Quartel, Mestre General da Divisão dos Voluntários Reais: o qual pretende entrar na Academia Real Militar em qualidade de Lente. ${ }^{194}$

Para além de qualificar o currículo do novo lente - formado em matemática pela Academia Real da Marinha de Lisboa

193 GOUVEA, R. da C. "Resposta pública à denúncia secreta que tem por título 'Representação que sua majestade fez Antonio de Araújo de Azevedo em 1810' oferecida ao juízo do público e da posteridade”. Londres: Oficina de R. E. A. Taylor, 1820, p. 2-3.

194 Ofício da Junta Militar composta por Garção Stockler, João Manoel da Silva e Manoel Jacinto de Nogueira da Gama para o Príncipe Regente D. João, em 28 de Agosto de 1816. IG3-2. (sem numeração de páginas). 
além de ter se especializado em Arquitetura Militar, Tática, Artilharia, e Hidráulica na Academia Real Militar do Reino -, a Junta ainda destacava que este fora elevado "pelo seu mérito" ao posto de Segundo-Tenente do Real Corpo de Engenheiros. Ademais, serviu igualmente por cinco anos de forma voluntária e gratuita no Colégio Militar de Portugal como lente de Matemática e Fortificação. Segundo a Junta Militar, toda a experiência do novo docente era comprovada por "honrosos e autênticos documentos". ${ }^{195}$ A extensa correspondência explicava em detalhes a situação da Academia. As cadeiras de Cálculo e Mineralogia estavam vagas, o que forçou o professor de História Natural a assumir também a disciplina de Mineralogia. Ademais, o mestre do segundo ano ausentara-se por conta de uma diligência do Real Serviço, tendo no seu lugar um lente substituto. Também o docente de física, Luís António Barradas, encontrava-se doente, o que o impossibiliva de lecionar. Por fim, a morte do professor substituto Vasco José de Paiva, Tenente-Coronel do Real Corpo d' Engenheiros, tornava a situação caótica. Eis como termina o lamento dos diretores da Instituição:

Em consequência de todos esses acontecimentos foi forçoso suspender as Lições de Física: encarregar o Lente a cujo cargo estava a Cadeira de Geometria descritiva, da regência da Cadeira do segundo ano militar: e determinar que o Lente do quarto ano Mantemático se encarregasse também da regência da Cadeira do primeiro. ${ }^{196}$

Como podemos notar, a correspondência da Junta Militar com os ministros reais e com D. João é uma documentação riquíssima. A partir dela é possível que conheçamos não apenas

195 Ibid.

196 Ibid. 
a estrutura interna da Academia, mas também seus desafios cotidianos para mantê-la em funcionamento de acordo com as diretrizes do decreto régio de 1810 , assim como a disputa de poder que envolvia muitos sujeitos históricos: os ministros reais, os dirigentes do locus (Junta Militar), os docentes e, por fim, os alunos. Diante dessa complexa teia de relações sociopolíticas, notamos o esforço da Junta Militar de colocar em vigor a política de premiações. Em 20 de março de 1813, por exemplo, a Junta informava ao Conde das Galveias os discípulos que haviam se destacado no ano de 1812. Os premiados do segundo ano eram o Major do Estado Maior Luís Antonio de Abreu e Lima, o tenente da Artilharia da Corte João Paulo dos Santos, e o Tenente da Artilharia do Pará Diogo de [ilegível] Vasconcellos Cabral. Aos matriculados do terceiro ano, também eram premiados Firmino Herculano de Moraes Ancora, Manoel José de Oliveira, e João Carlos Pessoa, todos Primeiros-Tenentes de Artilharia da Corte. ${ }^{197}$ Já em dezembro de 1816, a Junta Militar noticiava o Marquês de Aguiar, então ministro da Guerra ${ }^{198}$, sobre uma querela interna referente à insubordinação do Lente de Desenho, o qual autorizava seus alunos a fazerem os exames sem terem frequentado as aulas. Segundo a Junta, tal atitude feria o decoro da Corporação dos lentes uma vez que

[...] só servia de [sic] demonstrar a inconsideração, com que o Professor, carecendo de direção sobre o modo de

197 Ofício de encaminhamento do mapa referente ao ano de 1812 para o Conde de Galveias. O documento foi assinado pela Junta Militar (Carlos Antonio Napion, João Manoel da Silva e Manoel Jacinto da Gama), em 20 de março de 1812. ANRJ. IG3-2, (sem numeração de páginas).

198 Depois da morte do Conde de Galveias, em 1814, Fernando José de Portugal e Castro (Marquês de Aguiar) assumiu o posto de Ministro dos Negócios Estrangeiros e da Guerra, dirigindo-o até o final de 1816. 
desempenhar os seus deveres, em vez de recorrer à Junta por sua Majestade criada para este efeito, preferiu entender-se com o lente do Sétimo Ano, cujos conselhos adotou como regra legítima de sua conduta. ${ }^{199}$

Para a Junta, o "espírito de insubordinação que vai ganhando neste Régio Estabelecimento" devia ser rigidamente punido por ser contrário às bases que norteavam a disciplina miltar, isto é, o absoluto respeito à hierarquia. Sob essa ótica, exaltavam o comprometimento de todos os envolvidos na defesa da ordem interna para preservar, consequentemente, a ordem pública. Alegavam ainda que sem esta premissa a existência útil do espaço ficava seriamente ameaçada. Para tanto, o chefe da Academia deveria ser "munido de um proporcionado grau de instrução e autoridade, para punir as faltas de seus súditos" através de castigos, considerados a melhor forma de correção. ${ }^{200}$

A concepção dos dirigentes militares revelava um traço muito forte da sociedade de corte: o valor à subordinação, compreendida como "ordem estabelecida entre certas pessoas, pelas qual uns dependem das outras que lhe são superiores, e tem o direito de as dirigir [sic]". ${ }^{201}$ Se a quebra da máxima de respeito à ordem monárquica fora transgredida, colocava-se em xeque também o poder da instrução, do arbítrio e, em última instância, da condução (e sucesso) do projeto político da Coroa, a salvaguarda da integridade imperial. Por essa razão, a Junta alertava o monarca para que tomasse medidas urgentes. É bom lembrar que esse fato ocorreu às vésperas de 1817, quando a crítica política ao Antigo Regime Português tomaria feições mais dramáticas

199 Ofício da Junta Militar para o Marquês de Aguiar, em 20 de Dezembro de 1816. ANRJ. IG3-2, (sem numeração de páginas).

200 Ibid.

201 Verbete Subordinação. Dicionário Moraes e Silva, Vol. 2, p. 732. 
nos dois lados do oceano. Nomeadamente, no Brasil, a Revolução Pernambucana de caráter republicano; em Portugal, a Conspiração de Gomes Freire.

Aqui fazemos uma importante ressalva sobre a revolta lusitana. De forte influência maçônica, a contestação foi de caráter estritamente militar e reuniu jovens oficiais insatisfeitos com os governadores do Reino e a sua submissão política aos militares ingleses no país, sob a direção de Beresford. Ademais, os revoltosos tiveram na figura de Gomes Freire o seu principal líder. "Freire tornara-se o confidente, o polo de confluência dos militares afastados ou licenciados por Beresford, de todos os descontentes" contextualiza o pesquisador Fernando Pereira Marques. A situação era alarmante: o atraso no pagamento dos soldos era uma grave realidade, sendo que o Real Erário não tinha meios financeiros para saná-la: “[...] por vezes uma parte dos tratamentos é paga em papel, e sucedem casos em que a alimentação falta aos soldados e aos subalternos", comenta o historiador. ${ }^{202}$

O movimento foi violentamente reprimido por Beresford e o governador D. Miguel Pereira Forjaz. Os envolvidos foram executados em praça pública e passaram à História como os "mártires da pátria". Segundo Marques, a repressão deixou Lisboa horrorizada: desde a execução dos Távora a cidade não assistia a um bárbaro espetáculo. Pela ótica de Forjaz e Beresford, era "necessário fazer uma demonstração de força, feroz e eloquente" que acabasse em definitivo com "com o espírito de rebelião que aumenta[va] por todo o lado" e colocava em causa a vigência do regência portuguesa, que dependia dos militares ingleses. ${ }^{203}$

${ }^{202}$ MARQUES, Fernando. Exército e sociedade em Portugal... Op. Cit., p. 180.

203 Ibid., p. 185-186. 
De fato, ao tornarem-se "o símbolo da revolta necessária"204, os insurgentes expunham uma situação política delicadíssima: a Coroa já não contava com o apoio incondicional do exército para a manutenção do Império Português no Velho Mundo. Começava a ruir uma de suas principais bases de sustentação em Portugal.

Deste lado do Atlântico, os anos de 1817 a 1821 foram de grande instabilidade política. Com a morte do Conde da Barca, Thomaz Antonio Vilanova Portugal despontava como o principal ministro de D. João. Com amplos conhecimentos de jurisprudência e economia política, Vilanova Portugal reuniu sob sua direção “o reino, o erário, os negócios estrangeiros e a guerra”. Entre os anos de 1818 e 1821 sua administração foi tão próxima ao monarca que Oliveira Lima o denominou de "ministro universal de um rei absoluto". ${ }^{205}$ Nesses anos, a efervescência política parecia também atingir a estabilidade da Academia Militar. Em 01 de janeiro de 1819, seus diretores remetiam a Vilanova Portugal o mapa referente ao resultado dos trabalhos realizados em 1818. As conclusões não eram nada animadoras:

[...] Nas diversas aulas da Academia apenas se matricularam sessenta e seis Discípulos [,] dos quais trinta perderam o ano, cinco não fizeram exame e um foi reprovado, vindo assim a aproveitar-se apenas trinta e três. Não houve quem frequentasse as aulas do sexto ano; e ninguém frequentou nem pôde frequentar a de Física, porque a correspondente Cadeira permanece vaga, apesar das representações e propostas da Junta da Direção da Academia.

É evidente a decadência em que vai este Estabelecimento, ainda comparando o ano letivo de 1818 [a]o de 1817 não

204 Ibid., p. 186.

${ }^{205}$ LIMA, Oliveira. D. João VI no Brasil... Op. Cit., p. 152. 
obstante o extraordinário motivo que então ocasionou a interrupção dos estudos de parte dos seus Alunos. ${ }^{206}$

Para além de apontar as causas do declínio do espaço de educação, a Junta referia-se ao impacto político da Revolução Pernambucana no Império Português, sobretudo em relação às providências governamentais para conter as consequências do movimento: entre elas, estavam o envio de oficiais militares para abolir a semente contestatória de caráter republicano no nordeste do país. "A revolução de 1817 acarreta o trancamento de matrícula de muitos alunos, que recebem ordem para seguir integrando as forças enviadas contra os revoltosos. Até professores deixaram suas cátedras e partiram com idêntico destino", informa Jehovah Motta. ${ }^{207}$ Os problemas políticos pareciam influir diretamente no declínio pedagógico da Academia. Com isso, a Junta Militar finalizava a carta com as informações acerca de sua atuação: as representações sobre os "defeitos inerentes a esta Régia Instituição", as propostas para saná-los, e a espera da consideração de D. João VI para "providenciar [as soluções] como convém ao bem do Seu Real Serviço" ${ }^{208}$ Sobre a formação intelectual dos militares, José Carlos de Oliveira ressalta que "a preocupação de elevação do nível científico dos oficiais do exército não se fazia sentir como algo objetivo e desejado pelos próprios oficiais", uma vez que estes "certamente não viam ganhos significativos nem financeiros ou práticos, já que diziam persuadidos de sua inutilidade para galgar postos superiores". ${ }^{209}$

\footnotetext{
206 Ofício da Junta Militar para Thomaz Antonio Vilanova Portugal, em 01 de janeiro de 1819. ANRJ. IG3-2 (sem numeração).

207 MOTTA, J. Formação do oficial do exército... Op. Cit., p. 36-37.

208 Ofício da Junta Militar para Thomaz Antonio Vilanova Portugal... Op. Cit.

209 OLIVEIRA, José Carlos. D. João VI, adorador do Deus das ciências?... Op. Cit., p. 197.
} 
Para além do pequeno número de discípulos, tinham que lidar cotidianamente com o problema da indisciplina. Para contê-la, a Junta Militar não hesitou em solicitar auxílio à Vilanova Portugal. Em meados de 1820, pediam os dirigentes da instituição ao ministro:

Que sua Majestade autorize para ordenar a sentinela do Corpo de Polícia que todos os dias se forem à porta da entrada da Academia, que logo que veja praticar daquela porta para dentro qualquer desordem entre os Discípulos; prenda os que nela tiverem parte à/ ordem de V. Ex. ${ }^{a}$ como Inspetor da Academia, e conduzindo-os ao Corpo de Guarda daí sejam remetidos para a Cadeia pública da onde não sejam soltos sem ordem de V. Ex. ${ }^{\text {a }}{ }^{210}$

Muito provavelmente, o temido espírito de insubordinação tornava-se recorrente dentro dos corredores da instituição. Tal situação era intrínseca à grave crise política enfrentada pelo Império Português: a crítica ao status quo ganhava cada vez mais a arena púbica, tornando-se objeto de discussão entre os súditos reais. Dentre eles, há que se destacar a importância social dos militares, cuja condição legitimava uma relação mais próxima com o monarca. "Ao conceder a graduação [o Rei] concedia também um estatuto social que modificava a estratificação tradicional. A nobilitação, o reconhecimento da importância de certas situações profissionais ou sociais, era função do serviço do Estado", conceitua o pesquisador Fernando Marques. ${ }^{211}$ Como já apontou José Carlos de Oliveira, foi "notória a instabilidade e fragilidade do cotidiano na Academia Real Militar.".12 Portanto, às vésperas

\footnotetext{
${ }^{210}$ Ofício da Junta Militar para Thomaz Antonio Vilanova Portugal.... Op. Cit.

211 MARQUES, Fernando. Exército e Sociedade em Portugal... Op. Cit., p. 53.

212 OLIVEIRA, José Carlos. D. João VI, adorador do Deus das ciências?... Op., Cit., p. 196.
} 
da Revolução do Porto, também deste lado do Atlântico a direção do locus necessitava da ajuda explícita da Intendência da Polícia para refrear a postura crítica que parecia prevalecer entre seus alunos, principalmente no que concernia ao ideal de respeito à hierarquia e, consequentemente, ao status quo, já tão fortemente abalado depois de 1817. Desde então, "estava nítido, dentro do governo, o perigo da ruptura das relações entre Brasil e Portugal, que atingia a própria condição do soberano e seus vínculos necessários e imprescindíveis com o seu povo, conformado nas Cortes”. ${ }^{213} \mathrm{Na}$ prática, portanto, o princípio máximo de autoridade real e soberania do Império passava a ser questionado.

Os anos de 1820-1821 marcaram transformações profundas na cena política luso-brasileira. No Reino os Vintistas exigiam a convocação das Cortes e faziam-no em nome da "salvação da Pátria". ${ }^{214}$ Ao elevarem a bandeira da monarquia constitucional, os revolucionários colocavam em xeque a concepção do poder absoluto: a luta era em prol de um novo pacto político, no qual o equilíbrio entre os poderes evitaria os males do despotismo. No Manifesto da Nação Portuguesa aos Soberanos e Povos da Europa, as reivindicações se justificavam pelas "luzes do século, e as circunstâncias políticas do mundo civilizado". ${ }^{215}$ Era o sinal dos novos tempos, agora pautado pela emergência do espaço público liberal.

Os ecos da Revolução do Porto deste lado do Atlântico foram amplos e irreversíveis. No raiar do ano de 1821 as adesões das províncias às Cortes, que aconteciam por todo o Brasil com

\footnotetext{
213 SCHIAVINATTO, Iara Lis. Pátria Coroada: o Brasil como Corpo Político Autônomo 1780-1831, Ed. Unesp, 1999. p. 78.

214 LYRA, Maria de Lourdes Viana. A utopia... Op. Cit., p. 171.

215 FERNANDES, Thomaz. Manifesto da Nação Portuguesa aos Soberanos e Povos da Europa, p. 219. Apud. SCHIAVINATTO, Iara Lis Carvalho. Pátria Coroada... Op. Cit., p. 83.
} 
repercussões absolutamente diferenciadas, davam o tom da cena política. ${ }^{216}$ No Rio de Janeiro, especialmente, nasciam novos atores políticos protagonizados pelo grupo dos "liberais", homens que "desde fins do século XVIII, buscavam construir fortunas e ascender na esfera pública" ${ }^{217}$ e se contrapunham aos políticos da alta burocracia portuguesa, representada pela nobreza emigrada, os comerciantes de grosso trato, como a família Carneiro Leão, e os ministros de Estado, entre eles Silvestre Pinheiro Ferreira e Vilanova Portugal.

Na capital do Império duas mobilizações políticas marcariam o os primeiros meses de 1821. Em 26 de fevereiro, a manifestação militar liderada pelos liberais no largo do Rocio ${ }^{218}$ exigia o juramento de D. João VI à constituição de Lisboa e a substituição dos principais ministros de Estado, sendo eles também partidários da monarquia constitucional e da volta do Rei para Portugal. Pacífico, o movimento contou com a maciça adesão dos militares. Em um primeiro momento, os liberais se articularam com as tropas de linha e milícias, que se encontravam

\footnotetext{
216 SILVA, Ana Rosa Cloclet da. Inventando a Nação... Op. Cit., p. 292-299. O Pará foi a primeira província a aderir ao projeto constitucional em $1^{\circ}$ de Janeiro de 1821, seguido do Maranhão e do Piauí. Em 10 de fevereiro era a vez da Bahia. Segundo Cloclet da Silva, "nesta capitania, como na de Pernambuco, o movimento resultou, em grande parte, da ação de brasileiros libertos da revolução de 1817, cujos ânimos conseguiram ser totalmente sufocados pelos esforços dos respectivos governadores locais." (p. 298).

217 OLIVEIRA, Cecília Helena Lorenzini Salles. A astúcia liberal. Op. Cit., p. 107. Entre os principais líderes estavam Joaquim Gonçalves Ledo, Januário da Cunha Barbosa, José Clemente Pereira, Luís Pereira da Nóbrega de Souza Coutinho e Manoel dos Santos Portugal.

218 Para a compreensão dos múltiplos interesses desse grupo, suas divergências políticas e as estratégias de luta ver OLIVEIRA, Cecília, A astúcia liberal... Op. Cit, cap. III. (107-196); NEVES, Lúcia Bastos. Corcundas, constitucionais e pés de chumbo: A cultura política da independência (1820-1822). Rio de Janeiro: Ed Revan, FAPERJ, 2003. Parte II e Parte III (p. 119-285).
} 
"insatisfeitos com a demora para efetivar as promoções e que perceberam, nesta manifestação, um modo de expressar seu desgosto e exigir providências". ${ }^{219}$ As reivindicações das tropas referiam-se aos baixos salários e soldos atrasados; já os soldados portugueses lutavam pelo retorno à Pátria.

A cidade acordava aos tiros de canhões contando com a presença da Artilharia Montada da Corte, o Batalhão de Infantaria português n. 2, o Batalhão de Caçadores n. 3 do exército luso, o Regimento de Artilharia de Guarnição. Além disso, houve adesão de outros batalhões, o que deu ainda mais força ao movimento. ${ }^{220}$ Essa estratégia de grande aparato militar alcançou a vitória almejada. D. João VI aceitou todas as reivindicações, com destaque para o respeito à Constituição.

Em meados de abril de 1821, a radicalização da situação de grande tensão política ainda contava com dificuldades econômicas nada desprezíveis. Em 07 de março D. João havia anunciado a sua volta à Lisboa no mesmo momento em que convocava a reunião de eleitores paroquiais, responsáveis por escolherem os representantes das comarcas que, por fim, elegeriam os deputados para comporem as Cortes. ${ }^{221}$ Em fins de abril, entretanto, a sociedade joanina ainda aguardava a publicação dos decretos assinados pelo Rei, o que causava ainda mais tensão entre os diversos grupos políticos em disputa.

A antecipação em um dia da reunião que garantiria os moldes do governo de D. Pedro (a data oficial era 22 de abril)

\footnotetext{
219 SCHIAVINATTO, Iara Lis. Pátria Coroada... Op.Cit., p. 93.

${ }^{220}$ Relação dos Acontecimentos do Rio de Janeiro em 26 de Fevereiro em 1821 e algumas circunstâncias que o precederam e o produziram. BNP. Seção de Reservados. Cód.10.759.

${ }^{221}$ Para a compreensão desse intrincado sistema eleitoral e interesses políticos em jogo ver OLIVEIRA. Cecília. A astúcia liberal ... Op. Cit., Cap. 3.
} 
provocou graves conflitos entre os liberais e os demais grupos políticos, nomeadamente os nobres emigrados e comerciantes de grosso trato que objetivavam o controle das decisões. Mais uma vez, o espaço público foi palco de uma parada militar. Desta vez, no entanto, o tom não foi nada pacífico. Com o apoio das tropas milicianas e regimentos policiais, os liberais organizaram uma manifestação na Praça do Comércio. Como conceitua Marco Morel, "as praças aparecem como espaços abertos e de certo modo, em aberto, isto é, como passiveis de serem apropriados por determinadas interferências coletivas”. Estes espaços públicos, portanto, ao mesmo tempo em que fixavam identidades também tendiam a transformá-las, como decorrência de uma intensa disputa. ${ }^{222}$

Neste dia a Praça do Comércio também contou com a presença do "povo". 223 Enquanto os liberais defendiam alguns princípios da Constituição Espanhola de 1812, dentre eles o que designava o poder soberano aos cidadãos (que entre outras coisas perpassava a garantia de direitos individuais de propriedade e total liberdade de imprensa ${ }^{224}$ ), o "povo" - composto por mascates, artífices, caixeiros, milicianos, homens pobres livres, sapateiros, professores régios, ourives e outros tantos - atuou ativamente, exigindo que suas propostas políticas também fossem

\footnotetext{
222 MOREL, Marco. As transformações dos espaços públicos... Op. Cit., p. 164-165. ${ }^{223}$ Ibid., p. 165-189. Como nos esclarece Marco Morel, a noção de povo "era estabelecida segundo critérios de representatividade da época, no quadro do liberalismo constitucional e das eleições censitárias e indiretas que serviam para designar os parlamentares." Porém, essa multidão que não possuía direitos políticos representativos, mas que impostavam suas vozes de maneira ativa nas decisões a serem tomadas, já começavam a caracterizar, segundo Morel, a acepção moderna de "Povo", segundo a qual "não apenas os comerciantes, seus agregados e clientes, mas também diferentes camadas da população, que iam marcando presença na cena urbana, como membros das elites letradas e mesmo membros da 'plebe"'

224 OLIVEIRA, Cecília. Astúcia liberal... Op Cit., p. 142.
} 
contempladas, o que desencadeou uma explosão de ânimos. Pela ótica dos liberais, o "povo" deveria compor a multidão na praça sendo, antes, usado como massa de manobra. Porém, ao contrário do previsto, a face de centenas de pessoas alijadas do processo eleitoral passou a ter contornos bem precisos. Devido ao reboliço e ao acirramento de exigências, com pontos de vista díspares e conflituosos, D. Pedro autorizou a atuação repressiva das tropas de linha e de regimento da divisão portuguesa. Segundo o contemporâneo dos fatos José Domingues Moncorvo,

A $6^{\text {a }}$ companhia do batalhão de caçadores de Portugal, tendo a sua testa o major graduado Peixoto, apresentou-se na frente da porta do edifício em linha de batalha com 25 filas de frente, e deu para dentro uma descarga de 50 litros, e logo dobrando filas entraram no salão, e carregaram a baioneta calada os cidadãos desacautelados que se achavam dentro [...]. Outras pessoas do povo foram indistintamente mortas e, um número maior, lançando-se ao mar com precipitação, encontrou nas ondas a morte que evitava. Porém, o que denegria estes soldados desencaminhados e ferozes, foi que, não contentes de tirarem a vida de seus próprios concidadãos, traficavam nelas, recebiam ou roubavam o que achavam de mais precioso, e saquearam os móveis da prata do serviço da casa. ${ }^{225}$

Ao contrário do movimento de 26 de fevereiro, a manifestação de 21 de abril foi violentamente reprimida pelas tropas do governo. $\mathrm{O}$ episódio teve várias versões. ${ }^{226} \mathrm{~A}$ despeito disso, nos

\footnotetext{
225 MONCORVO, José Domingues de Attaíde. "Sobre os acontecimentos dos dias 21 e 22 de Abril de 1821 na Praça do Comércio do Rio de Janeiro. Escrita em Maio do mesmo ano por uma testemunha presencial", In: Revista Trimensal do Instituto Histórico Geográfico e Etnográfico do Brasil, tomo XXVII, parte primeira, Rio de Janeiro, Tipografia Luis dos Santos, 1864. p. 288.

${ }^{226}$ MEIRELLES, Juliana. Imprensa e poder na corte joanina... Op. Cit., p. 204-208.
} 
interessa aqui destacar, mais uma vez, a importância dos militares nesses acontecimentos: como críticos do status quo, em fevereiro, ou mantenedores da ordem, em abril, estes sujeitos históricos alcançaram seus objetivos. Seja pela presença organizada em batalhões, seja pelo uso da força física desmedida. Dentro ou fora dos muros da Real Academia Militar, agindo de forma pacífica ou violenta, a presença desses sujeitos históricos foi decisiva durante todo o período joanino. Não foi à toa que a formação intelectual desses homens foi objeto de tamanha atenção por parte da Coroa portuguesa nos dois lados do Atlântico. ${ }^{227}$ Eles eram os "guardiões da ordem pública", aqueles que deveriam apreender uma específica cartilha pedagógica: do ensino das primeiras letras ao conhecimento científico de ponta. Para os militares do Império Português, teoria e prática eram intrínsecas ao principal desafio governamental: a manutenção do Estado monárquico soberano.

A soberania política do Império Português também contou com um capital simbólico de peso: a constituição das bibliotecas régias nos dois lados do Atlântico. Possuir um locus de cultura que congregasse toda memória possível acerca das grandezas da monarquia foi uma tarefa absolutamente valorizada pela Coroa lusitana, sobretudo em tempos de ilustração. Neste sentido, os livros, os leitores e as múltiplas leituras acerca da realidade vivida apareciam como objeto de constante preocupação. O capítulo que se segue tem como tema justamente o nascimento, estruturação e vigência das bibliotecas régias no Império português, entre o final do século XVIII e o raiar do XIX. A manutenção da integridade imperial perpassava, necessariamente, pelas leituras que os súditos ilustrados fariam acerca da força do Império.

${ }^{227}$ Sobre a determinação de D. João referente ao ensino militar no Reino, ver FERNANDES, Rogério. Os caminhos do ABC: Op. Cit., p. 369-398. 


\section{A REAL BIBLIOTECA E A GRANDEZA DA MONARQUIA LUSO-BRASILEIRA}

\subsection{Preâmbulo}

[Não há] nenhum meio mais honesto e seguro para adquirir uma grande fama entre os povos, que construir belas e magníficas bibliotecas, para depois voltá-las e consagrá-las ao público. Por isso, é verdade que esse empreendimento nunca enganou nem decepcionou os que o souberam conduzi-lo bem; ele sempre foi julgado de tais consequências, que não somente os particulares

o fizeram resultar em sua vantagem [...], que mesmo os mais ambiciosos sempre quiseram se servir dele para coroar e aperfeiçoar todas as suas belas ações, como se faz com a pedra angular, que fecha a abóbada e serve de brilho e ornamento a todo o resto do edifício.

Gabriel Naudé, $1627 .{ }^{1}$

1 NAUDÉ, Gabriel. Advis pour dresser une bibliothèque (Conselhos para organizar uma biblioteca) Apud CHARTIER, Roger. "O príncipe, a biblioteca e a dedicatória”. In: BARATIN, Marc; JACOB, Christian. O poder das bibliotecas: a memória dos livros no ocidente. Trad. Marcela Mortara. 2. ed. Rio de Janeiro: Editora UFRJ, 2006. p. 184. 
A arguta observação do bibliotecário francês em meados do século XVII nos aponta para uma importante estratégia política das monarquias absolutistas na Idade Moderna: a consolidação do poder real perpassava necessariamente pela construção simbólica da sua autoridade. Como já bem analisou Peter Burke, Luís XIV (1643-1715) contou com o auxílio de homens do governo para a construção de sua imagem durante todo o seu reinado, o que implicava marcar sua figura entre os súditos como o rei acessível, protetor das artes e das letras. Enfim, ao idealizá-lo como o mais poderoso monarca do universo, seus homens de Estado tiveram a árdua tarefa de estruturar uma ampla propaganda das qualidades do Rei Sol em múltiplos sentidos. ${ }^{2}$ Do cunho das medalhas às Academias. Das cerimônias públicas às peças de teatro. Do patrocínio de artistas às coleções de livros.

Se a promoção do Estado francês foi presente nos diversos locus de cultura com vistas a manter um diálogo cultural eficiente, nos interessa aqui ressaltar a importância e o sentido da biblioteca real no governo de Luís XIV. Como definiu o historiador Roger Chartier, a biblioteca

[...] não é um solitarium, um lugar de retiro fora do mundo, e de gozos secretos. Abertas aos literatos, aos eruditos, mesmo aos simples curiosos (é o caso na biblioteca do rei a partir de 1692), suas coleções de manuscritos e impressos podem ser mobilizadas a serviço do saber, da história da monarquia, da política ou da propaganda do Estado. ${ }^{3}$

Ao enfocar os diversos usos da biblioteca do rei, concebida no Ocidente como o lugar de memória ${ }^{4}$, Chartier também coloca

\footnotetext{
2 BURKE, Peter. A fabricação do rei. A construção da imagem pública de Luis XIV. Rio de Janeiro: Jorge Zahar, 1994.

${ }^{3}$ CHARTIER, Roger. "O príncipe, a biblioteca e a dedicatória”. In: BARATIN, Marc; JACOB, Christian. O poder das bibliotecas:... Op. Cit., p. 185.

${ }^{4}$ De acordo com o historiador Christian Jacob, "[...] a história das bibliotecas no Ocidente é indissociável da história da cultura e do pensamento, não só
} 
em cena uma questão de suma relevância: a composição das coleções reais evidencia vários gestos historicamente circunscritos advindos de múltiplos sujeitos. Isto é, do confisco de obras após expedições militares vitoriosas à doação de livros pela própria realeza, perpassando a aquisição (e concessão) de obras particulares adquiridas no exterior por súditos, viajantes, ministros reais ou correspondentes, notamos que, a despeito do caminho trilhado nesse processo, há, sim, um explícito interesse coletivo com fortes vieses sociopolíticos - na manutenção desse locus de cultura como espaço de destaque. "A constituição das coleções da biblioteca é fruto de uma política sistemática de aquisições, que busca a completude, a acumulação de todas as formas de saber e de criação confiadas à escrita, aptas a serem em seguida redistribuídas pela classificação nas grandes categorias", afirma o historiador Christian Jacob. ${ }^{5}$

Desde Alexandria, a força simbólica de inúmeros livros concentrados em um mesmo lugar, cujo conhecimento se põe ao alcance do público tornou-se, sem dúvida, uma manifestação de superioridade intelectual e poder político; razão pela qual, segundo Gabriel Naudé, "um número quase infinito de muitos monarcas" acumulou milhares de obras e mandou construir "bibliotecas muito curiosas e bem providas". ${ }^{6}$ É por esse prisma, portanto, que compreendemos o sentido da acumulação do conhecimento nos

como lugar de memória, no qual se depositam os estratos das inscrições deixadas pelas gerações passadas, mas também como espaço dialético no qual, a cada etapa da história, se negociam os limites e as funções da tradição, as fronteiras do dizível, do legível, e do pensável, a continuidade das genealogias e das escolas, a natureza cumulativa dos campos do saber ou suas fraturas internas e suas reconstruções." JACOB, Christian. "Prefácio". In: BARATIN, Marc; JACOB, Christian. O poder das bibliotecas:... Op. Cit., p. 11.

${ }^{5}$ Ibid., p. 51.

${ }^{6}$ NAUDÉ, Gabriel. Advis pour dresser une bibliothèque... Op. Cit., p. 184. 
diversos campos do saber - as belas letras, teologia, ciências e arte, história e jurisprudência ${ }^{7}$ - como uma base imprescindível de sustentação política das monarquias europeias na Idade Moderna.

O reinado de D. João V (1706-1750) foi contemporâneo ao de Luís XIV. Vividos no auge do Antigo Regime, ambos os governos foram marcados pela magnanimidade. Enquanto na França resplandecia pela Europa a suntuosidade e força de Versailles, em Portugal D. João V dedicava-se a uma de suas célebres realizações, a construção do Palácio de Mafra. Para além do Convento, a constituição das bibliotecas do Reino - com destaque para a biblioteca real - foi concebida como mola-mestra de sua política cultural. Segundo pesquisadores portugueses, toda a preocupação joanina com as bibliotecas como locus de saber de alta consideração, fez parte de um "programa criteriosamente delineado que procurava inspiração e modelo no que de melhor se fazia na Europa". ${ }^{8}$ Delineava-se, assim, a profícua comunicação entre a coroa lusitana e seus súditos enviados para as cortes mais polidas do Velho Mundo, como Inglaterra, França e Países Baixos. Em 1721, o súdito português Antonio Galvão de Castelo Branco fazia um extenso relatório acerca das bibliotecas inglesas, onde garantia a patente diferença com os conventos lusitanos. ${ }^{9}$

Os constantes pedidos de $\mathrm{D}$. João $\mathrm{V}$ pouco a pouco enriqueciam o locus, que chegou a ter 70 mil volumes. ${ }^{10}$ De listas de

\footnotetext{
${ }^{7}$ Aqui utilizamos a classificação herdada da Encyclopédie vigente no século XVIII que adentrou o início do século XIX, uma vez que é justamente esse o nosso recorte temporal da pesquisa (1792-1821).

8 CLUNY, Isabel; BARATA, Paulo. J. S. "A propósito de um documento da política cultural joanina”. In: Leituras. Revista da Biblioteca Nacional. S.3. n ${ }^{\circ} 3$. Lisboa: 1998. p. 132.

${ }^{9}$ FERRAUD, Luís Almeida. “D. João V e a biblioteca real”. Revista da Universidade de Coimbra. N. ${ }^{\circ}$ XXXVI, 1991. p. 431.

${ }_{10}$ Verbete: Livraria Real. In: <http://www.infopedia.pt/\$livraria-real>. (Data do acesso: 06/07/2012).
} 
manuscritos e livros avulsos à compra de livrarias inteiras, o amplo mosaico de temas e coleções ganhava grande visibilidade. ${ }^{11}$ Ao fim da década de 1720, a biblioteca lisboeta já era considerada uma das maiores e mais preciosas da Europa, despertando o interesse, inclusive, de livreiros internacionais que passaram a frequentar a corte lusitana. ${ }^{12}$ A grandiosidade desse espaço, por si só, já justificava o fato de o monarca ter sido batizado como o Rei Sol português.

A despeito do sucesso da política cultural joanina, o terremoto de 1755 destruiu boa parte de Lisboa, não poupando um dos maiores empreendimentos governamentais: a livraria real, situada no Paço da Ribeira. Sua reconstrução durante a segunda metade do século XVIII, assim como a transladação de parte importante de seu acervo para o Brasil, no início d'Oitocentos, é um tema que tem despertado grande interesse da historiografia luso-brasileira nas últimas décadas. ${ }^{13}$

\footnotetext{
${ }^{11}$ FERRAUD, Luís Almeida. “D. João V e a biblioteca real”... Op. Cit., p. 421.

12 "Um dos mercadores de livros mais importantes da época, o francês Pedro Gendron, homem erudito em conhecimentos bibliográficos e que conhecia muitas bibliotecas da Europa, afirmava que nenhuma vira provida de tantas edições antigas como a Real." DOMINGOS, Manoela. "A primeira biblioteca pública portuguesa, 1775-1795. Planos, projetos e primeiros fundos". Cadernos BAD (1) 1994. p. 59.

13 Entre muitos estudos, destacamos: DOMINGOS, Manuela. "Historial da Biblioteca Nacional”. In: DOMINGOS, Manuel; LOPES, Inês; OLIVEIRA, Antonio Lopes de. Biblioteca Nacional de Portugal. Lisboa: ABINIA, 1994; SCHWARCZ, Lilia M., AZEVEDO, Paulo César de; COSTA, Ângela Márquez da, A longa viagem da biblioteca dos reis: do terremoto de Lisboa à Independência do Brasil, São Paulo: Cia das Letras, 2002; NEVES, Lúcia Maria Bastos Pereira das. "O livro para se fazer memória de todas as obras que entrarem na Real Biblioteca” In: ALGRANTI, Leila Mezan; MEGIANI, Ana Paula. (Org.). O Império por escrito: formas de transmissão da cultura letrada no mundo ibérico. Séc. XVI-XIX. São Paulo: Ed. Alameda, 2009. p. 277-296; SILVA, Maria Beatriz Nizza. A cultura luso-brasileira:... Op. Cit.
} 
Neste capítulo, o nosso foco está na compreensão da política cultural durante a governança de D. João (1792-1821) tendo a biblioteca real como um dos pilares de sustentação da monarquia portuguesa no auge da crise do Antigo Regime. Transladar um enorme acervo para o Rio de Janeiro, em três viagens distintas ${ }^{14}$, esteve longe de ser um empreendimento tranquilo. Apesar disso, se mostrou fundamental no processo de metropolização da nova corte. "Mais do que um edifício com prateleiras, uma biblioteca representa uma coleção e seu projeto. Afinal, qualquer acervo não só traz embutida uma concepção implícita de cultura e saber, como desempenha diferentes funções, dependendo da sociedade em que se insere", conceitua a antropóloga Lilia Schwarcz. ${ }^{15}$

Em março de 1811, adentrava no Brasil a segunda remessa de livros vindos de Lisboa sob a responsabilidade de Luís Joaquim dos Santos Marrocos, funcionário régio que cuidou da travessia do precioso acervo bibliográfico da realeza. Marrocos viveu deste lado do Atlântico até o fim da vida e durante o período que nos interessa exerceu um cargo de destaque na sociedade de corte: foi bibliotecário régio, além de ser um astuto observador da nova realidade carioca.

Três anos depois de sua chegada, em 1814, a real biblioteca abria suas portas ao público. Mesmo sem ter acesso ao espaço nos três anos precedentes, a sociedade joanina já contava com os livros produzidos pela Impressão Régia desde 1808. A despeito da atuante censura joanina, a produção, circulação e leitura de livros, almanaques e diversos periódicos como a Gazeta do Rio de Janeiro, O Patriota e O Investigador Portuguez se tornava

14 SCHWARCZ, Lilia M., AZEVEDO, Paulo César de; COSTA, Ângela Márquez da. A longa viagem da biblioteca... Op. Cit., p. 268-269.

15 Ibid., p. 120. 
uma realidade no Rio de Janeiro no alvorecer do século XIX. Tais medidas governamentais impulsionaram transformações sociopolíticas e culturais importantes ao longo dos treze anos de vigência da corte no Brasil, mudando em definitivo a face da América Portuguesa.

Enfim, surgia a possibilidade de se fazer novas leituras críticas acerca de um mundo em crise ideológica e em rápida mutação, que via novos sujeitos emergirem no espaço urbano da corte. O papel desses múltiplos sujeitos e a força transformadora dos livros no período joanino é o assunto central deste capítulo. Como magistralmente nos esclarece o historiador Robert Darnton, os livros não respeitam fronteiras linguísticas ou nacionais, não se limitando, portanto, a relatar a história. Eles a fazem. ${ }^{16}$

\subsection{Soberania política e a constituição da Real Biblioteca Pública da Corte}

A política não é sempre a causa das revoluções de Estado. Fenômenos espantosos mudam frequentemente a face dos Impérios. Pode dizerse que esses desastres da natureza são algumas vezes necessários porque eles podem mais do que qualquer outra coisa contribuir e aniquilar certos sistemas que se encaminham a invadir o universal Império [...] Porém dirão é necessário que sobre a terra se transportem províncias, que se subvertam cidades para dissipar a cegueira de certas nações, ilustrá-la no conhecimento dos seus

16 DARNTON. Robert. O Beijo de Lamourette: mídia, Cultura e Revolução, São Paulo: Cia das Letras, 1995. p. 130. 
verdadeiros interesses. Sim, atrevidamente o digo, em um certo sentido assim é necessário.

Sebastião de Carvalho e Melo, 1755.

A reflexão acima faz parte do Discurso político sobre as vantagens que o reino de Portugal pode alcançar da sua desgraça por ocasião do memorável Terremoto de $1^{\circ}$ de novembro de 1755 , feito pelo então futuro primeiro-ministro de D. José I em meio aos escombros de Lisboa. Como sabemos, as consequências do terremoto foram desastrosas: com milhares de mortos e a miséria que se abateu sobre a sociedade portuguesa, a reconstrução da cidade se fazia urgente. Coincidentemente, a reedificação da corte - ocorrida sob o paradigma do Iluminismo, em que vigorava a concepção de cidade ilustrada ${ }^{17}$ - teve na figura do futuro Marquês de Pombal o seu principal expoente. Ministro ilustrado de D. José I, Pombal utilizou-se do terremoto para ganhar visibilidade na política europeia.

O Estado português tomou medidas emergenciais para tirar a capital do Reino do caos: do alojamento dos sobreviventes ao enterro em massa dos mortos, o cuidado com a salubridade foi de primeira ordem. Ademais, o socorro a Portugal veio de todas as partes: do Brasil à Inglaterra, as cortes estrangeiras estiveram atentas e dispostas a ajudar materialmente o país. Apesar disso, nos interessa enfatizar a administração pombalina sobretudo no que se refere à reconstrução da biblioteca real que, como já dissemos, foi um dos mais destacados locus de cultura de sustentação política das monarquias absolutistas. Neste particular, como

17 CARVAlHO, Marieta Pinheiro de. Uma idéia de cidade ilustrada: as transformações urbanas no Rio de Janeiro de D. João VI (1808-1821). Rio de Janeiro: Odisséia, 2008. p. 28. 
apontou a análise da historiadora portuguesa Manuela Domingos, na reconstrução de Lisboa, agora pelo prisma das Luzes, foi intrínseca a elevação de novos edifícios e novas instituições, sobremaneira as de explícito caráter cultural, ou seja, as bibliotecas, universidade e centros de ensino. ${ }^{18}$

Por essa ótica, já em 1756, o governo josefino buscava viabilizar uma nova coleção. Uma das soluções encontradas por Pombal a fim de evitar outra perda significativa dos livros foi a transferência da Real Livraria para o Palácio da Ajuda, onde a realeza passava a residir. Além disso, a tragédia também impulsionou a idealização de dois grandes acervos. "Ao mesmo tempo em que se organizava a Real Biblioteca junto ao novo paço da Ajuda, erguia-se de forma autônoma, a Real Biblioteca pública", contextualiza a autora Lilia Schwarcz, que também realça o fato de esta ter sido criada "no âmbito da Real Mesa Censória e dimensionada na medida das grandes bibliotecas europeias". ${ }^{19}$ A primeira Biblioteca Pública da Corte (1775-1795) foi um projeto pombalino cujo destaque devia ser a desvinculação com o ensino jesuítico. Neste sentido, a "política do livro" no espaço privilegiava o ensino laico. ${ }^{20}$

A nova coleção da Real Biblioteca da Ajuda contou com três aquisições de destaque. A primeira delas foi a livraria privada do Conde de Redondo, negociada pessoalmente por D. José I. Sob a custódia de sua esposa, a Condessa de Redondo, o acervo contava com um respeitável número de obras e também manuscritos de história que primavam pela qualidade da conservação. A nobre proprietária sabia do valor de seu empreendimento, uma

18 DOMINGOS, Manuela. "Historial da Biblioteca Nacional"...Op. Cit., p. 6.

19 SCHWARCZ, Lilia M. A longa... Op. Cit., p. 140.

20 DOMINGOS, Manoela. "A primeira biblioteca pública portuguesa, 1775 1795...,, Op. Cit., p. 60-61. 
vez que pedia ao rei três mil cruzados em dinheiro e seis em padrão de juro para fechar o negócio. ${ }^{21}$ A livraria do gazeteiro José Maria Monterroio de Mascarenhas foi a segunda conquista real. Composta por dicionários e livros genealógicos, a biblioteca de Mascarenhas destacava-se pela natureza de suas obras de origem castelhana, inglesa e portuguesa. ${ }^{22}$ Porém, o investimento de maior vulto intelectual da Coroa foi a aquisição da coleção do abade Diogo Barbosa Machado, negociada por Frei Manoel do Cenáculo Vilas Boas, entre os anos de 1770 e $1773 .{ }^{23}$

De acordo com o pesquisador Rodrigo Bentes Monteiro, a doação da coleção à Real Biblioteca expressa bem o coroamento de uma trajetória. Se durante os anos 1770 a 1772 Barbosa Machado prestou serviço ao rei, cuja atuação destacava-se pelo mecenato e interesse em associar sua imagem régia à preciosa compilação, o agradecimento do monarca também foi à altura, vindo através de mercê em forma de pensão. ${ }^{24} \mathrm{O}$ significado simbólico do desempenho do proeminente bibliófilo está, segundo Monteiro, intrinsecamente associado ao valor da construção póstuma de sua memória. Neste sentido, o fato de sua coleção atravessar o Atlântico, viajando com a corte para o Brasil, o enobrecia historicamente. Isto é, em meio às memórias dos reis, nobres, heróis de batalha, sacerdotes insignes e santos, aparecia a figura de Barbosa

\footnotetext{
21 SCHWARCZ, Lilia M. A longa... Op. Cit., p. 141.

22 Sobre a atuação de Mascarenhas enquanto Gazeteiro ver BELO, André. As Gazetas e os Livros: a Gazeta de Lisboa e a vulgarização do impresso (1715-1760). Lisboa, 2001; MEIRELLES, Juliana Gesuelli. Imprensa e poder... Op. Cit., p. 49-55.

23 Para as biografias de ambos os religiosos e homens de letras - Diogo Barbosa Machado (1682-1772) e Frei Manoel do Cenáculo Vilas Boas (1724-1814), ver http://www.arqnet.pt/dicionario/barbosamachadod.html e http://www.arqnet. $\mathrm{pt} /$ dicionario/vilasbcenaculo.html respectivamente.

24 MONTEIRO, Rodrigo Bentes. "Folhetos em ordem na coleção Barbosa Machado”. In: ALGRANTI, Leila Mezan; MEGIANI, Ana Paula. (Org.). O Império por escrito... Op. Cit., p. 209.
} 
Machado. "Essas histórias conferiam superioridade a este colecionador apaixonado, como ficção de sua soberania viva", conclui Monteiro. ${ }^{25}$

Rodrigo B. Monteiro tem como prisma de análise o trabalho desse súdito português na lógica da conservação e transmissão do conhecimento, própria ao Antigo Regime Português, sobremaneira no que tange à força da censura régia. Das escolhas temáticas aos múltiplos sentidos da classificação de suas obras, o historiador também investiga o impacto da coleção de Barbosa Machado deste lado do Atlântico desde 1810, quando houve a incorporação do acervo à Real Biblioteca do Rio de Janeiro, atual Biblioteca Nacional. ${ }^{26}$ Assim sendo, é imprescindível realçar a centralidade do abade de Santo Adrião de Server como homem de letras, bibliófilo e colecionador da história do Império Português. Biblioteca Lusitana. História, Crítica e Cronologia é de sua autoria e foi considerada por ele próprio a sua obra maior.

Organizada em quatro tomos, Biblioteca Lusitana foi dedicada aos monarcas D. João V e D. José I, tendo como principal finalidade apresentar ao leitor as personagens de renome da história do país. Em forma de biografia, mais de cinco mil figuras são catalogadas em ordem alfabética, com ênfase para os líderes políticos, intelectuais, nobres e religiosos. Na análise de Monteiro, a obra de Machado constitui um "valioso instrumento de

25 Ibid., p. 209.

${ }^{26}$ MONTEIRO, Rodrigo Bentes. "Reis, príncipes e varões insignes na coleção Barbosa Machado”. Anais de História de Além-Mar, Lisboa, v. VI, n. 2005. p. 215-251, 2005. A importância da coleção Barbosa Machado é um tema ainda pouco estudado pela historiografia brasileira. Apesar de exaltarmos a importância do assunto, ressaltamos que o objetivo central desta tese é compreender a biblioteca como um locus de cultura fundamental dentro da política cultural do governo joanino; nesse sentido, o aprofundamento das especificidades de tal discussão acadêmica extrapola os limites desse trabalho. 
consulta para pesquisadores, espécie de dicionário dos conhecimentos em Portugal e de seus grandes vultos". Já pela ótica de Schwarcz, a mesma obra representa um exercício de exaltação do poder real. ${ }^{27}$ Para nosso trabalho, no entanto, nos interessa trazer à luz o empenho da monarquia portuguesa em relação à aquisição da biblioteca de Barbosa Machado, a ponto de o cuidado com o deslocamento dos livros ter sido tratado como questão prioritária do Estado. A empreitada contou com a assídua colaboração do então diretor da Imprensa Régia, o livreiro-impressor italiano Nicolau Pagliarini, que também dirigia as livrarias do Paço das Necessidades e do Colégio dos Nobres. Além disso, Pagliarini era publicamente antijesuíta, o que corroborava com a reforma educacional pombalina. ${ }^{28}$

De viés laicizante e pragmático, a reforma pedagógica atingiu todos os níveis de ensino no país, das primeiras letras à universidade. Se o ápice dessas transformações deu-se com a reforma da Universidade de Coimbra (1772), desde a expulsão dos jesuítas do Império Português, em 1759, o Estado assumiu diretamente a responsabilidade sobre a instrução escolar, cobrando um imposto, o subsídio literário, e introduzindo as aulas régias. ${ }^{29}$ E dentro desse contexto político, a criação da Real Mesa Censória é uma questão singular que esteve indissociável tanto da nova concepção de educação ilustrada dos súditos da monarquia - que ganhava cada vez mais centralidade -, quanto da "política

SCHWARCZ, Lilia M. A longa... Op. Cit., p. 145.

${ }^{28}$ DOMINGOS, Manuela. “A primeira biblioteca pública portuguesa..., Op. Cit., p. 64.

29 VILLALTA, Luiz Carlos. "O que se fala e o que se lê: língua, instrução e leitura”, In: SOUZA, Laura de Melo e (org.). Cotidiano e vida privada na América Portuguesa, História da vida privada no Brasil. São Paulo: Cia das Letras, 1997. p. 348. 
do livro" ${ }^{" 30}$, que o primeiro-ministro tentava imprimir ao Império Português. "Com a criação da Real Mesa Censória, em abril de 1768, Pombal retirou do tribunal do Santo Ofício e do Ordinário a prerrogativa de responsáveis pela censura religiosa e passou-a para a alçada do Estado, secularizando a ação da censura e tornando-a, assim, um instrumento do Estado absolutista", ratifica a historiadora Leila Mezan Algranti. ${ }^{31}$ Ainda sobre essa importante transformação política, a autora realça a responsabilidade do novo órgão estatal no processo de censura e fiscalização de toda a produção impressa que circularia nos dois lados do Atlântico, em que pesava também a posição dos censores régios, homens diretamente subordinados ao rei e, portanto, de sua estrita confiança.

Foi também durante o governo pombalino que se iniciou o projeto da primeira Biblioteca Pública portuguesa (1775-1795). A idealização do novo espaço teve como autor frei Manuel do Cenáculo Villas-Boas, um dos mais eminentes colaboradores do primeiro-ministro no campo do ensino e da cultura. Em relação à composição do acervo, Cenáculo propôs o subsídio literário ${ }^{32}$ que, segundo ele, seria usado para "formar uma das mais importantes Bibliotecas da Europa, também decorada de preciosos Manuscritos e dos livros raros escolhidos" tanto quanto compor um "MUSEU DE RARIDADES de que dão exemplo de estímulo e paixão as Nações cultas que em breve receberiam exemplo

\footnotetext{
${ }^{30}$ Utilizo essa expressão da historiadora portuguesa Manoela Domingos. DOMINGOS, Manoela. "A primeira biblioteca pública portuguesa..., Op. Cit., p. 60-61. 31 ALGRANTI, Leila Mezan. Livros de Devoção..., Op. Cit., p. 135.

32 De acordo com Manuela Domingos, o subsídio literário consistia em um imposto sobre as bebidas alcoólicas cujo fim seria o financiamento de redes de escolas menores em todo o país. Tal subsídio também serviria para pagar os professores régios assim como editar novos manuais pedagógicos. DOMINGOS, Manuela. “A primeira biblioteca pública portuguesa..., Op. Cit., p. 62.
} 
significativo desta capital". ${ }^{33} \mathrm{O}$ discurso do frei nos coloca diante de uma questão muito cara aos homens de letras portugueses da segunda metade do século XVIII: o compasso cultural entre Portugal e a Europa do norte era primordial e deveria ser atingido através do progresso da razão e das artes, sendo os livros um dos principais objetos culturais responsáveis por essa transformação. ${ }^{34}$

Por esse prisma, a reflexão de Roger Chartier acerca da política editorial dos impressores da Biblioteca Azul, na França da idade moderna, é de grande relevância. Apesar de ser de natureza absolutamente diferente de uma biblioteca real, justamente por ter sido ambulante e voltada para um público popular e rural ${ }^{35}$, todos os catálogos da Biblioteca Azul foram escolhidos "porque parecem poder ser comprados por um grande público e, portanto, suscetíveis de responder a uma expectativa partilhada, seja de ordem de devoção, da utilidade ou do imaginário". ${ }^{36}$ É precisamente neste aspecto que devemos nos atentar.

A despeito das peculiaridades de cada sociedade e, mormente da concepção de duas bibliotecas com características tão distintas, não podemos deixar de considerar um ponto de confluência entre os dois empreendimentos culturais: em ambos os casos a constituição do acervo bibliográfico não deixa de ser o resultado de uma escolha muito bem arquitetada, seja por impressores franceses independentes ou pelos súditos ilustrados do

33 VILLAS-BOAS, Manuel do Cenáculo. Apud DOMINGOS, Manuela. "A primeira biblioteca pública portuguesa..., Op. Cit., p. 62. (Grafia do Original).

${ }^{34}$ CURTO, Diogo Ramada. "Mercado e gentes do livro no século XVIII". In: . Cultura Escrita. Lisboa: ICS, Imprensa de Ciências Sociais, 2007. p. 208.

${ }_{35}$ CHARTIER, Roger. "Do livro à leitura”. In: CHARTIER, R. Práticas de leitura. Trad. Cristiane Nascimento. São Paulo: Estação Liberdade, 1996. p. 99.

${ }^{36}$ Ibid., p. 100. 
governo português, cuja responsabilidade se delineou em torno da nova política impressa que ocorria concomitantemente à reestruturação da biblioteca régia.

De acordo com o pesquisador Diogo Ramada Curto, entre o final do século XVIII e o início do século XIX a "política do livro" na França e na Inglaterra buscava a conciliação entre a liberdade de escrita e de imprensa e a capacidade de consumo e formação de um amplo mercado de livros. Tal política, segundo o autor, garantia um maior progresso civilizacional, uma vez que a sociedade comercial permitiu a correspondência entre as mais diversas nações e partes do mundo com uma frequência jamais vista. Em relação aos escritores, ao mesmo tempo em que se emancipavam do conflituoso jogo do mecenato, passavam a depender dos livreiros e editores, "uma espécie de novo mecenas, mas desinteressado de qualquer tipo de adulação". Ademais, ao estarem mais direcionados para o grande público, os escritores tinham a possibilidade de se tornarem os "favoritos do povo soberano". ${ }^{37}$

Na prática, isso demonstrava uma importante mudança de comportamento dessas sociedades guiada pela Filosofia das Luzes: o homem dava os primeiros passos em direção à maioridade intelectual, apregoada por Immanuel Kant, em 1784. Ou seja, o uso público da razão passava a ser compreendido também pelo viés do olhar dos leitores para a literatura em particular, e a palavra impressa, em geral. Especialmente no caso lusitano, nessa tarefa o Estado foi o principal interventor, cabendo à monarquia o encargo de instruir e "civilizar" a nação através de uma política cultural que atendesse aos anseios e projetos governamentais. É justamente por esse prisma que a concepção da Biblioteca

37 CURTO, Diogo Ramada. "Mercado e gentes do livro..., Op. Cit., p. 206. 
pública como um novo espaço laico do conhecimento e de acesso à sociedade letrada ganhava maior sentido. Afinal, como já bem definiu Roger Chartier, na tradição a biblioteca é sinal de um saber ou de um poder. ${ }^{38}$

Se ao longo de duas décadas (1775-1795) a primeira Biblioteca Pública da Corte sofreu avanços e retrocessos ${ }^{39}$, não podemos nos esquecer que o espaço também serviu como base fundamental para a fundação de sua congênere, em 1796. Nossa discussão situa-se precisamente acerca da estruturação desta instituição - a Real Biblioteca Pública da Corte - tendo como foco a política governamental mariana e joanina. Uma das principais bases da ação real nesse novo locus de cultura foi deixar sua inspeção geral sob a responsabilidade do Ministro da Real Fazenda, à época, D. Tomás Xavier de Lima Teles da Silva, o Marquês de Ponte de Lima. ${ }^{40}$ Apesar de o papel do ministro da Real Fazenda ter sido "largamente indefinido até pelo menos 1812 " 41 , particularmente no que concernia à administração da biblioteca pública, sua colocação era, primordialmente, auxiliar e prever tudo o que considerasse conveniente ao progresso da biblioteca e, em última instância, da monarquia.

Quanto às diretrizes do Alvará, estas já definiam as linhas mestras do espaço. Vejamos:

Eu a Rainha faço saber aos que este alvará virem: que sendo um dos objetos que ocupam a Minha Real Consideração o cuidado de promover, eficazmente os progressos da Literatura Portuguesa, e conhecendo o quanto será útil e

38 CHARTIER, Roger. "Do livro à leitura... Op. Cit., p. 90.

39 DOMINGOS, Manuela. "A primeira biblioteca pública portuguesa... Op. Cit., p. 68-69.

${ }^{40}$ MARTINS, Ana Canas Delgado. Governação e Arquivos:... Op. Cit., p. 6.

41 Ibid., p. 6. 
vantajoso, para se conseguir este fim, o estabelecimento de uma Livraria Pública, a qual servirá como um tesouro de todas as Artes e Ciências, e aonde se achem com os livros mais preciosos da sua raridade, e estimação os monumentos mais respeitáveis das mesmas artes, e Ciências que constituam um riquíssimo depósito não só de conhecimentos humanos, mas também dos meios mais próprios para conduzir os homens a conseguirem a virtuosa sabedoria, que constitui a felicidade e tranquilidade pública dos Estados, e é inseparável da piedade da Religião: querendo Eu reduzir a efeito este importante objeto da Minha Real Consideração por um modo eficaz de que resulte o desejado fim do maior aproveitamento a que aspiram os meus vassalos, que se dedicam a louvável cultura das ciências, e das artes com honra sua, e da paixão em que nasceram. ${ }^{42}$

Com o afastamento de $\mathrm{D}^{\text {a }}$ Maria I por questões de saúde, desde 1792 o Império Português era conduzido politicamente sob a regência de fato do Príncipe Regente D. João (tendo, inclusive, este documento a sua chancela). Todavia, é mister advertirmos que a produção discursiva do alvará tem importantes questões simbólicas. Para além de ter sido publicado pela voz da Rainha o que o referencia como um projeto governamental situado nos limites do seu reinado (até porque D. João assume a regência institucionalmente apenas em 1799) -, o documento também nos coloca diante de uma questão capital para a monarquia portuguesa, mormente em tempos de crise: a constituição de uma biblioteca pública delineava explicitamente a relação entre a soberania política e a constituição de um lugar institucionalizado onde o conhecimento público aliado à memória real fosse preservado.

42 Alvará de criação da Real Biblioteca Pública da Corte. BNP. Seção de Reservados. Cód.10610. 
Ademais, a aquisição do conhecimento era considerada o meio fundamental no processo de conquista da sabedoria, sendo nítida a concepção governamental de livraria pública em que pesava a indissociabilidade entre política e religião, dois pilares fundamentais do absolutismo português. Entretanto, como bem sugere a pesquisadora Manuela Domingos, apesar de a biblioteca ser apresentada à sociedade como uma "instituição de cultura ao serviço de todos os vassalos de S.M Rainha $\mathrm{D}^{\mathrm{a}}$ Maria I", ${ }^{\prime \prime 3} \mathrm{o}$ acesso ao acervo foi restrito. "Não se tratava porém, - contrariamente às tradições das Bibliotecas europeias suas congêneres -, de colocar à disposição de sábios, eruditos ou curiosos os tesouros manuscritos e impressos, colecionados de modo mais ou menos ostentatório, de uma Biblioteca Real, tornada pública", analisa a autora. ${ }^{44}$ Portanto, é sob esta perspectiva que as determinações do Alvará ganham ainda mais sentido e nos ajudam a melhor compreender as peculiaridades do universo cultural letrado português, ainda tão marcado por valores aristocráticos da sociedade de corte em que pesava, por exemplo, a distinção dos lugares sociais.

O Alvará de 1796 é composto por nove ordens. Da estruturação das oficinas e uso da biblioteca, sendo este "perpetuamente destinado ao bem das Letras, em benefício contínuo dos meus vassalos" ${ }^{\prime 4}$, perpassando a organização da numerosa coleção de livros e a administração do espaço, o documento detalhava todas as funções administrativas e tramitações burocráticas referentes ao novo locus de cultura. A quarta ordem, por exemplo, exigia que "a dita Real Biblioteca vá sempre em um contínuo aumento, e digna reputação, e haja nela um cuidado nunca interrompido e

${ }^{43}$ DOMINGOS, Manuela. "Historial da Biblioteca Nacional... Op. Cit., p. 3.

44 Ibid. (Grifo do Original.)

45 Alvará de criação da Real Biblioteca Pública da Corte. BNP. Seção de Reservados. Cód.10610. 
um zelo vigilante, qual convém que haja em um estabelecimento tal" ${ }^{46}$ Dentre as nove ordens presentes no Alvará, a sexta em especial nos interessa, uma vez que trata do funcionamento interno da biblioteca e dos papéis exercidos por seus profissionais. $\mathrm{O}$ destaque dava-se para o Bibliotecário Maior, que seria o responsável por sua direção geral, devendo responder diretamente ao Ministro da Real Fazenda. Personagem fundamental dentro da estruturação e manutenção deste locus de cultura, um dos principais desígnios do Bibliotecário Maior era servir ao bem público "com utilidade e prontidão", primando, assim, pelo efetivo atendimento aos "estudiosos" que forem à biblioteca. ${ }^{47}$ Abaixo dele, encontramos o segundo bibliotecário, cujo dever era ajudar "o Bibliotecário maior no que necessário for", substituindo-o "na sua ausência e em seus impedimentos". 48

A análise detida dos decretos de nomeação dos dois agentes basilares da recém-fundada Real Biblioteca Pública da Corte - Antonio Ribeiro dos Santos, o Bibliotecário Mor, e Agostinho José da Costa de Macedo, o segundo bibliotecário - indica-nos que, muito provavelmente, a escolha desses sujeitos históricos pela governança portuguesa era sustentada por um rígido critério de seleção. Sobre as qualidades do Bibliotecário Maior, o aviso destacava que este deveria ser uma

[...] pessoa em quem concorram as circunstâncias de se ter amplos conhecimentos das mais depurada literatura, experiência, madureza e probidade, e que com o título de Bibliotecário Maior dela, tenha a seu cargo a Administração Geral, e Governo da referida Biblioteca, com quanto dela pertencer, e haja desempenhar louvavelmente um

\footnotetext{
46 Ibid.

47 Ibid.

48 Ibid.
} 
emprego de tanta consideração, e importância: havendo respeito a que na pessoa do Doutor Antonio Ribeiro dos Santos, Desembargador Ordinário da Caixa da Suplicação, concorrem com as referidas circunstâncias as boas provas que já tem dado do seu zelo, e préstimo nos lugares do meu Real Serviço. ${ }^{49}$

Como bem demonstra este decreto, a escolha de Antonio Ribeiro dos Santos (1745-1818) para assumir tão ilustre cargo na nascente Real Biblioteca Pública da Corte foi baseada especialmente em um critério de distinção: a sua biografia. Apesar de não ter linhagem nobre, sua trajetória intelectual o qualificava como homem de vasta erudição e retidão moral. ${ }^{50}$ Clérigo formado em Direito pela Universidade de Coimbra, onde também exerceu o magistério (1779 - 1795) e atuou como bibliotecário da Livraria do Estudo (1777-1796), sua grande projeção profissional nos meios ilustrados portugueses deu-se desde os tempos da política reformista pombalina, da qual foi um crítico contumaz; aspecto que, mais uma vez, o distinguia entre seus pares, sobretudo em tempos de viradeira. ${ }^{51}$ Nesse contexto, sua concepção política de viés tradicionalista defendia, na visão de José Esteves Pereira, uma "transformação do tipo reformista que, salvaguardando as estruturas do poder, permitisse uma maior intervenção

\footnotetext{
49 Decreto da Nomeação de Bibliotecário Maior da Real Biblioteca Pública da Corte na Pessoa do Desembargador Antonio Ribeiro dos Santos. BNP. Seção de Reservados. Cód.10610.

${ }^{50}$ DIAS, Luís Fernando de Carvalho. Algumas cartas do Doutor Antonio Ribeiro dos Santos aos seus contemporâneos. Separata da Revista Portuguesa de História. Tomo XIV. Coimbra, 1974. p. 417.

51 Sobre a "apreciação negativa do pombalismo" de Antonio Ribeiro dos Santos, ver a análise do historiador português José Esteves Pereira, autor da expressão acima referida. PEREIRA, José Esteves. O pensamento político em Portugal no século XVIII: António Ribeiro dos Santos. Lisboa: Imprensa Nacional Casa da Moeda, 1983. p. 118-124.
} 
social". ${ }^{2}$ Tal postura, na prática, convergia com as diretrizes políticas dos primeiros anos do governo mariano, pautada principalmente pela ampla valorização da religião católica. "A participação dos valores socialmente considerados e definidos pelo espírito zeloso do teólogo e do canonista, permitiam, sem perigo, a leitura cristã de uma visão mais aberta, experiencial, sem subversão dos fundamentos teológicos, políticos e jurídicos", contextualiza Pereira. ${ }^{53}$ Logo, tal situação o abalizava ainda mais aos olhos da realeza.

Sobre o tema da reforma pedagógica universitária, assim se expressava Ribeiro dos Santos em epístola para um amigo:

Meu amigo. Vem vossa carta Lamentando [sic] a decadência dos estudos acadêmicos, e pranteais a falta do Marquês de Pombal. Mas que havia ele fazer agora, se fez pouco no princípio? Se edificou um edifício ruinoso, como havia agora de o ter [sic] em pé? Deixai-me soltar meus sentimentos, ainda que vos pareçam paradoxo, e que sejam contra a opinião comum [...]. Cumpre ver as coisas por dentro. O Marquês não fez o que convinha fazer. Este Ministro apesar de tudo o quanto disseram dele os seus Panegiristas, não talhou um Plano útil, que honrasse a sua Nação e o seu século. ${ }^{54}$

Escrita na ocasião da morte de Pombal, esta missiva fazia uma crítica direta ao modo pelo qual o primeiro ministro de D. José tratou a expulsão dos jesuítas do Império Português: o furor em eliminá-los, demonstrando como estes haviam "estragado a Literatura Portuguesa, e que era necessário a Portugal novos esforços para restaurar outra vez as Artes e as Ciências", o que o

${ }^{52}$ Ibid., p. 194.

53 Ibid., p. 195.

54 SANTOS, Antonio Ribeiro dos. (31ª Carta). In: DIAS, Luís Fernando de Carvalho. Algumas cartas do Doutor... Op. Cit., p. 448-449. 
motivara a recusar toda a contribuição dessa ordem religiosa. Em outra carta, Santos reiterava esta política pombalina ressaltando sua pouca perspicácia em não preservar as pinturas e bibliotecas jesuíticas, as últimas consideradas por ele "as melhores do nosso Reino". Eis o seu lamento: “[...] dos Livros, uns furtaram-se, outros converteram-se em papelão na oficina de Pallerini [sic], aonde se viu se andar de rojo pelo chão, das pinturas umas se roubaram, outras se perderam, apodrecendo em lugares aonde nunca mais se cuidou" ${ }^{55}$ A importância do papel de Ribeiro dos Santos como crítico durante o governo de Pombal, justamente quando o ambiente cultural permitia um diálogo mais próximo com as Luzes é abordado pelo historiador José Esteves Pereira. Segundo ele, "Faltava, em plena liberdade de movimentos, organizar e sintetizar as coordenadas ideológicas que contestassem o pensamento veiculado por essas obras." Nesse contexto, alguns pensadores lusitanos, entre eles Ribeiro dos Santos, acompanharam de perto o que Pereira denominou de "vicissitudes da política cultural pombalina", sendo, dessa forma, comprometidos com o confronto e a crítica do pensamento heterodoxo. ${ }^{56}$

Homem de leis e letras de renome, Antonio Ribeiro dos Santos é uma importante figura política do reformismo ilustrado português. Neste trabalho nos interessa enfatizar notadamente a sua atuação como bibliotecário, uma vez que a estruturação da Real Biblioteca Pública da Corte como locus de cultura na monarquia portuguesa é nosso objeto de investigação neste item. Durante o tempo em que desempenhou o cargo em Coimbra, Ribeiro dos Santos reorganizou a livraria da Universidade, o que

\footnotetext{
55 Ibid. (62 ${ }^{\text {a }}$ Carta)..., p. 479.

56 PEREIRA, José Esteves. O pensamento político em Portugal... Op. Cit., p. 121 (Grifos Nossos).
} 
realizou no âmbito das reformas pombalinas, tendo como finalidade a promoção do progresso dos estudos. Ademais, elaborou a Minuta para o regimento da Livraria da Universidade de Coimbra, onde discutiu questões de disposição interna, tratamento documental e criação de catálogos. Além disso, propôs que os fundos da Livraria se tornassem públicos, sendo permanentemente ampliados e atualizados.

A instalação condigna dos livros, assim como a forma de escolhê-los, também foi tema de sua reflexão. Aqui, a ênfase dava-se para as bibliografias, jornais, efemérides, mercúrios e gazetas sem contarmos com as novas produções literárias. ${ }^{57}$ Tal opção deveu-se especialmente ao fato de Portugal tecer um importante diálogo com o movimento editorial estrangeiro, pautado pelo critério da atualidade. ${ }^{58}$ Já a sua devoção aos livros é o mote do poema Do Autor. Aos seus livros.

Salve, ó meus Livros, Livros escolhidos Por vossos próprios méritos sublimes, Minha saúde e vida, meus prazeres:

Mimos dos olhos meus, altas delícias Do meu esp'rito [sic], que vos ama terno:

Que seria de mim, se o iniquo fado Me forçasse a viver de vós ausente!

Mais adiante, exalta os Filósofos da Antiguidade e a Bíblia Sagrada, ambos tidos como dádivas para o aperfeiçoamento do espírito.

${ }^{57}$ http://www.uc.pt/bguc/DocumentosDiversos/AntonioRibeiroSANTOS. Acesso em: 14 set. 2012.

58 ARAÚJO, Ana Cristina. A Cultura das Luzes em Portugal. Temas e Problemas. Lisboa: Livros Horizonte, 2003. p. 72. 
Salve, imortais Filósofos, famosos,

Epítecto, Plutarco, Xenofonte,

Que as virtudes morais nos ensinastes.

E sobretudo salve, ó Livro Eterno

Das sublimes verdades, que benigno

O Céu por nosso bem mandou à terra, Farol luzente da carreira humana.

O diálogo com a produção do conhecimento pelas diversas nações também fez parte das transformações capitais da humanidade. Exaltá-los publicamente era, sem dúvida, a melhor maneira de agradecê-los.

Salve, vós outros todos das mais classes,

Das Nações várias, de diferentes Línguas, Que eu sempre muito amei, que aqui não posso

Um por um nomear, bem que sois ricos

De elegância e doutrina, salve todos,

Não uma, duas, três, porém, mil vezes;

E ouvi as preces, que eu por vós só faço:

Rogo aos Céus que depois que vos eu deixe,

Finado esses meus dias já cansados,

Passeis a doutas mãos, que vos estimem

Como eu cá sempre voz prezei amigo. ${ }^{59}$

Como amante da literatura pátria e universal, o experiente homem de letras assumia seu novo posto de Bibliotecário Maior com um salário no valor de $600 \$ 000$ réis. ${ }^{60} \mathrm{~A}$ despeito do bom rendimento, o bibliotecário contou com a ajuda de um seleto

\footnotetext{
59 SANTOS, Antonio Ribeiro dos. O Autor. Aos seus livros. In: CUNHA, Xavier. Antonio Ribeiro dos Santos. Bibliophilo. Lisboa: Imprensa L. da Silva, 1913. p. 25-27.

60 Decreto da Nomeação de Bibliotecário Maior da Real Biblioteca Pública da Corte na Pessoa do Desembargador Antonio Ribeiro dos Santos. BNP. Seção de Reservados. Cód.10610.
} 
grupo de súditos, que também estavam incumbidos de levar avante (com sucesso) o novo empreendimento real. A começar pelo Guarda-Mor, que seria responsável pela custódia e segurança da Real Biblioteca, assim como pela arrumação, asseio e a arrecadação dos móveis, instrumentos e papéis. ${ }^{61}$ Além dele, o espaço era composto por dois oficiais escriturários, cuja função destinava-se a "escrever nos diversos catálogos da Biblioteca nos Livros da Receita, e despesa na reformação e traslados dos manuscritos, de que a livraria deve enriquecer-se", servindo também em tudo o que dissesse respeito ao Cartório e escrituração da casa. Outros seis oficiais bibliógrafos seriam divididos pelas diversas salas e gabinetes da Biblioteca, a fim de subministrarem ao público às consultas do acervo real: livros, manuscritos e outros monumentos das Artes e Ciências, que se quisessem ver. Estes bibliógrafos ainda tinham o auxílio de seis ajudantes, cuja tarefa era a vigia constante das salas. Por fim, a Biblioteca tinha a proteção de um porteiro, além do apoio de um agente, responsável pela diligência dos negócios externos relativos à Biblioteca e suas oficinas. ${ }^{62}$ Mesmo com a constante ajuda de diversos funcionários, durante os 20 anos (1796-1816) em que esteve à frente da direção da Real Biblioteca Pública da Corte, Antonio Ribeiro dos Santos realizou um trabalho hercúleo, mormente se considerarmos as dramáticas condições históricas em que se efetivou esse empreendimento cultural.

Na década de 1790 iniciavam-se os graves desdobramentos políticos advindos do processo revolucionário francês no Velho Mundo e, neste contexto, a situação de Portugal na diplomacia europeia tomava novos rumos. Desde a Campanha do Rossilhão

\footnotetext{
${ }^{61}$ Alvará de criação da Real Biblioteca Pública da Corte. BNP. Seção de Reservados. Cód.10610.

${ }^{62}$ Ibid.
} 
$(1793)^{63}$, a tradicional neutralidade portuguesa foi visivelmente ameaçada. A aliança militar que a Rainha travara com a Coroa espanhola converter-se-ia, dois anos depois, em um difícil xadrez político. Em meados de 1796, a assinatura do Tratado de Santo Idelfonso ${ }^{64}$, se selava a aproximação entre França e Espanha, também colocava Portugal em grandes dificuldades. Ou seja, a Península Ibérica ficava ainda mais vulnerável tornando-se, na análise de Jorge Pedreira e Fernando Costa, "um palco possível para o conflito entre a aliança franco-espanhola e a Inglaterra." ${ }^{65}$ Se Madri era, agora, explicitamente inimiga de Londres; Lisboa não o era: muito pelo contrário, desde o início do século XVIII a monarquia lusitana contava com a proteção militar britânica. ${ }^{66}$

Portanto, foi em meio às intrincadas manobras diplomáticas da Coroa Portuguesa que Antonio Ribeiro dos Santos deu início à nobre função. Por possuir um amplo olhar sobre o funcionamento de uma biblioteca, seu projeto cultural priorizava a divisão do acervo com foco na organização por temas e boa utilização do espaço. A livraria foi arranjada em dez seções - História,

\footnotetext{
63 A Campanha do Rossilhão (1793 a 1795) foi uma campanha militar em que Portugal aliou-se à Espanha e Inglaterra, contra a França revolucionária. Nesta ação militar, Portugal, o exército lusitano contribuiu homens que ficaram sob o comando do general britânico John Forbes.

${ }^{64}$ Tratado assinado entre os soberanos de Portugal e Espanha (1777), em Santo Ildefonso (Espanha), que de certa maneira reafirmava os pontos constantes do Tratado de Madrid. Os dois países acordaram no estabelecimento dos limites das suas colónias na América do Sul. Portugal cedeu a colônia do Sacramento, as missões da margem esquerda do Rio Uruguai e a soberania sobre o Rio da Prata. A Portugal foi restituída a Ilha de Santa Catarina (Brasil). Disponível em: <http:// www.infopedia.pt/\$tratado-de-santo-ildefonso> Acesso em: $01 \mathrm{dez} .2012$.

65 PEDREIRA, Jorge; COSTA, Fernando Dores. D. João VI... Op. Cit., p. 66.

${ }^{66}$ FALCON, Francisco José Calazans. "O império luso-brasileiro e a questão da dependência inglesa - um estudo de caso: a política mercantilista durante a época pombalina, e a sombra do tratado de Methuen”. In: Nova economia. Belo Horizonte: UFMG, Departamento de Ciências Econômicas, v. 15, n.2, 2005. p. 11-34.
} 
Belas Letras, Ciências Naturais e Artes, Ciências Civis e Políticas, Ciências Eclesiásticas, Poligrafia, Manuscritos e Antiguidades ${ }^{67}$ sendo ainda equipada com a constante atualização das novas produções científicas e culturais. Quanto ao acervo, destacavam-se a Biblioteca da Real Mesa Censória e o fundo da extinta Academia Real de História. ${ }^{68}$ Sobre a herança da Real Mesa Censória, Manoela Domingos considera-a "uma pesada carga" que foi assimilada ao longo dos anos sendo, posteriormente, convertido em um "grande tesouro", uma vez que revelava impressos preciosos do início da tipografia, ou ainda manuscritos posteriormente analisados como de grande relevância e originalidade. ${ }^{69}$

Ademais, as duas doações de colecionadores sui generis como a de Frei Manuel do Cenáculo e a dos Clérigos Regulares da Divina Providência (Teatinos) distinguiam o espaço entre as demais bibliotecas públicas do Reino, circunscritas aos conventos de S. Francisco e S. Domingos da Cidade e à Casa de N . Sr. ${ }^{a}$ das Necessidades. "Que sobressalto de consolação e alegria foi o meu quando vi pela primeira vez a lava Bíblia Sixtina [sic]. Este livro de ouro só poderia vir das mãos mil vezes benéficas e preciosas de V. Ex..", exclamava Ribeiro dos Santos diante da importante doação de Cenáculo. Segundo o bibliotecário, possuir um "tesouro literário" entre os destaques do acervo real servia para "fazer o esplendor e ornamento da Biblioteca, e aumentar-lhe infinitamente o seu valor". Tal fato, segundo ele, também contribuía para o enriquecimento da capital, que passava a contar com subsídios

${ }_{67}$ PEREIRA, José Esteves. O pensamento político em Portugal... Op. Cit., p. 76-77. ${ }^{68}$ Aviso de Sua Alteza em que mandou depositar na Real Biblioteca de Lisboa os Documentos, e Mss. da Academia Real de História Portuguesa. BNP. Seção de Reservados. Cód.10612.

69 DOMINGOS, Manuela. "Historial da Biblioteca Nacional..., Op. Cit., p. 9. 
cruciais para o novo impulso e energia aos progressos da literatura universal. ${ }^{70}$

Neste sentido, as cartas de Antonio Ribeiro dos Santos para Frei Manuel de Cenáculo entre os idos de 1796 e 1797 são uma riquíssima documentação do período em que podemos perceber vieses da atividade própria do bibliotecário real e da maneira de gerir e pensar a estrutura do novo locus de saber. ${ }^{71}$ Quanto à composição do acervo e sua respectiva organização, é notável a admiração do literato diante da experiência do "primeiro benfeitor e diretor" da Real Biblioteca Pública da Corte, mormente em dois aspectos: a catalogação das obras e a relação com o Estado. ${ }^{72}$ Vejamos, então, como o bibliotecário tentava conduzir o estabelecimento:

Já se extraiu em bilhetes o relatório de todos os livros, que V. Ex. ${ }^{a}$ tem mandado e deles se estão formando dois catálogos, um para a Biblioteca, e outro para se apresentar a Sua Alteza, pela Secretaria de Estado, porque assim melhor saiba, quão imenso cabedal de doutrina civil e sagrada lhe tem entrado pela capital. Estimará para então já ter recebido de V. Ex. ${ }^{a}$ as suas ordens e instruções, que já pedi por via do Sr. Sá ${ }^{73}$, sobre a natureza e forças do equivalente, que pode ser mais análogo e mais conforme aos interesses e satisfação de V. Ex. ${ }^{a}$, para eu saber, por que maneira devo fazer a Sua Alteza a apresentação do catálogo e cumprir para com V. Ex. ${ }^{a}$ os ofícios de servidão, em que estou empenhado por tantos títulos. ${ }^{74}$

\footnotetext{
${ }^{70}$ Cartas de Ribeiro dos Santos (Bibliotecário Real) de 1796-1797. BNP. Seção de Reservados. Mss. 160, 80-84. Carta n. ${ }^{\circ} 80$.

71 Ibid. Mss. 160, 80-84.

${ }_{72}$ Ibid. Mss. 160, 80-84. Carta n. ${ }^{\circ} 84$.

${ }^{73}$ Muito provavelmente, Ribeiro dos Santos se refere a José Antonio de Sá, Desembargador português no período. Para maiores informações acerva de sua atuação pública, ver: <http://www.arqnet.pt/dicionario/sajoseant.html >. Acesso em: 02 out. 2012.

${ }^{74}$ Cartas de Ribeiro dos Santos (Bibliotecário Real) de 1796-1797. BNP. Seção de Reservados. Mss. 160, 80-84. Carta n. ${ }^{\circ} 80$.
} 
Em dezembro de 1796, Frei Manuel de Cenáculo enviava a Ribeiro dos Santos dez caixas de livros. ${ }^{75}$ Nessa remessa de doações, o destaque deu-se para a literatura oriental, que despertou o apreço do bibliotecário: estas, por sua raridade, seriam objetos de grande estima em qualquer biblioteca europeia. Além dessa distinta coleção, Cenáculo ainda oferecia "outras raridades da Antiguidade" e fazia uma doação em dinheiro. ${ }^{76}$ Todas essas ações visavam o enaltecimento do novo locus diante das demais bibliotecas do Velho Mundo e, em última instância, a elevação e força do Estado. Nas monarquias absolutas, tal qual o gesto de escritores quando faziam dedicatórias aos príncipes como forma de elevá-los diante do Céu e da Terra, as doações aparentemente desinteressadas ${ }^{77}$ de colecionares de renome também serviam ao mesmo propósito. Como bem salientou Roger Chartier, "Na imagem da relação entre o soberano e o escritor, o livro tomou o lugar do edifício sagrado, o autor o do fundador, e o rei o do Deus, do qual ele é a terra e o lugar-tenente" ${ }^{78}$ No caso da Real Biblioteca Pública da Corte, $\mathrm{D}^{\mathrm{a}}$ Maria I não foi apenas a fundadora do espaço; foi, antes, a sua principal mecenas. Não foi à toa, portanto, que em uma sala central os leitores se deparavam com a estátua pedestre da soberana; o que, na prática, simbolizava a filiação do locus à política cultural da rainha.

Neste universo de mercês e reverências cortesãs, Frei Manuel de Cenáculo aparecia como um importante orientador

\footnotetext{
75 PEREIRA, José Esteves. O pensamento político em Portugal... Op. Cit., p. 79.

${ }^{76}$ Cartas de Ribeiro dos Santos (Bibliotecário Real) de 1796-1797. BNP. Seção de Reservados. Mss. 160, 80-84. Carta n. ${ }^{\circ} 82$.

77 De acordo com José Esteves Pereira, "A oferta de Cenáculo não era desinteressada, em absoluto, como consta de um requerimento de Ribeiro dos Santos para D. Rodrigo de Sousa Coutinho, reiterando as doações iniciais da doação." PEREIRA, José Esteves. O pensamento político em Portugal..., Op. Cit., p. 80.

78 CHARTIER, Roger. “O príncipe, a biblioteca e a dedicatória..., Op. Cit., p. 186.
} 
político e intelectual de Ribeiro dos Santos, ajudando-o a valorizar o seu capital intelectual e simbólico diante da realeza. Sob esse prisma, o religioso cedeu os seus catálogos ao bibliotecário da nova instituição e foi por ele publicamente reverenciado. "Os catálogos que V. Ex. a foi servido mandar-me dos livros, que tem destinado da sua riquíssima livraria para a Real Biblioteca Pública desta Corte, vieram aumentar sobremaneira o conceito que formava à muitos tempos dos imensos trabalhos, e aquisições de literatura de V. Ex. ${ }^{\text {"” }}$, agradecia o homem de letras. ${ }^{79}$

Como pudemos notar, a digníssima tarefa de organização e classificação dos livros reais foi intrínseca à troca de saberes em âmbito intelectual assim como à experiência política desses sujeitos, que deveriam conhecer profundamente as vicissitudes do Reino para, então, assumirem um cargo de tamanha responsabilidade. Em especial no caso de Ribeiro dos Santos, a sua polêmica trajetória dentro da Universidade de Coimbra é um importante demonstrativo do seu intenso interesse pela reforma pedagógica. ${ }^{80}$ Além disso, os cargos de censor régio, Comissário da Junta da Diretoria Geral dos Estudos do Reino (1799), Desembargador (1800), Deputado da Nova Junta do Código Militar Penal (1802) e Deputado da Mesa de Consciência e Ordens (1802) nos mostram que, aos olhos da realeza, Ribeiro dos Santos tinha todos os atributos de um súdito fiel, sendo, ainda, um homem de ampla versatilidade intelectual à altura de ser conselheiro do Príncipe Regente, como de fato o foi, a partir de 1802.

Foi dentro dessa concepção que entre os anos de 1796 e 1802 a Coroa Portuguesa investiu maciçamente na ampliação do

\footnotetext{
79 Cartas de Ribeiro dos Santos (Bibliotecário Real) de 1796-1797. BNP. Seção de Reservados. Mss. 160, 80-84. Carta n. ${ }^{\circ} 83$.

${ }^{80}$ Sobre sua trajetória coimbrã ver PEREIRA, José Esteves. O pensamento político em Portugal... Op. Cit., p. 13-74.
} 
acervo. Em maio de 1798, por exemplo, o Mordomo-Mor ordenava que Ribeiro dos Santos despendesse até 1:200\$ réis (um conto e duzentos mil reis) na compra de livros necessários para o enriquecimento do espaço. ${ }^{81}$ Quatro anos depois, em meados de 1802, o Príncipe Regente estabelecia a quantia de 1:600\$ réis (um conto e seiscentos réis), tendo como meta a aquisição de livros e jornais. As razões para as novas conquistas foram assim delimitadas:

Querendo aliviar a falta que há de fundos na Real Biblioteca desta Corte, para a compra e subscrição de obras periódicas, outros livros, que ministrem aos meus fiéis vassalos o conhecimento das úteis descobertas que se encontram em muitos anais e jornais literários, e científicos que se costumam publicar nas cortes mais polidas da Europa, hei por bem que no Meu Real Erário se pague anualmente pelo cofre do subsidio literário um conto e seiscentos mil réis; que sou servido consignar para as despesas dos ditos jornais, e livros, de que a mesma Biblioteca deve fazer aquisição. ${ }^{82}$

O decreto era dirigido a Dom Rodrigo de Souza Coutinho, então Presidente do Real Erário e também ministro encarregado da inspeção da Biblioteca da Corte. Como podemos notar, se o discurso real enfatizava a carência das obras, o fazia por uma ótica comparativa em relação à Europa do norte, considerada o berço das Luzes no século XVIII. Ademais, a educação dos súditos da monarquia também era foco de todas as atenções da realeza. Em Elementos da Civilidade e da Decência, para instrução da

\footnotetext{
${ }^{81}$ Aviso que ordena se possa comprar até 1:200\$réis de Livros. BNP. Seção de Reservados. Cód. 10610.

${ }^{82}$ Decreto em que S. Alteza Estabelece a quantia de um conto e seiscentos mil réis para a compra de livros e jornais. BNP. Seção de Reservados. Cód. 10612.
} 
mocidade de ambos os $\operatorname{sexos}^{83}$, um dos manuais de bom comportamento da sociedade cortesã da época, a relação entre leitura e conversação era estabelecida como um meio primordial para a educação da razão e dos sentidos.

A História e as Belas Letras devem ser o tesouro, onde devemos ir prover-nos das coisas, que ornam o nosso espírito para entreter uma conversação com agrado. No estudo da História e das Belas Letras acharemos o útil, e o agradável. Que poderoso motivo não é esse para obrigar um mancebo à aplicação delas! Que melhor matéria poderia ele escolher? ${ }^{84}$

Mais do que elevar a História e as Belas Letras como os dois grandes pilares do conhecimento, a obra ainda tinha um forte caráter pragmático, ensinando aos seus leitores os caminhos e vieses para a aquisição das 'luzes', ou na expressão de Immanuel Kant, do uso público da razão. Se as notícias adquiridas tinham o poder de desembaraçar as faculdades da alma, era, contudo, necessário que o aprendiz soubesse digeri-las para, assim, evitar cometer erros sobre os princípios do bom, tomando o falso pelo verdadeiro. ${ }^{85}$ Não por acaso, esse processo pedagógico esteve muito próximo ao conceito de crítica que vigorava na Europa no século XVIII, cujo significado geral, segundo Reinhart Koselleck, estava vinculado "à arte de julgar, e, portanto, de distinguir". ${ }^{86}$

\footnotetext{
${ }^{83}$ [Anônimo] Elementos da Civilidade e da decência, para instrução da mocidade de ambos os sexos: traduzidos do francês em vulgar. Lisboa: Tipografia Rollandiana, 1801, s/n. Com Licença do Desembargo do Paço.

84 Ibid., p. 217-219.

${ }^{85}$ Ibid., p. 219.

${ }^{86}$ KOSELLECK, Reinhart, Crítica e Crise: uma contribuição à patogênese do mundo burguês. Tradução de Luciana Villas Boas Castelo Branco. Rio de Janeiro: Ed. Uerj: Contraponto, 1999. p. 93.
} 
Particularmente em relação ao universo português em fins do Setecentos e princípios d'Oitocentos, o historiador José Augusto dos Santos Alves nos chama a atenção para as transformações de postura política da sociedade lusitana. "Os cidadãos interessados na coisa pública, podem desde logo optar por uma atitude crítica e pelo uso público da palavra como formas de legitimação política, econômica ou social, antes recusadas no espaço público representativo", analisa o autor. ${ }^{87} \mathrm{Ou}$ seja, esta nova concepção de espaço público em formação foi intrínseca à ascensão de uma esfera crítica em que a troca de opiniões e discussões emergia também e, sobretudo, das mudanças ocorridas nas práticas culturais. E é por este prisma que consideramos a biblioteca como um importante locus de produção do conhecimento que possibilitava múltiplas leituras e reflexões acerca de uma realidade em constante mutação. Como bem conceitua Roger Chartier, "A leitura não é somente uma operação abstrata de intelecção; ela é engajamento do corpo, inscrição num espaço, relação consigo e com os outros". 88

Apesar da crise do sistema absolutista na Europa, cuja dimensão ganhava maiores proporções à medida que se acentuava o processo revolucionário na França, a Coroa portuguesa empenhava-se em dar continuidade à política cultural da Livraria Pública da Corte, realizando-a, inclusive, como uma maneira de manter-se politicamente estável diante de países como França, Inglaterra e Espanha. Esta postura é o que nos indica o aviso de 30 de Março de 1803, que colocava em pauta o importante papel dos ministros Plenipotenciários do Príncipe Regente

\footnotetext{
87 ALVES, José Augusto dos Santos. A opinião... Op. Cit., p. 25

${ }^{88}$ CHARTIER, Roger. A ordem dos livros. Leitores, autores e bibliotecas na Europa entre os séculos XIV e XVIII. Tradução Mary Del Priori. Brasília: Editora da Universidade de Brasília, 1999. p. 16.
} 
residentes nas Cortes estrangeiras. A partir de então, estes homens de Estado da Coroa Portuguesa também atuariam como agentes culturais, tendo como responsabilidade a "abertura das correspondências literárias que se farão necessárias para a aquisição de bons livros, de que carecia prover-se a Real Biblioteca Pública de Lisboa". ${ }^{89}$ Não obstante a pouca variedade de obras que Ribeiro dos Santos tentou suprir ao longo de vinte anos (1796-1816), Manoela Domingos nos adverte que o estabelecimento assumiu-se como "lugar privilegiado da ostentação erudita da realeza”, mostrando-se, dessa forma, mais aberto aos interesses do Estado e da sociedade letrada. ${ }^{90}$

A atuação do então Ministro dos Negócios Estrangeiros e da Guerra, Antonio de Araújo de Azevedo, entre maio de 1805 e janeiro de 1806 também demonstra a mesma política de Estado no que tange à aquisição de livros. Neste período, Araújo negociou com o embaixador português em Londres, D. Domingos de Souza Coutinho, o transporte de sua livraria particular deixada em Haia, Holanda, quando da sua permanência no cargo de ministro plenipotenciário da monarquia portuguesa (17901799). ${ }^{91}$ Mesmo que o caso refira-se a uma biblioteca particular, os trâmites diplomáticos enfrentados para a condução do acervo até Lisboa compõem um episódio importante da Coroa lusitana, especialmente se considerarmos as personalidades envolvidas. Como sabemos, Azevedo e Coutinho situavam-se em polos

\footnotetext{
89 Aviso em que se determina se abra as correspondências com os Ministros de S.A residentes nas cortes estrangeiras. BNP. Seção de Reservados. Cód. 10612. p. 31.

90 DOMINGOS, Manuela. "Historial da Biblioteca Nacional..., Op. Cit., p. 8.

91 Para informações detalhadas sobre esse a atuação política de Azevedo neste período, ver: PINHEIRO, Andréa de Souza; MUNIZ, Luciana. "Antônio de Araújo de Azevedo, o Conde da Barca: política, ciências e saberes na biblioteca de um diplomata português”. Disponível em: <http://bndigital.bn.br/200anos/ araujense.html>. Acesso em: 7 fev 2011.
} 
ideológicos divergentes, sendo o primeiro conhecido na Corte como o representante do "Partido Francês", e o segundo assumidamente anglófilo. ${ }^{92}$

$\mathrm{Na}$ correspondência de 02 de maio, Araújo informava a Coutinho sobre o pedido que fizera ao Príncipe Regente no qual requeria "facilidades" para solicitar junto ao Governo Britânico um Salvo Conduto para os caixotes que constituíam a livraria, rogando-lhe que estes não sofressem "embaraço algum no seu trânsito", vindo igualmente em "Navio neutro". ${ }^{93}$ Apesar de Coutinho ter conseguido a proteção inglesa para o transporte das 62 caixas contendo livros, minerais, estampas e cartas $^{94}$, em início de agosto o navio havia sido tomado (e depois liberado) pelos britânicos. Como ainda não tinha notícias sobre a localização dos seus pertences, Azevedo utilizou-se, mais uma vez, da intervenção pessoal de D. João na negociação. Segundo o ministro, o Príncipe Regente determinava que "[se] faça diligência por saber se as ditas Caixas que me pertencem estarão já desimpedidas, e quando não estejam o representará a esse Governo que espero não fará a menor dificuldade em as mandar [sic] pôr livres". ${ }^{95}$ Dias depois, seu correspondente em Amsterdã o deixava ciente sobre o paradeiro da embarcação, que se encontrava em Yarmouth; porém, mesmo já conhecendo o paradeiro de seus pertences Araújo se mostrava muito receoso de haver alguma baldeação que pudesse atrapalhar ou mesmo adiar o envio. Por isso, apelava à Coutinho que fizesse "todas as diligências para haver a menor danificação

\footnotetext{
92 Sobre essa discussão acerca das posturas diplomáticas divergentes, ver PEDREIRA, Jorge; COSTA, Fernando Dores. D. João VI... Op. Cit., p. 88-91.

93 ANTT. Ministério dos Negócios Estrangeiros. Cx.152. Carta n. 61.

${ }^{94}$ Ibid. Carta n. 79.

95 Ibid. Carta n. 79.
} 
possível nos meus efeitos"96 que podiam ser identificados pela "marca AA", as iniciais do seu nome. ${ }^{97}$

Enfim, em janeiro de 1806 encerrava-se o episódio tendo Antonio de Araújo de Azevedo reavido a sua livraria. No entanto, para que o ministro recuperasse um objeto cultural que lhe era tão caro, foi necessário que alguns personagens capitais da diplomacia europeia se envolvessem no caso. Da parte britânica, para além de Souza Coutinho, Azevedo teve a ajuda de Lord Strangford e Lord Mulgrave ${ }^{98}$; já do lado francês, contou com a autorização de Junot, que lhe concedeu o passaporte para o livre trânsito da livraria. ${ }^{99}$

Neste intricado processo, o ministro fez questão de destacar que seu acervo possuía dois retratos de figuras ilustres da monarquia portuguesa, sendo um do Marquês de Pombal e outro de D. Luis da Cunha. ${ }^{100}$ Ao final do imbróglio, Azevedo não poupou agradecimentos "às pessoas públicas que nessa Corte [de Londres] se interessaram a favor desta restituição" ${ }^{101}$ Convém lembrar que todas essas estratégias retóricas utilizadas pelo ministro lusitano eram próprias à cultura diplomática da época, da qual era um dos mais destacados agentes. Nesse sentido, Antonio de Araújo tentava deixar claro que a sua influência como homem de Estado, assim como o prestígio da monarquia lusitana com as Coroas francesa $\mathrm{e}$ britânica, tinham sido as duas grandes razões para o sucesso dessa difícil missão, sobretudo em tempos de guerra.

Enquanto isso, Antonio Ribeiro dos Santos compunha os vários Catálogos da Livraria Pública, uma experiência crucial

\footnotetext{
${ }^{96}$ Ibid. Carta n. 83.

97 Ibid. Carta n. 83.

${ }_{98}$ Ibid. Carta n. 88.

99 Ibid. Carta s/n.

100 Ibid. Carta n. 83.

101 Ibid. Carta n. 86.
} 
para que o locus alcançasse o esplendor objetivado pela monarquia. ${ }^{102}$ A composição desses manuscritos, contudo, envolvia uma complexa rede de agentes circunscritos ao mundo da palavra impressa: do contato com correspondentes, livreiros e impressores em âmbito internacional às escolhas dos livros a serem adquiridos e cuidadosamente organizados, o bibliotecário ia tecendo importantes relações sócio-políticas nesse múltiplo circuito de informações, ao mesmo tempo em que dava forma a um amplo e novo mosaico de obras. ${ }^{103}$

A classificação dos títulos impressos que compunham (ou comporiam) o acervo da biblioteca é uma questão que deve ser reverenciada. Ao analisar a inserção e impacto dos livros religiosos na Colônia no mesmo período, a historiadora Leila Mezan Algranti destacou a complexidade dessa atividade. "[...] se o ato de classificar é por si algo que depende dos critérios da seleção

\footnotetext{
${ }^{102}$ Nesta pesquisa trabalharemos com o seguinte Catálogo: SANTOS, Antonio Ribeiro dos. Lista de livros e periódicos estrangeiros que a Biblioteca Nacional de Lisboa necessita adquirir de novo ou para completar colecções. 1796-1816. BNP. Seção de Reservados. Cód. 565. Esta opção deveu-se, principalmente, pelo fato do respectivo manuscrito tratar de diversas coleções de naturezas diferentes da Real Biblioteca Pública da Corte ao longo de todo o período em que Ribeiro dos Santos atuou como bibliotecário, isto é, entre os anos de 1796 e 1816. A íntegra deste documento pode ser conferida ao final desta teste (Anexo II). Os demais Catálogos conhecidos são: Catálogos de livros escolhidos (BNP. Seção Fundo Geral. Cód. 4622,Cód.4625, Cód.4626 e Cód.4627), Catálogos de livros para sortimento da Real Biblioteca de Lisboa e um Catálogo de livros que se devem mandar vir de fora (BNP. Seção Fundo Geral. Cód. 4631), Bibliotecas de legislação (BNP. Seção Fundo Geral. Cód. 4628), e, por fim, Biblioteca de história política de Portugal (BNP. Seção Fundo Geral. Cód. 4629).

103 Sobre a complexidade desse circuito de informação no mundo luso-brasileiro ver BELO, André, As Gazetas e os Livros... Op. Cit.; LISBOA, João Luís Lisboa, "News and newsletters in Portugal". In: Enlightement, Revolution and the periodical press, Voltaire Foundation, Oxford, 2004; LISBOA, João Luís; MIRANDA, Tiago C.P. dos Reis e OLIVAL, Fernanda, Gazetas Manuscritas da Biblioteca Pública de Évora (1729-1731), vol. 1. Lisboa: Edições Colibri, 2002; MEIRELLES, Juliana Gesuelli. Imprensa... Op. Cit.
} 
adotada e estes podem levar em consideração vários elementos, dificilmente encontraríamos dois sistemas classificatórios iguais para os livros religiosos" 104 , conceitua a autora. As diferenças nos sistemas classificatórios apontadas por Algranti constituíram um problema dos homens de letras ${ }^{105}$ do Antigo Regime e, portanto, se estendiam para todos os tipos de livros independentemente da temática.

Considerando-se que a produção e classificação de um Catálogo de obras impressas é um ato de poder, a personificação dessa atividade na figura de um homem de letras de destaque no caso Antonio Ribeiro dos Santos - representava, na prática, a exaltação da sua concepção particular de leitura, sobretudo em tempos de Encyclopédie onde a disputa pelo prestígio intelectual tornara-se moeda de grande valia dentro do conflituoso universo da República das Letras. No caso do renomado bibliotecário régio, ao colocar o seu saber a público este não apenas ratificava a sua força intelectual, mas especialmente atribuía os seus hábitos de leitura para os leitores em geral. E como bem demonstrou o pesquisador Rodrigo Bentes Monteiro ao estudar os folhetos de Diogo Barbosa Machado, ao escolherem e organizarem as suas coleções, esses homens de letras tinham seus critérios de relevância. ${ }^{106}$ A tentativa de desvendá-los, talvez, nos ajude a adentrar em

104 ALGRANTI, Leila Mezan. Livros de Devoção... Op. Cit., p. 179.

105 Utilizamos o conceito de homem de letras defendido pela filósofa Hannah Arendt. Segundo a autora, "os homens de letras se educaram e cultivaram suas mentes em uma reclusão pela qual optaram livremente, colocando-se portanto a uma distância calculada, tanto do social como do político - dos quais de qualquer sorte, haviam sido excluídos -, a fim de observá-los em uma perspectiva apropriada." ARENDT, Hannah. Da Revolução... Op. Cit., p. 33-36.

106 MONTEIRO, Rodrigo Bentes. "Portugal e as conquistas ultramarinas nos folhetos de Diogo Barbosa Machado" Disponível em: <http://www2.iict.pt/index.php?idc=102\&idi=13077>. Acesso em: 15 out. 2012. 
vieses relevantes da concepção de leitura desses sujeitos do final do século XVIII e princípios do século XIX. ${ }^{107}$ Por outro lado, não podemos nos esquecer do amplo aparato censor vigente no Império Português que tinha na Inquisição, no Ordinário e no Desembargo do Paço a sua base institucional desde fins de $1794 .{ }^{108}$ Como bem analisou Algranti, o sistema de censura da sociedade de corte luso-brasileira da segunda metade do século XVIII era regido pela premissa da desigualdade, em que pese o fato de algumas leituras (geralmente as tidas como proibidas) serem consideradas boas para alguns e não para outros. ${ }^{109}$ Nesse contexto, por mais que Ribeiro dos Santos, por sua posição privilegiada, tivesse o beneplácito real para ler as obras consideradas sediciosas, seu critério de relevância dos livros e periódicos que compuseram o acervo da Biblioteca Pública Real da Corte, foi guiado dentro dos limites considerados aceitáveis pela realeza.

A difícil tarefa de classificação das obras também pode ser apreendida na análise de um de seus Catálogos, cujo critério de

\footnotetext{
107 DARNTON, Robert. O Beijo de Lamourette:... Op. Cit.

108 Para informações mais detalhadas referente ao aparato censor da monarquia portuguesa conferir a Introdução desta tese além das seguintes obras. ALGRANTI, Leila Mezan. Livros de Devoção... Op. Cit.; NEVES, Lúcia Maria Bastos P. "Comércio de livros e censura de ideias: a atividade dos livreiros franceses no Brasil e a vigilância da Mesa do Desembargo do Paço (1795-1822)”. In: Ler História, 23, 1992; VILLALTA, Luiz Carlos, "Censura literária e inventividade dos leitores no Brasil Colonial”. In: TUCCI, Maria Carneiro (Org.), Minorias Silenciadas: História da Censura no Brasil. São Paulo: Edusp, 2002.

109 ALGRANTI, Leila Mezan. Livros de Devoção... Op. Cit., p. 173. De acordo com a autora, "Na segunda metade do século XVIII, muitos padres, mas também leigos, dirigiram-se ao monarca a fim de obter a desejada licença para ler obras proibidas. Geralmente as justificativas apoiavam-se no desejo de adquirir maior instrução relacionada com o exercício das profissões. Estudantes e bacharéis em leis, médicos e cirurgiões submeteram pedidos desse tipo e foram atendidos. Mas também fidalgos - burocratas de carreira no Ultramar - consideravam o privilégio de ler livros proibidos um sina de status distinção, assim sendo requeriam ao monarca licenças desse tipo." Idem.
} 
relevância priorizou os centros literários considerados de grande reconhecimento público na Europa Iluminista. Ou seja, a seleção dos títulos que interessavam ao bibliotecário adquirir, sendo estes considerados balizas importantes para o progresso das letras em Portugal, foi prioritariamente europeia e esteve circunscrita a seis locais, entre países e cidades. Espanha, França, Itália, Nápoles, Berlim e Inglaterra, nesta ordem, aparecem como os espaços de produção que mereciam ser reverenciados nas estantes da biblioteca.

Tal como Barbosa Machado em sua coleção de folhetos, em que predominava a "ordem entre os continentes", sendo que os títulos referentes “à Ásia, vêm antes de América e África, contrariando a lógica que destaca a importância do Brasil na conjuntura do século XVIII"110, Antonio Ribeiro dos Santos também hierarquizou os lugares com os quais dialogava: a Península Ibérica foi reverenciada pela Espanha na abertura do seu Catálogo, com um total de 32 publicações impressas consideradas de interesse para as estantes reais lusitanas. Depois, França e Itália, com 53 e 28 títulos respectivamente. Se a primeira era a "essência do espírito enciclopédico", na expressão de Franco Venturi ${ }^{111}$, a segunda era a grande referência da Antiguidade greco-romana, tão apreciada pelos europeus desde a Renascença. Neste particular, também podemos incluir Nápoles, que, juntamente com Milão, constituíram-se nos principais centros do Iluminismo italiano a partir de $1760 .{ }^{112}$ Por fim, nesse movimento sobressaíram-se Berlim e Inglaterra que, para além de terem sido grandes apreciadores e admiradores do movimento enciclopédico, também brilhavam como centros filosóficos. Da Grã-Bretanha, por exemplo,

${ }^{110}$ MONTEIRO, Rodrigo Bentes. "Portugal e as conquistas..., Op. Cit.

111 VENTURI, Franco. Utopia e Reforma no Iluminismo. Trad. Modesto Florenzano. Bauru, SP: EDUSC, 2003. p. 226.

112 Ibid., p. 233. 
advinha a ideologia deísta, que saiu da Ilha para dominar o continente. Sendo Ribeiro dos Santos um antideísta ferrenho ${ }^{113}$, não é de se espantar que a Inglaterra tenha sido relegada ao último centro intelectual de seu Catálogo, tendo tido os periódicos britânicos maior importância do que as obras clássicas do país.

Em relação às obras de forma geral, o literato faz comentários sobre os títulos que constituíam o acervo ou que deviam ser comprados. Analisa-os com um discurso detalhado - informando o local e ano da publicação, além de, em alguns casos, fazer uma pequena descrição da obra, caracterizando-a. Para além de facilitar o seu próprio trabalho de catalogação interna, esta postura do bibliotecário também tinha o intuito de promover as atividades dos seus ajudantes, quando entravam em contato com os leitores do espaço, fossem eles frequentadores eventuais ou assíduos. Com as informações minuciosas do acervo, os agentes da biblioteca podiam direcionar melhor a pesquisa e os interesses do seu público leitor.

Nesse sentido, a análise do historiador João Luís Lisboa sobre as bibliotecas públicas em Portugal entre 1780 e 1820 nos é muito elucidativa. "Não há dúvida de que estas bibliotecas eram frequentadas, mas normalmente dentro de um espírito de 'trabalho' e de 'investigação"'114, esclarece o autor. Logo, é dentro desse paradigma que um leitor pedirá uma novela para ler. "[...] em princípio [esse leitor] deseja conhecer algum tipo de literatura, ou algum autor, e não alguém que procure distrair-se ou

\footnotetext{
113 Sobre a concepção religiosa de Antonio Ribeiro dos Santos e a crítica ao deísmo, ver: PEREIRA, José Esteves. O pensamento político em Portugal... Op. Cit., p. 179-240.

114 LISBOA, João Luís. Ciência e Política. Ler nos finais do Antigo Regime. Lisboa: Instituto Nacional de Investigação Científica, Centro de História da Cultura, Universidade Nova de Lisboa, 1992. p. 44.
} 
entreter-se. É essa leitura que as bibliotecas facultam, e o público não poderá sair de um círculo de "estudiosos", laicos ou religiosos, conclui Lisboa. ${ }^{115}$ Nesse contexto, compreendemos melhor as escolhas temáticas de Antonio Ribeiro dos Santos. Vejamos, então, como classificou a lista de algumas Obras Periódicas de Espanha:

Memorial Literário o Bibliotheca Periódica de Ciências y Artes. (temos o tomo I., ano primeiro. Madri, em la Imprenta de Garcia e Comp. ${ }^{\text {a }}$. Octubre de 1801.);

Bibliotheca Española Economico_Política (É coleção de extratos, e se abriu por subscrição em 1802 e tem já saído seis pequenos cadernos, ou n ${ }^{\circ} \mathrm{s}$. [)].

Correio literário de Xeres (Começou em 1800, e subscreve-se em Madri na Casa de Esparza).

Semanário de Agricultura y Artes (Publicam-se por ordem Superior. Temos o tomo IX e X. Impressos em Madri em $4^{\circ}$ em 1801 na Imprenta de Villal Pando[)].

Mercurio de España Madrid: (Há m.tos anos que sai, e necessitamos de todos os tominhos [sic] que tem saído até agora [)].

Anales de Ciências Naturaes (Publicam-se por Ordem Superior, julgamos serem já 14 tomos [)].

Anales de Artes y Manufacturas por R. O. Reylli. ${ }^{116}$

Já para a "lista [rasurado] de alguns livros de Espanha que necessita a Real Biblioteca”, por exemplo, selecionou as seguintes obras:

Memorias Políticas, y Economicas sobre los frutos Commercio, Fabricas, y Minas de España, por D. Eugenio Lavruga 1792. (46 tomos de $4^{\circ}$ e talvez haverá mais).

D. Luiz Luniga. Plano de Antiguidades Espanolas [sic] (em casa de Castilla frente a las grades de S. Filippe).

${ }^{115}$ Ibid., p. 44.

116 SANTOS, Antonio Ribeiro dos. Lista de livros e periódicos estrangeiros... Op. Cit. BNP. Seção de Reservados. Cód. 565. 
Introduction a la Historia Natural y a la Geografia física de Espana por D. Guillermo Bowles. 1 tomo. $4^{\circ}$ [)].

Historia de Políbio Megapolitano traducida del Griego por D. Ambrosio Ruy Bomba. 3. V. $4^{\circ}$.

Obras Poéticas de Píndaro em Metro Castellano con el texto Griego y notas Críticas , por D. Fran.co Patricio de Berguiza. 12. ${ }^{\circ}$

Los diez libros de Diogenes Laercio sobre las vidas de los Filosofos traducidas del Griego por D. Jozé Ortiz. 2 V. $4^{\circ}$. Oraciones e Cartas de Socrates traducidas del Griego, y illustradas con notas por D. Antonio Ranz Ramanellos. $3 \mathrm{~V} .{ }^{\circ}{ }^{\circ}$ maior.

Examen de la possebilidad [sic] de fixar la significacion de los sinonimos de la língua Castellana, por D. Jozé Lopes de la Huerta. 1V. $8^{\circ}$.

D. Juan de la Reguera Val de tomar Resumem de la Historia Cronologica del Derecho y Leis de España. Tomos dez Fueros.

D. Rennan Lavaro de Dou Instituiciones del Derecho Publico Geral de Espana.

D. Dionizio Marcate e Dias . Leciones de Navegacion e Arte de la cria de Gusanos de Seda por Juan Lanes y Durval. 1 V.8. ${ }^{\circ}$

Elementos de Higiene trad. De Esteban Soustelle por D. Luiz Mexia.

D. Segismundo Malats. Elementos de Veterinarian el . Dissertacion sobre la explicacion y uso de um Maquina agramadera para agramar Canais e linos em $4 .^{\circ}$

Descripcion de las Maquinas de mas general utilidade que hay em el Real Gabinete de ellas en el Buen Retiro. V. 1.2.3.4.

Dicionario histórico de las Artes de la Pesca nacional por D. Antonio Sanez Reguard. 5. tomos $4^{\circ}$ maior.

Reflexiones sobre las Maquinas y Maniobras del uso de à bordo pr D. Francisco Ciscar. 1 tomo. $4^{\circ}$.

Memoria elemental sobre los nuevos pesos, $y$, medidas decimales fundados en la natureza por el mismo. Tratado de Navegacion por d. Joseph de Mendoza y Rios. 2V. $4^{\circ}$. 
Ensayos políticos econômicos y filosóficos del Conde de Rumtoro. Traduciodos por D. Domingos Aguero y Neyva. Elementos del Arte de tenir de Mr. Berthollet traduc. con addiciones D. Domingos Garcia Fernandes. 2V. $8^{\circ}$.

Ordenanzas Generales dela Armada Naval. 2 tomos. Fol. D. Jayme Bovells y D. Ignacio Lacaba. Curso completo de Anatomia.

Diccionario elemental de Farmacia por D. Manuel Hermandez de Gregorio 2 tomos. $4^{\circ}$.

Diccionario General de Medallas de D. Thomaz de Gulseme. $1773.6 \mathrm{~V} .4^{\circ}$.

Casto Gonzales Instrucciones Antiquario Lapidarias, traducidas de la língua Toscana. Madrid 1794. 1 V. $4^{\circ} .^{117}$

Como podemos notar, o bibliotecário privilegiou as obras de História, Geografia, Política, Jurisprudência, Medicina, Letras (Literatura e Ortografia, com ênfase para os dicionários), e Ciência em geral. A natureza deste corpo documental assim como a intervenção de Antonio Ribeiro dos Santos na montagem do Catálogo e na classificação das obras, provavelmente obedeceu a uma tradição literária com dois polos [?] distintos: Portugal e Europa. No país, destacava-se a relevância do trabalho do bibliófilo Diogo Barbosa Machado, que teve um grande peso entre os homens de letras da segunda metade do século XVIII. Já no Continente, a classificação da Encyclopédie era a grande referência. ${ }^{118}$

A organização e classificação das obras da coleção de Barbosa Machado já deixava claro o eminente valor dado à palavra

117 Ibid.

118 Como bem salienta Robert Darnton, a classificação proposta pelos filósofos da Encyclopédie deixava claro que "a própria tentativa de impor uma nova ordem ao mundo tornou os enciclopedistas conscientes das arbitrariedades de toda ordenação." DARNTON, Robert. O grande massacre de gatos e outros episódios da história francesa, tradução de Sonia Coutinho. 4. ed. Rio de Janeiro: Ed Graal, 2001. p. 252. 
escrita; aspecto que a diferenciava das demais compilações do período, tão voltadas "para medalhas, moedas e outros vestígios materiais do passado."119 Para Monteiro e Caldeira, o destaque de tal postura dá-se, sobretudo, por expressar o predomínio da civilização da escrita, na acepção do historiador Fernando Bouza. Por ser o grande objeto da livraria de Diogo Barbosa Machado, a palavra impressa ganhava uma nova dimensão: estreitava-se o vinculo entre o poder e a tipografia, o que muito influenciou as escolhas de Antonio Ribeiro dos Santos na composição do acervo real.

Diferentemente da Espanha, a catalogação dos títulos da França foi separada em duas listas: livros e periódicos. Para o primeiro acervo, o foco esteve na lista "das continuações de que necessita a Biblioteca de Lisboa para completar as obras que já tem", sendo estas estruturadas em seis temas: 1 . História Civil e Política; 2. História Literária; 3. Filosofia e Artes; 4. Medicina em particular [sic]; 5. Poligrafia; e 6. Outras Obras de novo [sic]. Já o segundo, foi intitulado De Jornais e mais obras Periódicas que necessita a Biblioteca de Lisboa, sendo a prioridade os periódicos de História Natural, Arte e Ciência, Literatura e Política. Para a Itália, o bibliotecário fez uma classificação semelhante. Se o princípio foi a seleção temática - 1. História Literária; 2 . História Civil e Política; 3. Ciências e Artes; 4. Medicina em particular [sic]; e 5. Poligrafia - notamos duas importantes diferenças quando comparamos com o arranjo dos impressos franceses. A primeira delas refere-se à ordem dos temas (enquanto para França História Civil e Política aparece no topo da lista, para a Itália o destaque é dado à História Literária) e a segunda à classificação propriamente dita.

119 MONTEIRO, Rodrigo. Bentes; CALDEIRA, Ana Paula Sampaio. "A ordem de um tempo: folhetos na coleção Barbosa Machado” In: Revista TOPOI, v. 8, n. 14, jan.-jun. 2007, p. 78 (Grifo do Original). 
Para os livros franceses, Ribeiro dos Santos denominou as obras de "Filosofia e Artes", enquanto os livros italianos de categoria análoga foram categorizados como "Ciências e Artes".

Ambas as denominações, no entanto, respeitam a ordem classificatória do século XVIII, inclusive a veiculada na Encyclopédie, e, à época, eram consideradas sinônimos. Como bem contextualizou João Luís Lisboa, "A noção de Filosofia, se exclui a Teologia e Jurisprudência, inclui então como parte muito importante a chamada 'Filosofia Natural', onde cabiam as ciências da natureza". ${ }^{120}$ Esse tipo de leitura é tão valorizado no período que em 1815 a Gazeta de Lisboa anunciava um "jogo otimanente encadernado da Enciclopedia, ou Dicionário Geral das Ciências, Artes e Ofícios, por Diderot e d'Alembert" cuja edição, tida como "asseada e cômoda", era composta por 39 volumes, podendo ser compradas na loja de Livros de João Henriques, na Rua Augusta N.1. ${ }^{121}$ Em relação às outras produções impressas italianas de que necessitava a biblioteca, definiu-as como "coleções e extratos", sendo as obras de Nápoles divididas em "coleções" e "outras obras". Finalmente, se Berlim e Inglaterra também foram contempladas como grandes centros culturais, a catalogação de seus livros foi feita de forma mais geral. Para a cidade germânica, o bibliotecário selecionou obras de História, Ciências e Artes. Já para as obras inglesas compôs duas listas: a primeira, referente aos jornais, papéis e periódicos que precisavam ser adquiridos; e a segunda, alusiva aos livros especificamente.

É curioso observamos ainda as obras selecionadas pelo bibliotecário régio, independente dos espaços de produção. A ênfase do Catálogo foi circunscrita aos títulos impressos na se-

${ }^{120}$ LISBOA, João Luís, Ciência e Política... Op Cit., p. 91.

121 GL. 1815. n. 116. 
gunda metade do século XVIII, com especial destaque para os livros e coleções produzidos entre as décadas de 1770 e 1780. Essa perspectiva, contudo, não desviou seu interesse para os livros e periódicos veiculados na Europa durante a Idade Moderna. De Britannica Lingua Institutiones, obra de Joann Cambro publicada na Inglaterra em 1592 à coleção de extratos da Bibliotheca Española Econômico-Política, impressos na Espanha a partir de 1802, Ribeiro dos Santos procurou compor as estantes com referências clássicas. Nos títulos da Itália encontramos, por exemplo, a procura pela coleção de História Antiga, L'Abbate Viviani Collecione dell'Historici antiqui Herodoto Thucydides V. Vulgarizati, publicada em Roma, em 1790. Para a Espanha, uma das escolhas recaiu em Historia de Políbio Megapolitano traduzida do grego. Já em relação a França, Histoire del Academie Royale des Scciences de Paris apareceu como um dos destaques da categoria "Filosofia e Artes".

Essa atividade quase febril de Antonio Ribeiro dos Santos, que fazia da biblioteca inclusive seu lugar de descanso ${ }^{122}$, contribuiu sobremaneira para a institucionalização da palavra impressa no Brasil a partir de 1808, data em que a Corte portuguesa chegava à América. A fundação da Real Biblioteca do Rio de Janeiro, em 1811, assim como o trabalho do bibliotecário Luís Joaquim dos Santos Marrocos, entre os anos de 1811 e 1821, foram

\footnotetext{
122 Segundo o depoimento de Antonio Feliciano de Castilho, seu contemporâneo, "Era a biblioteca o íntimo retiro deste ermitão de Parnaso, fugida para longe das casas, posto que quietas e frescamente assentada em meio de muitas sombras, verduras e aromas do seu jardim, horta e pomares. Grandíssima cópia de livros, longamente procurados e custosamente juntos, e entre os quais se estremavam, no número e riqueza, os gregos, os romanos, e os antigos portugueses... Um Apollo de mármore, com a sua lira em punho parecia estar-se muito bem cabido no meio daquele seu alcaçar.[sic]". CASTILHO, Antonio Feliciano. Acerca da pessoa do Sr. Antonio Ribeiro dos Santos. In: A primavera, Lisboa, 1837, p. 325-326. Apud PEREIRA, José Esteves. O pensamento político em Portugal... Op. Cit., p. 83.
} 
altamente inspirados na sua congênere lisboeta e no mais dileto de seus funcionários, Ribeiro dos Santos. A compreensão desse diálogo interatlântico marcado pela trajetória de uma seleta coleção real que atravessou o Atlântico em três viagens distintas, tornando-se o primeiro acervo da nova instituição da corte, é o tema do próximo item.

\subsection{A nova Corte do Rio de Janeiro joanino: a Impressão Régia e o mundo dos livros}

Uma das grandes transformações ocorridas no Rio de Janeiro a partir de 1808 foi a introdução da tipografia. Com o nascimento da Impressão Régia deste lado do Atlântico, sancionada pelo decreto de 13 de maio de 1808, a sociedade fluminense passou a conviver cotidianamente com a circulação da palavra impressa. ${ }^{123}$ Dos decretos reais aos livros que "saíam à luz" ou se "achavam à venda" 124 , perpassando os almanaques, cartazes e a própria Gazeta do Rio de Janeiro, entre outros periódicos, os habitantes da nova capital do Império Português - a despeito da atuação dos censores - tinham ao seu alcance a possibilidade de

123 Peça fundamental no processo de comunicação interatlântica, intimamente associado à veiculação da propaganda do Estado e, consequentemente, à sustentação do Império Português nos dois lados do Atlântico, a Impressão Regia tinha numerosas funções que extrapolavam a impressão exclusiva dos papéis ministeriais e diplomáticos do serviço real de todas as repartições, como os alvarás, decretos e cartas régias. Ficava sob a sua responsabilidade também imprimir as obras de particulares, tanto quanto produzir e fazer circular a Gazeta do Rio de Janeiro.

124 As duas categorias das obras foram objetos de estudo da historiadora Maria Beatriz Nizza da Silva. Os livros que "saíam à luz" referiam-se aqueles produzidos na Corte, já os que "se achavam à venda" incluíam-se os importados da metrópole. SILVA, Maria Beatriz Nizza da. "Livro e sociedade no Rio de Janeiro". Separata da Revista de História No 94. São Paulo - Brasil. 1973. p. 443. 
realizarem múltiplas leituras acerca da realidade vivida. ${ }^{125}$ Segundo o historiador Marco Morel, a difusão das palavras independentemente de sua natureza - falada, manuscrita ou impressa ultrapassava as fronteiras sociais e perpassava amplos setores da sociedade não ficando estanque ao restrito círculo de letrados. Apesar disso, eram estes homens de letras que detinham o poder de produção e leitura direta da palavra impressa, com destaque para a imprensa. ${ }^{126}$

Este foi o caso do físico-mor Manoel Vieira da Silva. Personalidade de grande prestígio na Corte, o ilustre súdito publicou, a pedido do Príncipe Regente, a obra Reflexões sobre alguns dos meios propostos por mais conducentes para a melhoria do clima da cidade do Rio de Janeiro. As moléstias da cidade preocupavam D. João, que pedia urgência na escrita da obra para, assim, resolver os problemas da saúde pública. ${ }^{127} \mathrm{O}$ pragmatismo da ordem monárquica teria resposta ainda em 1808, quando o livro foi impresso pela Tipografia Real sendo, portanto, uma das primeiras publicações veiculadas pela Impressão Régia. ${ }^{128}$ No Prólogo, Vieira da Silva justificava a rápida impressão. “[D. João] Ordenou o seu Físico-mor que dissesse por escrito o que pensava sobre esta matéria, para assim excitar as pessoas instruídas a fazerem públicos os seus sentimentos, e apurar-se pela discussão um artigo, que

\footnotetext{
125 Para uma análise sobre a multiplicidade desse universo impresso, ver SILVA, Maria Beatriz Nizza da. "A imprensa periódica na época joanina". In: NEVES, Lúcia Maria Bastos Pereira das. Livros e Impressos: retratos do Setecentos e do Oitocentos. Rio de Janeiro: EdUERJ, 2009. p. 15-30; MOREL, Marco. “Das gazetas tradicionais aos jornais de opinião: metamorfoses da imprensa periódica no Brasil". In: NEVES, Lúcia Maria Bastos Pereira das. Livros e Impressos: retratos do Setecentos e do Oitocentos. Rio de Janeiro: EdUERJ, 2009. p. 153-184; MEIRELLES, Juliana Gesuelli. Imprensa... Op. Cit.

${ }^{126}$ MOREL, Marco. “Das gazetas..., Op. Cit., p. 163.

127 SILVA, Manoel Vieira da. Reflexões sobre... Op. Cit.

128 GRJ. 1808. No14. (Edição de 29/10/1808).
} 
todo se dirige para bem dos Povos". ${ }^{129}$ Ainda no Prólogo, Silva convidava "os mais sábios e inteligentes para dizerem coisas melhores"; o que propiciaria tanto a execução das "boas sugestões" pelo governo quanto à satisfação do público que tiraria "as vantagens que tanto são para desejar". ${ }^{130}$

Para além de propor a reorganização da saúde pública da nova capital, cujo tema, segundo ele, "em todos os tempos tem merecido as primeiras atenções dos grandes legisladores"131, Manoel Vieira da Silva impulsionava uma discussão que se pretendia coletiva; até porque os problemas do Rio de Janeiro perpassavam a vida de todos os seus habitantes, cujo número aumentava significativamente desde que a urbe se tornara a residência da Coroa portuguesa. ${ }^{132}$ Ademais, com a circulação da Gazeta do Rio de Janeiro, a partir de setembro de 1808, notamos o interesse dos leitores na publicação de anúncios. ${ }^{133}$ Dentre as vastíssimas temáticas que englobaram a Seção de Avisos ao longo dos treze anos em que a realeza residiu no Brasil (1808-1821), destacamos o universo impresso e o empenho desses sujeitos na veiculação de seus projetos literários.

\footnotetext{
129 SILVA, Manoel Vieira da. Reflexões sobre alguns... Op. Cit., p. iii (Grifos Nossos). ${ }^{130}$ Ibid. (Grifos Nossos). cipe regente D. João mudaria radicalmente o universo sociocultural da capital da Colônia. A começar pelo crescente número de habitantes entre os anos de 1808 e 1821. Se até 1808 o Rio de Janeiro era uma cidade com cerca de 60.000 habitantes, o censo de 1821 já apontava para uma população em torno de 79.321 pessoas, contando o alto número de estrangeiros que fixaram residência, escravos, libertos e a população livre. Para uma análise historiográfica sobre o crescimento da população no período, ver ALGRANTI, Leila Mezan. O feitor ausente. Estudo sobre a escravidão urbana no Rio de Janeiro (1808-1821). Petrópolis: Ed. Vozes, 1988. p. 30.

${ }^{133}$ Para a compreensão do interesse da sociedade joanina na veiculação de anúncios na Gazeta, ver: MEIRELLES, Juliana. Imprensa e poder... Op. Cit., p. 155-180; e SILVA, Maria Beatriz Nizza da. Gazeta do Rio de Janeiro:... Op. Cit.
} 
Em 1815, por exemplo, a Gazeta anunciava mais um título produzido pela Tipografia Real: Corografia Brasílica, do clérigo Manuel Aires do Casal. ${ }^{134}$ Segundo o anúncio, a obra achava-se pronta para a impressão e aqueles que quisessem subscrevê-la deveriam depositar $1 \$ 600$ réis por cada exemplar, na loja de Manuel Mandillo. ${ }^{135}$ Segundo a lista que acompanhava a edição, houve um total de 93 subscritores, com 133 exemplares subscritos. ${ }^{136}$ Em abril de 1816 o livro não tinha saído do prelo, pois Luís Joaquim dos Santos Marrocos informava ao pai que estava realizando a sua revisão ${ }^{137}$; ainda em maio do mesmo ano, o livro se encontrava em fase de produção. A demora na impressão foi motivo de grande desconforto para o prefeito da Real Biblioteca, o Padre Joaquim Dâmaso, que escrevia à Silvestre Pinheiro Ferreira $^{138}$, pedindo as devidas explicações à Junta da direção da Tipografia Régia.

Desde novembro se trabalha na obra do P. Aires de Casal; semanas tem havido em que tem saído 4 folhas, e em outras cinco, e apesar disto tem saído 25 folhas só, tantas tem sido as Semanas: Que razão terá havido para não serem todas as semanas iguais? Será por não se pagar quando querem, e adiantado? Será por falta de papel? Nenhuma destas faltas tem havido. Será por se demorarem as provas? Também não; porque se vem pela manhã, vão à

${ }^{134}$ Sobre a figura de Aires de Casal e a importância de sua obra para a História do Brasil, ver: GUIMARÃES, Lúcia Paschoal. "Manoel Aires do Casal" In: NEVES, Lúcia Bastos Pereira das; VAINFAS, Ronaldo. Dicionário do Brasil Joanino... Op. Cit., p. 316-317.

135 GRJ. 1815. n. 59.

136 SILVA, Maria Beatriz Nizza da. "Livro e sociedade no Rio de Janeiro"... Op. Cit., p. 446.

${ }_{137}$ MARROCOS, Luís Joaquim dos Santos. Cartas do Rio de Janeiro... Op. Cit., p. 333. [Carta 98].

${ }^{138}$ Silvestre Pinheiro Ferreira era um dos diretores da Impressão Régia e da Gazeta do Rio de Janeiro. 
tarde, se vem de tarde, vão pela manhã, e muito o mesmo autor se vê na Tipografia: se os dois CC. [sic] tem sido demorada, porque o Autor desesperado com o desprezo que na Tipografia fazem a sua obra e da sua Pessoa, intentava abrir mão dela inteiramente; e quem tem a culpa?

\section{O clérigo ainda exaltava o bom comportamento de Aires de Casal:}

A civilidade com que o Autor trata a todos, não merecia que uma Oficina, e Oficina Régia, se tratem as pessoas de similhante [sic] forma, e isto em uma Oficina que necessita acreditar-se. Em todas as Oficinas, nenhuma Obra deve ser preferida à já começada, e muito mais sendo esta útil; e portanto, por experiência temos observado que sem fadiga se pode dar 4 folhas a cada semana, e se a Junta não quer que a Oficina as dê, então o autor quer se lhe entregue o Original, e pagar o que resta a dever do que se lhe entregar. ${ }^{139}$

Mesmo muito extensa, a carta do bibliotecário nos esclarece alguns aspectos importantes dos bastidores da Impressão Régia. É patente o conflito de interesses entre os diretores da Tipografia Régia e o autor da obra. Muito provavelmente, as obras a serem produzidas sem custos eram escolhidas, em última instância, pelo Príncipe Regente, o que podia causar desconforto aos dirigentes da Impressão Régia. Se estes não ousavam questionar as preferências literárias do monarca, acabavam por realizar o projeto selecionado dentro dos prazos que eles próprios estabeleciam, ou seja, sem data limite para a conclusão. Na ocorrência de Casal - através da irregularidade na entrega do material aos

139 Joaquim Dâmaso. Real Biblioteca, 01 de maio de 1816. Apud CAMARGO, Ana Maria de Almeida; MORAES; Rubens Borba de. Bibliografia... Op. Cit., Vol. 1.p. 182. 
editores do projeto (que se incluem aí os funcionários da Biblioteca, entre eles Luís Marrocos), os diretores optaram por dar morosidade à produção do livro e desprezar as súplicas do seu autor.

A intervenção de Padre Dâmaso também pode ser lida como um alerta aos chefes da Tipografia Real: se a Coroa prezava pela consolidação de uma instituição tão vinculada a um projeto específico de Império - que perpassava educar politicamente seus súditos através da produção de obras pedagógicas, da arte à ciência -, era inadmissível uma atitude tão desrespeitosa por parte de seus diretores. Em outras palavras, o Padre advertia-os: como súditos responsáveis pela estruturação e funcionamento dessa instituição, eles deveriam reverenciar, acima de outros interesses, o status quo.

Ao final da carta, apesar de Dâmaso justificar sua "impertinência" através da "Justiça da Causa"140, notemos que este se dirigiu aos seus colegas diretores em pé de igualdade, demonstrando a autoridade do seu lugar de Prefeito da Real Biblioteca. Em tempos de institucionalização da palavra impressa no Rio de Janeiro - em que pese o nascimento de novos livros e de sua circulação e leitura pela cidade e, quiçá, pelos dos dois lados do Atlântico -, a figura do bibliotecário parecia ser imprescindível. E sua intervenção, indiscutível. Tanto é, que enfim, depois de tantos desentendimentos, em 1817, a obra "saía à luz". Deste episódio ainda podemos entrever o quanto o trabalho dos funcionários da Real Biblioteca e da Impressão Régia eram interdependentes, mormente quando se tratava de preservar a instrução.

Ainda em 1815, Roberto Ferreira da Silva anunciava que pretendia "dar ao prelo uma coleção de perspectivas dos mais interessantes pontos desta corte e seus subúrbios". Para o sucesso do

140 Joaquim Dâmaso. Real Biblioteca, 01 de maio de 1816. 
empreendimento, no entanto, o autor também rogava ao público que subscrevesse a sua obra. Os interessados podiam dirigir-se à loja de José Antônio Pinheiro Filho, na Rua Direita, onde pagariam pela subscrição. ${ }^{141}$ Como nos informa Maria Beatriz Nizza da Silva, o alto custo da obra impossibilitou a impressão. Dois anos depois, contudo, Ferreira da Silva realizava o seu projeto literário. Com um orçamento mais barato, em 1817 publicava pela Impressão Régia a obra Elementos de Pintura e Regras Gerais da Perspectiva, que contou com 172 subscritores, entre eles nomes da nobreza portuguesa e dos negociantes fluminenses. ${ }^{142}$

Enquanto algumas obras saíam do prelo, outras ficavam apenas no projeto. Ainda de acordo com Nizza da Silva, estas duas situações ocorriam por razões distintas. Quando a Impressão Régia editava as obras "por ordem de S.A.R”, os custos da impressão saíam do Real Erário, não gerando despesas financeiras para os autores. Por outro lado, a Tipografia Real também aceitava publicar textos de escritores desconhecidos. Estes originais, além de serem submetidos à censura, precisavam recorrer ao tradicional sistema de subscrição para virem à luz, dado o alto valor da impressão. ${ }^{143}$ Em maio de 1817, por exemplo, Marrocos avisava a seu pai sobre a subscrição da obra Retratos e elogios dos varões e donas que ilustraram a nação portuguesa, anunciada na Gazeta do Rio de Janeiro e cujo exemplar fora enviado juntamente com a carta. ${ }^{144}$

141 GRJ. 1815, No 20.

${ }^{142}$ SILVA, Maria Beatriz Nizza da. Gazeta do Rio de Janeiro (1808-1822)... Op. Cit., p. 181.

${ }^{143}$ Ibid., p. 179-180.

144 A subscrição ainda podia ser feita na Loja de Saturnino, na rua da Alfândega, Manoel Mandillo, na rua Direita, e Manoel da Silva Porto, na rua da Quitanda. GRJ. 1817. № 37. 
[...] tenho na Livraria uma folha de Subscrição, de que me fez favor encarregar-se o Padre Joaquim Dâmaso, e na qual por suas diligências já se assinaram mais de 16 pessoas, assim literatas, como da primeira grandeza, que ali concorrem; e se espera aumentar este número consideravelmente, porque não só uns servem de estímulo aos outros, mas tem à vista o exemplar que daí [Lisboa] se me remeteu, e que sem o desfrutar tenho-o ali para este fim depositado. ${ }^{145}$

Como já analisamos anteriormente, as subscrições de uma obra não apenas davam visibilidade pública ao subscritor, como também era um caminho possível para o alcance de futuras mercês; afinal de contas, como bem demonstrou Marrocos, se em uma sociedade de corte a hierarquia ditava os lugares sociais, a subscrição de uma obra aparecia como um privilégio para poucos. Como bem analisou Tania Ferreira, nesse período, "a expressão de opinião e a manifestação estética não eram compreendidas, tal como ocorre hoje, como direitos". ${ }^{146}$ Para além dos múltiplos sentidos e dificuldades vigentes neste mundo, a produção editorial da primeira tipografia brasileira era ampla, diversificada e muitos de seus livros tinham grande valor cultural. Entre 1808 e 1822, foram impressos 720 títulos de naturezas diversas: opúsculos, sermões, prospectos, obras literárias e científicas sobre matemática, história, ciência política, econômica e filosofia, teatro, romances, dramas, entre outros, constituíram os gêneros literários mais populares no período. ${ }^{147}$

145 MARROCOS, Luís Joaquim dos Santos. Cartas do Rio de Janeiro (18111821)... Op. Cit., p. 355. [Carta 105].

146 FERREIRA, TANIA Maria Tavares Bessone. "Redatores, livros, e leitores em O Patriota". In: KURY, Lorelai. (Org.) Iluminismo e Império no Brasil: O Patriota (1813-1814). Rio de Janeiro: Editora Fiocruz, 2007. p. 53.

147 CAMARGO, Ana Maria; MORAES, Rubens Borba de. Bibliografia da Impressão... Op. Cit., p. 229. 
Os constantes anúncios de venda de livros, folhetos e impressos no Rio de Janeiro, cotidianamente veiculados na Gazeta, indicam-nos que o estabelecimento da tipografia foi de grande importância para o enraizamento da prática da leitura na sociedade joanina. Além disso, as numerosas listas de livros à espera de liberação da censura na alfândega da cidade, como demonstrou Leila Mezan Algranti, colocavam o Rio de Janeiro em um novo estágio da cultura literária: para além de produtor de novos títulos, e provavelmente centro distribuidor de obras impressas para as demais capitanias, a nova capital também atraiu livreiros responsáveis pelo comércio legal de livros, assim como os que se envolviam com o tráfico ilícito de obras. ${ }^{148}$

Os possíveis gostos e preferências do público leitor/consumidor da época também podem ser apreendidos pelos numerosos avisos literários veiculados na Gazeta que, em sua grande maioria, conservava a tradição literária herdada do século XVIII: belas letras, teologia, ciências e arte, história e jurisprudência. ${ }^{149}$ A publicação da nova edição em prosa de Carta de Heloísa a Abelardo, vendida nas lojas de Manoel Joaquim da Silva Porto, e na Loja da Gazeta, por 320 réis ou a tradução da obra de Edmund Burke pelo Visconde de Cairu, entre os ilustrados da Corte, são importantes exemplos dessa tradição. ${ }^{150}$

\footnotetext{
148 ALGRANTI, Leila Mezan, Livros de Devoção... Op. Cit., p. 161.

149 Para maiores informações sobre a quantidade de anúncios de obras literárias e impressos publicados na Gazeta do Rio de Janeiro entre 1808 e 1822, ver NEVES, Lúcia Ma . Bastos P. das. "Comércio de livros e censura de idéias: a atividade dos livreiros franceses no Brasil e a vigilância da Mesa do Desembargo do Paço (1795-1822)”. In: Ler História, 23, p. 62, 1992.

${ }^{150}$ Para a obra Carta de Heloísa a Aberlado, ver GRJ. 1812. N 97. Já para o impacto da tradução de feita por José da Silva Lisboa (Visconde de Cairu), ver KIRSCHNER, Tereza Cristina. "D. Rodrigo de Souza Coutinho e os ilustrados na Corte de D. João”. In: MARTINS, Ismênia; MOTTA, Márcia. 1808: a corte no Brasil. Rio de Janeiro: Editora da UFF, 2010. p. 228.
} 
No Brasil do início do Oitocentos, a prática da leitura passava por um significativo processo de transição. Inscritos na lógica vigente do Antigo Regime, os primeiros anos de estadia da Coroa portuguesa foram marcados pelo predomínio de uma leitura cujas características privilegiavam a oralidade e a leitura coletiva feita em voz alta. "A leitura ouvida não distingue o ler do contar e alimenta-se dos mesmos textos escutados muitas vezes - o que é a própria condição de sua compreensão possível, a despeito da leitura pouco inteligível que aí é feita", afirma Roger Chartier. ${ }^{151} \mathrm{Na}$ prática, ainda eram comum os pregões, os bandos, as exposições de cartazes impressos ou manuscritos nas ruas, que expandiam o ato de ler para além dos limites impostos pela alfabetização. Por essa perspectiva, os editais afixados na cidade tinham esse propósito: veicular de forma ampla as decisões e notícias governamentais. Em 24 de Junho de 1808, por exemplo, o Intendente da Polícia afixou o Edital que decretava que competia à junta administrativa vigente "examinar os papéis e livros que se mandassem publicar e fiscalizar para que nada se imprimisse contra a religião, a moral e os bons costumes." Em uma ação complementar à dos administradores da tipografia, o intendente da polícia também tinha licença para prender aqueles que transgredissem a "segurança pública", sob pena de multa de duzentos mil réis. Transgredir significava veicular publicações consideradas sediciosas como "obras, escritos estrangeiros, impressos, ou não impressos" ou mesmo fazer circular manuscritos pela cidade com ideias contrárias ao governo. Todos viviam sob a constante atenção da polícia, que admitia e incentivava denúncias em segredo. ${ }^{152}$ Essa atitude

151 CHARTIER, Roger. (Org). "Do livro à leitura..., Op. Cit., p. 84.

${ }^{152}$ Instrução de 24 de junho de 1808. Apud RIZZINI, Carlos. O livro, o jornal e a tipografia no Brasil. Rio de Janeiro: Livraria Kosmos Editora, 1946. p. 317. 
sofreu uma crítica feroz de Hipólito da Costa, redator do Correio Braziliense, que, ao publicar o edital no jornal (com data de 30 de maio de 1809), refletia sobre suas "incoerências legais":

[...] há umas que se fazem mui conspícuas: uma o erige em intendente da Polícia em legislador, arbitrando multas de sua própria autoridade; outra admitir, contra os princípios da justiça universal, as denúncias ocultas [...] porque em fim nenhum jurisconsulto, criminalista, hoje em dia, deixa de reconhecer as acusações particulares. ${ }^{153}$

A crítica do jornalista traz a tona uma questão muito relevante para a leitura no período joanino: a proibição da escrita, circulação e publicação de obras manuscritas e impressas cerceava a liberdade de pensamento ao mesmo tempo em que estabelecia a autoridade autorizada da escrita como "um instrumento de poder que aproxima o autor do poder real". ${ }^{154}$ Em 1809, a notícia na Gazeta do Rio de Janeiro sobre a apreensão de uma Gazeta manuscrita na Corte, contendo blasfêmias contra Beresford, afirmava que "a vulgarização destas falsas notícias tem por particular objeto semear a desunião, e desconfiança entre este Governo, e o de S. M. Britânica", razão pela qual o redator sentiu-se autorizado "a desmentir completamente tudo o que contém aquele infame papel contra cujos faltores [sic], ou contra os que procuram vulgarizá-lo, mandará certamente S.A.R proceder com toda a severidade das leis". ${ }^{155}$

Por outro lado, esse mesmo cenário impulsionava os estudos e a formação filosófica dos súditos luso-brasileiros. Este é o caso de Silvestre Pinheiro Ferreira, um dos conselheiros de

${ }^{153}$ CB. Vol. III, p. 341.

154 SCHIAVINATTO, Iara Lis Franco. “Entre os manuscritos..., Op. Cit., p. 19.

155 GRJ. 1809. N ${ }^{\circ} 127$. 
D. João no Brasil. Além de ministro régio, Ferreira era um homem de vasta cultura. Político, diplomata e filósofo, sua atuação intelectual foi de muita relevância para o avanço do conhecimento na Corte. Com a obra Preleções Philosophicas, publicada pela Impressão Régia entre os anos de 1813 e 1820, Ferreira difundia e exaltava o valor dado à retórica. De acordo com José Murilo de Carvalho a visão de Pinheiro Ferreira se parecia com a de Verney. "Para o autor das Preleções, a retórica não deveria separar-se da lógica e da gramática [...] Isto é, a arte de pensar não se devia separar da arte de falar com clareza, a retórica não devia ser enfeite mas instrumento cotidiano de argumentação e persuasão". ${ }^{156}$

Tal foi a valorização das suas Preleções pelo governo joanino que a Gazeta do Rio de Janeiro e O Investigador Portuguez em Inglaterra anunciavam a novidade. Enquanto o primeiro periódico avisava os moradores da Corte sobre o horário e local onde aconteciam as aulas ${ }^{157}$, o segundo divulgava, do outro lado do Atlântico, as principais ideias do autor. Em missiva ao pai, em maio de 1813, Marrocos contextualizava o momento: "Silvestre Pinheiro está metido a Projetista, e as suas lições reduzem-se a uma mescla científica que se não sabe o que é: estamos no tempo das Gramaticas Filosóficas, e o Sistema de todas as Línguas reduzido a uma só praxe". ${ }^{158} \mathrm{Na}$ edição de outubro de 1814,

\footnotetext{
156 CARVALHO, José Murilo de. "História intelectual no Brasil: a retórica como chave de leitura". TOPOI. Rio de Janeiro, no 1, p. 133-134. Ver também SILVA, Maria Beatriz Nizza da. Silvestre Pinheiro Ferreira: ideologia e teoria, Lisboa: Sá da Costa, 1975.

157 Segundo o aviso da Gazeta, as aulas aconteciam as segundas, quartas e sextas-feiras, às 17 hs, no Colégio de $\mathrm{S}$. Joaquim. O jornal ainda noticiava o conteúdo teórico das aulas, assim como as atividades práticas, que englobavam "a lição e análise de alguma obra escolhida dos principais Filósofos, Oradores e Poetas, assim antigos, como modernos, sagrados e profanos." GRJ. 1813. № 30.

158 MARROCOS, Luís Joaquim dos Santos. Cartas do Rio de Janeiro... Op. Cit., p. 185. [Carta 43A].
} 
O Investigador informava os seus leitores acerca do recebimento da obra ${ }^{159}$; já no número seguinte, abria um amplo espaço para os interlocutores conhecê-la.

De uma obra desta natureza é impossível fazer bons extractos, e até dignos do seu mui relevante merecimento. Parece-nos pois que a melhor ideia que por ora podíamos dar era publicar uma espécie de Índice dos pontos importantes de que trata. Se tivermos porém ocasião, publicaremos tão bem ainda por inteiro as ditas Prelecções, para que a sua leitura mais se generalize, e assim prepare todas as utilidades que pode e deve produzir um tal género de instrução Elementar. ${ }^{160}$

Logo após o comentário dos redatores, a folha publicava a Ideia Geral da Obra, destacando os principais pontos acerca da Física e da Dinâmica. Diferentemente ds comentários elogiosos d'O Investigador, Luís Joaquim dos Santos Marrocos era um crítico contumaz do autor. "Não sei, se será erro meu em dizer que Silvestre Pinheiro é daqueles homens, que tem habilidade em infundir veneração científica; e inculcando-se Corifeu enciclopédico, granjeia um partido, que ouvem suas palavras soltas, como vozes de Oráculo", observava o bibliotecário. ${ }^{161}$ Quanto à repercussão e importância da obra, o exame desse seleto homem de letras foi ainda mais ácido.

O Padre Joaquim Dâmaso [...] nos inculca[-o] sempre por superior a todos, nos tempos actuais, em luzes e conhecimetos; e eu, ao contrário, vejo nas suas Prelecções impressas Definições e Teoremas, que por sua ostentação

159 IP. Vol. X, p. 627.

${ }^{160}$ Ibid., Vol. XI, p. 53.

161 MARROCOS, Luís Joaquim dos Santos. Cartas do Rio de Janeiro Op. Cit., p. 327. [Carta 96]. 
de novidade só me causam riso, ou nojo; apesar da ilustrada Análise, qu lhes fazem os Redactores do Investigador Português, elevando-as às nuvens. ${ }^{162}$

Nesta carta ao pai, Luís Marrocos demonstrava a insatisfação com a atiude de seu superior, o Padre Dâmaso, assim como reiterava a sua leitura crítica sobre as funções "filosóficas" que, por ventura, a obra intentava atingir. Ainda como leitor assíduo d'O Investigador, fazia uma análise acerca da publicidade que o jornal dava à obra. Por mais que respeitasse o trabalho de seus redatores, achava-o um tanto exagerado. Todas essas transformações do mundo público, associadas à leitura perspicaz de Marrocos, nos ajudam a melhor compreender os caminhos trilhados pelos manuscritos e impressos no Rio de Janeiro, no raiar do século XIX. Segundo a historiadora Iara Lis Schiavinatto "Aos poucos, o manuscrito deixaria de gozar do mesmo prestígio, crédito e capacidade de afirmar a verdade que o impresso", passando a se aproximar "do rumor, da murmuração, do ouvir-dizer". ${ }^{163}$ Com o predomínio das publicações impressas na Corte, portanto, vemos o nascimento e constituição de um novo espaço público cujo centro será a imprensa, compreendida como uma arena de debates. ${ }^{164}$ Há a emergência das leituras individuais e privadas perceptíveis mais nitidamente a partir de 1821 , onde a pluralidade de periódicos e o debate sobre as questões políticas permitiram, segundo Marco Morel, "a formação de uma opinião de caráter mais abstrato, fundada sobre o julgamento crítico de cada cidadão-leitor e representando uma espécie de somatório das opiniões". ${ }^{165}$

\footnotetext{
162 Ibid.

163 SCHIAVINATTO, Iara Lis. "Entre os manuscritos e os impressos..., Op. Cit., p. 14.

164 MEIRELLES, Juliana Gesuelli. Imprensa e poder... Op. Cit., p. 165.

165 MOREL, Marco. As transformações... Op. Cit., p. 205. Para as características da leitura no Antigo Regime na França ver ROCHE, Daniel. O povo de Paris... Op. Cit., cap. 7, p. 267-309.
} 
É dentro desse universo da cultura letrada - em que a posse, leitura e circulação de livros ganhavam cada vez mais proeminência na Corte -, que ocorreu o processo de transladação da Real Biblioteca para este lado do Atlântico. Do nascimento da Impressão Régia (1808) à abertura da Real Biblioteca do Rio de Janeiro (1814), o acesso à leitura sofreu uma guinada. Nesse período, houve uma crescente variedade de gêneros e títulos, inclusive com um aumento significativo do interesse dos leitores pelas ideias dos filósofos iluministas, como Voltaire, Rousseau e Montesquieu. Apesar da curiosidade, as obras mais famosas eram consideradas "sediciosas" pelos censores de D. João, que vedavam constantemente a sua circulação. "O Sistema da Natureza, de Holbach, best seller entre as obras proibidas na França nessa época, parece também ter sido desejado pelos leitores da Colônia, pois os livreiros estrangeiros e portugueses tentavam introduzi-lo com frequência no país", afirma Leila Algranti. ${ }^{166}$

Se, por um lado, os censores dedicavam especial atenção para a entrada dos livros proibidos, a exemplo das obras francesas, com destaque para Émile, de Rousseau, Historie philosophique, do abade Raynal e Os direitos do Cidadão, de Mably, por outro, também escolhiam e incentivavam a produção de livros muito procurados ou populares à época, como os 23 volumes de A sagrada Bíblia traduzida em português pelo padre Antonio Pereira, ao preço de 28 mil réis, e o Índice da $1^{a}$ parte da já citada Preleções Filosóficas, dispostas em ordem alfabética; ambos vendidos na loja de livros de Francisco Luís Saturnino. ${ }^{167}$ Além disso, podiam ser facilmente comprados em outras casas livreiras da cidade. Em 1817, os interessados em livros de jurisprudência

166 ALGRANTI, Leila Mezan. Livros de devoção, atos de censura... Op. Cit., p. 149 167 GRJ. 1818. Nº5. 
tiveram a oportunidade de arrematá-los em leilão. Para o evento, José Balbino Barbosa de Araújo, oficial da Secretaria de Estado dos Negócios do Brasil, anunciava obras portuguesas, francesas e inglesas sobre o tema, além de outros folhetos. ${ }^{168}$ Especificamente em relação à formação da Biblioteca Real do Rio de Janeiro, a antropóloga Lilia Schwarcz nos informa que nos transtornos do embarque, em novembro de 1807, a primeira remessa de livros ficou abandonada no porto de Belém até que alguns dias depois retornou ao Palácio d'Ajuda. ${ }^{169}$ Apesar disso, o transporte das obras e coleções foi tratado como questão prioritária de Estado, sendo, ao todo 60 mil peças, entre "obras raras, livros de educação, tratados, costumes, geografia ou ciências; documentos da Coroa, manuscritos, incunábulos, livros de oras e demais obras de oração, assim como desenho, mapas e gravuras" que foram cuidadosamente colocados em 317 caixotes com a devida classificação. ${ }^{170}$

$\mathrm{O}$ acervo foi acomodado em uma das salas do Hospital do Convento da Ordem Terceira do Carmo, na Rua Direita. Segundo Padre Perereca, o hospital foi escolhido "não só por causa da vizinhança do Paço, mas também pela capacidade deste edifício o melhor que se podia encontrar para este fim". Ainda de acordo com o clérigo, com a acomodação do acervo neste local, o hospital foi transferido para o recolhimento de Nossa Senhora do Parto que, por sua vez, transferiu as meninas que ali viviam para o recolhimento da Santa Casa da Misericórdia. ${ }^{171}$

A proteção e conservação das bibliotecas reais foram temas constantemente discutidos nas correspondências diplomáticas.

\footnotetext{
168 Ibid., $\mathrm{N}^{\circ} 38$.

169 SCHWARCZ, Lilia M. A longa... Op. Cit., p. 262.

170 SCHWARCZ, Lilia. "Biblioteca Real”. In: NEVES, Lúcia Bastos Pereira das; VAINFAS, Ronaldo. Dicionário do Brasil Joanino... Op. Cit., p. 61.

171 SANTOS, Luiz Gonçalves dos. Memórias para servir... Op. Cit., p. 425.
} 
Em 12 de outubro de 1808, Antonio Alexandre das Neves ${ }^{172}$, bibliotecário da Real Biblioteca d'Ajuda, vangloriava-se de ter salvado os papéis públicos e caixotes de livros das quatro tentativas do governo francês de dilapidação do patrimônio nacional. Segundo o súdito, o sucesso de tal preservação, no entanto, devia-se mais à ação da Providência Divina, que fizera com que os invasores se esquecessem de pegar as chaves do estabelecimento. ${ }^{173}$ Ainda em janeiro de 1809, o mesmo funcionário mencionava o envio de mais caixotes para a América Portuguesa.

Para não aumentar o susto que se vai espalhando por Lisboa, vendo-se os preparos dos Negociantes Ingleses para saírem; e considerando-se em que tais acontecimentos não deixam de proceder de reflexões mui[to] sérias: trato com os meus companheiros de encaixotar mui[to] ocultamente os Papéis particulares, e Manuscritos, e os mais livros os que couberem nos caixões que existem dentro das mesmas bibliotecas. Porém são precisos muitos outros caixões, e algum socorro aos Empregados. ${ }^{174}$

Neves referia-se à eminência de uma nova invasão francesa, que acabou por acontecer em março do dito ano. A mensagem estava dada: a Coroa não podia mais contar com a sorte, sendo absolutamente necessário fazer o envio das "preciosidades" do Estado Português para o Brasil. Ainda em janeiro, o governo português mandou um Aviso para Antonio Ribeiro dos Santos alusivo aos livros reais:

\footnotetext{
172 De acordo com Ana Cristina Araújo, Antonio Alexandre das Neves era sócio e guarda-mor dos estabelecimentos literários da Academia Real das Ciências e diretor da Junta da direção literária da Imprensa Régia e Real Biblioteca da Ajuda. ARAÚJO, Ana Cristina. "Uma longa despedida: Cartas familiares de Luís Joaquim dos Santos Marrocos". In: MARROCOS, Luís Joaquim dos Santos. Cartas do Rio de Janeiro... Op. Cit., p. 20.
}

${ }_{173}$ ANTT. Ministério do Reino. Mç. 279. Caixa. 372.

${ }^{174}$ Ibid. 
O Príncipe regente Nosso Senhor é servido, que V.S. ${ }^{a}$ mande encaixotar sem perda de tempo o monetário da livraria Pública ${ }^{175}$, e mais preciosidades da mesma, para se provem em segurança nas embarcações da Coroa; apresentando relação do número dos caixotes com as dimensões de cada um deles, logo que se perder [sic] calcular o mesmo número, ao secretário do governo encarregado do Real Erário, para determinar o navio, em que se embarcaram imediatamente. ${ }^{176}$

Desde a instalação da Corte no Brasil, em 1808, que a necessidade da Coroa em preservar o seu patrimônio literário se colocava como uma de suas mais destacadas preocupações. Sendo a livraria um "espaço emblemático da Corte", na expressão de Ana Cristina Araújo ${ }^{177}$ (o que na prática lhe concedia grande respeitabilidade como signo da monarquia e da nobreza), era imprescindível que a realeza constituísse esse locus de saber na nova sede de sua residência. Só que para isso, o governo português precisava transladar seguramente um dos seus bens mais preciosos: a coleção de livros e manuscritos raros. Diante de um empreendimento de tal monta a escolha dos profissionais não poderia ser mais

\footnotetext{
175 "É sabido que os bibliotecários e arcebispos deixaram algumas obras para a biblioteca pública. Os fundos iniciais foram constituídos com os generosos donativos do Fundador, que terá deixado de acordo com as suas palavras, para cima de 40.000 volumes mais um monetário com 2995 espécimes de ouro, prata e cobre e que depois foi roubado pelos franceses em 1808." A análise do pesquisador Francisco António Lourenço Vaz sobre a Biblioteca Pública de Évora no período joanino nos indica que, possivelmente, o monetário correspondia a doações para a Biblioteca em metais preciosos. VAZ. Francisco António Lourenço. "Os bibliófilos eborenses e a Biblioteca Pública de Évora (18051955)”. Disponível em; <http://www.projectos.uevora.pt/cenaculo/pub_pdf/ VAZ4_2007_BibliofilosEborenses.pdf>. Acesso em: 01 dez. 2012.

176 Aviso em que manda encaixotar o monetário, e mais preciosidades. BNP. Seção de Reservados. Cód.10612 (Grifo nosso).

177 ARAÚJO, Ana Cristina. “Uma longa despedida:..., Op. Cit., p. 25.
} 
coerente: tamanha incumbência ficava nas mãos de dois diletos homens de letras da corte lusitana, os bibliotecários régios, que conheciam em detalhes os acervos de suas respectivas instituições: a Real Biblioteca d'Ajuda e a Real Biblioteca Pública de Lisboa. Ambos, portanto, sabiam catalogá-lo da forma mais adequada à organização de sua congênere no Brasil. Aqui reiteramos o fato de uma biblioteca ser um dos maiores símbolos de status na Idade Moderna, sendo a posse de livros e/ou a alfabetização duas qualidades distintivas na sociedade de Corte. ${ }^{178}$

Neste cenário nos interessa discutir as transformações que vigoraram na cidade, mormente em relação ao mundo dos livros, em particular, e da circulação da palavra impressa, em geral. Sobre a transferência da residência real para a América e o processo de estruturação do aparato governamental, Ana Cristina Araújo é enfática:

A capitalidade política do Rio de Janeiro implicava a existência de rituais de informação e cerimônias públicas, até então distantes ou apenas imagináveis, mas que ao materializarem-se no grandioso cenário dos trópicos, contribuíam para impor uma imagem inédita e perdurável da materialidade do poder real. ${ }^{179}$

Principalmente nos primeiros anos de estadia (1808 a 1815), o governo joanino cuidou da proteção de seu patrimônio intelectual por outras vias que não apenas a estruturação, abertura e funcionamento da Real Biblioteca do Rio de Janeiro. A Impressão Régia autenticava a visibilidade ao domínio simbólico almejado pela Coroa através da circulação dos papéis oficiais, assim como das demais produções impressas que saíam dos

178 DARNTON, Robert. O grande massacre... Op. Cit., p. 284-292.

179 ARAÚJO, Ana Cristina. "Uma longa despedida:..., Op. Cit., p. 31. 
prelos reais. "[O governo] nunca se divorciou de outras exigências de leitura, encarregando-se da publicação de obras políticas, econômicas, literárias, científicas e filosóficas", afiança Araújo. ${ }^{180}$ Ademais, como já demonstramos anteriormente, os periódicos produzidos pela mesma Tipografia - a Gazeta do Rio de Janeiro (1808-1821) e O Patriota (1813-1814) - ou aqueles patrocinados pela Coroa - como foi o caso d'O Investigador Portuguez em Inglaterra (1811-1819) também foram parte fundamental da política cultural da monarquia lusitana. ${ }^{181}$

Para além da atividade impressa, a coerção aos súditos com leituras críticas à ordem estabelecida foi uma constante. No início de 1810, por exemplo, o Conde de Aguiar escrevia da Corte para o Patriarca Eleito de Lisboa sobre a prisão dos insultantes do governo. No discurso do ministro uma questão se sobressai: o processo de repressão àqueles contrários ao governo e a justificativa para as prisões. ${ }^{182}$

[Sobre a] medida que esse governo tomou de mandar prender nas fortalezas alguns indivíduos, e repreender outros, constantes da relação de n.5 por continuarem com as suas declamações, e práticas insultantes, e sediciosas; e

180 Ibid., p. 31.

181 Sobre a política cultural do governo joanino voltada exclusivamente para os periódicos de circulação interatlântica, ver o Capítulo 1 deste livro intitulado "A imprensa como locus de saber". Para a compreensão deste processo especificamente em relação à Gazeta do Rio de Janeiro, ver MEIRELLES, Juliana. G. Imprensa e poder... Op. Cit., Cap. 2, p. 91-154.

${ }_{182}$ Entre os anos de 1808 e 1812, Fernando José de Portugal e Castro, Conde de Aguiar (1752-1817) ocupou dois cargos de relevo no governo joanino: para além de atuar no Ministério dos Negócios do Reino ainda era presidente do Real Erário e ministro assistente do despacho, função equivalente à de Primeiro Ministro, segundo a historiadora Lúcia Paschoal Guimarães. Para mais informações sobre trajetória do ministro, ver: GUIMARÃES, Lúcia Paschoal. "Fernando José de Portugal e Castro.” In: NEVES, Lúcia Bastos Pereira das; VAINFAS, Ronaldo. Dicionário do Brasil Joanino... Op. Cit., p. 163-164. 
recomenda nesta matéria toda a cautela, circunspecção, e vigilância para se manter a tranquilidade pública; o que sendo sempre necessário, de muito mais em circunstâncias tão críticas ... ${ }^{183}$

Aguiar se referia à expulsão dos franceses do Reino. Em um cenário de guerra todo o cuidado era pouco. A alta vigilância da Intendência da Polícia era um imperativo e, na prática, recaia principalmente sobre os estrangeiros e os homens de imprensa, os últimos produtores das notícias que circulavam no país. ${ }^{184}$ A censura à circulação de impressos sediciosos foi indissociável das diretrizes políticas do governo de D. João. A ordem de proibição e supressão dessas folhas na Impressão Régia, a apreensão do periódico Correio Braziliense, em 1809, a referência à prisão do Conde de Egas, por causa de seus papéis escritos de Paris, para o Conde de Almada - tendo, neste caso, a polícia como agente interrogador, compôs o rico mosaico de atitudes reais diante da instabilidade política de Portugal no raiar do século XIX.

Mas as ações governamentais não paravam por aí. A preservação dos Arquivos da Coroa em Lisboa e a valorização das qualidades morais das pessoas que tomavam conta da documentação oficial, nomeadamente contra o furor dos franceses, a licença real de impressão das obras, a vigilância dos censores e a relação com a manutenção do bem comum do Estado, a atuação da Intendência da Polícia com foco para a proteção eficaz de todo o território do Brasil, assim como a ação direta do Príncipe Regente que listou todas as obras da Real Biblioteca a serem enviadas para o

183 ANTT. Ministério do Reino. Livro 380.

184 Sobre a repressão do governo português em relação aos impressos no período, ver: TENGARRINHA, José. História da imprensa... Op. Cit., p. 57-99; MEIRELLES, Juliana Gesuelli. Imprensa e poder... Op. Cit., p. 101-133. 
Brasil $^{185}$, são exemplos fundamentais da amplitude das diretrizes monárquicas que englobavam a política cultural joanina especialmente no que concerne ao universo da palavra impressa e à coibição das ideias revolucionárias em ambos os lados do Atlântico. ${ }^{186}$ Em meio a esse conturbado contexto político europeu dava-se a constituição da Real Biblioteca do Rio de Janeiro, que, aos poucos, tomava forma sui generis. É justamente sobre a formação desse locus de cultura que agora deteremos a nossa atenção.

\subsection{O governo joanino e o projeto de uma Biblioteca Pública no Rio de Janeiro}

Ao longo de 1809 a urgência no envio do acervo da Real Biblioteca Pública de Lisboa arrefeceu-se devido ao fracasso no avanço militar dos franceses. Por outro lado, acontecia o movimento oposto com a coleção de obras pertencentes à Real Biblioteca d'Ajuda, que começavam a ser transferidas em segredo para a nova Corte em princípios de 1810. De acordo com a pesquisadora Lilia Schwarcz, a primeira leva de caixotes foi acompanhada por José Joaquim de Oliveira, servente da Real Biblioteca. Este funcionário, segundo a mesma autora, "vinha trazendo também os 'estratégicos' Manuscritos da Coroa e uma coleção de 6 mil códices que se achavam em um arquivo reservado na Livraria do Paço da Necessidades, em Lisboa". ${ }^{187} \mathrm{O}$ cuidado com esse importante acervo documental carregava consigo simbolicamente a superioridade política da nação portuguesa perante os europeus. Era a história de suas grandes conquistas e vitórias que atravessava

\footnotetext{
185 ANTT. Ministério do Reino. Livro 380, p. 459-465.

${ }^{186}$ Ibid. Livro 380.

187 SCHWARCZ, Lilia M. A longa... Op. Cit., p. 266 (Grifo Nosso).
} 
o oceano. Agora do outro lado do Atlântico, sob a direção do Príncipe Regente D. João, o Império lusitano começava a reescrever e a repensar a magnitude deste novo Império, já muito fragilizado. De acordo com Maria de Lourdes Viana Lyra, a utilização do termo "novo Império" tinha duas grandes expressões políticas: para além do sentido de mudança na estruturação do império reformulado, exprimiu também a imagem de renovação da Monarquia portuguesa que, a partir de então, revigorava-se com as novas perspectivas que se abriam, mormente em relação ao domínio absoluto das imensas riquezas de suas possessões coloniais. ${ }^{188}$

Em duas viagens distintas em 1811, a Coroa portuguesa completava a travessia do rico acervo documental. A segunda leva de caixotes chegava em março, com Luís Joaquim dos Santos Marrocos. Já em setembro, este mesmo bibliotecário informava a seu pai sobre a entrada dos "últimos 87 caixotes de livros" no Rio de Janeiro, que vinham sob a responsabilidade de José Lopes Saraiva, servente da Real Biblioteca. ${ }^{189}$ Se por um lado a transladação das preciosidades reais, enfim, estava a salvo; por outro, os funcionários régios da nova instituição tinham um trabalho hercúleo pela frente.

A direção do novo espaço estava nas mãos do Padre Joaquim Dâmaso (1777-1833), pertencente à Congregação do Oratório de Lisboa, e frei Gregório José Viegas, da terceira ordem

188 LYRA, Maria de Lourdes Viana. A utopia... Op. Cit., p. 119.

189 MARROCOS, Luís Joaquim dos Santos. Cartas do Rio de Janeiro Op. Cit., p. 96 (Carta N. ${ }^{\circ}$ 10). Ao crermos na narrativa de Marrocos, seu colega de ofício José Lopes Saraiva enfrentou alguns problemas pessoais sérios em sua estadia no Brasil. Se em setembro de 1813, Marrocos relatava ao pai a pública traição de sua esposa, que o indispôs publicamente com d. Carlota Joaquina (Carta N. ${ }^{\circ} 54$, p. 222), em abril de 1814 relatava a sua prisão há mais de quatro meses por conta de uma "desordem que tivera com um Filho de certa Criada" que, segundo boatos, teria ficado "cego de um olho". (Carta N.65, p. 252). 
de São Francisco. Dâmaso supervisionou as três levas de livros que adentravam no Rio de Janeiro, entre 1810 e 1811 e, desde então, responsabilizou-se pelo arranjo e conservação do acervo da biblioteca. Com Viegas, a quem coube à administração geral do locus $^{190}$, dividiu o cargo de "Prefeito" - maior autoridade na hierarquia social da instituição. ${ }^{191}$ Eles ainda contavam com a ajuda de dois serventes - Feliciano Joaquim José de Oliveira e José Lopes Saraiva - além de Luís Joaquim dos Santos Marrocos, na função de ajudante de bibliotecário. $\mathrm{O}$ emprego de servente também tinha sido regulamentado em 1802, e entre as funções capitais destacava-se o conhecimento bibliográfico. ${ }^{192} \mathrm{De}$ acordo com Ana Cristina Araújo, "No fundo, com graduações, ordenados e funções diferentes, todos estes indivíduos eram remunerados como funcionários do Paço e nele serviam com exclusiva assistência à livraria”. ${ }^{193}$

Neste contexto, a riquíssima produção epistolar de Luís Joaquim dos Santos Marrocos ao longo de dez anos (1811 -1821), para além de compor uma excepcional documentação do período joanino, também pode ser compreendida em uma perspectiva histórica mais ampla. Ao circunscrever os significados da carta no universo setecentista português, a historiadora Adriana Angelita Conceição definiu a formação da prática epistolar "enquanto um objeto de troca de sensibilidades, sociabilidades

190 SCHWARCZ, Lilia M. "Joaquim Dâmaso" [A longa viagem da biblioteca dos reis..., p. 266]. In: NEVES, Lúcia Bastos Pereira das; VAINFAS, Ronaldo. Dicionário do Brasil Joanino... Op. Cit., p. 262.

191 As atribuições ao cargo de Prefeito foram regulamentadas no $\$$. I. do Regulamento Provisional das Reais Bibliotecas mandado observar pelo Príncipe Regente Nosso Senhor, decretado em 24/09/1802. Regulamento Provisional das Reais Bibliotecas mandado observar pelo Príncipe Regente Nosso Senhor. ANTT. Ministério do Reino. Livro 99, p. 2.

192 Ibid., p. 3.

193 ARAÚJO, Ana Cristina. “Uma longa despedida:..., Op. Cit., p. 21. 
e representações". ${ }^{194}$ Por este viés, a autora ainda reitera o fato de que a "significação das palavras não se estabelece de modo dado ou imposto, mas através dos usos e necessidades das sociabilidades partilhadas". 195

Especificamente em relação à figura de Marrocos e à produção de suas cartas, destacamos a análise de dois pesquisadores: Ana Cristina Araújo, que o considera "um protagonista oculto dos acontecimentos colectivos e um narrador comprometido, com muitas histórias para contar"196, e Emílio Lopes, para quem "As Cartas de Marrocos expressavam um 'protocolo de leitura' próprio, devido ao local em que o protagonista se situava, marcado por conflitos pessoais, lutas por ascensão social e por prestígio". ${ }^{197}$ Mesmo concordando com a análise dos dois autores, achamos necessário circunscrever a ótica particular da nossa leitura do personagem: consideramos as correspondências de Marrocos a narrativa de um súdito ilustrado de pouca visibilidade em busca de ascensão social na nova corte. A partir também deste viés, a leitura de suas missivas impõe alguns cuidados. Por mais que a sua narrativa nos permita compreender melhor as múltiplas especificidades da sociedade de corte luso-brasileira no raiar do século XIX, Marrocos lia os acontecimentos à sua volta de um lugar específico: é um português com grandes dificuldades iniciais de adaptação à vida no Rio de Janeiro; um funcionário público em busca do reconhecimento real que, para isso, procura

194 CONCEIÇÃO, Adriana Angelita da. Sentir, escrever e governar. A prática epistolar e as cartas de D. Luís de Almeida, $2^{\circ}$ Marquês de Lavradio (1768-1779). Tese de doutoramento. São Paulo: Faculdade de Filosofia e Ciências Humanas USP, 2011. p. 18.

195 Ibid., p. 67.

196 ARAÚJO, Ana Cristina. “Uma longa despedida:..., Op. Cit., p. 14.

197 LOPES, Emilio Carlos Rodrigues. Festas Publicas... Op. Cit., p. 59. 
tecer relações políticas complexas favoráveis a si no universo da alta cúpula ministerial. ${ }^{198}$

A despeito dessas circunstâncias, e acrescentando o fato de Marrocos não ter tido um cargo de alta hierarquia dentro da livraria, ou mesmo dentro de outras instituições governamentais ${ }^{199}$, é mister lembrarmos que ele desempenhou muitas atividades dentro da Real Biblioteca, o que o permitiu conhecer a estruturação e funcionamento da instituição em detalhes. Se muitas vezes suas cartas nos colocam diante de um homem ressentido, que se sentia preterido em relação a "contendores mais bem apadrinhados"200,

\footnotetext{
198 Marrocos parecia ser mais próximo a D. Rodrigo de Souza Coutinho e seus aliados. No entanto, mesmo quando o ministro era vivo, o bibliotecário solicitava ao pai que mandasse para Antonio de Azevedo de Araújo uma carta de recomendação para que ele pudesse se introduzir junto ao conselheiro real. O pai atendeu o seu pedido, enviando ao Conde da Barca uma Carta referente às qualidades do filho. Para maiores esclarecimentos, ver MARROCOS, Luís Joaquim dos Santos. Cartas do Rio de Janeiro Op. Cit., Carta No16, p. 113-114; Carta No 20, p. 127-128 e Carta No 69, p. 261.

199 Em setembro de 1817, Luís Marrocos foi nomeado oficial da Secretaria de Estado dos Negócios do Reino por Thomaz Antonio Vilanova Portugal. A partir de então, deixou de trabalhar na Biblioteca Real, mas sem perder a função. Além disso, continuou sendo o responsável pelo cuidado dos manuscritos. Em 1821, Marrocos voltava à labuta dentro da Real Biblioteca, agora, porém, no cargo de Direção e Arranjamento, em substituição ao padre Viegas, que fora nomeado bispo em Pernambuco. Sobre a sua ascensão profissional, ver MARROCOS, Luís Joaquim dos Santos. Cartas do Rio de Janeiro... Op. Cit., p. 361 [Carta N. o 106]. ${ }^{200}$ MALERBA, Jurandir. A corte no exílio:... Op. Cit., p. 217. Esta situação pode ser apreendida em inúmeras cartas do bibliotecário, porém, a carta ao pai datada de 29 de outubro de 1811, quando Marrocos chegara ao Rio há pouco mais de seis meses, já nos esclarece alguns de seus objetivos. Ao recomendar a vigilância do pai diante da aparição de "Ofício aí [Lisboa] decente e de sofrível rendimento", justifica suas razões: "Isto tudo é para ver se posso tentar fortuna, aproveitando-me das Pessoas, que me atendem e me obsequeiam; ainda que isto agora está muito esgotado, pois vejo aqui alguns Criados (e não poucos) de sua Real Alteza com 3 e 4 Ofícios de mil cruzados; mas eu não gosto de prender-me nesta terra, que julgo para mim de Degredo; e por isso me lembro do que me podes fazer conta em Lisboa, para estar seguro a todo o tempo. [...]”. MARROCOS, Luís Joaquim dos Santos. Cartas do Rio de Janeiro... Op. Cit., ver Carta N. ${ }^{\circ}$, p. 88; Carta No 171, p. 500.
} 
desejoso de voltar a Lisboa, elas também nos mostram a face de um sujeito que conheceu em profundidade o locus de saber que nos interessa investigar. Nesta pesquisa, portanto, pensamos o seu relato a partir de sua experiência particular como ajudante de bibliotecário; um súdito que por mais que almejasse sempre novas regalias e mercês, trabalhou arduamente na concretização do nascimento e vigência da Real Biblioteca do Rio de Janeiro.

Luís Joaquim dos Santos Marrocos fez a travessia atlântica em substituição a seu pai, Francisco José dos Santos Marrocos, professor régio de Filosofia Racional e Moral em Lisboa, e funcionário da Real Biblioteca d’Ajuda com muitas relações ligadas ao mundo da cultura letrada. Por mais que Luís Marrocos tenha crescido em um profícuo ambiente literário e frequentado a Universidade de Coimbra, aos 30 anos de idade ainda era um homem solteiro e dependente da família. Apesar disso, desde 1801 trabalhava sob os olhos paternos no registro de preciosas colecções régias de livros e documentos. Esta atividade lhe garantiu, dez anos depois, a experiência necessária para atravessar o oceano com a missão de levar a segunda leva de livros ao Brasil. ${ }^{201} \mathrm{Na}$ nova Corte, mais próximo à Coroa, teria maiores chances de se destacar profissionalmente.

Assim como os demais funcionários da instituição, Marrocos tinha casa paga pela Real Fazenda e um ordenado de $400 \$ 000$ réis; valor nada desprezível para a sua função. ${ }^{202}$ Passado pouco mais de três meses de sua chegada ao Rio de Janeiro, Marrocos fazia um importante pedido ao pai.

\footnotetext{
201 ARAÚJO, Ana Cristina. "Uma longa despedida:..." Op. Cit., p. 20-21.

202 Sobre a situação profissional de Marrocos ver: MARROCOS, Luís Joaquim dos Santos. Cartas do Rio de Janeiro... Op. Cit., p. 82. [Carta N. . 5, p. 82] e [Carta N. ${ }^{\circ}$ 6, p. 84].
} 
Rogo a Vossa Mercê com todo o seu empenho me mande extrair um Cópia dos Estatutos da Biblioteca de Espanha, que existe na sua mão, porque já fui insinuado a arranjar uma Obra tal, em competência da do Padre Serra ${ }^{203}$; e como não tenho, e não posso ter uma base de bom calibre para esta empresa, fiquei assombrado com a vista do raio. ${ }^{204}$

Esta súplica nos indica que os bibliotecários régios já estavam, há algum tempo, em busca do documento espanhol e, muito provavelmente, tinham pressa para finalizarem o trabalho de organização do acervo bibliográfico do novo locus de saber. Porém, para realizá-lo de modo a "favorecer, e excitar os estudo das letras divinas e humanas entre os seus vassalos no Brasil", como exaltava o Padre Perereca, necessitavam de um modelo distinto de biblioteca que não apenas a portuguesa. ${ }^{205}$ Como vemos, a escolha recaiu para a instituição espanhola, cujo esplendor deu mostras ao longo de todo o século XVIII.

Com o início dos trabalhos, que duraram quatro anos (1810-1814) até que a Real Biblioteca abrisse suas portas ao público, em 1814, houve muitas transformações. Já em outubro de 1811, um ano após o decreto que mandava erigir a Real Biblioteca na nova corte ${ }^{206}$, Marrocos informava ao pai sobre a criação de um grande "Plano de Estabelecimento Público, e Arranjamento melhor dos empregados das Reais Bibliotecas, com bons ordenados, ração, foros de criados, etc., etc.". ${ }^{207}$ Em novembro de 1811,

\footnotetext{
203 Padre Francisco José da Serra Xavier.

204 Ibid., p. 80. [Carta N.o 3].

205 SANTOS, Luiz Gonçalves dos. Memórias para servir... Op. Cit., vol. 1, p. 426.

206 O decreto real é datado de 29 de outubro de 1810. O documento pode ser lido na íntegra em <http://www.planalto.gov.br/ccivil_03/revista/Rev_69/Decreto.htm>. Acesso em: 29 out. 2012.

207 MARROCOS, Luís Joaquim dos Santos. Cartas do Rio de Janeiro Op. Cit., p. 88. [Carta N. ${ }^{\circ}$ ].
} 
pedia-lhe que "remetesse em Carta pelo Correio uma Cópia do Sistema de Classificação Bibliográfica feita pelo Doutor António Ribeiro dos Santos para a Biblioteca Pública”, ressaltando que estes "são papelinhos aqui de muita estimação, pois é terra de tudo estéril". ${ }^{208}$ Dois meses depois, em janeiro de 1812, o pai lhe enviava os estatutos da Biblioteca da Espanha. Considerando-se que na época a travessia interatlântica durava, em média, de dois a três meses, Francisco José dos Santos Marrocos atendia rapidamente às solicitações profissionais do filho.

Ao agradecer-lhe o despacho, o bibliotecário também conjecturava sobre as possibilidades de melhorias dentro da instituição: "Sobre este ponto, creio com toda a probabilidade que vão a aumentar-se [sic] os Ordenados dos Empregados, isto é, a cada um dos serventes a quantia de $100 \$ 000$ mais anualmente, e a mim mais 200\$000 réis, ficando assim com 600\$000 metálicos". Marrocos ainda via um horizonte profissional para além dos muros da biblioteca. "Ouço [o Conde de Aguiar] rosnar muito ao longe, em razão do meu exercício no Paço, dar-me mais de Ordenado outros $600 \$ 000$ réis, graduação de Oficial da Secretaria, e condecorado com o Hábito de Cristo", empolgava-se. ${ }^{209}$ Em junho do mesmo ano, Marrocos tinha em mãos o Plano da Biblioteca Pública, emitido para o Brasil em março. ${ }^{210}$

Estes episódios nos remetem para uma dimensão relevante no mundo luso-brasileiro, especialmente no que tange à comunicação interatlântica: a importância de delimitarmos quem são os interlocutores das correspondências. Neste caso, particularmente, é preciso salientar não apenas a figura do autor das cartas

\footnotetext{
208 Ibid., p. 93. [Carta N. ${ }^{9}$ 9].

209 Ibid., p. 101. [Carta N. $\left.{ }^{\circ} 12\right]$.

${ }^{210}$ Ibid., p. 136. [Carta N. $\left.{ }^{\circ} 25\right]$.
} 
- Luís Marrocos - mas, sobretudo, a de Francisco José, seu principal interlocutor. Para além de ser seu pai, Francisco José era um funcionário com acesso direto à documentação da Real Biblioteca d'Ajuda que havia ficado em Lisboa, sendo, ainda, um homem com grande experiência nas relações sociopolíticas da sociedade de corte, fosse como súdito da monarquia ou como bibliotecário régio.

O filho, Luís Joaquim, não apenas conhecia as relações políticas do pai, como também reconhecia (e respeitava) a sua vasta experiência profissional. Nesse sentido, apesar dos avanços e retrocessos na comunicação entre pai e filho, ao longo de uma década (1811-1821), é bem provável que Luís Joaquim tenha concebido o pai como seu orientador político e intelectual. ${ }^{211}$ Através dos "bons conselhos" advindos da figura paterna, Marrocos podia se movimentar de forma mais "tranquila" politica e socialmente na nova corte do Rio de Janeiro. O olhar experiente do pai ajudava-o a correr menos riscos, dentro e fora da Biblioteca Real.

211 Sobre a inconstância da comunicação entre pai e filho, cf. ARAÚJO, Ana Cristina. "Uma longa despedida..., Op. Cit., p. 15-16. Já quanto à relação de respeito à hierarquia familiar, é possível percebê-la em muitas de suas cartas. A seguir, selecionamos algumas delas que nos servem de bons guias. "vivo na esperança de ser algum dia mais do que sou: rogo portanto a Vossa Mercê me ajude com os seus conselhos para o bom acerto das minhas acções, e enviando súplicas aos Céu, para que me ilustre e ilumine." [Carta N. ${ }^{4}$, p. 84-85]; "Agradeço-te a remessa dos versos ao Botas, assim como as mais notícias; que me mandas, e a respeito de me escreveres menos vezes por eu não gastar tanto importe no Correio, não repares nisso, porque antes eu quero ler uma Carta tua, do que ver uma Ópera." [Carta N. o 25A, p. 115-116]; "Espero da sua bondade me tenha sempre na lembrança, favorecendo-me com o seu conselho, letras, amizade, bênção, sendo estes os bens, com o que desejo conservar-me, julgando-me mui[to] feliz na consideração de ser com a maior vaidade." [Carta N. ${ }^{\circ} 20$, p. 128]; "Depois de ficar ciente do conteúdo da Carta de Vossa Mercê, faço esta, que ainda não serve de resposta, mas é de prevenção ante omnia, a retractar-me de tudo que escrevi na Carta 5, que foi sem dúvida de escandalizar [...] não é minha tenção afrontá-lo, nem desobedecer-lhe em coisa alguma, antes mostrar para todos os modos o extremo de amor e respeito, que lhe é devido [...]. " [Carta N.o 35, p. 164]. 
As cartas trocadas entre a família Marrocos nesse período é uma fonte documental ainda pouco explorada pela historiografia luso-brasileira. Nesta pesquisa, sugerimos algumas leituras possíveis acerca da relação entre pai e filho, sendo nosso objetivo contribuir para um debate profícuo sobre a importância desses dois personagens para a história da estruturação da Real Biblioteca do Rio de Janeiro, em particular, e da política cultural joanina, em geral. Sendo por um lado a relação entre eles um tema que merece maiores pesquisas; por outro, é fato que Luís Joaquim alcançou um lugar de maior responsabilidade na corte, a partir de outubro de 1811. Desde então, passava a ser o responsável pela seção de manuscritos da Real Biblioteca. Sua narrativa sobre o episódio nos é muito profícua. Em reunião com o Visconde de Vilanova da Rainha, Marrocos soube que

[...] tendo sua Alteza Real pleno conhecimento da minha pessoa e conduta, e estando muito satisfeito dos bons desejos, que eu tinha de lhe servir bem, lhe tinha ordenado me chamasse logo e logo para ir tomar conta e cuidar do arranjamento [sic] e conservação dos Manuscritos da Biblioteca da Coroa (que Sua Alteza Real quis que permanecessem junto de Sua Pessoa) e dos mais Papéis, que sua Alteza Real ordenasse para o futuro. Que estava inteirado das boas informações do Senhor João Diogo ${ }^{212}$ a meu respeito, e como pessoa fidedigna me confiava este Cargo de segredo, importância e responsabilidade. [...] Faz-me muita honra esta distinção, por ser Sucessor de Frei António de Arrábida nesta incumbência, e principalmente pela especial lembrança de Sua Alteza Real em me chamar, sem eu o requerer. ${ }^{213}$

212 João de Barros Leitão de Carvalhosa.

213 MARROCOS, Luís Joaquim dos Santos. Cartas do Rio de Janeiro... Op. Cit., p. 84. [Carta N. ${ }^{\circ}$ 6] (Grifos do Original). 
Apesar de longa, a narrativa de Marrocos explicita-nos uma série de questões fundamentais à monarquia portuguesa. A primeira delas já é conhecida: D. João escolhia pessoalmente os lugares políticos de seus súditos e, para o sucesso de suas metas, não media esforços. ${ }^{214}$ No caso da atribuição ao novo cargo de Luís Marrocos, o Príncipe Regente não só foi um excelente observador da trajetória do ajudante de bibliotecário na corte, como também confiou no olhar de outros súditos considerados fiéis para deliberar sobre uma função de tamanha consideração. Em segundo lugar, o monarca pedia que a substituição dos profissionais ficasse em segredo, o que já denotava a grande autoridade dada aos manuscritos reais. Lilia Schwarcz aponta as diferenças entre os livros da biblioteca - considerados uma joia para expor ao público - e os manuscritos. Estes, segundo a autora, "cumpriam uma função política delimitada e reservada". ${ }^{215}$ Para exercerem devidamente o seu papel político, portanto, foram organizados em um criterioso catálogo produzido e classificado pelo bibliotecário. ${ }^{216}$ Por fim,

\footnotetext{
214 A historiadora Leila Mezan Algranti destacou que "o cargo público no estado absolutista dignificava os indivíduos, e sempre foi uma forma de conquista de status, de prestígio e até de título de nobreza por parte daqueles que o ocupavam." Algranti ressalta ainda que esses funcionários tinham perspectivas "de atrair a estima do rei, além de recompensas generosas pelos bons serviços prestados." Desse modo, os leais servidores de D. João não poupavam esforços para conquistar sua confiança que, na prática, significava um importante reconhecimento público além de chamar para si a estima e recompensa por parte do soberano. ALGRANTI, Leila Mezan. Livros de Devoção... Op. Cit., p. 225-226.

215 SCHWARCZ, Lilia. "Luís Joaquim dos Santos Marrocos”. In: NEVES, Lúcia Bastos Pereira das; VAINFAS, Ronaldo. Dicionário do Brasil Joanino... Op. Cit., p. 304. Sobre a importância dos manuscritos ver também MORAES, Rubens Borba de. Livros e Bibliotecas no Brasil colonial. São Paulo: Livros Técnicos e Científicos, 1979. p. 84.

216 Sobre o Catálogo, relatava ao pai: "Eu por ora vou continuando em meu trabalho: concluí um Mapa Sistemático da Classificação, como já anunciei à Vossa Mercê em outra [carta]; este Mapa hei-de [sic] mostrá-lo primeiramente ao Frei António de Arrábida, que me pediu essa preferência, e ao depois hei-de
} 
Marrocos se envaidecia de estar sob a mira do Príncipe Regente, uma vez que, na sociedade do Antigo Regime, estar próximo ao rei era um dos maiores prestígios almejados pelos cortesãos.

A ascensão de Luís Joaquim dos Santos Marrocos não foi vista com bons olhos por muitos palacianos. Segundo ele, por conta da nova função, passou a ser "vítima de intriga". No relato desses problemas ao pai, dizia ter sido obrigado a não ir ao Paço por dois dias sucessivos, já que tinha sido expulso do seu lugar de trabalho. Isto ocorreu, justificava, "não por motivos de honra, que me envergonhem, graças a Deus, mas porque queriam persuadir a Sua Alteza Real que eu não devia ver certos Papéis enquanto estes se conservassem na Sala de Manuscritos". O imbróglio foi rapidamente resolvido com a interferência do Visconde de Vila Nova da Rainha, que agiu em seu favor diretamente com D. João. ${ }^{217}$

A proteção do Visconde de Vila Nova da Rainha surtia efeito no olhar que o Regente tecia para Marrocos. No raiar de 1813, o bibliotecário tinha sob suas mãos a chave da Sala de Manuscritos. Tal honra era motivo de grande vaidade para o súdito real: "quem quiser ir a ela [sala] há-de [sic] vir primeiro à bajulação",

[sic] entregá-lo ao Visconde de Vila Nova da Rainha para este apresentar à Sua Alteza Real.” MARROCOS, Luís Joaquim dos Santos. Cartas do Rio de Janeiro... Op. Cit., p. 143. [Carta N. ${ }^{\circ}$ 28]. A pesquisadora Lilia Schwarcz cita a existência desse Catálogo, que segundo ela, contava com 75 páginas, sendo dividido em 08 temas: Política (180 documentos), Teologia (76 documentos), Direito Canônico (86 documentos), Direito Civil (64 documentos), História Eclesiástica (83 documentos), História Civil (33 documentos), História Literária (04 documentos), Ciências, Belas Artes e Belas Letras. (44 documentos). Apesar de citar em detalhes a documentação, a autora não indica a referência documental. Marrocos, tampouco, o faz em suas cartas. Portanto, como não tivemos acesso à documentação, nos limitamos apenas em reiterar, por Schwarcz, a sua possível existência. Cf. SCHWARCZ, Lilia. A longa viagem... Op. Cit., p. 284.

217 MARROCOS, Luís Joaquim dos Santos. Cartas do Rio de Janeiro... Op. Cit., p. 139. [Carta N. ${ }^{\circ}$ 26]. 
vangloriava-se. ${ }^{218}$ Coincidentemente, neste mesmo período, o monarca determinava o conserto e reparo na livraria. Para tal intento, o Real Erário concedia $100 \$ 000$ réis por mês para cobrir as despesas. "Confesso que ficará uma Casa mui[to] linda, e mui[to] bem arranjados os Livros." Quanto à finalização do trabalho com as obras, informava: "Abriram-se já os últimos 67 Caixões de Livros que ainda existiam fechados, e tive grande satisfação de ver louvado o bom acondicionamento deles nos ditos Caixões". ${ }^{219}$

Enfim, em 1814 a Real Biblioteca do Rio de Janeiro era aberta ao público. Sobre esse evento, destacamos a observação de Padre Perereca.

[...] a Real Biblioteca tem sido muito bem arranjada, e repartida por diversas salas, segundo as diferentes classes de objetos científicos, ou de literatura de que tratam os livros de que ela se compõe, os quais estão hoje por uma ordem muito metódica, e fácil de se encontrar qualquer deles, quando são procurados pelos estudiosos. Esta Real Biblioteca tem chegado a ser a primeira, e a mais insigne, que existe no Novo Mundo, não só pelo copioso número de livros de todas as ciências, e artes, impressos nas línguas antigas, e modernas, cujo número passa de sessenta mil volumes, mas também pela preciosa coleção de estampas, mapas, manuscritos, e outras ricas e singulares coisas, que muito a enriquecem, e que cada vez mas se aumentam devido a munificência de Sua Alteza Real. ${ }^{220}$

A descrição do religioso nos coloca a par do trabalho dos funcionários da instituição entre os anos de 1810 e 1814 . O espaço organizado em salas específicas, as coleções distribuídas por temas e as obras classificadas. Um trabalho de tal monta, segundo

${ }^{218}$ Ibid., p. 167. [Carta N. $\left.{ }^{\circ} 37\right]$.

219 Ibid., p. 170. [Carta N.o 37].

220 SANTOS, Luiz Gonçalves dos. Memórias para servir... Op. Cit., p. 425-426. 
o clérigo, contou com a ativa colaboração do Príncipe Regente, que não só se empenhava em mover toda uma equipe especializada para a transladação das preciosidades intelectuais da Coroa, como também se preocupava em manter viva a constituição do acervo, juntamente com os seus bibliotecários, responsáveis pela aquisição de novas obras e zelo do espaço. De fato, como já mostrou Rubens Borba de Moraes, a Biblioteca Real do Rio de Janeiro foi enriquecida constantemente. ${ }^{221}$

Além de Luís Marrocos ter conseguido a Propina da Impressão Régia, que na prática enviava uma cópia para a Biblioteca "de tudo o quanto se tem impresso, e houver de imprimir-se"222, em 1811 a instituição recebeu, por doação o espólio literário de Frei Mariano da Conceição Veloso, que contava com cerca de 2.500 livros. Isto sem contar com as estampas e os desenhos originais da Flora Fluminensis. ${ }^{223}$ No final de 1812, D. João determinava que viesse de Lisboa um exemplar de cada obra produzida pela extinta tipografa do Arco do Cego, cujo material chegou ao Rio de Janeiro em setembro de 1813. Dois anos depois, em 1815, a realeza comprava a biblioteca de Manuel Inácio de Silva Alvarenga, que, inclusive, tinha obras proibidas em seu acervo, de quase 1.600 volumes ${ }^{224}$; em 1818 era vez de adquirir a coleção do arquiteto português dos teatros joaninos de São Carlos (Lisboa) e São João (Rio de Janeiro), José da Costa e Silva, que, entre as

\footnotetext{
${ }^{221}$ MORAES, Rubens Borba de. Livros... Op. Cit., p. 85.

222 MARROCOS, Luís Joaquim dos Santos. Cartas do Rio de Janeiro... Op. Cit., p. 99. [Carta N. $\left.{ }^{\circ} 11\right]$.

${ }^{223}$ Para a observação de Marrocos sobre a doação da coleção de Veloso, ver MARROCOS, Luís Joaquim dos Santos. Cartas do Rio de Janeiro... Op. Cit., p. 93. [Carta N. 9].

${ }^{224}$ Sobre as especificidades da livraria de Silva Alvarenga, ver: TUNA, Gustavo Henrique. "A livraria de Manuel Inácio Silva Alvarenga: representante das Luzes na América Portuguesa?" In: ALGRANTI, Leila M.; MEGIANI, Ana Paula. (Org.). O Império por escrito..., p. 265-276.
} 
raridades, tinha "uma valiosa série de estampas, manuscritos e, principalmente, grande número de desenhos originais de mestres da renascença italiana”. ${ }^{225}$ Em 1822, um ano depois da volta de D. João para Lisboa, D. Pedro arrematava a célebre livraria do Conde da Barca. ${ }^{226}$ Como já salientou Lilia Schwarcz, o acervo da Real Biblioteca também contou com pequenas doações, porém, de grande valia. Se entre 1817 e 1820 foi registrada a entrada de 317 obras, os seus benfeitores eram a elite do Paço. Para além de D. João, seus ministros agiam constantemente em prol do esplendor do espaço. Entre os doadores, Schwarcz destacou o Marquês de Marialva, Thomaz Antonio Vilanova Portugal e Francisco Borja Garção Stockler (dois ministros e um censor régio). ${ }^{227}$ Ademais, a pesquisa de Lúcia Pereira das Neves já demonstrou o interesse desses homens de prestígio em doar suas obras. Esta atitude, segundo a autora, reafirmava a importância da Biblioteca como instância simbólica de consagração da monarquia, além de reiterar o papel político e social desses sujeitos na sociedade de Corte. ${ }^{228}$

Em relação aos dias de funcionamento da Real Biblioteca, Padre Perereca nos informa que "exceto nos domingos, dias santos e feriados por motivos de anos das pessoas reais, ou por alguma causa pública, a instituição estava sempre aberta, e patente, tanto de manhã quanto de tarde, a todas as pessoas, que a querem frequentar". ${ }^{29}$ Se considerarmos as características do calendário

\footnotetext{
225 MORAES, Rubens Borba de. Livros... Op. Cit., p. 85.

226 O exame detalhado da biblioteca do Conde da Barca foi tema de investigação da historiadora Maria Beatriz Nizza da Silva. Para a análise da autora, ver as seguintes obras: D. João: príncipe e rei no Brasil. Lisboa: Livros Horizonte LDA, 2008. p. 88-89; e A cultura luso-brasileira: da reforma da universidade à independência do Brasil. Lisboa: Editorial Estampa, 1999. p. 139-141.

227 SCHWARCZ, Lilia. A longa... Op. Cit., p. 281.

228 NEVES, Lúcia. “O livro para se fazer nele memória..., Op. Cit., p. 295.

229 SANTOS, Luiz Gonçalves dos. Memórias para servir... Op. Cit., p. 426.
} 
real - pautado pelo viés religioso e político - os compromissos da monarquia no espaço público do Rio de Janeiro eram constantes, podendo ser contabilizados pelas paradas militares, dias santos, datas natalícias da realeza etc. ${ }^{230} \mathrm{Tal}$ fato nos mostra que, provavelmente, o acesso do público ao acervo da Real Biblioteca tenha sido bem menor do que quer nos fazer crer o Padre Perereca. De qualquer forma, as cartas de Marrocos nos indicam que as visitações ao locus eram uma prática cotidiana, pelo menos para os membros da realeza e da elite intelectual da corte, incluindo-se aí os viajantes. ${ }^{231}$ É o caso de Lord Strangford, que, em abril de 1815, voltava para a Inglaterra levando consigo dois títulos da Real Biblioteca: O Cancioneiro (que a instituição tinha outro exemplar) e o Blasonero geral, que se perdia, pois era único exemplar. ${ }^{232}$ Ainda de acordo com Luís Joaquim, pouco antes da abertura da instituição, era comum a presença quase diária da família real pelos corredores da biblioteca que, segundo ele, se preparava para inaugurar com todo asseio e magnificência. ${ }^{233}$

Dentro desse cenário intelectual em que o livro e a leitura emergiam como instrumentos fundamentais na formação de novas ideias críticas ao status quo e do delineamento sutil, mas definitivo, de uma nova cultura política ${ }^{234}$, emergem-nos algumas dúvidas. Apesar da rica descrição do Padre Perereca sobre a

\footnotetext{
230 Para uma análise histórica sobre o significado do calendário no período joanino, ver LOPES, Emílio Carlos. Festas Públicas... Op. Cit., p. 87-124.

231 Para conhecer os possíveis visitadores da Biblioteca Real, ver SILVA, Maria Beatriz Nizza da. D. João: príncipe e rei no Brasil. Lisboa: Livros Horizonte LTDA, 2008. p. 82-83; SCHWARCZ, Lilia. A longa.... Op. Cit., p. 277.

${ }^{232}$ MARROCOS, Luís Joaquim dos Santos. Cartas do Rio de Janeiro... Op. Cit., p. 284. [Carta N. ${ }^{\circ}$ 79].

${ }^{233}$ Ibid., p. 246. [Carta N. ${ }^{\circ} 63$ ].

${ }^{234}$ Sobre as transformações na cultura política em fins do período joanino, destacamos o trabalho de NEVES, Lúcia Maria Bastos P. Corcundas, constitucionais e pés de chumbo: Op. Cit.
} 
organização interior do espaço, como as estantes foram dispostas? E a catalogação das obras? Que tipos de livros estavam à disposição dos leitores? Como já bem demonstraram os pesquisadores Rubens Borba de Moraes e Maria Beatriz Nizza da Silva, devido à grandiosidade do acervo não é possível termos uma noção exata dos volumes e tipos de livros existentes na livraria régia ${ }^{235}$; a despeito disso, a conservação de um Catálogo da Real Biblioteca intitulado "Catálogo por ordem alfabética das iniciais dos títulos de uma série de obras pertencentes à Real Biblioteca" nos dá importantes indicações sobre o interior do espaço. ${ }^{236}$

O manuscrito nos revela a existência de 306 títulos divididos em 65 estantes. Sem data e autoria, as obras foram catalogadas por ordem alfabética, de "A" a "V" e os temas respeitam as escolhas literárias clássicas do século XVIII. De acordo com Lúcia Pereira das Neves, a classificação das obras da Real Biblioteca do Rio de Janeiro tinha por base o critério retirado do Catálogo do Conde da Barca, dividido em cinco categorias: Jurisprudência, Ciências e Artes, Belas Letras, História e Teologia. ${ }^{237}$ Dentro dessas áreas do saber, o autor elegeu a História como a grande protagonista. As obras referentes ao tema aparecem em quase todo o alfabeto, porém, a maior referência esteve circunscrita à letra " $H$ "

${ }^{235}$ MORAES, Rubens Borba de. Livros... Op. Cit., p. 84; SILVA, Maria Beatriz Nizza da. A cultura luso-brasilera... Op. Cit., p. 145. Segundo Moraes, a investigação dos Catálogos da Coleção Barbosa Machado, Catálogo da Exposição Permanente dos Cimélios da Biblioteca Nacional (Rio, 1885) e o Catálogo dos Incunábulos da Biblioteca Nacional nos dão uma ideia mais precisa do acervo. (p. 84). Já Nizza da Silva, cita a existência do "Catálogo por ordem alfabética das iniciais dos títulos de uma série de obras pertencentes à Real Biblioteca". (p. 145).

${ }^{236}$ BNRJ. Catálogo por ordem alfabética das iniciais dos títulos de uma série de obras pertencentes à Real Biblioteca. Seção de Manuscritos. I - 13,02,056.

237 NEVES, Lúcia. “O livro para nele se fazer memória..., Op. Cit., p. 279. 
do Catálogo, somando, ao todo, 55 títulos. ${ }^{238} \mathrm{E}$ os subtemas são bem amplos. Da História Militar e Naval à História da Botânica, perpassando a História Antiga, História da Europa Ocidental, História Oriental, História Eclesiástica e, obviamente, a História de Portugal. ${ }^{239}$ Esta escolha não é, de modo algum, inusitada. Pelo contrário, dialogava com a tendência dos livreiros europeus do período, que no início do século XIX passaram a manifestar importância crescente entre os livros de História. ${ }^{240}$

Porém, de forma mais geral, entre os subtítulos há o predomínio para as obras militares, que compõem um total de 23 livros. Entre as Ciências, a valorização da Física e da Matemática é patente, inclusive com obras de Belidor e Saint Remy. Quanto às obras de mineralogia, astronomia e agricultura, mesmo que em menor número, mereceram destaque por todo o Catálogo. Nas Belas Letras, a ênfase deu-se para os Dicionários. Dentro dessa classificação, contudo, também encontramos novelas, poesia e obras de retórica.

Ademais, a deferência à produção intelectual francesa seja através da seleção de autores clássicos ou de obras traduzidas para o francês - é indiscutível: composto pela quase totalidade das obras selecionadas (226), o Catálogo privilegia temas da literatura política e das belas-letras, incluindo-se aí o teatro. Entre as celebridades da República das Letras, encontramos Montaigne, Erasmo de Rotterdam, Maquiavel, Bossuet, Fenellon e Corneille.

238 Sobre a entrada de livros e periódicos na Real Biblioteca entre os anos de 1817 e 1824, ver NEVES, Lúcia Maria Bastos Pereira das. "O livro para se fazer memória de todas as obras que entrarem na Real Biblioteca” In: ALGRANTI, Leila Mezan; MEGIANI, Ana Paula. (Org). O Império por escrito: Op. Cit., p. 277-296.

239 Vide Catálogo, em Anexo [ $\left.\mathrm{n}^{\circ}\right]$

${ }^{240}$ GUEDES, Fernando. O livro e a leitura em Portugal. Subsídios para a sua história. Séculos XVIII e XIX. Lisboa: Ed. Verbo, 1987. p. 135. 
Quanto aos filósofos iluministas, a referência foi Voltaire. Com Annales de L'Empire depuis Charles Magne (1754), Siecle de Luis 14 (1756) e Histoire universelle, o autor sedicioso também estava presente. Todos ao alcance dos leitores nas estantes da Biblioteca. O Catálogo também prestigia títulos em português (55), sendo as menções, obviamente, para atores nacionais renomados. Obras completas do Padre Vieira, Escola de Belém Jesus Nascido no Presépio (1730), por Alexandre de Gusmão e três obras de Manuel de Faria \& Sousa (Histoire del Reyno de Portugal (1730), Nobi lario do Conde de Barcellos Dom Pedro (1646) e Rimas Varias de Luís [de] Camões (1685)) são os destaques do acervo lusitano. Em menor escala ainda encontramos obras em latim (9), italiano (4) e espanhol (9). Como bem analisa Roger Chartier, "Graças à difusão dos catálogos, o mundo fechado das bibliotecas singulares pode ser transformado em um universo infinito de livros assinalados, recenseados, visitados, consultados e, eventualmente, emprestados" ${ }^{241}$

Reiteramos que o ato de classificar é guiado por critérios de relevância particulares ao autor do manuscrito ${ }^{242}$, que elevam a classificação como um exercício de poder. Segundo Robert Darnton, "um livro colocado errado na prateleira pode desaparecer para sempre [...]. Toda ação social flui através de fronteiras determinadas por esquemas de classificação, tenham ou não uma elaboração tão explícita quanto a de catálogos de bibliotecas". ${ }^{243}$ Por este prisma, mesmo sem conhecermos a data e a identidade do autor do Catálogo, há a hipótese de que ele tenha sido produzido por um dos bibliotecários régios, uma vez que o título

${ }^{241}$ CHARTIER, ROGER. A ordem dos livros... Op. Cit., p. 74.

${ }^{242}$ Discutimos a importância dos critérios de relevância para autores de Catálogos Bibliográficos no item I deste Capítulo.

${ }^{243}$ DARNTON, Robert. O grande massacre de gatos... Op. Cit., p. 249. 
do manuscrito faz referência à "Real Biblioteca" (denominação da instituição até 1825, quando passou a ser Biblioteca Imperial e Pública da Corte). Neste sentido, é plausível supormos que as obras selecionadas, talvez sejam as que mais interessavam à Coroa adquirir. "Estabelecer categorias e policiá-las é, portanto, assunto sério", analisa Darnton ao investigar as atividades dos filósofos dentro da Encyclopédie como empreendimento cultural. Para termos uma ideia da composição das estantes, vejamos um exemplo:

Tabela 2. A estante n. ${ }^{\circ} 56$ da Real Biblioteca do Rio de Janeiro

\begin{tabular}{|c|c|}
\hline Títulos & $\begin{array}{l}\text { Local/ ano de } \\
\text { publicação }\end{array}$ \\
\hline $\begin{array}{l}\text { Astronomie Nautique ou Elements d'Astronomie por un } \\
\text { Observatoire fixe, ou mobile .................par Maupertais. }\end{array}$ & Paris \\
\hline $\begin{array}{l}\text { Abrege de la Perfection Christienne du Pere Affone } \\
\text { [ilegível] Jezuitte. }\end{array}$ & Nantes, 1744 \\
\hline $\begin{array}{l}\text { Apparas Royal ou Nouveau Dictionnaire Francaise \& Latin } \\
\text { Nouvelle Edition Paris. }\end{array}$ & Paris, 1752 \\
\hline Cathecisme Historique par Heury. & 1745 \\
\hline $\begin{array}{l}\text { Dictionnaire Abregé de la Bible pour la connoissance des } \\
\text { Tableaux Historique. }\end{array}$ & Lion, 1756 \\
\hline $\begin{array}{l}\text { Dialogue sur la eloquence \& de la chaire en particulier } \\
\text { par Fenellon. }\end{array}$ & Paris, 1753 \\
\hline $\begin{array}{l}\text { Discours sur la Histoire Universelle par Jaque Begnigne } \\
\text { Bossuet. }\end{array}$ & Paris, 1741 \\
\hline $\begin{array}{l}\text { Geographie Universelle abregée avec les generalités de Fran- } \\
\text { ce \& les Villes ou l'on Cat Monnoye. }\end{array}$ & Lion, 1672 \\
\hline Gentilhomme Christien quivent se santifies. & Londres, 1719 \\
\hline $\begin{array}{l}\text { Historie Des Empereurs Romaine ecrite en Latin por Sue- } \\
\text { tone \& Traduite por Dateil avec Nottes \& Figures. }\end{array}$ & Lion, 1689 \\
\hline Historie Des Variations de l'Églize Protestante por Bossuet. & Paris, 1740 \\
\hline Historie Sur les Anglais \& Français \& sur les Voyages. & 1725 \\
\hline
\end{tabular}


Heures a luzage des Pensionnaires des jesuites por Le Père Troisel.

Letres de Madame du Montier a la Marquise de XX a fille \& le Reponses.

Bruxelas, 1756

Memoirs de Montecuculi Generalissime des Troupes de L'Empereur Itransburg.

Memoirs de Duque Trouin Lientenant General des Armées Amsterdã, Navales de France. 1755

Memoirs de Duque Trouin Lientenant General des Armées Navales de France.

Amsterdã, 1755

Memoirs contenant leprecis des faits avec pieces justificatives pour reponse aux Ministres Anglois.

Paris, 1756

Manuel des Ceremonies Romaines. 1691

Mœurs des Iseralites \& des Christiens por Fleury. Paris, 1755

Oeuvres de Marmontel. 1757

Revolution de Portugal par L'Abée du Vertot.

Haia, 1755

Traitté de Lortografie française en forme de Dicttionnaire avec des Nottes Critiques.

1755

Vie de Mahomet Traduite \& Compilée de Laceran des Traductions authentiques \& meilleurs Autheurs Arabes par Jean Gagnus.

Amsterdã,

1748

Como podemos observar, há uma grande variedade de títulos na estante 56. Obras científicas, dicionários, livros de História, Geografia, Ortografia, Literatura e Política. Três escritores, todavia, nos chamam a atenção. Fénelon (1651-1715), um autor muito lido por D. João VI ${ }^{244}$, Jacques Bossuet (1627-1704), um dos mais importantes teóricos do absolutismo no século XVII, e Marmontel (1723-1799), literato francês de renome, que já tinha

${ }^{244}$ PEDREIRA, Jorge; COSTA, Fernando Dores. D. João VI... Op. Cit., p. 43. 
caído no gosto português desde meados de $1800 .{ }^{245} \mathrm{O}$ que notamos em todo o Catálogo, mas, especificamente, nesta estante, é que a seleção dos livros para comporem o mesmo espaço não obedece, necessariamente, um critério temático, temporal ou por nações. A variedade de títulos parecia ser a regra. Ressaltamos ainda que esta observação necessita de uma investigação mais detalhada em todo o Catálogo, para que possamos tirar outras conclusões mais precisas. Nosso objetivo na análise deste manuscrito em específico era conhecer em linhas gerais o que tinha dentro da biblioteca e perceber as nuanças da atividade do bibliotecário; por essas razões, selecionamos uma estante, em particular, apenas a título de exemplo. A análise de cada uma dessas estantes talvez seja uma indicação para futuras pesquisas.

Coincidentemente, no mesmo ano em que a Real Biblioteca abria, definitivamente, as portas ao público leitor, a Europa vivia o fim do pesadelo napoleônico. Com a queda de Bonaparte e a volta da monarquia francesa ao poder, com Luís XVIII, tentava-se restabelecer a velha ordem no Continente, sendo o Congresso de Viena o símbolo máximo dessa tentativa. No Rio de Janeiro, as comemorações públicas (oficiais ou não) pelas ruas da cidade ${ }^{246}$ ou através do discurso da Gazeta do Rio de Janeiro exaltavam a alegria com o fim de uma era "maldita". ${ }^{247}$ Se esta situação configurava um alívio político para a monarquia portuguesa, não havia mais razões para D. João e seu séquito permanecerem no Brasil. A volta da realeza para Lisboa, a partir de então, seria uma questão de tempo? Eis a grande interrogação.

245 GUEDES, Fernando. O livro e a leitura em Portugal... Op. Cit., p. 138.

${ }^{246}$ MARROCOS, Luís Joaquim dos Santos. Cartas do Rio de Janeiro... Op. Cit., p. 266. [Carta N. ${ }^{\circ}$ 70].

247 Sobre o discurso da Gazeta do Rio de Janeiro sobre a queda de Napoleão Bonaparte, ver MEIRELLES, Juliana. Imprensa e poder... Op. Cit., p. 127-133; STOIANI, Raquel. Napoleão visto.... Op. Cit., p. 134-164. Disponível em: <http:// www.teses.usp. br/teses/disponiveis/8/8138/tde-19022010-125213/>. 
Em meio às conjecturas acerca do possível retorno da realeza nos dois lados do Atlântico, encontramos duas cartas sui generis de Luís Joaquim dos Santos Marrocos. Sobre os rumores ocorridos no Rio de Janeiro, em 12 de maio de 1814, o bibliotecário dizia ao pai que "nunca se pensou menos nessa matéria, do que agora". ${ }^{48}$ Menos de um mês depois, as súplicas dos Governadores do Reino já se faziam públicas e constantes na Corte. Para Marrocos, apesar das embarcações de diversas nações no cais, que congratulavam a aliança com a Coroa portuguesa, os preparativos para o retorno ainda eram incertos. Sobre a sua situação particular e a da livraria, contudo, Luís Joaquim fazia uma curiosa conjectura:

Quando Sua Alteza Real se retirar para Lisboa, ou levará consigo a Livraria, ou não; se a levar, creio não nomeará pessoas de fora, quando tem empregados antigos para tratar dela, até que chegue a ocasião de embarcar. Os dois Padres, que aqui se acham, não podem ficar, um por ser Confessor de sua Alteza as Senhoritas, e o outro por ser Companheiro do Confessor, que por força hão-de [sic] acompanhar suas Amas: na falta destes dois Padres não há outro de Casa, em quem possam pôr a albarda, senão em mim: e que será de mim, se eu disser que não quero, e que só quero ir-me embora? ${ }^{249}$

Mesmo sendo apenas suposições sobre o possível destino da realeza portuguesa, seu relato colocava em cena a problemática da materialidade do poder monárquico, simbolizado pela existência da Livraria. Ficar ou partir? Esta dúvida crucial tornou-se um tema de reconhecida centralidade no alto escalão

248 MARROCOS, Luís Joaquim dos Santos. Cartas do Rio de Janeiro... Op. Cit., p. 256. [Carta N. $\left.{ }^{\circ} 67\right]$.

${ }^{249}$ Ibid., p. 261. [Carta N. $\left.{ }^{\circ} 69\right]$. 
governamental, tendo, inclusive, sido, à época, objeto de reflexão do conselheiro Silvestre Pinheiro Ferreira (1814). ${ }^{250}$ A partir do final de 1815, quando o Brasil foi elevado a Reino Unido a Portugal e Algarves, os contornos em torno da definição política diante da questão "qual deveria ser o lugar hegemônico do poder no mundo luso-brasileiro", na acepção de Ana Rosa Cloclet da Silva, começavam a endossar a patente fragilidade do Império e do sistema absolutista, cuja predominância para a valorização do Brasil na conjuntura imperial passava a ser cada vez mais clara. ${ }^{251}$

Segundo a autora, se no Brasil a repercussão do novo status político foi interpretada pelas "múltiplas noções de unidade, igualdade e identidade"252, em Portugal forjava-se entre os Governadores do Reino "um sentimento de reação à nova categoria política do Brasil, acirrando o processo de reivindicação pelo retorno da Monarquia à sua antiga sede". ${ }^{253}$ Neste contexto, a particular preocupação do bibliotecário em transladar novamente a Real Biblioteca para a capital do Império, independentemente de ser Lisboa ou Rio de Janeiro, parecia ser, antes, uma inquietação da própria Coroa, que concebia este locus de saber como símbolo máximo de força, vitalidade e independência da monarquia luso-brasileira.

As livrarias foram consideradas espaços de saber de suma importância para a política cultural joanina em fins do Setecentos

\footnotetext{
250 Sobre as ideias de Silvestre Pinheiro Ferreira acerca da volta de D. João VI, ver seu escrito "Memórias Políticas sobre os abusos gerais e o modo de os reformar e prevenir a revolução popular redigidas por ordem do Príncipe Regente no Rio de Janeiro em 1814 e 1815. In: Revista Trimestral do Instituto Histórico Geográfico e Etnográfico do Brasil, tomo XLVII. parte.1. Rio de Janeiro: Typografia Universal de H. Laemmert e \&, . 1884.

251 SILVA, Ana Rosa Cloclet da. Inventando a Nação:... Op. Cit., p. 246-252.

252 Ibid., p. 250 (Grifos do Original).

253 Ibid., p. 254.
} 
e início do Oitocentos. Apenas na Corte, a Coroa portuguesa gerenciou o nascimento de dois locus: a Real Biblioteca do Rio de Janeiro, e a biblioteca da Academia dos Guarda-Marinhas $(1810)^{254}$; isto sem contar com as principais livrarias conventuais de São Bento e São Francisco, existentes desde o século XVIII. Porém, como nos relembra Rubens Borba de Moraes, a divulgação da cultura não estava presa exclusivamente às livrarias dessas instituições. Para além dos estabelecimentos já citados, ainda funcionavam na cidade diversos institutos de estudos superiores criados pelo governo, tais como a Real Academia Militar, o Laboratório Químico-Prático, a Academia Médico-Cirúrgica, o Arquivo Militar e a Academia dos Guarda-Marinhas. ${ }^{255}$

Quanto ao restante do país, o grande empreendimento foi a Biblioteca Pública da Bahia. O Plano para o estabelecimento deste espaço na cidade de Salvador, além de ter sido aprovado pelo Conde dos Arcos, governador da capitania, foi veiculado n'O Investigador Portuguez, na sua edição de estreia, em julho de 1811. Mesmo tendo sido uma "inciativa privada da elite culta da segunda cidade do Brasil" 256 , o locus teve total apoio da Coroa, que disponibilizou as páginas do seu jornal em Londres para a divulgação do projeto. Esta postura reitera, mais uma vez, o uso da imprensa interatlântica como mola-mestra dos projetos

${ }^{254}$ De acordo com Maria Beatriz Nizza da Silva, este locus de saber contou com um Catálogo, concluído em 1812, sendo um espaço voltado exclusivamente para o estudo das Ciências em geral, com destaque para as Ciências Naturais, Ciências Matemáticas, Ciências e Artes Navais, Ciências e Artes Militares de Terra e também a Polimatia, que abarcava uma ampla gama de conhecimentos. SILVA, Maria Beatriz Nizza da. A cultura luso-brasilera... Op. Cit., p. 146-148. Para uma análise mais profunda do espaço, ver artigo da mesma autora: "A livraria Pública da Baía em 1818: obras de História”, Revista de História. (São Paulo), n.87., 1971. p. 225-239.

255 MORAES, Rubens Borba de. Livros... Op. Cit., p. 87.

256 SILVA, Maria Beatriz Nizza da. A cultura luso-brasilera... Op. Cit., p. 142. 
culturais sustentados pelo governo joanino. Para a vigência do Plano, de autoria de Pedro Gomes Ferrão Castelo Branco, Nizza da Silva relata que

[...] convidavam-se os sócios a ali depositarem as suas bibliotecas particulares, ou pelo menos algumas obras que pudessem separar-se. Quem assim procedesse teria o seu nome divulgado na gazeta ${ }^{257}$ e seria considerado "bem-feitor [sic] do público, amigo da pátria e zeloso dos verdadeiros interesses do soberano". O autor do Plano foi o primeiro a dar o exemplo, oferecendo em doação perpétua todos os seus livros, além de $50 \$ 000$ réis para o fundo inicial da Livraria Pública. ${ }^{258}$

A abertura da livraria deu-se em agosto de 1811. Sete anos depois, em 1818, quando o espaço passava a receber as duplicatas da Real Biblioteca do Rio de Janeiro, o seu acervo era de 5.361 obras. ${ }^{259}$ Com uma ampla variedade de temas - da literatura de viagem à ciência, perpassando a literatura europeia, seu conteúdo, segundo Nizza da Silva, correspondia verdadeiramente aos interesses de leitura dos sócios, já que a encomenda dos livros dependia de suas escolhas. Estas, entretanto, tinham que ser aprovadas previamente pelos censores. ${ }^{260}$

O governo joanino ainda dirigiu deste lado do Atlântico os destinos das principais bibliotecas reais lisboetas, assim como endossou o projeto dos negociantes portugueses exilados na Inglaterra referente à estruturação da Biblioteca Lusitana em Lon-

\footnotetext{
257 Idade d'Ouro do Brasil.

258 SILVA, Maria Beatriz Nizza da. A cultura luso-brasilera...Op. Cit., p. 143.

259 "Catálogo dos livros que se acham na Livraria Pública da cidade da Baía, em maio de 1818” Apud SILVA, Maria Beatriz Nizza da. A cultura luso-brasilera... Op. Cit., p. 143.

260 Ibid., p. 145.
} 
dres. No gerenciamento dos espaços do Reino alguns eventos nos chamam a atenção. Em maio de 1812, por exemplo, o Príncipe Regente pedia a Ribeiro dos Santos que enviasse (pela secretaria do Estado dos Negócios Estrangeiros e da Guerra) a relação dos empregados na Biblioteca Pública da Corte, com as devidas "declarações e explicações" sobre a rotina dos funcionários e do estabelecimento. ${ }^{261}$ Dois meses depois, D. João determinava que o mesmo bibliotecário recebesse e guardasse "na devida arrecadação os livros pertencentes ao Ex. ${ }^{\circ}$ Marques de Alorna, que na mesma Biblioteca forem mandados entregar pelo Intendente $\mathrm{Ge}$ ral da Polícia”."262

As queixas e pedidos dos súditos reais vinculados a esses espaços também chegavam às mãos do monarca e, por vezes, eram atendidos. Em 1814, Antonio Ribeiro dos Santos fazia duas reclamações aos governadores do Reino: a falta de estantes "para se arranjarem muitos dos livros que têm acrescido à Biblioteca Pública", e a necessidade de se arrumar um novo ajudante, uma vez que José Gonçalves Ramiro, oficial da outra Biblioteca não servia o seu cargo há dois anos. Do Rio de Janeiro, D. João mandava "expedir as ordens necessárias para se aproximarem as estantes precisas" e ordenava que "se o dito oficial não for servir com efetiva residência como deve", prometia colocar outro em seu lugar. ${ }^{263}$

Para além das questões burocráticas, o Príncipe também estava a par das aquisições de novas obras e das traduções que

\footnotetext{
261 Aviso em que manda pedir uma relação dos empregados na Biblioteca. BNP. Seção de Reservados. Cód. 10612.

${ }^{262}$ Aviso em que manda receber os livros do Ex. Marquês de Alorna. BNP. Seção de Reservados. Cód. 10612.

263 Aviso em que manda servir José Gonçalves Ramiro com efetiva residência. BNP. Seção de Reservados. Cód. 10612.
} 
cotidianamente ocorriam. Em 1816, por exemplo, o governador do Reino, João Antonio Salter de Mendonça, avisava Antonio Ribeiro dos Santos sobre os trâmites para a tradução da Eneida. "El Rei Nosso Senhor manda remeter a V. S. ${ }^{\text {a }}$ o manuscrito original da tradução da Eneida de Virgílio por Leonel da Costa, para guardar na Real Biblioteca Pública da Corte, com a cautela que merece uma obra de tal preço." ${ }^{264}$ A ordem real ainda determinava que o bibliotecário fizesse uma cópia do dito manuscrito, conservando-a na Biblioteca, uma vez que esta seria usada quando fosse autorizada a impressão do livro. Por fim, em maio de 1816, o Regente decretava a aposentadoria de Antonio Ribeiro dos Santos, "tomando em consideração [sua] avançada idade, moléstias e bons serviços", e nomeava para o mesmo cargo o Doutor Joaquim José Ferreira Gordo, que, além de membro do Conselho Real, ainda era prelado da Santa Igreja de Lisboa. O despacho era enviado para o Reino com a rubrica do próprio D. João e do Marquês de Aguiar, ministro e assistente no Despacho do Real Gabinete, e presidente do Real Erário. ${ }^{265}$

Já o projeto da Biblioteca Lusitana em Londres foi veiculado n'O Investigador Portuguez em Inglaterra, em novembro de 1815. Este concebia o locus como um ponto de reunião comum da comunidade portuguesa, onde os sócios poderiam consagrar-se aos deleites da literatura nacional, a base do fortalecimento do patriotismo, conservarem a pureza de sua língua, "que mui arriscados andam à viciar e perder, vivendo em país estrangeiro sem o próprio antídoto" e ainda se instruírem "nas histórias, e mais coisas de sua nação, que é obrigação de todos não ignorar, e que,

264 Aviso em que remete a tradução da Eneida por Leonel da Costa. BNP. Seção de Reservados. Cód. 10612.

265 Decreto da aposentadoria do Bibliotecário Maior Antonio Ribeiro dos Santos e, nomeação de D. Joaquim José Ferreira Gordo para o dito lugar. BNP. Seção de Reservados. Cód. 10612. 
em ponto de ricas, e interessantes, por nenhuma das modernas são excedidas." A biblioteca também contaria com mapas, gazetas e jornais das mais diversas nações. ${ }^{266}$

Nos meses de julho e agosto de 1816, O Investigador publicou duas cartas referentes ao tema. Escrita sob o pseudônimo de "BIBLIOMANÍACO", a pimeira correspondência pedia informações sobre o espaço. "[...] li ainda fora da Inglaterra tanto no seu Jornal como nos outros portugueses, que se ia estabelecer uma Biblioteca Lusitana em Londres, acabo agora de aqui chegar, e o meu primeiro cuidado foi perguntar pela dita Biblioteca, de que ninguém me tem sabido dar notícia”. O autor ainda solicitava o endereço da "Dulcineia encantada", inquirindo o número da casa em que ela vivia. ${ }^{267}$

No número seguinte, o jornal publicava uma resposta ao "Inquiridor". Sob o pseudônimo de "BIBLIÓFILO", o autor adentrava em uma polêmica pública, justificando as razões para a demora do empreendimento: "Dirigi-me portanto a um dos promotores da mencionada Biblioteca; e observando a nota do Bibliomaníaco, publicado no seu Jornal, disse: - 'Que Literato aventureiro é esse, que parece ter vindo da Lourinham? [sic]'. - Ignora ele acaso as dificuldades que encontra qualquer instituição portuguesa?”. Ao fim, o Bibliófilo assegurava aos redatores e leitores d'O Investigador que a "nova Dulcineia encantada não espera[va] pelos esforços de Quixote algum científico, para sair a público", sendo-lhe realizados os preparos. ${ }^{268}$ Não sabemos se a Biblioteca veio a público, mas pelo silêncio do periódico a partir de 1817 (que não faz mais nenhuma referência sobre o empreendimento), tudo indica que o projeto não tenha saído do papel.

266 IP. Vol. XIV, p. 246-248.

267 Ibid., p. 177 (Grifos do Original).

268 Ibid., p. 267-268 (Grifos do Original). 
A política cultural do governo joanino em relação à sua "coleção de bibliotecas" distribuídas nos dois lados do Atlântico expressava a concepção real de que estes locus de saber compunham uma das principais faces de um espelho, cuja imagem era a de um Império vigoroso e politicamente forte e saudável. Tamanha pretensão, no entanto, se desvaneceu ao longo do tempo. Desde o início da tormenta revolucionária no Velho Mundo, em 1789, que a Coroa Portuguesa lutava pela estabilidade do Império. No Reino, tal projeto foi inviável. Com a invasão napoleônica iminente, a travessia oceânica tornou-se uma realidade, que durou treze anos. Do Brasil, a tentativa de implantar um novo e poderoso Império também não se concretizou: com a morte de d. Rodrigo de Souza Coutinho (1812), o fim da era napoleônica (1815) e o ápice da crise do sistema absolutista português, a partir de 1817, era preciso repensar a estrutura do frágil Império que se tinha sob as mãos. Dirigí-lo de qual sede, Rio de Janeiro ou Lisboa?

A resposta chegou antes do previsto por D. João VI. Pouco mais de três anos depois de ter sido aclamado rei na América (1818), a Revolução do Porto (1820) exigia providências urgentes. Era a monarquia constitucional que se afigurava no horizonte. A dívida com os súditos portugueses, enfim, teria de ser paga. Por não tolerarem mais tamanha humilhação política, os revoltosos do Porto chamavam às Cortes. Na efervescente ebulição política dos anos 1820-1822, a emergência do novo espaço público liberal luso-brasileiro mostrava toda sua face. Este espaço, se se transformava em uma velocidade voraz, tinha como protagonista a própria sociedade. $\mathrm{O}$ conceito de cidadania agora fazia parte do vocabulário comum. ${ }^{269}$ Eram os cidadãos que lutavam por um

269 "Resultante da linguagem política das Luzes, cidadão, no entanto, segundo Telmo dos Santos Verdelho, não entrou na maneira de falar cotidiana do povo 
novo pacto político nos dois lados do oceano. Eram os cidadãos que à frente do Real Teatro de S. João no Rio de Janeiro exigiam que D. João aceitasse a constituição, em 26 de fevereiro de 1821. O Império Português, finalmente, tinha novos atores políticos e o Antigo Regime era obrigado a negociar com uma nova ordem em praça pública. "A prática liberal considerava a igualdade perante a lei como condição inerente ao cidadão, dando uma nova conotação política ao exercício da cidadania”, contextualiza Lúcia Pereira das Neves. ${ }^{270}$

Em 1821, uma parte dos manuscritos reais atravessava o oceano juntamente com D. João e seu séquito rumo ao Velho Mundo. Estavam quase a salvos, não fosse ter deixado no Rio de Janeiro o mais precioso de seus bens: a Real Biblioteca, que valia quatro vezes mais do que toda a prataria real. ${ }^{271}$ Não bastasse isso, ainda em 1821, os funcionários da livraria régia imprimiam seu Estatuto, que simbolizava, nas palavras de Lilia Schwarcz, "uma verdadeira carta de alforria do estabelecimento, que decididamente se assentava em terras tropicais". 272

Ao longo desses anos a opinião tornava-se senhora da razão e tomava as ruas do Império. Em Coimbra ou em Belém do

português. Ao contrário do uso à época da Revolução Francesa, quando foi empregado como um título que substituía os termos senhor ou dom, a palavra, um nome comum, indiferenciado, referia-se a qualquer membro da sociedade. [...] No Brasil, o termo [cidadão] significava a designação oficial do indivíduo politicamente integrado à Nação: 'usando de nossos direitos naturais, começamos a ser homens, [...]pelo exercício de nossos direitos civis principiamos a ser cidadãos". Ainda de acordo com Neves, "Insistia-se, assim, nos vários níveis de cidadania política, ficando claro que o cidadão destaca-se por seu mérito e suas posses. Todos podiam ser chamados de cidadãos, com exceção dos escravos, no Brasil”. NEVES, Lúcia Maria Bastos P. Corcundas... Op. Cit., p. 180-181.

270 Ibid., p. 181.

271 SCHWARCZ, Lilia. A longa viagem... Op. Cit., p. 400.

272 Ibid., p. 403. 
Pará, em Salvador ou no Porto, em Lisboa, ou no Rio de Janeiro. A crítica ao status quo adentrava o século XIX luso-brasileiro. Mesmo com toda a política governamental de coibição das ideias sediciosas, os sujeitos históricos d'Oitocentos liam a realidade à sua volta de uma maneira muito diferente de antes da Revolução Francesa. A imprensa? Os manuscritos? Os livros? As peças de teatro? A biblioteca? Sim, todos estes espaços de saber, ou de produção de novas leituras, olhares e conhecimentos, foram fundamentais para a formação de outra identidade coletiva. Esta, no início da década de 1820, começava a trilhar o caminho da soberania política. 


\section{CONSIDERAÇÕES FINAIS}

Em 26 de abril de 1821 D. João VI e seu séquito retornavam ao Velho Mundo, depois de treze anos habitando o Brasil. A notícia da partida do maior representante da monarquia bragantina, no periódico da Corte, não escondia a aura de melancolia e tristeza. Chancelado nas palavras do gazeteiro Manoel Ferreira de Araújo Guimarães, na Gazeta do Rio de Janeiro, o discurso oficial tinha um tom saudosista, emblemático de um tempo de grandes mudanças, avanços e conquistas. ${ }^{1}$ Em 1808, como Príncipe Regente há dezesseis anos (1792-1808), D. João havia escolhido a sua possessão americana como residência para consolidar uma de suas mais delicadas missões: a salvaguarda da integridade política do Império Português, em meio à grave crise em que a Europa estava imersa devido às guerras napoleônicas. Sete anos depois da sua chegada ao Rio de Janeiro, o Regente elevava o Brasil a Reino Unido de Portugal e Algarves (1815). Também do lado americano do Atlântico, o monarca foi aclamado Rei do Império luso-brasileiro (1818), assim como, três anos depois (1821), aceitou as exigências políticas interatlânticas da sociedade joanina que clamava pelas Cortes reivindicando o constitucionalismo. Enfim, se D. João chegou ao Brasil ainda Príncipe Regente absoluto, retornava à Europa Rei constitucional.

1 GRJ. 1821. № 34. 
As transformações sociopolíticas e culturais foram profundas. Para compreendê-las, procuramos esclarecer as linhas mestras da política joanina ao longo de sua governança (17921821) no mundo luso-brasileiro, tendo em vista a importância da estruturação e vigência de quatro locus de cultura do Império Português: a imprensa interatlântica, os reais teatros, a Real Academia Militar e as reais bibliotecas. Sob as diretrizes do iluminismo luso-brasileiro, a investigação das especificidades de cada um desses espaços de ampla interlocução social, nos apontou as principais bases da política cultural de D. João VI, sobretudo em relação à produção, troca de saberes e circulação de informações nos campos da arte e da ciência entre o Velho Continente e o Novo Mundo.

Através da perspectiva interatlântica, vislumbramos vieses fundamentais da política cultural da monarquia portuguesa, entre os anos de 1792 a 1821. A política cultural joanina esteve intrinsecamente associada à atuação política mais ampla da Coroa tanto na relação de D. João com seus principais homens de Estado, incluindo-se os Intendentes Gerais da Polícia, quanto com a formação intelectual de seus súditos ilustrados nos diversos espaços de cultura e educação nas cidades politicamente fundamentais na sustentação do Império Português, alicerçadas em Lisboa e Rio de Janeiro, com destaque diplomático também para Londres. A despeito das divergências políticas, a Coroa britânica foi a principal aliada da Coroa portuguesa na Europa neste período. Ainda na capital inglesa, eram produzidos os principais jornais do período, O Correio Braziliense e O Investigador Portuguez em Inglaterra.

Ao investigarmos o complexo universo da imprensa como locus de produção de saber, adentramos em uma situação deveras particularizada. Seja através da liberdade de imprensa que 
vigorava em Londres, seja em meio ao sistema de censura vigente no Império Português, a produção da palavra impressa veiculada nos jornais luso-brasileiros esteve intimamente associada às relações políticas e diplomáticas da Coroa portuguesa com as nações europeias, mormente França e Inglaterra. Ademais, as discussões públicas de temas caros à formação da opinião pública mostraram como a condução da pena desses homens de letras tinha uma missão comum: o debate acerca dos melhores caminhos para que a sociedade civil luso-brasileira fosse instruída e educada dentro da concepção de progresso da época, cujo sentido estava intrínseco ao adiantamento em proveito das artes e ciências, dois campos do saber ainda tão interdependentes e vinculados à força do pragmatismo pedagógico.

Já a complexidade do universo artístico apreendia outras dimensões simbólicas. Do nascimento desses espaços de cultura, como o Real Teatro de São Carlos (Lisboa) ou os Reais Teatros de São João (Porto e Rio de Janeiro), notamos a conexão entre os novos tempos pós Revolução Francesa e a emergência política e inserção das novas classes sociais, como a burguesia portuguesa, no Reino, e os negociantes de grosso trato e a nobreza lusitana, no Rio de Janeiro. Neste sentido, para a sociedade de corte luso-brasileira, o teatro foi um espaço importante de sociabilidade em que era possível polir as maneiras à semelhança das nações mais cultas da Europa, mas também delinear novas relações sociopolíticas que garantissem, no futuro, voos mais altos nos quesitos de visibilidade pública (sobretudo para a realeza) e riqueza. Neste sentido, o apoio financeiro a este empreendimento tornava-se, pouco a pouco, uma moeda de peso nas relações políticas entre a monarquia e seus súditos ilustrados. Para a Coroa, a construção e manutenção de uma casa artística de tamanha magnitude simbolizava o ápice da civilização dos costumes: um locus onde 
a realeza poderia celebrar as suas glórias políticas; um espaço de pedagogia política onde se educava os súditos através da exaltação dos valores morais mais caros ao Antigo Regime sem, com isso, abrir mão do refinamento do gosto através da valorização da alta cultura europeia.

Com as Reais Academias Militares a Coroa portuguesa objetivava metas ainda mais ousadas. Para além da educação moral dos súditos, calcada no respeito à hierarquia militar, primava-se pela formação intelectual institucionalizada desses sujeitos. Ao valorizar o estudo em diversos níveis - das primeiras letras à produção e apreensão de um conhecimento científico de ponta -, a Coroa buscava garantir a segurança territorial do Império Português em tempos de paz ou em tempos de guerra. Assim, com a alta profissionalização do exército real, o governo joanino também almejava a formação de um amplo contingente de mão de obra civil especializada: os engenheiros, que cuidariam das obras de infraestrutura nos dois lados do Atlântico. No Brasil, especificamente, o espaço também teve um viés simbólico muito forte: a estruturação e defesa deste amplo território apagava a mácula da humilhação política vivida pela Coroa Portuguesa ao transladar a capital do Império para a América, às vésperas da invasão de Napoleão Bonaparte a Lisboa. Enfim, se as Reais Academias Militares visavam, no plano ideal, provar a grandeza e solidez do Império, no plano real, enfrentaram grandes obstáculos e dificuldades: para além dos problemas infraestruturais - com a carência de material pedagógico e corpo docente e discente - a Real Academia Militar era um projeto exclusivo de d. Rodrigo de Sousa Coutinho. Com a sua morte, portanto, as objetivações de seus ideais ficaram em segundo plano para os ministros que o sucederam. A despeito disso, a exaltação do discurso de valorização do progresso através do conhecimento científico foi uma tônica 
imprescindível que extrapolou os muros da instituição e constituiu uma característica típica da figura do militar no período joanino. Ademais, foi também das salas da Real Academia Militar que se iniciou a formação dos quadros políticos que comporiam a administração estatal ao longo da primeira metade do século XIX.

A constituição das Bibliotecas Reais foi um projeto ambicioso da Coroa portuguesa desde D. João V (1706-1750). Se o riquíssimo acervo da Biblioteca Real ficou entre os escombros do terremoto de 1755, os reinados de D. José I, Da Maria I e D. João VI tratariam de manter uma sistemática política de recuperação do espaço (com a formação de novos acervos) através da constituição de três novos locus: a Real Biblioteca d'Ajuda (1756), a Real Biblioteca Pública da Corte (1794) e a Real Biblioteca do Rio de Janeiro (1810). O árduo esforço governamental para a consolidação desses lugares de cultura no Império Português é intrínseco à força simbólica de uma Biblioteca Régia na Idade Moderna: estas eram o lugar da memória da monarquia, representavam a superioridade intelectual e independência política do Império. E por essas razões absolutamente centrais para os reis absolutos, D. João não mediu esforços para o sucesso do processo de transladação da Biblioteca Real para a nova capital imperial, o Rio de Janeiro.

Desta forma, a constante política de aquisição e preservação de novas obras (fossem elas raras ou não) também colocava em cena a figura do bibliotecário: um súdito de fundamental importância escolhido por rígidos critérios de relevância. Para além da ampla formação intelectual geralmente vinculada à Universidade de Coimbra, este funcionário régio deveria ser um súdito fiel e leal à monarquia. Os bibliotecários eram homens que, entre muitas outras funções, pensavam o processo de leitura que interessava à Coroa veicular. Em outras palavras, tinham que ser 
bons leitores da realidade política do Império Português. ${ }^{2} \mathrm{~A}$ importância da Biblioteca Real foi de tamanha grandeza simbólica que, em 1825, o espaço entrou como um dos principais objetos intelectuais de negociação no processo de reconhecimento da Independência do Brasil. A consolidação desse difícil processo de separação política do Brasil custaria a D. Pedro I uma pesada indenização. Na Conta dos objetos que Portugal teria direito a reclamar ao Brasil, D. João VI cobrou do filho 800 mil contos de réis pelo acervo da Real Biblioteca que ficara no Rio de Janeiro. ${ }^{3}$ Com os devidos acertos financeiros, abria-se uma nova página na história do recente Império do Brasil sob a coroa de D. Pedro I.

Neste sentido, entrevemos pontos em comum entre os quatro locus de saber estudados nesta pesquisa. Todos visavam celebrar as glórias políticas da monarquia luso-brasileira com objetivos pedagógicos muito circunscritos: agir em prol da formação intelectual dos súditos através do ideal ilustrado intrinsecamente associado à educação. Porém, assim como os filósofos da Europa do Norte, também no Império Português o processo de formação dos súditos era perpassado por uma concepção de educação elitista e excludente. Isto é, adentrar no mundo do conhecimento era mérito para poucos.

Com isso, a política cultural da Dinastia de Bragança sob a cabeça de D. João VI visou a engrandecer-se simbolizando a sua força política através da constituição e engendramento de espaços de cultura nos dois lados do Atlântico. Em relação ao Brasil, a formação de tais locus não foi pensada única e exclusivamente para o deleite da Coroa, mas, antes, para preservar as representações

\footnotetext{
2 Sobre a importância dos homens de talento no período joanino, ver ALGRANTI, Leila Mezan. Livros de Devoção... Op. Cit., (cap. 7, p. 223-251).

3 SCHWARCZ, Lilia M., AZEVEDO, Paulo César de; COSTA, Ângela Márquez da, A longa viagem ... Op. Cit., p. 395.
} 
políticas da monarquia luso-brasileira. Os espaços iluminados vigentes na outra capital deveriam fazer parte da vida da corte, a partir de 1808. Por esse prisma, o que tem no Reino, necessariamente deve existir também na nova Corte, já que a residência do monarca tem que ser digna de sua persona. Cada uma dessas instituições compõe as imagens e símbolos do poder real, sendo diferentes expressões de uma mesma questão: a manutenção da integridade imperial pelo viés da formação pedagógica de bons súditos ilustrados.

Essa obra, portanto, buscou evidenciar a complexidade das relações sociopolíticas e culturais do Império Português em meio à grave crise política na Europa através da compreensão das ações governamentais para quatro locus de cultura de naturezas diferenciadas. O estudo desses espaços por uma perspectiva transatlântica foi crucial para delinearmos as dimensões da política cultural joanina que, em última análise, esteve voltada para a superação da crise política e a salvaguarda da integridade imperial luso-brasileira. Neste contexto, a consolidação de um novo Império com sede no Brasil era parte fundamental desse projeto, sendo imprescindível a busca pelo equilíbrio político nas (tensas) relações diplomáticas de Portugal com o Velho Mundo. Neste processo, a capitalidade do Rio de Janeiro como centro do Império, assim como a manutenção desse difícil diálogo político e diplomático ao longo de todo o período com a Europa, ganhou novas dimensões e tonalidades políticas, também tecidas dentro desses quatro locus de cultura. Cada um desses espaços de saber contou com o trabalho de muitos funcionários régios de diversos perfis intelectuais: dos homens de Estado aos homens de letras e ciência, D. João VI os escolhia através de um rígido critério de relevância. Porém, para além de suas diferenças, todos foram nomeados para seus respectivos cargos por serem, antes, súditos 
leais à monarquia. Isto é, para manter a Coroa sob sua cabeça com o devido respeito das demais nações europeias, D. João VI considerou vital a formação moral e intelectual de seus súditos ilustrados.

A despeito das especificidades culturais de cada um desses locus de saber, a governança joanina foi marcada sobremaneira por uma política cultural vinculada à busca da autonomia intelectual do Império Português que, em última instância, contribuiu profundamente para a consolidação de um novo ambiente cultural nos dois lados do oceano, com um maior grau de novidade no Rio de Janeiro. Dessa forma, ao apoiar institucionalmente grandes e diferentes projetos culturais com inspirações em suas respectivas congêneres lusitanas (gazetas e jornais, teatros, livros, bibliotecas, academias...), a Coroa portuguesa incentivava novas leituras da realidade entre muitos sujeitos históricos que viviam o cotidiano desse Império, incluindo aí também os escravos. Estes, mesmo marginalizados deste processo, vivenciaram pelas ruas da nova capital as novas reflexões sobre a política no espaço público sabendo esquadrinhar - com seus gritos e vozes públicas -, uma importante atuação política no espaço urbano, um domínio em que muitas vezes se sentiam senhores. Essas mudanças produziam consigo um constante jogo de apropriações de sentidos. ${ }^{4}$ Neste processo, o governo joanino, mesmo mantendo um amplo sistema de censura, também propiciou o florescimento de um novo espaço público de tonalidades liberais onde vigorou a crítica ao status quo. Como havia apregoado Immanuel Kant, em 1784, o Homem era culpado pela sua menoridade e, para transcendê-la, era imprescindível que este fizesse o uso público da razão. Eis o caminho a ser trilhado na senda do

\footnotetext{
${ }^{4}$ MOREL, Marco. As transformações... Op. Cit., p. 230.
} 
esclarecimento. ${ }^{5}$ Com as devidas ressalvas e limitações próprias ao iluminismo luso-brasileiro, a sociedade joanina apreendia algumas nuanças da lição do filósofo.

No raiar d'Oitocentos, a sociedade joanina nos dois lados do Atlântico emergia com uma força política inimaginável antes da Revolução Francesa: clamava pela monarquia constitucional, exigia representatividade nas Cortes, saía às ruas de forma coletiva (política e militarmente) organizada para discutir no espaço público seus desejos coletivos e direitos políticos. Propunha a liberdade de expressão com irrestrita liberdade de imprensa, fazendo desta uma importante arena de debates. Lia livros clássicos e, nas brechas da censura, tinha sob as mãos jornais e obras proibidas. Escrevia novas obras. Enfim, ousava recriar as suas identidades culturais criticamente, já que ao longo de pouco mais de trinta anos (1789-1821), apreendia o verdadeiro sentido da crítica intrínseco à morte do rei e à emergência do cidadão em um novo espaço público liberal onde todos seriam julgados igualmente perante a lei. ${ }^{6}$ Todas essas transformações também moldaram a persona D. João VI. De Príncipe Regente a Rei constunstitucional, D. João foi um monarca que viveu em um momento histórico de grandes turbulências políticas. Força e fragilidade eram as tônicas do seu tempo, do seu espaço e, quiçá, da sua personalidade. Um rei que consultava e parecia se orientar pelas opiniões, no geral contrastantes, de seus súditos ilustrados, quer sejam ministros ou escritores. Um rei que negociava mercês com seus súditos que de alguma forma o auxiliavam nas múltiplas tarefas da governança. Um rei que também se movimentava pela pressão da sociedade, visando sobretudo a garantir a coesão e integridade do todo, em

\footnotetext{
${ }^{5}$ KANT, Immanuel. Resposta à pergunta: ... Op. Cit., p. 104.

${ }^{6}$ KOSELLECK, Reinart. Crítica e Crise. Op. Cit., p. 103-104.
} 
outras palavras, a conservação do Império; tomou a iniciativa de propor e administrar instituições que atendessem seus interesses particulares, mas também as expectativas desta sociedade. Enfim, um rei que soube articular magnamente as chaves da diplomacia, pois estava situado entre a preservação do poder para a dinastia, as reivindicações conflitivas da sociedade e a competição internacional. ${ }^{7}$

Neste contexto, com a formação e vigência de todos esses novos espaços de cultura e saber, a nova capital do Império (Rio de Janeiro) começava a igualar-se em muitos sentidos à antiga sede do poder (Lisboa). Esse processo histórico evidenciou uma questão central: onde o Rei se encontrasse, os símbolos e expressões do seu poder estariam presentes, ratificando a sua força e superioridade dentro de uma visão ilustrada de mundo.

Em 1821, treze anos depois de sua chegada ao Brasil, a Coroa portuguesa voltava para o Velho Mundo. Se, porém, a realeza retornava sob os ventos liberais que elegiam um novo modelo político - o constitucionalismo -, fazia-o de forma muito habilidosa: independentemente das transformações políticas interatlânticas, a monarquia lusitana conseguiu sobreviver e se fortalecer ao longo do tempo, sem se curvar aos desígnios políticos e militares da França Napoleônica. Poucos monarcas alcançaram tal façanha. D. João VI foi um deles.

\footnotetext{
${ }^{7}$ Nesta reflexão, agradeço à professora Izabel Marson pelo diálogo profícuo acerca da persona de D. João VI.
} 


\section{FONTES E BIBLIOGRAFIA}

\section{Fontes}

\section{MANUSCRITAS}

\section{$\rightarrow$ PORTUGAL}

\section{- Biblioteca Nacional de Portugal (BNP)}

Seção de Reservados.

Livro do registo de alvará, avisos, decretos e ordens régias e de ordens e portarias da Inspecção Geral relativas à Real Biblioteca Pública. 1795-1844. Códice 10610.

Livro do registo de alvarás, avisos, decretos e ordens régias e de ordens e portarias da Inspecção Geral relativas à Real Biblioteca Pública. 1795-1808. Códice 10612.

Apontamentos. V. Nogueira (Ricardo Raimundo). Códice 7207.

Antonio Ribeiro dos Santos. Lista de livros e periódicos estrangeiros que a Biblioteca Nacional de Lisboa necessita adquirir de novo ou para completar colecções. 1796-1816. Códice 565.

Relação dos Acontecimentos do Rio de Janeiro em 26 de Fevereiro em 1821 e algumas circunstâncias que o precederam e o produziram. BNP. Seção de Reservados. Códice 10.759. 
Brotero, Félix de Avelar. Ofícios acerca do Jardim Botânico da Ajuda (1823-1825). Mss. 31, 41.

Cartas de Ribeiro dos Santos (Bibliotecário Real) de 1796-1797. Mss. 160, 80-84.

Memória sobre a regulação do teatro do Porto, de 1805. Mss. 184, 30.

Ofício de 28 de Setembro de 1820 para o $1^{\circ}$ Conde da Lapa, Manuel de Almeida e Vasconcelos, ministro plenipotenciário na corte da Rússia. Mss. 246, n. 28.

\section{- Arquivo Nacional da Torre do Tombo (ANTT)}

Correspondência do bibliotecário das Reais Bibliotecas. 18081832. Antonio Ribeiro dos Santos. Ministério do Reino. maço 279.

Correspondência Diplomática do Conde de Funchal (18121814). Ministério dos Negócios Estrangeiros. Livro 451.

Registro das cartas enviadas pelos governadores de Portugal para o Rio de Janeiro. Ministério do Reino. Livro 315.

Registro das ordens expedidas pelo príncipe regente aos governadores do reino. Ministério do Reino. Livro 380.

Regulamento Provisional das Reais Bibliotecas mandado observar pelo Príncipe Regente Nosso Senhor. Ministério do Reino. Livro 99.

Originais de despachos da Corte, $n .^{\circ}$ 14. Ministério dos Negócios Estrangeiros. Cx.152.

\section{- Arquivo Histórico Ultramarino}

ATESTADO do intendente geral da Polícia, João de Matos Vasconcelos Barbosa de Magalhães, declarando que a atriz do Teatro 
Nacional, Maria Amália, natural de Lisboa, está apta para receber seu passaporte com destino à Corte do Rio de Janeiro levando em sua companhia uma órfã menor de idade por nome Teresa de Jesus. AHU_ACL_CU_017, Cx. 284, D. 19957

REQUERIMENTO do ator do Teatro Nacional [de Lisboa], João Evangelista da Costa, [natural de Lisboa], ao rei [D. João VI], solicitando passaporte com destino à Corte do Rio de Janeiro. AHU_ACL_CU_017, Cx. 284, D. 19948.

REQUERIMENTO do ator cômico do Real Teatro de São João, Antônio José Pedro, ao rei [D. João VI], solicitando passaporte com destino à Corte do Rio de Janeiro. AHU_ACL_CU_017, Cx. 284, D. 19952.

REQUERIMENTO do músico instrumentista da Real Câmara, Joaquim Antônio Nunes de Oliveira, ao rei [D. João VI], solicitando passaporte com destino à Corte do Rio de Janeiro. AHU_ ACL_CU_017, Cx. 284, D.19976.

\section{$\rightarrow$ BRASIL}

\section{- Biblioteca Nacional do Rio de Janeiro. (BNRJ)}

Coleção Linhares. Mss. I - 29, 18, 1, n. 4.

Catálogo por ordem alfabética das iniciais dos títulos de uma série de obras pertencentes à Real Biblioteca. Seção de Manuscritos. Mss. I - 13,02,056.

MORÃES, Alexandre José de Melo. Dados sobre a chegada ao Rio de Janeiro da Família Real, problemas de habitação para a comitiva, vida social e política, hábitos da família real, volta para 
Portugal, falecimento de D, João VI e Pedro I como imperador, S.l, s.d, Original (transcrição feita por Cecília Coelho, maio de 2001). Mss. II-30, 23, 6,7.

\section{- Arquivo Nacional do Rio de Janeiro (ANRJ)}

Ministérios dos Negócios do Brasil. Tribunal do Desembargo do Paço. "Declaração de guerra aos franceses". Cx. 231, pct. 1. Doc. 1.

Ministérios dos Negócios do Brasil. Fundo Diversos. GIFI (OI), 6J-83.

Ministérios dos Negócios do Brasil. Fundo. Série Guerra. IG3-2.

Ofício de Manuel Ferreira de Araújo Guimarães à Junta Militar (Carlos Antonio Napion, João Manoel da Silva e Manoel Jacinto da Gama), em 12 de março de 1812. (Sem numeração de páginas).

Ofício de encaminhamento da Junta Militar para o Conde das Galveias sobre o pedido de Manoel Ferreira de Araújo Guimarães, em 21 de março de 1812. (Sem numeração de páginas).

Ofício de encaminhamento do mapa referente ao ano de 1812 para o Conde de Galveias. O documento foi assinado pela Junta Militar (Carlos Antonio Napion, João Manoel da Silva e Manoel Jacinto da Gama), em 20 de março de 1812. (Sem numeração de páginas).

Ofício da Junta Militar composta por Garção Stockler, João Manoel da Silva e Manoel Jacinto de Nogueira da Gama para o Príncipe Regente d. João, em 28 de Agosto de 1816. (Sem numeração de páginas).

Ofício da Junta Militar para o Marquês de Aguiar, em 20 de Dezembro de 1816. (Sem numeração de páginas). 
Ofício da Junta Militar para o Marquês de Aguiar, em 20 de Dezembro de 1816. (Sem numeração de páginas).

Ofício de Francisco José da Costa Azevedo para Thomaz Ant. Vilanova Portugal, datado de 29 de junho de 1818. (Sem numeração).

Ofício da Junta Militar para Thomaz Antonio Vilanova Portugal, em 01 de janeiro de 1819. (Sem numeração).

Polícia da Corte. Códice 323, vol.1

Polícia da Corte. Códice 329, 4 vols.

Polícia da Corte. Códice 403, vol.1.

- Arquivo Histórico do Itamarati

Legação de Londres. Correspondência ostensiva e reservada a D. Luís de Sousa.

\section{IMPRESSAS}

- Correspondências, Memórias e Relatos de Viagem

Amigo da Justiça. Provas da Falsidade, e Injustiça com que o editor do Correio Braziliense intentou desacreditar Antonio de Araujo Azevedo e algumas reflexões acerca desse jornal oferecidas aos seus leitores. Lisboa: Nova Oficina de João Rodrigues Neves, 1810. Com Licença da Mesa do Desembargo do Paço.

[Anônimo]. Elementos da civilidade e da decência, para instrução da mocidade de ambos os sexos: traduzidos do francês em vulgar. Lisboa: Tipografia Rollandiana, 1801. 
CARNEIRO, Heliodoro Jacinto de Araújo. Cartas dirigidas a S. M. el-rei D. João VI desde 1817 acerca do estado de Portugal e Brazil, e outros mais documentos escritos. Imprenta Londres: Impreçaô de Mess. Cox e Baylis, [1821].

. Exposição resumida do que durante os dezoito mezes que estive em Lisboa soffri à facção e os acelerados que dominavam el-rei e o levaram à sepultura. Pariz: Officina Typ. de Paulo Renourd, 1826.

CONSTÂNCIO, Francisco Solano. "Ideias sobre a Educação da Mocidade portuguesa nas Ciências Físicas e nas Artes”. In: SOUSA, Maria Leonor Machado de. Portugal e o mundo nos primeiros decênios do século XIX: Francisco Solano Constâncio. Lisboa: Arcádia, 1979.

COSTA, Hipólito José da. Diário da minha viagem a Filadélfia (1798-1799). Lisboa: ICS. Imprensa de Ciências Sociais. 2007.

COUTINHO, D. Rodrigo de Sousa. "Sobre os melhoramentos dos domínios de S. Majestade na América”, 1810, p.25 In: LIMA, Américo Pires de. Memória de D. Rodrigo de Sousa Coutinho (10 Conde de Linhares). Coimbra: Coimbra Editora Limitada, 1948.

DEBRET, Jean, Baptiste. Viagem pitoresca e histórica do Brasil. Trad. e Notas Sérgio Milliet. Belo Horizonte/ São Paulo: Itatiaia/ Edusp, 1989.

DIDEROT, Denis. Discurso sobre a poesia dramática. Tradução, apresentação e notas L. F. Franklin de Matos. São Paulo: Editora Brasiliense, 1986.

FERREIRA, Silvestre Pinheiro. "Memórias Políticas sobre os abusos gerais e o modo de os reformar e prevenir a revolução popular 
redigidas por ordem do Príncipe Regente no Rio de Janeiro em 1814 e 1815. In: Revista Trimestral do Instituto Histórico Geográfico e Etnográfico do Brasil. Rio de Janeiro: Typografia Universal de H. Laemmert e \&, Tomo XLVII, parte.1, 1884.

GOUVEA, R. da C. Resposta pública à denúncia secreta que tem por título 'Representação que sua majestade fez Antonio de Araújo de Azevedo em 1810' oferecida ao juízo do público e da posteridade. Londres: Oficina de R. E. A. Taylor, 1820.

LEITE, Antonio Bressane. A União Venturosa. Rio de Janeiro: Impressão Régia, 1811. p. 1-2. Disponível em: <http://www.iar. unicamp.br/cepab/libretos/uniao.htm>.

LUCCOCK, John. Notas sobre o Rio de Janeiro e partes meridionais do Brasil, tomadas durante uma estada de dez anos nesse país, de 1808 a 1818. Trad. Milton da Silva Rodrigues. São Paulo: Livraria Martins, 1942.

MARROCOS, Luís Joaquim dos Santos. Cartas do Rio de Janeiro (1811-1821). Coordenação. Elisabet Carceller Guillamet; Pesquisa e Revisão. Maria Conceição Geada; Transcrição e Índices. Cristina Pinto Basto, Elisabet Carceller Guillamet. Lisboa: Biblioteca Nacional de Portugal, 2008.

Memória com que se demonstra a preferência, que a Companhia Nacional deve ter à Italiana no arrendamento do Real Teatro São João da Cidade do Porto para o futuro ano de 1814. Biblioteca Nacional de Portugal. Seção de Obras Gerais. (Microfilme).

Memória Histórica e Política sobre a creação e estado actual da Academia Real Militar. Arquivo do Instituto Histórico e Geográfico Brasileiro. L. 17 - N. ${ }^{\circ}$ 366. In: Revista do Instituto Histórico e Geográfico Brasileiro. Rio de Janeiro, v. 236, 1957. 
MENDONÇA, Hipólito José da Costa Pereira F. de. Narrativa da Perseguição de Hippolyto Joseph da Costa Pereira Furtado de Mendonça, natural da Colonia do Sacramento, no Rio da Prata. Preso e processado em Lisboa pelo presente crime de framaçon ou Pedreiro Livre. Londres: W. Lewis, 1811.

MONCORVO, José Domingues de Attaíde. "Sobre os acontecimentos dos dias 21 e 22 de Abril de 1821 na Praça do Comércio do Rio de Janeiro. Escrita em Maio do mesmo ano por uma testemunha presencial", In: Revista Trimensal do Instituto Histórico Geográfico e Etnográfico do Brasil. Rio de Janeiro: Tipografia Luís dos Santos, , Tomo XXVII, parte primeira, 1864.

RATTON, Jacome. Recordaçõens sobre ocurrencias do seu tempo em Portugal, durante o lapso de sessenta e três anos e meio, aliás de Maio de 1747 a Septembro de 1810. Londres: $H$. Breyer, 1813.

Regulamento para os Hospitais Militares de Sua Alteza Real O Príncipe Regente Nosso Senhor, em tempo de Paz, como em tempo de guerra. Lisboa: Impressão Régia, 1805.

RUDERS, Carl Israel. Viagem em Portugal. 1798-1802. Trad. de António Feijó, pref. e notas de Castelo Branco Chaves. Lisboa: Biblioteca Nacional, 2002. 2 v.

SANTOS, Luís Gonçalves dos. Memórias para servir a História do Reino do Brasil. Belo Horizonte/São Paulo: Itatiaia/ Edusp, 1981. $2 \mathrm{v}$.

SILVA, Manoel Viera da. Reflexões sobre alguns dos meios propostos por mais conducentes para melhorar o clima do Rio de Janeiro. Rio de Janeiro: Impressão Régia, 1808. 
VIANA, Paulo Fernandes. "Abreviada demonstração do trabalho da polícia em todo o tempo que a servio o desembargador do paço Paulo Fernandes Viana.” In: Revista do Instituto Histórico e Geográfico Brasileiro. Rio de Janeiro, v. 55, Parte 1.

Brasil. Leis etc. Coleção das Leis do Brazil. Rio de Janeiro: Imprensa Nacional, 1891. Disponível em: <http://www.planalto.gov. br/CCIVIL_03/revista/Rev_66/Decreto.htm>.

\section{- Periódicos}

Gazeta de Lisboa (1800-1815)

Gazeta do Rio de Janeiro (1808-1821)

Correio Braziliense (1808-1821)

O Investigador Portuguez em Inglaterra (1811-1819)

O Patriota (1813-1814)

Observador lusitano em Paris (1815)

\section{BIBLIOGRAFIA GERAL}

\section{- Livros, Capítulos em livros, Dissertações e Teses}

ALEXANDRE, Valentim. Os sentidos do Império: questão nacional e questão colonial na Crise do Antigo Regime Português. Lisboa: Edições Afrontamento, 1993.

ALGRANTI, Leila Mezan. O feitor ausente. Estudo sobre a escravidão urbana no Rio de Janeiro (1808-1821). Petrópolis: Ed. Vozes, 1988. 
. Censura e comércio de livros no período de permanência na corte portuguesa no Rio de Janeiro (1808-1821). Faculdade de Letras da Universidade de Coimbra, Coimbra, 1999.

. Livros de Devoção, Atos de Censura: cultura religiosa na América Portuguesa. São Paulo: Editora Hucitec /FAPESP, 2004.

ALGRANTI, Leila Mezan, MEGIANI, Ana Paula Torres (Orgs.). O Império por escrito: formas da transmissão da cultura letrada no mundo ibérico (Sécs. XVI-XIX). São Paulo: Ed. Alameda, 2009.

ALVES, José Augusto dos Santos. A opinião pública em Portugal. (1788-1820). Lisboa: Universidade Autónoma, 2000.

. O poder da Comunicação. A história dos Media dos primórdios da imprensa aos dias da Internet. Lisboa: Casa das Letras, 2005.

ANDRADE, Francisco Ayres de. Francisco Manuel da Silva e seu tempo (1808-1865). Uma fase musical do Rio de Janeiro à luz de Novos Documentos. Rio de Janeiro: Ed. Tempo Brasileiro, Ltda, 1967. P. 63-111.

ANSART, Pierre. "As Humilhações Políticas". In: MARSON, Izabel; NAXARRA, Márcia. Sobre a humilhação: sentimentos, gestos, palavras. Uberlândia: EDUFU, 2005. p. 15-30.

ARAÚJO, Ana Cristina de. "As invasões francesas e a afirmação das ideias liberais". In: MATTOSO, José. História de Portugal: o liberalismo. vol. 5. Lisboa: Editora Estampa, 1994. p. 17-44.

. A cultura das Luzes em Portugal: temas e problemas.

Lisboa: Livros Horizontes, 2003.

. "Uma longa despedida: Cartas familiares de Luís Joaquim dos Santos Marrocos". In: MARROCOS, Luís Joaquim dos Santos. 
Cartas do Rio de Janeiro (1811-1821). Coordenação. Elisabet Carceller Guillamet; Pesquisa e Revisão. Maria Conceição Geada; Transcrição e Índices. Cristina Pinto Basto, Elisabet Carceller Guillamet. Lisboa: Biblioteca Nacional de Portugal, 2008. p. 13-39.

A Cultura das Luzes em Portugal. Temas e Problemas. Lisboa: Livros Horizonte, 2003.

ARENDT, Hannah. Da Revolução. São Paulo: Ática; Brasília: UnB, 1988.

ASSUNÇÃO, Paulo. Ritmos da Vida: momentos efusivos da família real nos trópicos. Rio de Janeiro: Arquivo Nacional, 2008

BARATA, Alexandre Mansur. Maçonaria, Sociabilidade Ilustrada e Independência do Brasil (1790-1822). São Paulo-Juiz de Fora: Annablume-EDUFJF-FAPESP, 2006.

BARRA, Sérgio. Entre a Corte e a Cidade: o Rio de Janeiro no tempo do rei (1808-1821). Rio de Janeiro: José Olympio Editora, 2008.

BASTOS, Débora. "A trajetória de Domingos Antonio de Sousa Coutinho: o Conde de Funchal (1760-1833)”, p. 8. Disponível em: $<$ http://www.ecsbdefesa.com.br/defesa/fts/TDAC.pdf $>$.

BELO, André. As Gazetas e os Livros: a Gazeta de Lisboa e a vulgarização do impresso (1715-1760). Lisboa, 2001.

BENEVIDES, Francisco da Fonseca. O Real Theatro de S. Carlos de Lisboa. Desde a fundação até à atualidade. Lisboa: Typ. Castro \& Irmão, 1888.

BOISVERT, Georges. "La presse périodique portugaise de Londres. Notes sur les circonstances de son apparition et de son 
développement." Sillages. Sus la direction de R.A. Lawton. N. 4. (1974). Poitiers: Département d'Études Portugaises et Brésiliennes de l'Université de Poitiers, 1974. p. 69-88.

. "Le comte de Palmela et la presse potugaise libre (18161820) d’aprés des documents diplomatiques inédites." Arquivo do Centro Cultural Português. Paris: Fundação Calouste Gulbenkian/Centro Cultural Português, 1982. p. 459-509.

BOURDIEU, Pierre. Economia das trocas simbólicas. [Introdução, organização e seleção de Sergio Miceli]. São Paulo: Perspectiva, 2007.

BOUZA, Fernando. Corre Manuscrito - uma historia cultural Del siglo de Oro. Madri: Marcial Pons. 2001.

BRAGA, Teófilo. História do Theatro Portuguez. Vol. 1. Porto: Imprensa Portugueza Ed. 1870-1871.

. História do Theatro Portuguez. Vol. 4. Porto: Ed Imprensa Portugueza. 1871.

BRANCO, João de Freitas; Jayme Duarte de Almeida. O teatro de São Carlos (1793-1956). Lisboa: 1956.

BRESCIANI, Maria Stella Martins. Londres e Paris no século XIX. O espetáculo da pobreza. 2. ed. São Paulo: Ed. Brasiliense, 1984.

BRIGOLA, João Carlos Pires. Colecções, gabinetes e museus em Portugal no século XVIII. Lisboa: Fundação Calouste Gulbenkian, 2003.

BUENO, Beatriz Piccolotto Siqueira. Desenho e Desígnio: o Brasil dos engenheiros militares (1500-1822). São Paulo: EDUSP/ Fapesp, 2011. p. 137-138. 
BURKE, Peter. A fabricação do rei. A construção da imagem pública de Luis XIV. Rio de Janeiro: Jorge Zahar, 1994.

CAMARGO, Ana Maria de Almeida; MORAES, Rubens Borba de. Bibliografia da Impressão Régia do Rio de Janeiro. São Paulo: Edusp, 1993.

CANO, Jefferson. $O$ fardo do homem de letras. Tese de doutorado. UNICAMP. 2000.

CARDOSO, José Luís. Domingos Vandelli. Memórias de História Natural. Porto: Porto Editora, 2003.

CARREIRA, Laureano. $\mathbf{O}$ teatro e a censura em Portugal na segunda metade do século XVIII. Lisboa: Imprensa Nacional Casa da Moeda, 1988.

CARVALHO, José Murilo de. "História intelectual no Brasil: a retórica como chave de leitura". TOPOI. Rio de Janeiro, $\mathrm{n}^{\circ} 1$, pp. 133-134.

CARVALHO, Marieta Pinheiro de. Uma ideia de cidade ilustrada: as transformações urbanas no Rio de Janeiro de D. João VI (1808-1821). Rio de Janeiro: Odisséia, 2008.

CARVAlHO, Mário Vieira de. Pensar é Morrer ou o Teatro de São Carlos na mudança de sistemas sociocomunicativos desde fins do séc. XVIII aos nossos dias. Lisboa: Imprensa Nacional Casa da Moeda, 1993.

CASTILHO, Antonio Feliciano. Acerca da pessoa do Sr. Antonio Ribeiro dos Santos. In: A primavera, Lisboa, 1837, p. 325-326. Apud PEREIRA, José Esteves. O pensamento político em Portugal no século XVIII: António Ribeiro dos Santos. Lisboa: Imprensa Nacional Casa da Moeda, 1983. p. 83. 
CASTRO. Giovanna Milanez de. O Palco da realeza: as transformações no espaço urbano e nas práticas sociais no Rio de Janeiro (1808-1821). Monografia. 2012.

CAVALCANTI, Nireu. O Rio de Janeiro setecentista: a vida e a construção da cidade da invasão francesa até a chegada da Corte. Rio de Janeiro: Ed. Jorge Zahar, 2004.

CHACON, Valmireh. O Conde de Linhares. Brasília: Theseaurus, 2008.

CHARTIER, R. Práticas de leitura. Trad. Cristiane Nascimento. São Paulo: Estação Liberdade, 1996.

A ordem dos livros. Leitores, autores e bibliotecas na Europa entre os séculos XIV e XVIII. Tradução Mary Del Priori. Brasília: Editora da Universidade de Brasília, 1999.

. "O príncipe, a biblioteca e a dedicatória". In: BARATIN, Marc; JACOB, Christian. O poder das bibliotecas: a memória dos livros no ocidente. Trad. Marcela Mortara. 2. ed. Rio de Janeiro: Editora UFRJ, 2006.

COELHO, Teixeira. Dicionário Crítico de Política Cultural: Cultura e Imaginário. 3. ed. São Paulo: Editora Iluminuras/ Fapesp, 2004. p. 318.

CONCEIÇÃO, Adriana Angelita da. Sentir, escrever e governar. A prática epistolar e as cartas de D. Luís de Almeida, $2^{\circ}$ Marquês de Lavradio (1768-1779). Tese de doutoramento. São Paulo: Faculdade de Filosofia e Ciências Humanas USP, 2011.

CRANMER, David John. Opera in Portugal 1793-1828: a study in repertoire and its spread. Tese de Doutorado. London: University of London, 1997. 
CRUZ, Manuel Ivo. O Teatro Nacional de S. Carlos. Lisboa: Lello e Irmão - Editores, 1992.

CUNHA, Xavier. Antonio Ribeiro dos Santos. Bibliophilo. Lisboa: Imprensa L. da Silva, 1913.

CURTO, Diogo Ramada. Cultura Escrita. Lisboa: ICS, Imprensa de Ciências Sociais, 2007.

Cultura Imperial e Projetos Coloniais (séculos XV a XVIII). Campinas, SP: Editora da Unicamp, 2009.

DARNTON, Robert. O Beijo de Lamourette: mídia, Cultura e Revolução. São Paulo: Cia das Letras, 1995.

. O grande massacre de gatos e outros episódios da história francesa. Tradução de Sonia Coutinho. 4. ed. Rio de Janeiro: Ed Graal, 2001.

DARNTON, Robert; ROCHE, Daniel. Revolução Impressa: a imprensa na França (1775 - 1800). São Paulo: Edusp, 1996.

DIAS, Maria Odila da Silva. "A interiorização da Metrópole (1808-1853)”. In: MOTTA, Carlos Guilherme (Org.). 1822: Dimensões. São Paulo: Ed. Perspectiva, 1972.

DINES, Alberto. Vínculos do fogo I: Antonio Jose da Silva, o Judeu, e outras historias da Inquisição em Portugal e no Brasil. São Paulo: Companhia das Letras, 1992.

DOMINGOS, Manuela. "Historial da Biblioteca Nacional". In: DOMINGOS, Manuela; LOPES, Inês; OLIVEIRA, Antonio Lopes de. Biblioteca Nacional de Portugal. Lisboa: ABINIA, 1994. 
DOURADO, Mecenas. Hipólito da Costa e o Correio Braziliense. Rio de Janeiro: Biblioteca do Exército, 1956. 2v.

DUARTE, Elaine Cristina Ferreira. Da Real Academia à escola militar: a profissionalização das armas e a consolidação do ensino militar no Brasil (1810-1855). Dissertação de Mestrado. UERJ, 2004.

ELIAS, Norbert. O Processo Civilizador: uma história dos costumes. Rio de Janeiro: Jorge Zahar Editor, 1994.

A sociedade de Corte. Trad. Ana Maria Alves, Lisboa: Stampa, 1987.

FAORO, Raymundo. Os donos do poder: formação do patronato politico brasileiro. 10. ed. 2 vols. São Paulo, SP: [s.n.]; [S.l.]: Globo: Publifolha, 2000.

FARIA, Paulo Manuel Miranda. Gil Vicente - o Mestre da Corte de D. Manuel e de D. João III. Dissertação de Mestrado. Universidade do Minho, Braga. 2005.

FERNANDES, Rogério. Os caminhos do ABC: sociedade portuguesa e ensino das primeiras letras. Porto: Porto editora, 1994.

FERNANDES, Thomaz. Manifesto da Nação Portuguesa aos Soberanos e Povos da Europa, p. 219. Apud SCHIAVINATTO, Iara Lis Franco. Pátria Coroada: o Brasil como Corpo Político Autônomo 1780-1831. São Paulo: Ed. Unesp, 1999. p. 83.

FERREIRA, Luís Tarujo. “Teatro de Cordel e a Censura em Portugal: contributos para a compreensão das suas complexas relações na segunda metade do século XVIII". Disponível em: <web. letras.up.pt/porprisao/Luís\%20Tarujo\%20Ferreira.pdf>. 
FERREIRA, Tania Maria Tavares Bessone. "Redatores, livros, e leitores em O Patriota”. In: KURY, Lorelai. "Apresentação” In: KURY, Lorelai. (Org.) Iluminismo e Império no Brasil: O Patriota (1813-1814). Rio de Janeiro: Editora Fiocruz, 2007.

FERRREIRA, João Pedro Rosa. O Jornalismo na emigração. Ideologia e Política no Correio Braziliense. Lisboa: CLC/UNL, 1992.

FORJARZ, J. (Frei). Oração congratulatória pelo restabelecimento da importantíssima saúde do sereníssimo príncipe do Brasil nosso senhor na solene festa que celebrarão dos gentis-homens de sua Câmara no dia 5 de setembro de 1789.

FOUCAUlT, Michel. Vigiar e Punir. Nascimento da Prisão. Trad. Raquel Ramalhete. Petrópolis: Ed. Vozes, 2000.

GERBI, Antonello. O Novo Mundo: História de uma polêmica: 1750-1900. Trad. Berrnando Joffily. São Paulo: Companhia das Letras, 1996.

GOUVÊA, Maria de Fátima Silva. "As bases institucionais da construção da unidade. Dos poderes do Rio de Janeiro joanino: administração e governabilidade no Império luso-brasileiro". In: JANCSÓ, István. Independência: história e historiografia. São Paulo: Hucitec: Fapesp, 2005. p. 707-752.

GUEDES, Fernando. O livro e a leitura em Portugal. Subsídios para a sua história. Séculos XVIII e XIX. Lisboa: Ed. Verbo, 1987.

GUIMARÃES, Lúcia Paschoal. "Fernando José de Portugal e Castro," In: NEVES, Lúcia Bastos Pereira das; VAINFAS, Ronaldo. Dicionário do Brasil Joanino. Rio de Janeiro: Objetiva, 2008. p. 163-164. 
GUIMARÃES, Manoel Luiz Salgado. "As luzes para o Império: história e progresso nas páginas de O Patriota”. In: KURY, Lorelai (Org.). Iluminismo e Império no Brasil: O Patriota (1813-1814). Rio de Janeiro: Editora Fiocruz, 2007. p. 67-101.

HABERMAS, Jurgen. Mudança Estrutural da esfera pública: investigações quanto a uma categoria da sociedade burguesa. Trad. de Flávio R. Kothe, Rio de Janeiro: Ed. Tempo Brasileiro, 1984.

HOBSBAWM, Eric. J. A era das revoluções. Europa 1789-1848. Trad. Maria Tereza Lopes Teixeira. Marcos Penchel. 6. ed. Rio de Janeiro: Ed. Paz e Terra, 1988.

JACOB, Christian. O poder das bibliotecas: a memória dos livros no ocidente. Trad. Marcela Mortara. 2. ed. Rio de Janeiro: Editora UFRJ, 2006.

JANCSÓ. István. "A sedução da liberdade: cotidiano e contestação política no final do século XVIII." In: SOUZA, Laura de Melo (Org.). Cotidiano e vida privada na América Portuguesa, História da vida privada no Brasil. São Paulo, Cia das Letras, 1997.

KANT, Immanuel. "Resposta a pergunta: 'Que é o esclarecimento?"' In: KANT, Immanuel. Textos Seletos. 2. ed. Trad. Raimumdo Vier e Floriano de Sousa Fernandes. Petrópoles: Editora Vozes, 1985.

KANTOR, Iris. Esquecidos e Renascidos: historiografia acadêmica luso-brasileira (1724-1759). São Paulo: HUCITEC/Centro Estudos Baianos, 2004.

KIRSCHNER, Tereza Cristina. "D. Rodrigo de Souza Coutinho e os ilustrados da Corte de D. João" In: MARTINS, Ismênia; 
MOTTA, Márcia. 1808: a corte no Brasil. Rio de Janeiro: Editora da UFF, 2010.

KOSELLECK, Reinhart. Crítica e Crise: uma contribuição à patogênese do mundo burguês. Tradução de Luciana Villas Boas Castelo Branco. Rio de Janeiro: Ed. Uerj: Contraponto, 1999.

Futuro Passado: contribuição a semântica dos tempos históricos. Rio de Janeiro: Ed. PUC-Rio: Contraponto, 2006.

KURY, Lorelai. (Org.) Iluminismo e Império no Brasil: O Patriota (1813-1814). Rio de Janeiro: Editora Fiocruz, 2007.

LEITE, Antonio Pedro de Sousa. O Conde da Barca e o seu papel em alguns aspectos das relações culturais de Portugal com a Inglaterra e a Alemanha. Braga: Edição do autor, 1962. p. 13-42.

LESSA, Clado Ribeiro de. "Introdução" In: MAWE, John. Viagens ao interior do Brasil. Trad. Selena Benevides Viana. Belo Horizonte: Editora Itatiaia; São Paulo: Edusp, 1978.

LIMA, Madalena. Aspectos da vida cotidiana na cidade do Rio de Janeiro na visão de três viajantes estrangeiros: Debret, $\mathrm{Ru}$ gendas e Maria Graham. Dissertação de Mestrado. UFRJ, 2000.

LIMA, Oliveira. D. João VI no Brasil. 3. ed., Rio de Janeiro: Topbooks, 1996.

LISBOA, João Luís Lisboa. "News and newsletters in Portugal". In: Enlightement, Revolution and the periodical press. Voltaire Foundation, Oxford, 2004;

Ciência e Política. Ler nos finais do Antigo Regime. Lisboa: Instituto Nacional de Investigação Científica, Centro de História da Cultura, Universidade Nova de Lisboa, 1992. 
LISBOA, João Luís; MIRANDA, Tiago C. P. dos Reis; OLIVAL, Fernanda. Gazetas Manuscritas da Biblioteca Pública de Évora (1729-1731). Lisboa: Edições Colibri, 2002. V. 1.

LISBOA, José da Silva. Observações sobre a prosperidade do Estado pelos liberais princípios da nova legislação do Brasil. Rio de Janeiro: Impressão Régia, 1810.

LOPES, Emilio Carlos Rodrigues. Festas Públicas, Memória e Representação: um estudo sobre manifestações políticas na Corte do Rio de Janeiro: 1808-1822. São Paulo: Humanitas, 2004.

LOPES, Maria Margaret. O Brasil descobre a pesquisa científica: as ciências naturais e os museus no século XIX. 2a. ed. São Paulo: HUCITEC, UnB, 2009.

LUSTOSA, Isabel. "A pátria de Hipólito” In: COSTA, Hipólito José da. Correio Braziliense ou Armazém Literário. São Paulo: SP: Imprensa Oficial do Estado; Brasília, DF: Correio Braziliense, 2001.

LYRA, Maria de Lourdes Viana. A utopia do poderoso império. Portugal e Brasil: bastidores da política (1798-1822). Rio de Janeiro: Sette Letras, 1994.

LOUSADA, Maria Alexandre. Espaços de Sociabilidade em Lisboa: finais do século XVIII a 1834. Lisboa: Tese de doutoramento. 1995.

MACHADO, Adelaide Maria Vieira. O Investigador Portuguez em Inglaterra, Jornal Literário, Político. \& C., nos primeiros anos de publicação (1811-1813). Dissertação de Mestrado. Universidade Nova de Lisboa, 1996.

O Investigador Português em Inglaterra, Jornal Literário, Político. \& C., nos primeiros anos de publicação (18111813). Lisboa: UNL/CLC, 1998. p. 474. 
. COUTINHO, Domingos António de Sousa - $1^{\circ}$ Conde e Marquês de Funchal (1760-1833). In: Dicionário do Vintismo e do Primeiro Cartismo (1821-1823 e 1836-1828). Lisboa: Edições Afrontamento, Vol. I, 2002, p. 534-545.

MALERBA, Jurandir. A corte no exílio: Civilização e poder no Brasil às vésperas da Independência (1808-1821). São Paulo: Cia. das Letras, 2000.

MALERBI, Eneida Maria Cherino. Relações Comerciais entre Brasil e França: 1815-1848. Dissertação de Mestrado. USP. São Paulo, 1993.

MARQUES, Fernando Pereira. Exército e Sociedade em Portugal no declínio do Antigo Regime e advento do liberalismo. Lisboa: A regra do jogo, 1981.

MARSON, Izabel; NAXARRA, Márcia. Sobre a humilhação: sentimentos, gestos, palavras. Uberlândia: EDUFU, 2005.

MARTINS, Ana Canas Delgado. Governação e Arquivos: D. João VI no Brasil. Lisboa: Instituto dos Arquivos Nacionais, 2007.

MARTINS, Ismênia; MOTTA, Márcia. 1808: a corte no Brasil. Rio de Janeiro: Editora da UFF, 2010.

MARTINS, Wilson. A palavra escrita: história do livro, da imprensa e da biblioteca. 2. ed. São Paulo: Editora Ática, 1996.

MATTOS, Ilmar. R. O tempo saquarema. 2. ed. São Paulo: Ed. Hucitec, 1990.

MATTOSO, José. História de Portugal: o liberalismo. vol. 5. Lisboa: Editora Estampa, 1994 
MAXWELL, Kenneth. Marquês de Pombal: paradoxo do Iluminismo. 2. ed. Rio de Janeiro: Paz e Terra, 1997.

MEDINA, João. História de Portugal: dos tempos pré-históricos aos nossos dias. Lisboa: Ediclube, 1993.

MEIRELLES, Juliana Gesuelli. Imprensa e Poder na Corte Joanina: a Gazeta do Rio de Janeiro (1808-1821). Rio de Janeiro: Ed. Arquivo Nacional, 2008.

MELLO, Evaldo Cabral de. A outra independência: o federalismo pernambucano de 1817 a 1824. São Paulo: Ed. 34, 2004.

MONTEIRO, Maurício. A construção do gosto: música e sociedade na Corte do Rio de Janeiro 1808 -1821. São Paulo: Ateliê Editorial, 2008.

MONTEIRO, Rodrigo Bentes. "Folhetos em ordem na coleção Barbosa Machado”. In: ALGRANTI, Leila Mezan; MEGIANI, Ana Paula. (Org.). O Império por escrito: formas de transmissão da cultura letrada no mundo ibérico. Séc. XVI-XIX. São Paulo: Ed. Alameda, 2009. p. 201-228.

MORAES, Alexandre José de Melo. Dados sobre a chegada ao Rio de Janeiro da Família Real, problemas de habitação para a comitiva, vida social e política, hábitos da família real, volta para Portugal, falecimento de D, João VI e Pedro I como imperador. S.l, s.d, Original (Transcrição feita por Cecília Coelho, maio de 2001), p. 116. BNRJ. Divisão de Manuscritos. II-30, 23, 6,7.

MORAES, Rubens Borba de. Livros e Bibliotecas no Brasil colonial. São Paulo: Livros Técnicos e Científicos, 1979. 
MOREIRA, Ariadna Gonçalves. The Influence of the Portuguese Royal Court on the development of opera, the opera nova, and the real teatro São João in Rio de Janeiro from 1808 to 1824. Doctoral Essay. University of Miami, 1998.

MOREL, Marco. "Das gazetas tradicionais aos jornais de opinião: metamorfoses da imprensa periódica no Brasil”. In: NEVES, Lúcia Maria Bastos Pereira das. Livros e Impressos: retratos do Setecentos e do Oitocentos. Rio de Janeiro: EdUERJ, 2009. p. 153-184.

- "Pátrias Polissêmicas: República das Letras e Imprensa na Crise do Império Português na América” In: LORELAI. (Org.) Iluminismo e Império no Brasil. O Patriota (1813-1814). Rio de Janeiro: Editora FIOCRUZ, 2007. p. 15-39.

As transformações dos espaços públicos: imprensa, atores políticos e sociabilidade na cidade imperial (1820-1840). São Paulo: Editora Hucitec, 2005.

MORMÊLLO, Ben Hur. O ensino de matemática na Academia Real Militar no Rio de Janeiro de 1811 a 1874. Dissertação de Mestrado. IMECC. Unicamp. 2010.

MOTTA, Jehovah. Formação do oficial do Exército. Rio de Janeiro: Companhia Brasileira de Artes Gráficas, 1976.

MUNARO, LUÍS. "A unidade do Reino luso-brasileiro: uma discussão jornalística em Londres.” In: VIII Encontro Nacional de História da Mídia. 2011. (p. 1-15). Disponível em: <http://paginas.ufrgs. br/alcar/encontros-nacionais-1/8o-encontro-2011-1/artigos/.>

NEVES, Lúcia Bastos Pereira das. Corcundas, constitucionais e pés de chumbo: A cultura política da independência (18201822). Rio de Janeiro: Ed Revan, FAPERJ, 2003. 
Napoleão Bonaparte: imaginário e política em Portugal (c.1808-1810). 1. ed. São Paulo: Alameda, 2008.

NORTON, Luís. A corte de Portugal no Brasil: (Notas, alguns documentos diplomáticos e cartas de imperatriz Leopoldina). 3. ed. Ilus. São Paulo: Nacional, 2008.

NOVAIS, Fernando. Portugal e Brasil na Crise do Antigo Sistema Colonial: séculos XVI-XVIII. São Paulo: Ed. Hucitec, 1974.

Aproximações: estudos de história e historiografia. São Paulo: CosacNaify, 2005.

NUNES, Rossana Agostinho. Nas sombras da libertinagem. Francisco de Mello Franco: entre luzes e censura no mundo luso-brasileiro (1757-1822). Dissertação de Mestrado. UFF. 2011.

OLIVAL, Fernanda. As ordens militares e o Estado Moderno. Honra, mercê e venalidade em Portugal (1641-1789). Lisboa: Estar, 2001.

OLIVEIRA, Cecília Helena Lorenzini Salles. A astúcia liberal. Relações de mercado e projetos políticos no Rio de Janeiro (18201824). São Paulo: EDUSP; ICONE, 1999.

PACHECO, Alberto José Vieira. Castrati e outros virtuoses. A prática vocal carioca sobre a influência de D. João VI. São Paulo: Annablume; Fapesp, 2009.

PAIM, Antonio. "D. Rodrigo de Sousa Coutinho (1755-1812): notícia biobibliográfica” In: PAIM, Antonio (Org.). Pombal e a cultura brasileira. Rio de Janeiro: Fundação Cultural Brasil-Portugal; Tempo Brasileiro, 1982. 
PAULA, Sérgio Goes de (Org.). Hipólito José da Costa. São Paulo: Ed. 34, 2001.

PEDREIRA, Jorge; COSTA, Fernando Dores. D. João VI. Um príncipe entre dois continentes. São Paulo: Cia das Letras, 2008.

PEDROSA, Alcino. "Introdução" In: COSTA, Hipólito José da. Diário da minha viagem a Filadélfia (1798-1799). Lisboa: ICS. Imprensa de Ciências Sociais, 2007.

PEREIRA, José Esteves. O pensamento político em Portugal no século XVIII: António Ribeiro dos Santos. Lisboa: Imprensa Nacional Casa da Moeda, 1983.

PEREIRA, Esteves; RODRIGUES, Guilherme. (Org.). Portugal. Dicionário Histórico, Chorographico, Biographico, Bibliographico, Heraldico, Numistatico e Artistico. Lisboa: João Romano Torres \& Cia - EDITORES. 1885, Vol. VI.

PIMENTA, João Paulo Garrido. O Brasil e a América Espanhola (1808-1822). Tese de doutorado. São Paulo: USP, 2003.

PIRASSINUNGA, Adailton Sampaio. O Ensino Militar no Brasil. Rio de Janeiro: Biblioteca do Exército, 1958.

RIZZINI, Carlos. Hipólito da Costa e o Correio Braziliense. São Paulo: Companhia Editora Nacional, 1957.

O livro, o jornal e a tipografia no Brasil. Rio de Janeiro: Livraria Kosmos Editora, 1946.

ROCHE, Daniel. O Povo de Paris: ensaios sobre a cultura popular no século XVIII. Trad. de Antonio de Pádua Danesi, EDUSP, SP, 2004. 
. Revolução Impressa: a imprensa na França (1775 - 1800). São Paulo: Edusp, 1996.

RODRIGUES, Graça Almeida. Breve história da censura literária em Portugal. Lisboa: ICALP, 1980.

ROUSSEAU, Jean Jacques. Ensaio sobre a origem das línguas. Trad. Fulvia M. L. Moretto. 2. ed. Campinas, SP: Editora da Unicamp, 2003.

. Discurso sobre as ciências e as artes. Trad. Lourdes Santos Machado. São Paulo: Ed. Victor Civita, 1983.

SARRAUTE, Jean-Paul. Marcos Portugal. Lisboa: Fundação Calouste Gulbenkian, 1979.

SCHIAVINATTO, Iara Lis Franco. Pátria Coroada: o Brasil como Corpo Político Autônomo 1780-1831. São Paulo: Ed. Unesp, 1999.

. "Entre os manuscritos e os impressos" In: LESSA, Mônica Leite; FONSECA, Sílvia C. Pereira de Brito. Entre a monarquia e a república: imprensa, pensamento político e historiografia (1822-1889). Rio de Janeiro: Eduerj, 2008. p. 13-33.

SCHULTZ, Kirsten. Versalhes Tropical: império, monarquia e a Corte Real portuguesa no Rio de Janeiro, 1808-1821. Trad. Renato Aguiar. Rio de Janeiro: Civilização Brasileira, 2008.

SCHWARCZ, Lilia M. O sol do Brasil: Nicolas Antoine Taunay e as desventuras artísticas dos artistas franceses na corte de d. João. São Paulo: Companhia das Letras, 2008.

SCHWARCZ, Lilia M.; AZEVEDO, Paulo César de; COSTA, Ângela Márquez da. A longa viagem da biblioteca dos reis: do 
terremoto de Lisboa à Independência do Brasil. São Paulo: Cia das Letras, 2002.

SERRÃO, Joaquim Veríssimo. História de Portugal: a instauração do liberalismo (1807-1832). 3. ed. Vol. VII. Lisboa: Ed. Verbo, 1994.

SILVA, Ana Rosa Cloclet da. Inventando a Nação: intelectuais ilustrados e estadistas luso-brasileiros no crepúsculo do Antigo Regime Português: 1750-1822. São Paulo: Hucitec; Fapesp, 2006.

SILVA, Andrée Mansuy-Diniz da. Portrait d'un homme d'État: D. Rodrigo de Souza Coutinho, Comte de Linhares, 1755 - 1812. Lisboa: Fundação Calouste Gulbenkian, 2006.

SILVA, Maria Beatriz Nizza da. Silvestre Pinheiro Ferreira: ideologia e teoria, Lisboa: Sá da Costa, 1975.

Cultura e sociedade no Rio de Janeiro (1808-1821). São Paulo: Cia Nacional, 1978.

A Primeira Gazeta da Bahia: Idade d'Ouro do Brasil. São Paulo: Editora Cultrix, 1978.

. Cultura luso-brasileira: da reforma da universidade à independência do Brasil. Lisboa: Editorial Estampa, 1999.

A Gazeta do Rio de Janeiro (1808-1821): cultura e sociedade. Rio de Janeiro: EDUERJ, 2007.

. D. João: príncipe e rei no Brasil. Lisboa: Livros Horizonte LDA, 2008.

. "A imprensa periódica na época joanina". In: NEVES, Lúcia Maria Bastos Pereira das. Livros e Impressos: retratos do Setecentos e do Oitocentos. Rio de Janeiro: EdUERJ, 2009. p. 15-30. 
SLEMIAN, Andréa. O difícil aprendizado da política na Corte do Rio de Janeiro (1808-1824). Dissertação de Mestrado. USP, São Paulo, 2000.

SOUSA, Maria Leonor Machado de. “The Ghost” e Francisco Solano Constâncio. Lisboa: Universidade Nova, 1978.

SOUZA, Roberto Acízelo de. O Império da Eloquência. Retórica e Poética no Brasil Oitocentista. Rio de Janeiro: EdUERJ, EdUFF, 1999.

SOUZA, Simone Cristina Mendonça de. Primeiras impressões: romances publicados pela Impressão Régia do Rio de Janeiro (1808-1822). Tese de Doutorado. Unicamp, Campinas, 2007.

SPINA, Segismundo. "Introdução". In: Gil Vicente: O Velho da Horta; Auto da Barca do Inferno; A Farsa de Inês Pereira. São Paulo: Editora Brasiliense, 1996.

STOIANI, Raquel. Napoleão visto pela luneta d'El Rei: construção e usos políticos do imaginário francês e napoleônico na América Portuguesa. Tese de Doutorado. USP. São Paulo, 2009.

TAUNAY, Afonso de. A Missão Artística de 1816. Publicações da Diretoria do Patrimônio Histórico e Artístico Nacional, 1956.

TENGARRINHA, José. "Os Comerciantes e a Imprensa Portuguesa da Primeira Emigração". Estudos em Homenagem a Luís Antonio de Oliveira Ramos. Faculdade de Letras da Universidade do Porto, 2004, p.1069-1084.

História da imprensa periódica portuguesa. 2. ed. Lisboa: Editora Caminho, 1989.

TUCCI, Maria Carneiro (Org.). Minorias Silenciadas: História da Censura no Brasil. São Paulo: Edusp, 2002. 
TUNA, Gustavo Henrique. "A livraria de Manuel Inácio Silva Alvarenga: representante das Luzes na América Portuguesa?" In: ALGRANTI, Leila Mezan; MEGIANI, Ana Paula. (Org.). O Império por escrito: formas de transmissão da cultura letrada no mundo ibérico. Séc. XVI-XIX. São Paulo: Ed. Alameda, 2009. p. 265-276.

URFALINO, Philippe. “A história da política cultural”. In: RIOUX, Jean-Pierre; SIRINELLI, Jean-François (direção). Para uma historia cultural. Lisboa: Editorial Estampa, 1998. p. 293-305.

VAINFAS, Ronaldo. (Direção). Dicionário do Brasil Colonial (1500-1808). Rio de Janeiro: Ed. Objetiva, 2000.

VARELA, Alex. Gonçalves. Atividades Científicas na "Bela e Bárbara” na Capitania de São Paulo (1796-1823). São Paulo: Annablume, 2009.

VENTURI, Franco. Utopia e Reforma no Iluminismo. Trad. Modesto Florenzano. Bauru, SP: EDUSC, 2003.

VILLALTA, Luiz Carlos. "O que se fala e o que se lê: língua, instrução e leitura”. In: SOUZA, Laura de Melo (Org.). Cotidiano e vida privada na América Portuguesa, História da vida privada no Brasil. São Paulo: Cia das Letras, 1997. p. 332-385.

. Reformismo ilustrado e práticas de leitura: usos do livro na América Portuguesa. Tese de doutorado. USP, São Paulo, 1999.

. "Censura literária e inventividade dos leitores no Brasil Colonial”. In: TUCCI, Maria Carneiro (Org.). Minorias Silenciadas: História da Censura no Brasil. São Paulo: Edusp, 2002.

. "Libertinagens e livros libertinos no mundo luso-brasileiro”. In: ALGRANTI, Leila Mezan, MEGIANI, Ana Paula Torres 
(Org.). O Império por escrito: formas da transmissão da cultura letrada no mundo ibérico (Sécs. XVI-XIX). São Paulo: Ed. Alameda, 2009. p. 523-563.

WILCKEN, Patrick. Império à Deriva. A corte Portuguesa no Rio de Janeiro 1808-1821. Trad. de Vera Ribeiro. Rio de Janeiro: Objetiva. 2005.

\section{-Artigos em Revistas e Anais}

ALVES, Joaquim Jaime B. Ferreira. "Ensaio sobre a arquitectura barroca e neoclássica a norte da bacia do Douro". In: Revista da Faculdade de Letras Ciências e técnicas do Património. Porto: 2005. I Série, vol. IV, p. 137.

. "A Revolução Francesa e o seu eco em Portugal nos arquivos da Intendência Geral da Polícia em finais do século XVIII e princípios do século XIX”. In: Revista de História e Teoria das Ideias. Vol. XVIII. Lisboa: 2004.

BICALHO, Maria Fernanda. "O Rio de Janeiro no século XVIII: a transferência da capital e a construção do território centro-sul da América Portuguesa". Disponível em: <www.ifch.unicamp.br/ ciec/revista/artigos/dossie1.pdf >.

BOTO, Carlota. "A dimensão iluminista da reforma pombalina de estudos: das primeiras letras à universidade" In: Revista Brasileira de Educação. Rio de janeiro, V. 15, vol.15, n. 44, maio/ ago. 2010.

CHARTIER, R. O mundo como representação. Estudos Avançados. [online]. 1991, vol. 5, n. 11. 
. O mundo como representação. Estudos Avançados. [online]. 1991, vol.5, n. 11.

CLUNY, Isabel; BARATA, Paulo. J. S. "A propósito de um documento da política cultural joanina”. In: Leituras. Revista da Biblioteca Nacional. Lisboa, S. 3. n 3., p. 129-139, 1998.

DIAS, Luís Fernando de Carvalho. Algumas cartas do Doutor Antonio Ribeiro dos Santos aos seus contemporâneos. Separata da Revista Portuguesa de História. Tomo XIV. Coimbra, 1974.

DIAS, Maria Odila da Silva. "Aspectos da Ilustração no Brasil". Revista do Instituto Histórico Geográfico e Brasileiro. Rio de Janeiro: vol. 278, 1968.

DINES, Alberto. “O patrono e o seu modelo.” In: Dines e Isabel Lustosa. (Org.). Correio Braziliense. São Paulo: Imprensa Oficial do Estado de São Paulo/UNIEMP/Correio Brasiliense, 2001, v. 1, p. Xxv-Xxxviii.

DOMINGOS, Manoela. "A primeira biblioteca pública portuguesa, 1775-1795. Planos, projetos e primeiros fundos". Cadernos BAD (1), 1994.

DOMINGUES, Angela. "Notícia do Brasil Colonial: a imprensa científica e política a serviço das elites (Portugal, Brasil e Inglaterra)." In: Revista Varia História. Belo Horizonte, Vol. 22. N.35, p. 150-174, 2006.

DUARTE, Elaine Cristina Ferreira. "Academia Militar do Rio de Janeiro: berço e alma de um novo militar." In: Sociedade Brasileira de Pesquisa Histórica (SBPH). Anais do XXIII Reunião. Curitiba: 2003. 
FALCON, Francisco José Calazans. "O império luso-brasileiro e a questão da dependência inglesa - um estudo de caso: a política mercantilista durante a época pombalina, e a sombra do tratado de Methuen". In: Nova economia. Belo Horizonte: UFMG, Departamento de Ciências Econômicas, v. 15, n. 2, p. 11-34, 2005.

FERRAUD, Luís Almeida. “D. João V e a biblioteca real”. In: Revista da Universidade de Coimbra. N. ${ }^{\circ}$ XXXVI, p. 413-438, 1991.

FILHO, Oswaldo Munteal Filho; DAHÁS, Nashla. "Acadêmicos e letrados na crise do Antigo Regime luso-brasileiro - Século XVIII”. Revista Intellectus. Ano 05. Vol. I., p. 8, 2006. Disponível em: <www2.uerj.br/ intellectus $>$.

FONSECA, Thais Nivia de Lima e. "Portugueses em Minas Gerais no Século XVIII: cultura e escrita e práticas educativas" In: Anais do II Encontro Internacional de História Colonial. Mneme - Revista de Humanidades. UFRN. Caicó (RN), v. 9. n. 24, Set/ out. 2008.

GUIMARÃES, Alberto Carlos de Araújo. "Ação Cultural e Política no governo de D. João VI". In: Anais da Revista do Instituto Histórico e Geográfico. Rio de Janeiro, v.3, p. 259-292, 1938-1941.

HARDEN, Alessandra R. de Oliveira. "Manoel Jacinto Nogueira da Gama: Ciência e tradução no final do século XVIII". Tradução em Revista. n. 9, 2010.

LOPES, Maria Margaret; SILVA, Clarete Paranhos; FIGUEIRÔA, Sívia F. de M.; PINHEIRO, Rachel. Scientific culture and mineralogical sciences in the Luzo-Brazilian Empire - The work of João da Silva Feijó (1760-1824) in Ceará. Science in Context, v. 18, p. 201-224, 2005. 
LUSTOSA, Isabel. "O período joanino e a eficiência de alguns textos desbravadores". Disponível em: <http://www.casaruibarbosa. gov.br/dados/DOC/revistas/Escritos_2/FCRB_Escritos_2_16_ Isabel_Lustosa.pdf.>

MACHADO, Adelaide Maria Vieira Machado. "Domingos António de Sousa Coutinho (1760-1833) $1^{\circ}$ Conde e Marquês de Funchal. Pensamento e acção". In: Congresso Histórico 98. Amarante: 1998 . p. 471-481.

MARQUES. Vera Regina Beltrão. "Escola de homens de ciências: a Academia Científica do Rio de Janeiro, 1772-1779”. In: Educar. Curitiba: Editora UFPR, n. 25. p. 39-57, 2005.

MATTOS, Franklin de. "A querela do teatro no século XVIII. Voltaire, Diderot, Rousseau." In: Revista $\mathrm{O}$ que nos faz pensar. PUC-RJ. n. 25, p. 7-22, 2009.

MONTEIRO, Rodrigo Bentes. "Portugal e as conquistas ultramarinas nos folhetos de Diogo Barbosa Machado". Disponível em: $<$ http://www2.iict.pt/index.php?idc=102\&idi=13077>.

. "Reis, príncipes e varões insignes na coleção Barbosa Machado". Anais de História de Além-Mar, Lisboa, v. VI, p. 215-251, 2005.

MONTEIRO, Rodrigo Bentes; CALDEIRA, Ana Paula Sampaio. "A ordem de um tempo: folhetos na coleção Barbosa Machado" In: Revista TOPOI, v. 8, n. 14, p. 78, jan.-jun. 2007.

NEVES, Lúcia Bastos Pereira das. "Comércio de livros e censura de ideias: a atividade dos livreiros franceses no Brasil e a vigilância 
da Mesa do Desembargo do Paço (1795-1822)”. In: Ler História. N. 23, 1992.

. "O privado e o público nas relações culturais do Brasil com França e Espanha no governo joanino". In: Seminário Internacional D. João VI: um rei aclamado na América. Rio de Janeiro, Museu Histórico Nacional, 2000. p. 189-207.

NICOLAZZI, Fernando. “Entre 'letras \& Armas', a história como disputa. Considerações sobre a historiografia luso-brasileira no século XVIII". In: Revista Eletrônica Semestral Almanaque Braziliense. IEB-USP. São Paulo, n.11,. maio 2010.

OLIVEIRA, José Carlos de. D. João VI, Adorador do Deus das Ciências? A constituição da cultura científica no Brasil (18081821). Rio de Janeiro: E-papers, 2005. p. 198-224.

- "Os periódicos portugueses de Inglaterra e a Cultura Científica Brasileira (1808-1821)". Revista da SBHC, n. 19, p. 3162, 1998.

PINHEIRO, Andréa de Souza; MUNIZ, Luciana. "Antônio de Araújo de Azevedo, o Conde da Barca: política, ciências e saberes na biblioteca de um diplomata português." Disponível em: $<$ http://bndigital.bn.br/200anos/araujense.html>.

PONDÉ, Francisco de Paula e Azevedo. "Academia Real Militar". In: Anais do Congresso da Independência do Brasil. Rio de Janeiro: IHGB, 1975.

. "D João VI e a emancipação intelectual do Brasil”. In: Revista do Instituto Histórico e Geográfico. Rio de Janeiro, tomo 279, 1968. 
PRADO JR, Bento. Gênese e estrutura dos espetáculos (Notas sobre a Lettre à D'Alembert de Jean-Jacques Rousseau). Estudos CEBRAP, 14, p. 5-34, 1975.

ROSANVALLON, Pierre. "Por uma história conceitual do político.” Revista Brasileira de História. São Paulo, v. 15, n. 30, p. 9-22, 1995.

SANTOS, Afonso Carlos Marques dos. "A fundação de uma Europa possível” In: Seminário Internacional D. João VI: um rei aclamado na América. Rio de Janeiro, Museu Histórico Nacional, 2000.

SILVA. Maria Beatriz Nizza da. "A livraria Pública da Baía em 1818: obras de História”. Revista de História. São Paulo, n. 87, p. 225-239, 1971.

. "Livro e sociedade no Rio de Janeiro". Separata da Revista de História No 94. São Paulo - Brasil. 1973.

. "A impressão Régia do Rio de Janeiro e a Cultura Científica" In: Revista Portuguesa de História do livro. Ano XII Vol.23. Lisboa: Edições Távola Redonda, 2009. p. 215-231.

VAZ. Francisco António Lourenço. "Os bibliófilos eborenses e a Biblioteca Pública de Évora (1805-1955)”. Disponível em: <http:// www.projectos.uevora.pt/cenaculo/pub_pdf/VAZ4_2007_BibliofilosEborenses.pdf>. Acesso em: 01 dez. 2012.

WEHLING, Arno. O fomentismo português no século XVIII: doutrinas, mecanismos, exemplificações. Revista do Instituto Histórico Geográfico Brasileiro, Rio de Janeiro, v. 316, p. $170-278,1978$. 
WEHLING, Arno; WEHLING, Maria José. "Exército, milícias e ordenanças na Corte Joanina: permanências e modificações”. In: Revista Da Cultura, 14. Disponível em: <www.funceb.org.br/revista14/pdf $>$.

\section{FONTES DE REFERÊNCIA}

BLAKE, Augusto Vicctorino Alves Sacramento. Dicionário Bibliográfico Brasileiro. Rio de Janeiro: Conselho Federal de Cultura, 1970.

BLUTEAU, Raphael. Vocabulario portuguez \& Latino: aulico, anatomico, architectonico... Coimbra: Collegio das Artes da Companhia de Jesus, 1712 - 1728. [dicionários]

COELHO, Teixeira. Dicionário Crítico de Política Cultural: Cultura e Imaginário. 3. ed. São Paulo: Editora Iluminuras/ Fapesp, 2004.

HUTTON, Charles. A Philosophical and Mathematical Dictionary Containing Memoirs of the Lives and Writings of the Most Eminent Authors. 1815. Disponível em: <http://books.google.com. br/books?id=1_E1AAAAQAAJ\&printsec=frontcover\&hl=pt-BR\&source=gbs_ge_summary_r\&cad $=0 \# v=$ onepage\&q\&f=false.>

NEVES, Lúcia Bastos Pereira das; VAINFAS, Ronaldo. Dicionário do Brasil Joanino. Rio de Janeiro: Objetiva, 2008.

INFOPÉDIA. Porto: Porto Editora, 2003-2011. Disponível em: $<$ http://www.infopedia.pt $>$.

PORTUGAL. Carta de lei de 28 de agosto de 1772. Dispõe sobre os Estatutos da Universidade de Coimbra. Lisboa, Regia Officina Typografica, 1772. [Parte referente à Faculdade de Matemática]. 
Vol III, Segunda Parte. Disponível em: $<$ http://scientia.artenumerica.org/estatutos_1772.html.>

SILVA, Antonio de Moraes. Diccionário de Língua Portuguesa Recopilado. Tipographia Lacerdina, 1789, 2 v. Disponível em: $<$ http://www.brasiliana.usp.br/pt-br/dicionario/edicao/2>

VAINFAS, Ronaldo. (Direção). Dicionário do Brasil Colonial (1500-1808). Rio de Janeiro: Ed. Objetiva, 2000.

VOLTAIRE. “Dicionário Filosófico” In: Voltaire. Vida e Obra. São Paulo: Editora Abril, 1978. Disponível em: <http://www.arqnet.pt/dicionario/>. 


\section{ANEXOS}

\section{ANEXO ।}

Auxílio que V. M. manda dar ao Teatro de S. Carlos por aviso de 23 de Agosto de 1818. Apontamentos. V. Nogueira (Ricardo Raimundo). BNP. Seção de Reservados. Códice 7207. (Doc. 3).

Em todas as loterias que se extraírem cidade (?) uma porção regulará pelo governo na proporção que lhe parecer justa com o capital de cada uma.

O pagamento dos camarotes que tiveres repartições até agora tinham de graça; o que devem conservar e pagar por suas respectivas folhas.

A decisão desta ordem Régia prende da decisão de várias questões:

1. Em todas as loterias que se extraírem nesta cidade [sic] Apesar da generalidade da expressão, não julgo que V. M. quisesse gravar quaisquer loterias as que se fazem todos os anos, a saber, duas da Misericórdia, duas dos Juros, e uma da Casa da Pia: parecendo que não seria da mente do mesmo Sr. impôs semelhante tributo à loteria, por exemplo, de 12000 bilhetes que concedam ao Cabido da Guarda para re[ilegível]cação da Sé e a outras de igual natureza como foi a da Fábrica das Sedas, o da Academia a benefício da utilidade vacinica. [sic] Sendo assim deve o Teatro ser auxiliado com certo número de bilhetes em cada uma das ditas 5 loterias. 
2. Qual deve ser estes números? [sic] Parece-me que não pode ser mais de 10 por cento em cada loteria, isto é, que tendo sido elas sempre de 20000 bilhetes se concedam ao Teatro de S. Carlos em cada uma dois mil, capitais às despesas correspondentes a este número.

3. Deverão os dois mil bilhetes tirarem-se dos 20000 que formam o total de cada uma das loterias ou seria mais conveniente acrescentá-los e fazê-las de 22000 bilhetes?

Julgo preferencial o segundo método; porque a extrema falta de meios em que se acha o Erário não permita que se possa distrair para diferentes objetos um só real das pessoas que nele entram; muito mais estando o proveito das loterias das juntas dos juros aplicados para pagamento de certos criadores, cujo direito seria fraudado se se [sic] lhe desse direto destino, em grave prejuízo do crédito do Erário, já sobremaneira debilitado. Acresce o mais efeito que isto faria na opinião pública que escandalizaria de ver os cômicos o que devia dar-se aos credores do Estado.

4. V. M. manda que as Repartições que se tem camarotes, como o Governo, Senado, Polícia, ou outros, os conservem e sejam pagos pelas folhas das despesas das respectivas estações. Deve notar-se. - $1^{\circ}$ Que o governo nunca mandou tomar camarote para si, porque não julgou justo gravar os empresários com estes encargos que os privava do lucro que poderia tirar do mesmo Camarote. Manoel Batista de Paula [,] diretor do Teatro da Rua dos Condes foi quem de seu modo (?) próprio ofereceu ao governo um camarote em seu Teatro e outro no de S. Carlos, quando para ele passou a sociedade de que era chefe. Seria pois para desejar que V. M. permitisse ao governo largar o camarote para poupar esta despesa à Fazenda Real, e para não ter o dissabor de que em uma repartição toda gratuita, se forme uma folha que não há e cuja primeira e última adição consiste no aluguel do 
Camarote de S. Carlos. $2^{\circ}$ - Que além dos Camarotes declarados no Aviso, há um em que está o Ministro Inspetor do Teatro e, e outro destinado para o oficial que comanda a guarda da Polícia. Deveriam estes também ser pagos? E por quais repartições?

Peço que quando S. M encarregou o Barão de Porto Covo [sic] e João Pereira de Sousa Caldas da direção do Teatro de S. Carlos, se tiraram todos os camarotes gratuitos, à exceção de um que foi destinado para o inspetor e para o comandante da guarda. Creio que esta ordem há de entrar na Secretaria dos Negócios Estrangeiros, por ser o Conde da Barca [riscado] quem nesse tempo tomou a si a repartição: pois que não se acha na do Reino, aonde já se procurou.

$3^{\circ}$. Que nos Teatros não só há Camarotes, mas há lugares de platéia gratuitos. O juiz do Povo, o seu escrivão, toda ou parte da Casa dos 24 e não sei quantos mais (mais creio que não poucos) tem a entrada livre, e os do Meritíssimo Inspetor. É claro que toda esta gente se deve pagar se vai para se divertir, da sua algibeira, e se vai em serviço pelas repartições respectivas.

5. - Quais são as obrigações a que se devem sujeitar-se os atuais sócios e os seus abonadores Constantino Joaquim de Mattos, e Gonçalo José de Sousa Lobo? As que a sociedade permitir ao público no impresso e que saiu em 16 de Novembro de 1818. Ela estava nesse tempo na classe de qualquer particular; e por conseguinte quem com ela entrasse devia examinar a sua abonação e que meios que tinha para cumprir o que permitia, devendo só equipar-se da sua credulidade se se [sic] achasse enganado. Mas agora mudou o negócio de face: S. M. manda dar-lhe certo auxílio para que a mesma sociedade possa cumprir ele aquilo mesmo, o que se havia obrigado antes de o ter. É portanto necessário que se haja toda a certeza do V. cumprimento sem o risco de se fechar o Teatro depois de ter recebido o mencionado auxílio. 
8. Podendo orçar-se o produto das loterias, e o preço dos camarotes em pouco mais de trinta mil cruzados, será este auxílio suficiente para sustentar o Teatro de S. Carlos junto com o que se recebe à ponta? Certamente não! Porque um Teatro de Música é por extremo dispendioso. Só a despesa diária de cada noite monta a trinta moedas, e talvez mais o que os 200 restas (?) o que a presente sociedade se obrigou importa setenta e dois mil cruzados. Mas além disto há a enorme despesas dos salários, vestuário, cenário, compra e cópia de música, viagens dos atores e dançarinos que se manda vir da Itália e das comissões que os vai ajustar V.S. Este grande desembolso só admite a economia que pode resultar de uma administração vigilante e bem regulada; porque se se [sic] quiser aplicar ao mesmo espetáculo, diminuindo o seu aparato, enfraquecendo a orquestra, assalariando cantores, e bailarinos medíocres, V. S. será a perda muito maior, porque faltarão os espectadores . Isto é o que se principia a experimentar-se em São Carlos, aonde apesar da magnificência do Cenário e vestuário o pouco merecimento dos cantores faz que a casa seja pouco freqüentada e cada vez o será menos, porque o espectador é todo para os olhos e nada interessante para os ouvidos. Por todas estas razões estou [ilegível] que a empresa, ainda recebendo o sobredito auxílio de trinta mil cruzados há de ficar no fim do ano alcançada em mais de trinta. (a)

[escrito à margem esquerda] - Há um negociante de Lisboa, Luis Chiari [sic], em que diz que o Teatro não pode subsistir sem um auxílio de 40 contos.

Daqui vem que semelhante Teatros são próprios de sua corte, aonde reside o Soberano, a Nobreza que rodeia o trono, e o Ministério Estrangeiro, e aonde concorrem as pessoas principais das [ilegível] que vem tratar das suas [ilegível] e desejas achar um divertimento público de que gozem pelo seu dinheiro. Mas nem 
mesmo neste estado de coisas se pode jamais sustentar o Teatro da ópera em Lisboa sem auxílios mui[to] extraordinários, pois que a empresa de Francisco Antonio Lobo para conservar o Teatro em bom pé [,] foi socorrida com favores e mercês, que residiam anualmente centos de mil cruzados, e a Direção do Barão de Portofora, e João Pereira de Sousa Caldas, que se lhe seguiu ficou alcançada em somas consideráveis, apesar de se lhe conservarem alguns dos vossos auxílios (b)

O Senhor Diretor diz em outros requerimentos que ao todo [?], depois de ter a empresa por 3 anos, fora no fim ser-lhes obrigados a pagá-las para se arruinar!

Nem é de admirar que Lisboa, ainda o citado de [ilegível] sea [sic] maior esplendor, não pudesse sustentar um Teatro de Música; quando todos sabem que o governador francês auxilia a ópera de Paris com 500 e 600 mil francos anuais, sendo aliás este capital um dos mais populares da Europa, e tendo aquela Nação a maior paixão por toda a carta de espetáculos.

É[,] portanto[,] absolutamente impossível que no estado de decadência, em comércio, com imensas perdas e diminuídas as faculdades de todas as classes de cidadãos, se mantenha um divertimento tão dispendioso, sem que a Fazenda Real se encarregue de lhe prestar anualmente uma soma, que nem é impraticável com as forças do Erário, nem se poderia aplicar a um tal objeto sem grave escândalo das Nações, vendo dar a músicos e bailarinos o dinheiro que se devia destinar para o pagamento de dívidas sagradas.

Concluo daqui que a presente empresa não chega há um ano. Quando o Teatro se abriu em 7 de dezembro do ano passado estavam concorridos [?] que 120 contos em que importas os pendos [sic] com que achará alcançada em 2:400\$856 réis como informa inspetor. E suposto tenha recebido desde esse tempo o produto das entradas, o qual sendo o maior ao princípio, está já 
muito diminuído, e cada vez o estará mais; contudo é notório que tem também feito despesas com duas novas óperas, e duas danças, que posteriormente puseram em cena, as quais provavelmente terão muito o [ilegível] produto.

Por consequência [,] o que de tudo isto se pode esperar é que chegando os meses de verão, em que os teatros são pouco freqüentados, faltem absolutamente os meios para que o de S. Carlos continue a trabalhar, e que a sociedade, apesar do termo que assinou perante o inspetor a 2 de dezembro passado, se seja obrigada a fechar o Teatro, porque nem tem capitais próprios para o sustentar, nem os caixas e outros negociantes que lhe tem acudido com dinheiros adiantados serão tão nescios [sic] que sacrifiquem os seus cabedais a uma perda certa e considerável.

Pode se que os associados ao Teatro Italiano julguem estes receios mal fundados, e pode ser que o tempo mostre que a sua opinião foi acertada. Nesse caso nada mais há que tratar: continuam os auxílios e, continua o Teatro e tudo vai bem. Mas suponhamos que os mesmos receios se verificam e que a empresa não pode ir avante, que deveria fazer-se?

Os empresários responderão que se devem aumentar os auxílios, e puderam o dar 5 Casas de Sortes [sic] que estavam aplicadas para o Teatro de S. Carlos. Eles porém devem saber que sendo este subsídio destinado para a manutenção do V. Teatro, foi tão insuficiente, que sem embargo de se lhe anexar o da Rua dos Condes, que tenha também 3 Casas de Sortes e produzia bastante lucro, e enorme despesas dos espetáculos em música observam o rendimento das mesmas casas de Sortes, a do Teatro Português, denuncia que quando o de S. Carlos se fechou, se achava a sua caixa onerada com uma dívida de quarenta mil cruzados, e o diretor Manoel Baptista de Paula, único sócio abonado, que podia se responder por ela, e com quem os credores tinham contratado, exposto a uma ruína infalível. 


\section{ANEXO}

SANTOS, Antonio Ribeiro dos. Lista de livros e periódicos estrangeiros que a Biblioteca Nacional de Lisboa necessita adquirir de novo ou para completar colecções. [Publicação entre 1796 e 1816]. BNP. Seção de Reservados. Códice 565.

\section{- ESPANHA}

Lista de algumas obras periódicas de Espanha.

Memorial Literário o Bibliotheca Periódica de Ciências y Artes. (Temos o tomo I., ano primeiro. Madri, em la Imprenta de Garcia e Comp.a. Octubre de 1801.)

Bibliotheca Española Economico_Política (É coleção de extratos, e se abriu por subscrição em 1802 e tem já saído seis pequenos cadernos, ou nos. []).

Correio literário de Xeres (Começou em 1800, e subscreve-se me Madri na Casa de Esparza).

Semanário de Agricultura y Artes (Publicam-se por ordem Superior. Temos o tomo IX e X. Impressos em Madri em 4 ${ }^{\circ}$ em 1801 na Imprenta de Villal Pando[)].

Mercurio de España Madrid: (Há m.tos anos que sai, e necessitamos de todos os tominhos que tem saído até agora [)].

Anales de Ciências Naturaes (Publicam-se por Ordem Superior, julgamos srem já 14 tomos [)].

Anales de Artes y Manufacturas por R. O. Reylli. 
Lista [rasurado] de Alguns Livros de Espanha que necessita da Real Biblioteca de Lisboa.

Memorias Políticas, y Economicas sobre los frutos Commercio, Fabricas, y Minas de España, por D. Eugenio Lavruga 1792. (46 tomos de $4^{\circ}$ e talvez haverá mais).

D. Luiz Luniga. Plano de Antiguidades Espanolas [sic] (em casa de Castilla frente a las grades de S. Filippe).

Introduction a la Historia Natural y a la Geografia física de Espana por D. Guillermo Bowles. 1 tomo. $4^{\circ}[$ ] ].

Historia de Políbio Megapolitano traducida del Griego por D. Ambrosio Ruy Bomba. 3. V. $4^{\circ}$.

Obras Poéticas de Píndaro em Metro Castellano con el texto Griego y notas Críticas , por D. Fran.co Patricio de Berguiza. 12. Los diez libros de Diogenes Laercio sobre las vidas de los Filosofos traducidas del Griego por D. Jozé Ortiz. 2 V. $4^{\circ}$.

Oraciones e Cartas de Socrates traducidas del Griego, y illustradas con notas por D. Antonio Ranz Ramanellos. 3V. 8. ${ }^{\circ}$ maior.

Examen de la possebilidad [sic] de fixar la significacion de los sinonimos de la língua Castellana, por D. Jozé Lopes de la Huerta. 1V. $8^{\circ}$.

D. Juan de la Reguera Val de tomar Resumem de la Historia Cronologica del Derecho y Leis de España. Tomos dez Fueros.

D. Rennan Lavaro de Dou Instituicones del Derecho Publico Geral de Espana.

D. Dionizio Marcate e Dias . Leciones de Navegacion e Arte de la cria de Gusanos de Seda por Juan Lanes y Durval. 1V.8. ${ }^{\circ}$ 
Elementos de Higiene trad. De Esteban Soustelle por D. Luiz Mexia.

D. Segismundo Malats. Elementos de Veterinarian el .

Dissertacion sobre la explicacion y uso de um Maquina agramadera para agramar Canais e linos em $4 .^{\circ}$

Descripcion de las Maquinas de mas general utilidade que hay em el Real Gabinete de ellas em el Buen Retiro. V. 1.2.3.4.

Dicionario histórico de las Artes de la Pesca nacional por D. Antonio Sanez Reguard. 5. tomos $4^{\circ}$ maior.

Reflexiones sobre las Maquinas y Maniobras del uso de à bordo pr D. Francisco Ciscar. 1 tomo. $4^{\circ}$.

Memoria elemental sobre los nuevos pesos, $y$, medidas decimales fundados en la natureza por el mismo.

Tratado de Navegacion por d. Joseph de Mendoza y Rios. 2V. $4^{\circ}$.

Ensayos políticos econômicos y filosóficos del Conde de Rumtoro. Traduciodos por D. Domingos Aguero y Neyva.

Elementos del Arte de tenir de Mr. Berthollet traduc. con addiciones D. Domingos Garcia Fernandes. 2V. $8^{\circ}$.

Ordenanzas Generales dela Armada Naval. 2 tomos. Fol.

D. Jayme Bovells y D. Ignacio Lacaba. Curso completo de Anatomia.

Diccionario elemental de Farmacia por D. Manuel Hermandez de Gregorio 2 tomos. $4^{\circ}$.

Diccionario General de Medallas de D. Thomaz de Gulseme. 1773. 6 V. $4^{\circ}$. 
Casto Gonzales Instrucciones Antiquario Lapidarias, traducidas de la língua Toscana. Madrid 1794. 1 V. $4^{\circ}$.

\section{$\rightarrow$ FRANÇA}

Lista [rasurado] das continuações de que necessita a Biblioteca de Lisboa para completar as obras que já tem de História Civil, e Política.

La chef du cabinet des Princes dek Europe 16. ${ }^{\circ}$ (Temos $25 \mathrm{~V}$ de Juillet de 1704 jusque a Juillet de 1716).

Suplement de la clet. [ ?]ou Journal Historique-Verdun - $12 .^{\circ}$ (temos dois Vols. 1713).

Sist. [ ?]de la clet [ ?]... Paris $12 .^{\circ}$ (temos 110 Vol. De 1717 Juillet de 1771).

\section{De história Literária}

L’Avant coureur . 8. ${ }^{\circ}$ (temos até 1772.$)$

Bibliotheque raisonèe des Ouvrages des Scavans del Europe (temos até 1753).

Histoire Critique des Journaux (Temos o Vol. $2^{\circ}$. falta o $1 .^{\circ}$ e os mais, se há).

Journaul Encyclopedique (Temos até fevereiro de 1776).

Journaul Litteraire (Temos de Maio def 1713 até a primeira [ilegível] de 1737)

Journaul [ilegível] societè de Academeciens (Temos de 1772 até 1776). 
Journaul de Politique et Litterature (Temos até 1775 até ao tom. 11 de 1778)

Journaul de Litterature (Temos de 1780 até 1783.)

Castillon $=$ Journaul des Sciences et des Belles Arts (Temos 1776 e 1777, mas faltam os três primeiros meses de 1777).

Journaul des Sciences et Beaux Arts pour une Societé de Gens de Lettres (Temos 1778).

Journaul Estranger (Temos de 1754 até 1762.)

Memoires pour l'Histoire des Sciences (temos de 1701 até 1775)

Memoires Secretes (temos de 1762 até 1775)

Novelles de la Republique des Lettres (temos de 1684 até Maio de 1708).

Novelles Litteraires. (temos de 1715 a 1720[)].

\section{De Filosofia, e Artes.}

Histoire del Academie Royale des Sciences de Paris - 4 (temos até 1788).

Observations sur la Physique. $4^{\circ}$ (temos 45 vol. De 1773 até 1792).

Memoires d'Agriculture par la Societé Royalle d'Agriculture. (temos de 1785 a 1788). mas faltou nos destes mesmos Inverno, e Primavera de 1785 e Outono de 1785).

Rosier. Cours d'Agriculture (temos 9 vol.) 


\section{De Medicina em Particular}

Histoire de la Societé Royale de la Medicine. Paris. (temos 9 volumes de 1776 a 1788).

Memoires Litteraires, Critiques, e Philosophiques de la Medicine. Paris. $4 .^{\circ} .1775$.

Memoires de la Academia [sic] Royale de Chirurgie. Paris. 12.. (temos 15 volumes de 1781 a 1789).

Journal de Medicine et Chirurgie. 8. ${ }^{\circ}$. (temos até 1789).

Recueil de Pieces qui out concuru pour le prix de la Academie. Paris. $12 .^{\circ}$. (temos 13 volumes de 1778 a 1782).

\section{De Polygraphia}

Collection Academique d'Dijon et Paris - chamada vulgarmente a Colecção de S. Petresburg [sic]. (temos de 1759 até 1779).

\section{De Outras Obras, de novo}

La Grande Carte de la France, levée par l'Academie des Sciences sous la direction de Cassini avec la carte des triangles et tableau indicatif. 8 folhas par capitaine.

M. Milin. Antiquetes Nationales ou Recueil des Monumens por servir a l'Histoire de la France.

Introduction a l'etude des Monumens antiques. $8^{\circ}$

Introduction a l'etude des Pierres Gravées. $8^{\circ}$

Introduction a l'etude des Medailles. $8^{\circ}$ 
Lista [rasurado] De Jornaes, e mais obras Periódicas de que necessita a Biblioteca de Lisboa.

Almanach des Physiciens par C. Lalande. Paris. Années de Chymie. Bibliotetheque Françoise ouvrage periodique redigé pour Pougens. Paris. $8 .^{\circ}$.

Bibliotetheque Britannique

Bulettin des Sciences de la Societé Philomatique de Paris.

Decade Philosophique Litteraire et Politique.

La Feville du Cultivateur.

Journal d'Histoire Naturelle redigé par M. M. Lamarck. Brugiere. Olivier. Hauyet et Pettetier. Paris.

Journal des Mines publie par le Conseil des Mines de la Republique.

Journal General de la Literature de France ou Reportoire methodique des livres nouveaux.

Journal General de Literature Etrangere. Paris (Papel periódico).

[ilegível] . 12 Cadernos cada hum ano.

Blondeau Journal de Marine, ou Biblioteque laisonée de la Science de Navigateur. (Obra periódica).

Magazin. Encyclopedique, ou Journal des Sciences des Lettres, et des Arts: redige par Millin Noel et Varens. Paris.

Magazin. Philosophique de Millin.

Spectateur du Novo. Journal Politique Litteraire. Hambourg. 
Journal de l'Ecole Polytechnique ou bulletin du travail fait à cette Ecole publie par le Conseil d'Instruction et Administration de cet Etablisement. Paris.

Annuare du Republicain.

Memoires de l'Institut National des Sciences et Arts.

[ilegível] au Corps Legislatif por Institut National des Sciences et Arts.

Notícia, e Extracto dos Mss. Da Bibliotheca Nacional de Paris, e de outras várias publicado pelo Instituto Nacional de França.

\section{$\rightarrow$ ITÁLIA}

Lista das Continuações que faltam a Bibliotheca de Lisboa para completar as obras que já tem.

\section{De História Literária}

Cemelli - Bibliotheca Volante. (falta o 10, 11 e de 13 por diante). Annalli Litterari d'Italia. $4 .^{\circ}$ (temos até 1762).

Efemeridi Litteraire di Roma. (temos de 1772 a 1789)

Giornali de Litterati di Pisa (temos 30 tomos de 1771 até 1778). (De 1785 até 1791 . Os tomos de 1785 são 48 e 49 e por esta conta parece faltam os tomos de 31 a 47 e os mais que se seguem a 1791).

Nuovi Giornali de Litterati di Italia (temos 12 tomos de 1773 até 1777). 
Giornali de Litterati col título de novelle Litteraire. Obra Montane-Roma (temos de 1794 a 1759).

Memoire per servir all' Istoria Litteraria [sic] (temos de 1753 até 1758).

Novelle de la Republica Litteraria. (temos de 1736 a 1759). publicate in Firenze. (temos de 1740 até 1777).

\section{De História Civil e Política.}

[Ilegível] - Il Mercurio Político. (falta o vol. 21 q hé o tomo 13).

\section{De Sciencias, e Artes.}

Opusculi [ilegível] sulla science, e sulla arti. Milano. $4^{\circ}$. (temos 13 vol. De 1778 até 1790$)$. Temos mais 1782.2 vol. $4 .^{\circ}$.

\section{De Medicina em particular}

Giornali de Medicina - Milano. 4.․ (temos 14 vol. De 1763 até 1777).

Raccolta de Opusculi Medico Patrici. Firenze. 8º (temos de 1773 até 1776).

De Polygraphia

Ozzi Litterari. Torino. (temos atpw 1787).

Saggi di Disertationi Academiche - Roma. (temos de 1742 até 1758). 
Nuova Raccolta d'Opusculi Siciliani-Venezia. 12. (temos 28 vol. De 1755 até 1776).

Efemeride Astronomiche per Lanno de 1779 dal Abatte Angelo de Cesaris. Milano. $8^{\circ}$. (temos só este anno).

\section{Lista [rasurado] De várias Colecções, e Extractos de que precisa} a Bibliotheca

L'Abatte Viviani Collezione dell Historici antiqui

Herodoto. Thucydides. Vulgarizati. Roma. 1790.3 vol. $4^{\circ}$.

Raccolta d'Opusculi attenenti all educaczione della Giventa Vicenza. 1779.

Raccolta di Lettere Sulla Pittura . Roma. 1757. 1768. 6 vol. $4^{\circ}$.

Colezione di Scritture di Regia Giurisdizioni. (Não declara o lugar, mas sabe-se que foi impresso em Florença)

Atti della Societata Patriotica di Milano diretta all avanzamento dell Agricultura delle Arti, e delle Manufacture. Milano. 17831793. 3 vol. $4 .{ }^{\circ}$.

Saggi Scientifici e Letterari del' Academia di Padova. Padova. 1786-1795. 3 vols.

Atti dell Academia delle Scienze di Siena detta de Fisiocritici. Siena. $1761-1781.6$ vols. $4 .^{\circ}$

Atti, e Memorie dell'Academia del Cimento.

Memorie di Matematica e Física della Societá Italiana. Verona. $1781-1794.7$ vols. $4 .^{\circ}$ 


\section{$\rightarrow$ NÁPOLES}

Lista [rasurado] das Continuações que faltam a Bibliotheca de Lisboa para completar as obras que já tem.

Opusculi di A. A. Siciliani. Palermo. 12 vols de 4. ${ }^{\circ}$ (temos de 1759 até 1771).

\section{Lista [rasurado] De Colecções}

Atti della Reale Academia delle Scienze e Belle Lettere di Napoli. Napoli.

\section{Lista [rasurado] De Outras Obras}

Corte du Royanme de Napoles par Zanoni. 4 folhas.

Filipo Paruta la Sicilia. Fol.

Conte Carli Obras. [sic].

\section{$\rightarrow$ BERLIM}

Lista de alguns livros de que necessita a Real Bibliotheca de Lisboa.

Memoires depuis l'avenement de Federic Guillaulme II [sic] au Throune 1792-1793.

Car. Godofr. Hagen. Programa primum de Plantis in Prússia cultis Konisberg [sic]. 1791. 1 vol. 8. ${ }^{\circ}$ (e a continuação se houver). Comementarii Societatis Regia Scientarum Gottingensis Gotting. 1752. $4^{\circ}$.

Sam. Christiani Holmanni. Comentationum in Reg. Scientiarum. Sylloge. Gotting. 1765. $4^{\circ}$. 
Comentationum in Reg. Scient Societat gotting. An. 1753 et 1754. Recencitarum Sylloge altera. [ilegível]. 1775. 4. ${ }^{\circ}$

Lista [rasurado] Das continuações de Livros de que necessita a Bibliotheca.

Histoire del'Academie Royale des Sciences e des Belles Lettres de Berlin [sic]. 4. ${ }^{\circ}$ (temos 31 vol. De $4 .^{\circ}$ desde 1746 até 1774).

Commentarii Novi Regia. Societatis Regia Scientiarum Gottingensis. (temos 7 vols. de $4 .^{\circ}$ desde 1771 até 1777).

\section{$\rightarrow$ INGLATERRA}

Lista de alguns jornaes, e Livros, e Papeis Periódicos de que necessita a Bibliotheca.

Monthly Review

Critical Review

Analitical Review, of new Litteracy Journal.

Nicholson Journal of natural Philosophy.

[ilegível] Philosophical Magazini.

Repertory of Arts.

Annual Register.

Asiatic Annual Register.

Duncans Annals of Medicini [sic]. 
[ilegível]. Annals of Agriculture.

Parlamentary Register.

Correios de Londres em Francês (temos de 16 de fevereiro de 1798 por diante).

Lista [rasurado] de alguns livros de que necessita a Real Bbliotheca de Lisboa.

Sylvestre Giraldo. Itinerarium Cambria Baxter Glossarium Antiquitum Britannicarium.

Geographi Veteres Minores. [ilegível]. 1698. 1712. $4^{\circ}$ vol. 8. ${ }^{\circ}$

Hicker Thesauvrus Linguarium Septentrionaliu. [ilegível]. 1705. 3 vol. Fol.

Thomas Hayne [sic]. De linguarium Harmonia. Londini. 1648. $8^{\circ}$

Joann Davies Cambro -Britannica. Lingua Institutiones London. 1592. Fol.

. Antique lingua Britannica vel cambricg [sic]. Dicionarium duplex. Londini. 1632. 2 fol.

Jona Dryander. Catalogues Bibliotheca Historico - Naturalis. Josephi Banks. Baroneti. Londini. 1796-1800. $8^{\circ}$.

Horacio. De Joao Pini. Londres. 1733. 2 vol. $8^{\circ}$.

Milton. Edição de Baskerville. 1 vol. Ou a de 1760. 4 vol. $8^{\circ}$. Ou alguma outra edição se há melhor.

Paper. Obras 15 vol. $8 .^{\circ}$

Luís de Camões. Traducção Ingleza de Willian Julius Mickle. Oxford. 1776. 